\title{
Cheilostome Bryozoa \\ in the Danian Deposits of East Denmark
}

\author{
By \\ Ole Berthelsen \\ Dansk sammendrag: \\ Cheilostome Bryozoer i Østdanmarks \\ Danienaflejringer
}

I kommission hos

C. A. REITZELS FORLAG ( $\varnothing R G E N$ SANDAL)

KØBENHAVN 1962 


\title{
Cheilostome Bryozoa in the Danian Deposits of East Denmark
}

\author{
By \\ Ole Berthelsen
}

Dansk sammendrag:

Cheilostome Bryozoer i Østdanmarks

Danienaflejringer 
Med 28 tavler

With 28 plates

Printed in Denmark by Andelsbogtrykkeriet i Odense 


\section{PREFACE}

A good number of years ago Professor CHR. POULSEN in a lecture on paleontology expressed his astonishment at the prevailing defective knowledge of the Bryozoa in Danish Danian deposits. This remark roused my curiosity and led me the investigations into the Bryozoan fauna of the Danian deposits the preliminary results of which are presented in this book.

The work thus has lasted for a number of years, interrupted by long intervals, voluntary as well as involuntary. The beginning was groping and uncertain, but thanks to encouragement and assistance from various quarters I succeeded in keeping my course. It is my pleasant duty here to offer my most cordial thanks to a number of persons who have assisted, guided, and encouraged me during the work, thus Dr. Chr. Poulsen, Professor of Paleontology at the University of Copenhagen, and Dr. Alfred Rosenkrantz, Professor of the Geology of Denmark at the University of Copenhagen, who partly in encouraging and inspiring discussions, partly by lending me Bryozoan material from the rich collections of the Mineralogical Museum, have given me valuablesupport. Dr. H. ØDuM, Director of the Geological Survey of Denmark, has taken a great interest in my investigations; I am very grateful that it has been made possible for me to complete my studies of the Bryozoa concurrently with institution work proper, as well as for the fact that the work has been included in the series of publications of the institution.

While studying in Hamburg and London I met with invaluable helpfulness on the part of Professor EhrH. Voigt, Ph.D., of the University of Hamburg, and Dr. H. Dighton Thomas, British Museum, respectively. The expenses for my stays abroad have been covered by the CARLSEN-LANGes LegATSTIFTELSE and IAPETUS STEENSTRUPS LEGAT.

Very valuable assistance has been furnished by Miss Anna Tonnessen, who has made a fair copy of the finished manuscript, Mrs. Rigmor BORG, who has drawn maps and diagrams, and Mr. CHr. WestergaArD, who has been in charge of the takings of the photographs. My father-in-law, Mr. A. C. GREGERSEN, has with great patience assisted me at the measurements and the extensive countings of fragments.

Mr. Niels Haislund, M. A., has been in charge of the translation of the manuscript into English.

I offer my cordial thanks to all those mentioned above.

I am especially obliged to my wife, Mrs. Mete-Marie Berthelsen, who for 
eleven years has had to forego normal family life. She has come to terms with these extraordinary conditions with unique understanding and never failing good spirits.

The English manuscript was finished in December 1961.

Lyngby, February 18, 1962.

Ole BerTheLsEN 


\section{CONTENTS}

Abstract . . . . . . . . . . . . . . . . . . . . 7

I. Introduction . . . . . . . . . . . . . . . . . . . . . . . . 9

II. Description of Localities . . . . . . . . . . . . . . . . . . . . . 11

Stevns . . . . . . . . . . . . . . . . . 11

Kagstrup . . . . . . . . . . . . . . . . . . . 15

Thorslunde . . . . . . . . . . . . . . . . . . 19

Faxe . . . . . . . . . . . . . . . . . 21

Copenhagen . . . . . . . . . . . . . . . . . 25

Saltholm . . . . . . . . . . . . . . . . . . . 29

Herfølge . . . . . . . . . . . . . . . . . . . . 32

Klintholm . . . . . . . . . . . . . . . . . 35

III. Paleontology . . . . . . . . . . . . . . . . . . . . 39

1. Classification .............. . . . . . 39

2. Remarks on the Description of Species . . . . . . . . . . 39

3. Terminology. . . . . . . . . . . . . . . . . . 41

4. Bibliography . . . . . . . . . . . . . . . . . . . . 43

5. Systematic Descriptions . . . . . . . . . . . . . . . . . 50

Suborder Anasca Levinsen . . . . . . . . . . . . . . . . . 51

Division Malacostega Levinsen . . . . . . . . . . . . . . . . 51

Membraniporidae Busk . . . . . . . . . . . . . . . . . 51

Electridae LagaAiJ . . . . . . . . . . . . . . . . . . 69

Hincksinidae CANU and BASSLER . . . . . . . . . . . . . 71

Calloporidae Norman . . . . . . . . . . . . . . . . . . 78

Division Coilostega Levinsen . . . . . . . . . . . . . . . . . 107

Onychocellidae Jullien . . . . . . . . . . . . . . . . . 108

Microporidae Hincks . . . . . . . . . . . . . . . . . . . 130

Lunulitidae LAGAAIJ . . . . . . . . . . . . . . . . . 152

Thalamoporellidae LEVINSEN . . . . . . . . . . . . . . 155

Division Pseudostega Levinsen . . . . . . . . . . . . . . . . 158

Coscinopleuridae CANU . . . . . . . . . . . . . . . 158

Suborder Cribrimorpha LANG . . . . . . . . . . . . . . . 160

Cribrilinidae HINCKS . . . . . . . . . . . . . . . . . . . 162

Lagynoporidae LANG . . . . . . . . . . . . . . . . . . . 163

Andrioporidae LANG . . . . . . . . . . . . . . . . . 164

Pelmatoporidae LANG . . . . . . . . . . . . . . . . . . . 173

Suborder Ascophora Levinsen . . . . . . . . . . . . . . . . . 193

Porinidae d’OrbignY . . . . . . . . . . . . . . . . . . . . . 193

Cyclicoporidae Hincks . . . . . . . . . . . . . . . . . . . 208

Hippothoidae LeVINSEN . . . . . . . . . . . . . . . . . . 209

Stomachetosellidae CANU and BASSLER . . . . . . . . . . 211

Schizoporellidae JuLLIEN . . . . . . . . . . . . . . . . . 212

Mucronellidae LEVINSEN . . . . . . . . . . . . . . . 215

Reteporidae Sмітт . . . . . . . . . . . . . . . . 217

Celleporidae Busk . . . . . . . . . . . . . . . . . . . . . 219 
IV. Stratigraphical Investigations . . . . . . . . . . . . . . . . . 224

1. Purpose . . . . . . . . . . . . . . . . . . . . . . . . . 224

2. Method and Results . . . . . . . . . . . . . . . . . . 224

3. Development of the Terminology . . . . . . . . . . . . 225

4. Characterization of the Rocks of the Danian . . . . . . . . . . 225

5. Lithological Evaluation . . . . . . . . . . . . . . . . . . . 227

6. Paleoecological Evaluation . . . . . . . . . . . . . . 235

7. Faunistic Evaluation . . . . . . . . . . . . . . . . . . . . . 242

8. Biostratigraphical Evaluation . . . . . . . . . . . . . 254

V. Stratigraphical Position of the Sandy-limestone on Saltholm . . . . . 257

Dansk sammendrag . . . . . . . . . . . . . . . . . . . . . . 263

Bibliography . . . . . . . . . . . . . . . . . . . . . . . . . . 282

Index of Bryozoa . . . . . . . . . . . . . . . . . . . . . . . . 288 


\section{ABSTRACT}

In the present work the results are presented of some investigations into the paleontology and distribution of the Cheilostome Bryozoa within the Danian deposits in East Denmark.

In the Introduction an account is given of the extent and development of these investigations.

The following chapter includes descriptions of localities, a short survey being made of situation, literature, lithology, stratigraphy, and material for each of the localities treated: Stevns, Kagstrup, Thorslunde, Faxe, Saltholm, Copenhagen, Herfølge, and Klintholm.

The paleontological chapter is introduced by a section on the systematic classification. Next, a few remarks for the reader's guidance are offered concerning the descriptions of species, thus as regards measurements, material, types, and distribution. A terminological section includes definitions of the morphological terms used in descriptions of species, while the following section comprises a chronological survey of papers in which Cheilostome Bryozoa in Danian deposits from Denmark, Sweden, or North Germany are described, pictured, or mentioned. In the systematic part 117 Cheilostome species and subspecies are described, 42 of which have not previously been treated. The species examined are pictured on 28 plates at the end of the work.

The stratigraphical chapter is introduced by a section about the purpose of the stratigraphical investigations. First of all it has been the author's aim to obtain a more reliable standard of comparison than the one existing, by taking fresh samples from the localities selected. Next, the task has been to elucidate the extent to which the Bryozoa have participated in the formation of the various cretaceous rocks, partly to learn the composition of the Bryozoan assemblages within the various zones of the Danian - with due reference to the possible influence of conditions of environments.

In the lithological section the analyses made are discussed in more detail. These investigations have shown that the share of the Bryozoa in the formation of rocks is smaller than has so far been supposed. The contents of Bryozoa do not exceed 40 per cent. in any of the samples examined; in most of the samples the Bryozoa constitute a considerably smaller percentage. Furthermore it proves that Cyclostome Bryozoa have contributed to the formation of rocks to a greater extent than the Cheilostome species.

In the Paleoecological section it has been tried to estimate conditions of bottom, depth, temperature, and current, the supply of nutrients, and the 
salinity in the sea in which the Danian Bryozoa lived. The measurements of zooecia, etc., have been discussed in some detail in the same section. The character forms of the localities and biozones are treated in a special section, after which, in conclusion of the stratigraphical chapter a biostratigraphical evaluation of the Bryozoan material is made. The species naturally are distributed on four groups, corresponding to the four Tylocidaris zones. The stratigraphical grouping of the localities on the basis of the occurrence of the Bryozoa is in agreement with the experiences won through the study of the distribution of other animal groups, with one exception, viz. Saltholm. If the limestone on Saltholm should be placed in the stratigraphical diagram on the basis of the Bryozoa alone, both Bryozoan Limestone and Sandy-limestone should be referred to the T. brünnichi zone.

This deviation from the current view has made it necessary to go through the faunistic and lithological arguments applied in the documentation of the reference of Sandy-limestone to the $T$. vexillifera zone. Such a revision is made in the last chapter of the work. The conclusion of these investigations was that there is no information in the geological literature about Saltholm which decidedly goes against referring the Sandy-limestone on Saltholm to the T. brünnichi zone. 


\section{INTRODUCTION}

This work is a presentation of the results of some investigations into the paleontology and distribution of Cheilostome Bryozoa within the Danian deposits in East Denmark. The studies were begun in 1950, the starting-point selected being material from the Bryozoan Limestone at Herfølge. The collections of fossils in the Mineralogical Museum of Copenhagen from this locality are very extensive, but the selection was further motivated by the state of preservation of the Herfølge Bryozoa, which made them particularly suitable for paleontological investigations.

However, it proved to be rather difficult to determine the species of a great many of the fragments of colonies on the basis of the existing Bryozoan literature, which is mainly based on studies of material from Faxe and of Danian blocks in the Quaternary layers and of the Senonian deposits. The explanation might be that the facial conditions at Herfølge were different from e. g. those at Faxe, but the possibility might also be imagined that the difficulties of identification reflected a difference in the stratigraphical placing of the two localities within the Danian, or, in other words, that the Bryozoa were a suitable aid in the stratigraphical evaluation of the Danian deposits. LANG (1921-22) and VoigT (1930) had demonstrated the utility of this group of animals within the stratigraphy of the Senonian, so it was a natural idea to undertake a corresponding analysis of the occurrence of the Bryozoa within the Danian.

As a consequence, the investigations were extended to include Bryozoan material from a number of other occurrences so that all zones of the Danian were represented by at least two localities. The following table shows the classification into zones according to ØDUM (1926, p. 217) and RosEnKRANTZ (1937, p. 201) and the localities from which Bryozoan material was taken.

The initial stratigraphical investigations were exclusively based on museum material, as in the Mineralogical Museum of Copenhagen there is a comprehensive collection of assorted Bryozoa collected, examined, and to some extent determined as to genera and species by Dr. BRüNNICH NIELSEN. In order to obtain a more homogeneous and stratigraphically more reliable basis of comparison this material was later supplemented with Bryozoan material from 


\begin{tabular}{|c|c|c|c|}
\hline & ROSENKRANTZ & ØDUM & Localities \\
\hline \multirow[t]{2}{*}{ Upper Danian } & The Tylocidaris vexillifera zone $\ldots \ldots \ldots \ldots$ & Zone D & $\begin{array}{l}\text { Saltholm } \\
\text { Copenhagen } \\
\text { Herfølge } \\
\text { Klintholm }\end{array}$ \\
\hline & The Tylocidaris brünnichi zone ......... & Zone C & $\begin{array}{l}\text { Thorslunde } \\
\text { Faxe }\end{array}$ \\
\hline \multirow[t]{3}{*}{ Lower Danian } & The Tylocidaris abildgaardi zone $\ldots \ldots \ldots$ & Zone B & $\begin{array}{l}\text { Kagstrup } \\
\text { Stevns }\end{array}$ \\
\hline & The Tylocidaris odumi zone ........... & & \\
\hline & Cerithium-limestone $\ldots \ldots \ldots \ldots \ldots \ldots$ & Zone A & \\
\hline
\end{tabular}

samples of limestone collected and examined by the present writer. This collection in what follows is termed the stratigraphical material as distinct from the museum material. 


\section{DESCRIPTION OF LOCALITIES}

The Danian localities described in this chapter are sketched in on the geological map, Fig. 1. The localities are discussed in stratigraphical order, those representing the Lower Danian being mentioned first.

The references to literature mainly include fairly recent publications dealing with the lithology and stratigraphy in the respective localities. Paleontological papers are treated in the stratigraphical chapter p. 257. Earlier publications (i.e. prior to 1908) are summarized in the historical surveys in

(1) K. Rørdam, Kridtformationen i Sjælland i Terrænet mellem København og Køge, og på Saltholm. Résumé en français: Le système crétacique en Séeland, dans le terrain situé entre Copenhague et Köge, et dans l'île de Saltholm. 1897. D.G.U. II. Series. No. 6, pp. 18-45 and pp. 131-135.

(2) J. P. J. RavN, Molluskerne i Danmarks Kridtaflejringer. III. Stratigrafiske Undersøgelser. Résumé en français: Recherches sur la stratigraphie du Crétacé en Danemark. 1903. Vidensk. Selsk. Skr. 6. Række, naturv. og math. Afd. XI. 6, pp. 5-38.

(3) V. Milthers, Beskrivelse til Geologisk Kort over Danmark, Kortbladene Faxe og Stevns Klint. Résumé en français. 1908. D.G.U. I. Series. No. 11, pp. 140-156. Bibliography, pp. 140-142.

\section{Situation.}

\section{Stevns Klint.}

Stevns Klint is a cliff on the east coast of the Stevns peninsula about $12 \mathrm{~km}$. in length and up to $41 \mathrm{~m}$. in height, running north from Rødvig (Fig. 2).

\section{Literature.}

1908. V. Milthers, Kortbladene Faxe og Stevns. D.G.U. I. Series. No. 11, pp. 19-32. Summary: pp. 278-280.

1917. K. Brünnich Nielsen, Cerithiumkalken i Stevns Klint. D.G.U. IV. Series. Vol. 1. No. 7.

1924. A. Rosenkrantz, Nye Iagttagelser over Cerithiumkalken i Stevns Klint med Bemærkninger om Grænsen mellem Kridt og Tertiær. Medd. D.G.F. Vol. 6, pp. 28-31.

1937. A. Rosenkrantz, Bemærkninger om det østsjællandske Daniens Stratigrafi og Tektonik. Medd. D.G.F. Vol. 9, pp. 199-211. 

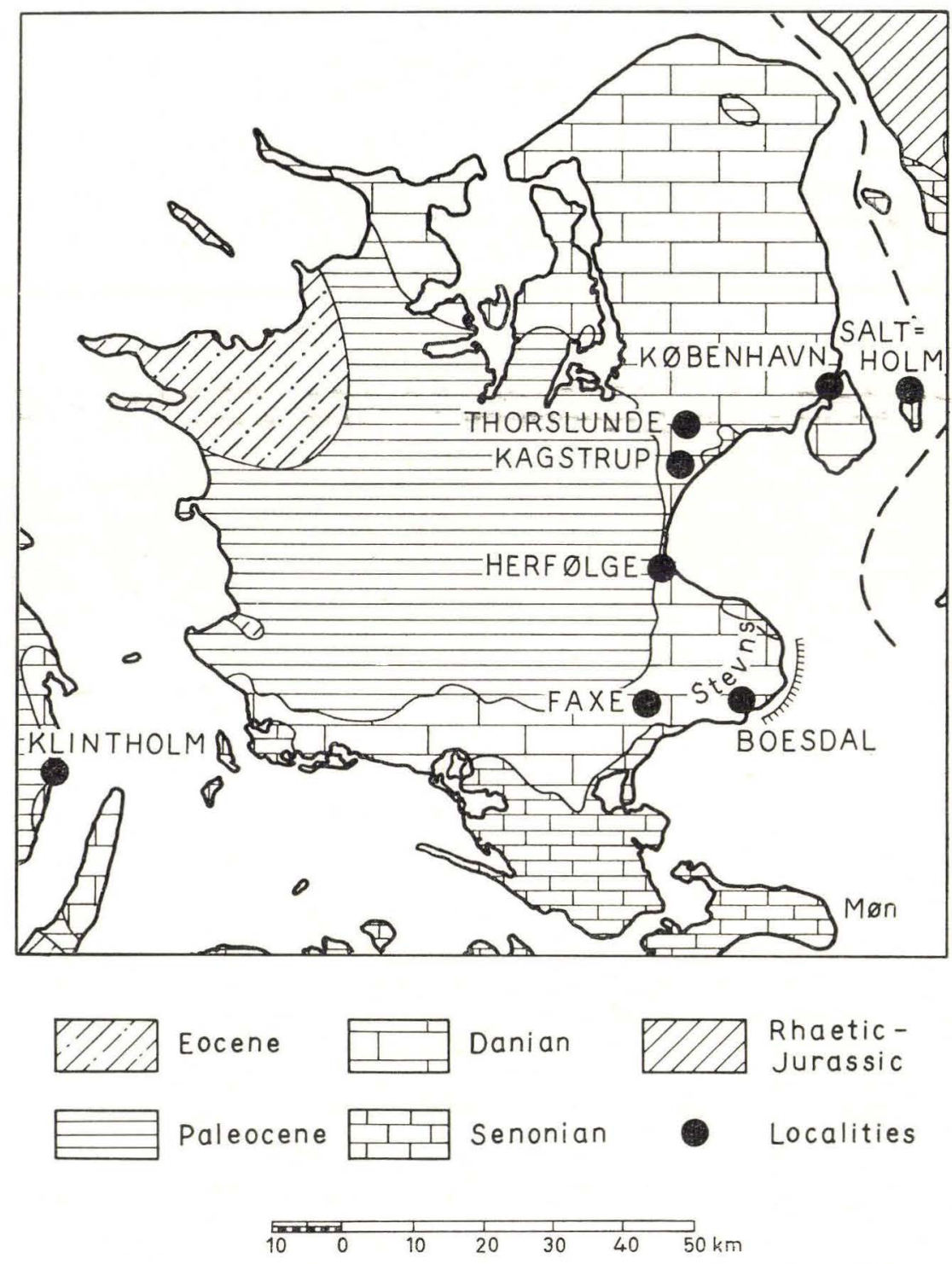

Fig. 1. Geological map of East Denmark with selected Danian-localities. (Acc. to Sorgenfrei, 1954). 


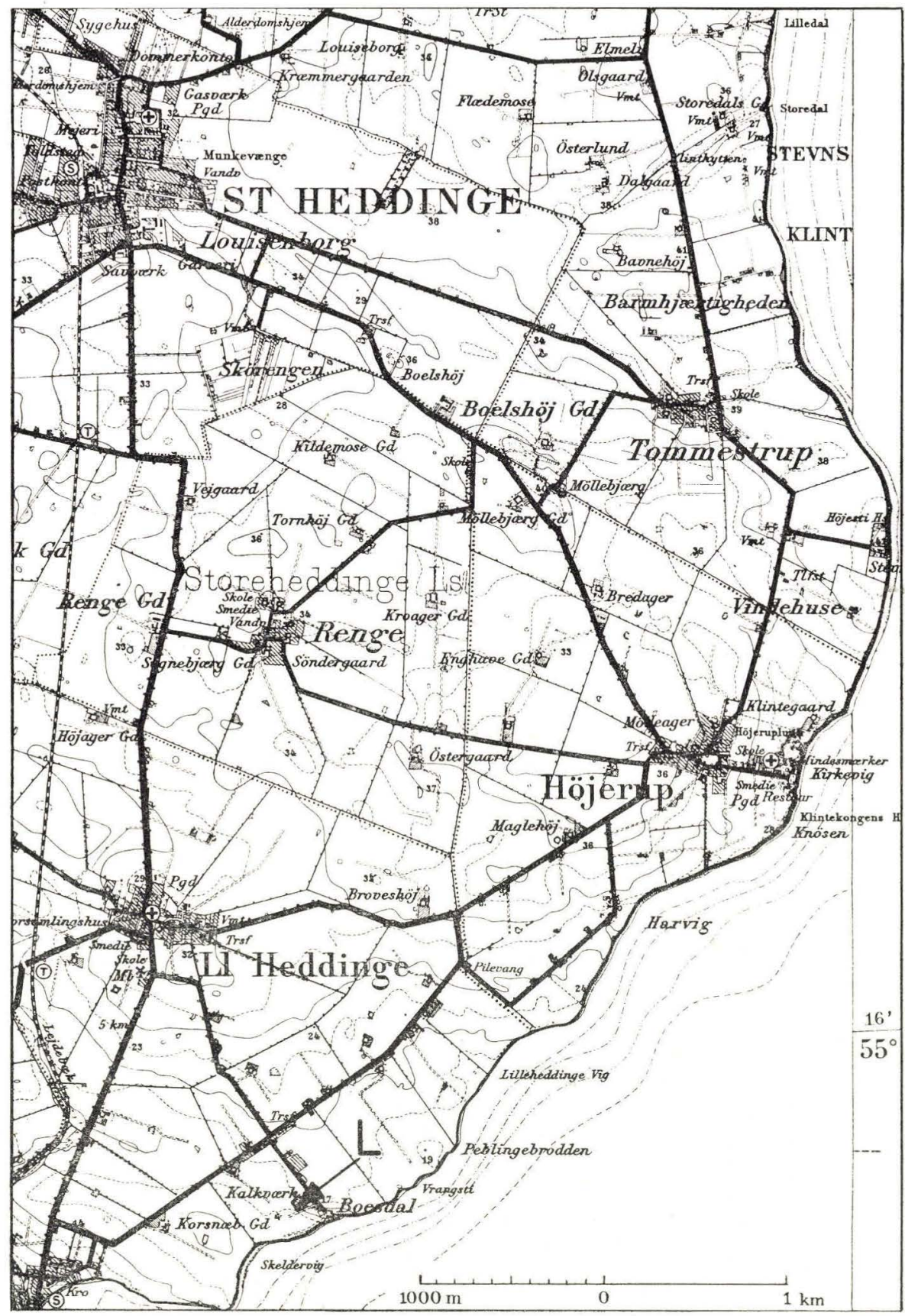

Fig. 2. Section of map sheet No. 3628 (1:40,000) including the southern part of the peninsula of Stevns and Stevns Klint. L indicates the place where the stratigraphical samples were taken. 


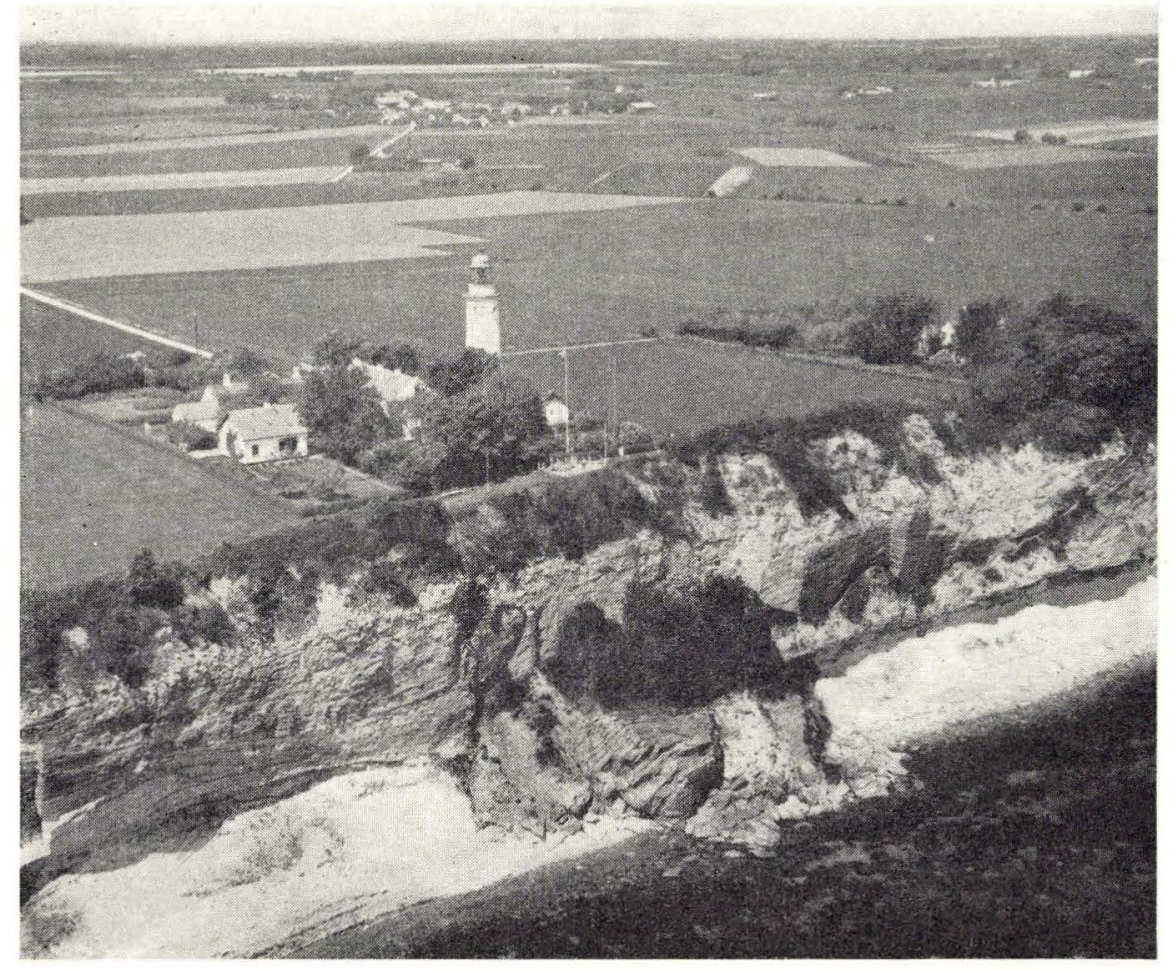

Fig. 3. Stevns Klint at Stevns Lighthouse. Above, morainic deposits, in part covered by plantation. Below that, Bryozoan Limestone with bank structure (the vertical part of the profile). Lowest, White Chalk.

\section{Lithology (Fig. 3).}

The basal deposit in the cliff of Stevns Klint consists of White Chalk. The lower part of this stratum is yellowish-white, fine-grained, with horizontal beds of nodulous flint concretions. The contents of Bryozoa are rather poor. The uppermost 2-3 m. of the chalk are greyish-white, coarser, here and there argilliferous, with an abundance of Bryozoan remains, and with coalescent bands of flint. These bands are arciform as a consequence of formations of banks.

Depressions between the banks appear as shallow, oval basins, the horizontal extent of which varies between 10 and $30 \mathrm{~m}$. The basins are filled in by the oldest deposits of the Danian series, Fish-clay and Cerithium-limestone, with a total thickness of between $\frac{1}{2}$ to $1 \mathrm{~m}$.

Fish-clay is a conglomeratically developed rock consisting of pebbles of White Chalk and rolled Senonian fossils in a dark, argillaceous groundmass. The Cerithium-limestone is a yellowish, indurated, brecciated, coccolithic limestone. The upper part of the grey chalk between the basins has also developed as a yellowish, hard rock, the result of induration in connection 
with an interruption of sedimentation after the depositing of the Cerithiumlimestone. The upper margin of this indurated horizon appears as a slightly undulate plane of abrasion (RosenKRANTZ, 1937, p. 209).

The indurated zone is covered by Bryozoan Limestone, a white or yellowishgrey, dense, rather hard limestone composed largely of Bryozoan fragments and developed as large, massive banks. The maximum thickness of the deposit is $12 \mathrm{~m}$., the average thickness $10 \mathrm{~m}$. It is divided into beds of $1-1 \frac{1}{3} \mathrm{~m}$. in thickness, alternating with $20-30 \mathrm{~mm}$. thick, greatly curved layers of light, grey flint.

The stratigraphical material was taken in the limestone quarry at Boesdal ( $\mathrm{L}$ in Fig. 2). The south wall of the quarry (Fig. 4) forms a section about $12 \mathrm{~m}$. in height (elevation $+16 \mathrm{~m}$ ), the uppermost 3-4 m. of which consists of boulder clay, while the remaining part is composed of Bryozoan Limestone and flint.

\section{Stratigraphy.}

The White Chalk in Stevns Klint is by Brotzen (1945, p. 41) referred to the Upper Maastrichtian, Stevnsian. The Danian, as mentioned above, has by ØDUM been subdivided into the zones A-D (ØDUM, 1926, p. 217, and 1928, p. 63). Fish-clay and Cerithium-limestone are referred to Zone A and Bryozoan Limestone to Zone B. In the biostratigraphical subdivision on the basis of species belonging to the genus Tylocidaris (BRüNNICH Nielsen, 1937, p. 126, Rosenkrantz, 1937, pp. 201 and 203), Bryozoan Limestone in Stevns Klint includes the Tylocidaris ødumi zone, the T. abildgaardi zone, and the lower part of the T. brünnichi zone.

\section{Material.}

1. Museum material marked "Bryozokalk, Stevns" or "Danien, Stevns".

2. Stratigraphical material including 6 samples taken from the south wall in the quarry of Boesdal. The places where the samples were taken are marked a-f in Fig. 4.

\section{Kagstrup (Karlstrup).}

\section{Situation.}

Old limestone quarry at the village of Kagstrup (now Karlstrup), about $10 \mathrm{~km}$. north of Køge and about $30 \mathrm{~km}$. southwest of Copenhagen (Fig. 1). In 1958-59 a cement works was built there to utilize this deposit of limestone, the result being a considerable expansion of the quarry. The original and present sizes of the quarry are shown on the map section, Fig. 5. 


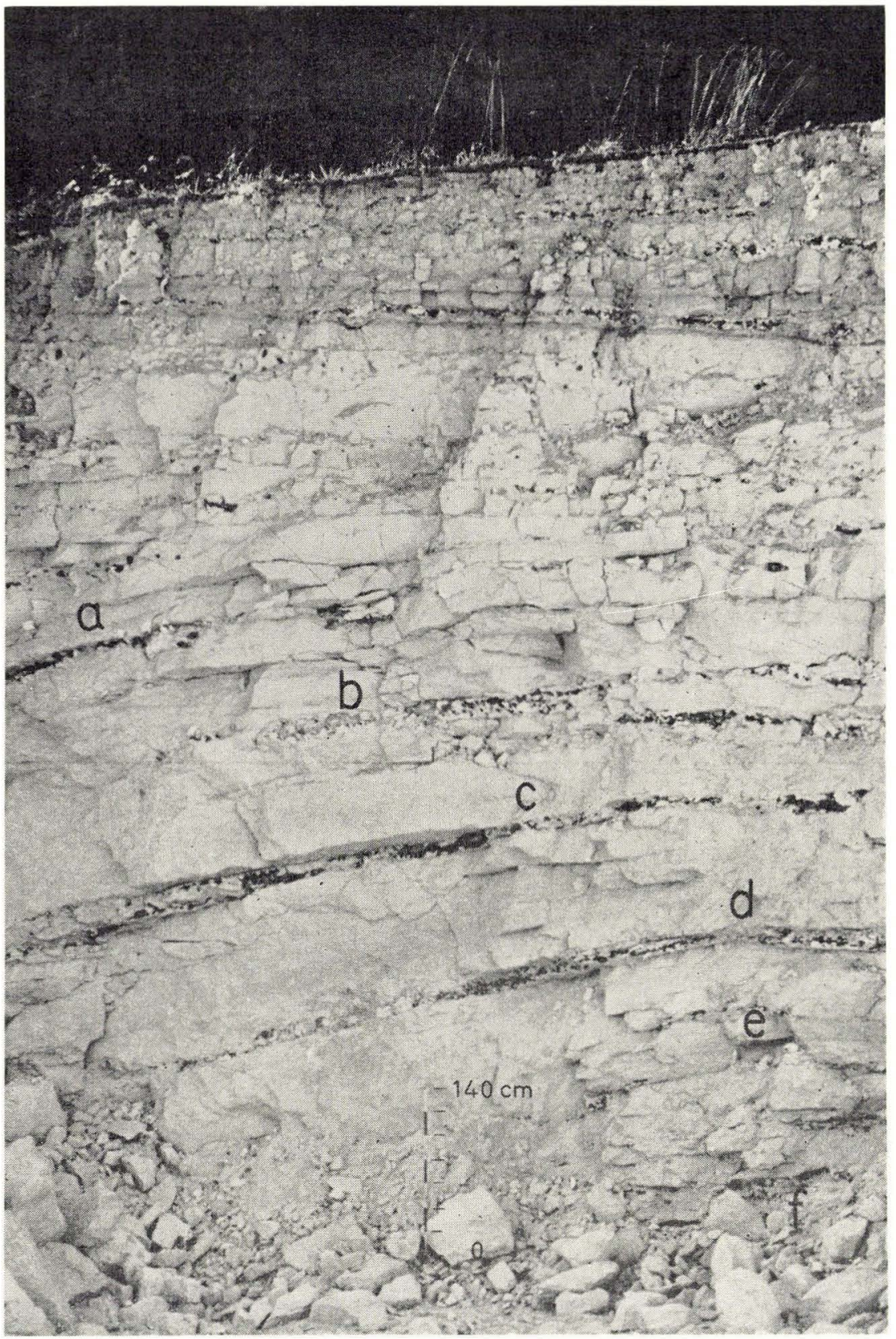

Fig. 4. Profile from the south wall in the limestone quarry of Boesdal, showing the places (a-f) where stratigraphical samples where taken, in relation to the curved strata of flint.

(Phot. Chr. Westergaard). 


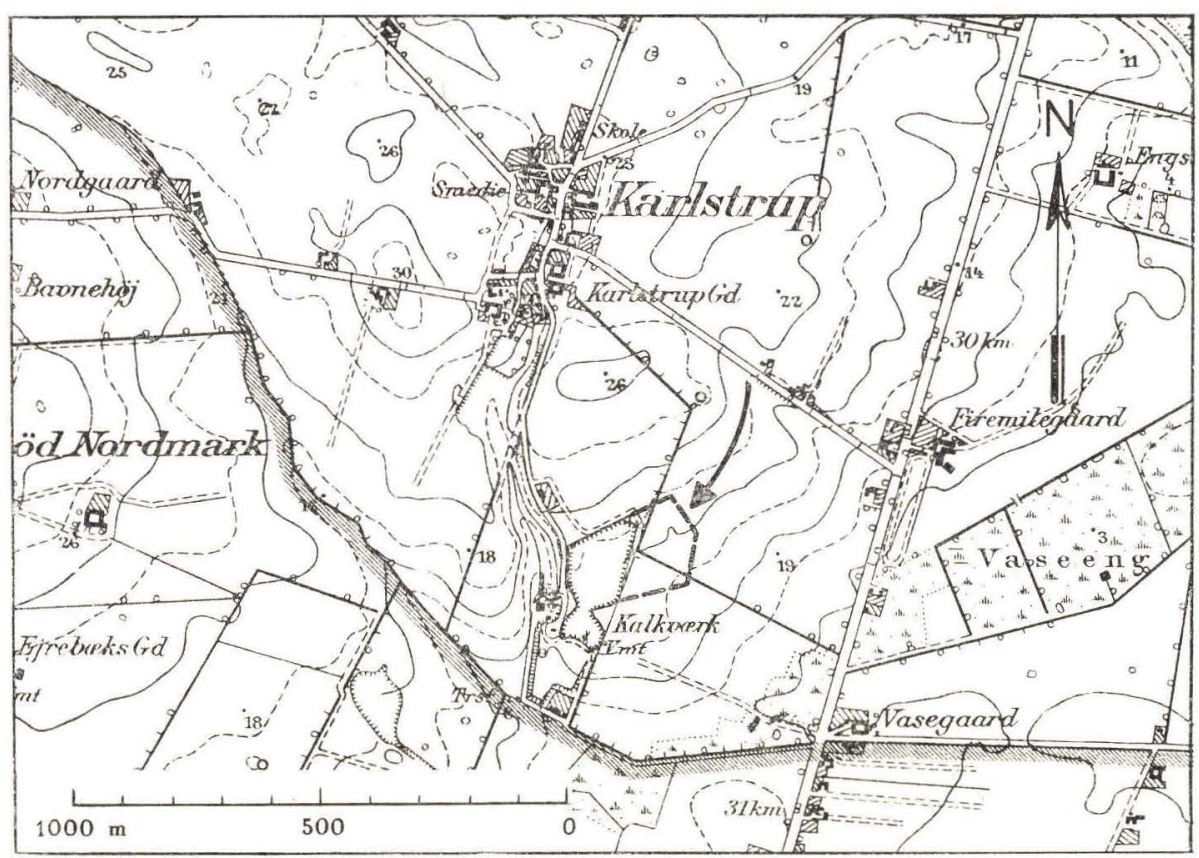

Fig. 5. Section of map sheet No. $3328(1: 20,000)$ showing the site of the limestone quarry at Kagstrup (Karlstrup). The broken line denotes the present extent of the quarry towards the east.

Authorized by the Geodetic Institute of Denmark

\section{Literature.}

1897. K. Rørdam, Kridtformationen i Sjælland. Résumé en français: Le système crétacique en Séeland. D.G.U. II. Series. No. 6, pp. 33-36, 65-70, 133-134.

1909. K. BRÜnNiCh Nielsen, Brachiopoderne i Danmarks Kridtaflejringer. Vidensk. Selsk. Skr., 7. Række, naturv. og math. Afd. VI. 4, p. 14 (140). 1935. V. Milthers, Nordøstsjællands Geologi. D.G.U. V. Series. No. 3 (2. edit.), p. 10.

\section{Lithology.}

Fig. 5 shows that the original quarry was a long rectangle in shape with its main axis running almost north-south. The photograph Fig. 6 is a view looking north and gives an impression of the shape and size of the quarry before the cement works started operations. At that time the walls of the quarry presented a series of layers consisting of $10-12 \mathrm{~m}$. of Bryozoan Limestone and flint in regular alternation superposed by boulder clay. Elevation about $+18 \mathrm{~m}$. As a result of the intensive utilization of the limestone the quarry is now several metres deeper. 


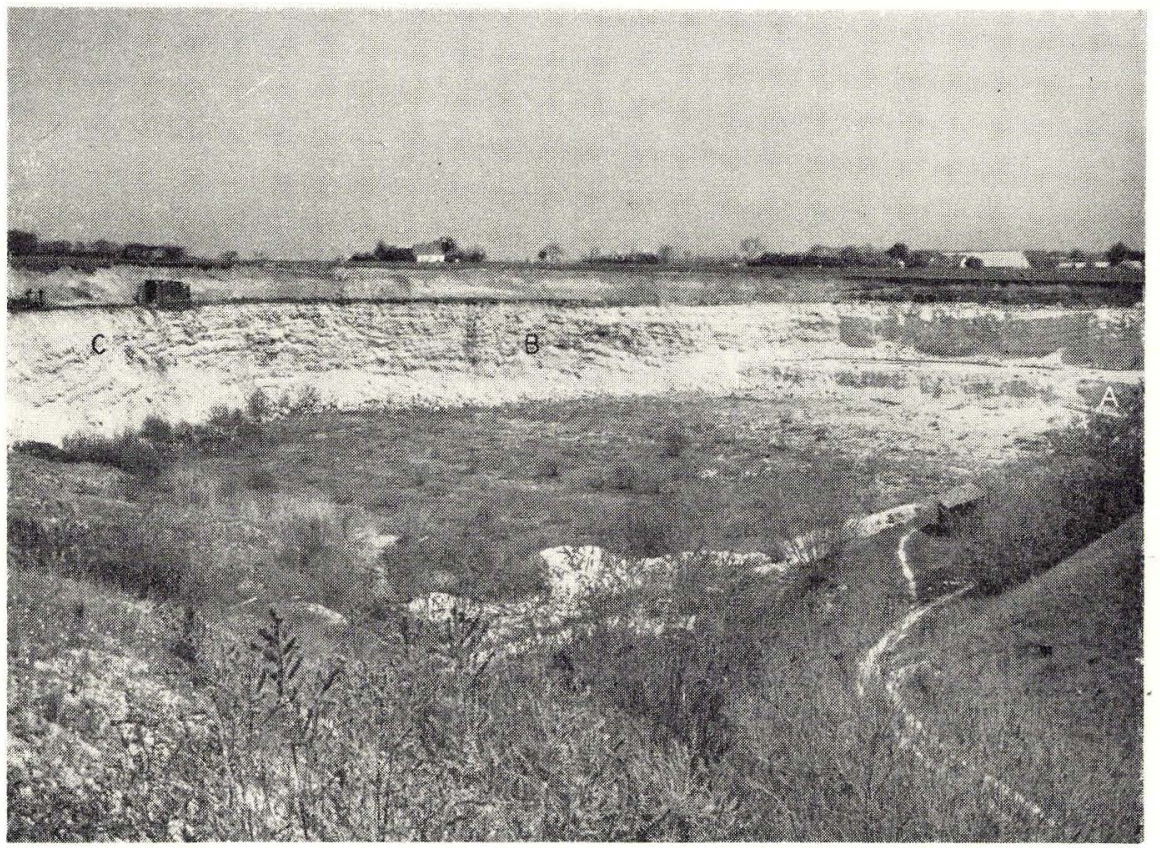

Fig. 6. The limestone quarry at Kagstrup before the extension. The letters A, B, and C denote the places where the stratigraphical samples were taken from the $T$. odumi zone, the $T$. abilgaardi zone, and the $T$. brünnichi zone, respectively.

(Phot. Aalborg Portland Cementfabrik).

The material from these samples has in tables been indicated as $\mathrm{Aa}, \mathrm{Ba}$, and $\mathrm{Ca}$ in order to avoid a confusion with the stratigraphical denotations of zones, A-D.

The limestone is yellowish-white, rich in ooze, and to a great extent composed of Bryozoan fragments. Indurating processes have transformed the lime into a compact, hard limestone occurring in beds 1-2 m. thick, alternating with bands of flint. In the north wall of the quarry there are argilliferous, conglomeratic horizons.

The flint is black or dark grey. The bands of flint in the north wall are almost horizontal with a slight dip towards the sides, while in the east and the west wall they form a system of concentric arcs, evidence of formations of banks similar to the development in Stevns Klint.

Excavation work in connexion with the building of a pumping station revealed the surface of the White Chalk a few metres below the bottom of the quarry. Between the strata of limestone and chalk there was a marked bed of flint, whereas Fish-clay and Cerithium-limestone was not found (cf. Stevns Klint). 


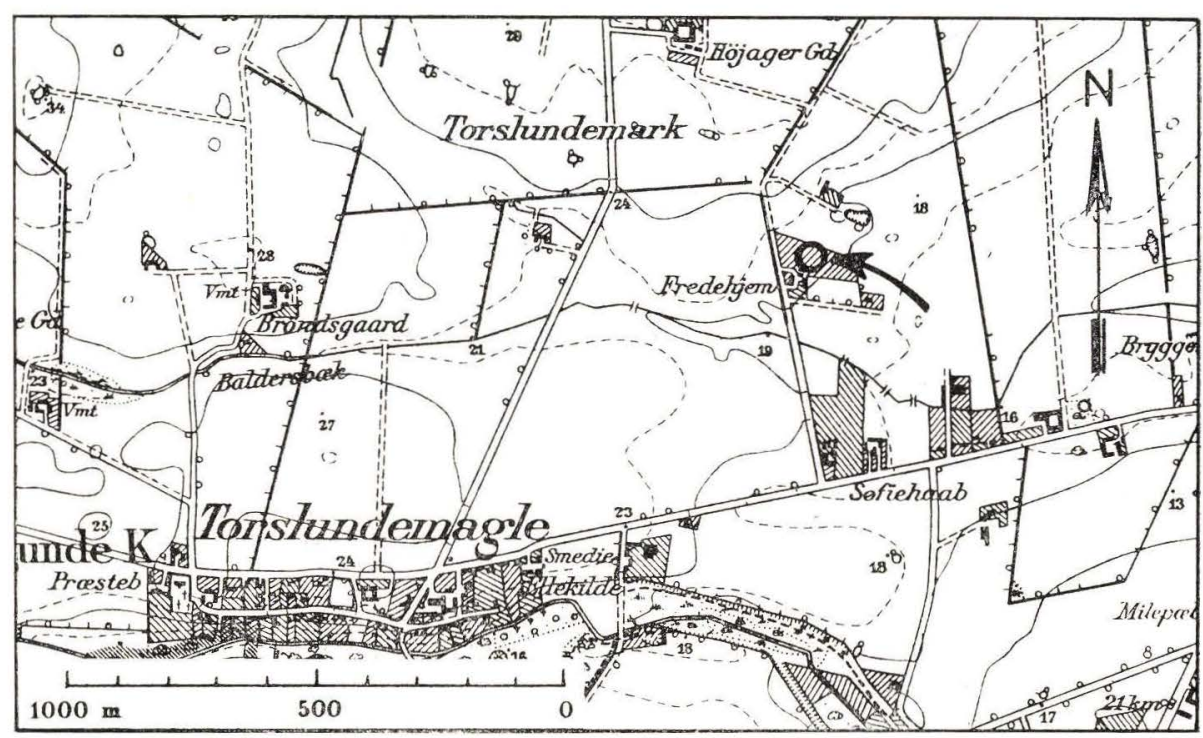

Fig. 7. Section of map sheet No. $3228(1: 20,000)$ showing the site of the old limestone quarry north of Thorslunde (on the map indicated as Torslundemagle).

Authorized by the Geodetic Institute of Denmark

\section{Stratigraphy.}

The greater part of the limestone series in the Kagstrup quarry may be referred to the Tylocidaris abildgaardi zone. In the lower part of the east wall the Tylocidaris ødumi zone has developed, while echinid spines of the Tylocidaris brünnichi type have been found in the upper part of the west wall.

The Bryozoan Limestone at Kagstrup is thus stratigraphically similar to that of Stevns Klint.

\section{Material.}

Museum material marked "Bryozokalk, Kagstrup". 2. Stratigraphical material comprising three samples taken from the lower part of the east wall (the $T$. ødumi zone), from the north wall (the $T$. abildgaardi zone), and from the upper part of the west wall (the T. brünnichi zone). The places where the samples were taken are indicated in Fig. 6 by A, B, and C, respectively. The material from the samples has in tables been indicated as $\mathrm{Aa}, \mathrm{Ba}$, and $\mathrm{Ca}$ in order to avoid a confusion with the stratigraphical denotations of zones, A-D.

\section{Thorslunde.}

\section{Situation}

Old limestone quarry near the former poorhouse in the village of Thorslunde (or Torslunde) about $20 \mathrm{~km}$. west-south-west of Copenhagen (Figs. 1 and 7). 


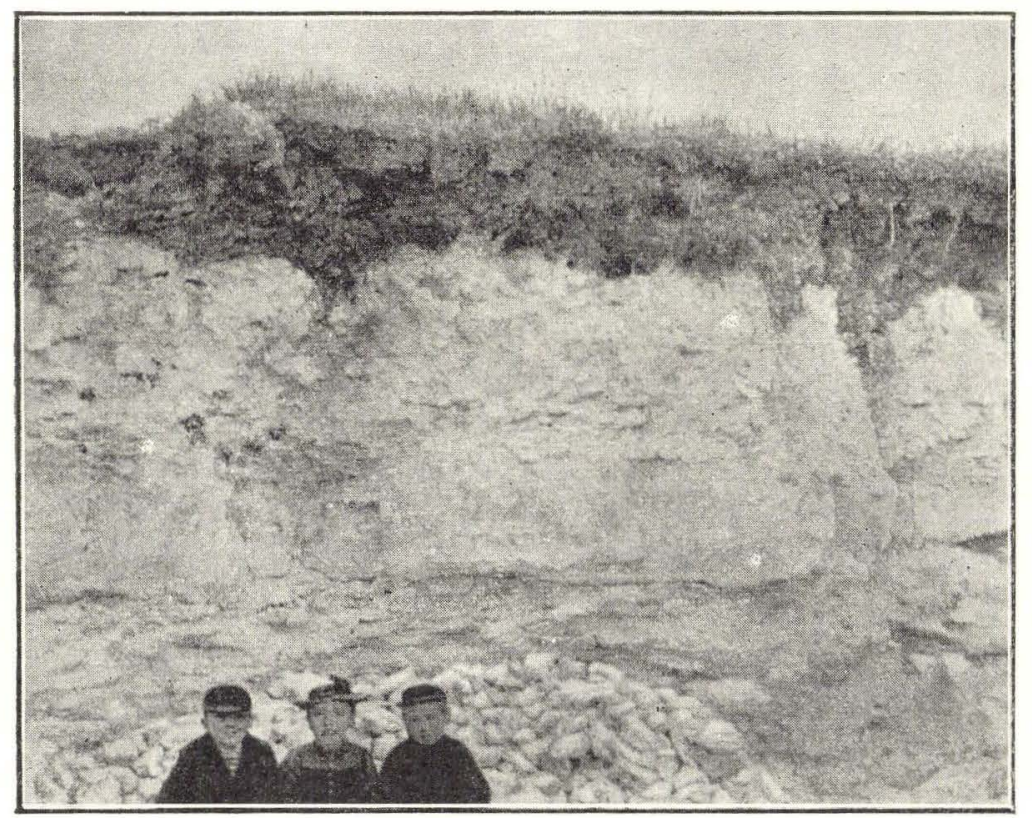

Fig. 8. Profile from the limestone quarry near the former poorhouse at Thorslunde.

\section{Literature.}

1897. K. Rørdam, Kridtformationen i Sjælland. Résumé en français: Le système crétacique en Séeland. D.G.U. II. Series. No. 6, pp. 31-33, 63. 1909. K. BrÜNNICH-NIELSEN, Brachiopoderne i Danmarks Kridtaflejringer. Vidensk. Selsk. Skr., 7. Række, naturv. og math. Afd. VI. 4, p. 14 (140). 1935. V. Milthers, Nordøstsjællands Geologi. D.G.U. V. Series No. 3 (2. edit.), p. 14.

Lithology (Fig. 8).

Section about $3 \mathrm{~m}$. high consisting of $\frac{1}{2}-1 \mathrm{~m}$. mouldy clay underlain by Bryozoan Limestone and flint. The limestone is yellowish-white, mainly composed of Bryozoan fragments. In places, however, the content of ooze is predominant. The abundance of flint is the characteristic element of the series of layers in this locality. The flint occurs not only in compact layers $25-40 \mathrm{~cm}$. in thickness, but is also interspersed in the interjacent limestone beds, about $50 \mathrm{~cm}$. thick.

\section{Stratigraphy.}

According to RAVN (1928, p. 9) the Bryozoan Limestone must be referred to the Tylocidaris brünnichi zone (ØDUM's Zone C).

Material. Museum material marked "Bryozokalk, Thorslunde". 


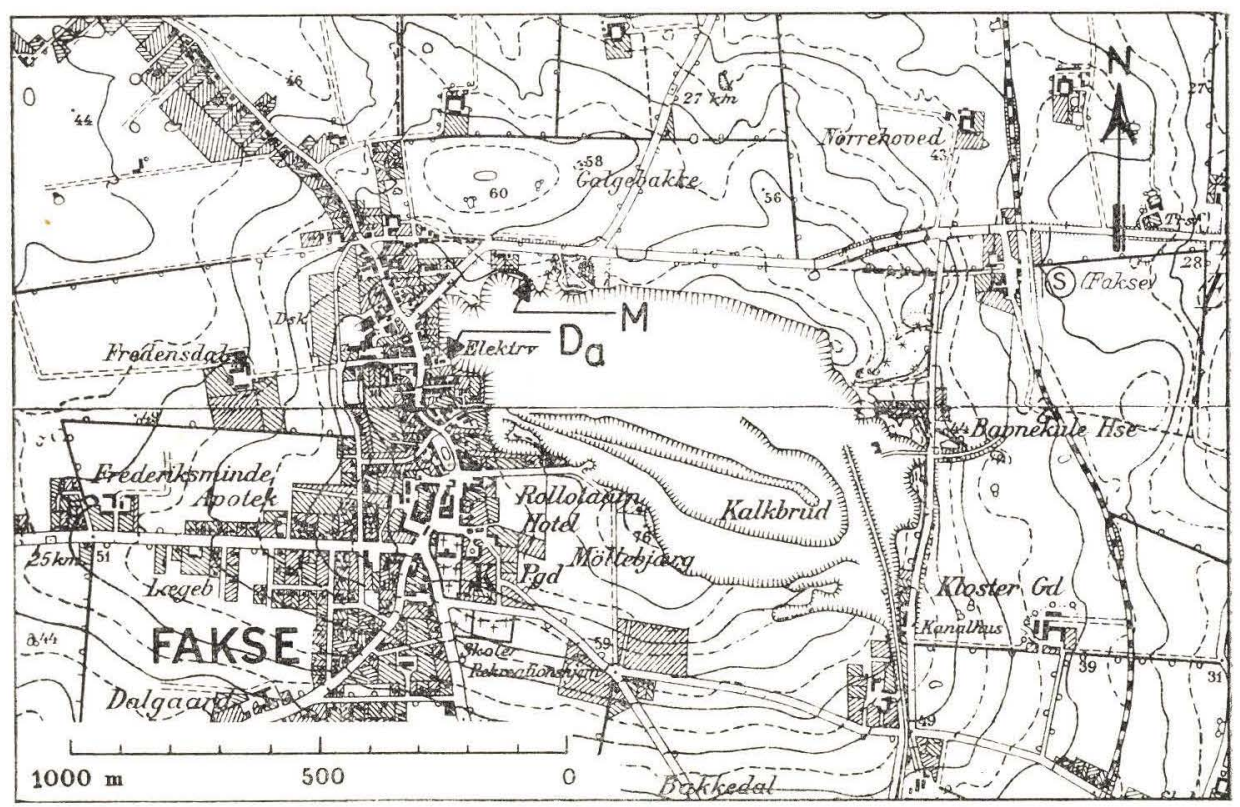

Fig. 9. Section of map sheets Nos. 3727 and 3827 (1:20,000) showing the situation and extent of the limestone quarry of Faxe. Da and $\mathbf{M}$ indicate the places where the stratigraphical material from Hvedeland and the north wall of the quarry, respectively, were taken.

Authorized by the Geodetic Institute of Denmark

Faxe.

Situation.

Limestone quarry immediately east of the town of Faxe, about $65 \mathrm{~km}$. southsouth-east of Copenhagen. The largest limestone quarry in Denmark, measuring about $1 \mathrm{~km}$. in length and nearly $50 \mathrm{~m}$. in depth (Figs. 1, 9, and 10).

\section{Literature.}

1908. V. Milthers, Kortbladene Faxe og Stevns Klint. D.G.U. I. Series. No. 11. pp. 43-56. Rés.: pp. 280-281.

1911. K. Brünnich Nielsen, Brachiopoderne i Faxe. Medd. D.G.F. Vol. 3, pp. 599-618.

1937. A. Rosenkrantz, Bemærkninger om det østsjællandske Daniens Stratigrafi og Tektonik. Medd. D.G.F. Vol. 9, pp. 199-212.

\section{Lithology.}

Fig. 11 shows a section through Faxe Hill (from a survey in 1933 by RosenKRANTZ (1937, p. 200)). It is seen that the hill in which the quarry is situated, is composed of irregularly alternating Coral-reef Limestone and Bryozoan Limestone. 


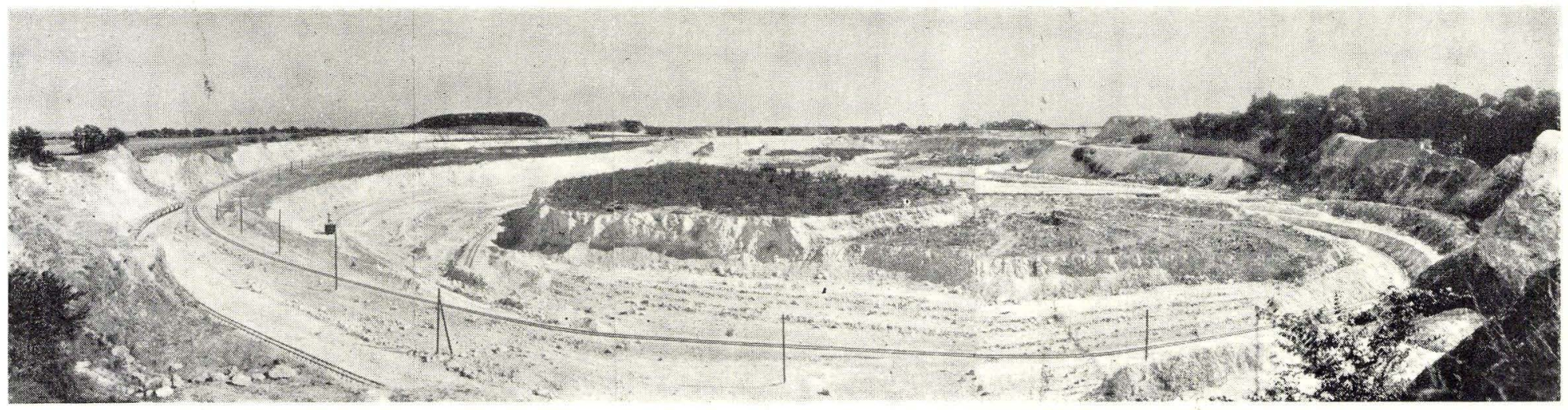

Fig. 10. The limestone quarry of Faxe as seen from the northwest.

(Phot. Chr. Westergatird) 


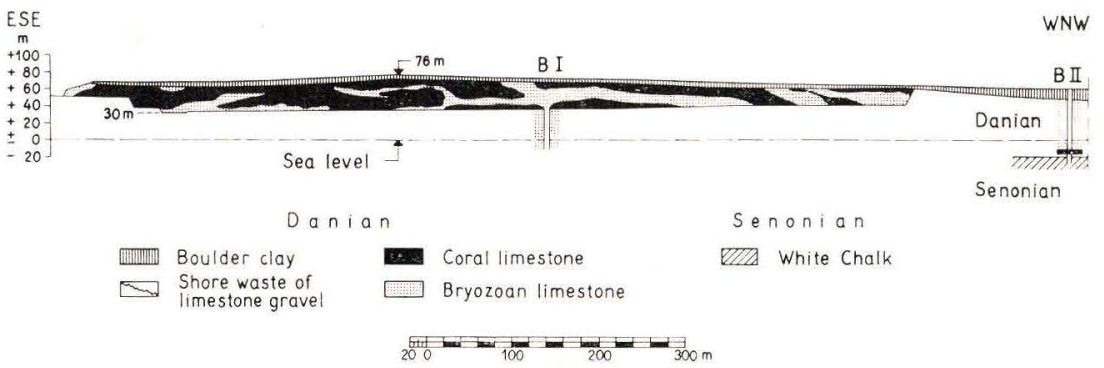

Fig. 11. Schematic section through the hill of Faxe (from Rosenkrantz, 1937).

The main element of the Coral-reef Limestone is branches of Hexa- and Octocorals, usually embedded in hardened calcareous silt. There are a number of types of limestone dependent on the degree of induration and contents of silt. The limestone is yellowish-grey, devoid of flints, and otherwise characterized by its great wealth of fossils.

The Bryozoan Limestone is yellowish-white and contains flints. This rock, too, presents different varieties, from crumbly, decomposing lime to hard, compact limestone. On the whole the contents of Bryozoan fragments are high.

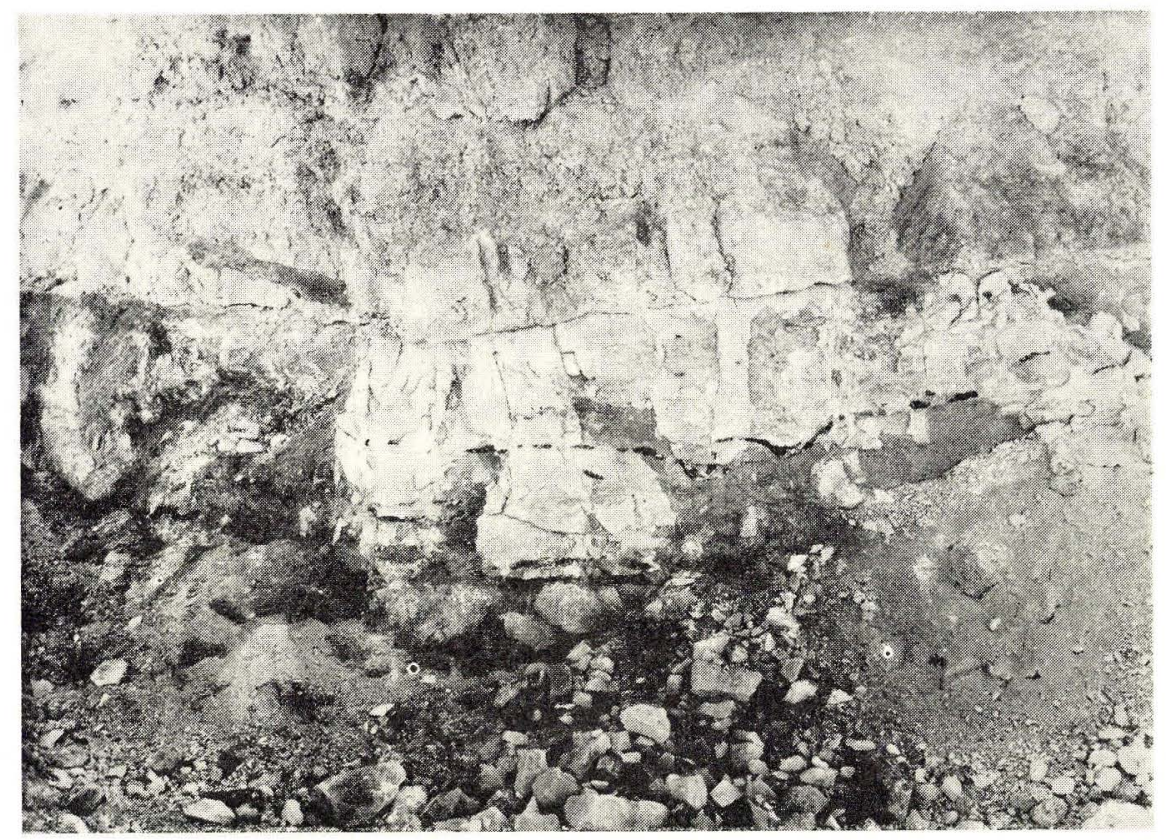

Fig. 12. Profile from the limestone quarry of Faxe showing Bryozoan Limestone with thin beds of flint covered by Coral-reef Limestone (without flint).

(Phot. Chr. Westergaard). 
The flint forms curved bands, but the contents of flint are not high. Fig. 12 shows a characteristic section in the quarry, with Bryozoan Limestone and flint superposed by Coral-reef Limestone.

A well at Faxe Brewery (B II in Fig. 11) encountered the following section (Rosenkrantz, 1937, p. 199. D.G.U. Well File, No. 217. 26):

0-13 m. Boulder clay.

13-66 m. Bryozoan Limestone with 18 flint beds.

66-67.5 m. Moltkia-limestone.

67.5-71 m. Coral-reef Limestone, massive.

71-79.35 m. Moltkia-limestone with 3 flint beds.

79.35-79.5 m. Cerithium-limestone with Fish-clay.

79.5-83 m. White Chalk.

The Moltkia-limestone is a peculiar rock, more than half of which consists of fragments of an Octocoral, Moltkia isis STEenstrup.

\section{Stratigraphy.}

The layers of Coral-reef Limestone and Bryozoan Limestone in the quarry all belong to the Upper Danian, the Tylocidaris brünnichi zone, whereas the Coralreef Limestone in the well mentioned above may be referred to the Tylocidaris abildgaardi zone.

\section{Material.}

The investigations comprised (1) material from the collections of the Mineralogical Museum of Copenhagen, marked "Faxe", (2) Bryozoa sorted out by BRÜNNICH NIELSEN from samples taken by him in the quarry in 1909 for use in an examination of the stratigraphical conditions on the basis of the occurrence of the Brachiopods (BRÜNNICH Nielsen, 1911, pp. 599-618). He took samples of Bryozoan Limestone in 13 places in the quarry, these places being marked I-XIII in Fig. 13. Of this material the Bryozoa from I, II, and XI have been subjected to a close examination by the present writer. As it proved impossible to demonstrate any faunistic difference between the samples from the three places mentioned, the Bryozoa from there have, for clearness' sake, been combined with the other Faxe material in the lists of fauna on pp. 221223 , while the distinction has been maintained in the material lists within the descriptions of species.

The stratigraphical material comprises (3) a sample taken at the west end of the quarry (Hvedeland), about $2 \mathrm{~m}$. above the floor of the quarry (at Da in Fig. 9). Furthermore (4), four samples from the north wall of the quarry (at $M$ in Fig. 9, height above sea level about $+60 \mathrm{~m}$.) taken at depths of $4 \mathrm{~m}$., $7 \mathrm{~m}$., $17 \mathrm{~m}$., and $20 \mathrm{~m}$., respectively. 


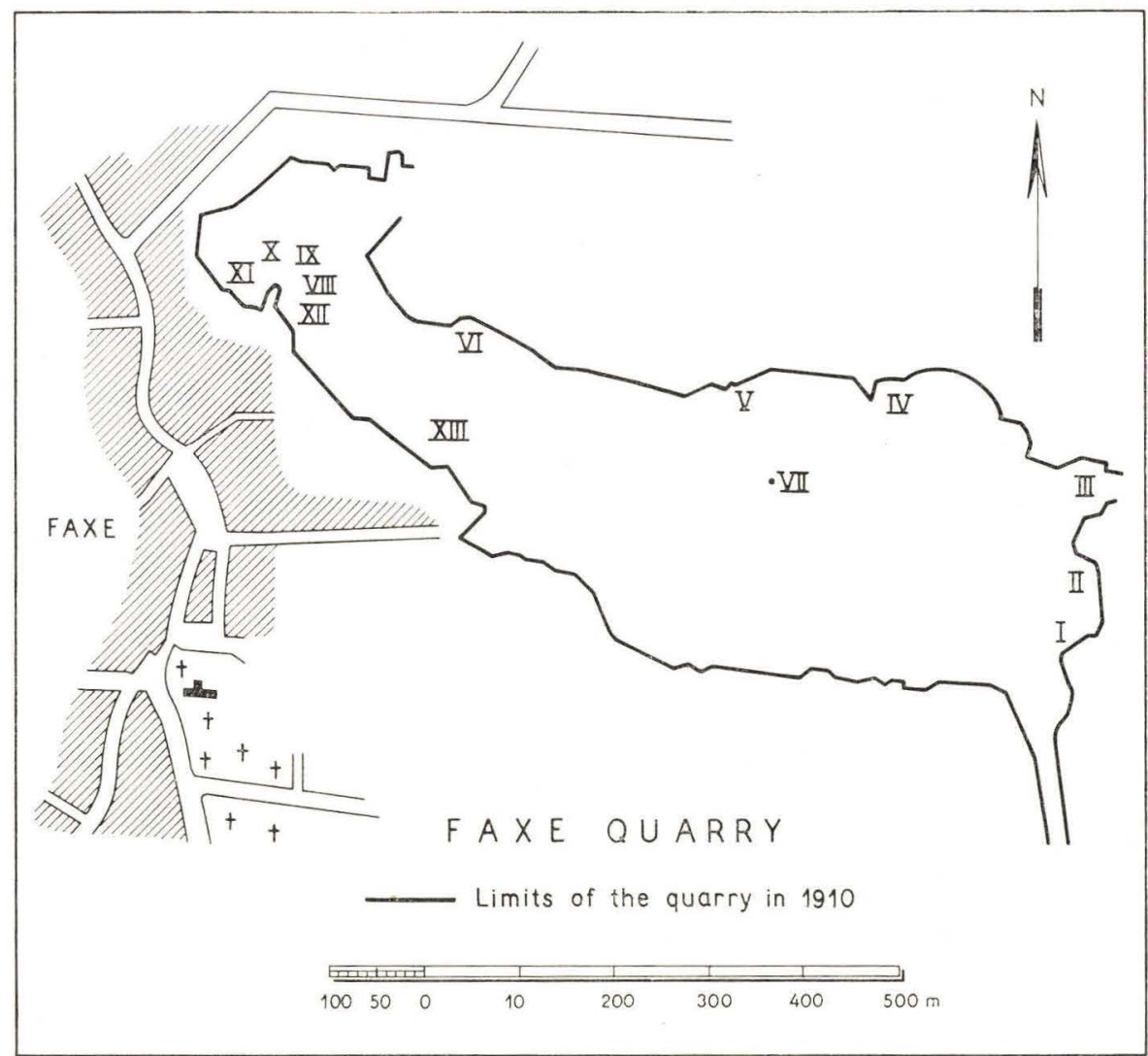

Fig. 13. Sketch map of the limestone quarry of Faxe in 1910 with indication of the places where BRünNiCH NiElsen's Faxe material was sampled.

\section{Situation.}

\section{Copenhagen.}

Bryozoa from four localities have been examined. On the map section Fig. 14 these have been marked as "Sydhavnen" (the South Harbour), "Sundkrogen", "Svanemøllen", and "Hyttehusvej".

\section{Literature.}

1920. A. Rosenkrantz, Craniakalk fra Kjøbenhavns Sydhavn. Résumé: Calcaire à Crania du port sud de Copenhague. D.G.U. II. Series. No. 36, pp. $1-79$.

1920. A. Rosenkrantz, En ny københavnsk Lokalitet for forsteningsførende Paleocæn. Medd. D.G.F. Vol. 5. No. 20, pp. 1-10.

1922. P. HARdER, Om Grænsen mellem Saltholmskalk og Lellinge Grønsand og nogle Bemærkninger om Inddelingen af Danmarks ældre Tertiær. Résumé: Sur la limite entre le Calcaire de Saltholm et le Sable vert de Lellinge 


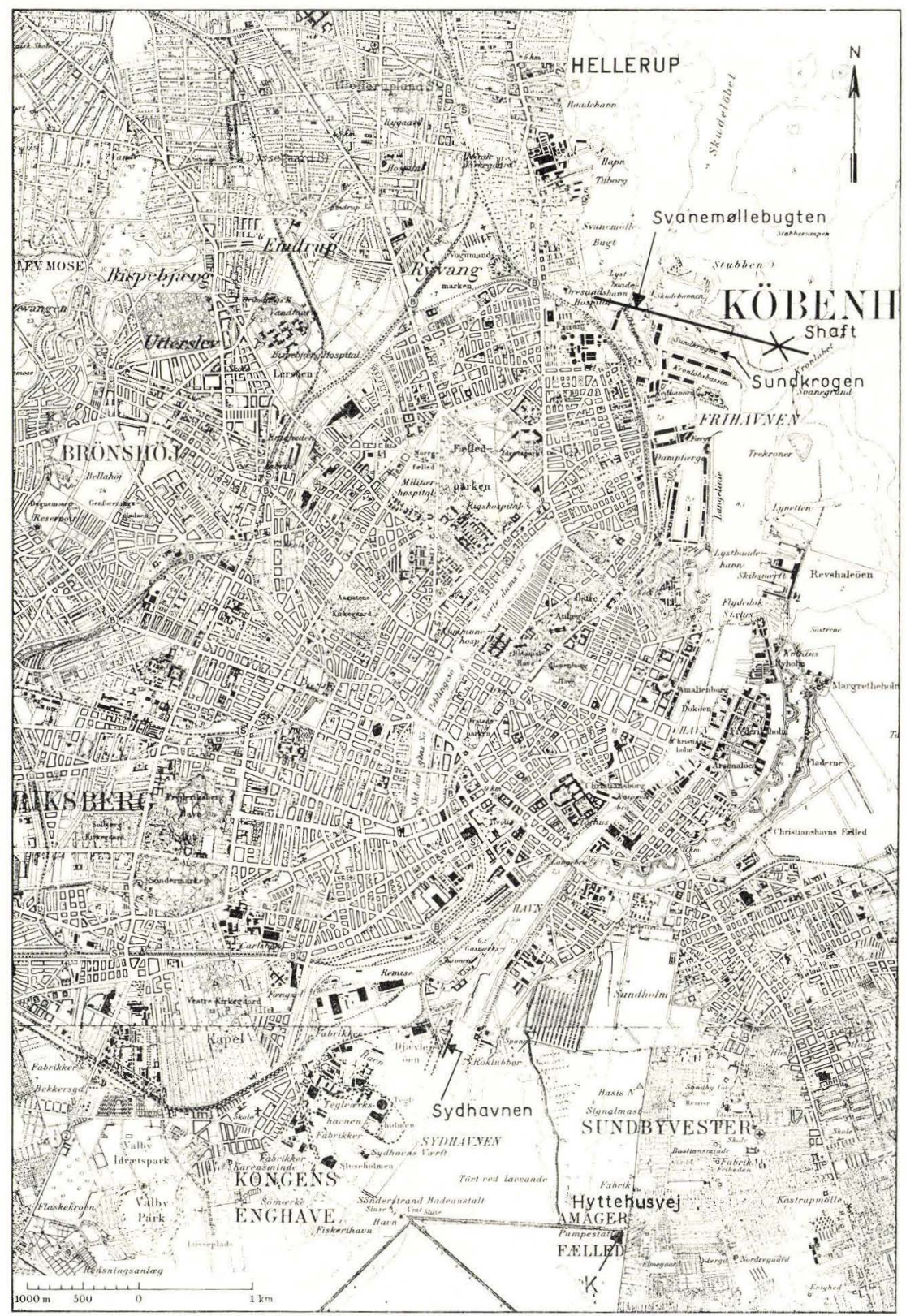

Fig. 14. Section of map sheets Nos. 3030 and $3230(1: 40,000)$ showing the sites of the localities Svanemøllen, Sundkrogen, and Sydhavnen (the South Harbour). K indicates the place where the stratigraphical sample was taken (marked Hyttehusvej). 

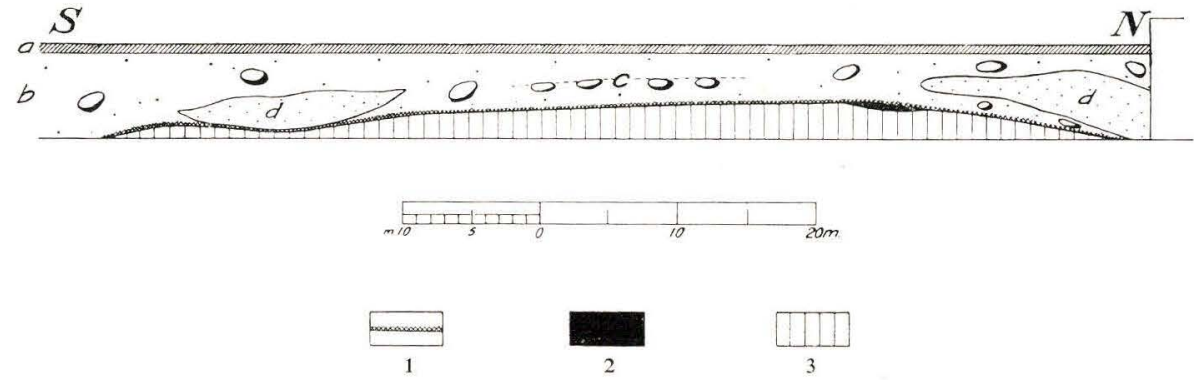

Fig. 15. Profile I from the South Harbour of Copenhagen (from Rosenkrantz, 1920). 1. Limestone breccia. 2. Paleocene bottom conglomerate. 3. Sandy-limestone.

a. Saltwater alluvium. b. Boulder clay. c. Boulder horizon. d. Displaced floes of fluvioglacial sands.

avec quelques remarques sur la division đu Tertiaire inférieur. du Danemark. D.G.U. II. Series. No. 38, pp. 1-108.

1924. A. Rosenkrantz, De københavnske Grønsandslag og deres Placering i den danske Lagrække. Medd. D.G.F. Vol. 6. No. 23, pp. 1-39.

1925. A. Rosenkrantz, Undergrundens tektoniske Forhold i København og nærmeste Omegn. Medd. D.G.F. Vol. 6. No. 26, pp. 1-17.

1937. A. Rosenkrantz, Bemærkninger om det østsjællandske Daniens Stratigrafi og Tektonik. Medd. D.G.F. Vol. 9, pp. 199-212.

1941. A. Rosenkrantz, Ekskursion til Tunnelanlægget Svanemøllen-Middelgrund. Medd. D.G.F. Vol. 10, pp. 64-65.

1955. A. Rosenkrantz, Københavns klippegrund og trafikproblemer. Salmonsen Leksikon-Tidsskrift, 1955, p. 653-662.

1959. Th. SorgenfreI, Dybgrundens geologi. I.J.P. Trap: Danmark. Vol. I, 2. Storkøbenhavn I, pp. 354-359.

\section{Lithology.}

1. Sydhavnen (the South Harbour). The material originates from two excavations made in 1917-19 in the southern part of the harbour of Copenhagen. Rosenkrantz (1920) surveyed the sections shown in Figs. 15 and 16. The Sandylimestone is characterized by ROSENKRANTZ as a greyish, fine-grained, somewhat crystalline limestone with dark or light grey flint. At one place in Section I the limestone was superposed by Paleocene Greensand-limestone. In Excavation II an about $10 \mathrm{~cm}$. thick Greensand-conglomerate superposed by Greensand-limestone could be observed in the southernmost part of the section above the limestone. Farther north in the section the Greensand-limestone was found to be resting directly on the Sandy-limestone.

2. Sundkrogen. In 1920-21 excavations and test wells were made at Sundkrogen as preliminaries to an extension of the Free Port. HARder (1922, p. 22) summarized his observations in a schematic section shown in Fig. 17. According 

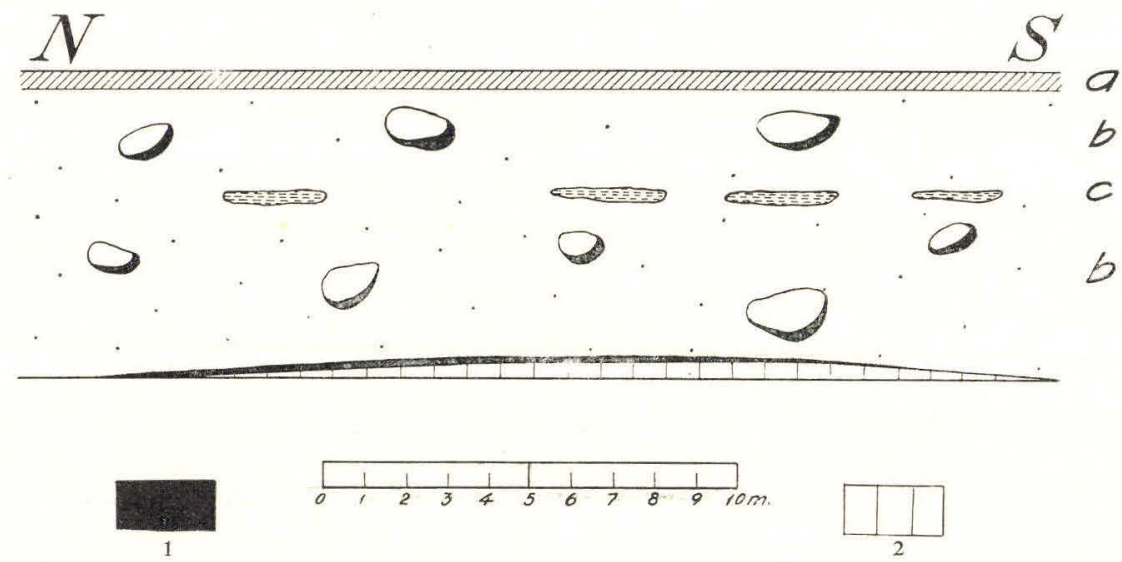

Fig. 16. Profile II from the South Harbour of Copenhagen (from Rosenkrantz, 1920).

1. Paleocene bottom conglomerate. 2. Sandy-limestone.

a. Saltwater alluvium. b. Boulder clay. c. Row of limestone flakes.

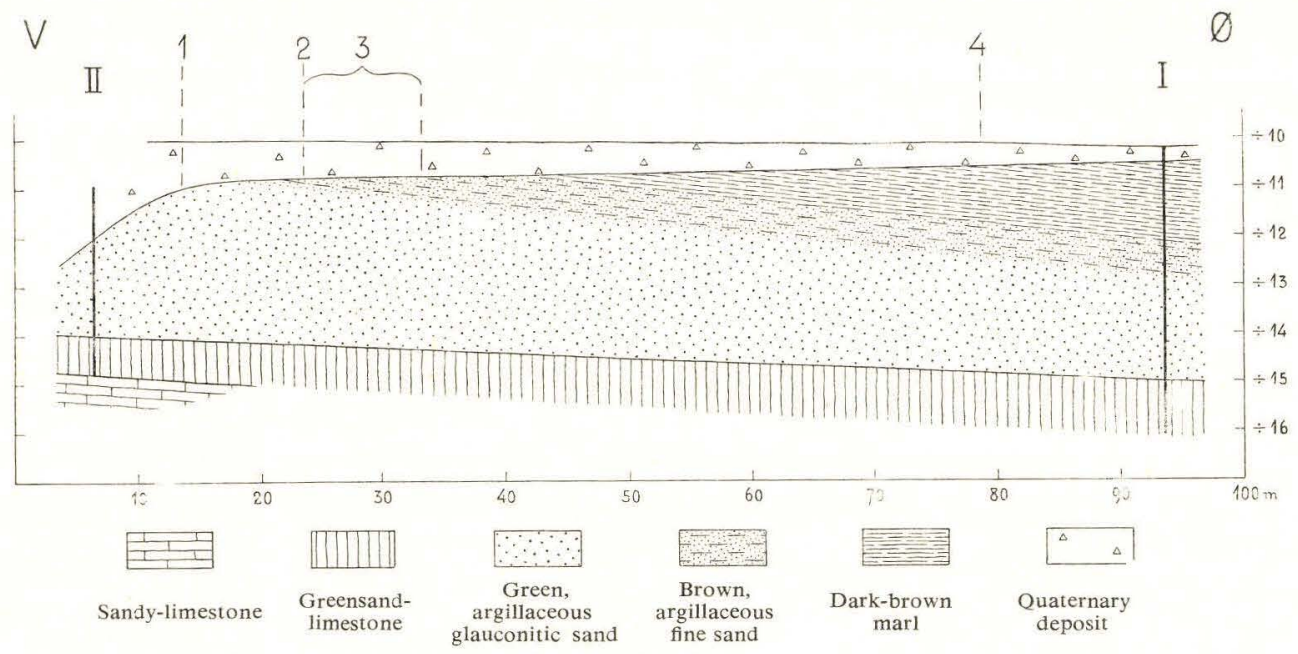

Fig. 17. Schematic profile from Sundkrogen (from HARDER, 1922).

Scale for lengths: $1: 800$, for heights: $1: 200$.

to Rosenkrantz $(1924$, p. 8) the limestone under the Paleocene series is Sandylimestone, but there is no further information about this rock. However, this is of no practical importance in the present instance as the Bryozoan material examined originates from the Greensand layer overlying the Greensandlimestone.

3. Svanemøllen. For the purpose of draining off sewage a tunnel was cut in the limestone deposits between Svanemøllen and Middelgrunden. RosENKRANTZ (1941, p. 65) described the limestone as being typical Sandy-limestone with hard and soft beds alternating. Some wells revealed Paleocene Greensand-conglomerate and Greensand-limestone overlying the limestone. 
4. Hyttehusvej. During excavations for the purpose of building a pumping station at Hyttehusvej the following section was surveyed:

$$
\begin{array}{ll}
+1.9--3.5 \mathrm{~m} . & \text { Boulder clay. } \\
-3.5--5.0 \mathrm{~m} . & \text { Large boulders. } \\
-5.0-10.0 \mathrm{~m} . & \text { Sandy-limestone. }
\end{array}
$$

Stratigraphy.

In geological literature the Sandy-limestone in the Copenhagen area is referred to Zone D, the Tylocidaris vexillifera zone.

\section{Material.}

The South Harbour: Bryozoan material collected by Rosenkrantz (1920, pp. 51-52) and determined by S. J. PindBorG (marked "N. Craniakalk" (=Sandy-limestone)).-Sundkrogen: Bryozoan fragments from the argillaceous greensand bed, collected by HARDER (the collection of D.G.U.). - Svanemøllen: Material marked "Svanemølleskakten, paleocæn Bundkonglomerat. -11.65-11.75 m.", kindly lent me by Professor A. Rosenkrantz.

Stratigraphical material: Sample of Sandy-limestone from a depth of $7 \mathrm{~m}$. from the excavation at Hyttehusvej. The locality is marked "K" in Fig. 14.

\section{Situation.}

\section{Saltholm.}

An island in the Sound, about $12 \mathrm{~km}$. east-south-east of Copenhagen (Fig. 1). At intervals since 1231 limestone has been quarried in the island from small pits, the largest being situated on the north coast (Fig. 18). Because of too high a water level in the pit the quarrying ceased there long ago.

\section{Literature.}

1897. K. Rørdam, Kridtformationen i Sjælland i Terrænet mellem København og Køge, og paa Saltholm. Résumé: Le système crétacique en Séeland, dans le terrain situé entre Copenhague et Køge, et dans l'île de Saltholm. D.G.U. II. Series. No. 6, pp. 38-44.

1909. K. BRÜnnich Nielsen, Brachiopoderne i Danmarks Kridtaflejringer. Vidensk. Selsk. Skr., 7. Række, naturv. og math. Afd. VI. 4, p. 14 (140). 1920. A. Rosenkrantz, Craniakalk fra Kjøbenhavns Sydhavn. Résumé: Calcaire à Crania du port sud de Copenhague. D.G.U. II. Series. No. 36, p. 58. 1925. A. Rosenkrantz, Undergrundens tektoniske Forhold i København og nærmeste Omegn. Medd. D.G.F. Vol. 6. No. 26, p. 14.

1926. K. Brünnich Nielsen, Kalken paa Saltholm. Summary: The Limestone 


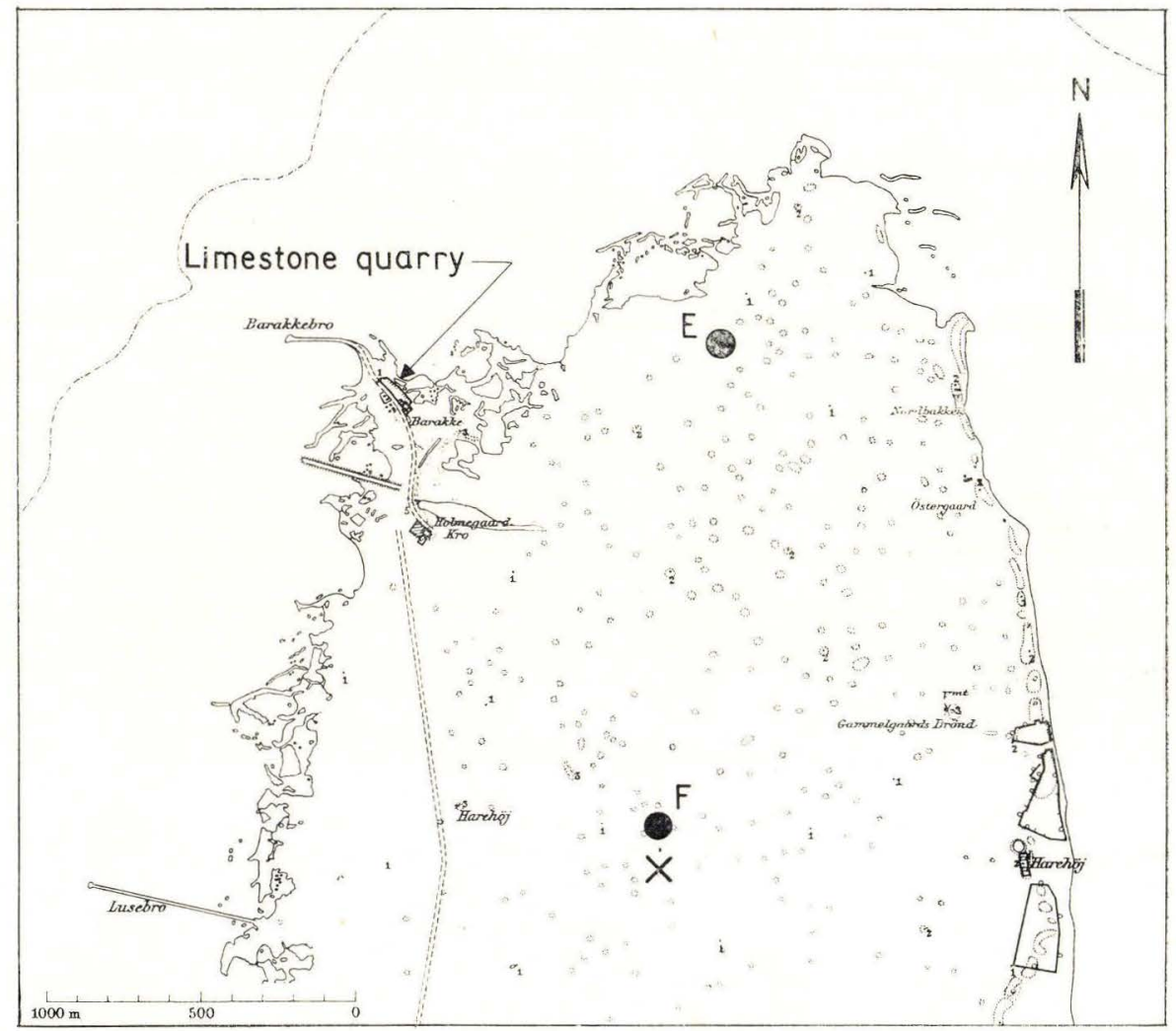

Fig. 18. Section of map sheet No. $3232(1: 20,000)$ showing the northern part of Saltholm. E and F indicate the wells 201.396 and 201.402 (nos. of D.G.U. Well File), from where the stratigraphical material originates. $X$ shows the site of the General Madsen entrenchment, where some of the museum material was sampled.

Authorized by the Geodetic Institute of Denmark

of the Isle of Saltholm in the Sound. D.G.U. IV. Series. Vol. 1. No. 20, pp. 1-23.

1935. V. Milthers, Nordøstsjællands Geologi. D.G.U. V. Series. No. 3 (2. edit.), p. 17.

1935. A. Rosenkrantz, Ekskursion til Saltholm. Medd. D.G.F. Vol. 8, pp. $547-548$.

\section{Lithology.}

The northern pit was temporarily drained in 1935, when it was possible to observe a section $6 \mathrm{~m}$. in height, composed of the following deposits: Lowest there were about $2 \mathrm{~m}$. Bryozoan Limestone, mainly consisting of Bryozoan fragments; next above it a conglomerate with glauconite-coated, head-sized pebbles in a dark, argillaceous groundmass (Fig. 19). Overlying the conglomerate or in places where this had not developed, i.e. between the Bryozoan 


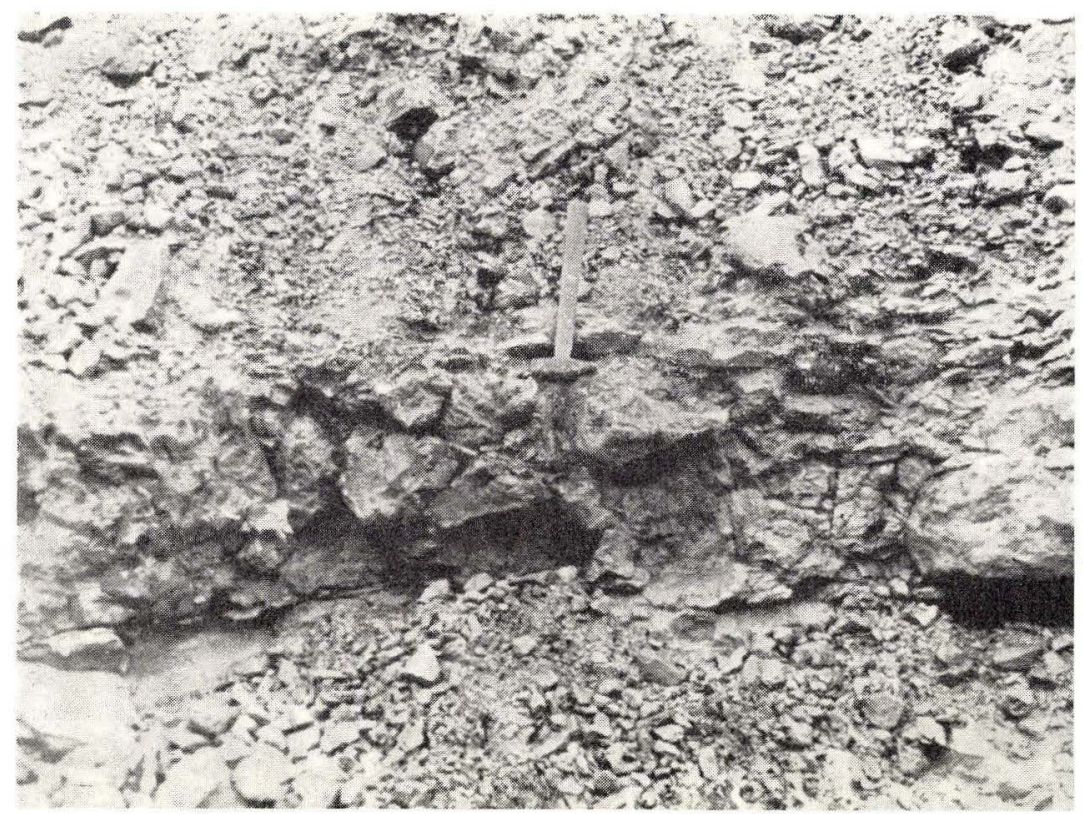

Fig. 19. The Conglomerate on Saltholm between Bryozoan Limestone and Sandy-limestone. The hammer-head shows the upper margin of the Conglomerate. (Phot. A. Rosenkrantz).

Limestone and limesand, it was possible to see a band of clay, $2 \mathrm{~cm}$. thick, superposed by limesand the lower part of which was argillaceous. A few beds in the limesand were transformed into hard, dense limestone, and the whole series was interspersed with more or less continuous bands of dark flint.

The layers in the pit dip westwards, with the result that farther east the Bryozoan Limestone lies so high as to be observable in the excavations leading down to the pit.

\section{Stratigraphy.}

Apart from Nautils (RosENKRANTZ, 1944, p. 445) no fossils are mentioned in the geological literature in the Bryozoan Limestone from Saltholm. The limestone is referred to the Tylocidaris brünnichi zone (Zone C of ØDUm). On account of its faunistic fellowship with i.a. the Calcarenite at Herfølge the limesand series is placed to the $T$. vexillifera zone.

The present author's view of the stratigraphical position of the Saltholm deposits is advanced in the chapter on stratigraphy, p. 257.

\section{Material.}

The collections of the Mineralogical Museum of Copenhagen include Bryozoan material marked (1) "Saltholm" (or "Saltholmen") and (2) "Bryozokalk, Saltholm". The former material probably originates from the heaps of limestone 
dug out at the quarry and at the pier. In ROSENKRANTZ's opinion (1935, p. 548) this limestone mainly originates from the layers around the boundary between Bryozoan Limestone and limesand. The species of Bryozoa contained in BRÜNNICH NiELSEN's list of fossils (1926, p. 17) must also be referred to this boundary zone. In the lists of material within the respective descriptions of species this material is marked "Saltholm" without any specification of rocks.

The Bryozoa from the Bryozoan Limestone may have been taken from the limestone in situ east of the quarry, but may also originate from fragments of Bryozoan Limestone in the heaps of debris. The Bryozoan material from this category is marked "Bryozoan Limestone, Saltholm" in the descriptions of species.

In the Mineralogical Museum there is also a small collection of Bryozoa, marked "General Madsens Skanse". It originates from a small Sandy-limestone quarry farther south (marked " $X$ " in Fig. 18). Bryozoa from this occurrence appear in the lists of material under the term "Sandy-limestone, Saltholm".

The stratigraphical material was taken from the test series from two wells on northern Saltholm. At well No. 1 (D.G.U. Well File, No. 201. 396 - in Fig. 18 marked "E") the following order of strata was found:

Elevation: $+1 \mathrm{~m}$.

$0-0.3 \mathrm{~m}$. Peat.

0.3-5.1 m. Alternating layers of hard and soft Bryozoan Limestone.

From this well a sample from a depth of $5 \mathrm{~m}$. has been examined.

Well No. 2 (D.G.U. Well File, No. 201. 402 - in Fig. 18 marked "F") was drilled through the following order of strata:

Elevation: $+1 \mathrm{~m}$.

$0-0.2 \mathrm{~m}$. Sandy mould.

0.2-ab. $4 \mathrm{~m}$. Sandy-limestone.

ab. 4-20.2 m. Bryozoan Limestone.

From this series a sample of Bryozoan Limestone from a depth of $6 \mathrm{~m}$. (Sample Fc) and two samples of Sandy-limestone ( $\mathrm{Fa}$ and $\mathrm{Fb}$ ) from depths of 2 and $3 \mathrm{~m}$., respectively, have been analyzed.

Situation.

\section{Herfølge.}

An old limestone quarry just north of the church at Herfølge ("Herføgle" in earlier literature), about $5 \mathrm{~km}$. south-east of Køge and about $43 \mathrm{~km}$. southeast of Copenhagen (Fig. 20). The quarry is now incorporated in the cemetery arrangement. 


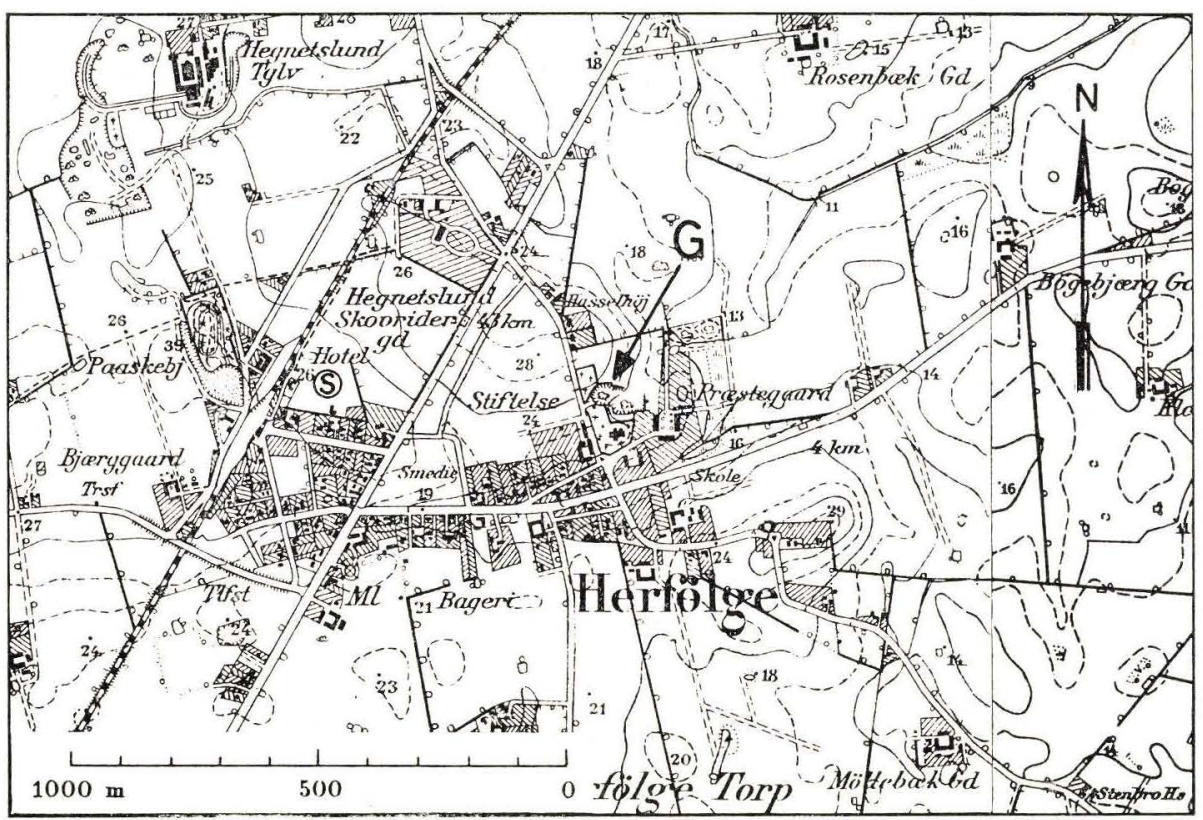

Fig. 20. Section of map sheets Nos. 3527 and 3528 (1:20,000). G indicates the place where the stratigraphical samples were taken.

Authorized by the Geodetic Institute of Denmark

\section{Literature.}

1908. V. Milthers, Kortbladene Faxe og Stevns Klint. Résumé en français. D.G.U. I. Series. No. 11, pp. 39-41, 56-60, 280-282.

1909. K. Brünnich Nielsen, Brachiopoderne i Danmarks Kridtaflejringer.

Vidensk. Selsk. Skr., 7. Række, naturv. og math. Afd., VI. 4, p. 15 (141). 1920. A. Rosenkrantz, Craniakalk fra Kjøbenhavns Sydhavn. D.G.U. II. Series. No. 36, p. 60.

1931. A. Rosenkrantz, Jordskorpebevægelser i Yngre Danien-Tid inden for

Øresundsomraadet. Medd. D.G.F. Vol. 8, p. 138.

\section{Lithology.}

The quarry was only worked for brief periods in its history, and consequently the lower part of the limestone series in most cases was concealed under fallen debris. In the summer of 1951 members of "Steno", the club of students of geology, excavated a section about $2 \mathrm{~m}$. wide and about $8 \mathrm{~m}$. high in the north wall of the quarry. This section (Fig. 21), has been described as follows:

Elevation: $+22.5 \mathrm{~m}$.

0-1.5 m. Boulder clay, its lower part having the character of local moraine, greatly intermixed with fragments of Calcarenite. 


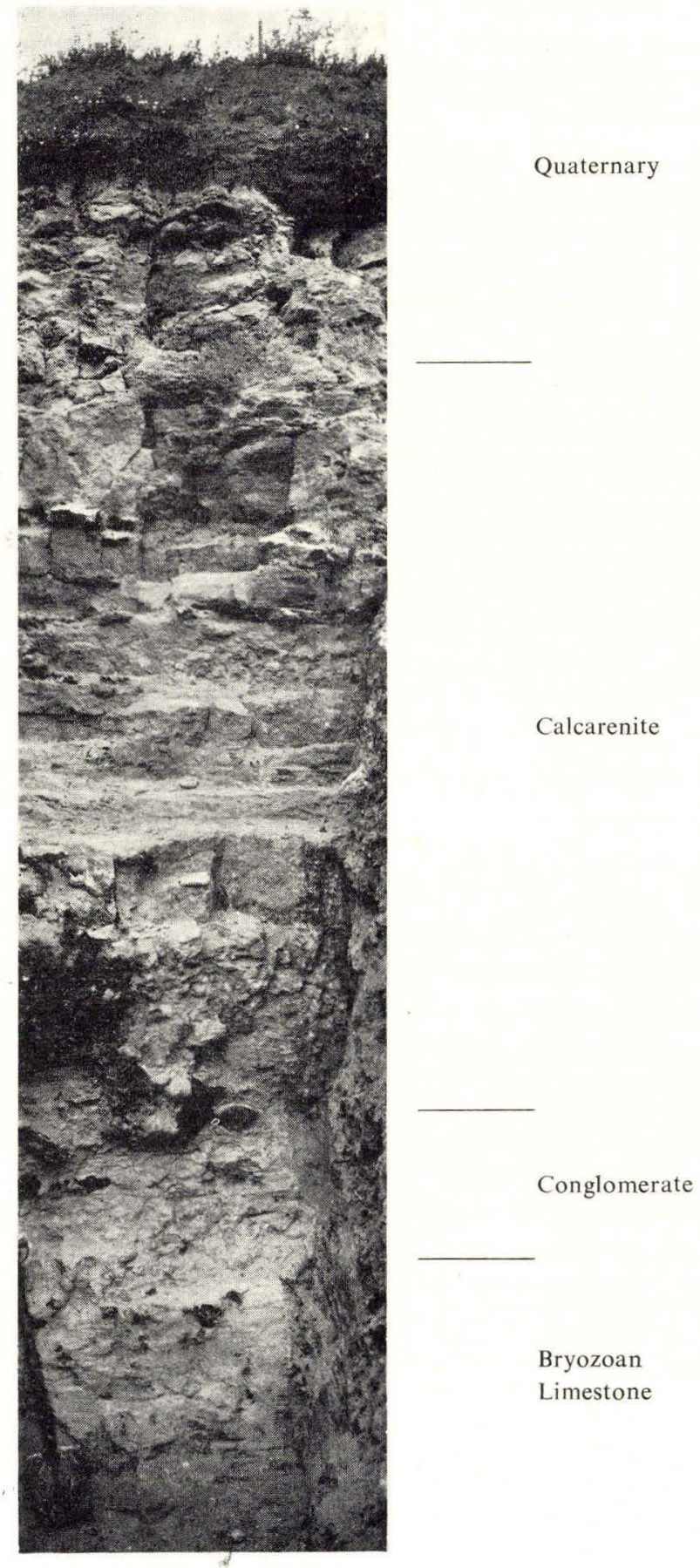

Fig. 21. The limestone quarry at Herfølge. Profile in the north wall of the quarry. (Phot. A. BuCH). 
1.5-5.94 m. Calcarenite, in alternating beds of soft lime and hard limestone, interrupted by bands of flint and flint nodules. The lime grains decrease in size down through the series.

at $5.94 \mathrm{~m}$. Bed of clay, yellowish, about $4 \mathrm{~mm}$. thick.

5.94-6.28 m. Conglomerate of hand-size clods of Bryozoan Limestone in a groundmass of Calcarenite.

6.28-6.73 m. Transitional layer, soft limestone (Bryozoan Limestone?) with sporadic flint nodules.

6.73-7.15 m. Bryozoan Limestone, yellowish, silty.

7.15-7.35 m. Bryozoan Limestone, yellowish, with some fossils.

In earlier geological literature Calcarenite is termed "Crania-limestone". It is discussed in more detail in the lithological section, pp. 225-227. The Conglomerate between Bryozoan limestone and Calcarenite has been dealt with on p. 259.

\section{Stratigraphy.}

As a rule Bryozoan Limestone as well as Calcarenite is referred to the Upper Danian, the Tylocidaris vexillifera zone (Zone D).

\section{Material.}

The museum material is marked "Bryozokalk, Herfølge" and "Craniakalk, Herfølge".

The stratigraphical material includes 6 samples taken during the excavation of the above-mentioned section (Fig. 21) at the depths of $2.15 \mathrm{~m} ., 3.75 \mathrm{~m}$., $4.65 \mathrm{~m}$., $5.80 \mathrm{~m}$., $6.75 \mathrm{~m}$., and $7.15 \mathrm{~m}$.

\section{Situation.}

\section{Klintholm.}

A limestone quarry near the Great Belt, about $15 \mathrm{~km}$. south of Nyborg (Figs. 1 and 22). During the past twenty years limestone has been excavated in about ten pits of varying sizes. Most of the pits have caved in and are water-logged.

\section{Literature.}

1949. Th. Sorgenfrei, Nyere undersøgelser over Fyns undergrund. Medd. D.G.F. Vol. 11, pp. 490-493.

1949. K. Milthers, Ekskursion til Sydfyn og Langeland. Medd. D.G.F. Vol.11, p. 495.

\section{Lithology.}

In 1946 TH. Sorgenfrei surveyed a section in the west wall of the largest of the pits (marked "H" in Fig. 22). The section is shown in the sketch, Fig. 23. 


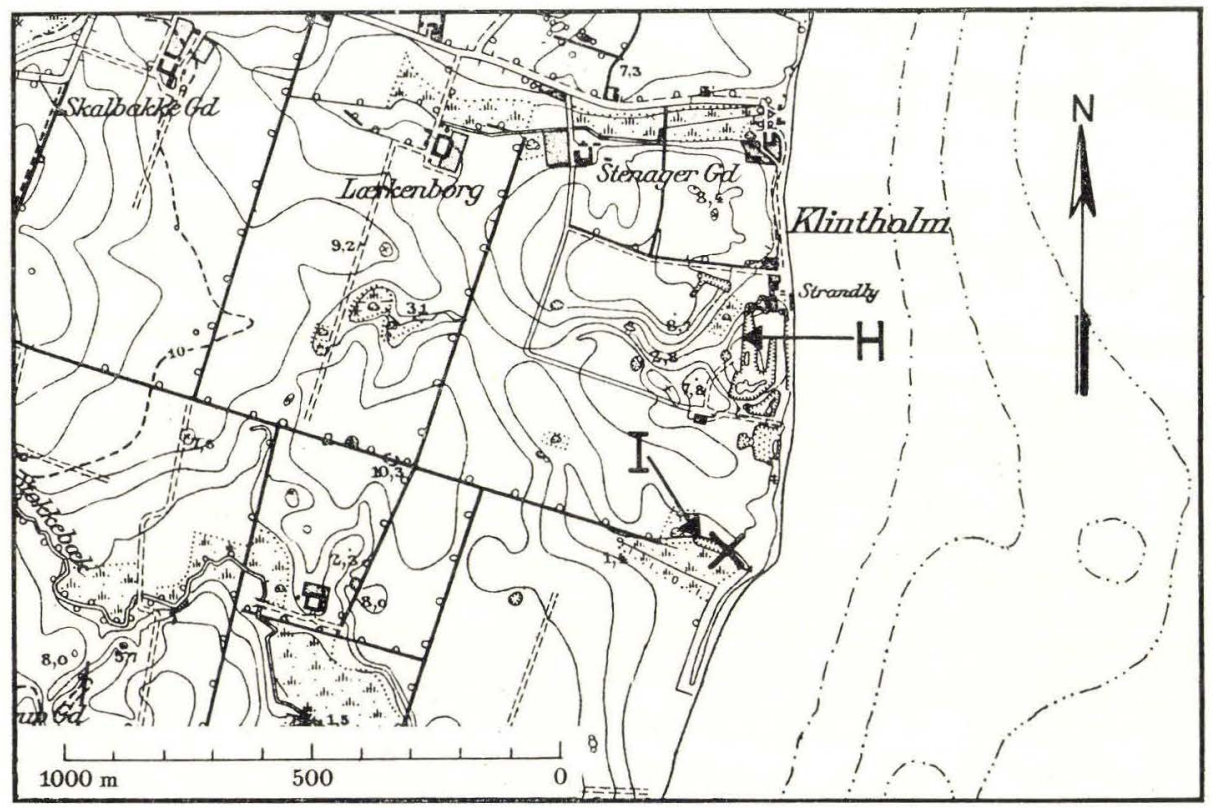

Fig. 22. Section of map sheet No. $3918(1: 20,000)$ showing the site of the limestone quarry at Klintholm. $\mathrm{H}$ indicates partly the place where some of the stratigraphical material was taken, partly the wall in the largest of the pits where the profile fig. 23 was measured. I indicates the place where the remaining part of the stratigraphical material was collected. $\mathrm{X}$ shows the site of the southernmost pit, from where the pictures Figs. 24 and 25 originate.

Anthorized by the Geodetic Institute of Denmark

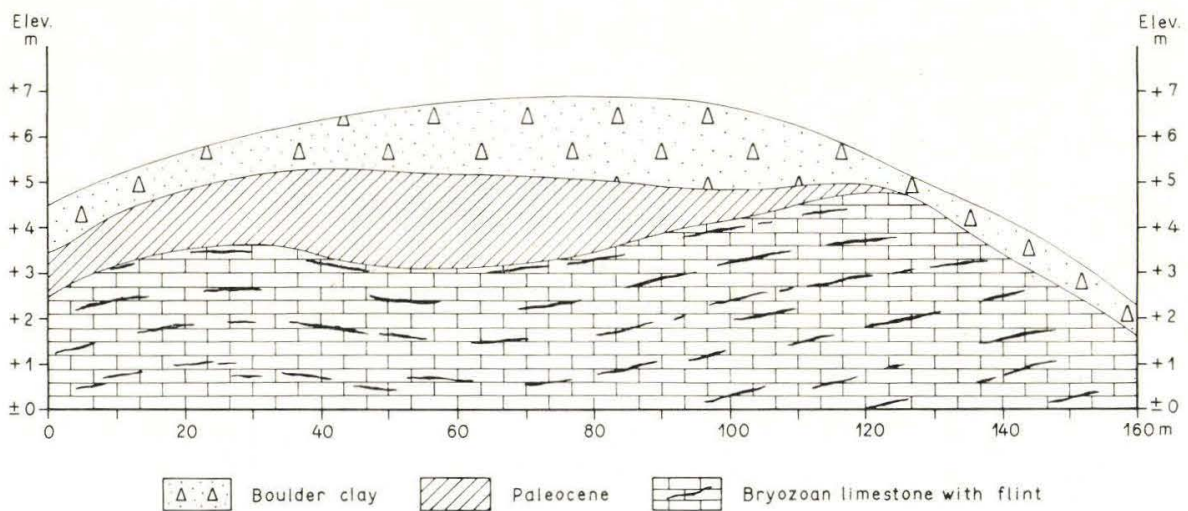

Fig. 23. Profile from the west wall in the largest of the pits at Klintholm, measured by TH. SORGENFREI. 


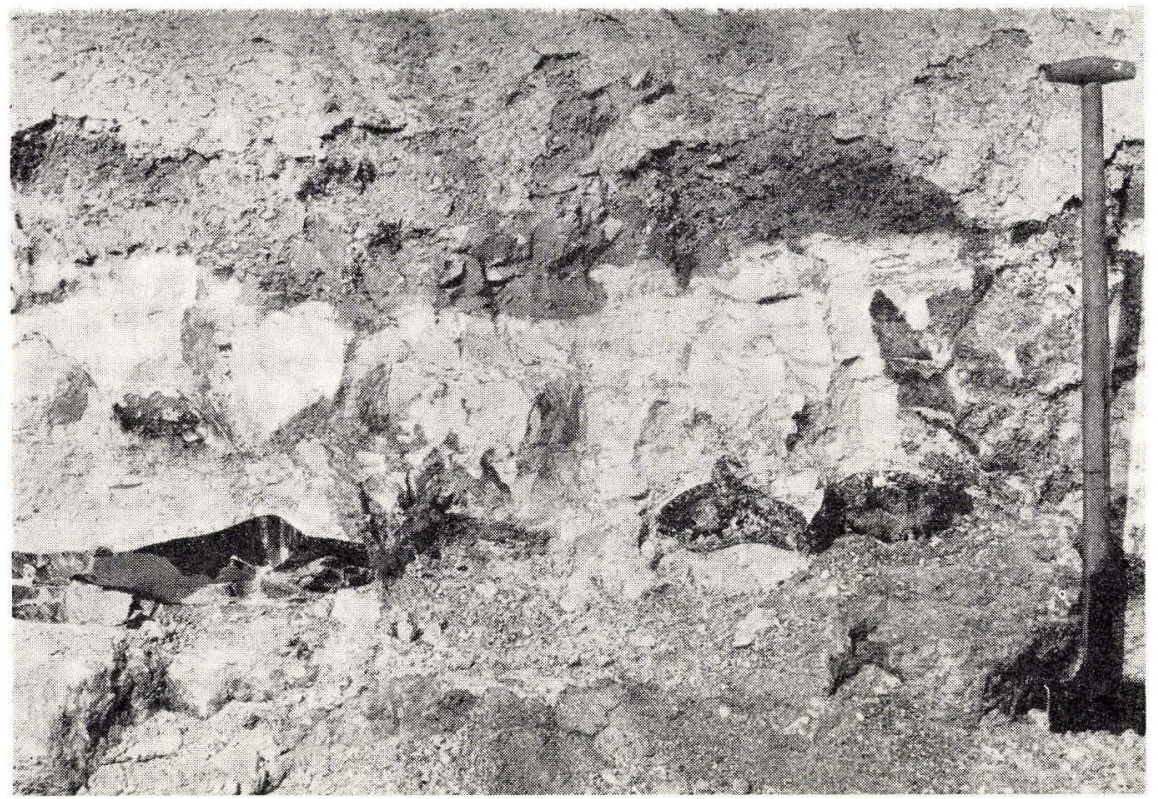

Fig. 24. Klintholm. The border zone between the dark Paleocene marl and the light, flinty Bryozoan Limestone. North wall in the southernmost pit.

(Phot. Chr. Westergaard).

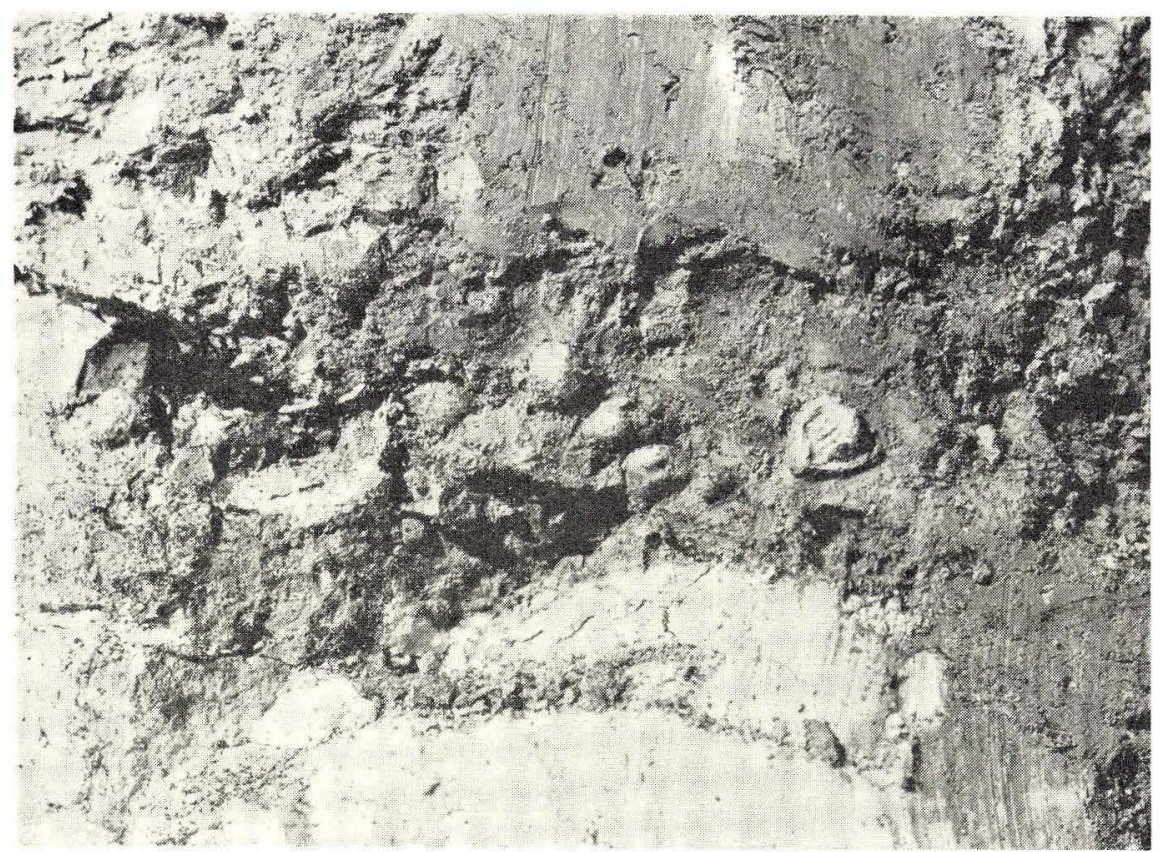

Fig. 25. Close-up of the same subject as that of Fig. 24 showing rolled spines of Tylocidaris vexillifera in the bottom layer of Paleocene marl.

(Phot. Chr. Westergatrd). 
The limestone is yellowish-white, silty, soft Bryozoan Limestone interspersed with layers of flint nodules. The uppermost $30 \mathrm{~cm}$. or so are brecciated and rather highly impregnated with glauconite. The content of glauconite decreases steadily downwards.

Overlying the limestone there is a Paleocene basal conglomerate, 5-10 cm. in thickness, mainly composed of rolled Tylocidaris spines in a dark, argillaceous groundmass. Superimposed upon this there are 3-5 cm. thick stripes of alternating dark and light clay. The light colour is due to a high calcium content originating from decomposed Danian (Bryozoan fragments, Tylocidaris spines, and calcareous silt). This lower Paleocene zone has a thickness of about $30 \mathrm{~cm}$. and passes smoothly into grey Paleocene marl, the maximum thickness of which in the section has been measured at $1.92 \mathrm{~m}$. As appears from Fig. 23, the Paleocene series thins out towards the north. The surface of the limestone rises slightly in the same direction. The Quaternary cover consists of boulder clay, which in places has the character of morainic sand.

In some of the other limestone pits it has been possible to observe a series of layers like the one described above. The bands of flint in the limestone mostly are horizontal, and the uppermost band of flint normally occurs immediately below the conglomerate. In some of the pits (or in parts of them) the Paleocene series is completely absent. In such cases the subglacial erosion has generally been stopped by a bed of flint.

The western half of the southernmost pit ( $\mathrm{X}$ in Fig. 22) lacks the Paleocene. At the eastern end the boundary surface between Danian and Paleocene is highly uneven, large and small irregular depressions in the surface of the limestone being full of dark Paleocene clay (Fig. 24). There is no conglomerate, but some few rolled Tylocidaris spines have been found in the clay in the depressions.

\section{Stratigraphy.}

The Bryozoan Limestone at Klintholm belongs to the Upper Danian, the Tylocidaris vexillifera zone (Zone $\mathrm{D})$.

\section{Material.}

There is no sorted-out museum material. The stratigraphical material includes 3 samples, 2 of which were taken at Pit H (Fig. 22), the upper sample representing the zone rich in glauconite (Elevation $+3.5 \mathrm{~m}$.), the other sample (taken at elevation $+3.1 \mathrm{~m}$.) consisting of yellowish-white Bryozoan Limestone. Sample 3, which was kindly placed at my disposal by Mr. Kr. Skou, originates from the heaps of limestone beside the southernmost pit. The place where the sample was taken is in Fig. 22 marked "I". 


\section{PALEONTOLOGY}

\section{Classification.}

With a few exceptions the systematic division of the material of Bryozoa investigated follows BASSLER's classification as worked out in the Treatise on Invertebrate Paleontology, Part G, Bryozoa (1953). The chief deviation is that BASSLER's division Cribrimorpha is referred to an independent suborder ranking with the Anasca and Ascophora (Cf. Buge, 1957, p. 29).

It has proved impossible to arrange a fairly large number of "Membranipora" forms according to BASSLER's system. VOIGT has already referred to these difficulties as follows (1957, pp. 7-8):

"Nachdem die Gattung Membranipora Blainville, 1830, als Typusgattung der Membraniporidae Busk, 1854, in ganz bestimmtem Sinne festgelegt ist, entstehen bei der Einreihung der sehr zahlreichen "Membranipora"-Arten der Oberkreide erhebliche Schwierigkeiten, da sie sich nicht oder nur schwer in die bestehenden Familien und Gattungen einreihen lassen. Eine Aufteilung des Materials in die in Frage kommenden 4 Familien der Membraniporidae, der Electrinidae, der Hincksinidae und der Calloporidae bleibt schematisch und daher unbefriedigend, da die rezenten Membraniporen, auf denen diese Einteilung beruht, nur den Rest einer ehemals sehr viel formenreicheren Gruppe bilden, von denen die meisten Vertreter bereits am Ende der Kreide erloschen sind.

Eine neue Systematik der kretazischen Membraniporen, die sich nicht an die rezenten Vertreter anlehnt, sondern der explosiven Entfaltung der Anasca in der Oberkreide gerecht wird, erscheint daher unumgänglich notwendig."

For lack of another expedient the species in question have been referred to the genus "Membranipora", the generic name being in inverted commas in order to emphasize the temporary solution.

\section{Remarks on the Descriptions of Species.}

The descriptions are based on Bryozoa in the collections of the Mineralogical Museum of Copenhagen, the good state of preservation of this material making it particularly suitable for the purpose. Three of the species treated (Floridina fragilis n.sp., Semiescharinella pulchra CANU and BASSLER, and Aechmella tenuis n.sp.) were only discovered during examination of material collected by the author. 
In the case of all species a characterization has been prepared which with regard to species previously established is based on published descriptions, supplemented by the author's own observations. This comparatively detailed mention is motivated by the fact that a large number of the species in question have been described in periodicals, etc., which are only obtainable with difficulty. For the same reason all the species treated are figured in the plates.

The measurements accompanying the descriptions of species have been made so that for each species, as far as is possible, out of the various types of cells at least 20 normal cells have been measured on different colonies from all the localities in which the species appears. These measurements are used to indicate the range of the cell types, and the average of these values is given in a separate column. Thus the averages are based on rather slender grounds from a statistical point of view, but their object is only to serve as an aid to comparison, partly of the dimensions of the same species within the various localities, partly of the species mutually. Where only one value is listed in the column for the range, and this figure is repeated as an average, this indicates that no variations have been found. If the column for averages is not filled in, this means that there were less than 20 cells available for calculations of the average.

The following abbreviations have been used:

Lz: length of zooecium
lz: width of zooecium
ho: length of opesium
lo: width of opesium
hr: length of orifice
lr: width of orifice
ha: length of aperture
la: width of aperture

Lz: length of zooecium

1z: width of zooecium

ho: length of opesium

lo: width of opesium

hr: length of orifice

rifice

la: width of aperture
hov: length of ovicell
lov: width of ovicell
Lav: length of avicularium
lav: width of avicularium
Lon: length of onychocellarium
lon: width of onychocellarium
Lv: length of vibraculum
lv: width of vibraculum

In the column headed material only that museum material is indicated which has been included in the investigations. This collection of Bryozoa in the Mineralogical Museum of Copenhagen, is arranged according to species.

The Bryozoa discovered during the supplementary stratigraphical investigations, have not been arranged according to species. The number of fragments of the various species is indicated in the diagrams, pp. 243-250. The material is kept in the collections of the Geological Survey of Denmark, Charlottenlund.

In the case of a few species Professor EHRH. VoIgT, Hamburg, has kindly placed supplementary material at the author's disposal.

The author has used three categories of types in the paleontological section: lectotypes, holotypes, and paratypes. The lectotypes have been selected from the specimens in LEVINSEN's collection of Bryozoa as types of the species set up by LEVINSEN. This material is found in the collections of the Zoological Museum of Copenhagen. 
Holotypes and the supplementary paratypes have been selected among the examined colonies from the collections of the Mineralogical Museum and accordingly are found in the type collection of this museum.

The distribution of the various species is assessed from museum material as well as from material collected by the author.

\section{Terminology.}

The following definitions of the morphological terms used in the systematic descriptions have been mainly compiled from the papers of LEVINSEN (1909), LaGaAiJ (1952), BRown (1952), and Bassler (1953).

Ancestrula. The primary zooecium of a zoarium, formed by the metamorphosis of the larva.

Anter. The superior distal portion of the aperture.

Apertural bar. The first pair of fused costae proximally to the orifice in the Cribrimorpha. Aperture. The outermost opening of the zooecium; among Cheilostomes having a calcified frontal wall and peristomie, the aperture is synonymous with the term peristomice.

Areolar pore. One of a series of openings arranged around the frontal margin of some Ascophora.

Ascopore. A median small opening in the frontal wall of some Cheilostomes (Ascophora) leading to the compensatrix, located proximally with reference to the aperture.

Autozooecium. A normal zooecium containing a polypide.

Avicularium. A specialized Cheilostome zooid with reduced polypide but strong muscles, which operate a mandible-like operculum.

Bifoliate. Consisting of 2 layers of zooecia growing back to back with a double-walled median lamina between them.

Bilamellar. Same as bifoliate.

Cardelle. A denticle for hingement of the operculum.

Communication pore. An opening in the zooecial wall that serves as passageway for soft tissue connecting adjacent polypides in some zoaria.

Compensatrix. A membranous sac into which water is drawn by the muscular action which produces evagination of the living polypide. It is situated below the frontal wall and opens to the exterior at or near the poster by means of a sinus or an ascopore.

Condyle. A rounded protuberance or denticle for hingement of the operculum (syn., cardelle).

Costa. A radially disposed rib or ridge forming part of frontal shield that arches over the frontal membrane in the Cribrimorpha.

Costule. Same as costa, but somewhat smaller and commonly spiniform.

Cryptocyst. A shelflike calcareous lamina beneath frontal membrane extending inward from the proximal mural rim.

Dichotomous. Dividing into two branches.

Dietella. A small enclosed space near the base of distal parts of zooecial wall containing communication pores traversed by mesenchymatous fibres.

Distal. The parts of a structure on the side away from the origin of growth or the ancestrula.

Ectooecium. The outer layer of an ovicell, commonly calcareous.

Ectocyst. A thin chitinous outermost layer covering the zooecium.

Endocyst. A thin membrane lining interior of the zooecium and enclosing polypide.

Endooecium. The inner calcareous layer of an ovicell. 
Endozooecial. Type of ovicell which appears to be deeply immersed in the next distal zooecium.

Extraterminal front-wall. Same as gymnocyst.

Frontal. Pertaining to the exposed side of zooecial chambers which bears the apertura.

Frontal shield. A calcareous cover of fused spines over-arching the frontal membrane in the Cribrimorpha.

Frontal wall. A calcareous cover on the external side of the compensatrix in the Ascophora.

Gymnocyst. A peripheral calcified portion of the frontal membrane, developed especially in the proximal region, not covered by the membranous ectocyst.

Heterozooecia. All zooecia that are not autozooecia.

Hyperstomial. Type of external ovicell, resting on or indenting the distal wall of the associated zooecium.

Incrusting. Attached along one side to a foreign body.

Intraterminal front-wall. Same as frontal shield.

Kenozooecium. A modified zooecium without polypide or operculum and generally no aperture or muscles.

Lacuna. A gap or pore commonly consisting of a simple slit between adjacent cos tae or costules in the Cribrimorpha.

Lyrule. A median, commonly anvil-shaped tooth on the proximal edge of the orifice.

Mucron. A rounded or spinelike projection at the proximal edge of the peristome in some Ascophora, located on the proximal side of the lyrule.

Multilamellar. Type of growth in which successive zooecial layers grow over and cover older ones.

Mural rim. A raised edge of zooecial side walls on the frontal side in some Anascan Cheilostomes, commonly spine-bearing.

Olocyst. The innermost, thin and smooth, calcified layer of the frontal wall.

Onychocellarium. A modified, generally asymmetrical avicularium, typical of the Onychocellidae.

Operculum. A chitinous or calcareous hinge-valve closing the orifice of the zooecium.

Opesiular intendations. Paired lateral perforations in the proximal lip of the opesia, homologous to the opesiules.

Opesiule. One of the small grooves in the cryptocyst for passage of the depressor muscles attached to the ectocyst.

Opesium. The uncalcified frontal area remaining after development of the cryptocyst.

Oral. Any organ (spines, avicularia, etc.) placed in the neighbourhood of the aperture.

Orifice. The primary opening of the zooecium for extrusion of the polypide, covered by the operculum.

Ovicell. A general term for any structure serving to contain Bryozoan larvae during their development.

Pelma. Opening in costa or costula.

Pelmatidium. Small opening in costa or costula.

Peristome. A rim surrounding the orifice.

Peristomice. The opening at the outer extremity of the peristomie.

Peristomie. A tubelike extension of the peristome outward from the operculum-bearing orifice.

Pivot. A calcareous bar dividing the opesium of the avicularium into two portions.

Polypide. A collective term for the soft parts of the zooid, freely movable within the zooecium.

Poster. The anterior proximal portion of the aperture.

Proximal. The parts of a structure on the side near to the origin of growth.

Cuincuncial. Characterized by an arrangement consisting of four objects symmetrically placed around a fifth. 
Radicle. A rootlike structure formed by kenozooecia serving for zooarial attachement.

Rimule. A fissure or small cleft at the proximal edge of the orifice serving as opening to the compensatrix.

Sinus. Same as rimule.

Termen. A marginal rim of the frontal walls surrounding the opesium.

Tremocyst. The perforate calcareous layer of the frontal wall.

Tremopore. A large perforation in the tremocyst.

Vibraculum. A highly modified chitinous or calcareous avicularian heterozooecium with an asymmetrically articulated seta.

Zoarium. The entire Bryozoan colony.

Zooeciule. An immature zooecium or kenozooecium occurring sporadically among normal zooecia.

Zooecium. The individual member of the zoarium.

\section{Bibliography}

of papers dealing with Cheilostome Danian Bryozoa in Denmark and Sweden and in erratic blocks in Northern Germany.

1. 1886. Éd. Pergens and A. Meunier: La faune des bryoozoaires gamruniens de Faxe.Extrait des Annales de la Société Royale Malacologique de Belgique. Tome XXI. 60 pages, 5 plates.

The following species are described:

Stevns Klint (Lilledal):

Spiropora vertebralis STOLICzKa, p. $28(210),=$ Columnotheca cribrosa MARSSON. PI. XI, Fig. 2.

Membranipora elliptica $\mathrm{v}$. HAGENOW, $=$ ? Membranipora johnstrupi n.sp. p. 53 (237).

Saltholm:

Membranipora reticulum LINNÉ f. typica, $=$ Membranipora hexagona

Faxe:

$$
\text { p. } 54 \text { (236). (v. HAGENOW). }
$$

Spiropora vertebralis StoliczKa, p. $28(210),=$ Columnotheca cribrosa MARSSON. PI. XI, Fig. 2.

Vincularia sculpta D'ORBIGNY, p. 49 (231) = Puncturiella sculpta (D’ORBIGNY).

Vincularia cretacea D'ORBIGNY, p. $49=$ ?

Vincularia regularis D'ORBIGNY, p. $50(232)=$ Aechmella tenuis n.sp.

Vincularia canalifera D'ORBIGNY, p. $50(232)=$ ? Vincularia prismatica V. Hagenow.

Vincularia areolata v. Hagenow, p. $50(232),=$ Taenioporina articulata VoIGT. P1. XIII, Fig. 11.

Vincularia ogivalis D'ORBIGNY, p. $51(233)=$ ?Semiescharinella pulchra ULRICH and BASSLER.

Eschara eurita D'ORBIGNY, p. $52(234)=$ Membraniporidra inermis LEVINSEN.

Eschara Desmaresti v. Hagenow, p. $52(234)=$ ?Beisselina celleporioides VoIGt.

Membranipora elliptica v. Hagenow, $\quad=$ ?Membranipora johnstrupi n.sp. p. 53 (235).

Membranipora reticulum LINNÉ f. typica, $=$ Membranipora hexagona p. 54 (236).

v. HAGENOW.

Membranipora reticulum LinNÉ f. Lacroixii, = ? p. 55 (237). 
Membranipora reticulum LINNÉ f. subtilimargo, p. 55 (237).

Membranipora lacrymopora D'ORBIGNY, p. 56 (238).

Membranipora angulosa REUss, p. 56 (238) =

Membranipora elegans v. HAGENOW, p. 57 (239).

Amphiblestrum formosum var. confertum Seguenza, p. 58 (240), Pl. XIII, Fig. 5.

Amphiblestrum bidens $\mathrm{V}$. HAGENOW, p. 58 (240), Pl. XIII, Fig. 6.

Amphiblestrum Delarueanum D'ORBIGNY, = ? Onychocella $\mathrm{sp}$. p. 59 (241).

Foveolaria Lundgreni n.sp., p. 60 (242), = Pachythecella lundgreni P. and M.
$=$ Ellisina humiliata BRYDONE.

= Membraniporidra lacrymoporoides n.sp.

(Tertiary form).

$=$ Amphiblestrum elegans v. Hagenow.

$=$ Floridina piriformis VorgT

(1930, p. 472).

$=$. Aechmella sp.

2. 1892. A. Hennig: Studier öfver Bryozoerna i Sveriges Kritsystem. I. Cheilostomata. Lunds Universitets Årsskrift, Tom. XXVIII. 46 pages, 2 plates.

In this paper 16 species from the Danian at Annetorp and Limhamn in Skåne are described.

Membranipora reticulum LINNÉ, p. $11 .=$ ? (Several species, cf. LeVINSEN, 1925

Membranipora elliptica v. HAGENOW, p. 13, Pl. 1, Figs. 1-2. p. 343).

$=$ Several species;

Periteichisma formosum var. confertum Seguenza, p. 22.

Periteichisma ringens $\mathrm{V}$. HAGENOW, p. 23, Pl. 1, Fig. 9.

Fig. 2 = Callopora monocera

(MARSSON).

= Floridina piriformis VoIGT (1930, p. 472).

$=$ Amphliblestrum ringens $\mathrm{v}$. HaGENOW and/or Amphiblestrum elegans

v. HAgENOW.

Periteichisma nonna v. HAGENOW, p. $24=$ ? Hoplitaechmella nonna $\mathrm{v}$. HaGenow.

Periteichisma Smittii n.sp., p. 25, Pl. 1, = Hoplitaechmella smitti (HENNIG). Figs. 10-11.

Periteichisma hippocrepis Goldfuss, p. 26, = Aechmella latistoma n.sp.

Pl. 1, Fig. 13 (non 12) (partim).

Periteichisma regulare D'ORBIGNY, p. $27=$ ?Aechmella tenuis n.sp.

Periteichisma? erectum $\mathrm{v}$. Hagenow, $\quad=$ ? Micropora convexa CANU. p. 29, Pl. 2, Fig. 21.

Rhagasostoma elegans v. HAGENOW, p. 33, Pl. 2, Figs. 22-24.

= Coscinopleura elegans elegans

v. HAGENOW and

C. angusta angusta BERTHELSEN.

Steganoporella? sculpta D'ORBIGNY, p. 35, Pl. 1, Fig. 20.

= Puncturiella sculpta D'ORBIGNY.

Steganoporella nobilis ESPER, p. 35, Pl. 2, = ?Micropora hennigiana n.sp. Figs, 25-26.

Foveolaria Lundgreni Pergens and Meunier, = Pachythecella lundgreni P. and M. p. 37.

Cribrilina quadrisulcata n.sp., p. 38, Pl. 2, = Monoceratopora quadrisulcata Figs. 31-32. (HENNIG).

Columnotheca cribrosa MARSSON, p. 42.

Mucronella hians n.sp., p. 44, Pl. 2, Fig. 42. 
3. 1894. A. Hennig: Studier öfver Bryozoerna i Sveriges Kritsystem. II. Cyclostomata. Lunds Universitets Årsskrift. Tom. XXX. 46 pages, 2 plates.

Spiropora vertebralis Stoliczka, p. $18 .=$ Columnotheca cribrosa MARsson.

4. 1910. K. Brünnich Nielsen: Om det i Københavns Havn ved Knippelsbro fundne yngste Danien. - Meddelelser fra Dansk Geologisk Forening, Vol. 3. No. 16. 12 pages.

In this paper the fauna in a deposit of limesand from the harbour of Copenhagen (Upper Danian) is discussed. The list of fossils includes three species of Cheilostome Bryozoa:

Coscinopleura elegans MARsson (= Coscinopleura angusta angusta Berthelsen), Porina flabellata v. HAGENOW (= Beisselinopsis oblita KADE) and Foveolaria lundgreni Pergens and Meunier (= Pachythecella lundgreni P. and M.).

5. 1913. E.P. Bonnesen, O.B. Bøggild og J.P.J. Ravn: Carlsbergfondets Dybdeboring i Grøndals Eng ved København 1894-1907 og dens videnskabelige Resultater. Museum de Minéralogie et de Géologie de l'Université de Copenhague. Communications géologiques. No. 3. 105 pages.

This work includes a survey of the scientific results obtained by the drilling of a $861 \mathrm{~m}$. deep well in Copenhagen. The Bryozoan material acquired was investigated by G. M. R. LeVINSEN.

From the Danian series (the interval 11-44 m.), termed Saltholm Limestone, LEVINSEN determined the following Cheilostome species:

Membranipora cincta MARSSON (= Pithodella cincta MARsson), Membranipora elegans v. HaGenow (= Amphiblestrum elegans v. HaGenow), Rhagasostoma Nysti V. HAGENOW (= Onychocella columella n.sp.), Micropora n.sp. Levinsen (probably = Micropora angulata LeVINSEN), Micropora hippocrepis Goldfuss var. microstoma Marsson (= Aechmella microstoma Marsson), Porina salebrosa Marsson, Porina Bosqueti Beissel (= Pachythecella filiformis D'ORBIGNY), Porina filiformis D'OrBignY (= Pachythecella filiformis D'Orbigny), "Foveolaria" Lundgreni Pergens and Meunier (= Pachythecella lundgreni P. and M.), Haswellia cribrosa MARsson (= Columnotheca cribrosa MARSSON), Systenostoma n.sp. LeVINSEN(= Systenostoma verticillata LeVINSEN).

6. 1914. W. D. Lang: On Herpetopora, a New Genus containing 3 New Species of Cretaceous Cheilostome Polyzoa. - Geological Magazine. Dec. VI. Vol. I, pp. 5-8.

In this paper a new species, Herpetopora danica, is established on the basis of material from Faxe.

7. 1914. W. D. Lang: Some New Genera and Species of Cretaceous Cheilostome Polyzoa. - Geological Magazine. Dec. VI. I, pp. 436-444.

The author here describes and pictures Allantopora stomatoporoides. Type locality: Faxe.

8. 1916. W. D. Lang: A Revision of the "Cribrimorph" Cretaceous Polyzoa. - The Annals and Magazine of Natural History. 8. Series. Vol. 18, pp. 81-112, 381-410.

The author establishes a number of new species, the following of which are based on Faxe material: Auchenopora guttur, Pliophloea palea, Pliophloea gluma, Trilophora trifida, Tricephalopora cerberus, Haplocephalopora uniceps, Hesperopora danica, Diacanthopora bispinosa, and Pachydera densa.

These species thus were mentioned for the first time in 1916, but the actual descriptions of species and the illustrations belonging to them were not published by LANG until 1921-22 in the Catalogue of Cretaceous Bryozoa, Vols. III-IV. 
9. 1919. K. Brünnich Nielsen: En Hydrocoralfauna fra Faxe og Bemærkninger om Danien'ets geologiske Stilling. - Danmarks Geologiske Undersøgelse. IV. Series. Vol. 1, No. 10. 65 pages.

This paper, in which the author first of all deals with the Hydrocorals, also includes a section on Bryozoa, as the author has determined some of the Bryozoan species found in the Coral-reef Limestone. He mentions the following Cheilostome species (p. 29): Membranipora elliptica v. Hagenow (= ?Membranipora johnstrupi n.sp.), Porina sp., and Columnotheca cribrosa MARsson.

10. 1920. A. Rosenkrantz: Craniakalk fra Kjøbenhavns Sydhavn. - Danmarks Geologiske Undersøgelse. II. Series. No. 36. 79 pages.

From the Lower Crania-limestone (= Sandy-limestone) the author adduces the following species of Cheilostome Bryozoa (p. 52): Membranipora canaliculata D'ORBIGNY (= Vincularia prismatica v. HAGENOW), Membranipora oculata D'ORBIGNY (= Callopora lyraeformis VOIGT), Membranipora declivis MARSSON (= M. declivis MARsson and M. marssoniana VOIGT), Membranipora lyra MARsson (= Callopora lyra (MARSSON)), Membranipora inermis? LEVINSEN (= Membraniporidra inermis (LEVINSEN)), Membranipora pristis LeVINSEN ( = Stamenocella pristis (LeVINSEN)), Eschara esperi v. Hagenow (= ? - (Onychocella esperi v. HAG. is a Senonian form)), Semieschara subgranulata v. HAGENOW (= Semiescharinella complanata D'ORBIGNY), Semieschara impressipora MARSSON var. faxensis LEVINSEN (= Floridina pulchella Kade), Periteichisma irregularis v. Hagenow (= Onychocella poulseni n.sp.), Vincularia areolata v. HAGENOW (= Taenioporina articulata VOIGT), Micropora exsculpta (= Puncturiella sculpta D'ORBIGNY), Micropora angulata LeVInSEN, Rhagasostoma elegans v. HAGENOW (= Coscinopleura angusta angusta Berthelsen), Foveolaria Lundgreni Pergens and Meunier (= Pachythecella lundgreni Perg. and Meun.), Monoporella Bosqueti BeISSEL (= Pachythecella filiformis D'ORBIGNY), Monoporella nobilis LeVINSEN ( = Beisselina nobilis (Levinsen)), Porina flabellata D'OrbIGNY (= Beisselinopsis oblita KADE), Porina salebrosa MARsson, Porina seriata? MARSsoN $(=$ Beisselina seriata (MARsSON) $)$ and Porina angusta $?$ LEVINSEN $=$ ? Psilosecos an gustidens LEVINSEN.

11- 1921-1922. W.D. Lang: Catalogue of the Fossil Bryozoa in the Department of

12. Geology, British Museum. The Cretaceous Bryozoa. Vol. III-IV. The Cribrimorphs.

The following species from Faxe are described and pictured in Vol. III :

Auchenopora guttur LANG, p. 164, text Fig. 78, Pl. V, Fig. 6.

Pliophloea palea LANG, p. 187, text Fig. 87, Pl. VI, Fig. 2.

Pliophloea gluma LANG, p. 188, text Fig. 88, Pl. VI, Fig. 3.

Trilophora trifida LANG, p. 195, text Fig. 91, PI. VI, Fig. 7.

Vol. IV:

Tricephalopora cerberus LANG, p. 86, text Fig. 24, Pl. I, Fig. 9.

Haplocephalopora uniceps LANG, p. 95, text Fig. 28, PI. II, Fig. 1.

Hesperopora danica LANG, p. 173, text Fig. 54, Pl. III, Fig. 13.

Diacanthopora bispinosa LANG, p. 231, text Fig. 71, Pl. V, Fig. 4.

Pachydera densa LANG, p. 383, text Fig. 122, Pl. VIII, Fig. 7.

13. 1923. Erh. Voigt: Über einige neue und wenig bekannte Bryozoen der Gattung Floridina aus dem Danien von Faxe. - Meddelelser fra Dansk Geologisk Forening. Vol. 6. No. 20. 8 pages, 1 plate.

In this paper the following species are described and pictured: 
Floridina impar n. sp., p. 4, Pl. I, Figs. 1-2.

Floridina trifolium n.sp., p. 5, Pl. I, Fig. $3=$ Floridina canui BRYDONE

(1906, p. 289).

Floridina variabilis n.sp., p. 6, P1. I, Figs. 4-5 = Floridina pulchella KADE (1852).

Floridina tubulosa n.sp., p. 7, Pl. I, Figs. 6-7.

Floridina gothica D'OrbignY, p. 7, PI. I, Fig. 8.

14. 1924. Erh. Voigt: Über neue Bryozoen aus Daniengeschieben Anhalts. - Paleontologischen Zeitschrift. Band VI, Heft 1. 10 pages, 1 plate.

The author in this paper describes the following Cheilostome species from erratic blocks of Danian Limestone found at Köthen and Rosslau in Anhalt:

Membranipora Marssoniana n.sp., p. 6, Pl. I, Fig. 13.

Membranipora Huckeana n.sp., p. 8, Pl. I, = Membraniporidra huckeana Vorgt. Figs. 24-26.

Floridina variabilis VoIGT, p. 8, PI. I, $=$ Floridina pulchella KADE (1852). Figs. 22-23.

Homalostega parvicella n.sp., p. 9, Pl. I, = Gargantua parvicella VoIGT. Figs. 28-31.

Homalostega erratica n.sp., p. 9, Pl. I, $=$ Micropora erratica VoIGt.

Fig. 27.

Porina cylindrica n.sp., p. 10, Pl. I, Fig. 37.

The species mentioned above are also stated to occur at Faxe. Besides, the following species are treated:

Membranipora diluvii n.sp., p. 7, Pl. I, Figs. 15-18.

Homalostega tenera n.sp., p. 8, Pl. I, $\quad=$ Puncturiella tenera (VoIGT).

Figs. 32-33.

Aechmella hippocrepis Goldfuss, p. 9, PI. I, = Aechmella pindborgi n.sp. (Figs. 35

Figs. 34-36. and 36) and

Aechmella latistoma n.sp. (Fig.34)

Pliophloea vincularioides n.sp., p. 11, PI. I, Figs. 38-39.

Distansescharella glabra n.sp., p. 12, Pl. I, Fig. 40.

15. 1925. G. M. R. Levinsen: Undersøgelser over Bryozoerne i den danske Kridtformation. - D. Kgl. Danske Vidensk. Selsk. Skrifter, naturvidensk. og mathem. Afd., 8. Række, VII. 3. 165 pages, 8 plates.

In this work the author describes and pictures 206 Bryozoan species from Danish Cretaceous deposits, among them the following new Cheilostome Danian species and varieties from Faxe (F), Stevns (S), and Karleby Klint in Jutland (K):

Membranipora aperta, p. 305, Pl. VIII, Fig. 1, (F).

Membranipora coronata, p. 311, PI. I, $\quad=$ Callopora coronata (LEV.).

Fig. 5, (F).

Membranipora impressa, p. 313, PI. I, $\quad=$ Callopora impressa (LEV.).

Fig. 8, (F).

Membranipora clavata, p. 315, Pl. I, $\quad=$ Aplousina fulgora BRYDONE.

Fig. 10a-b, (S, F).

Membranipora magnispina, p. 317, Pl. I, Fig. 11, (S).

Membranipora elliptica (v. HAG.) var. $=$ Membranipora johnstrupi n.sp.

faxensis, p. 318, Pl. I, Fig. 12c-d, (F).

Membranipora pristis, p. 324, Pl. VIII, = Stamenocella pristis (LEV.).

Fig. 3, (F).

Membranipora gigantea p. 330, P1. III, = Membraniporidra gigantea (LEV.).

Fig. 24a-c, (F). 
Membranipora maxima, p. 331, PI. III, Fig. 25, (F).

Membranipora elegans (v. HAG.) var. $\quad=$ Amphiblestrum elegans faxensis faxensis, p. 339, (F).

(LEv.).

Membranipora reticulata, p. 339, PI. III, = Ellisina humiliata BRYDONE. Fig. 33a-b, (S, F).

Membranipora laximaculata, p. $340, \mathrm{Pl} . \mathrm{III},=$ Ellisina britannica (BRYDONE). Fig. 34a-b, (S, F).

Membranipora inermis, p. 345, P1. IV, $=$ Membraniporidra inermis (LEv.). Fig. 38, (F).

Membranipora scutata, p. 345, Pl. IV, $=$ Floridina scutata (LEV.). Fig. 39, (F).

Onychocella faxensis, p. 354, PI. VIII, $=$ Lunulites faxensis (LEV.). Fig. 4, (F).

Onychocella elongata, p. 359, PI. IV, Fig. 47, (F).

Onychocella irregularis (v. HAG.) $\quad=$ Onychocella poulseni $\mathrm{n} . \mathrm{sp}$. var. faxensis, p. 360, (F).

Micropora angulata, p. 363, Pl. IV, Fig. 51, (F).

Micropora gracilis, p. 365, Pl. IV, $=$ Micropora erratica VoIGT. Fig. 52, (S, F).

Micropora stevensis, p. 366, Pl. V, Fig. 53, (S).

Micropora minuta, p. 366, PI. V, Fig. $54,(\mathrm{~F})=$ Gargantua parvicella VoIGT.

Cribrilina sparsiporis, p. 375, Pl. V, Fig. 57, (S).

Cribrilina intermixta, p. 378, Pl. V, $\quad=$ Anornithopora minuta VoIGT. Fig. 60, (S, F, K).

Membraniporella circumvallata, p. 382, = Tricephalopora circumvallata (LEv.). Pl. VIII, Fig. 5, (F).

Membraniporella stylifera, p. 383, P1. VI, Fig. 64, (F).

Membraniporella rapax, p. 383, P1. VI, Fig. 65, (S, F).

Barroisina repens, p. 388, Pl. VI, $\quad=$ Andriopora repens (LEV.). Fig. 68a-b, (F).

Kelestoma umbilicatum, p. 392, Pl. VI, = Tricephalopora cerberus LANG. Fig. 73, (F).

Kelestoma cordiforme, p. 393, Pl. VI, $\quad=$ Phractoporella cordiformis (Lev.). Fig. 74a-b, (F, K).

Kelestoma distomum, p. 394, P1. VIII, $=$ Haplocephalopora uniceps LANG. Fig. 9, (F).

Monoporella (?) angustidens, p. 397, P1. VII, = Psilosecos angustidens (LEv.). Fig. 75, (F).

Monoporella confusa, p. 402, Pl. VII, $\quad=$ Brydonella vulcani (BRYDONE). Fig. 80, (F).

Monoporella nobilis, p. 403, Pl. VII, = Beisselina nobilis (LEV.).

Fig. 81, (F).

Systenostoma verticillatum, p. 410, Pl. VII, Fig. 86a-b, (F, K).

16. 1925. Erh. Voigt: Neue cribrimorphe Bryozoen aus der Familie der Pelmatoporidae in Kreidegeschieben Anhalts. - Zeitschrift für Geschiebeforschung. Bd. 1, Heft 3. 7 pages, 4 text figs., 1 plate.

Here the following species are described on the basis of material from erratic blocks of Danian limestone from Rosslau:

Pelmatopora daniensis n.sp., p. 100, text Fig. 2, Pl. 3, Figs. 4-6.

Anornithopora (?) minuta n.sp., p. 102, text Fig. 3, Pl. 3, Figs. 1-3.

Batrachopora ultima n.sp., p. 103, text Fig. 4, Pl. 3, Figs. 7-8. 
17. 1926. K. Brünnich Nielsen: Kalken paa Saltholm. - Danmarks Geologiske Undersøgelse. IV. Series. Vol. 1. Nr. 20.

The author's list of the fauna from the limestone on Saltholm includes the following Cheilostome Bryozoa:

Membranipora elliptica V. HAG. (= ?Membranipora johnstrupi), Membranipora declivis MARsson, Membranipora monocera MARSSON (= Callopora monocera MARSs.), Membranipora inermis LEVINSEN (= Membraniporidra inermis (LEV.), Membranipora subgranulata v. HAG. (= Semiescharinella complanata D'ORB.), Membranipora fossata LEVINSEN ( = ?), Onychocella irregularis v. HAG. (= Onychocella poulseni n.sp.), Onychocella faxensis LEVINSEN (= Lunulites faxensis Lev.), Micropora erecta v. HAG. (= ?Micropora convexa CANU, 1911, p. 250), Micropora hippocrepis Goldfuss (= Aechmella pindborgi n.sp. and/or Aechmella latistoma n.sp.), Micropora amphora v. HAG., Micropora microstoma MARsson (= Aechmella microstoma (MARss.)), Rhagasostoma elegans v. HAG. (= Coscinopoeura angusta angusta BerthelseN), Rhagasostoma Nysti v. HAG. (= ?Onychocella columella n.sp.), Thalamoporella impressipora MARSSON (= Floridina pulchella (KADE)), Lepralia hians HenNIG (= Mucronella hians Hennig), Porina flabellata D'Orb. (= Beisselinopsis oblita KADE), Porina cancellata Goldfuss (= ?Taenioporina articulata VoIGT), Porina salebrosa Marsson, Monoporella cribrosa Marsson, (= Columnotheca cribrosa Marss.), Monoporella angustidens LEVINSEN (= Psilosecos angustidens (LEV.)), Monoporella nobilis Levinsen ( = Beisselina nobilis (Lev.)), Monoporella Lundgreni Pergens and Meunier $(=$ Pachythecella lundgreni (P. and M.)), Kleidionella grandis CANU and BAssLeR (= Beisselina celleporioides VOIGT).

18. 1928. Erh. Voigt: Neue artikulierte cheilostome Bryozoen aus einem Kreidegeschiebe obersenonen Alters von Cöthen in Anhalt. - Zeitschrift für Geschiebeforschung. Bd. IV, Heft 3. 8 pages, 1 plate.

Here, among others, the author describes two species, Dimorphostylus tetrastichus n.sp., p. 109, Pl. 1, Figs. 6-10, Quadricellaria excavata D'OrBignY, p. 112, Pl. 1, Figs. 1-5, from Faxe and from erratic Danian blocks from Köthen and Rosslau in Anhalt.

19. 1930. Erh. Voigt: Morphologische und stratigraphische Untersuchungen über die Bryozoenfauna der oberen Kreide. I. Teil. Die cheilostomen Bryozoen der jüngeren Oberkreide in Nordwestdeutschland, im Baltikum und in Holland. - Leopoldina. Berichte der Kaiserlich Leopoldinischen Deutschen Akademie der Naturforscher zu Halle. VI. Band. 200 pages, 39 plates.

In this impressive monograph the author describes 533 Bryozoan species, of which 121 species have been found in Danian deposits.

From Faxe the following new species and varieties are described:

Herpetopora faxensis, p. 410, Pl. 1, Fig. 4.

Marssonopora catenularia, p. 412, Pl. 1, Figs. 16-17.

Membranipora ravni, p. 416, Pl. 2, Fig. 17.

Membranipora (Membraniporidra) galeifera, p. 427, PI. 4, Fig. 13.

Membranipora tecta, p. 429, P1. 5, Fig. 13.

Membranipora sparsispina, p. 432, P1. 7, Figs. 17-18.

Membranipora bruennichi, p. 433, P1. 7, Fig. 19.

Floridina piriformis, p. 472, P1. 20, Fig. 5.

Andriopora fissa (= Fissuricella fissa VolGt), p. 496, Pl. 26, Figs. 22-23.

Tricephalopora dichotoma, p. 508, Pl. 29, Figs. 15-18.

Anornithopora polygona, p. 510, P1. 30, Figs. 11-12. 
Kleidionella celleporioides (= Beisselina celleporioides), p. 529, PI. 37, Fig. 4.

Taenioporina articulata, p. 534, Pl. 37, Figs. 17-19.

The following new species from Herfølge are adduced:

Membranipora orbavicularia, p. 435, P1. 7, Fig. 23.

Floridina bifoliata (=Floridina voigti BASSLER, 1936), p. 468, Pl. 20, Figs. 6-8.

From erratic Danian blocks from Köthen and Rosslau in Anhalt the following new species and varieties are described:

Membranipora magnispina Levinsen var. pygmaa, p. 432, Pl. 7, Fig. 5.

Membranipora (Callopora) woodwardi BRYDONE var. spinata, p. 442, Pl. 6, Figs. 5-6.

Stamenocella filiformis, p. 450, PI. 14, Figs. 8-9.

Stamenocella tumida, p. 450, PI. 14, Fig. 10.

Floridina siphonata p. 468, P1. 21, Figs. 12-13.

Floridina brydonei, p. 469, Pl. 20, Fig. 9.

Floridina scutata LeVInSEN var. excavata, p. 471, Pl. 21, Figs. 4-6.

Micropora erratica Volgt, p. 475, Pl. 22, Fig. 12.

Aechmella schmitti, p. 479, PI. 23, Fig. 14.

Andriopora daniensis, p. 497, Pl. 26, Fig. 19.

Pachytheca anhaltina (= Pachythecella anhaltina VorGT), p. 521, Pl. 33, Fig. 12.

Cellepora daniensis, p. 528, Pl. 36, Fig. 17.

20. 1948. Ole Berthelsen: Studies on the Bryozoan Species Coscinopleura elegans and Coscinopleura angusta n.sp. from the Senonian and Danian Deposits of Denmark. Danmarks Geologiske Undersøgelse. IV. Series. Vol. 3. No. 3. 15 pages, 4 text figs.

The author describes and pictures Coscinopleura angusta n.sp. (= Coscinopleura angusta angusta BERTHELSEN (VOIGT, 1956).

21. 1956. Erh. Voigt: Untersuchungen über Coscinopleura Marsson und verwandte Gattungen. - Mitteilungen aus dem Geologischen Staatsinstitut in Hamburg. Heft 25. 50 pages, 12 plates.

In connexion with a revision of the genus Coscinopleura the author of this paper offers supplementary information concerning Coscinopleura angusta angusta BERTHELSEN.

22. 1959. Erh. Voigt: Über Fissuricella n.g. - Neues Jahrbuch für Geologie und Paläontologie. Band 108, H. 3, pp. 260-269.

Here a new genus is established, Fissuricella, comprising $F$. vermiculata n.sp. and F. fissa Voigt. The latter species is identical with Andriopora fissa Vorgt (1930, p. 496).

\section{Systematic Descriptions.}

\section{CHEILOSTOMATA BUSK, 1852}

The zoaria are mostly calcareous, generally delicate and highly variable in form. The zooecia are almost exclusively short, rounded or angular chambers, arranged serially and in general side by side. The orifice is distal and closed by a hinged, chitinous operculum. Heterozooecia with different functions (ovicells, avicularia, and vibracula) are common. 
SUBORDER ANASCA LEVINSEN, 1909

A zooecial hydrostatic system, compensation sac, for extrusion of the polypide is wanting, but a zoarial hydrostatic system, hypostege, occurs between the cryptocyst and the ectocyst. The cryptocyst is membranous or calcareous.

\section{DIVISION MALACOSTEGA LEVINSEN, 1909}

The frontal wall is quite or partially uncalcified. The extrusion of the polypide occurs through depression by parietal muscles, which are attached to the chitinous cryptocyst. The operculum is a membranous valve.

MEMBRANIPORIDAE BUSK, 1854

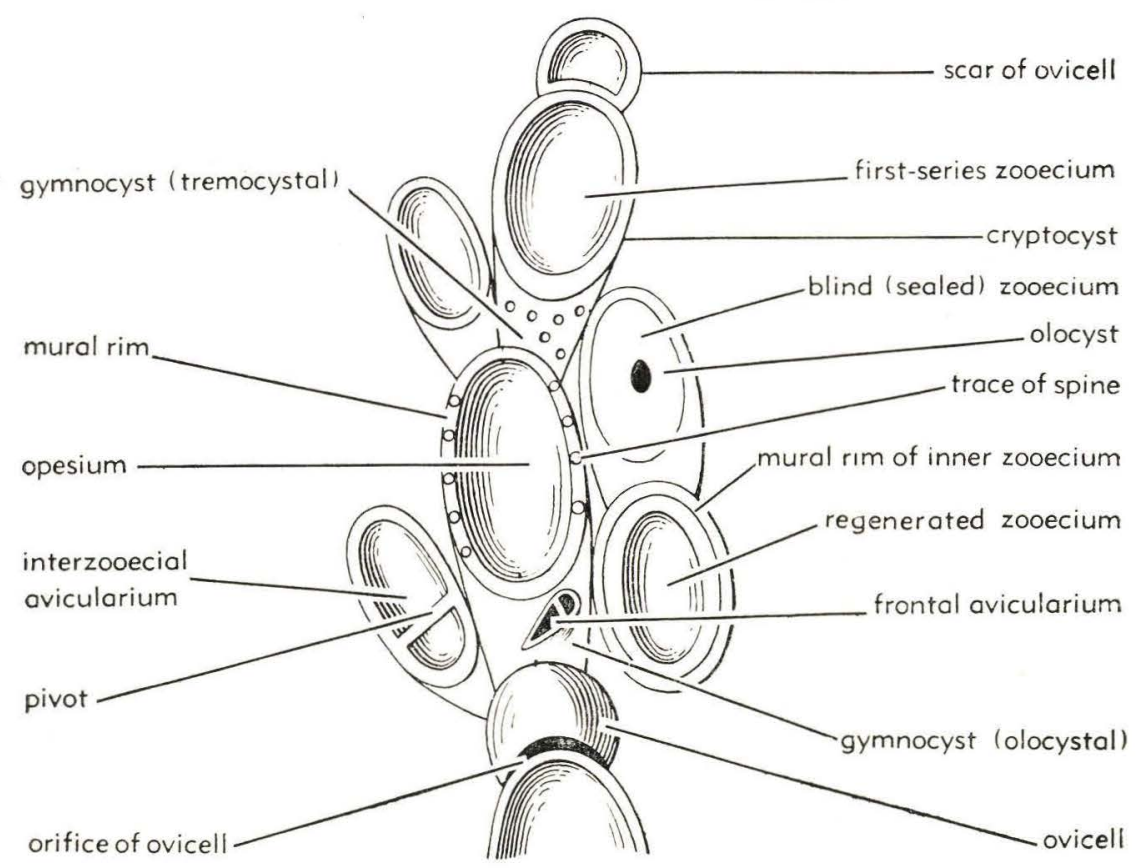

Fig. 26. Morphological features of Membraniporidae (BASSLER, 1953).

MEMBRANIPORA BLAINVILLE, 1830

\section{1. "Membranipora" hexagona (v. Hagenow) \\ Plate 1, Figs. 1-2.}

1839 Cellepora hexagona v. Hagenow. N. Jahrb. f. Min., p. 276, Pl. IV, Fig. 12.

1887 Membranipora velamen (non Goldfuss) Marsson. Pal. Abh. IV. 1, p. 56, Pl. 5, Fig. 12.

1930 Membranipora velamen (non Goldfuss) VoIGT. Leopoldina. VI, p. 415, Pl. 2, Fig. 16.

1959 Membranipora hexagona (v. Hagenow) Voigt. Geologie. Beiheft 25, p. 29, Pl. V, Fig. 1. 
Description.

The zoarium forms free, unilamellar plates with the zooecia in regular, alternating longitudinal rows. The back of the colony presents a rhombic, imbricate structure.

The zooecia are hexagonal or rhomboidal. The opesium is infundibular, oval; it is situated in the anterior part of the zooecium, surrounded by a flat, rounded, wide mural rim; the proximal zooecial edge is often straight. On the distal part of the rim there is a maximum of two traces of spines.

Ovicells occur rarely; they are slightly convex, not sharply delimited from the distal zooecium.

Avicularia are found only on some few colonies (VoIGT 1930); they are of the same shape as the zooecia, but generally larger and arciform at the distal end; there, the avicular rim seems to be thickened and projecting rooflike.

\section{Measurements.}

\begin{tabular}{|c|c|c|c|c|}
\hline \multirow{3}{*}{ Faxe. } & & & Range & Average \\
\hline & $\mathrm{Lz}$ & $\ldots \ldots \ldots \ldots \ldots \ldots$ & $0.62-0.78 \mathrm{~mm}$. & $0.71 \mathrm{~mm}$. \\
\hline & $1 z$ & $\ldots \ldots \ldots \ldots \ldots \ldots \ldots \ldots$ & $0.57-0.81-$ & 0.70 \\
\hline & ho & $\ldots \ldots \ldots \ldots \ldots \ldots \ldots \ldots$ & $0.31-0.44$ & 0.35 \\
\hline & lo & $\ldots \ldots \ldots \ldots \ldots \ldots \ldots$ & $0.26-0.44$ & 0.36 \\
\hline Saltholm. & $\mathrm{Lz}$ & $\ldots \ldots \ldots \ldots \ldots \ldots \ldots \ldots$ & $0.52-0.68 \mathrm{~mm}$. & $0.66 \mathrm{~mm}$ \\
\hline & $1 \mathrm{z}$ & $\ldots \ldots \ldots \ldots \ldots \ldots \ldots$ & $0.68-0.88-$ & $0.78-$ \\
\hline & ho & $\ldots \ldots \ldots \ldots \ldots \ldots \ldots \ldots$ & $0.36-0.47$ & 0.42 \\
\hline & lo & $\ldots \ldots \ldots \ldots \ldots \ldots \ldots$ & $0.47-0.52$ & 0.48 \\
\hline
\end{tabular}

Material. Faxe -14 specimens; Saltholm -2 specimens.

\section{Remarks.}

The description above is based upon Senonian material. In Danian deposits there is an occasional form which conforms to this description in its principal features; it differs from the Senonian form by having a wide lip on the proximal margin of the opesium. I have not thought it reasonable to set the Danian form up as a sub-species because of this one deviating character, the more so as my material comprises only 14 small fragments from Faxe and 2 specimens from Saltholm. For this species in particular a sufficiently large comparative material is important, for it has many variations in shape and size-a fertile source of faulty identification and specification in the past.

The difficulties are well illustrated by LEVINSEN's studies of Membranipora velamen (Goldfuss). His collection of Bryozoa at the Zoological Museum includes a tube of fragments labelled Membranipora velamen, another labelled $M$. velamen dentata, and two marked Membranipora velamen minuta. The $M$. velamen material came from Møn and includes specimens of $M$. hexagona and M. aedificata Brydone (1913, p. 198, Pl. VII, Figs. 10-11). It is the latter form which LEVINSEN illustrates on his Pl. IV, Fig. 37a. The M. velamen 
dentata material is from Faxe and is identical with Floridina impar Vorgt. As to the two tubes of $M$. velamen minuta one lacks particulars of the locality and contains specimens of Membranipora huckeana VoIGT, whereas the other tube is labelled Møn and contains fragments of Membranipora tenebrosa Brydone (1912, p. 433, Pl. XXII, Figs. 6-8); on Levinsen's Plate IV this is illustrated as Fig. 37 b.

\section{Distribution.}

Senonian: Germany: Rügen: Erratic boulders at Köthen and Rosslau. Denmark: Møn.

Danian: Germany: Erratic boulders at Wulmstorf near Hamburg (verbal communication from Prof. VorgT). Denmark: Kagstrup, Faxe, Saltholm, Herfølge, and Klintholm.

\section{2. "Membranipora" hexagona bredsdorffi n. subsp.}

Plate 1, Figs. 3-4.

Diagnosis.

A subspecies of Membranipora hexagona (v. HaGENOw), having the following characters: The zoarium consists of sinuous, uni- or multilamellar plates; the zooecial surface is finely granulated, the inner edge of the rim finely striated; the opesium has a rounded proximal margin; the gymnocyst is low.

\section{Description .}

Except for the characters indicated in the diagnosis the subspecies agrees with Membranipora hexagona (v. HaGeNOW).

Measurements.

\begin{tabular}{|c|c|c|c|c|c|c|}
\hline \multirow{2}{*}{ Herfølge. } & \multirow{3}{*}{$\begin{array}{l}\mathrm{Lz} \\
\mathrm{lz}\end{array}$} & & \multicolumn{2}{|l|}{ Range } & \multicolumn{2}{|c|}{ Average } \\
\hline & & & $0.68-0.78$ & $\mathrm{~mm}$. & 0.73 & $\mathrm{~nm}$. \\
\hline & & $\ldots \ldots, \ldots, \ldots, \ldots, \cdots$ & $0.52-0.88$ & - & 0.74 & - \\
\hline & ho & & $0.36-0.57$ & - & 0.45 & - \\
\hline & lo & 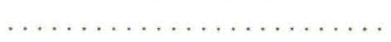 & $0.31-0.49$ & - & 0.42 & - \\
\hline & hov & 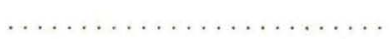 & $0.18-0.21$ & - & 0.20 & - \\
\hline & lov & $\ldots \ldots$ & 0.26 & - & 0.26 & - \\
\hline
\end{tabular}

Material.

Herfølge, Bryozoan Limestone - 45 specimens, Calcarenite - 12 specimens; Klintholm, Bryozoan Limestone -2 specimens.

Holotype. P1. 1, Fig. 3. Type locality: Herfølge, Bryozoan Limestone. 
Remarks.

This subspecies is named after the linguist and geologist JACOB HoRnEMANN BREDSDORFF (1790-1841), who published the first geological description of the limestone quarry at Herfølge in 1824.

Distribution. Upper Danian: Herfølge and Klintholm.

\section{3. "Membranipora" plicatelloides n.sp.}

Plate 1, Figs. 5-7, Plate 2, Fig. 1.

Diagnosis.

Zoarium unilamellar, tubular; zooecia rounded-hexagonal, with oblong-oval, terminal opesium and two longitudinal furrows on the gymnocyst.

\section{Description.}

The zoarium is free, unilamellar, tubular, with dichotomous ramification. The zooecia are arranged in alternating longitudinal rows; in the bifurcation area there is some irregularity as a consequence of the varying shape of the zooecia. The individual zooecia are separated by fine, but distinct furrows.

The zooecia are rounded-hexagonal; the opesium is oblong-oval, situated distally, sometimes faintly constricted by lateral projections from the mural rim. Apart from the distal part the rim is wide, with no traces of spines. Two longitudinal furrows running from the proximal corners of the opesium divide the gymnocyst into three areas.

The ovicells appear as slightly convex projections passing smoothly into the distal zooecium.

Avicularia have not been observed.

Measurements.

\begin{tabular}{|c|c|c|c|c|}
\hline Measureme & ents. & Range & & Average \\
\hline Stevns, & Width of zoarium ............. & $1.04-3.02 \mathrm{n}$ & $\mathrm{nm}$. & $2.36 \mathrm{~mm}$ \\
\hline Thorslunde, & $\mathrm{Lz} \quad \ldots \ldots \ldots \ldots \ldots$ & $0.57-0.78$ & - & $0.65-$ \\
\hline Faxe, & $\ldots \ldots \ldots \ldots \ldots \ldots \ldots \ldots$ & $0.44-0.62$ & - & 0.55 \\
\hline Herfølge. & $\ldots \ldots \ldots \ldots \ldots \ldots \ldots \ldots$ & $0.26-0.42$ & - & 0.34 \\
\hline & $\ldots \ldots \ldots \ldots \ldots \ldots \ldots \ldots$ & $0.21-0.31$ & - & 0.27 \\
\hline & hov $\ldots \ldots \ldots \ldots \ldots \ldots \ldots \ldots$. & 0.10 & - & \\
\hline & $\operatorname{lov}(\ldots \ldots \ldots \ldots \ldots \ldots \ldots$ & 0.42 & - & \\
\hline
\end{tabular}

\section{Material.}

Stevns, Bryozoan Limestone - 2 specimens; Thorslunde - 1 specimen; Faxe 6 specimens; Herfølge, Bryozoan Limestone - 50 specimens; Herfølge, Calcarenite -3 specimens. 
Holotype. Plate 1, Fig. 5. Type locality: Herfølge, Bryozoan Limestone.

Remarks.

The trivial name has reference to the close similarity of this species to Membranipora plicatella BRYDONE (1913, p. 198, Pl. VII, Fig. 9), especially as regards the zooecial shape and size. The tubular form is more pronounced in $M$. plicatelloides than in $M$. plicatella, in which the recurved lateral edges of the fragments suggest that the colony was tubular in shape. Among deviating features mention must be made of six traces of spines on the mural rim (see Plate 1, Fig. 7) on $M$. plicatella; no such spinal traces have been observed on $M$. plicatelloides; $M$. plicatella has been identified in Senonian deposits in Germany, England and Denmark ( $\AA$ lborg, Møn, and Stevns) and erratic Danian blocks in Germany (Köthen, Rosslau, and Wulmstorf).

There is also some likeness to "Membranipora" hexagona v. Hagenow as concerns the shape and appearance of the zooecia; this applies particularly to the zooecia in the bifurcation area, where the width of the zooecia may be equal to or in excess of their length.

\section{Distribution.}

Danian: Denmark: Stevns, Kagstrup, Thorslunde, Faxe, Saltholm, Herfølge, and Klintholm.

\section{4. "Membranipora" selandica n.sp.}

Plate 2, Figs. 2-5.

Diagnosis.

Zoarium discoidal, bi- or multilamellar. Zooecia spatulate, with oval, embedded, terminal opesium. Regenerated zooezia with a crenulate, pitted inner rim are common. Sealed zooecia with a free, lobate distal part occur. Avicularia interzooecial, large, with a roof-like overhang.

\section{Description.}

The zoarium consists of free, bi- or multilamellar, thick plates. The zooecia are arranged in alternating longitudinal rows and are separated by fine, but distinct furrows. On the multilamellar plates the orientation of the uppermost zooecia is often different from that of the underlying zooecia, e.g. at right angles to them (cf. Pl. 2, Fig. 4).

The zooecia are spatulate with a broad, rounded anterior part, which is demarcated by convex lateral lines and a tapering posterior part with concave lateral lines. The gymnocyst is well-developed, convex, sometimes divided into three areas by two furrows running from the proximal corners of the opesium. The mural rim is gradually tapering towards the distal end, and slopes steeply 
down to the embedded, terminally placed opesium. Generally the opesium is oblong-oval or angularly oval in shape, but subcircular or slightly hourglassshaped opesia occur. Terminally placed septula are present. In one of the proximal corners of the gymnocyst-rarely at the centre-occasional zooecia have a small oval pore within a narrow, elevated rim.

Regenerated zooecia are very common; on these the outer part of the opesium is sealed by a projecting rim, of which the outer side is crenulate and provided with four to six pores; on these zooecia the opesium is subrectangular or subcircular. Sealed zooecia also occur; the closure may have been effected by a thin, plane calcium membrane furnished centrally with an oval pore, but most frequently the opesium is covered by a sinuate plate whose posterior part descends steeply, whereas the lobate anterior part projects freely forwards and upwards. On the border between the two parts of the plate there are two small, circular pores.

In a few instances the convex gymnocyst continues proximally in a broad, slightly convex roof overhanging the opesium of the proximal zoecium; the roof terminates in a broad, rounded arc. The base of the ovicell is embedded in the substratum. In all probability it may be a matter of hyperstomial ovicells.

Avicularia are rare. They are usually larger and especially wider than the surrounding zooecia; the opesium is large and irregular in shape; above it is a rounded-acuteangled roof-like process.

\begin{tabular}{|c|c|c|c|c|c|c|}
\hline \multicolumn{3}{|c|}{ Measurements. } & \multicolumn{2}{|l|}{ Range } & \multicolumn{2}{|c|}{ Average } \\
\hline Herfølge. & $\mathrm{Lz}$ & & $0.52-0.78$ & $\mathrm{~mm}$. & 0.65 & $\mathrm{~mm}$. \\
\hline & $\mathrm{lz}$ & & $0.47-0.68$ & - & 0.52 & - \\
\hline & ho & $\ldots \ldots \ldots \ldots \ldots \ldots \ldots \ldots \ldots$ & $0.16-0.36$ & - & 0.24 & - \\
\hline & lo & $\ldots \ldots \ldots \ldots \ldots \ldots \ldots \ldots \ldots$ & $0.16-0.31$ & - & 0.22 & - \\
\hline & hov & $\ldots \ldots \ldots \ldots \ldots \ldots \ldots$ & 0.10 & - & & \\
\hline & lov & 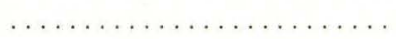 & 0.31 & - & & \\
\hline & Lav & 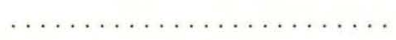 & $0.78-0.88$ & - & 0.83 & - \\
\hline & lav & $\ldots \ldots \ldots \ldots \ldots \ldots$ & $0.68-0.73$ & - & 0.71 & - \\
\hline
\end{tabular}

The fragments from the Bryozoan Limestone at Herfølge and Klintholm have a disc thickness of $\frac{1}{2}-1 \mathrm{~mm}$., whereas those from the Calcarenite at Herfølge are between 1 and $2 \mathrm{~mm}$. thick.

\section{Material.}

Herfølge, Bryozoan Limestone - 282 specimens; Calcarenite - 9 specimens; Klintholm - 7 specimens; the South Harbour (Sydhavnen) - 1 specimen.

Holotype. Pl. 2, Fig. 4, Herfølge, Bryozoan Limestone.

Paratypes. Pl. 2, Figs. 2, 3, and 5, Herfølge, Bryozoan Limestone. 
Remarks.

The trivial name is derived from Selandia $=$ Sjælland (Zealand). $M$. selandica n.sp. is one of the characterizing forms in the Bryozoan fauna at Herfølge. The multilamellar zoaria, the characteristic, regenerated zooecia, and the peculiar closure of the sealed zooecia give this species an isolated position in relation to the other "Membranipora"-forms.

The large avicularia with the distal roof-like overhang are also observable on M. sparsispina VoIGT and M. hexagona v. HaGENow.

Distribution. Upper Danian: Denmark: Copenhagen, Herfølge, and Klintholm.

\section{5. "Membranipora" sparsispina Voigt}

Plate 2, Figs. 6-7.

1930 Membranipora sparsispina VoIGt. Leopoldina. VI, p. 432, Pl. 7, Figs. 17-18.

\section{Description.}

The zoarium forms free, dichotomous stems, which may partly be columnar, consisting of 4-8 rows of zooecia (Pl. 2, Fig. 6), partly bilamellar (Pl. 2, Fig. 7). The zooecia are separated by fine, but distinct grooves.

The zooecia are rounded-hexagonal. The opesium is relatively small, oval. On well-preserved specimens about 10 spinal traces are to be seen on the mural rim. Regenerated zooecia, which are convex and sealed, often occur among the normal ones.

Avicularia are fairly rare and found on the bilamellar specimens. They are larger than the zooecia and have a large opesium. Above the latter there is a rounded acute- or obtuse-angled, roof-like process.

\section{Measurements.}

\begin{tabular}{|c|c|c|c|c|c|c|c|}
\hline \multirow{5}{*}{$\begin{array}{l}\text { Stevns, Kagstrup. } \\
\text { Thorslunde, Saltholm. } \\
\text { Faxe. } \\
\text { Herfølge. }\end{array}$} & \multirow{2}{*}{\multicolumn{3}{|c|}{ Width of zoarium ..... }} & \multirow{2}{*}{\multicolumn{2}{|c|}{$\begin{array}{l}\text { Range } \\
0.52-0.78 \mathrm{~mm} .\end{array}$}} & \multicolumn{2}{|c|}{ Average } \\
\hline & & & & & & 0.62 & $\mathrm{~mm}$. \\
\hline & & - & $\ldots \ldots$ & $0.73-1.14$ & - & 0.88 & - \\
\hline & & - & ..... & $0.94-1.77$ & - & 1.35 & - \\
\hline & & - & & $0.73-1.14$ & - & 0.96 & - \\
\hline Stevns, Kagstrup, & $\mathrm{Lz}$ & & & $0.47-0.57 \mathrm{l}$ & $\mathrm{mm}$. & 0.53 & $\mathrm{~mm}$. \\
\hline Thorslunde, Saltholm, & $\mathrm{lz}$ & .... & $\ldots \ldots$ & $0.29-0.34$ & - & 0.31 & - \\
\hline Faxe, Herfølge. & ho & $\ldots \ldots \ldots \ldots \ldots$ & $\ldots$. & $0.21-0.26$ & - & 0.23 & - \\
\hline & lo & $\ldots \ldots \ldots \ldots \ldots$ & $\ldots \ldots$ & $0.10-0.16$ & - & 0.13 & - \\
\hline & Lav & $\ldots \ldots \ldots \ldots$ & $\ldots \ldots$ & $0.70-0.73$ & - & 0.72 & - \\
\hline & lav & & & $0.52-0.57$ & - & 0.55 & \\
\hline
\end{tabular}




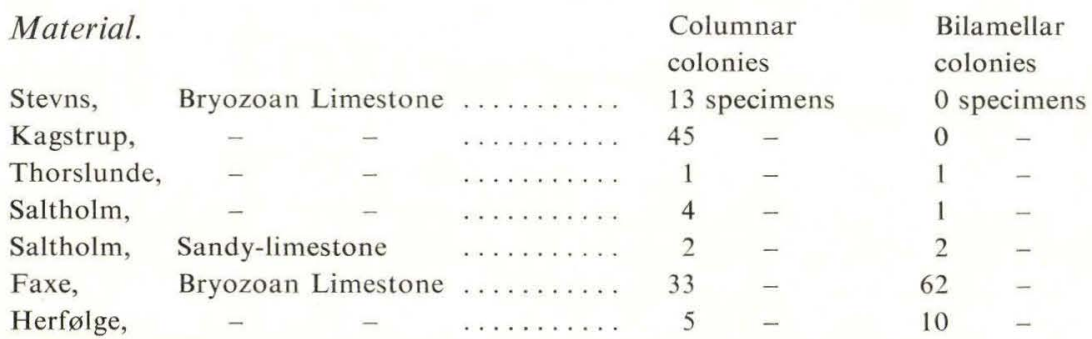

Remarks.

The survey of the material and the measurements of the zoarial width shows that the columnar form of colony reigns supreme in the Lower Danian, whereas the bilamellar form dominates in the Upper Danian.

VOIGT has not observed avicularia, probably because he had nothing but columnar zoaria available for description.

Avicularia of the same type also occur on the species placed by Voigt (1930, p. 415) to the Membranipora velamen group and on the Senonian genus Thyracella Voigt.

Distribution.

Danian: Denmark: Stevns, Kagstrup, Thorslunde, Faxe, Saltholm, Herfølge, and Klintholm.

\section{6. "Membranipora" johnstrupi n.sp.}

Plate 4, Figs. 1-2.

1925 Membranipora elliptica faxensis LeVInSEN, Vidensk. Selsk. Skr. 8. Ser. VII. 3, p. 318, Pl. I, Figs. 12c-d.

Diagnosis.

Zoarium encrusting; zooecia irregularly arranged, elliptical or circular, separated by deep triangular depressions; mural rim rounded without traces of spines; opesium large, embedded. Sealed zooecia with a convex olocyst occur. Avicularia rounded pentagonal or hexagonal with circular opesia. Ovicells hyperstomial, wide, convex.

\section{Description.}

The zoarium is encrusting, with irregularly arranged zooecia, which are separated by deep depressions forming triangular areas with concave lateral rims in the corners between the zooecia.

The zooecia are elliptical or circular, or sometimes rounded-triangular. The mural rim is rounded, without traces of spines; the gymnocyst is slightly 
developed. The opesium is placed terminally, embedded, variable of shape: elliptical, circular, or rounded-triangular. Sealed zooecia with a thin, convex olocyst are of frequent occurrence.

The ovicells are hyperstomial, highly convex, wide, embedded in the distal zooecium.

The avicularia are mostly interzooecial, rounded-pentagonal or - hexagonal with a circular opesium.

\begin{tabular}{|c|c|c|c|c|c|c|}
\hline \multicolumn{3}{|c|}{ Measurements. } & \multicolumn{2}{|l|}{ Range } & \multicolumn{2}{|c|}{ Average } \\
\hline \multirow[t]{8}{*}{ Herfølge. } & $\mathrm{Lz}$ & $\ldots \ldots \ldots \ldots \ldots \ldots \ldots \ldots \ldots$ & $0.31-0.52$ & $\mathrm{~nm}$. & 0.43 & $\mathrm{~nm}$. \\
\hline & $\mathrm{lz}$ & $\ldots \ldots \ldots \ldots \ldots \ldots \ldots \ldots$ & $0.29-0.36$ & - & 0.33 & - \\
\hline & ho & $\ldots \ldots \ldots \ldots \ldots \ldots \ldots \ldots \ldots$ & $0.23-0.42$ & - & 0.33 & - \\
\hline & lo & $\ldots \ldots \ldots \ldots \ldots \ldots \ldots \ldots$ & $0.21-0.29$ & - & 0.24 & - \\
\hline & hov & $\ldots \ldots \ldots \ldots \ldots \ldots \ldots \ldots \ldots$ & $0.16-0.18$ & - & 0.17 & - \\
\hline & lov & $\ldots \ldots \ldots \ldots \ldots \ldots \ldots \ldots$ & $0.21-0.23$ & - & 0.22 & - \\
\hline & Lav & $\ldots \ldots \ldots \ldots \ldots \ldots \ldots \ldots \ldots$ & 0.16 & - & & \\
\hline & lav & $\ldots \ldots \ldots \ldots \ldots \ldots \ldots \ldots$ & 0.16 & - & & \\
\hline \multirow[t]{6}{*}{ Saltholm. } & $\mathrm{Lz}$ & $\ldots \ldots \ldots \ldots \ldots \ldots \ldots \ldots$ & $0.39-0.62$ & $\mathrm{~nm}$. & 0.47 & $\mathrm{~mm}$. \\
\hline & $1 z$ & $\ldots \ldots \ldots \ldots \ldots \ldots \ldots \ldots$ & $0.31-0.47$ & - & 0.36 & - \\
\hline & ho & $\ldots \ldots \ldots \ldots \ldots \ldots \ldots \ldots \ldots$ & $0.31-0.47$ & - & 0.39 & - \\
\hline & 10 & $\ldots \ldots \ldots \ldots \ldots \ldots \ldots$ & $0.26-0.36$ & - & 0.28 & - \\
\hline & Lav & $\ldots \ldots \ldots \ldots \ldots \ldots \ldots \ldots$ & $0.18-0.21$ & - & & \\
\hline & lav & $\ldots \ldots \ldots \ldots \ldots \ldots \ldots \ldots$ & 0.21 & - & & \\
\hline \multirow[t]{8}{*}{ Faxe. } & $\mathrm{Lz}$ & $\ldots \ldots \ldots \ldots \ldots \ldots \ldots \ldots$ & $0.26-0.36$ & $\mathrm{~nm}$. & 0.33 & $\mathrm{~mm}$. \\
\hline & $1 z$ & $\ldots \ldots \ldots \ldots \ldots \ldots \ldots \ldots$ & $0.21-0.36$ & - & 0.29 & - \\
\hline & ho & $\ldots \ldots \ldots \ldots \ldots \ldots \ldots \ldots \ldots$ & $0.21-0.31$ & - & 0.25 & - \\
\hline & lo & $\ldots \ldots \ldots \ldots \ldots \ldots \ldots \ldots$ & $0.21-0.26$ & - & 0.22 & - \\
\hline & hov & $\ldots \ldots \ldots \ldots \ldots \ldots \ldots \ldots \ldots \ldots$ & $0.10-0.16$ & - & 0.13 & - \\
\hline & lov & $\ldots \ldots \ldots \ldots \ldots \ldots \ldots \ldots$ & $0.16-0.23$ & - & 0.19 & - \\
\hline & Lav & $\ldots \ldots \ldots \ldots \ldots \ldots \ldots \ldots$ & $0.16-0.23$ & - & & \\
\hline & lav & $\ldots \ldots \ldots \ldots \ldots \ldots \ldots \ldots$ & $0.16-0.21$ & - & & \\
\hline
\end{tabular}

\section{Material.}

Faxe - 27 specimens; Faxe II - 7 specimens; Saltholm - 1 specimen; Thorslunde - 1 specimen; Herfølge, Bryozoan Limestone - 3 specimens.

Holotype. Pl. 4, Fig. 1, Faxe, Bryozoan Limestone.

Paratype. Pl. 4, Fig. 2, Faxe, Bryozoan Limestone.

\section{Remarks.}

The species is named after J. F. Johnstrup (1818-1894), Professor of Geology at the University of Copenhagen 1866-1894, in memory of his thorough investigations into geological conditions at Faxe (JoHnstruP, Faxekalkens Dannelse og senere undergaaede Forandringer, 1864). 
M. johnstrupi is identical with the form which LEVINSEN assumed to be a variety of Membranipora elliptica v. HAGENOw. The zooecial dimensions of $M$. johnstrupi agrees with those of $M$. elliptica (Lz: 0.42-0.52 mm., lz: 0.310.42 , ho: $0.26-0.34 \mathrm{~mm}$., lo: $0.16-0.23 \mathrm{~mm}$.) and, to some extent, the shape of the zooecia is similar. The elliptical form, however, is more common in $M$. elliptica than in $M$. johnstrupi. The latter differs from v. HaGENOW's species by lacking traces of spines on the mural rim, whereas $M$. elliptica has three pairs of such traces. Furthermore, the ovicells in $M$. elliptica are smaller (hov: 0.10 , lov: $0.14 \mathrm{~mm}$.) than in $M$. johnstrupi, and the avicularia are elliptical with elongate opesia (Lav: $0.21 \mathrm{~mm}$., lav: $0.13 \mathrm{~mm}$.). Finally, the difference in stratigraphical distribution should be noted, M. elliptica being known only from the Chalk on Rügen, Møn, Aalborg, and Maastricht, whereas M. johnstrupi seems to occur exclusively in Danian deposits.

Distribution.

Denmark: Upper Danian: Faxe, Thorslunde, Saltholm, and Herfølge.

\section{7. “Membranipora" declivis Marsson 1887}

Plate 3, Fig. 1.

1887 Membranipora declivis Marsson. Pal. Abh. IV. 1, p. 57, Pl. V, Fig. 13.

1925 Membranipora declivis Marsson. Levinsen. Vidensk. Selsk. Skr. 8. Ser. VII. 3, p. 320, Pl. II, Fig. 15a (non b).

1930 Membranipora declivis Marsson. VoIgt. Leopoldina. VI, p. 422, Pl. 10, Fig. 18, Pl. 12, Fig. 1.

\section{Description.}

The zoarium is encrusting or forms free, often thick, sinuous, plates with irregularly arranged zooecia, which are separated by narrow, but distinct depressions.

The zooecia are highly variable in shape. Usually they are rather wide, irregular, rounded-pentagonal or -hexagonal. The opesia are oval, often with small constrictions in the anterior third, owing to projections from the margins; they are frequently deeply embedded, with steeply ascending, wide rims. The outer edge of the rim may be more or less distinctly marked as a band-like edging.

Ovicells occur rarely; they are rather large and very prominent, somewhat depressed.

The avicularia have a rounded-rectangular or pentagonal shape, and as a rule their posterior end is depressed at an acute angle between the anterior ends of two proximal zooecia. They are furnished with a median pivot. 


\begin{tabular}{|c|c|c|c|c|c|c|}
\hline \multicolumn{3}{|c|}{ Measurements. } & \multicolumn{2}{|l|}{ Range } & \multicolumn{2}{|c|}{ Average } \\
\hline Faxe, & $\mathrm{Lz}$ & & $0.62-0.78$ & $\mathrm{~mm}$. & 0.70 & $\mathrm{~mm}$. \\
\hline Saltholm, & $\mathrm{lz}$ & $\ldots \ldots \ldots \ldots \ldots \ldots \ldots \ldots$ & $0.52-0.68$ & - & 0.57 & - \\
\hline \multirow[t]{6}{*}{ Herfølge. } & ho & $\ldots \ldots \ldots \ldots \ldots \ldots \ldots \ldots$ & $0.31-0.52$ & - & 0.39 & - \\
\hline & 10 & $\ldots \ldots \ldots \ldots \ldots \ldots \ldots \ldots$ & $0.26-0.34$ & - & 0.28 & - \\
\hline & hov & $\ldots \ldots \ldots \ldots \ldots \ldots \ldots \ldots \ldots$ & 0.31 & - & 0.31 & - \\
\hline & lov & $\ldots \ldots \ldots \ldots \ldots \ldots \ldots \ldots$ & $0.36-0.42$ & - & 0.39 & - \\
\hline & Lav & $\ldots \ldots \ldots \ldots \ldots \ldots \ldots \ldots$ & $0.31-0.36$ & - & 0.35 & - \\
\hline & lav & $\ldots \ldots \ldots \ldots \ldots \ldots \ldots \ldots$ & $0.21-0.26$ & - & 0.24 & - \\
\hline \multirow[t]{8}{*}{ Møn. } & $\mathrm{Lz}$ & $\ldots \ldots \ldots \ldots$ & $0.62-0.88$ & $\mathrm{~mm}$. & 0.75 & $\mathrm{~mm}$. \\
\hline & $1 z$ & $\ldots \ldots \ldots \ldots \ldots \ldots \ldots \ldots$ & $0.52-0.55$ & - & 0.53 & - \\
\hline & ho & $\ldots \ldots \ldots \ldots \ldots \ldots \ldots \ldots$ & $0.36-0.52$ & - & 0.46 & - \\
\hline & lo & $\ldots \ldots \ldots \ldots \ldots \ldots \ldots \ldots$ & $0.23-0.31$ & - & 0.29 & - \\
\hline & hov & $\ldots \ldots \ldots \ldots \ldots \ldots \ldots \ldots$ & $0.31-0.36$ & - & 0.34 & - \\
\hline & lov & $\ldots \ldots \ldots \ldots \ldots \ldots \ldots \ldots$ & 0.36 & - & 0.36 & - \\
\hline & Lav & $\ldots \ldots \ldots \ldots \ldots \ldots \ldots \ldots$ & $0.36-0.42$ & - & 0.38 & - \\
\hline & lav & $\ldots \ldots \ldots \ldots \ldots \ldots \ldots \ldots \ldots$ & 0.26 & - & 0.26 & - \\
\hline
\end{tabular}

Material.

Faxe -41 specimens; Faxe XI - 1 specimen; Herfølge -6 specimens.

Remarks.

LEVINSEN distinguished between 3 forms within this species: (1) Variety a, which is identical with MARSSON's M. declivis, (2) Variety b, which differs from the main form by having a pronouncedly oval, deeply embedded opesium and large avicularia, whose anterior half is surrounded by a prominent rim, and (3) Variety c, to which Levinsen referred Membranipora argus (D'ORBIGNy). The latter variety is identical with VolGT's species M. marssoniana (see below), whereas Variety b should be placed under the main species, as the diverging features indicated must be regarded as an expression of the variation range of the species. The above measurements from Møn were made on the material marked Var. b in LEVINSEN's type collection. The values do not differ particularly from the corresponding values of the Danian material.

\title{
Distribution.
}

Senonian: Germany: Rügen; Holland: Maastricht; Denmark: Møn.

Danian: Germany: Erratic Danian blocks from Köthen; Denmark: Faxe and Herfølge.

\section{8. "Membranipora" marssoniana Voigt}

\author{
Plate 3, Figs. 2-3.
}

1887 Biflustra variabilis Marsson (non D'Orbigny). Pal. Abh. IV. 1, p. 52, Pl. V. Fig. 3.

1924 Membranipora marssoniana VoIGT. Pal. Zeitschr. VI. 1, p. 6, Pl. 1, Fig. 13.

1925 Membranipora declivis var. c. LevinSEn. Vidensk. Selsk. Skr. 8. Ser. VII. 3, p. 321, Pl. II, Fig. 15b (non a).

1930 Membranipora marssoniana VoIGT. Leopoldina. VI, p. 422, Pl. 12, Figs. 14-15. 


\section{Description.}

The zoarium consists of slender quadrangular or pentagonal, dichotomous stems with the zooecia arranged in fairly regular longitudinal rows. The zooecia are separated by narrow, but distinct furrows.

The zooecia are elongated, rounded-hexagonal. The opesium is placed in the distal part of the zooecium, oblong-oval, sometimes faintly constricted anteriorly, owing to projections from the margins. It is surrounded by a wide, smoothly ascending mural rim.

The ovicells are hyperstomial, convex, very prominent.

Avicularia are rare; in shape they are rounded-quadrangular or -pentagonal and their postal part is embedded at an acute angle between two proximal zooecia. They have a median pivot.

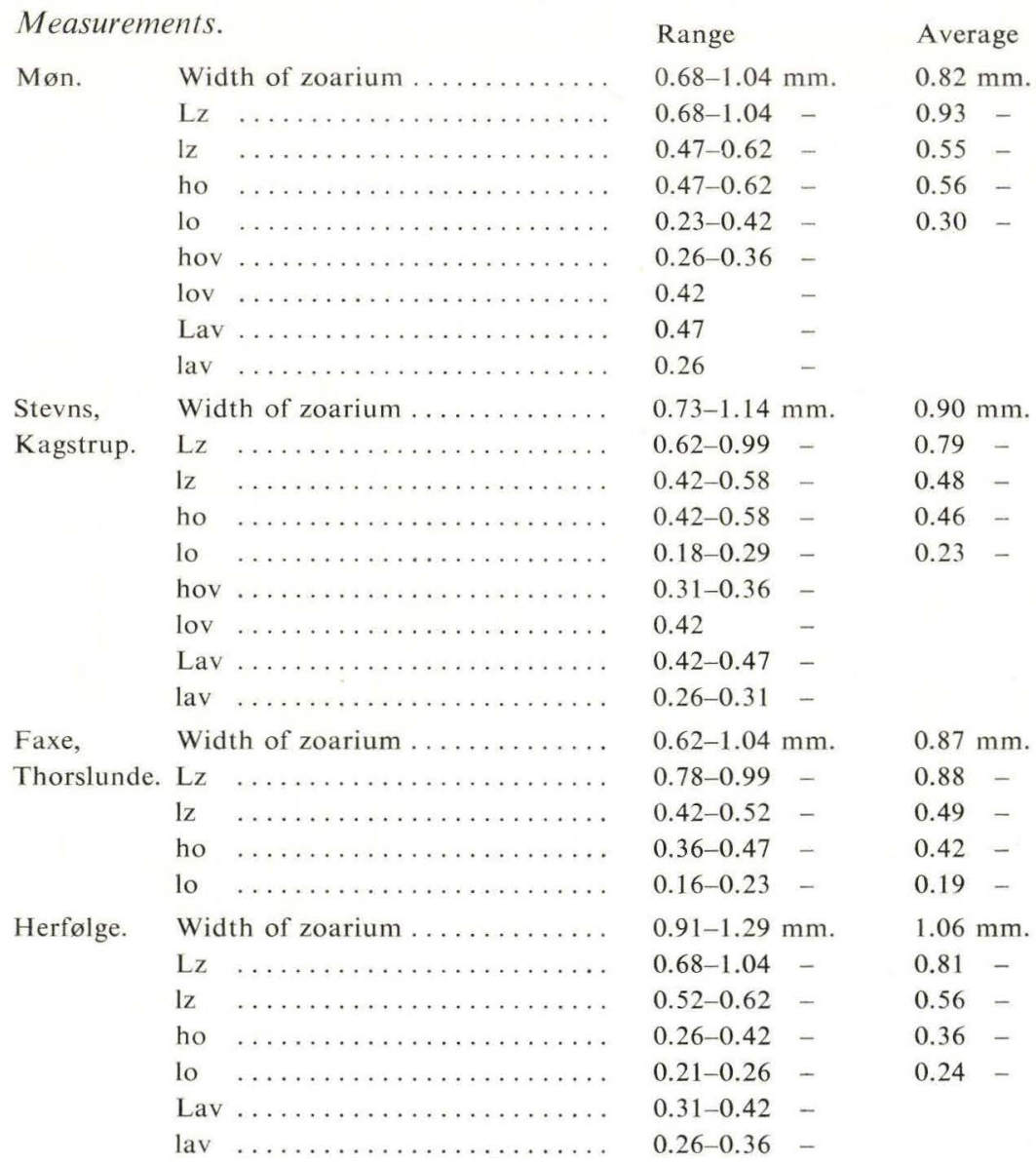

Generally the zoarial width is greatest in the Herfølge material and smallest in the Senonian fragments from Møn. On the other hand, the latter have the 
largest zooecia and avicularia; the opesia on the Møn specimens are also longer and wider than on the Danian specimens, among which the colonies from the Lower Danian have the largest opesia.

Material.

Stevns, Bryozoan Limestone - 30 specimens; Kagstrup - 63 specimens; Thorslunde -5 specimens; Saltholm - 3 specimens; Faxe -7 specimens; Faxe II 3 specimens; Herfølge, Bryozoan Limestone - 316 specimens; and Herfølge, Calcarenite -5 specimens.

\section{Remarks.}

In LEVINSEN's opinion his $M$. declivis var. $c$ was identical with Membranipora argus D’Orbigny (1852, p. 253, Pl. 689, Figs. 1-4). In fact, however, M. argus differs from $M$. marssoniana by having more slender, hexagonal stems and smaller zooecia and by lacking avicularia. Sealed zooecia, which are common in $M$. argus, are unknown in M. marssoniana.

In 1930 VoIGT established a variety of $M$. marssoniana: var. moeniensis (1930, p. 422, Pl. 12, Figs. 16-19), on the basis of material from Møn; this variety differs from the type form in having smaller, especially narrower zooecia and shorter avicularia, which are of common occurrence.

In the English Chalk at Weybourne Brydone (1930, p. 41, Pl. XV, Figs. 16-19) found a species, Vincularia weybournensis, which with regard to zooecial shape and to type of zooecia and avicularia very strongly recalls $M$. marssoniana; it differs from the latter in having traces of spines on the mural rim.

\section{Distribution.}

Senonian: Germany: Rügen and erratic blocks; Denmark: Møn, North Jutland.

Danian: Germany: Erratic blocks, Rosslau and Köthen; Denmark: Stevns, Kagstrup, Thorslunde, Faxe, Saltholm, Herfølge, and Klintholm, i.e. all zones of the Danian, principally Bryozoan Limestone.

\section{9. "Membranipora" præcipua herfolgensis n. subsp.}

Plate 4, Figs. 3-4.

1914 Membranipora pracipua Brydone. Geol. Mag. Dec. VI. Vol. 1, p. 482, Pl. XXXV, Figs. 5-7.

\section{Diagnosis.}

A subspecies of Membranipora pracipua BRYDONE with the following characters: Colony-and zooecial form as $M$. procipua, but smaller zooecia and opesia 
(0.53 mm. as against $0.65 \mathrm{~mm}$.); two avicularium types of the same appearance as on M. pracipua, but smaller; scar of ovicell with the greatest width at the distal part.

\section{Description.}

1. Membranipora pracipua. BRYDONE's description:

"Zoarium unilaminate, adherent.

Zooecia large with fairly thick side-walls overhanging very slightly; areas elliptical, average length from $0.65 \mathrm{~mm}$. upwards, breadth from $0.35 \mathrm{~mm}$. upwards.

Ooecia abundant but delicate, slightly globular, the free edge coinciding with the outline of the area, the side-wall of which is exceedingly thin beneath them.

Avicularia of two types: (1) Interstitial, having one end raised into a smooth hood, nearly as large as the zooecia and tending to introduce new rows of zooecia; the hood is straight or even slightly concave in outline at the upper end, and has a free edge embracing the upper half of the aperture and then curving round and backwards to a point of attachment on the outer margin; there are distinct traces of a bar across the aperture just below the hood. (2) Vicarious, long drawn out and very gently curving, extreme instances of the hour-glass type with traces of a bar across the lower end.

The vicarious avicularia are extremely capricious in occurrence; the interstitial ones are also rather capricious, but it is very rare for any zoarium of decent size, which suggests this species by the dimensions of its zooecia, not to show at least one recognizable, even if damaged, avicularium of this type."

\section{2. "Membranipora" precipua herfolgensis, n.ssp.}

Brydone's description holds good of the subspecies with the following modifications: (a) zooecial and opesial lengths are shorter on $M$. pracipua herfolgensis than on $M$. pracipua (cf. the measurements below); (b) correspondingly the lengths of both interstitial and vicarious avicularia are smaller on $M$. pratcipua herfolgensis; (c) on M. prccipua the scar of ovicell is widest in the middle, in conformity with the globular shape of the ovicell, whereas on the subspecies the scar has its greatest width in the distal part of the ovicell.

\begin{tabular}{|c|c|c|c|c|c|c|}
\hline \multicolumn{3}{|c|}{ Measurements. } & \multicolumn{2}{|l|}{ Range } & \multicolumn{2}{|c|}{ Average } \\
\hline Herfølge. & $\mathrm{Lz}$ & $\ldots \ldots \ldots \ldots \ldots \ldots \ldots \ldots \ldots \ldots$ & $0.60-0.78$ & $\mathrm{~mm}$. & 0.65 & $\mathrm{~mm}$. \\
\hline & $1 \mathrm{z}$ & $\ldots \ldots \ldots \ldots \ldots \ldots \ldots$ & $0.42-0.57$ & - & 0.51 & - \\
\hline & ho & $\ldots \ldots \ldots \ldots \ldots \ldots \ldots \ldots \ldots \ldots$ & $0.47-0.62$ & - & 0.53 & - \\
\hline & lo & $\ldots \ldots \ldots \ldots \ldots \ldots \ldots \ldots \ldots$ & $0.34-0.42$ & - & 0.37 & - \\
\hline & hov & $\ldots \ldots \ldots \ldots \ldots \ldots \ldots \ldots$ & 0.21 & - & & \\
\hline & lov & $\ldots \ldots \ldots \ldots \ldots \ldots \ldots \ldots$ & 0.26 & - & & \\
\hline
\end{tabular}




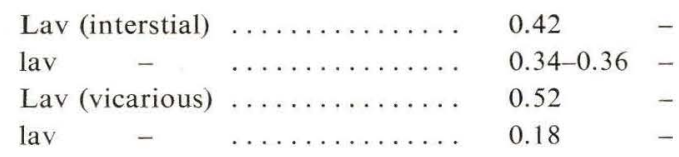

Material. Herfølge, Bryozoan Limestone - 5 specimens.

Holotype. Pl. 4, Fig. 4, Herfølge, Bryozoan Limestone.

Paratype. Pl. 4, Fig. 3, Herfølge, Bryozoan Limestone.

Remarks.

The subspecies has been named after Herfølge, the only locality where it has been found so far.

M. prceipua herfolgensis is very similar to Membranipora sacerdotalis BRYDONE (1914, p. 482, Pl. XXXV, Figs. 8-10) as regards the shape and size of the interstitial and vicarious avicularia; however, M. sacerdotalis has pyriform zooecia and narrow ovicells.

\section{Distribution.}

M. pracipua BRYDONE is known only from the British Senonian at Trimingham. $M$. procipua herfolgensis n.ssp. has been found exclusively in the Bryozoan Limestone at Herfølge (Zone D).

\section{0. "Membranipora" aperta Levinsen}

Plate 3, Fig 4.

1925 Membranipora aperta Levinsen. Vidensk. Selsk. Skr. 8. Ser. VII. 3, p. 305, Pl. VIII, Fig. 1.

1930 Membranipora aperta Levinsen. Voigt. Leopoldina. VI, p. 443, Pl. 9, Fig. 12-13.

\section{Description.}

The zoarium is encrusting with irregularly arranged zooecia, which are separated by distinct narrow depressions.

The zooecia are variable in size and shape, mostly rounded-angular or oval. The opesium occupies the greater part of the zooecial surface and is surrounded by a narrow mural rim without traces of spines.

The ovicells are hyperstomial, rather large and prominent, smoothly convex, with a rounded-quadrangular outline.

Avicularia occur sparsely among the zooecia. They are usually of the same shape and about the same size as these. The oval opesium is surrounded by a wide rim and provided with a pivot placed slightly below the middle. Ac- 
cording to LEVINSEN occur sometimes long, sole-shaped avicularia with constricted lateral margins and with the pivot in the rearmost quarter of the avicularium.

\begin{tabular}{|c|c|c|c|c|c|c|}
\hline Meas & ents. & & Range & & Aver & age \\
\hline Faxe. & $\mathrm{Lz}$ & $\ldots \ldots$ & $0.52-0.62$ & $\mathrm{~nm}$. & 0.57 & $\mathrm{~mm}$. \\
\hline & $1 z$ & $\ldots \ldots \ldots \ldots \ldots \ldots \ldots \ldots$ & $0.42-0.52$ & - & 0.48 & - \\
\hline & ho & $\ldots \ldots \ldots \ldots \ldots \ldots \ldots$ & $0.36-0.42$ & - & 0.40 & - \\
\hline & lo & $\ldots \ldots \ldots \ldots \ldots \ldots$ & $0.29-0.42$ & - & 0.34 & - \\
\hline & hov & $\ldots \ldots \ldots \ldots \ldots \ldots \ldots$ & $0.16-0.21$ & - & 0.19 & - \\
\hline & lov & & $0.26-0.31$ & - & 0.28 & - \\
\hline & Lav & $\ldots \ldots \ldots \ldots \ldots \ldots \ldots \ldots$ & $0.42-0.52$ & - & 0.46 & - \\
\hline & lav & $\ldots \ldots \ldots \ldots \ldots \ldots \ldots$ & $0.36-0.42$ & - & 0.39 & - \\
\hline
\end{tabular}

Lectotype.

LeVinsen's type collection at the Zoological Museum, Copenhagen, Plate VIII, Fig. 1 (1925). Type locality: Faxe.

Material. Faxe, Bryozoan Limestone -4 specimens.

Remarks.

VoıgT referred this species to the gioup Callopora under Membranipora. It is a feature common to the representatives of this group that the mural rim round the opesium has traces of spines. As no such traces occur on M. aperta, this placing is untenable.

Distribution. This species is found only in the Danian at Faxe.

\section{1. "Membranipora" maxima Levinsen}

Plate 3, Figs 5-6.

1925 Membranipora maxima Levinsen. Vidensk. Selsk. Skr. 8. Ser. VII. 3, p. 331, Pl. 3. Fig. 25.

1930 Membranipora maxima Levinsen. Voigt. Leopoldina. VI, p. 418, Pl. 2, Fig. 18.

\section{Description.}

The zoarium is encrusting, with irregularly arranged zooecia which are separated by deep depressions.

The zooecia are large, somewhat variable in shape, usually rounded-hexagonal. Dwarf zooecia occur occasionally. The opesium is oval or roundedangular; it is surrounded by a fairly wide rim, the lower part of which is embedded against the opesium and relatively sharply delimited outwards. On this inner rim there is a distinct striation. 
The ovicells are large, hyperstomial. According to LEvinSEN they are convex and have a distinct longitudinal streak along the middle. The scars of ovicell are rounded-quadrangular.

The avicularia are narrow and long, often longer than the zooecia, with an oval opesium, the length of which is only about half of that of the avicularium. The opesium is surrounded by a broad rim which at the tip has an oblongoval, rather deep depression. Sometimes the floor of this depression is pierced, giving the avicular orifice an elongated shape and seemingly with a marked constriction in the middle.

\begin{tabular}{|c|c|c|c|c|c|c|}
\hline \multicolumn{3}{|c|}{ Measurements. } & \multicolumn{2}{|l|}{ Range } & \multicolumn{2}{|c|}{ Average } \\
\hline Faxe. & $\mathrm{Lz}$ & & $0.78-0.94$ & $\mathrm{~mm}$. & 0.85 & $\mathrm{~mm}$. \\
\hline & lz & $\ldots \ldots \ldots \ldots \ldots \ldots \ldots \ldots$ & $0.57-0.83$ & - & 0.68 & - \\
\hline & ho & $\ldots \ldots \ldots \ldots \ldots \ldots \ldots$ & $0.42-0.57$ & - & 0.49 & - \\
\hline & lo & & $0.34-0.47$ & - & 0.38 & - \\
\hline & hov & $\ldots \ldots \ldots \ldots \ldots \ldots \ldots \ldots \ldots$ & 0.31 & - & & \\
\hline & $\operatorname{lov}$ & $\ldots \ldots \ldots \ldots \ldots \ldots \ldots$ & $0.36-0.42$ & - & & \\
\hline & Lav & $\ldots \ldots \ldots \ldots \ldots \ldots \ldots \ldots$ & $0.83-0.99$ & - & 0.94 & - \\
\hline & lav & $\ldots \ldots \ldots \ldots \ldots \ldots \ldots$ & $0.42-0.52$ & - & 0.46 & - \\
\hline
\end{tabular}

Material. Danian: Faxe - 20 specimens; Faxe II - 1 specimen.

Lectotype. Plate III, Fig. 25 (Levinsen, 1925). Type locality: Faxe.

Remarks.

Avicularia of the same type as those of M. maxima also occur on M.pseudelea VoIGT from the German Senonian at Misburg.

Distribution. Upper Danian: Faxe.

VINCULARIA DEFRANCE, 1829

12. Vincularia prismatica (v. Hagenow)

Plate 4, Fig. 5.

1839 Glauconome prismatica v. HaGenow. N. Jahrb. f. Min., p. 293.

?1851 Vincularia bisinuata D'Orbigny. Pal. Franç. Terr. Crét., p. 85, Pl. 659, Figs. 1-3.

1887 Vincularia canalifera (non v. HaG.) MARsson. Pal. Abh. IV. 1, p. 64.

1959 Vincularia prismatica v. Hagenow. Voigt. Geologie. Beiheft 25, p. 45, Pl. VII, Figs. 7-8.

\section{Description.}

The zoarium forms slender, columnar stems with the zooecia in 8-10 alternating longitudinal rows separated by faint, mostly indistinct furrows. 
The zooecia are elongated, inversely vase-shaped, with a narrow proximal part. Peripherally there is a narrow, elevated rim, from which the lateral and distal parts of the zooecial surface slope steeply down towards the deeply situated opesium, while the groove-like median section of the proximal cryptocyst slopes down smoothly towards the opesium, which is oblong-oval with a tapering posterior end.

The ovicells are hyperstomial, of equal length and width and embedded in the substratum.

\begin{tabular}{|c|c|c|c|c|c|c|}
\hline \multicolumn{3}{|c|}{ Measurements. } & \multicolumn{2}{|l|}{ Range } & \multicolumn{2}{|c|}{ Average } \\
\hline \multirow[t]{7}{*}{ Herfølge. } & Wid & th of zoarium ............ & $0.88-1.14$ & $\mathrm{~mm}$. & 1.02 & $\mathrm{~mm}$. \\
\hline & $\mathrm{Lz}$ & $\ldots \ldots \ldots \ldots \ldots \ldots \ldots \ldots \ldots \ldots \ldots$ & $0.52-0.57$ & - & 0.56 & - \\
\hline & $1 z$ & $\ldots \ldots \ldots \ldots \ldots \ldots \ldots \ldots$ & 0.26 & - & 0.26 & - \\
\hline & ho & $\ldots \ldots \ldots \ldots \ldots \ldots \ldots \ldots$ & 0.26 & - & 0.26 & - \\
\hline & 10 & $\ldots \ldots \ldots \ldots \ldots \ldots \ldots \ldots$ & $0.13-0.16$ & - & 0.15 & - \\
\hline & hov & $\ldots \ldots \ldots \ldots \ldots \ldots \ldots \ldots \ldots$ & $0.13-0.16$ & - & 0.15 & - \\
\hline & lov & $\ldots \ldots \ldots \ldots \ldots \ldots \ldots \ldots \ldots \ldots \ldots$ & 0.16 & - & 0.16 & - \\
\hline \multirow[t]{5}{*}{ Saltholm. } & Wid & th of zoarium $\ldots \ldots \ldots \ldots$ & $0.68-0.99$ & $\mathrm{~mm}$. & 0.81 & $\mathrm{~mm}$. \\
\hline & $\mathrm{Lz}$ & $\ldots \ldots \ldots \ldots \ldots \ldots \ldots \ldots$ & $0.44-0.52$ & - & 0.49 & - \\
\hline & $\mathrm{lz}$ & $\ldots \ldots \ldots \ldots \ldots \ldots \ldots \ldots$ & $0.18-0.26$ & - & 0.24 & - \\
\hline & ho & $\ldots \ldots \ldots \ldots \ldots \ldots \ldots \ldots$ & $0.13-0.21$ & - & 0.16 & - \\
\hline & lo & $\ldots \ldots \ldots \ldots \ldots \ldots \ldots \ldots$ & $0.08-0.16$ & - & 0.12 & - \\
\hline \multirow[t]{5}{*}{ Kagstrup. } & Wid & th of zoarium $\ldots \ldots \ldots \ldots$ & $0.62-0.68$ & $\mathrm{~mm}$. & 0.65 & $\mathrm{~mm}$. \\
\hline & $\mathrm{Lz}$ & $\ldots \ldots \ldots \ldots \ldots \ldots \ldots \ldots$ & $0.52-0.57$ & - & 0.54 & - \\
\hline & $1 z$ & $\ldots \ldots \ldots \ldots \ldots \ldots \ldots \ldots$ & $0.23-0.26$ & - & 0.25 & - \\
\hline & ho & $\ldots \ldots \ldots \ldots \ldots \ldots \ldots \ldots$ & 0.21 & - & 0.21 & - \\
\hline & lo & $\ldots \ldots \ldots \ldots \ldots \ldots \ldots$ & $0.13-0.16$ & - & 0.14 & - \\
\hline
\end{tabular}

According to VoIgT (1959, p. 45) the Rügen material of this species has an average zoarial width of $0.8-0.9 \mathrm{~mm}$. and a zooecial length of about $0.55-$ $0.60 \mathrm{~mm}$.

\section{Material.}

Stevns, Bryozoan Limestone - 6 specimens; Kagstrup - 4 specimens; Thorslunde - 7 specimens; Faxe I - 1 specimen; Saltholm - 5 specimens; the South Harbour of Copenhagen - 28 specimens; Herfølge, Bryozoan Limestone 155 specimens.

Remarks.

Vorgt (1959, p. 45) has shown that in previous studies this species has been confused with Vincularia canalifera $v$. HAGENOW from Maastricht, from which it differs by having an oblong-oval opesium, which occupies about half of the length of the zooecium, while $V$. canalifera has a more rounded opesium with a straight lower margin; furthermore the length of the opesium at most amounts to a third of the length of the zooecium. 
The measurements of the Danian material show that the specimens from Herfølge agree with the material from Rügen as regards the ratio of opesial length to zooecial length, while the opesial length in the fragments from Saltholm constitute only about one third of the length of zooecium. The specimens from the latter locality, however, have the same shape of opesium as the material from Rügen and there can be no doubt that the colonies from Saltholm ought to be referred to $V$. prismatica.

Distribution. Senonian: Germany: Rügen.

Danian: Denmark: Stevns, Kagstrup, Thorslunde, Faxe, Saltholm, Copenhagen, Herfølge, and Klintholm.

\section{ELECTRIDAE LA GAAIJ, 1952}

HERPETOPORA LANG, 1914

\section{3. "Herpetopora" danica Lang}

Plate 4, Fig. 6.

1914 Herpetopora danica Lang. Geol. Mag. Dec. VI. Vol. I, p. 7, Pl. II, Fig. 6-7.

1920 Herpetopora danica LAng. CANU and Bassler. U.S. Nat. Mus. Bull. 106, p. 81, P1. 80, Fig. 1.

1930 Herpetopora danica Lang. Voigt. Leopoldina. VI, p. 410, Pl. 1, Fig. 6.

1932 Herpetopora danica Lang. Dartevelle. Ann. Soc. Roy. Zool. Belg. LXIII, p. 62.

\section{Description.}

The zoarium is encrusting, uniserial, with bilateral ramification. The zooecia are oblong-elliptical. In Herpetopora the normal zooecium (LANG, 1914, p. 7) consists of a distal "capitular" and a proximal "caudal" portion. In Herpetopora danica the caudal portion is not developed, whereas the capitular portion is large, almost occupied by the dominating opesium. According to LANG, sealed zooecia are common; heteromorphous individuals sometimes occur.

Ovicells: On the specimen P1. 4, Fig. 6 on the left above the lowest zooecium there is a cell whose size and shape might suggest an ovicell; however, it may be a heteromorphous zooecium.

Avicularia have not been observed.

\section{Measurements.}

\begin{tabular}{|c|c|c|c|c|}
\hline & & & Range & Average \\
\hline Faxe, & $\mathrm{Lz}$ & . . & $0.73-0.94 \mathrm{~mm}$. & $0.83 \mathrm{~mm}$. \\
\hline Thorslunde. & $\mathrm{lz}$ & $\ldots \ldots \ldots \ldots \ldots \ldots \ldots$ & $0.52-0.68-$ & $0.59-$ \\
\hline & ho & $\ldots \ldots \ldots \ldots \ldots \ldots \ldots \ldots \ldots$ & $0.57-0.68$ & 0.63 \\
\hline & lo & $\ldots \ldots \ldots \ldots \ldots \ldots \ldots$ & $0.36-0.47$ & 0.43 \\
\hline
\end{tabular}

Material. Faxe - 4 specimens; Thorslunde - 1. specimen. 
Remarks.

According to ThOMAS and LARWOOD (1956, p. 371; 1960, p. 370), Herpetopora LANG is to be regarded as a junior synonym of the genus Pyripora D'OrbignY. Their diagnosis of this genus is as follows (1960, p. 370): "Zoarium encrusting, uni- or pluri-serial; zooecia pyriform, budded distally and uni- or bi-laterally or both, proximally tapered, often with a very slender, tubular proximal cauda; aperture longitudinally oval; cryptocyst usually present, forming aproximal shelf or a narrow shelf round most of the opesia; gymnocyst well developed proximally; no calcified basal wall; no ovicells, spines or avicularia."

As regards Herpetopora danica LANG the authors (1960, p. 381) state: "Prof. E. VoIGT has very kindly lent us a well-preserved specimen from the Upper Maastrichtian of Hemmoor, encrusting a piece of echinoid test. This specimen is like the holotype in its fundamental features, but at least three zooecia have prominent hyperstomial ovicells. It is clear that although ovicells occur they are not frequent and that in less extensive zoaria they may not therefore be present - as in the case in the holotype of Herpetopora danica LANG (D. 19429) and in the paratype (D. 44407). However, as all other zoarial and zooecial characters are so similar, the species as a whole may be regarded as ovicelled and therefore excluded from Pyripora. We would refer it provisionally to Membranipora s. 1."

I have preferred for the present to preserve the generic name "Herpetopora", this being in inverted commas in order to mark the temporary solution.

My material of $H$. danica has smaller zooecia than the specimens from Faxe which formed the basis of LANG's establishment of the species. In his description LANG gives an opesial length of $0.72-0.80 \mathrm{~mm}$. (opesial width $0.40 \mathrm{~mm}$.), CANU and BAssler $(1914$, p. 81) measured the same opesial length on their material from Alabama (Vicksburgian); for specimens from the Belgian Eocene (Lédian) DARTEVELLE gives the average zooecial length as $0.75 \mathrm{~mm}$., whereas VoIGT's material from Rügen (VoIGT, 1930, p. 410) exceeds $1 \mathrm{~mm}$. in zooecial length; in Coral-reef Limestone from Faxe VoIGT found a form whose length of cell is $0.88 \mathrm{~mm}$., i.e. the same order of magnitude as my material.

In Senonian White Chalk (Actinocamax quadratus zone) at Lägerdorf in Holstein VorgT $(1949$, p. 9) found specimens of $H$. danica which, owing to the size of the zooecium, he places to a new subspecies Herpetopora danica titania VoIGT. Here the zooecial length is $1.3-1.5 \mathrm{~mm}$.

\section{Distribution.}

Senonian: Germany: Rügen; England: Thorpe St. Andrew (Norfolk).

Danian: Denmark: Faxe, Thorslunde.

Eocene: Belgium: Forest; U.S.A.: Alabama. 
HINCKSINIDAE CANU AND BASSLER, 1927

APLOUSINA CANU AND BASSLER, 1927

\section{Aplousina fulgora (Brydone)}

Plate 4, Figs. 7-8.

1916 Membranipora fulgora Brydone. Geol. Mag. Dec. VI. Vol. 3, p. 434, PI. XVIII, Fig. 6.

1925 Membranipora clavata Levinsen. Vidensk. Selsk. Skr. 8. Ser. VII. 3, p. 315, Pl. 1, Fig. 10.

1930 Membranipora fulgora BRYDone. VoIgT. Leopoldina. VI, p. 415, PI. 2, Fig. 15.

1930 Membranipora fulgora BRydone. Further Notes on Chalk Polyzoa. I, p. 34, P1. XI, Fig. 16.

1930 Membranipora subfulgora BRYDONE. Further Notes on Chalk Polyzoa. I, p. 33, Pl. XI, Fig. 13.

\section{Description.}

The zoarium is encrusting, unilamellar, with irregularly arranged zooecia separated by slight depressions.

The zooecia are rather large, mostly broadly hexagonal or rounded-hexagonal but otherwise of rather variable, in part irregular shape. The opesium occupies the whole of the surface of the zooecium within the narrow, sometimes rough rim. The distal part of the base of the zooecium is embedded in relation to the rest of the basal part; dietellae are present.

The ovicells are endozooecial, wide and short; they are rare.

Avicularia occur interzooecially; they may equal the zooecia in length, but are normally only half as wide; they are sole-shaped, the width increasing towards the distal, rounded end of the avicularium.

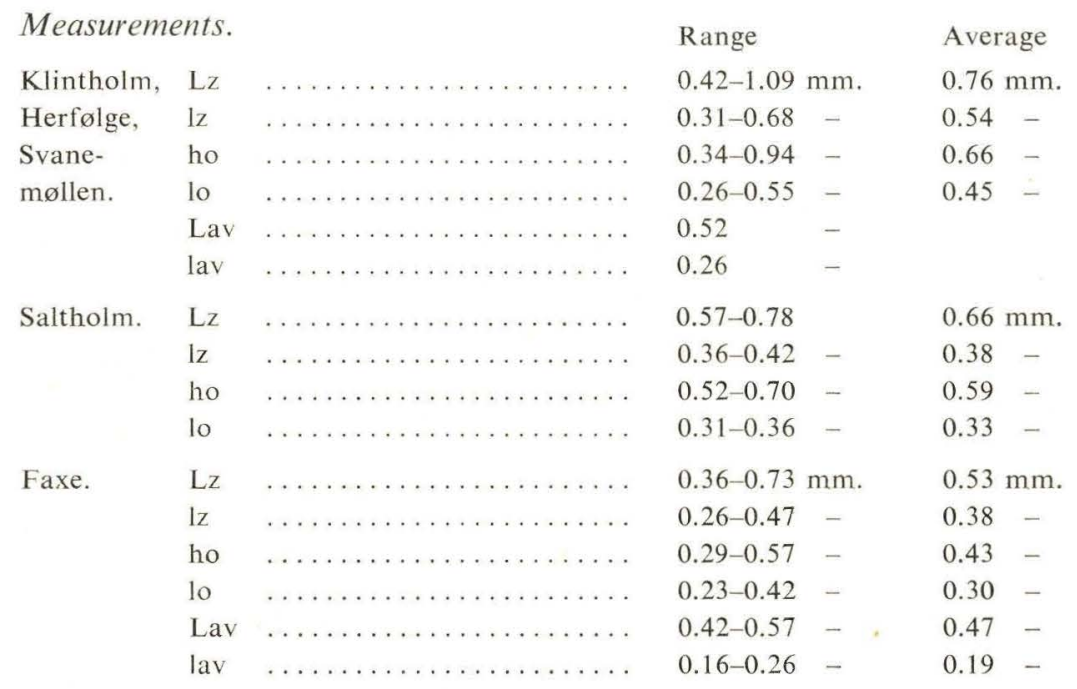




\begin{tabular}{|c|c|c|c|c|c|c|}
\hline \multirow{4}{*}{$\begin{array}{l}\text { Stevns, } \\
\text { Kagstrup. }\end{array}$} & \multirow{2}{*}{\multicolumn{3}{|c|}{ 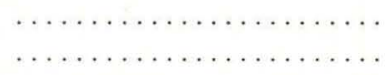 }} & $0.36-0.78$ & $\mathrm{~mm}$. & $0.62 \mathrm{~mm}$. \\
\hline & & & & $0.39-0.57$ & - & $0.43-$ \\
\hline & \multicolumn{3}{|c|}{$\ldots \ldots \ldots \ldots \ldots \ldots \ldots$} & $0.31-0.70$ & - & 0.49 \\
\hline & $\ldots$ & \multicolumn{2}{|c|}{$\ldots \ldots \ldots \ldots \ldots \ldots \ldots \ldots$} & $0.29-0.39$ & - & 0.35 \\
\hline \multirow{6}{*}{\multicolumn{2}{|c|}{$\begin{array}{l}\text { Erratic boulders, } \\
\text { Wulmstorf (Germany). }\end{array}$}} & $\mathrm{Lz}$ & $\ldots \ldots \ldots \ldots$ & $0.55-0.73$ & $\mathrm{~mm}$. & $0.66 \mathrm{~mm}$. \\
\hline & & $\mathrm{lz}$ & $\ldots \ldots \ldots \ldots$ & $0.36-0.57$ & - & $0.46-$ \\
\hline & & ho & $\ldots \ldots \ldots \ldots$ & $0.47-0.67$ & - & 0.59 \\
\hline & & lo & $\ldots \ldots \ldots \ldots$ & $0.36-0.49$ & - & 0.40 \\
\hline & & Lav & $\ldots \ldots \ldots$ & $0.57-0.62$ & - & \\
\hline & & lav & $\ldots \ldots \ldots \ldots$ & $0.16-0.21$ & - & \\
\hline \multirow{2}{*}{\multicolumn{2}{|c|}{ BRYDONE (1914, p. 434) }} & ho & $\ldots \ldots \ldots \ldots$ & 0.65 & $\mathrm{~mm}$. & \\
\hline & & lo & $\ldots \ldots \ldots \ldots$ & 0.50 & - & \\
\hline \multicolumn{2}{|c|}{$\begin{array}{l}\text { White Chalk of } \\
\text { Stevns Klint. }\end{array}$} & $\mathrm{Lz}$ & & $0.75-0.80$ & - & \\
\hline
\end{tabular}

\section{Material.}

Stevns, Bryozoan Limestone - 1 specimen; Kagstrup - 1 specimen; Faxe 7 specimens; Faxe II - 2 specimens; Faxe XI - 2 specimens; Saltholm, Bryozoan Limestone - 1 specimen; Svanemøllen, Bottom Conglomerate - 54 specimens; Herfølge, Bryozoan Limestone - 4 specimens; Klintholm, Bryozoan Limestone -5 specimens.

Remarks.

I consider A. subfulgora Brydone to be identical with A. fulgora Brydone. In BRYDONE's opinion (1930, p. 33) A. subfulgora is "a direct ancestor of $M$. fulgora, which has even thinner and lower walls, and irregularly shaped avicularia, without any internal front wall." Changes in the thickness and height of the walls probably reflect the existing environmental conditions and can hardly be used as a sure criterion for the delimitation of the species; nor is the more or less regular shape of the avicularia any reliable indication. The measurements indicated above show that this species is very variable, and that the variation is as pronounced among specimens from the same locality as among specimens of different stratigraphical positions.

The colonies of A. fulgora from Svanemøllebugten examined come from basal conglomerate of the Paleocene; all the specimens encrust Ditrupula schlotheimi ROSENKRANTZ.

\section{Distribution.}

Senonian: England: The Campanian of the Isle of Wight (A. subfulgora); Maastrichtian, Norfolk (A. fulgora). Denmark: Stevns (Maastrichtian).

Danian: Denmark: Stevns, Kagstrup, Faxe, Saltholm, Copenhagen, Herfølge, and Klintholm. 


\section{Aplousina ødumi n.sp.}

Plate 5, Figs. 1-2.

Diagnosis.

Zooarium free, unilamellar; zooecia large, oblong-hexagonal, with finely granular surface; opesia oblong-oval, terminal; ovicells endozooecial with thickened rim.

\section{Description.}

The zooarium forms unilamellar plates with the zooecia in alternating longitudinal rows (quincunx). The zooecia are separated by a slightly salient thread. The back of the colony is irregularly sinuous, with distinct longitudinal rows separated by narrow, deep depressions, which are mutually connected by more or less steeply ascending transverse ridges.

The zooecia are oblong-hexagonal or rounded-hexagonal; the opesium is terminal, oblong-oval, somewhat variable in shape, surrounded by a comparatively well-developed gymnocyst and wide lateral rims; the whole front is finely granulated. Regenerated zooecia occur.

The ovicells are endozooecial, convex. The wide curved aperture is provided with a thickened rim, which usually consists of two lateral halves, tapering towards the centre of the ovicell.

Avicularia have not been observed.

Measurements.

\begin{tabular}{|c|c|c|c|c|c|c|}
\hline \multirow{3}{*}{ Herfølge. } & \multirow{3}{*}{$\begin{array}{l}\mathrm{Lz} \\
\mathrm{lz}\end{array}$} & & \multicolumn{2}{|l|}{ Range } & \multicolumn{2}{|c|}{ Average } \\
\hline & & $\ldots \ldots \ldots \ldots \ldots \ldots \ldots \ldots$ & $0.75-1.00$ & $\mathrm{~mm}$. & 0.91 & $\mathrm{~mm}$. \\
\hline & & $\ldots \ldots \ldots \ldots \ldots \ldots \ldots$ & $0.52-0.78$ & - & 0.63 & - \\
\hline \multirow{8}{*}{ Faxe. } & ho & $\ldots \ldots \ldots \ldots \ldots \ldots \ldots$ & $0.42-0.68$ & - & 0.51 & - \\
\hline & lo & $\ldots \ldots \ldots$ & $0.26-0.47$ & - & 0.39 & - \\
\hline & lov & $\ldots \ldots \ldots \ldots \ldots \ldots \ldots \ldots$ & 0.52 & - & & \\
\hline & $\mathrm{Lz}$ & $\ldots \ldots \ldots \ldots \ldots \ldots \ldots \ldots$ & $0.73-1.20$ & $\mathrm{~mm}$. & 0.96 & $\mathrm{~mm}$. \\
\hline & $1 z$ & $\ldots \ldots \ldots \ldots \ldots \ldots \ldots$ & $0.57-0.94$ & - & 0.69 & - \\
\hline & ho & $\ldots \ldots \ldots \ldots \ldots \ldots$ & $0.52-0.68$ & - & 0.60 & - \\
\hline & lo & $\ldots \ldots \ldots \ldots \ldots \ldots \ldots$ & $0.29-0.47$ & - & 0.39 & -.. \\
\hline & lov & $\ldots \ldots \ldots \ldots \ldots \ldots \ldots \ldots$ & 0.52 & _- & & \\
\hline
\end{tabular}

Material.

Faxe - 22 specimens; Faxe II - 1 specimen; Herfølge, Bryozoan Limestone 72 specimens.

Holotype. Pl. 5, Fig. 2. Herfølge, Bryozoan Limestone.

Paratype. Pl. 5, Fig. 1. Herfølge, Bryozoan Limestone. 


\section{Remarks.}

The species is dedicated to Dr. H. ØDum, Director of the Geological Survey of Denmark.

A. ødumi bears great resemblance to the American species $A$. disjuncta GABB and Horn (see CANu and Bassler, 1933, p. 15, Figs. 1-6) from the Paleocene? Vincentown Limesand of New Jersey. Points of similarity are the shape, appearance, and size of the zooecia ( $\mathrm{Lz}: 0.85 \mathrm{~mm}$., lz: $0.55 \mathrm{~mm}$.), the presence of regenerated zooecia, and the type of ovicell. Features which are different are the shape of the colony, which in A. disjuncta is bifoliate and compressed; furthermore, there is a partial or total disjunction between the zooecia, an expression of an incomplete intercellular calcification.

The species also has features in common with the Senonian species Membranipora baltica Voigt (1930, p. 428, Pl. 5, Figs. 9-10=M. dilatata LeVINSEN (non Reuss), p. 322, Pl. II, Figs. 16a-d), especially regarding the shape of the zooecium. $M$. baltica has slightly smaller zooecia (Lz: 0.70-0.90 mm., lz: 0.60$0.75 \mathrm{~mm}$.), but larger, especially wider, opesia (ha: $0.50-0.70 \mathrm{~mm}$.), which are more deeply embedded than in $A$. odumi, and a slightly developed gymnocyst. The ovicell in the Senonian species is helmet-shaped, $0.28-0.30 \mathrm{~mm}$., and the form of the colony also differs, the zoaria being encrusting.

\section{Distribution.}

Danian: Denmark: Stevns, Faxe, Herfølge, and Klintholm.

\section{ELLISINA NORMAN, 1903}

\section{Ellisina humiliata (Brydone)}

Plate 5, Fig. 3.

1910 Membranipora humiliata BRydone. Geol. Mag. Dec. V. Vol. VII, p. 4, Pl. III, Figs. 1-3.

1925 Membranipora reticulata LeVInSEn. Vidensk. Selsk. Skr. 8. Ser. VII. 3, p. 339, PI. III, Fig. 33.

1930 Ellisina humiliata (BRydone). Volgt. Leopoldina. VI, p. 446, Pl. 13, Figs. 3, 17. 1930 Ellisina reticulata Levinsen. Voigt. Leopoldina. VI, p. 447, Pl. 13, Fig. 5.

\section{Description.}

The zoarium is encrusting, generally with irregularly arranged zooecia separated by fine furrows.

The zooecia are oblong, very variable in shape and measures. There is no frontal wall, and there are very low lateral walls with 10-18 dietellae, which appear as thin areas on the inside of the lateral rims. According to LEVINSEN the mural rim carries about 20 spines, but the traces of these are rarely distinct.

The ovicells are hyperstomial, small, semi-elliptical, numerous, and fragile; they occur immediately above the distal rim. 
The avicularia appear as small oval structures with a comparatively large oval opesium, generally placed distally to the ovicells.

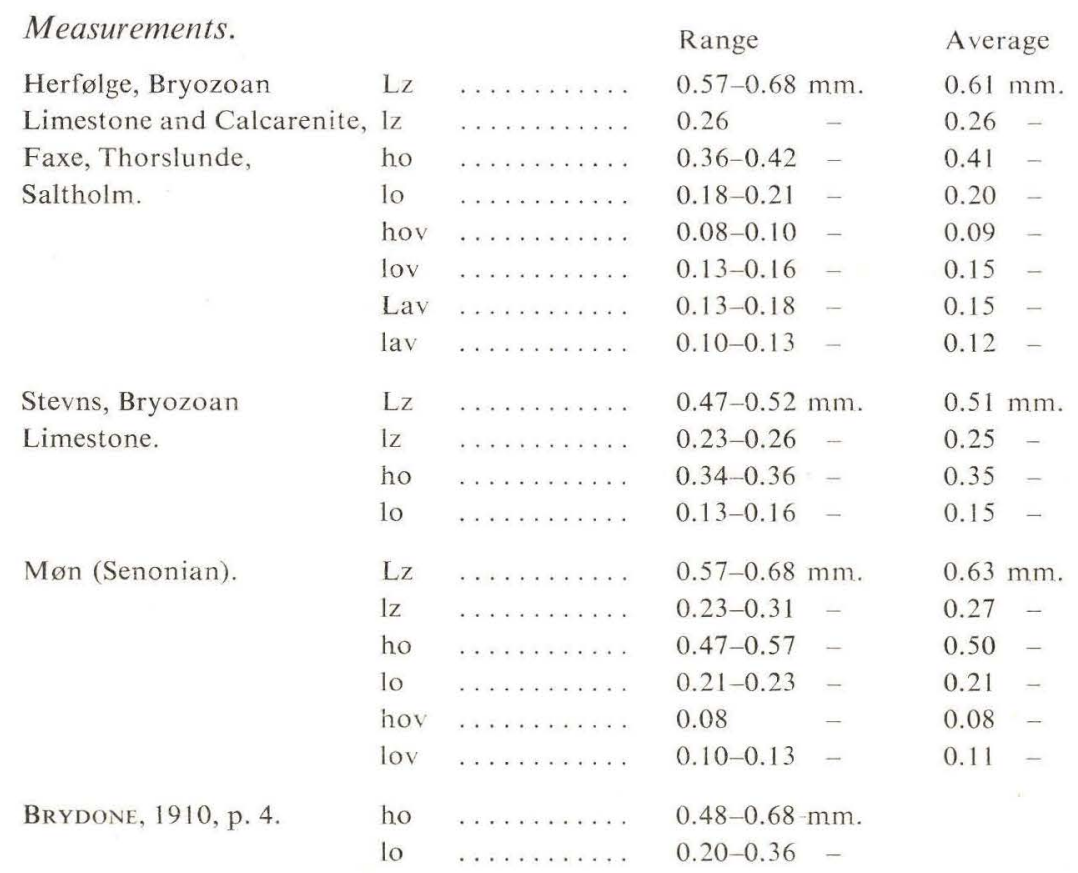

The measurements show that the length and width of zooecia are similar for specimens from the White Chalk on Møn and the colonies from the Upper Danian, while the fragments from the Lower Danian of Stevns have shorter zooecia. On the other hand, the length of the opesia in the Senonian specimens seems to be greater than in the Danian ones. BRYDONE's measurements of opesia suggest very large zooecia in the colonies from the English Chalk.

\section{Material.}

Stevns, Bryozoan Limestone - 9 specimens; Kagstrup - 6 specimens; Faxe 2 specimens; Saltholm - 3 specimens; Thorslunde - 5 specimens; Herfølge, Bryozoan Limestone -3 specimens; Calcarenite -1 specimen.

\section{Remarks.}

It is extremely doubtful whether the placing of the genus Ellisina in the family Hincksinidae can be maintained, considering that this family, among other things, is characterized by having endozooecial ovicells. Numerous Ellisina species have hyperstomial ovicells, and realizing this, CANU and BASSLER (1933, p. 18) set up a new genus, Ellisinidra, in which these species were grouped. In 
the Fossilium Catalogus (BAssler, 1934, p. 102) this genus is referred to the family Alderinidae, CANU and BASSLER 1927 (= Calloporidae Norman, 1903). However, in the Treatise on Invertebrate Paleontology, Part G (1953, p. 160), BASSLER has abolished Ellisinidra, and its species have been referred again to Ellisina (Hincksinidae CANU and BASSLER). It seems to me that it would have been preferable to have kept the original distinction and to have retained Ellisinidra in the Calloporidae, the more so as there is undoubtedly a close connexion between Ellisinidra and the genus Periporosella CANU and BASSLER, the chief difference being the bifoliate form of the colony.

There can be no doubt that LevinsEN's species, Membranipora reticulata, is identical with BRYDONE's $M$. humiliata. VolgT in his remarks on $M$. reticulata (1930, p. 447) has also mentioned the close relationship between the two species.

\section{Distribution.}

Senonian: England: Trimingham; Germany: Rügen; Denmark: Møn, Ålborg, and Stevns.

Danian: Denmark: Stevns, Kagstrup, Thorslunde, Faxe, Saltholm, Herfølge, and Klintholm.

\section{Ellisina britannica (Brydone)}

Plate 5, Fig. 4.

1910Membranipora Britannica Brydone. Geol. Mag. Dec. V. Vol. VII, p. 76, Pl. 8, Figs. 3-4.

1924 ?Callopora Britannica Brydone. Volgt. Pal. Zeitschr. VI. 2, p. 195, Pl. VI, Figs. 6-8.

1925 Membranipora laximaculata LeVinsen. Vidensk. Selsk. Skr. 8. Ser. VII. 3, p. 340, PI. 3, Fig. 34.

1930 Ellisina laximaculata Levinsen. Vorgt. Leopoldina. VI, p. 446, Pl. 13, Fig. 1.

\section{Description.}

The zoarium is encrusting, with the zooecia in fairly regularly alternating longitudinal rows. The zooecia are separated by fine, often almost invisible furrows.

The size and shape of the zooecia are very variable; mostly the zooecia are rounded-rhomboidal, but oblong-hexagonal zooecia also occur. Sometimes the tapering proximal part wedges in between the two proximally adjacent zooecia. The mural rim decreases in width towards the distal end. The opesium is terminal, oval, or rounded-rhomboidal, varying in size. One large and 2-4 smaller dietellae appear laterally.

The ovicells are hyperstomial, evenly convex with a semi-circular outline. They are more numerous in the Senonian than in the Danian material.

The avicularia are obliquely trapezoidal and are found on all zooecia except those bearing ovicells. The pointed distal end of the avicularia turns obliquely upwards and forwards; sometimes it is somewhat elongated and turns a little downwards. 
Measurements.

\begin{tabular}{|c|c|c|c|c|c|c|}
\hline \multirow{6}{*}{$\begin{array}{l}\text { Bryozoan } \\
\text { Limestone } \\
\text { of Herfølge } \\
\text { and } \\
\text { Saltholm. }\end{array}$} & \multirow{3}{*}{$\begin{array}{l}\mathrm{Lz} \\
\mathrm{lz}\end{array}$} & \multirow[b]{2}{*}{$\ldots \ldots \ldots \ldots \ldots \ldots \ldots \ldots$} & \multicolumn{2}{|l|}{ Range } & \multicolumn{2}{|c|}{ Average } \\
\hline & & & \multicolumn{2}{|c|}{$0.52-0.62 \mathrm{~mm}$} & \multicolumn{2}{|c|}{$0.59 \mathrm{~mm}$. } \\
\hline & & $\ldots \ldots \ldots \ldots \ldots \ldots \ldots$ & $0.36-0.47$ & - & 0.43 & - \\
\hline & & $\ldots \ldots \ldots \ldots \ldots \ldots \ldots$ & $0.36-0.55$ & - & 0.48 & - \\
\hline & 10 & $\ldots \ldots \ldots \ldots \ldots \ldots \ldots$ & $0.21-0.34$ & - & 0.29 & - \\
\hline & hov & $\ldots \ldots \ldots \ldots \ldots \ldots \ldots \ldots$ & 0.16 & - & & \\
\hline & lov & $\ldots \ldots \ldots \ldots \ldots \ldots \ldots$ & 0.21 & - & & \\
\hline & Lav & $\ldots \ldots \ldots \ldots \ldots \ldots \ldots \ldots$ & 0.10 & - & 0.10 & - \\
\hline & lav & $\ldots \ldots \ldots \ldots \ldots \ldots \ldots \ldots$ & $0.08-0.10$ & - & 0.09 & - \\
\hline \multirow[t]{8}{*}{ Faxe. } & $\mathrm{Lz}$ & $\ldots \ldots \ldots \ldots \ldots \ldots \ldots \ldots$ & \multicolumn{2}{|c|}{$0.47-0.73 \mathrm{~mm}$} & \multicolumn{2}{|c|}{$0.59 \mathrm{~mm}$. } \\
\hline & $1 z$ & $\ldots \ldots \ldots \ldots \ldots \ldots \ldots$ & $0.26-0.42$ & - & 0.34 & - \\
\hline & ho & $\ldots \ldots \ldots \ldots \ldots \ldots \ldots \ldots$ & $0.36-0.57$ & - & 0.47 & - \\
\hline & lo & $\ldots \ldots \ldots \ldots \ldots \ldots \ldots \ldots$ & $0.21-0.36$ & - & 0.27 & - \\
\hline & hov & $\ldots \ldots \ldots \ldots \ldots \ldots \ldots$ & 0.13 & - & & \\
\hline & lov & $\ldots \ldots \ldots \ldots \ldots \ldots \ldots \ldots$ & 0.21 & - & & \\
\hline & Lav & $\ldots \ldots \ldots \ldots \ldots \ldots \ldots$ & $0.13-0.16$ & - & 0.15 & - \\
\hline & lav & $\ldots \ldots \ldots \ldots \ldots \ldots \ldots \ldots \ldots$ & $0.13-0.18$ & - & 0.16 & - \\
\hline \multirow{4}{*}{$\begin{array}{l}\text { Stevns, } \\
\text { Kagstrup. }\end{array}$} & $\mathrm{Lz}$ & & \multicolumn{2}{|c|}{$0.47-0.52 \mathrm{~mm}$} & \multicolumn{2}{|c|}{$0.50 \mathrm{~mm}$. } \\
\hline & $1 \mathrm{z}$ & $\ldots \ldots \ldots \ldots \ldots \ldots \ldots \ldots$ & $0.31-0.36$ & - & 0.33 & - \\
\hline & ho & $\ldots \ldots \ldots \ldots \ldots \ldots \ldots$ & $0.36-0.47$ & - & 0.42 & - \\
\hline & lo & $\ldots \ldots \ldots \ldots \ldots \ldots \ldots \ldots$ & $0.21-0.29$ & - & 0.26 & - \\
\hline \multirow[t]{8}{*}{ Møn. } & $\mathrm{Lz}$ & $\ldots \ldots \ldots \ldots \ldots \ldots \ldots \ldots$ & \multicolumn{2}{|c|}{$0.52-0.62 \mathrm{~mm}$} & \multicolumn{2}{|c|}{$0.59 \mathrm{~mm}$} \\
\hline & $1 z$ & $\ldots \ldots \ldots \ldots \ldots \ldots \ldots \ldots$ & $0.31-0.47$ & - & 0.41 & - \\
\hline & ho & $\ldots \ldots \ldots \ldots \ldots \ldots$ & $0.44-0.52$ & - & 0.50 & - \\
\hline & lo & $\ldots \ldots \ldots \ldots \ldots \ldots \ldots \ldots$ & $0.26-0.39$ & - & 0.33 & - \\
\hline & hov & $\ldots \ldots \ldots \ldots \ldots \ldots \ldots$ & 0.21 & - & 0.21 & - \\
\hline & lov & $\ldots \ldots \ldots \ldots \ldots \ldots \ldots$ & $0.23-0.26$ & - & 0.25 & - \\
\hline & Lav & $\ldots \ldots \ldots \ldots \ldots \ldots \ldots \ldots$ & $0.26-0.29$ & - & 0.27 & - \\
\hline & lav & $\ldots \ldots \ldots \ldots \ldots \ldots \ldots$ & $0.13-0.16$ & - & 0.15 & - \\
\hline \multirow{8}{*}{$\begin{array}{l}\text { Hemmoor } \\
\text { (Germany) }\end{array}$} & $\mathrm{Lz}$ & $\ldots \ldots \ldots \ldots \ldots \ldots$ & \multicolumn{2}{|c|}{$0.68-0.78 \mathrm{~mm}$} & \multicolumn{2}{|c|}{$0.72 \mathrm{~mm}$} \\
\hline & $\mathrm{lz}$ & $\ldots \ldots \ldots \ldots \ldots \ldots \ldots$ & $0.31-0.47$ & - & 0.38 & - \\
\hline & ho & $\ldots \ldots \ldots \ldots \ldots \ldots \ldots$ & $0.52-0.57$ & - & 0.53 & - \\
\hline & lo & $\ldots \ldots \ldots \ldots \ldots \ldots \ldots$ & $0.26-0.36$ & - & 0.31 & - \\
\hline & hov & & $0.18-0.21$ & - & 0.20 & - \\
\hline & lov & & 0.21 & - & 0.21 & - \\
\hline & Lav & $\ldots \ldots \ldots \ldots \ldots \ldots \ldots$ & $0.18-0.26$ & - & 0.22 & - \\
\hline & lav & $\ldots \ldots \ldots \ldots \ldots \ldots \ldots$ & $0.10-0.18$ & - & 0.15 & - \\
\hline
\end{tabular}

The measurements show that the material from Herfølge, Saltholm, Faxe, and Møn has much the same zooecial and opesial dimensions, whereas the specimens from Stevns and Kagstrup have smaller zooecia and opesia. The fragment from Hemmoor in Germany (Maastrichtian), which was kindly submitted to me by Professor Vorgt, has considerably longer (but not wider) zooecia. 


\section{Material.}

Stevns, Bryozoan Limestone - 4 specimens; Kagstrup - 7 specimens; Saltholm, Bryozoan Limestone - 1 specimen; Faxe - 6 specimens; Faxe II 3 specimens; Herfølge, Bryozoan Limestone - 1 specimen; Herfølge, Calcarenite -2 specimens.

Remarks.

Ellisina britannica (BRYDONE) belongs to a group of species, which can only be distinguished with difficulty because of numerous common features and great variation in size and shape. Ellisina praecursor (BRYDONE) (1929, p. 29, Pl. IX, Fig. 16) (previously Membranipora britannica praecursor BR.), which perhaps is identical with Reptoflustrella simplex D'ORBIGNY (1852, p. 571, Pl. 731, Figs. 15-16), and Ellisina demissa (BRYdone) (1916, p. 98, Pl. VI, Fig. 5) also belong to this group. There can be no doubt that LEVINSEN's species, M. laximaculata belongs to this group, and I share BRYDONE's view (1936, p. 81) that M. laximaculata is identical with E. britannica "in its best state." The reason why VoigT's species, Callopora Britannica, from the Subhersynian Santonian (1924, p. 195), has been queried in the list of synonyms, is that Vorgt later (1949, p. 25) has come to doubt the justification of this reference, but cannot make a final decision until more material has been examined.

VolGT $(1930$, p. 446) has stated in his remarks on E. laximaculata that the Rügen material of this species has a zooecial length of about $0.90 \mathrm{~mm}$.; but as mentioned above, the length of the zooecia of the specimens from Møn is only about $0.60 \mathrm{~mm}$. It is possible that the German form with large zooecia ought to be separated as a distinct species.

\section{Distribution .}

Senonian: England: Trimingham; Germany: Rügen, Lüneburg, Gr.-Bülten (?); Holland: Maastricht; Denmark: Møn, Stevns, Ålborg, Gudumlund.

Danian: Denmark: Stevns, Kagstrup, Faxe, Saltholm, Herfølge, and Klintholm.

\section{CALLOPORIDAE NORMAN, 1903 \\ CALLOPORA GRAY, 1848}

\section{Callopora monocera (Marsson)}

Plate 5, Figs. 5-6.

1887 Membranipora monocera Marsson. Pal. Abh. IV. 1, p. 57, Pl. 5, Fig. 14.

1925 Membranipora monocera Marsson. Levinsen. Vidensk. Selsk. Skr. 8 Ser. VII, 3, p. 328.

1930 Membranipora monocera Marsson. Volgt. Leopoldina. VI, p. 420, PI. 4, Figs. 1-3. 


\section{Description .}

The zoarium forms frequently free, unilamellar, slightly curved plates, rarely encrusting or vincularian. The zooecia are placed in alternating longitudinal rows separated by distinct furrows. On the back of the zoarium the zooecia are oblong-hexagonal, nearly bottle-shaped, very convex, separated by deep furrows.

The zooecia are elongated, rounded-hexagonal, with tapering gymnocyst. The opesium is oval or angularly oval, embedded and surrounded by a narrow, ascending mural rim; on the outside of the rim, in the two distal corners, there is a pair of circular traces of spines. The gymnocyst is convex; on this, immediately below the opesium, there is a circular or semi-circular platform, from which there is a tubular projection outwards or obliquely upwards. This may be interpreted as either a vibraculum or perhaps an avicularium.

The ovicells are hyperstomial, convex, and very prominent; the scars of ovicells are rounded rectangles.

Avicularia: see above.

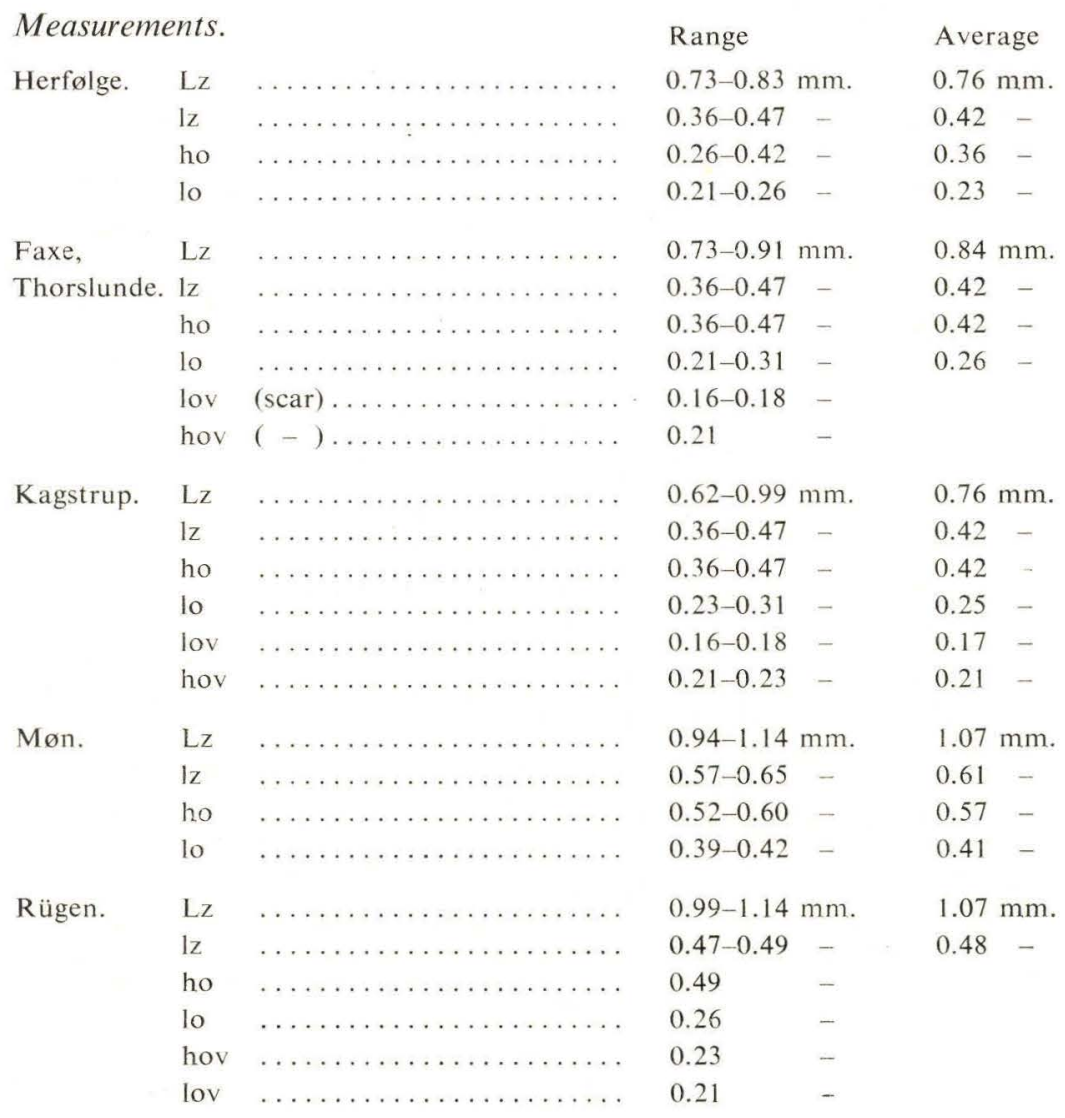


The measurements show that the Senonian material from Møn and Rügen has longer and wider zooecia than the Danian specimens, and correspondingly longer opesia. The measurements of ovicells cannot be compared directly, as the values from Rügen are based on the measurements of one ovicell, while the measurements of the Danian material were taken on scars of ovicells. There does not seem to be appreciable variation in zooecial and opesial dimensions within the Danian.

\section{Material.}

Danian: Stevns - 1 specimen; Kagstrup - 3 specimens; Faxe -69 specimens; Faxe II - 3 specimens; Faxe XI - 4 specimens; Herfølge -2 specimens.

\section{Remarks.}

The specimens from Herfølge examined are vincularian with slender stems. The other colonies from the Danian form curved plates which probably have been joined to form tubular colonies.

The distal pair of spine-traces on the apertural rim has not been mentioned in other descriptions of this species; it is presumably a feature characteristic of the Danian specimens. Still, LevinSEN states that on cylindrical stems there may be three rather large traces of spines on the distal half of the mural rim.

\section{Distribution.}

Senonian: Germany: Rügen; Denmark: Møn, Gudumlund, Stevns.

Danian: Germany: Erratic boulders from Köthen. Denmark: Stevns, Kagstrup, Faxe, Saltholm, Herfølge, and Klintholm.

\section{Callopora invigilata (Brydone)}

Plate 6, Fig. 1, Plate 28, Fig. 1.

1910 Membranipora invigilata Brydone. Geol. Mag. Dec. V. Vol. VII, p. 76, Pl. VIII, Figs. 1-2.

1930 Membranipora (Callopora) invigilata Brydone. Voigt. Leopoldina. VI, p. 441, Pl. 10, Figs. 4-6.

\section{Description .}

The zoarium is encrusting, unilamellar, with the zooecia placed in quincunx, mutually free or separated along lateral rims by distinct furrows.

The zooecia are elliptical, with large, centrally placed opesia, and broad mural rims, which slope evenly towards the opesia.

The ovicells are hyperstomial and globose, but rarely preserved; the scars of ovicells are rounded-rectangular.

Of avicularia there are two types: frontal and interzooecial. The frontal 
avicularia (or vibracula?) are semi-circular, tubular prominences rising from a semi-elliptical platform proximal to the opesium. The interzooecial avicularia are long, sole-shaped, with a wide distal part and a narrow proximal part; the latter type occurs only rarely in the Danian material.

\begin{tabular}{|c|c|c|c|c|c|c|}
\hline \multicolumn{3}{|c|}{ Measurements. } & \multicolumn{2}{|l|}{ Range } & \multicolumn{2}{|c|}{ Average } \\
\hline Herfølge, & $\mathrm{Lz}$ & $\ldots \ldots \ldots \ldots \ldots \ldots \ldots \ldots \ldots$ & $0.55-0.68$ & $\mathrm{~mm}$. & 0.60 & $\mathrm{~mm}$. \\
\hline Faxe, & $\mathrm{Iz}$ & $\ldots \ldots \ldots \ldots \ldots \ldots \ldots \ldots$ & $0.42-0.60$ & - & 0.47 & - \\
\hline Thorslunde. & ho & $\ldots \ldots \ldots \ldots \ldots \ldots \ldots \ldots$ & $0.31-0.44$ & - & 0.39 & - \\
\hline & lo & $\ldots \ldots \ldots \ldots \ldots \ldots \ldots \ldots$ & $0.23-0.36$ & - & 0.29 & - \\
\hline & hov & $\ldots \ldots \ldots \ldots \ldots \ldots \ldots \ldots$ & $0.13-0.16$ & - & 0.14 & - \\
\hline & lov & $\ldots \ldots \ldots \ldots \ldots \ldots \ldots \ldots$ & $0.18-0.31$ & - & 0.23 & - \\
\hline & Lav & (frontal) $\ldots \ldots \ldots \ldots \ldots$ & 0.10 & - & & \\
\hline & lav & $(-\quad) \ldots \ldots \ldots \ldots \ldots$ & 0.13 & - & & \\
\hline & Lav & (interzooecial) $\ldots \ldots \ldots \ldots$ & 0.62 & - & & \\
\hline & lav & $(\quad-\quad) \ldots \ldots \ldots \ldots$ & 0.26 & - & & \\
\hline
\end{tabular}

BRYDONE (1910, p. 76) gives the following measurements of material from Trimingham:

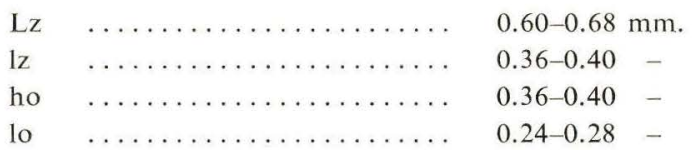

It appears from these measurements that the Senonian specimens from England have narrower zooecia than those from the Danian.

Material.

Thorslunde - 2 specimens; Faxe - 1 specimen; Herfølge - 13 specimens.

\section{Distribution .}

Senonian: England, Gravesend, Trimingham; Germany: Misburg, Rügen.

Danian: Denmark, perhaps all zones: Thorslunde, Faxe, Saltholm, Herfølge, and Klintholm.

\section{Callopora subcupolata n.sp.}

Plate 5, Fig. 7.

Diagnosis.

Zoarium encrusting, consisting of elliptical or hexagonal zooecia in alternating longitudinal rows. Opesium circular, placed centrally. Ovicells hyperstomial, globular, embedded, with a slight carina. Tubular avicularia appear in pairs above the opesium. 
Description.

The zoarium is encrusting, unilamellar, with the zooecia in alternating longitudinal rows. The demarcation of the individual zooecia is difficult to observe because of the placing of the avicularia (see below).

The shape of the zooecia is elliptical or rounded-hexagonal. The opesium is mostly circular, placed centrally.

The ovicells are hyperstomial, embedded, globular, with a slight carina. Laterally and distally they are surrounded by tubular avicularia.

Distally to the opesium there are two tubular avicularia (-or vibracula?-) with circular apertures. The avicularia together with those of the surrounding zooecia form a circle of six tubes which are mutually connected by low ridges.

Measurements.

\begin{tabular}{|c|c|c|c|c|c|c|}
\hline \multirow{3}{*}{ Faxe. } & \multirow[b]{2}{*}{$\mathrm{Lz}$} & \multicolumn{3}{|c|}{ Range } & \multicolumn{2}{|c|}{ Average } \\
\hline & & .... & 0.42 & $\mathrm{~mm}$. & 0.42 & $\mathrm{~mm}$. \\
\hline & & 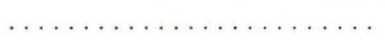 & $0.34-0.36$ & - & 0.35 & - \\
\hline & ho & 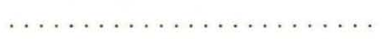 & $0.16-0.21$ & - & 0.17 & - \\
\hline & lo & & $0.16-0.21$ & - & 0.17 & - \\
\hline & hov & & $0.21-0.23$ & - & 0.21 & - \\
\hline & lov & 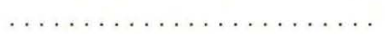 & 0.21 & - & 0.21 & - \\
\hline & Lav & 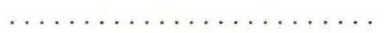 & $0.08-0.10$ & - & & \\
\hline & lav & …, & $0.10-0.13$ & - & & \\
\hline
\end{tabular}

Material.

Faxe - 8 specimens; Faxe XI - 1 specimen; Herfølge, Calcarenite - 1 specimen.

Holotype. Pl. 5, Fig. 7, Faxe, Bryozoan Limestone.

Remarks.

Callopora subcupolata n.sp. habitually bears a certain resemblance to Membranipora cupolata BRYDONE (Geol. Mag. 1916, p. 242, Pl. X, Figs. 5-6) from English Senonian. Apart from the deviation in stratigraphical distribution, $M$. cupolata differs from $C$. subcupolata by having more irregularly arranged zooecia, for which reason the tubular avicularia do not form circles as in the Danian form. Furthermore, $M$. cupolata is characterized by having elongate ovicells, which distally taper into a short spike.

Verticillate avicularia are also found in Callopora monilifera (D'ORBIGNY) (Pal. Franc. Terr. Crét. Vol. 5, p. 577, Pl. 732, Figs. 6-9) from Santonian deposits in France and Germany.

Distribution. Upper Danian: Faxe and Herfølge. 


\section{Callopora lyra (v. Hagenow)}

Plate 7, Fig. 1.

1839 Cellepora lyra v. Hagenow. N. Jahrb. f. Min., p. 269, PI. IV, Fig. 8.

1851 Cellepora (Dermatopora) lyra v. HAGENow. Die Bryozoen der Maastrichter Kreidebildung, p. 98, P1. XI, Fig. 2.

1887 (non) Membranipora lyra (v. Hagenow). Marsson, Pal. Abh. IV. 1, p. 59, Pl. V, Fig. 17.

1892 Membranipora lyra (v. Hagenow). Hennig, Lunds Univ. Årsskr. XXVIII, p. 14, Pl. 1, Fig. 3.

1910 Membranipora dolium Brydone. Geol. Mag. Dec. V. Vol. VII, p. 146, P1. XIV, Figs. 4-6.

1925 Membranipora bispinosa LevinSEn. Vidensk. Selsk. Skr. 8. Ser. VII, 3, p. 308, PI. I, Fig. 4.

1930 Membranipora (Callopora) lyra v. Hagenow. Vorgt, Leopoldina, VI, p. 436, PI. 8, Fig. 1.

\section{Description.}

The zoarium is encrusting, with the zooecia in alternating longitudinal rows.

The zooecia are rounded-hexagonal, with a broad, well demarcated lyriform rim round an angular-oval opesium.

The ovicells are hyperstomial, rounded-triangular, highly convex and prominent with a humpy top part, slightly carinate in the middle. The scar of the ovicell is rounded rectangular.

Of avicularia there are two types: (1) A pair of ring-shaped avicularia with circular or oval areas in the upper part of the lyriform rim, off the distal margin of the opesium; the rim is somewhat broader there than in the rest. (2) Long, narrow interzooecial avicularia with a constricted middle part. On the Danian material there are on the outer side of the rim-or in the furrow outside it-, nearly in the middle of the zooecium, a pair of oval pores surrounded by a narrow rim. A corresponding pair of pores occur on the posterior part of the rim; these pores may be avicularia.

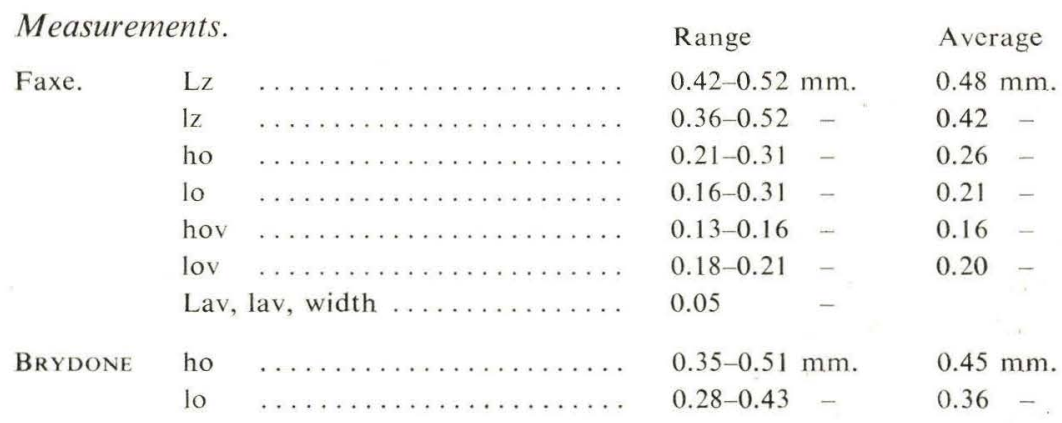

Material. Faxe - 10 specimens; Faxe XI - 1 specimen. 
Remarks.

The laterally and proximally placed pairs of pores on the Danian specimens apparently do not occur on Senonian material of this species. Hennig, however, states that between the zooecia there are often small pores surrounded by a rim. The narrow interzooecial avicularia have not been found on the material from Faxe, but as such, according to Vorgt, are rare, the cause may be that my material of this species is not sufficiently large. The measurements made suggest that the zooecia of the Faxe specimens are considerably smaller than those in Senonian colonies. Unfortunately the species is missing from LEVINSEN's collection of types, so that it has not been possible to investigate this problem in more detail.

It is conceivable that the Danian material of this species ought to be set up as a subspecies of Callopora lyra. I have not, however, found it reasonable to do so on the basis of the material examined.

\title{
Distribution.
}

Senonian: England: Hampshire (Lower Senonian). Bramford (Upper Senonian). Germany: Misburg (Lower Senonian), Rügen. Holland: Maastricht. Sweden: Quarnby.

Danian: Denmark: Faxe.

\section{Callopora cf. C. lyraeformis Voigt}

\author{
Plate 7, Fig. 2.
}

1887 Membranipora lyra Marsson (non v. Hagenow). Pal. Abh. IV. 1, p. 59, Pl. V, Fig. 17.

1925 Membranipora oculata LeVinsen (non D'Orbigny). Vidensk. Selsk. Skr. 8. Ser. VII. 3, p. 326 , Pl. II, Figs. $20 \mathrm{a}-\mathrm{a}_{1}$.

1925 Membranipora oculata var. lyra LeVINSEN. Vidensk. Selsk. Skr. 8. Ser. VII. 3, p. 327, Pl. II, Fig. 20d.

1930 Membranipora (Callopora) lyraeformis VolgT. Leopoldina. VI, p. 439, Pl. 8, Fig. 4.

\section{Description.}

The zoarium is encrusting or forms unilamellar, free, thin plates, with the zooecia in alternating longitudinal rows. On the back of the colonies the zooecia are hexagonal, with very prominent lateral corners, highly convex.

The zooecia are elliptical or hexagonal with greatly rounded angles, only touching the adjoining zooecia along the middle of the lateral rims. The mural rim falls off steeply towards the embedded opesium which is oblong-oval.

No ovicells have been observed on the Danian material examined. According to Voigt they are hyperstomial, small, and according to Levinsen they are rather greatly convex, widest and most prominent in the middle.

Above each zooecium there are two quadrangular or triangular avicularia 
(-or vibracula?-), the rims of which rise a little above the surrounding zooecia, and which fill in the intervals between these. The alternating position of the zooecia causes that each of these seems to be surrounded by six avicularia. Each avicularium is provided with a pore, which in the typical $C$. lyraeformis is comparatively large, rounded-triangular, while in the plateshaped Danian colonies it is small and circular.

\begin{tabular}{|c|c|c|c|c|c|}
\hline Measurements. & \multirow[b]{2}{*}{$\mathrm{Lz}$} & \multicolumn{3}{|c|}{ Range } & Average \\
\hline Herfølge, & & & $0.52-0.68 \mathrm{n}$ & $\mathrm{mm}$. & $0.60 \mathrm{~mm}$ \\
\hline Stevns, Bryozoan & $1 z$ & 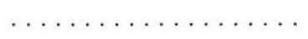 & $0.36-0.42$ & - & $0.39-$ \\
\hline \multirow[t]{4}{*}{ Limestone. } & ho & $\ldots \ldots \ldots \ldots \ldots \ldots \ldots$ & $0.36-0.47$ & - & $0.44-$ \\
\hline & 10 & $\ldots \ldots \ldots \ldots \ldots \ldots$ & $0.23-0.31$ & - & $0.28-$ \\
\hline & Lav & $\ldots \ldots \ldots \ldots-\ldots, \ldots$ & $0.10-0.16$ & - & 0.13 \\
\hline & lav: & $\ldots \ldots \ldots \ldots \ldots \ldots \ldots$ & $0.13-0.16$ & - & $0.14-$ \\
\hline \multirow[t]{6}{*}{ Rügen. } & $\mathrm{Lz}$ & $\ldots \ldots \ldots \ldots+\ldots \ldots$ & $0.57-0.62 \mathrm{r}$ & $\mathrm{mm}$. & $0.60 \mathrm{~mm}$ \\
\hline & $\mathrm{lz}$ & $\ldots \ldots \ldots \ldots \ldots \ldots$ & $0.39-0.52$ & - & $0.44-$ \\
\hline & ho & $\ldots \ldots \ldots-1, \ldots$ & $0.36-0.42$ & - & $0.38-$ \\
\hline & lo & ж., & $0.21-0.31$ & - & $0.23-$ \\
\hline & Lav & 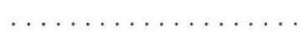 & 0.10 & - & $0.10-$ \\
\hline & lav & & 0.10 & - & $0.10-$ \\
\hline
\end{tabular}

The Danian material seems to have narrower zooecia, but longer and wider opesia and larger avicularia than the examined specimen from Rügen. VoIGT (1930, p. 439), however, gives the following measures in his description of species, which is also based on material from Rügen: Lz: about $0.60 \mathrm{~mm}$., lz: 0.25-0.30 mm., ho: $0.50 \mathrm{~mm}$., lo: $0.25 \mathrm{~mm}$.

\section{Material.}

Stevns, Bryozoan Limestone - 1 specimen (encrusting); Herfølge, Bryozoan Limestone - 11 specimens (plates).

\section{Remarks.}

The above-mentioned variation in the shape and size of the avicularian pore, as compared with the differences established by the measurements, and finally the stratigraphical distribution of the species have given occasion for the confer-statement.

From the Bryozoan Limestone in Stevns originates a single encrusting colony, the avicularia of which are of the same size as those of the Herfølge material, but the avicularian pore of which is of the same type as that of the Senonian material.

\section{Distribution.}

Senonian: Germany: Rügen; Denmark: Møn, Stevns, and Gudumlund.

Danian: Stevns, Faxe, Herfølge, and Klintholm. 


\section{Callopora acuminella n.sp.}

Plate 6, Figs. 2-3.

Diagnosis.

Zooarium encrusting. Mural rim with 14-20 traces of spines on small wartlike processes. Ovicells wider than long, very convex, with a slight median carina. Avicularia interzooecial or in regenerated zooecia, tapering lanceolately.

\section{Description.}

The zoarium is encrusting, unilamellar, with the zooecia in irregularly alter- nating longitudinal rows, separated by deep, narrow furrows.

The zooecia are varying in shape and size; rounded-hexagonal cells are the commonest type, but also elliptical and subcircular zooecia occur. The opesium is oval or angularly oval, embedded, placed distally, surrounded by a welldefined, convex mural rim provided with 14-20 spinal traces in the form of small wartlike processes with a circular pore at the top. The distal part of the mural rim is cut off straight, very narrow and without traces of spines in the middle. The gymnocyst is convex, as a rule decreases evenly in width proximally, but may sometimes be wedged in tapering form between the proximally situated zooecia. On a few zooecia the gymnocyst is very faintly developed.

The ovicells are hyperstomial, very convex with a slightly prominent carina, wider than long. The scars of ovicells have a rounded-quadrangular shape; they increase in width upwards and as a rule have straight upper and lower margins and curved sides. In a few specimens the ovicells appear in large numbers, but they are completely missing on the majority of the fragments examined.

Avicularia are common; they have lanceolately tapering frontal and distal parts and generally are interzooecial, the tapering posterior part being wedged between the zooecia behind it. Sometimes they fill in the opesium of regenerated zooecia. The opesium of the avicularium has a rounded posterior part and a tapering anterior part; the rests of a pivot is seen in the middle of the opesium.

\begin{tabular}{|c|c|c|c|c|}
\hline \multicolumn{3}{|c|}{ Measurements. } & Range & Average \\
\hline \multirow[t]{8}{*}{ Herfølge. } & $\mathrm{Lz}{ }^{\prime}$ & $\ldots \ldots \ldots \ldots \ldots \ldots \ldots \ldots$ & $0.47-0.62 \mathrm{~mm}$. & $0.56 \mathrm{~mm}$ \\
\hline & $\mathrm{lz}$ & $\ldots \ldots \ldots \ldots \ldots \ldots \ldots \ldots$ & $0.31-0.52-$ & $0.39-$ \\
\hline & ho & 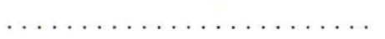 & $0.31-0.44$ & 0.36 \\
\hline & lo & 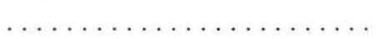 & $0.21-0.26$ & 0.23 \\
\hline & hov & $\ldots \ldots \ldots \ldots \ldots \ldots \ldots$, & $0.16-0.18$ & 0.16 \\
\hline & lov & 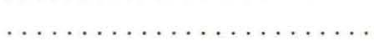 & $0.26-0.29$ & 0.28 \\
\hline & Lav & $\ldots \ldots \ldots \ldots$ & $0.34-0.36$ & 0.35 \\
\hline & lav & & $0.21-0.23-$ & $0.21-$ \\
\hline \multirow[t]{3}{*}{ Faxe. } & $\mathrm{Lz}$ & & $0.52-0.73 \mathrm{~mm}$. & $0.61 \mathrm{~mm}$ \\
\hline & $\mathrm{lz}$ & 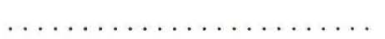 & $0.36-0.47-$ & $0.41-$ \\
\hline & ho & $\ldots \ldots \ldots \ldots \ldots \ldots \ldots \ldots$ & $0.31-0.42-$ & 0.37 - \\
\hline
\end{tabular}




\begin{tabular}{|c|c|c|c|c|}
\hline 10 & & $0.21-0.29$ & - & 0.24 \\
\hline hov & & $0.16-0.21$ & - & 0.18 \\
\hline lov & $\ldots \ldots \ldots \ldots \ldots \ldots \ldots \ldots$ & $0.29-0.31$ & - & 0.29 \\
\hline av & or & $0.29-0.42$ & - & 0.34 \\
\hline Iay & $\ldots \ldots \ldots \ldots \ldots \ldots \ldots \ldots \ldots$ & $0.16-0.26$ & - & 0.22 \\
\hline
\end{tabular}

\section{Material.}

Faxe - 36 specimens; Saltholm - 2 specimens; Herfølge, Bryozoan Limestone 5 specimens.

Holotype. Plate 6, Fig. 2. Faxe, Bryozoan Limestone.

Paratype. Plate 6, Fig. 3. Faxe.

\section{Remarks.}

The trivial name is derived from acumen "sharp point" with reference to the tapering avicularia. Among the Senonian and Danian deposits there are a number of species which i.a. are characterized by having a whorl of traces of spines round the opesium. This, e.g., applies to the following Danian species: Callopora impressa Levinsen (1925, p. 313, Pl. I, Fig. 8), C. coronata LevinSEN (1925, p. 311, Pl. I, Fig. 5), C. munita Marsson (1887, p. 58, Pl. V, Fig. 15), and $C$. woodwardi spinata VoIGT (1930, p. 442, Pl. 6, Figs. 5-6). C. impressa may have as many as 20 traces of spines, but deviates from $C$. acuminella by having rhombic-oval avicularia with the greatest width of opesium at the distal end and by the distal part of the mural rim being curved. This evaluation is based on LEVINSEN's description and pictures, the species lacking in his collection. C. coronata may also have up to 20 traces of spines on wartlike processes and a straight distal margin. It deviates from $C$. acuminella by having larger zooecia (average $0.82 \mathrm{~mm}$.) and by lacking avicularia. The shape of ovicell is deviating, too, the length of ovicell being greater than the width. This species is also missing from LEVINSEN's collection, but VoIGT has kindly submitted a specimen of $C$. coronata to me from an erratic block from H. Havighorst near Hamburg (Pl. 6, Fig. 4). C. munita forms free, vincularian stems; round the opesium there are 12-13 traces of spines; avicularia are rare. $C$. woodwardi spinata has the same type of avicularium as $C$. acuminella, but only about 10 spines round the opesium.

Among Senonian forms with which C. acumniella has features in common, prominence may be given to C. acuminata LeVINSEN (1925, p. 306, Pl. I, Fig. 1), C. vigintispinosa Levinsen (1925, p. 312, Pl. I, Fig. 6), C. securigera Levinsen (1925, p. 313, Pl. I, Fig. 7), C. capulus Levinsen (1925, p. 114, Pl. I, Fig. 9), and C. magnispina LeVINSEN (1925, p. 317, Pl. I, Fig. 11). C. acuminata (which according to VoIGT is identical with C. woodwardi pinquescens BRYDONE (1916, p. 98)), has avicularia of the same type as $C$. acuminella, but only $7-8$ indistinct 
traces of spines and narrow ovicells. C. vigintispinosa may have up to 20 traces of spines, but a different shape of the avicularia, which is oblong-oval, slightly tapering; the ovicells decrease in width downwards. C. securigera have 12-16 traces of spines, numerous avicularia, the anterior part of which is cut off straight. C. capulus has about 20 traces of spines and convex hood-shaped avicularia. C. magnispina mostly forms free colonies, rarely encrusting; it has 12 thick traces of spines and no avicularia.

\section{Distribution.}

Danian: Denmark: Kagstrup, Stevns, Faxe, Saltholm, Herfølge, and Klintholm.

\section{Callopora rosenkrantzi n.sp.}

Plate 6, Figs. 5-6.

Diagnosis.

A Callopora species with bilamellar, flabellate zoaria consisting of zooecia in 2-6 alternating longitudinal rows. Zooecia elongate hexagonal or rhombic, with about 16 traces of spines on the rim, faintly developed gymnocyst and elongate opesium with tapering proximal part. Regenerated zooecia with broad mural rim and an oval opesium. Avicularia interzooecial, triangular, with 2-3 traces of spines.

\section{Description.}

The zoarium forms free, bilamellar, flabellate stems with the zooecia in 2-6 alternating longitudinal rows, separated by narrow furrows or deep depressions.

The zooecia are elongate, rounded-hexagonal or rhombic. The gymnocyst is faintly developed; the mural rim is narrow, rounded, set with a maximum of 16 traces of spines in the form of small knob-shaped processes with a circular pore at the top. The spines are evenly distributed on the whole of the mural rim; often there are only 10 or 12 . The opesium is large, elongate, with an evenly rounded anterior part and a tapering proximal part. Regenerated zooecia are common in the anterior part of the colony. They are provided with a broad mural rim round an oval or tapering opesium.

Ovicells have not been observed.

The avicularia are interzooecial, rather small, triangular, with 2-3 traces of spines on the margin.

\begin{tabular}{lclll}
\multicolumn{2}{l}{ Measurements. } & & Range & Average \\
Faxe. & $\mathrm{Lz}$ & $\ldots \ldots \ldots \ldots \ldots \ldots \ldots \ldots \ldots$ & $0.57-1.04 \mathrm{~mm}$. & $0.71 \mathrm{~mm}$. \\
& $\mathrm{lz}$ & $\ldots \ldots \ldots \ldots \ldots \ldots \ldots \ldots \ldots$ & $0.31-0.52-$ & $0.66-$ \\
& ho & $\ldots \ldots \ldots \ldots \ldots \ldots \ldots \ldots$ & $0.31-0.73-$ & $0.43-$
\end{tabular}




\begin{tabular}{|c|c|c|c|c|}
\hline 10 & & $0.21-0.26$ & - & 0.25 \\
\hline ho & (regenerated zooecia) ...... & $0.16-0.26$ & - & 0.22 \\
\hline lo & $(-\quad-\quad) \ldots \ldots$ & $0.10-0.16$ & - & 0.12 \\
\hline Lav & $\ldots \ldots \ldots \ldots$ & $0.16-0.21$ & - & \\
\hline $\mathrm{V}$ & $\ldots \ldots \ldots \ldots \ldots \ldots \ldots$ & $0.10-0.16$ & - & \\
\hline
\end{tabular}

Material. Faxe - 4 specimens; Saltholm - 1 specimen.

Holotype. Plate 6, Fig. 5. Faxe, Bryozoan Limestone.

Paratype. Plate 6, Fig. 6. Faxe, Bryozoan Limestone.

\section{Remarks.}

The species is dedicated to A. Rosenkrantz, Professor of Geology at the University of Copenhagen.

The bilamellar, flabellate form of colony and the regenerated zooecia are also known within the genus of Stamenocella (see e.g. Pl. 9, Figs. 6-7). This genus, however, is characterized by having a small, sessile, salient avicularium. The features mentioned separates it from other known species within the genus Callopora.

Distribution. Denmark: Upper Danian, Faxe and Saltholm.

\section{Callopora stefniensis n.sp.}

Plate 6, Figs. 7-8.

Diagnosis.

Zoarium encrusting or unilamellar. Zooecium with embedded opesium, 2-3 pairs of apertural spines. Ovicell hyperstomial. Tapering avicularium with egg-shaped opesium and concave lateral margins.

\section{Description.}

The zoarium is encrusting or forms free, unilamellar plates with the zooecia in alternating longitudinal rows (quincunx), separated by narrow, but distinct furrows. The back of the zoarium shows an uneven curved surface with steeply ascending L-shaped transversal bands.

The zooecia are as a rule rounded-hexagonal. Sometimes, however, the proximal part is depressed at an acute angle between two zooecia situated below it. The surface of the gymnocyst falls off evenly towards the deeply situated opesium. It is sometimes provided with two shallow longitudinal furrows issuing from the proximal margin of the opesium and dividing it into a convex central part and two embedded lateral sections. The mural rim decreases in width towards the distal end; the outermost part of the rim is 
projecting, while the inner zone falls off steeply towards the opesium. On the outer rim there are 2-3 pairs of traces of apertural spines, small wartlike processes with circular pores. Two pairs of traces of spines placed distally to the opesium are always present and distinct, whereas the third pair, which is found laterally - nearly off the middle of the opesium - may be missing or be faintly developed. The terminally placed opesium is deeply embedded, subcircular or rounded-trapezohedral, with the narrower part turned towards the anterior end of the zooecium.

The ovicells are hyperstomial, embedded in the distal zooecium somewhat wider than long.

The avicularia are placed interzooecially; they taper evenly towards the rounded anterior end and are provided with an egg-shaped opesium. The middle and frontal part of the lateral margins are provided with a band-shaped process, which projects obliquely over the opesium.

\begin{tabular}{|c|c|c|c|c|c|}
\hline \multicolumn{2}{|c|}{ Measurements. } & & \multicolumn{2}{|l|}{ Range } & \multirow{2}{*}{ Average } \\
\hline Stevns. & $\mathrm{Lz}$ & $\ldots \ldots \ldots \ldots \ldots \ldots \ldots \ldots$ & $0.47-0.68$ & $\mathrm{~mm}$. & \\
\hline & $\mathrm{lz}$ & $\ldots \ldots \ldots \ldots \ldots \ldots \ldots \ldots$ & $0.42-0.52$ & - & $0.47-$ \\
\hline & ho & $\ldots \ldots \ldots \ldots \ldots \ldots \ldots \ldots$ & $0.21-0.31$ & - & 0.26 \\
\hline & 10 & $\ldots \ldots \ldots \ldots \ldots \ldots \ldots \ldots$ & $0.23-0.34$ & - & 0.29 \\
\hline & hov & $\ldots \ldots \ldots \ldots \ldots \ldots \ldots \ldots$ & 0.16 & - & \\
\hline & lov & $\ldots \ldots \ldots \ldots \ldots \ldots \ldots \ldots \ldots$ & 0.21 & - & \\
\hline & Lav & $\ldots \ldots \ldots \ldots \ldots \ldots \ldots$ & 0.42 & - & \\
\hline & lav & $\ldots \ldots \ldots \ldots \ldots \ldots \ldots \ldots$ & 0.36 & - & \\
\hline
\end{tabular}

Material. Stevns, Bryozoan Limestone - 2 specimens.

Holotype. Pl. 6, Fig. 7. Stevns Klint, Bryozoan Limestone.

Remarks.

The trivial name is derived from Stefnia, the Latin name of Stevns.

C. stefniensis has a certain habitual similarity to M. calceolus LEVINSEN from the Senonian White Chalk at Ålborg, on Møn, Stevns and Rügen (LevinSEN, 1925, p. 334, Pl. III, Figs. 28a-b); M. calceolus, however, is characterized by having 8 traces of spines and an inner zone on the rim, which is radially striated. The anterior part of the avicularium has concave lateral margins as in C. stefniensis, but the anterior margin is obliquely ascending, which gives the opesium a shape that reminds of the sole of a shoe. A similar avicularian type is found in Membranipora mundesia BRYDONE (BRYDONE, 1930, p. 23, Pl. V, Figs. 12-15) from the Senonian deposits of Trimingham in England, but in that species the avicularia are of the same size as or larger than the 
zooecia, which are provided with 3-4 pairs of traces of spines. The species mentioned thus seem to form a natural unit and perhaps ought to be united in an independent genus.

Distribution. Denmark: Lower Danian, Stevns.

ALLANTOPORA LANG, 1914

\section{Allantopora stomatoporoides Lang}

Plate 7, Fig. 3.

1914 Allantopora stomatoporoides LANG. Geol. Mag. Dec. VI. Vol. I, p. 438, Pl. XXXIV. Fig 2.

1930 Allantopora stomatoporoides LANG. VoIGT. Leopoldina. VI, p. 411, PI. 2, Fig. 4.

\section{Description.}

The zoarium is encrusting, uniserial and ramified.

The zooecia are pyriform, convex, with a distally placed, oval or roundedquandrangular opesium. Round the opesium the frontal wall forms a termen set with a maximum of 12 small circular dents after spines. Regenerated zooecia occur.

The ovicells are hyperstomial, probably spherical, the scars of ovicells being circular of subcircular.

Avicularia have not been observed.

\begin{tabular}{|c|c|c|c|c|}
\hline \multicolumn{2}{|c|}{ Measurements. } & & Range & Average \\
\hline Faxe. & $\mathrm{Lz}$ & $\ldots \ldots \ldots \ldots \ldots \ldots \ldots \ldots$ & $0.52-0.62 \mathrm{~mm}$. & $0.58 \mathrm{~mm}$. \\
\hline & $1 z$ & $\ldots \ldots \ldots \ldots \ldots \ldots \ldots \ldots$ & $0.42-0.47-$ & $0.44-$ \\
\hline & ho & $\ldots \ldots \ldots \ldots \ldots \ldots \ldots \ldots$ & $0.16-0.21$ & 0.18 \\
\hline & 10 & $\ldots \ldots \ldots \ldots \ldots \ldots \ldots \ldots$ & $0.10-0.16$ & 0.13 \\
\hline & hov & $\ldots \ldots \ldots \ldots \ldots \ldots \ldots$ & $0.21-0.26$ & \\
\hline & lov & $\ldots \ldots \ldots \ldots \ldots \ldots$ & $0.26-0.29$ & \\
\hline
\end{tabular}

Material. Faxe - 11 specimens.

Remarks.

Allantopora irregularis GABB and HoRN from the Vincentown Limesand in New Jersey has the same shape of colony as the present species. It differs by having larger zooecia and opesia (Lz: 0.8-0.9 mm., lz: 0.4-0.6 mm., ho: 0.4$0.45 \mathrm{~mm}$., lo: $0.22-0.25 \mathrm{~mm}$.), and by only having four or five pairs of large pores from spines. The pores are provided with a circular rim. In CANU and BASSLER's opinion (CANU and BASSLER, 1933, p. 24) the spines were hollow in conformity with the spines in the recent Allantopora translucens HARMER. Distribution. Danian, Faxe and Saltholm. 


\section{Membraniporidra huckeana Voigt}

Plate 7, Figs. 4-5.

1924 Membranipora Huckeana VoIGt. Pal. Zeitschr. VI. 1, p. 8, PI. 1, Figs. 24-26.

1930 Membranipora (Membraniporidra) huckeana VoIGT. Leopoldina. VI, p. 427, P1. 5, Fig. 6.

\section{Description.}

The zoarium is encrusting, unilamellar, with the zooecia arranged in irregular quincunx and separated by fine furrows.

The zooecia are hexagonal, rounded. The opesium is large, circular, placed at the distal end of the zooecium and surrounded by a very narrow, radially striated rim. The outer part of the mural rim and the gymnocyst are markedly convex ("inflated").

The ovicells are hyperstomial. The scars of ovicell are rounded-quadrangular, almost as wide as long.

Avicularia: According to Vorgt a prominent avicularian pore is sometimes visible below the opesium.

\begin{tabular}{|c|c|c|c|c|}
\hline \multicolumn{3}{|c|}{ Measurements. } & Range & Average \\
\hline Faxe, & $\mathrm{Lz}$ & $\cdots$ & $0.30-0.34 \mathrm{~mm}$ & $0.32 \mathrm{~mm}$ \\
\hline Saltholm, & $\mathrm{lz}$ & $\ldots \ldots \ldots \ldots \ldots \ldots \ldots \ldots$ & $0.27-0.30-$ & $0.29-$ \\
\hline Herfølge. & ho & . & $0.13-0.16$ & 0.15 \\
\hline & 10 & $\ldots \ldots \ldots \ldots \ldots \ldots \ldots \ldots$ & $0.13-0.16$ & 0.15 \\
\hline & hov & $\ldots \ldots \ldots \ldots \ldots \ldots \ldots \ldots$ & 0.10 & \\
\hline & lov & $\ldots \ldots \ldots \ldots \ldots \ldots \ldots \ldots$ & $0.16-0.21$ & \\
\hline
\end{tabular}

\section{Material.}

Faxe - 34 specimens; Saltholm, Bryozoan Limestone - 1 specimen; Saltholm 2 specimens; Herfølge, Bryozoan Limestone -15 specimens.

Remarks.

In a single, well-preserved colony from Faxe (Pl. 7, Fig. 5) the zooecia differ from the description above on the following points: (1) The radially striated opesial rim is wider and more pronounced. (2) On the outer margin of this rim there may be up to 6 distinct traces of spines. (3) The measures of the zooecia are generally larger: Lz: $0.36-0.42 \mathrm{~mm}$. (average $0.39 \mathrm{~mm}$.), lz: $0.31-$ $0.36 \mathrm{~mm}$. (0.33 mm.), diameter of opesium: $0.13-0.21 \mathrm{~mm}$. $(0.17 \mathrm{~mm}$.). The scars of ovicell are of the same shape and size as in the rest of the material. The ovicells are rounded-triangular with a prominent, hump-shaped upper region. 


\section{Distribution.}

Germany: Erratic Danian blocks at Köthen and Rosslau. Denmark: Upper Danian: Faxe, Saltholm, Herfølge, and Klintholm.

\section{Membraniporidra lacrymoporoides n.sp.}

Plate 8, Fig. 1.

1886 Membranipora lacrymopora D’Orbigny. Pergens and Meunier. Ann. Soc. Malac. Belg. XXI, p. 238.

1925 Membranipora lacrymophora D’Orbigny. Levinsen. Vidensk. Selsk. Skr. 8. Ser. ViI. 3, p. 341, Pl. III, Fig. 35.

1930 Membranipora lacrymopora (D'ORBIGNy) [partim]. VoIgt. Leopoldina. VI, p. 429, Pl. 10, Fig. 16.

\section{Diagnosis.}

Bilamellar, discoidal colonies, consisting of elongated, hexagonal zooecia with large, oblong, proximally tapering opesia. Hyperstomial ovicells with semi-elliptical scars.

\section{Description .}

The zoarium forms free, bilamellar plates with the zooecia arranged in fairly regular quincunx.

The zooecia are elongated, rounded-hexagonal, more or less unsymmetrical. They are separated by faint depressions. The opesium occupies almost the entire length of the zooecium. It is surrounded by a narrow, rounded rim without traces of spines and has an elongated, rounded-angular form, often tapering posteriorly.

The ovicells are hyperstomial. On the available specimens they are observable only as semi-elliptical scars above the zooecium. Sometimes they occur in large numbers on certain specimens, but the majority of the colony fragments examined lack scars of ovicells.

Avicularia have not been observed.

\begin{tabular}{|c|c|c|c|c|c|c|}
\hline \multicolumn{2}{|c|}{ Measurements. } & & \multicolumn{2}{|l|}{ Range } & \multicolumn{2}{|c|}{ Average } \\
\hline Faxe, & $\mathrm{Lz}$ & $\ldots$ & $0.68-1.20$ & $\mathrm{~mm}$. & 0.94 & $\mathrm{~nm}$. \\
\hline Thorslunde, & $1 z$ & & $0.26-0.57$ & - & 0.39 & - \\
\hline \multirow[t]{4}{*}{ Saltholm. } & ho & $\ldots \ldots \ldots \ldots$ & $0.62-1.04$ & - & 0.83 & - \\
\hline & lo & $\ldots \ldots \ldots \ldots \ldots \ldots \ldots \ldots$ & $0.21-0.42$ & - & 0.28 & - \\
\hline & hov & $\ldots \ldots \ldots \ldots \ldots \ldots \ldots \ldots$ & 0.10 & - & & \\
\hline & lov & $\ldots \ldots \ldots \ldots \ldots \ldots \ldots$ & $0.16-0.21$ & - & & \\
\hline
\end{tabular}

\section{Material.}

Faxe - 123 specimens; Thorslunde -15 specimens; Saltholm, Bryozoan Limestone -2 specimens.

Holotype. Pl. 8, Fig. 1, Faxe, Bryozoan Limestone. 
Remarks.

The trivial name refers to the great similarity to Membraniporidra lacrymopora D’Orbigny (Pal. Franç. Terr. Crét. V, p. 274, Pl. 695, Figs. 1-3, 1852).

The two species differ as regards stratigraphical and regional distribution, M. lacrymopora having been found exclusively in Senonian deposits in France, while M. lacrymoporoides is known only from the Danian in Denmark. Furthermore, the scars of ovicells in the French species are longer than wide, while in the Danish species they are nearly twice as wide as long. A corresponding comparison between the shapes of opesia in the two species shows that the opesium in M. lacrymopora (according to D'ORBIGNY's drawing, Pl. 695, Fig. 1) has a smoothly tapering proximal part, whereas the opesium in $M$. lacrymoporoides shows a pronounced tapering in a proximal direction.

\section{Distribution .}

Danian: Kagstrup, Thorslunde, Faxe, Saltholm, and Klintholm.

\section{Membraniporidra inermis (Levinsen)}

Plate 7, Fig. 6.

1886 Eschara eurita Pergens and Meunier (non d’Orbigny). Ann. Soc. Malac. Belg. XXI, p. 234.

1925 Membranipora inermis Levinsen. Vidensk. Selsk. Skr. 8. Ser. VII. 3, p. 345, Pl. IV, Fig. 38.

1930 Membranipora (Membraniporidra) inermis LeVInSEn. VoIgt. Leopoldina. VI, p. 429, Pl. 12, Fig. 5.

\section{Description.}

The zoarium forms free, bilamellar, dichotomous, thin, flabelliform plates with a narrow base or stems with parallel lateral margins; the zooecia in regularly alternating longitudinal rows (quincunx), separated by distinct, but not deep depressions.

The zooecia are elongate, vase-shaped or rounded-hexagonal. The opesium is placed in the anterior part of the zooecium; it is oblong-oval, sometimes slightly constricted in front as a consequence of small dentiform processes from the lateral margins. Sealed zooecia with oval pores in the olocyst may occur.

The ovicells are hyperstomial, depressed, slightly convex.

Avicularia have not been observed.

Measurements.

\begin{tabular}{|c|c|c|c|}
\hline & & Range & Average \\
\hline Faxe, & Width of zoarium ............ & $1.56-4.21 \mathrm{~mm}$. & $2.76 \mathrm{~mm}$. \\
\hline Saltholm, & Lz $\quad \ldots \ldots \ldots \ldots \ldots \ldots \ldots \ldots$ & $0.57-1.04-$ & $0.74-$ \\
\hline
\end{tabular}




\begin{tabular}{|c|c|c|c|c|c|}
\hline \multirow[t]{5}{*}{ Herfølge. } & lz & $\ldots \ldots \ldots \ldots \ldots \ldots \ldots \ldots$ & $0.31-0.52$ & - & 0.39 \\
\hline & ho & $\ldots \ldots \ldots \ldots \ldots \ldots$ & $0.16-0.31$ & - & 0.27 \\
\hline & 10 & . & $0.10-0.26$ & - & 0.18 \\
\hline & hov & $\ldots \ldots \ldots \ldots \ldots \ldots \ldots \ldots$ & $0.16-0.21$ & - & \\
\hline & lov & $\ldots{ }_{1}$ & $0.21-0.31$ & - & \\
\hline
\end{tabular}

Material.

Faxe - 365 specimens; Faxe II - 3 specimens; Faxe XI - 12 specimens; Saltholm - 1 specimen; Saltholm, Bryozoan Limestone - 2 specimens; Herfølge, Bryozoan Limestone - 284 specimens; Herfølge, Calcarenite - 46 specimens.

Lectotype. Plate IV, Fig. 38 (Levinsen, 1925). Type locality: Faxe.

Remarks.

Pergens and Meunier referred their material of this species to Eschara eurita D'Orbigny (1851, p. 174, Pl. 678, Figs. 16-18). According to Canu (1900, p. 411) E. eurita - now Euritina eurita - is known only from the French Turonian. CANU furthermore states that the French form has smaller zooecia than M. inermis.

Regarding shape of colonies and type of zooecia $M$. inermis reminds somewhat of Floridina voigti BASSLER, a similarity which is stressed by the small dentiform processes from the margin of the zooecium in $M$. inermis. F. voigti differs from the latter by having smaller zooecia (Lz: 0.47-0.61 mm., lz: 0.29 $0.36 \mathrm{~mm}$.) and by having a wide lip on the lower margin of the opesium.

\section{Distribution.}

Germany: Erratic blocks, Köthen and Rosslau. Denmark: Upper Danian, Bryozoan Limestone: Faxe, Saltholm, Herfølge, and Klintholm.

\section{PITHODELLA MARSSON, 1887}

\section{Pithodella cincta Marsson}

Plate 8, Figs. 2-3.

1887 Pithodella cincta Marsson. Pal. Abh. IV. 1, p. 53, Pl. V, Fig. 7.

1925 Membranipora oculata var. cincta Marsson. Levinsen. Vidensk. Selsk. Skr. 8. Ser. VII. 3, p. 327, Pl. 2, Figs. 20b-c.

1930 Pithodella cincta Marsson. Voigt. Leopoldina. VI, p. 444, Pl. 12, Figs. 21-24.

\section{Description.}

The zoarium forms free, quadrangular, hexagonal, or compressed, dichotomous stems with the zooecia in regular quincunx.

The zooecia are elongate with an evenly rounded distal part and a wide, plane gymnocyst. The mural rim is provided with two distinct traces of spines 
off the distal margin of the opesium. In a few specimens from Faxe and Stevns there are 10 spinal traces on the mural rim. The opesium is terminal, oblongoval, deeply embedded. The gymnocyst is quadrangular, demarcated by elevated rims, the distal one of which often projects over the posterior part of the opesium.

Ovicells are of rare occurrence, in the material examined only as scars of ovicells. They are hyperstomial, rounded, as a rule with the same length and width.

Avicularia are found in large numbers on some specimens and are missing on others. They are transverse, rounded-triangular, and placed in one of the distal corners of the gymnocyst. The opesium is rounded-triangular or eggshaped. The tapering anterior part of the avicularium projects freely over the surface of the gymnocyst.

\section{Measurements.}

\begin{tabular}{|c|c|c|c|c|c|c|}
\hline & & & Range & & Aver & age \\
\hline Herfølge, & Widt & h of zoarium ........... & $0.83-1.30$ & $\mathrm{~mm}$. & 0.98 & $\mathrm{~mm}$. \\
\hline Faxe. & $\mathrm{Lz}$ & $\ldots \ldots \ldots \ldots \ldots \ldots \ldots \ldots$ & $0.73-0.88$ & - & 0.82 & - \\
\hline & $1 z$ & $\ldots \ldots \ldots \ldots \ldots \ldots \ldots$ & $0.31-0.42$ & - & 0.37 & - \\
\hline & ho & $\ldots \ldots \ldots \ldots \ldots \ldots$ & $0.31-0.42$ & - & 0.37 & - \\
\hline & lo & $\ldots \ldots \ldots \ldots \ldots \ldots \ldots \ldots$ & $0.16-0.26$ & - & 0.22 & - \\
\hline & lov & $\ldots \ldots \ldots \ldots \ldots \ldots \ldots \ldots$ & 0.16 & - & 0.16 & - \\
\hline & hov & $\ldots \ldots \ldots \ldots \ldots \ldots \ldots \ldots$ & 0.16 & - & 0.16 & - \\
\hline & Lav & $\ldots \ldots \ldots \ldots \ldots \ldots \ldots \ldots$ & $0.10-0.13$ & - & 0.11 & - \\
\hline & lav & $\ldots \ldots \ldots \ldots \ldots \ldots \ldots \ldots$ & $0.18-0.21$ & - & 0.20 & - \\
\hline Thorslunde, & Widt & h of zoarium $\ldots \ldots \ldots \ldots \ldots$ & $0.62-1.25$ & $\mathrm{~mm}$. & 0.89 & $\mathrm{~mm}$. \\
\hline Saltholm. & $\mathrm{Lz}$ & $\ldots \ldots \ldots \ldots \ldots \ldots \ldots \ldots$ & $0.68-0.99$ & - & 0.82 & - \\
\hline & $\mathrm{lz}$ & $\ldots \ldots \ldots \ldots \ldots \ldots \ldots \ldots$ & $0.34-0.42$ & - & 0.36 & - \\
\hline & ho & $\ldots \ldots \ldots \ldots \ldots \ldots \ldots \ldots$ & $0.26-0.42$ & - & 0.34 & - \\
\hline & lo & $\ldots \ldots \ldots \ldots \ldots \ldots \ldots$ & $0.18-0.26$ & - & 0.22 & - \\
\hline & Lav & $\ldots \ldots \ldots \ldots \ldots \ldots \ldots \ldots$ & 0.10 & - & & \\
\hline & lav & $\ldots \ldots \ldots \ldots \ldots \ldots \ldots \ldots$ & $0.16-0.18$ & - & & \\
\hline Stevns, & Widt & h of zoarium ............ & $0.62-1.30$ & $\mathrm{~mm}$. & 0.92 & $\mathrm{~mm}$. \\
\hline Kagstrup. & $\mathrm{Lz}$ & $\ldots \ldots \ldots \ldots \ldots \ldots \ldots \ldots$ & $0.73-0.94$ & - & 0.80 & - \\
\hline & $1 z$ & $\ldots \ldots \ldots \ldots \ldots \ldots \ldots \ldots$ & $0.36-0.39$ & - & 0.37 & - \\
\hline & ho & $\ldots \ldots \ldots \ldots \ldots \ldots \ldots \ldots$ & $0.31-0.47$ & - & 0.38 & - \\
\hline & 1o & $\ldots \ldots \ldots \ldots \ldots \ldots \ldots \ldots$ & $0.16-0.23$ & - & 0.21 & - \\
\hline & lov & $\ldots \ldots \ldots \ldots \ldots \ldots \ldots \ldots$ & $0.16-0.21$ & - & 0.18 & - \\
\hline & hov & $\ldots \ldots \ldots \ldots \ldots \ldots \ldots$ & $0.18-0.21$ & - & 0.19 & - \\
\hline Møn. & Widt & h of zoarium ............ & 0.62 & $\mathrm{~mm}$. & & \\
\hline & $\mathrm{Lz}$ & $\ldots \ldots \ldots \ldots \ldots \ldots \ldots \ldots$ & $0.68-0.78$ & - & 0.74 & $\mathrm{~mm}$. \\
\hline & $\mathrm{lz}$ & $\ldots \ldots \ldots \ldots \ldots \ldots \ldots \ldots$ & $0.31-0.36$ & - & 0.33 & - \\
\hline & ho & $\ldots \ldots \ldots \ldots \ldots \ldots \ldots \ldots$ & $0.31-0.36$ & - & 0.33 & - \\
\hline & lo & $\ldots \ldots \ldots \ldots \ldots \ldots \ldots \ldots$ & $0.18-0.23$ & - & 0.21 & - \\
\hline & hov & $\ldots \ldots \ldots \ldots \ldots \ldots \ldots \ldots$ & $0.18-0.21$ & - & & \\
\hline & lov & $\ldots \ldots \ldots \ldots \ldots \ldots \ldots \ldots$ & $0.21-0.31$ & - & & \\
\hline
\end{tabular}


The specimen from Møn examined has a narrower zoarium, smaller zooecia and opesia, but larger-more especially wider-ovicells.

\section{Material.}

Stevns, Bryozoan Limestone - 126 specimens; Kagstrup - 234 specimens; Thorslunde - 14 specimens; Faxe - 234 specimens; Faxe I - 8 specimens; Faxe II - 1 specimen; Saltholm - 64 specimens; Sandy-limestone - 13 specimens; Bryozoan Limestone - 22 specimens; Copenhagen, the South Harbour 5 specimens; Herfølge, Bryozoan Limestone - 70 specimens.

\section{Remarks.}

The two distinct spinal traces on the upper part of the mural rim seem to be a characteristic feature of the Danian material. According to MARSSON the specimens from Rügen have on the mural rim some granules set with fine pores all over. LeVINSEN has pictured the two spinal traces in his figures (Plate II, Fig. 20b-c), but does not mention them in the text.

As to the presence of avicularia the Danian material also differs from the Senonian. At any rate neither MARSSON nor VoIGT mentions avicularia in their Senonian specimens, and Levinsen's description is based on material from Faxe. It is probably the external form of the avicularia that caused LEVINSEN to place $P$. cincta as a variety under Membranipora oculata (D'ORBIGNY) (now Callopora lyraeformis VOIGT).

As mentioned in the description of the species, avicularia occur in large numbers on some specimens, whereas they are completely absent on others. A counting of specimens with and without avicularia shows the following distribution:

\begin{tabular}{|c|c|c|c|c|}
\hline & & & $\begin{array}{l}\text { Specimens } \\
\text { without } \\
\text { avicularia }\end{array}$ & $\begin{array}{c}\text { Specimens } \\
\text { with } \\
\text { avicularia }\end{array}$ \\
\hline Stevns, & Bryozoan Limestone & $\ldots \ldots \ldots$ & 117 & 9 \\
\hline Kagstrup, & $-\quad-$ & $\ldots \ldots \ldots$ & 221 & 13 \\
\hline Faxe, & - & $\ldots \ldots \ldots$ & 80 & 163 \\
\hline Saltholm, & - & $\ldots \ldots \ldots$ & 17 & 5 \\
\hline Saltholm, & & & 40 & 24 \\
\hline Herfølge, & Bryozoan Limestone & $\ldots \ldots \ldots$ & 55 & 15 \\
\hline
\end{tabular}

This survey shows that specimens without avicularia are absolutely dominant in Lower Danian, while two thirds of the fragments from Faxe have avicularia; as regards the Herfølge material about one fifth of the colonies examined has avicularia.

It is possible that the Danian material of Pithodella cincta ought to be referred 
to another species deviating from the Senonian form as regards measures of zoarium, zooecia, and ovicells, number of pores, and the occurrence of avicularia. I have not, however, found it reasonable to make such a distinction before I have had an opportunity of supplementary investigations of Senonian material.

\section{Distribution.}

Senonian: Germany: Rügen; Holland: Maastricht; Denmark: Møn.

Danian: Sweden: Limhamn; Denmark: Stevns, Kagstrup, Thorslunde, Faxe, Saltholm, Copenhagen, Herfølge, and Klintholm.

\section{Pithodella bifoliata n.sp.}

Plate 8, Figs. 4-7.

Diagnosis.

Zoarium bifoliate, with the zooecia in quincunx. The rim round the embedded, oval opesium has a slanting inner zone and a narrow, elevated outer rim. Below the opesium there is an embedded, rectangular gymnocystal area, delimited from the outer rims of the adjoining opesia. Hyperstomial ovicells. Oval avicularia, covering the gymnocystal area, common on some colonies, rare on others.

\section{Description.}

The zoarium forms free, bifoliate stems, with the zooecia in alternating longitudinal rows (quincunx).

The zooecia are elongate. The mural rim, which is comparatively wide and without traces of spines, slopes down towards the embedded opesium; the outmost part of the rim forms a narrow, elevated edge. The opesium is terminal, oblong-oval. Below this there is an embedded, rather rectangular area with concave sides, the area being delimited by narrow, elevated edges, which surround the adjoining oval opesia. Sometimes the concavity is so prominent that the edges of the sides almost touch in the gymnocystal area. Medianly, immediately below the distal margin of the area, there is a small, circular pore. Calcified zooecia occur; they are provided with a small oval aperture in the olocyst.

The ovicells are hyperstomial. Only scars of ovicells, the form of which is rounded-quadrangular, with a greater width than length, have been found.

The avicularia are very variable as in Pithodella cincta MARsson. On some specimens they occur on each zooecium, on others they are completely missing. The shape is oblong-oval, with a wide obliquely placed rim; the opesium is oval or egg-shaped. The avicularium covers the whole of the embedded gymno- 
cystal area, and its posterior part is often elevated in relation to the rest.

Minor, rounded-triangular avicularia which cover only part of the embedded area, have been observed on a few fragments.

\section{Measurements.}

\begin{tabular}{|c|c|c|c|c|c|c|}
\hline \multirow{4}{*}{$\begin{array}{l}\text { Herfølge, } \\
\text { Saltholm, } \\
\text { Faxe. }\end{array}$} & \multirow{2}{*}{\multicolumn{2}{|c|}{ Width of zoarium . .............. }} & \multicolumn{2}{|l|}{ Range } & \multicolumn{2}{|c|}{ Average } \\
\hline & & & $1.40-2.70$ & & 2.04 & \\
\hline & $\mathrm{Lz}$ & & $0.73-1.09$ & - & 0.91 & - \\
\hline & lz & $\ldots \ldots \ldots \ldots$ & $0.29-0.47$ & - & 0.36 & - \\
\hline & ho & 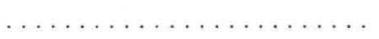 & $0.29-0.44$ & - & 0.37 & - \\
\hline & lo & . & $0.16-0.29$ & - & 0.20 & - \\
\hline & hov & … & $0.18-0.21$ & - & 0.20 & - \\
\hline & lov & 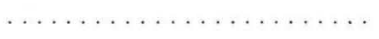 & $0.23-0.26$ & - & 0.25 & - \\
\hline & Lav & $\ldots \ldots \ldots \ldots \ldots \ldots \ldots \ldots, \ldots$ & $0.21-0.26$ & - & 0.25 & - \\
\hline & lav & 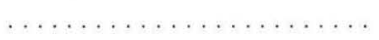 & $0.10-0.21$ & - & 0.14 & - \\
\hline
\end{tabular}

Material.

Faxe - 62 specimens; Saltholm, Bryozoan Limestone - 7 specimens; Sandylimestone -7 specimens; Saltholm, without specification -1 specimen; Copenhagen, the South Harbour - 10 specimens; Herfølge, Bryozoan Limestone 27 specimens.

Holotype. Pl. 8, Fig. 6. Bryozoan Limestone, Herfølge.

\section{Remarks.}

The trivial name refers to the bifoliate habit.

Pithodella bifoliata $n$.sp. differs from $P$. cincta MARsson by having no traces of spines on the mural rim, by having an elongate, embedded gymnocystal area and large elliptical avicularia. In D'ORBIGNY (1952) there are some species which-judging from the illustrations - bear a certain resemblance to the present species. This applies, e.g., to Flustrella irregularis D'OrBigny (Pl. 698, Figs. 8-11), Flustrella echinata D'OrBIGNY (Pl. 699, Figs. 10-13), and Flustrella marginata D'ORBIGNY (PI. 700, Figs. 7-9). As D'ORBIGNY's drawings are very schematic, it is difficult to decide what points of similarity and deviations exist between the French Senonian species mentioned and the Danian species.

Avicularia were observed on only 20 of the specimens from Herfølge; on a few of the fragments from Faxe and the South Harbour there are roundedtriangular avicularia; on the other specimens avicularia are absent.

\section{Distribution.}

Upper Danian: Faxe, Saltholm, Copenhagen, Herfølge, and Klintholm. 


\section{Amphiblestrum elegans (v. Hagenow) and \\ Amphiblestrum elegans faxensis (Levinsen) \\ Plate 9, Figs. 1-5.}

1851 Siphonella elegans (legend of plate S. gracilis) v. HaGENow. Bryozoen d. Maastrichter Kreidebildung, p. 84, Pl. 6, Fig. 7.

1887 Membranipora elegans v. Hagenow. Marsson. Pal. Abh. IV. 1, p. 59.

1925 Membranipora elegans (v. Hagenow). Levinsen. Vidensk. Selsk. Skr. 8. Ser. VII. 3, p. 338, Pl. III, Figs. 32a-b.

1925 Membranipora elegans faxensis LeVInSEN. Vidensk. Selsk. Skr. 8. Ser. VII. 3, p. 339.

1930 Amphiblestrum elegans (v. Hagenow). Voigt. Leopoldina. VI, p. 448, Pl. 13, Figs. 13-16.

1. Description of Amphiblestrum elegans. (Pl. 9, fig. 1).

The zoarium forms slender, hollow stems with dichotomous ramification, rarely encrusting. The zooecia in quincunx, separated by narrow furrows.

The zooecia are elongate, rhombic, or rounded-hexagonal. The opesium is terminal, oblong-oval, covers half the length of the zooecium or more, and half of its width.

The ovicells are hyperstomial, rounded, not particularly prominent, rare.

There is generally an avicularium above each zooecium. The commonest type has an unsymmetric trapezohedral shape with a triangular opesium; but sometimes this type is replaced by long, tapering, obliquely projecting avicularia with a trapezoid opesium.

2. Description of Amphiblestrum elegans faxensis. (P1. 9, fig. 2).

The zoarium forms slender, hollow stems.

The external shape of the zooecia is like that of $A$. elegans. The opesium is embedded, angularly oval, with a straight cut-off posterior edge; it occupies but one third or less of the zooecial length. The gymnocyst, which slopes evenly down towards the opesium, is provided with two longitudinal furrows issuing from the proximal corners of the opesium.

Only one avicularian type, which is unsymmetrically trapezoid with a triangular opesium.

\section{Description of untypical Amphiblestrum elegans material.}

Besides A. elegans faxensis in its typical form there are within the Danian some types which in certain respects are related to A. elegans, while in other respects they show a mutual connexion with $A$. elegans faxensis. They are mutually distinguished by the form of colony.

a. Encrusting (Pl. 9, Fig. 4). 
The opesium has a straight posterior edge as in A. elegans faxensis, but is longer than that of the latter, as it occupies about half of the zooecial length. The gymnocyst is provided with two longitudinal furrows. Avicularia are found only above a few zooecia. The shape is oval with a slight tapering towards the distal end; the orientation follows the longitudinal direction of the zooecium. The ovicells are hyperstomial, the scars of ovicells rounded-quadrangular with the same length and width.

b. Free, curved, unilamellar plates (PI. 9, Fig. 5).

The opesium has a rounded posterior edge as in A. elegans, but is shorter than that of the latter, about half of the zooecial length. Gymnocystal longitudinal furrows do not occur, or they, are only faintly developed. Avicularia occur above some of the zooecia; they are oval with a slight tapering. Presumably the zoaria have formed tubes enclosing some filamentous vegetable matter (algae or the like).

c. Coarse, tubular colonies with great internal diameter (Pl. 9, Fig. 3).

This type has rounded-quadrangular, embedded opesia with concave lateral margins. The length of opesium is about half of the length of zooecium. The zooecial rims are prominent. The gymnocyst is plane, widely triangular, evenly sloping down towards the opesium. The avicularia are rhombic with a large opesium; they occur on all zooecia.

Measurements.

The specimen from Maastricht has kindly been submitted to me by Professor VoIGT.

Amphiblestrum elegans v. Hagenow.

\begin{tabular}{|c|c|c|c|c|c|}
\hline \multirow{3}{*}{ Møn. } & \multirow{2}{*}{\multicolumn{2}{|c|}{ Width of zoarium ........... }} & \multicolumn{2}{|l|}{ Range } & Average \\
\hline & & & 0.88 & $\mathrm{~mm}$. & \\
\hline & $\mathrm{Lz}$ & $\ldots \ldots \ldots \ldots \ldots \ldots \ldots$ & $0.65-0.78$ & - & $0.71 \mathrm{~mm}$. \\
\hline & $1 z$ & $\ldots \ldots \ldots \ldots \ldots \ldots \ldots \ldots$ & $0.36-0.42$ & - & $0.38-$ \\
\hline & ho & $\ldots \ldots \ldots \ldots \ldots \ldots \ldots \ldots$ & $0.31-0.36$ & - & 0.35 \\
\hline & 10 & $\ldots \ldots \ldots \ldots \ldots \ldots \ldots$ & $0.21-0.23$ & - & 0.22 \\
\hline & Lav & $\ldots \ldots \ldots \ldots \ldots \ldots \ldots \ldots$ & 0.16 & - & \\
\hline & lav & $\ldots \ldots \ldots \ldots \ldots \ldots \ldots$ & 0.10 & - & \\
\hline \multirow[t]{7}{*}{ Maastricht. } & \multicolumn{2}{|c|}{ Width of zoarium ........... } & 0.99 & $\mathrm{~mm}$. & \\
\hline & $\mathrm{Lz}$ & $\ldots \ldots \ldots \ldots \ldots \ldots \ldots$ & $0.47-0.57$ & $\dot{-}$ & $0.54 \mathrm{~mm}$. \\
\hline & $1 z$ & $\ldots \ldots \ldots \ldots \ldots \ldots \ldots \ldots$ & 0.26 & - & $0.26-$ \\
\hline & ho & $\ldots \ldots \ldots \ldots \ldots \ldots \ldots \ldots$ & $0.21-0.26$ & - & 0.22 \\
\hline & 10 & $\ldots \ldots \ldots \ldots \ldots \ldots \ldots$ & $0.13-0.16$ & - & 0.15 \\
\hline & Lav & $\ldots \ldots \ldots \ldots \ldots \ldots \ldots \ldots$ & $0.13-0.16$ & - & \\
\hline & lav & $\ldots \ldots \ldots \ldots \ldots \ldots$ & 0.13 & - & \\
\hline
\end{tabular}


Amphiblestrum elegans faxensis LEvinsen.

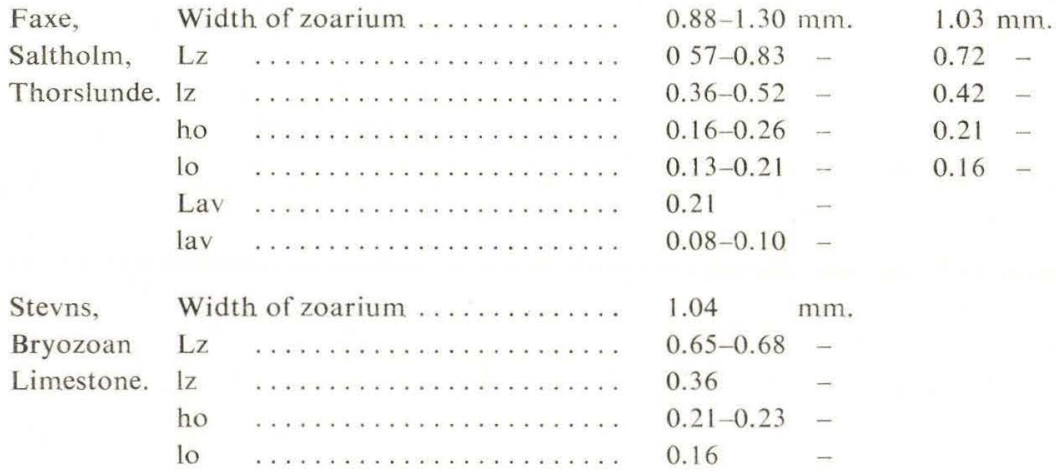

a. Encrusting zoarium.

\begin{tabular}{|c|c|c|c|c|c|c|}
\hline Stevns, & $\mathrm{Lz}$ & $\ldots \ldots \ldots \ldots \ldots \ldots \ldots \ldots \ldots$ & $0.57-0.62$ & $\mathrm{~nm}$. & 0.59 & $\mathrm{~mm}$. \\
\hline Kagstrup, & $\mathrm{lz}$ & $\ldots \ldots \ldots \ldots \ldots \ldots \ldots \ldots$ & $0.31-0.42$ & - & 0.36 & - \\
\hline Bryozoan & ho & $\ldots \ldots \ldots \ldots \ldots \ldots \ldots \ldots$ & $0.23-0.31$ & - & 0.27 & - \\
\hline Limestone. & 10 & $\ldots \ldots$ & $0.18-0.26$ & - & 0.21 & - \\
\hline & hov & $\ldots \ldots$ & 0.16 & - & & \\
\hline & lov & $\ldots \ldots \ldots \ldots \ldots$ & 0.16 & - & & \\
\hline & Lav & $\ldots \ldots \ldots \ldots \ldots \ldots \ldots \ldots$ & $0.10-0.21$ & - & 0.15 & - \\
\hline & lav & $\ldots \ldots \ldots \ldots \ldots \ldots \ldots \ldots$ & 0.10 & - & 0.10 & \\
\hline
\end{tabular}

b. Unilamellar plates.

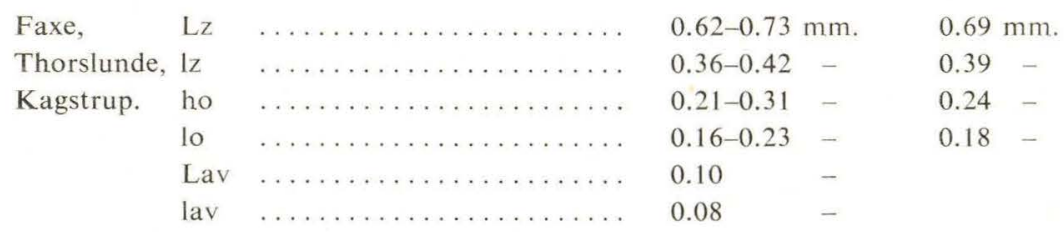

c. Coarse, tubular stems with great internal diameter.

\begin{tabular}{|c|c|c|c|c|c|c|}
\hline Herfølge, & $\mathrm{Lz}$ & $\ldots \ldots \ldots \ldots \ldots \ldots$ & $0.57-0.68$ & $\mathrm{~nm}$. & 0.64 & $\mathrm{~mm}$. \\
\hline Bryozoan Limestone & lz & & $0.38-0.46$ & - & 0.42 & - \\
\hline and Calcarenite. & ho & $\ldots \ldots \ldots \ldots$ & $0.27-0.30$ & - & 0.28 & - \\
\hline & lo & $\ldots \ldots \ldots \ldots \ldots$ & $0.23-0.27$ & - & 0.26 & - \\
\hline & Lav & $\ldots \ldots \ldots \ldots \ldots$ & $0.15-0.19$ & - & & \\
\hline & lav & $\ldots \ldots \ldots \ldots \ldots$ & 0.11 & - & & \\
\hline
\end{tabular}

\section{Material.}

The material examined is distributed on types of colonies and localities as follows: 


\begin{tabular}{|c|c|c|c|c|c|c|c|}
\hline & & & & $\begin{array}{l}\text { nphiblestrum } \\
\text { elegans } \\
\text { faxensis }\end{array}$ & $\begin{array}{c}\text { Encrusting } \\
\text { zoaria }\end{array}$ & $\begin{array}{l}\text { Unilamellar } \\
\text { plates }\end{array}$ & $\begin{array}{c}\text { Tubular } \\
\text { stems }\end{array}$ \\
\hline Stevns, & Bryozoan & Limestone & $\ldots$ & 1 & 4 & 0 & 0 \\
\hline Kagstrup, & - & - & $\ldots$ & 1 & 1 & 1 & 0 \\
\hline Thorslunde, & - & - & $\ldots$ & 0 & 0 & 3 & 0 \\
\hline Faxe, & - & - & $\ldots$ & 29 & 0 & 9 & 0 \\
\hline Saltholm, & - & - & $\ldots$ & 9 & 0 & 0 & 0 \\
\hline Saltholm: & $\ldots \ldots \ldots$ & $\ldots \ldots \ldots$ & $\ldots$ & 43 & 0 & 0 & 0 \\
\hline Herfølge, & Bryozoan & Limestone & $\ldots$ & 0 & 0 & 0 & 6 \\
\hline Herfølge, & Calcarenit & e........ & $\ldots$ & 0 & 0 & 0 & 1 \\
\hline
\end{tabular}

\section{Remarks.}

I think VoIGT is right when (1930, p. 449) considering Amphiblestrum elegans as a group of closely related species rather than as a single species. The slender material makes it unwarrantable to attempt a subdivision of this species in the case of the Danian.

\section{Distribution.}

Senonian: Germany: Rügen; Holland: Maastricht; Denmark: Møn.

Danian: Stevns, Kagstrup, Thorslunde, Faxe, Saltholm, Herfølge, and Klintholm.

\section{STAMENOCELLA CANU AND BASSLER, 1917}

\section{Stamenocella pristis (Levinsen)}

Plate 9, Fig. 6.

1925 Membranipora pristis Levinsen. Vidensk. Selsk. Skr. 8. Ser. VII. 3, p. 324, Pl. VIII, Fig. 3.

1930 Stamenocella pristis (Levinsen). Voigt. Leopoldina. VI, p. 450, Pl. 14, Fig. 5.

\section{Description .}

The zoarium forms free, compressed, bilamellar, flabellate stems, consisting of 2-6 longitudinal rows of zooecia in quincunx; the zooecia are separated by distinct furrows.

There are two types of zooecia: normal zooecia at the distal end of the colony and radicular zooecia in the basal part of the zoarium. The normal zooecia have an oblong-oval opesium surrounded by a narrow, rounded mural rim. The gymnocyst is embedded in relation to the rest of the surface of the zooecium, rectangular, narrow. On its posterior part there is a small circular pore. The radicular zooecia are calcified, plane or slightly convex, perforated in the middle by a round orifice.

The ovicells according to LEVINSEN are hyperstomial, small, with parallel lateral margins. They have not been observed in the material examined here.

On the foremost part of the gymnocyst there is a prominent avicularium. 
The median avicularia are cylindrical, with a circular orifice; the lateral ones are obliquely protracted with a rhombic orifice, while the avicularia placed edgeways are compressed, projecting tooth-like.

\begin{tabular}{|c|c|c|c|c|c|c|}
\hline \multicolumn{3}{|c|}{ Measurements. } & \multicolumn{2}{|l|}{ Range } & \multicolumn{2}{|c|}{ Average } \\
\hline Stevns, & Wid & of zoarium .... & \multicolumn{2}{|c|}{$0.83-2.18 \mathrm{~mm}$. } & \multicolumn{2}{|c|}{$1.27 \mathrm{~mm}$. } \\
\hline Faxe, & $\mathrm{Lz}$ & $\ldots \ldots \ldots \ldots$ & $0.42-0.57$ & - & 0.51 & \\
\hline Saltholm, & $1 z$ & … & $0.21-0.29$ & - & 0.24 & - \\
\hline \multirow[t]{4}{*}{ Herfølge. } & ho & 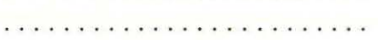 & $0.16-0.26$ & - & 0.20 & - \\
\hline & lo & & $0.13-0.18$ & - & 0.14 & - \\
\hline & Lav & $\ldots \ldots \ldots-1, \ldots$ & 0.08 & - & & \\
\hline & lav & $\ldots \ldots \ldots \ldots \ldots \ldots \ldots \ldots \ldots$ & 0.08 & - & & \\
\hline
\end{tabular}

\section{Material.}

Stevns, Bryozoan Limestone - 1 specimen; Thorslunde - 2 specimens; Faxe 7 specimens; Faxe I - 1 specimen; Faxe XI - 2 specimens; Saltholm -8 specimens; Copenhagen, Sundkrogen - 3 specimens; Herfølge, Bryozoan Limesone -6 specimens.

Lectotype. LeVInSEN's collection, Zoological Museum, Copenhagen.

Type locality. Faxe, Bryozoan Limestone.

\section{Remarks.}

S. pristis bears great resemblance to the American species Stamenocella oculata ULRICH and BASSLER from the Vincentown formation and Stamenocella midwayanica CANU and BASSLER from Midwayan (Clayton limestone). S. oculata has longer zooecia and opesia (Lz: $0.8 \mathrm{~mm}$., lz: $0.25 \mathrm{~mm}$, ho: $0.4 \mathrm{~mm}$, lo: $0.14 \mathrm{~mm}$.), but smaller avicularia; the orifice of the radicular zooecia is elliptical. The zooecia of $S$. midwayanica are of the same size as those of S. pristis (Lz: $0.50 \mathrm{~mm}$., lz: $0.20 \mathrm{~mm}$.), but the opesia are longer and narrower (ho: $0.24-0.30 \mathrm{~mm}$., lo: $0.10-0.12 \mathrm{~mm}$.).

\section{Distribution.}

Danian: Germany: Erratic blocks at Köthen; Sweden: Limhamn; Denmark: Stevns, Kagstrup, Thorslunde, Faxe, Saltholm, Copenhagen, Herfølge, and Klintholm.

\section{Stamenocella tumida Voigt}

Plate 9, Fig. 7.

1930 Stamenocella tumida VoIGT. Leopoldina. VI, p. 450, Pl. 14, Fig. 10.

\section{Description.}

The zoarium forms free, slightly compressed, flabellate stems, consisting of 
2-6 longitudinal rows of zooecia placed in quincunx. The zooecia are separated by narrow furrows.

On the specimens examined only radicular zooecia have been found. They consist of an oval, convex anterior part with an oblong-oval orifice and a very narrow, embedded gymnocyst which besides an avicularium is provided with 2-4 circular pores.

Ovicells have not been observed.

Most zooecia on the foremost part of the gymnocyst have a small avicularium, which is tubular, slightly compressed, smoothly ascending in a distal direction, with an elliptical opesium.

\begin{tabular}{|c|c|c|c|c|c|c|}
\hline Measure & ints. & & Range & & Aver & ge \\
\hline Herfølge. & Wid & of zoarium ............ & $1.04-1.66$ & $\mathrm{~nm}$. & 1.35 & $\mathrm{~nm}$. \\
\hline & $\mathrm{Lz}$ & $\ldots \ldots \ldots \ldots \ldots \ldots \ldots$ & $0.78-0.88$ & - & 0.82 & - \\
\hline & $1 z$ & $\ldots \ldots \ldots \ldots \ldots \ldots \ldots \ldots$ & $0.31-0.34$ & - & 0.33 & - \\
\hline & $\mathrm{hr}$ & $\ldots \ldots \ldots \ldots \ldots \ldots \ldots \ldots$ & $0.13-0.26$ & - & 0.22 & - \\
\hline & 1r & $\ldots \ldots \ldots \ldots \ldots \ldots \ldots$ & $0.10-0.21$ & - & 0.12 & - \\
\hline & Lav & $\ldots \ldots \ldots \ldots \ldots \ldots \ldots \ldots$ & 0.05 & - & 0.05 & - \\
\hline & lav & $\ldots \ldots \ldots \ldots \ldots \ldots$ & 0.05 & - & 0.05 & - \\
\hline
\end{tabular}

Material. Herfølge, Bryozoan Limestone - 3 specimens.

Distribution.

Danian: Germany: Erratic blocks from Köthen. Denmark: Upper Danian, Faxe and Herfølge.

FRURIONELLA CANU AND BASSLER, 1925

35. Frurionella daniensis n.sp.

Plate 9, Figs. 8-9.

Plate 10, Fig. 1.

Diagnosis.

A Frurionella with free, thick, compressed, dichotomous stems, consisting of zooecia without marginal delimitation. Circular or subcircular opesia surrounded by a circle of pores. Avicularia elliptical, frontal, with tubular cicatrix, or soleshaped, marginal.

\section{Description .}

The zoarium forms free, thick, compressed stems with dichotomous ramification. The zooecia are without marginal delimitations; the opesia are placed in quincunx. 
The frontal of the zooecium is convex, smooth. The opesium is circular or subcircular, sometimes - in the outermost longitudinal rows - slightly craterlike prominent, without mural rim. Round the opesium there is a circle of pores, varying in size and shape. The most frequent number of pores is 8 , but sometimes two small pores are united to form an elongate slit. In the circle of pores there is an avicularium which usually is placed proximally to the opesium, but also may occur laterally to it.

Ovicells have not been observed.

There are two types of avicularia: (1) Frontal avicularia, which-as mentioned above - enter in the circle of pores round the opesia. These avicularia are comparatively small, elliptical or tapering, with a central pivot placed transversely. If the avicularium has been destroyed, there is in its place a cicatrix, the size of which amounts to about half of that of the opesium. This cicatrix sometimes forms a tubular process, which may have a circular or oval aperture. (2) Marginal avicularia, which occur on the edges of the zoarium. They are long, sole-shaped, with the pivot placed at the posterior end of the cell.

\begin{tabular}{|c|c|c|c|c|c|}
\hline \multicolumn{2}{|c|}{ Measurements. } & \multicolumn{2}{|l|}{ Range } & \multicolumn{2}{|c|}{ Average } \\
\hline \multirow[t]{11}{*}{ Herfølge. } & Width of zoarium ........... & $1.98-3.74$ & $\mathrm{~mm}$. & 2.70 & $\mathrm{~nm}$ \\
\hline & ho $\quad \ldots \ldots \ldots \ldots \ldots \ldots \ldots \ldots \ldots$ & $0.16-0.18$ & - & 0.16 & - \\
\hline & 10 $\ldots \ldots \ldots \ldots \ldots \ldots \ldots \ldots$ & $0.13-0.16$ & - & 0.14 & - \\
\hline & Longitudinal distance between & & & & \\
\hline & opesia $\ldots \ldots \ldots \ldots \ldots \ldots$ & $0.52-0.73$ & - & 0.64 & - \\
\hline & Transversal distance between & & & & \\
\hline & opesia $\ldots \ldots \ldots \ldots \ldots$ & $0.42-0.57$ & - & 0.50 & - \\
\hline & 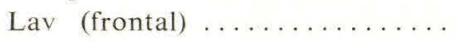 & 0.10 & - & 0.10 & - \\
\hline & lav $(-) \ldots \ldots$ & $0.05-0.08$ & - & 0.07 & - \\
\hline & Lav (marginal) $\ldots \ldots \ldots \ldots \ldots$ & 0.31 & - & 0.31 & - \\
\hline & lav $\left(-{ }^{\prime}\right) \ldots \ldots \ldots \ldots$ & $0.10-0.13$ & - & 0.11 & - \\
\hline
\end{tabular}

\section{Material.}

Herfølge, Bryozoan Limestone - 30 specimens; Calcarenite - 11 specimens.

Holotype. Pl. 9, Fig. 8. Herfølge, Bryozoan Limestone.

Paratypes. Pl. 9, Fig. 9, Pl. 10, Fig. 1. Herfølge, Bryozoan Limestone.

\section{Remarks.}

The trivial name refers to the fact that this species so far is the only representative of the genus Frurionella within the Bryozoan fauna of the Danian.

Besides $F$. daniensis the genus includes three species, two of which, $F$. parvipora CANu and Bassler (1926, p. 35, Pl. V, Figs. 6-18) and F. grandipora CANu and Bassler (1926, p. 36, Pl. VI, Figs. 1-3) have been found at Coon Creek in Tennessee (Maastrichtian), while the third, F. europaea VorGT (1951, 
p. 60, Pl. 9, Figs. 1-3) is known from Ilten near Hannover and Kunrade (Holland), also from deposits belonging to the Maastrichtian. All the species have thick, more or less compressed stems.

In both American species the frontal avicularium occurs in close connexion with the opesium. In F. parvipora "this avicularium is large, salient, elliptical, with a pivot; when destroyed it leaves a cicatrix larger than the opesium." F. parvipora has rather small, elliptical opesia (ho: $0.15-0.17 \mathrm{~mm}$., lo: 0.15$0.17 \mathrm{~mm}$.), which are surrounded by a very thin mural rim. Below the opesium there are two small median pores which may be united to form a slit-shaped depression. F. grandipora has large opesia (ho: $0.20-0.25 \mathrm{~mm}$., lo: $0.15-0.20$ $\mathrm{mm}$.), which also are surrounded by a thin mural rim. Below the opesium there are two large median pores. By means of thin sections CANU and BASSLER have been able to demonstrate the presence of hyperstomial ovicells in $F$. parvipora; they are buried in the thick cell wall and cannot be observed on the frontal. Presumably a corresponding type of ovicell occurs in $F$. daniensis.

F. europaea Voigt has subcylindrical stems about $1 \mathrm{~mm}$. in width, with $8-10$ rows of cells. The opesia are round or oval, with a diameter of 0.15 $0.25 \mathrm{~mm}$. The distance between the opesia is $0.40-0.50 \mathrm{~mm}$.

CANU and BASSLER by their careful examinations of F. parvipora have been able to demonstrate the presence of elongate and pyriform opesia, narrowed at the point of articulation of the opercular valve, which shows that this genus belongs to the Malocostega in spite of its resemblance to the Ascophora. Furthermore, longitudinal sections have substantiated that the median pores between the opesia are not ascopores, as they do not appear in the sections.

With its thick olocyst and with zooecia without marginal delimitation this genus occupies a place apart within the Malacostega (cf. VorGT, 1951, p. 61). The habitual similarity to species like Porina cylindrica VoIGT and Pachythecella anhaltina VOIGT invite investigations of the mutual relationship of Frurionella, Porina, and Pachythecella.

Distribution. Denmark: Upper Danian, Herfølge and Klintholm.

\section{DIVISION COILOSTEGA LEVINSEN, 1909}

The frontal wall has within the covering membrane a generally depressed, calcareous cover - the cryptocyst - surrounded by projecting margins, which either reaches the proximal margin of the operculum or is only separated from the latter by a small membranous portion. Lateral (parietal) muscles operating the frontal membrane above the cryptocyst pass downward to the dorsal wall distally to the cryptocyst by way of notches-opesiular intendations-at the sides, or through special foramina on either side - opesiules. The distal end of the polypide is more or less enclosed in a calcified polypide tube, when opesiules are well developed. 


\title{
ONY CHOCELLIDAE JULLIEN, 1881 \\ ONYCHOCELLA JULLIEN, 1882
}

\section{Onychocella gimense (Brydone)}

\author{
Plate 10, Fig. 2.
}

1925 Onychocella irregularis (v. Hagenow) [partim]. LeVInSEN. Vidensk. Selsk. Skr. 8. Ser. VII. 3, p. 359.

1936 Rhagasostoma Gimense BRYDONE. Further Notes on Chalk Polyzoa. Part III, p. 75, Pl. XXXVI, Figs. 10-12.

\section{Description.}

The zoarium is encrusting or forms unilamellar, free plates, with rather irregularly arranged zooecia.

The zooecia are hexagonally or rhombically rounded, though often of irregular shape. They are mutually demarcated by narrow prominent rims. The cryptocyst is plane or convex. The opesium is terminal, wider than long, almost rectangular, with a straight posterior edge and a slightly curved anterior edge; its length is about one fourth of the cell length.

Ovicells have not been observed.

The onychocellaria are large, longer than the zooecia, falciform. The opesium is small (its length corresponds to only one sixth of the onychocellarian length), quadrangular, almost square; it is provided with a small median slit on the proximal lip and two small dentiform processes on the distal lip.

\begin{tabular}{|c|c|c|c|c|c|c|}
\hline \multicolumn{2}{|c|}{ Measurements. } & & \multicolumn{2}{|l|}{ Range } & \multicolumn{2}{|c|}{ Average } \\
\hline Stevns, & $\mathrm{Lz}$ & $\ldots \ldots \ldots \ldots \ldots \ldots \ldots \ldots$ & $0.52-0.65$ & $\mathrm{~mm}$. & 0.58 & $\mathrm{~nm}$. \\
\hline Bryozoan & lz & $\ldots \ldots \ldots \ldots \ldots \ldots \ldots \ldots$ & $0.39-0.50$ & - & 0.46 & - \\
\hline \multirow[t]{4}{*}{ Limestone. } & ho & $\ldots \ldots \ldots \ldots \ldots \ldots \ldots$ & $0.13-0.18$ & - & 0.16 & - \\
\hline & lo & $\ldots \ldots \ldots \ldots \ldots \ldots \ldots$ & $0.16-0.23$ & - & 0.19 & - \\
\hline & Lon & $\ldots \ldots \ldots \ldots \ldots \ldots \ldots \ldots$ & $0.68-0.83$ & - & 0.74 & - \\
\hline & lon & $\ldots \ldots \ldots \ldots \ldots \ldots \ldots$ & $0.31-0.34$ & - & 0.33 & - \\
\hline \multirow[t]{6}{*}{ Møn. } & $\mathrm{Lz}$ & & $0.57-0.62$ & $\mathrm{~mm}$. & 0.59 & $\mathrm{~mm}$. \\
\hline & $\mathrm{lz}$ & $\ldots$ & $0.42-0.47$ & - & 0.46 & - \\
\hline & ho & $\ldots \ldots \ldots \ldots$ & $0.13-0.16$ & - & 0.14 & - \\
\hline & 10 & $\ldots \ldots \ldots \ldots \ldots \ldots \ldots$ & $0.18-0.21$ & - & 0.19 & - \\
\hline & Lon & $\ldots \ldots \ldots \ldots \ldots \ldots \ldots$ & $0.73-0.78$ & - & 0.74 & - \\
\hline & lon & $\ldots \ldots \ldots \ldots \ldots \ldots \ldots$ & $0.31-0.34$ & - & 0.32 & - \\
\hline
\end{tabular}

Material. Danian: Stevns, Bryozoan Limestone - 13 specimens.

Remarks.

Onychocella gimense (BRYDONE) belongs to the group of closely related species which Voigt (1930, p. 452) has united in the O. irregularis group. The typical 
O. irregularis (v. Hagenow, 1839, p. 264, Pl. IV, Fig. 2) forms bilamellar, dichotomous stems with $0.70-0.75 \mathrm{~mm}$. long zooecia. LeVINSEN's description of $O$. irregularis $(1925$, p. 359$)$ is based on bilamellar as well as discoidal and encrusting colonies; but his collection of types only includes free plates and encrusting specimens, which can all be referred to $O$. gimense. O. subirregularis VorgT (1959, p. 28, Pl. VII, Fig. 2) habitually bears a great resemblance to $O$. gimense, with which it agrees as regards shape of colony and lengths of zooecia and onychocellaria. The length of the opesium, however, is greater in $O$. subirregularis (at least one third of the length of cell). This species is furthermore characterized by having a large, oval opesium in the onychocellarium.

\section{Distribution .}

Senonian: England: Trimingham; Denmark: Møn.

Danian: Lower Danian: Stevns and Kagstrup.

\section{Onychocella poulseni n.sp.}

Plate 10, Fig. 3.

1925 Onychocella irregularis faxensis LeVINSEN. Vidensk. Selsk. Skr. 8. Ser. VII. 3, p. 360, P1. IV, Fig. 48.

1930 Onychocella irregularis faxensis Levinsen. VoIgt. Leopoldina. VI, p. 453, Pl. 15, Fig. 4.

\section{Diagnosis.}

An Onychocella species with tubular, slender zoaria, more rarely coarse, tubular stems or free, multilamellar plates. The zooecium has a deeply embedded cryptocyst and a large rounded-quadrangular or subcircular opesium. The onychocellaria are falciform with oval opesia.

\section{Description .}

The most frequent form of colony is slender, dichotomous tubular stems with the zooecia placed in alternating longitudinal rows. More rarely there are coarse tubular stems and free, uni- and multilamellar, lobate and curved plates with irregularly arranged zooecia.

The zooecia are comparatively small, hexagonal or rhombically rounded, sometimes oval. The cryptocyst is deeply embedded, plane or falling off slightly towards the opesium, which is rounded-quadrangular, sometimes almost circular. The length of the opesium as a rule is greater than one third of the length of the zooecium.

Ovicells are rare; they form small roof-like processes above the opesia.

The onychocellaria are falciform, longer than the zooecia, with an oval, deep-seated opesium, the length of which varies between one fourth and one third of that of the onychocellarium. 


\begin{tabular}{|c|c|c|c|c|}
\hline \multicolumn{3}{|c|}{ Measurements. } & \multirow{2}{*}{$\begin{array}{l}\text { Range } \\
0.94-1.60 \mathrm{~mm} .\end{array}$} & \multirow{2}{*}{$\begin{array}{l}\text { Average } \\
1.26 \mathrm{~mm}\end{array}$} \\
\hline Tubular. & Widt & $\mathrm{h}$ of zoarium $\ldots \ldots \ldots \ldots$ & & \\
\hline & $\mathrm{Lz}$ & $\ldots \ldots \ldots \ldots$ & $0.47-0.57-$ & $0.53-$ \\
\hline & $\mathrm{lz}$ & …, & $0.42-0.53$ & 0.47 \\
\hline & ho & 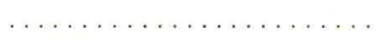 & $0.18-0.26-$ & 0.22 \\
\hline & lo & $\ldots \cdots, \cdots, \cdots, \cdots$, & $0.16-0.26$ & 0.20 \\
\hline & Lon & $\ldots \ldots, \cdots \cdots,{ }_{1}$ & $0.57-0.73$ & 0.68 \\
\hline & lon & $\ldots \ldots \ldots \ldots \ldots \ldots \ldots \ldots$ & $0.23-0.26$ & 0.25 \\
\hline \multirow[t]{6}{*}{ Discoidal. } & $\mathrm{Lz}$ & $\ldots$ & $0.47-0.57 \mathrm{~mm}$. & $0.52 \mathrm{~mm}$ \\
\hline & $1 z$ & $\ldots \ldots \ldots \ldots \ldots \ldots \ldots$ & $0.42-0.52-$ & 0.47 \\
\hline & ho & $\ldots \ldots, \cdots, \cdots, \cdots$, & $0.18-0.26$ & 0.22 \\
\hline & lo & $\ldots \ldots \ldots \ldots \ldots \ldots \ldots \ldots$ & $0.18-0.26$ & 0.21 \\
\hline & Lon & 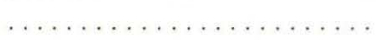 & $0.62-0.73$ & 0.69 \\
\hline & Ion & 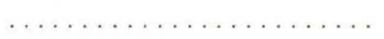 & $0.21-0.26$ & 0.25 \\
\hline
\end{tabular}

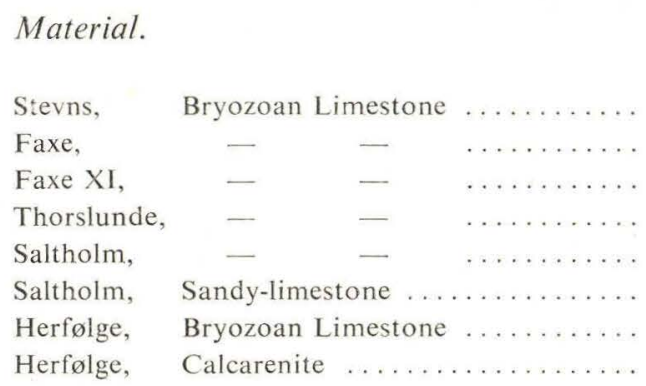

$\begin{array}{ccc}\text { Discoidal } & \begin{array}{c}\text { Coarse, } \\ \text { tubular } \\ \text { specimens }\end{array} & \begin{array}{c}\text { Slender, } \\ \text { tubular } \\ \text { specimens }\end{array}\end{array}$
14

$\begin{array}{rr}34 & 16 \\ & 2 \\ 9 & 2 \\ 2 & 2 \\ & 212 \\ & 14\end{array}$

Holotype. Pl. 10, Fig. 3. Herfølge, Bryozoan Limestone.

\section{Remarks.}

The species is dedicated to Chr. Poulsen, Ph.D., Professor of Paleontology at the University of Copenhagen.

As appears from the list of synonyms, LEVINSEN and VOIGT have considered this species as a variety of Onychocella irregularis v. HAGENOW. This form is, however, characterized by having bilamellar stems with $0.70-0.75 \mathrm{~mm}$. long zooecia. O. gimense BRydone ( $=0$. irregularis v. HagenOw in LeVINSEN, 1925, p. 359) also has longer zooecia (Lz: 0.52-0.65 mm.) and longer onychocellaria (Lon: 0.73-0.78 mm.). The opesium of the onychocellarium in $O$. gimense is small and quadrangular (about one sixth of the onychocellarian length), while in $O$. poulseni it is rather large and oval (between one fourth and one third of the length of the onychocellarium). O. poulseni differs from $O$. gimense in other respects as well; thus as regards the shape of the colonies, which in $O$. gimense are encrusting or unilamellar-discoidal; furthermore, as 
regards the shape and size of the opesium, as this in $O$. gimense is almost rectangular and comparatively small, whereas $O$. poulseni has a subcircular, comparatively large opesium.

\section{Distribution.}

Danian: Germany: Erratic Danian blocks at Köthen. Denmark: In Lower Danian mainly as discoidal, multilamellar colonies, in Upper Danian with tubular zoaria. Localities: Stevns, Kagstrup, Faxe, Thorslunde, Saltholm, Herfølge, and Klintholm.

\section{Onychocella ravni n.sp.}

Plate 11, Figs. 1-3.

Diagnosis.

An Onychocella species with a free, unilamellar, discoidal zoarium, hexagonal or rhombic zooecia with embedded cryptocyst and rectangular or subcircular opesium. Onychocellarium rounded, tapering with a large, widely oval or subcircular opesium with a median slit on the proximal margin.

\section{Description .}

The zoarium forms free, unilamellar, curved plates with the zooecia in fairly regular longitudinal rows. The back of the zoarium has an uneven undulate surface with prominent transversal furrows.

The shape of the zooecia is very variable, with hexagonal and rhombic cells as the commonest type. The margins of the zooecia meet in narrow, projecting edges, which surround the embedded, plane or slightly sloping cryptocyst. The opesium varies in shape between subcircular and rounded-rectangular, with the latter type as the more frequent one; the proximal rim often medianly has a slight convexity.

In some of the zooecia the distal margin forms a small, slightly convex roof-like process, below which there is a small chamber only open towards the opesium. It has not been possible to decide whether such processes represent remnants of ovicells.

The onychocellaria are nearly as long as the zooecia and rather wide. The posterior half has straight or concave lateral margins and a straight edge. The anterior part has convex, evenly tapering lateral margins, which meet in a rounded, acute angle. The opesium is large, widely oval or subcircular, embedded; the proximal margin is provided with a short slit. 


\begin{tabular}{|c|c|c|c|c|}
\hline \multicolumn{3}{|c|}{ Measurements. } & \multirow{2}{*}{$\begin{array}{l}\text { Range } \\
0.62-0.88 \mathrm{~mm} .\end{array}$} & \multirow{2}{*}{$\begin{array}{l}\text { Average } \\
0.73 \mathrm{~mm} .\end{array}$} \\
\hline Herfølge, & $\mathrm{Lz}$ & & & \\
\hline & $\mathrm{Iz}$ & & $0.57-0.73-$ & $0.63-$ \\
\hline & ho & & $0.21-0.26$ & 0.23 \\
\hline & lo & $\ldots \ldots \ldots \ldots \ldots$ & $0.26-0.36$ & 0.29 \\
\hline & Lon & $\ldots \ldots \ldots \ldots \ldots \ldots \ldots \ldots$ & $0.47-0.78$ & 0.64 \\
\hline & lon & & $0.31-0.47$ & 0.40 \\
\hline
\end{tabular}

Material.

Faxe -8 specimens; Herfølge, Bryozoan Limestone - 21 specimens; Calcarenite -2 specimens.

Holotype. Pl. 11, Fig. 1. Herfølge, Bryozoan Limestone.

Paratype. Pl. 11, Fig. 2. Herfølge, Bryozoan Limestone.

Remarks.

Onychocella ravni is dedicated to the memory of the late Dr. J. P. J. Ravn (1866-1951) in admiration of his valuable contributions to the elucidation of the stratigraphy and paleontology of the Danish cretaceous deposits.

The characteristic onychocellarium gives $O$. ravni a place apart within the genus Onychocella.

\section{Distribution.}

Denmark: Upper Danian, Bryozoan Limestone: Faxe, Herfølge, and Klintholm.

\section{Onychocella elongata Levinsen}

Plate 10, Figs. 4-5.

1925 Onychocella elongata Levinsen. Vidensk. Selsk. Skr. 8. Ser. VII. 3, p. 359, PI. IV, fig. 47.

Description.

The zoarium forms free, unilamellar, convex plates, which seem to originate from the cover of algal filaments or the like or from hollow stems. The zooecia are placed in alternating longitudinal rows. The back of the zoarium is provided with narrow longitudinal furrows. The areas between these furrows are divided into elongate parts by transversal, rounded crests.

The zooecia are hexagonal with a slightly embedded cryptocyst. The opesium is placed terminally, quadrangularly rounded. 
The ovicells form a convex, slightly projecting roof-like process above the opesia.

The onychocellaria have an elongate, tapering oval form. The opesium is deeply embedded, oval, with a tapering posterior end.

\section{Measurements.}

\begin{tabular}{|c|c|c|c|c|}
\hline \multirow{3}{*}{$\begin{array}{l}\text { Faxe, } \\
\text { Herfølge. }\end{array}$} & \multirow{3}{*}{$\begin{array}{l}\mathrm{Lz} \\
\mathrm{lz}\end{array}$} & \multicolumn{2}{|r|}{ Range } & Average \\
\hline & & & $0.52-0.62 \mathrm{~mm}$. & $0.60 \mathrm{~mm}$ \\
\hline & & & $0.34-0.52-$ & $0.39-$ \\
\hline & ho & $\ldots$ & $0.16-0.23$ & 0.21 \\
\hline & lo & 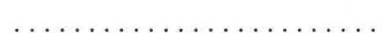 & $0.16-0.24$ & 0.19 \\
\hline & Lon & $\ldots \ldots \ldots \ldots \ldots \ldots \ldots \ldots$ & $0.57-0.70$ & 0.64 \\
\hline & lon & $\ldots \ldots \ldots \ldots \ldots \ldots \ldots$, & $0.23-0.26$ & 0.25 \\
\hline
\end{tabular}

\section{Material.}

Thorslunde - 14 specimens; Faxe - 22 specimens; Faxe II - 2 specimens; Herfølge, Bryozoan Limestone - 53 specimens.

Lectotype.

In LEVINSEN's collection in the Zoological Museum of Copenhagen; Faxe, Bryozoan Limestone.

\section{Remarks.}

According to LEVINSEN's description of the species $O$. elongata is known only from Senonian White Chalk of Møn. All specimens of this species in the type collection of the Zoological Museum of Copenhagen, however, are marked Faxe.

\section{Distribution.}

Upper Danian, Bryozoan Limestone: Kagstrup, Thorslunde, Faxe, Herfølge, and Klintholm.

\section{Onychocella columella n.sp.}

Plate 10, Figs. 7-8.

1925 Rhagasostoma Nysti (v. Hagenow) [partim]. Levinsen. Vidensk. Selsk. Skr. 8. Ser. VII. 3, p. 370.

1930 Onychocella auriculata (MARsson) [partim]. Vorgt. Leopoldina. VI, p. 459, Pl. 16, Fig. 18.

\section{Diagnosis.}

An Onychocella species with hexagonal to octagonal stems, consisting of hexagonal zooecia in alternating longitudinal rows, interzooecial onychocellaria and 
kenozooecia, the latter mainly in the bifurcation area. The opesium of the zooecia is small, semi-elliptical, with opesiular indentations and a broad proximal lip. The onychocellarium is evenly tapering with an embedded oval opesium.

\section{Description.}

The colonies form hexagonal to octogonal stems with dichotomous ramification and with the zooecia placed in fairly regular longitudinal rows. The irregularities are due partly to the onychocellaria, partly to the presence of kenozooecia. The zooecia are separated by narrow, but distinct furrows.

The zooecia are hexagonal with a rounded anterior margin and a straight posterior margin; the form, for that matter, is rather varying, in some specimens being spatulate, with a wide anterior part and a narrow proximal part, in others with the posterior part being as wide as or wider than the anterior part of the zooecium. The cryptocyst sometimes slopes steeply down to the deeply embedded opesium, the margins of the zooecia thus forming ridges between the zooecia with the separating furrow placed on the tops of these ridges. In other cases the opesium is only slightly embedded and the cryptocyst is consequently almost plane. The opesium is rather small, semi-elliptical with a straight posterior margin, which is placed above the middle of the zooecium. On well-preserved specimens two notches are seen, opesiular indentations, in the corners between the lateral and posterior margins, so that the posterior margin forms a slightly projecting lip.

Ovicells have been found on one fragment only. They form highly convex, rooflike processes above the opesia so that these are almost covered.

Onychocellaria mostly occur between the zooecia, only rarely above these or in regenerated zooecia. They are rounded in the rear and in front they taper into a long tip with projecting lateral rims. In the middle of the onychocellarium there is a depression in the anterior part of which the oval opesium is placed.

Kenozooecia occur partly separately, partly in groups at the bases of the ramifications. They have an irregular, often pentagonal or hexagonal rounded form and are each provided with a median circular pore.

\section{Measurements.}

\begin{tabular}{|c|c|c|c|c|c|c|}
\hline & & & Range & & Ave & \\
\hline Herfølge. & Wid & of zoarium ........... & $1.14-1.25$ & $\mathrm{~mm}$. & 1.18 & $\mathrm{~mm}$ \\
\hline Stevns, Faxe. & - & $-\quad-\quad \ldots \ldots \ldots$ & $0.68-1.00$ & - & 0.81 & - \\
\hline Stevns, Faxe, & $\mathrm{Lz}$ & $\ldots \ldots \ldots \ldots \ldots$ & $0.42-0.47$ & - & 0.44 & - \\
\hline Herfølge. & $1 z$ & $\ldots \ldots+\cdots, \ldots$ & $0.29-0.39$ & - & 0.33 & - \\
\hline & ho & жан, & $0.10-0.13$ & - & 0.11 & - \\
\hline & lo & & $0.10-0.13$ & - & 0.11 & - \\
\hline & Lon & $\ldots \ldots-\cdots, \ldots-\cdots$, & $0.23-0.31$ & - & 0.26 & - \\
\hline & lon & $\ldots \ldots \ldots \ldots \ldots$ & $0.13-0.16$ & - & 0.15 & - \\
\hline
\end{tabular}


Material.

Stevns, Bryozoan Limestone - 577 specimens; Kagstrup - 503 specimens; Thorslunde - 12 specimens; Faxe - 236 specimens; Saltholm - 37 specimens; Herfølge, Bryozoan Limestone - 107 specimens, Calcarenite -7 specimens.

Holotype. Pl. 10, Fig. 7. Faxe, Bryozoan Limestone.

\section{Remarks.}

The trivial name refers to the columnar zoarium.

The Danian material of Onychocella (Rhagasostoma) nysti (v. HaGENow) in LEVINSEN (1925, p. 370) is referred to $O$. columella n.sp. The Danian specimens in LEVINSEN's type collection of the Zoological Museum of Copenhagen is in perfect agreement with $O$. columella, which differs from the Senonian species, $O$. nysti, by having larger zooecia (Lz: $0.42-0.47 \mathrm{~mm}$. as against $0.31-0.36 \mathrm{~mm}$. in $O$. nysti) and evenly tapering onychocellaria. In $O$. nysti the posterior half of the onychocellarium is oblong-oval, while the anterior part is very tapering (see Plate 10, Fig. 6).

VoIGT $(1930$, p. 459) in his comments on Onychocella auriculata MARsSON has called attention to the fact that the Danian material of this species does not agree with MARSSON's illustration (1887, Pl. VI, Fig. 13), the Danian specimens having coarser, cylindrical stems with greater regularity of the position of the zooecia. Furthermore, the onychocellaria in typical $O$. auriculata are projecting hornlike and often placed above the zooecia, while in the Danian material they are embedded and generally occur intercellularly. On this basis I have found it justifiable to refer the Danian material of $O$. auriculata to $O$. columella, a point of view which is, indeed, supported by VoIGT's illustrations (1930, Pl. 16, Figs. 17-18).

\section{Distribution.}

Danian: Germany: Erratic Danian blocks at Anhalt. Denmark: Especially frequent in Lower Danian. Localities: Stevns, Kagstrup, Thorslunde, Faxe, Saltholm, Herfølge, and Klintholm.

\section{FLORIDINA JULLIEN, 1881}

\section{Floridina gothica (d'Orbigny)}

Plate 11, Fig. 4.

1851 Vincularia gothica d'Orbigny. Pal. Franç. Terr. Crét. V, p. 68, Pl. 654, Firs. 13-16.

1887 Vincularia gothica D'Orbigny. Marsson. Pal. Abh. IV. 1, p. 65.

1900 Floridina gothica (D'Orbigny). Canu. Bull. Soc. Geol. France. 3' Sér. XXVIII, p. 406.

1923 Floridina gothica (D'Orbigny). Volgt. Medd. Dansk Geol. Foren. Vol. 6. No. 20, p. 7, Pl. 1, Fig. 8 .

1930 Floridina gothica (D'Orbigny). Voigt. Leopoldina. VI, p. 468, Pl. 21, Figs. 7-10. 


\section{Description.}

The colonies consist of slender, prismatic, hexagonal stems with dichotomous ramification and the zooecia in alternating longitudinal rows, separated by slight, almost invisible furrows.

The zooecia are elongated, hexagonal, with almost straight marginal lines, a rounded anterior part and a straight posterior line. The cryptocyst is plane or slightly embedded. The opercular portion of the opesium is small, roundedtrapezohedral, with the broadest edge directed forward. In the opesiular region there are two large circular opesiules, separated from the opercular portion by a union of the opesial processes; a development like this is seen only on very well-preserved fragments. Normally the union is broken so that a trifoliate opesium appears, rests of the union forming small dentate processes from the lateral and proximal rim of the opesium. Sometimes the lateral teeth are more prominent than the proximal ones, which makes the opesium octagonal in shape.

Ovicells are rare. On the material examined they only appear in the form of cup-shaped depressions above and in connexion with the opesium.

Onychocellaria have not been observed in my material. They have been observed by Voigt on Senonian specimens and pictured (1930, Pl. 21, Fig. 9), but not described. They seem to be larger than the zooecia.

\begin{tabular}{|c|c|c|c|c|c|c|}
\hline Measuren & ents. & & Range & & Aver & \\
\hline Stevns, & Wid & h of zoarium ...... & $0.47-0.73$ & $\mathrm{~mm}$. & 0.61 & \\
\hline Kagstrup. & $\mathrm{Lz}$ & $\ldots \ldots$ & $0.47-0.57$ & - & 0.52 & - \\
\hline & $1 z$ & $\ldots \ldots \ldots \ldots \ldots \ldots \ldots \ldots$ & $0.21-0.31$ & - & 0.25 & - \\
\hline & ho & (opercular portion) ....... & $0.10-0.23$ & - & 0.17 & - \\
\hline & lo & $(-\quad-\quad) \ldots \ldots \ldots$ & $0.08-0.13$ & - & 0.12 & - \\
\hline & hov & $\ldots \ldots \ldots \ldots \ldots \ldots \ldots \ldots$ & 0.10 & - & & \\
\hline & lov & $\ldots \ldots \ldots \ldots \ldots \ldots$ & 0.13 & - & & \\
\hline
\end{tabular}

\section{Material.}

Stevns, Bryozoan Limestone - 58 specimens; Kagstrup - 37 specimens.

\section{Remarks.}

The Danian specimens seem to be slenderer than the Senonian colonies of this species. Perhaps they belong to an independent species or subspecies. In VoIGT's opinion (1930, p. 468) the trivial name gothica covers several species with vincularian stems as common features.

\section{Distribution .}

Senonian: France: Meudon; Germany: Rügen. Presumably also occurring in Danish White Chalk. 
Danian: Germany: Erratic Danian blocks in Anhalt. Denmark: Mainly Lower Danian, Stevns and Kagstrup; furthermore Faxe and Saltholm.

\section{Floridina tubulosa Voigt}

Plate 11, Fig. 5.

1923 Floridina tubulosa Vorgt. Medd. Dansk Geol. Foren. Vol. 6. No. 20, p. 7, P1. I, Figs. 6-7.

1930 Floridina tubulosa VoIGt. Leopoldina. VI, p. 469, Pl. 21, Fig. 2.

\section{Description.}

The zoarium forms hollow cylindrical or slightly infundibular stems with dichotomous ramification. The zooecia occur in alternating longitudinal rows, separated by narrow furrows.

The zooecia are hexagonal. The cryptocyst is plane or slightly sloping. The opesium is large, widely oval or rounded-triangular. The anterior part of the lateral zooecial rims is provided with a pair of symmetrical dentiform opesial processes. On well-preserved fragments there is a broad, low lip on the proximal margin of the opesium.

Ovicells have only been observed in the shape of rounded scars above the opesia. Their length and width are approximately the same.

Onychocellaria are rare. They are hexagonal, larger than the zooecia, have a trapezoid base, a large, widely oval opesium, and an evenly rounded anterior end.

\begin{tabular}{|c|c|c|c|c|c|}
\hline \multicolumn{3}{|c|}{ Measurements. } & Range . & \multicolumn{2}{|c|}{ Average } \\
\hline \multirow{7}{*}{$\begin{array}{l}\text { Kagstrup, } \\
\text { Stevns. }\end{array}$} & \multicolumn{2}{|c|}{ Width of zoarium ............ } & $0.83-1.14 \mathrm{~mm}$ & 0.99 & $\mathrm{~mm}$. \\
\hline & $\mathrm{L} z$ & $\ldots \ldots \ldots \ldots \ldots \ldots \ldots$ & $0.42-0.57-$ & 0.48 & - \\
\hline & $\mathrm{lz}$ & $\ldots \ldots \ldots \ldots \ldots \ldots \ldots$ & $0.21-0.36$ & 0.27 & - \\
\hline & ho & $\ldots \ldots \ldots \ldots \ldots \ldots \ldots$ & $0.13-0.29$ & 0.21 & - \\
\hline & lo & $\ldots \ldots \ldots \ldots \ldots \ldots \ldots$ & $0.13-0.21$ & 0.16 & - \\
\hline & hov & $\ldots \ldots \ldots \ldots \ldots \ldots \ldots$ & $0.13-0.16$ & & \\
\hline & lov & $\ldots \ldots \ldots \ldots \ldots \ldots \ldots \ldots$ & $0.16-0.18$ & & \\
\hline \multirow[t]{5}{*}{ Faxe. } & \multicolumn{2}{|c|}{ 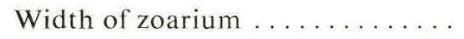 } & $1.04-1.35 \mathrm{~mm}$. & \multicolumn{2}{|c|}{$1.14 \mathrm{~mm}$. } \\
\hline & $\mathrm{Lz}$ & $\ldots \ldots \ldots \ldots \ldots \ldots \ldots$ & $0.42-0.57-$ & 0.49 & - \\
\hline & $\mathrm{lz}$ & $\ldots \ldots \ldots \ldots \ldots \ldots \ldots$ & $0.26-0.47$ & 0.34 & - \\
\hline & ho & $\ldots \ldots \ldots \ldots \ldots \ldots \ldots$ & $0.21-0.26$ & 0.24 & - \\
\hline & 10 & $\ldots \ldots \ldots \ldots \ldots \ldots \ldots \ldots$ & $0.16-0.31$ & 0.20 & - \\
\hline \multirow{6}{*}{$\begin{array}{l}\text { VolGt, } \\
1923 \text {, p. } 7 .\end{array}$} & $\mathrm{Lz}$ & $\ldots$ & \multicolumn{3}{|l|}{$0.45-0.54 \mathrm{~mm}$} \\
\hline & $\mathrm{lz}$ & $\ldots$ & \multicolumn{3}{|l|}{$0.37-0.50$} \\
\hline & ho & $\ldots \ldots \ldots \ldots \ldots \ldots \ldots \ldots$ & $0.22-0.37$ & & \\
\hline & lo & $\ldots \ldots \ldots \ldots \ldots \ldots \ldots$ & $0.17-0.21$ & & \\
\hline & Lon & $\ldots \ldots \ldots \ldots \ldots \ldots \ldots$ & $0.63-0.65$ & & \\
\hline & lon & $\ldots \ldots \ldots \ldots \ldots \ldots$ & $0.29-0.36$ & & \\
\hline
\end{tabular}


Material.

Stevns, Bryozoan Limestone - 34 specimens; Kagstrup - 74 specimens; Thorslunde -1 specimen; Faxe - 61 specimens; Faxe II - 1 specimen.

\section{Distribution.}

Danian: Germany: Erratic blocks in Anhalt; Denmark: Mainly Lower Danian: Stevns, Kagstrup; furthermore Thorslunde, Faxe, and Saltholm.

\section{Floridina voigti Bassler}

Plate 12, Fig. 1.

1930 Floridina bifoliata VoIgT. Leopoldina. VI, p. 468, PI. 20, Figs. 6-8.

1936 Floridina voigti BAssler. Journ. Wash. Acad. Sci. Vol. 26, No. 26, p. 161.

\section{Description.}

The zoarium forms thin, bifoliate plates with the zooecia in quincunx, separated by narrow, but distinct furrows.

The zooecia are oblong-hexagonal. The mural rim is in the posterior zooecial part separated from the convex, slightly sloping cryptocyst by two longitudinal furrows issuing from the proximal corners of the aperture. Sometimes the proximal part is tapering and wedges in between the two zooecia situated below. The opesium is trapezohedral or rounded-triangular, slightly trifoliate because of two dentiform opesial processes from the anterior part of the mural rim. The posterior margin of the opesium is provided with a broad low lip.

Ovicells have only been observed as depressions with triangularly rounded outlines above a few opesia.

Avicularia have not been observed.

\begin{tabular}{|c|c|c|c|c|}
\hline \multicolumn{3}{|c|}{ Measurements. } & \multirow{2}{*}{$\begin{array}{l}\text { Range } \\
0.47-0.68 \mathrm{~mm} .\end{array}$} & \multirow{2}{*}{$\begin{array}{l}\text { Average } \\
0.53 \mathrm{~mm} .\end{array}$} \\
\hline Klintholm, & $\mathrm{Lz}$ & & & \\
\hline Herfølge, & $1 z$ & & $0.29-0.36-$ & $0.34-$ \\
\hline Saltholm & ho & $\ldots$ & $0.13-0.23$ & 0.18 \\
\hline & lo & & $0.13-0.23=$ & 0.17 \\
\hline
\end{tabular}

\section{Material.}

Saltholm - 4 specimens; Klintholm - 1 specimen; Herfølge, Bryozoan Limestone - 11 specimens.

\section{Remarks.}

BASSLER (1936, p. 161) suggested the specific name of Floridina voigti instead of $F$. bifoliata, as this name has been preoccupied by Floridina bifoliata CANU and BASSLER (1920, p. 221), a Tertiary species from Mississippi. 
Floridina voigti in form of colonies and type of zooecia bears a certain resemblance to Membraniporidra inermis (LEVINSEN). The latter species, however, has larger zooecia ( $\mathrm{Lz}: 0.51-1.04 \mathrm{~mm} ., \mathrm{lz}: 0.31-0.52 \mathrm{~mm}$.) and has no lip on the lower margin of the opesium. It has also certain features in common with Floridina levinseni n.sp.; see below p. 126.

\section{Distribution.}

Danien: Germany: Erratic Danian blocks near Köthen. Denmark: Upper Danian: Faxe, Saltholm, Klintholm, and Herfølge.

\section{Floridina brydonei Voigt}

Plate 12, Figs. 5-6.

1930 Floridina Brydonei Voigt. Leopoldina. VI, p. 469, Pl. 20, Fig. 9.

\section{Description .}

The zoarium is encrusting or forms free, unilamellar plates, with the zooecia placed in quincunx, separated by narrow, slightly elevated bands. The backs of the plates consist of imbricate, rhombic scales with undulate and rugged margins.

The zooecia are large, especially wide, generally hexagonal. Sometimes there are pentagonal zooecia, the tapering posterior end of which wedges in between two proximal zooecia. The posterior half of the cryptocyst is elevated, convex, while the area below the opesium is plane, embedded, on a level with the opesium. This is rounded-trapezohedral or triangular, as a rule with opesiular indentations in the shape of semi-circular bulges from the proximal corners, the outline thus being trifoliate. The fertile zooecia have larger opesia than the sterile ones.

The ovicells appear as a greater convexity of the cryptocyst of the distal zooecium so that above the opesium there appears a convex roof-like process with a curved anterior margin, which laterally passes smoothly into the lateral rim of the zooecium. The opesium, as mentioned above, is larger, particularly wider, than the opesia of the zooecia which have no ovicells.

Onychocellaria have not been observed.

\begin{tabular}{|c|c|c|c|c|}
\hline Measurements. & & & Range & Average \\
\hline Herfølge. & $\mathrm{Lz}$ & & $0.57-0.62 \mathrm{~mm}$. & $0.60 \mathrm{~mm}$ \\
\hline Free, unilamellar. & $\mathrm{lz}$ & $\ldots \ldots \ldots \ldots \ldots \ldots$ & $0.47-0.62-$ & $0.57-$ \\
\hline & ho & $\ldots \ldots \ldots \ldots \ldots \ldots$ & $0.18-0.26$ & 0.22 \\
\hline & lo & $\ldots \ldots \ldots \ldots \ldots \ldots$ & $0.21-0.26$ & 0.25 \\
\hline & 10 & (fertile zooecium). & 0.31 & 0.31 \\
\hline
\end{tabular}




\begin{tabular}{|c|c|c|c|c|c|}
\hline \multirow[t]{5}{*}{ Encrusting. } & $\mathrm{Lz}$ & $\ldots \ldots \ldots \ldots \ldots$ & $0.62-0.68 \mathrm{~mm}$. & 0.64 & $\mathrm{~mm}$ \\
\hline & $\mathrm{lz}$ & $\ldots \ldots \ldots \ldots$ & $0.42-0.52-$ & 0.46 & - \\
\hline & ho & $\ldots \ldots \ldots \ldots$ & $0.18-0.21$ & 0.20 & - \\
\hline & lo & $\ldots \ldots \ldots \ldots$ & 0.21 & 0.21 & - \\
\hline & lo & (fertile zooecium). & 0.26 & 0.26 & - \\
\hline VoIGT, 1930, p. 469. & $\mathrm{Lz}$ & $\cdots \cdots \cdots \cdots \cdots$ & $\begin{array}{l}0.75 \mathrm{~mm} \text {. } \\
0.60-\end{array}$ & & \\
\hline
\end{tabular}

Material.

Herfølge, Bryozoan Limestone: Unilamellar plates - 62 specimens; encrusting 6 specimens.

Distribution.

Germany: Erratic Danian blocks near Köthen. Denmark: Upper Danian, Herfølge and Klintholm.

\section{Floridina impar Voigt}

Plate 12, Fig. 7.

Plate 13, Fig. 1.

1923 Floridina impar VoIgt. Medd. Dansk Geol. Foren. Vol. 6. No. 20, p. 4, Pl. I, Figs. 1-2. 1925 Membranipora velamen dentata LevinSEN. Vidensk. Selsk. Skr. 8. Ser. VII. 3, p. 344. 1930 Floridina impar Voigt. Leopoldina. VI, p. 471, Pl. 20, Fig. 16.

\section{Description.}

The zoarium is encrusting, with irregularly arranged zooecia, which are separated by narrow, almost invisible furrows.

The zooecia are elongated, generally rounded-hexagonal, but pentagonal, proximally tapering zooecia also occur. The posterior part of the cryptocyst is convex, on a level with the frontal, while the area behind the opesium is plane, slightly embedded. The shape of the opesium varies between pronouncedly trifoliate and rounded-triangular. In the former case the opesiular indentations form semi-circular bulges from the proximal corners of the opesium. The posterior margin of the opesium curves inward and the lateral rims are provided with a pair of dentate processes. Broken zooecia have a characteristic oblong-oval opesium with an unevenly undulate margin.

In the material examined ovicells have only been observed as cup-shaped depressions above a few opesia.

The onychocellaria are as a rule larger than the zooecia; they are oval with a smoothly tapering anterior end, little prominent, mostly slightly embedded. The opesium varies in size; its shape is semi-circular or trifoliate. 


\begin{tabular}{|c|c|c|c|c|}
\hline Measurements. & & & Range & Average \\
\hline Herfølge, Calcarenite. & $\mathrm{Lz}$ & $\ldots \ldots \ldots \ldots \ldots$ & $0.62-0.78 \mathrm{~mm}$. & $0.65 \mathrm{~mm}$. \\
\hline & $\mathrm{lz}$ & $\ldots \ldots \ldots \ldots \ldots$ & $0.47-0.57-$ & $0.52-$ \\
\hline & ho & $\ldots \ldots \ldots \ldots \ldots$ & $0.16-0.26$ & 0.18 \\
\hline & 10 & $\ldots \ldots \ldots \ldots \ldots$ & $0.16-0.26$ & 0.19 \\
\hline Stevns, Kagstrup, & $\mathrm{Lz}$ & $\ldots \ldots \ldots \ldots \ldots$ & $0.42-0.52 \mathrm{~mm}$. & $0.48 \mathrm{~mm}$. \\
\hline Faxe, Herfølge, & $1 z$ & $\ldots \ldots \ldots \ldots \ldots$ & $0.26-0.42-$ & $0.35-$ \\
\hline Bryozoan Limestone. & ho & $\ldots \ldots \ldots \ldots \ldots$ & $0.10-0.26$ & 0.18 \\
\hline & lo & $\ldots \ldots \ldots \ldots \ldots$ & $0.10-0.23$ & 0.17 \\
\hline VOIGT, 1923, p. 4. & $\mathrm{Lz}$ & $\cdots$ & $0.38-0.45 \mathrm{~mm}$. & \\
\hline & $1 z$ & $\ldots \ldots \ldots \ldots \ldots$ & $0.30-0.38-$ & \\
\hline & ho & $\ldots \ldots \ldots \ldots \ldots$ & $0.10-0.16$ & \\
\hline & lo & $\ldots \ldots \ldots \ldots \ldots$ & $0.09-0.12$ & \\
\hline & Lon & $\ldots \ldots \ldots \ldots \ldots$ & $0.54-0.60$ & \\
\hline & lon & $\ldots \ldots \ldots \ldots \ldots$ & $0.30-0.41$ & \\
\hline
\end{tabular}

The measurements show that the colonies from the Calcarenite of Herfølge have larger zooecia than the other Danian material.

\section{Material.}

Stevns, Bryozoan Limestone - 11 specimens; Kagstrup - 8 specimens; Faxe 23 specimens; Faxe II - 15 specimens; Faxe XI - 12 specimens; Herfølge, Bryozoan Limestone -5 specimens, Calcarenite -3 specimens.

\section{Remarks.}

Membranipora velamen dentata LEVINSEN has also been referred to this species. An examination of the material in LEVINSEN's type collection has shown that this reference is justifiable.

\section{Distribution.}

Danian: Germany: Erratic Danian blocks near Köthen. Sweden: Limhamn. Denmark: Stevns, Kagstrup, Faxe, Saltholm, Herfølge, and Klintholm.

\section{Floridina scutata (Levinsen)}

Plate 11, Fig. 8.

1925 Membranipora scutata Levinsen. Vidensk. Selsk. Skr. 8. Ser. VII. 3, p. 345, Pl. IV, Fig. 39.

1930 Floridina scutata Levinsen. Voigt. Leopoldina. VI, p. 470, P1. 20, Figs. 1-2.

\section{Description.}

The zoarium is encrusting, with irregularly arranged zooecia, which sometimes have an imbricate position, and which are separated by narrow, but distinct furrows. 
The zooecia are small, oval, or angularly oval, with a straight posterior line or with a tapering posterior part. The outermost part of the mural rim is narrow, prominent. The posterior part of the cryptocyst is convex, while the area behind the opesium is embedded, plane, on a level with the opesium. This is terminal, trifoliate; the opesiular indentations forms semi-circular bulges from the proximal corners of the opesium, and above these the mural rim is provided with a pair of small, dentate processes.

The ovicells form convex roof-like processes above the individual opesia and pass smoothly into the cryptocyst of the distal zooecium.

Onychocellaria have not been observed.

\begin{tabular}{|c|c|c|c|c|}
\hline \multicolumn{2}{|c|}{ Measurements. } & & Range & Average \\
\hline \multirow[t]{6}{*}{ Faxe. } & $\mathrm{Lz}$ & $\ldots \ldots \ldots \ldots \ldots \ldots \ldots$ & $0.36-0.47 \mathrm{~mm}$. & $0.40 \mathrm{~mm}$. \\
\hline & $1 z$ & $\ldots \ldots \ldots \ldots \ldots \ldots \ldots$ & $0.26-0.36-$ & $0.29-$ \\
\hline & ho & $\ldots \ldots \ldots \ldots \ldots \ldots \ldots \ldots$ & $0.10-0.16-$ & 0.11 \\
\hline & lo & $\ldots \ldots \ldots \ldots \ldots \ldots \ldots$ & $0.08-0.13$ & 0.11 \\
\hline & hov & $\ldots \ldots \ldots \ldots \ldots \ldots \ldots \ldots$ & 0.21 & \\
\hline & lov & $\ldots \ldots \ldots \ldots \ldots \ldots \ldots \ldots \ldots$ & 0.21 & \\
\hline \multirow{4}{*}{$\begin{array}{l}\text { Thorslunde, } \\
\text { Herfølge. }\end{array}$} & $\mathrm{Lz}$ & & $0.31-0.36 \mathrm{~mm}$ & $0.35 \mathrm{~mm}$. \\
\hline & lz & $\ldots \ldots \ldots \ldots \ldots \ldots \ldots$ & $0.21-0.31-$ & $0.25-$ \\
\hline & ho & $\ldots \ldots \ldots \ldots \ldots \ldots \ldots$ & $0.10-0.13$ & 0.10 \\
\hline & lo & $\ldots \ldots \ldots \ldots \ldots \ldots \ldots \ldots$ & $0.08-0.10-$ & 0.09 \\
\hline \multirow[t]{4}{*}{ Møn. } & $\mathrm{Lz}$ & & $0.34-0.36 \mathrm{~mm}$. & $0.35 \mathrm{~mm}$. \\
\hline & lz & $\ldots \ldots \ldots \ldots \ldots \ldots \ldots \ldots$ & $0.21-0.29-$ & $0.25-$ \\
\hline & ho & $\ldots \ldots \ldots \ldots \ldots \ldots \ldots$ & $0.08-0.10$ & 0.09 \\
\hline & lo & $\ldots \ldots \ldots \ldots \ldots \ldots \ldots \ldots$ & $0.08-0.10$ & 0.09 \\
\hline
\end{tabular}

\section{Material.}

Thorslunde - 5 specimens; Faxe -8 specimens; Faxe II - 6 specimens; Faxe XI - 2 specimens; Saltholm - 1 specimen; Herfølge, Bryozoan Limestone - 37 specimens.

Neotype. Pl. 11, Fig. 8. Faxe, Bryozoan Limestone.

\section{Remarks.}

Floridina scutata (LEVINSEN) bears great resemblance to the American species F. subscutata CANU and BASSLER from the Vincentown formation (1933, p. 34, Pl. 7, Fig. 1). CANU and Bassler "do not identify the two species as the same, because the Danish author did not note the onychocellarium. Our specific name recalls the close specific affinity." 
Distribution.

Senonian: Holland: Maastricht. Germany: Rügen. Denmark: Møn, Stevns.

Danian: Apparently only Upper Danian: Kagstrup, Thorslunde, Faxe, Saltholm, Herfølge, and Klintholm.

\section{Floridina trifolioides n.sp.}

Plate 13, Figs. 2-4.

Diagnosis.

A Floridina species with unilamellar, discoidal zoaria consisting of large transverse zooecia in quincunx. The opesium distinctly trifoliate, with large circular indentations, a curved posterior edge and lateral teeth immediately above the indentations. Fertile zooecia with larger opesia than sterile ones and with a convex, roof-like, slight process. No onychocellaria.

\section{Description.}

The zoarium forms free, unilamellar, sinuous plates with the zooecia in more or less regular quincunx and separated by narrow, but distinct furrows. The back of the colony consists of imbricate, rhombic scales.

The zooecia are comparatively large, hexagonal, transverse. Sometimes the zooecial width is equal to or greater than the length. The posterior part of the wide cryptocyst is projecting, convex, whereas the area below the opesium is plane or concave, sloping smoothly towards the embedded opesium. Sometimes the cryptocyst is provided with two oblique longitudinal furrows issuing from the opesiular indentations. The opesium is distinctly trifoliate. The opesiular indentations form large circular bulges from the proximal corners. These are directed obliquely backwards, the posterior margin of the opesium between the indentations thus obtaining the shape of a wide, curved, lip-like process. The trifoliate outline is further set off by two lateral teeth on the lateral margins of the opesium immediately above the opesiular indentations.

The fertile zooecia are characterized by having larger opesia than the sterile ones. Furthermore there is above the opesium a convex, roof-like, slight process.

Onychocellaria have not been observed.

\begin{tabular}{|c|c|c|c|c|}
\hline \multicolumn{3}{|l|}{ Measurements. } & Range & Average \\
\hline Herfølge, & $\mathrm{Lz}$ & & $0.52-0.68 \mathrm{~mm}$. & $0.59 \mathrm{~mm}$ \\
\hline Bryozoan Limestone & $\mathrm{lz}$ & & $0.44-0.62-$ & $0.55-$ \\
\hline and Calcarenite. & ho & $\ldots \ldots \ldots \ldots \ldots \ldots$ & $0.16-0.26$ & 0.20 \\
\hline Klintholm. & lo & $\ldots \ldots \ldots \ldots \ldots$ & $0.18-0.26$ & 0.23 \\
\hline & 10 & (fertile zooecium). & 0.31 & \\
\hline
\end{tabular}


Material.

Herfølge, Bryozoan Limestone - 166 specimens; Herfølge, Calcarenite - 21 specimens; Klintholm - 4 specimens.

Holotype. Pl. 13, Fig. 3. Herfølge, Bryozoan Limestone.

Paratypes. Pl. 13, Figs. 2 and 4. Herfølge, Bryozoan Limestone.

Remarks.

The trivial name refers to the trifoliate opesium.

Among the cretaceous Floridina species unilamellar, free plates also oecur in Floridina canüi BRYDONE (1913, p. 249, Pl. VIII, Figs. 10-11) and F. assimilis LeVInSEN (1925, p. 347, Pl. IV, Fig. 41), which are known from Senonian deposits, and from F. brydonei (see p. 119). In F. brydonei the back of the colony consists of rhombic, imbricate scales, as in F. trifolioides. Another feature common to them is the larger opesia in fertile zooecia. F. brydonei differs from $F$. trifolioides by having a rounded-trapezohedral or triangular opesium.

$F$. canui is, among other things, characterized by having rounded-hexagonal onychocellaria with small semi-circular opesia. As in F. trifolioides the opesium is distinctly trifoliate, but narrower (lo: $0.15-0.19 \mathrm{~mm}$.), and the posterior rim between the opesiular indentations is provided with a narrow tooth, which nearly touches the lateral teeth; the opercular portion of the opesium is not much larger than the opesiular region, while in $F$. trifolioides it is larger and particularly broader than this. F. canui BRYDONE is identical with $F$. trifolium VoIGT (1923, p. 5, Pl. 1, Fig. 3). In his description of the species VoIGT states that $F$. trifolium is found in the Danian at Herfølge, although rarely, whereas it is frequent in the White Chalk on Rügen. In his paper from 1930 (p. 470) Voigr established the identity of $F$. trifolium and $F$. canui. At the same time the stratigraphical distribution of the species was restricted to the Senonian (Rügen, Denmark, and Trimingham). There is a possibility that the specimens from Herfølge referred to $F$. trifolium belong to $F$. trifolioides.

Floridina assimilis LEVINSEN is characterized by chiefly having dichotomous, tubular zoaria. The zooecia are relatively narrow, and on well-preserved colonies 5 traces of spines are seen on the rim above the opesium.

Distribution. Denmark: Upper Danian: Herfølge and Klintholm.

\section{Floridina pulchella (Kade)}

Plate 11, Figs. 6-7.

1852 Siphonella pulchella KADE. Die losen Versteinerungen des Schanzenberges bei Meseritz, p. 28, Pl. 1, Fig. 17. 
1923 Floridina variabilis Volgt. Pal. Zeitschr. VI. 1, p. 8, Pl. 1, Figs. 22-23.

1923 Floridina variabilis Volgt. Medd. Dansk Geol. Foren. Vol. 6. No. 20, p. 6, Pl. I, Figs. 4-5.

1925 Thalamoporella impressipora faxensis LeVInSEN. Vidensk. Selsk. Skr. 8. Ser. VII. 3, p. 373 .

1930 Floridina variabilis VoIGT. Leopoldina. VI, p. 469, Pl. 21, Fig. 1.

\section{Description.}

The zoarium forms hollow, cylindrical or slightly infundibular stems with dichotomous ramification and the zooecia placed in alternating longitudinal rows.

The zooecia are hexagonal; anteriorly the mural rim is wide, rounded; posteriorly it passes smoothly into the plane or slightly sloping cryptocyst. The opesiular indentations are embedded, large and oval, anteriorly separated from the semi-elliptical transverse opercular portion of the opesium by the union of the opesial processes. If this bridge above the opesiules is broken, the shape of the opesium is trifoliate. Calcified zooecia are common; they are provided with a more or less convex olocyst with a median depression or pore.

Ovicells are not common. They form convex roof-like processes, which almost cover the opesia; the strongly curved anterior margin passes laterally into the lateral rims of the zooecium.

Onychocellaria have been observed only on a few fragments. They are larger than the surrounding zooecia, oval, with a wide, oval opesium, above which there is a rounded, roof-like process.

\begin{tabular}{|c|c|c|c|c|c|c|}
\hline \multicolumn{3}{|c|}{ Measurements. } & \multicolumn{2}{|l|}{ Range } & \multicolumn{2}{|c|}{ Average } \\
\hline \multirow[t]{9}{*}{ Herfølge. } & Widt & h of zoarium ............ & $0.83-1.25$ & $\mathrm{~mm}$. & 1.08 & $\mathrm{~mm}$. \\
\hline & $\mathrm{Lz}$ & $\ldots \ldots \ldots \ldots \ldots \ldots \ldots$ & $0.47-0.57$ & - & 0.51 & - \\
\hline & $\mathrm{lz}$ & $\ldots \ldots \ldots \ldots \ldots \ldots \ldots$ & $0.26-0.36$ & - & 0.31 & - \\
\hline & ho & $\ldots \ldots \ldots \ldots \ldots \ldots \ldots \ldots$ & 0.16 & - & 0.16 & - \\
\hline & lo & $\ldots \ldots \ldots \ldots \ldots \ldots \ldots \ldots$ & 0.16 & - & 0.16 & - \\
\hline & ho & (opercular portion) ........ & 0.05 & - & 0.05 & - \\
\hline & lo & $(-\quad-\quad) \ldots \ldots \ldots$ & $0.10-0.13$ & - & 0.10 & - \\
\hline & Lon & $\ldots \ldots \ldots \ldots \ldots \ldots \ldots \ldots$ & 0.68 & - & & \\
\hline & lon & $\ldots \ldots \ldots \ldots \ldots \ldots \ldots \ldots$ & 0.42 & - & & \\
\hline \multirow{5}{*}{$\begin{array}{l}\text { Faxe, } \\
\text { Saltholm. }\end{array}$} & \multicolumn{2}{|c|}{ Width of zoarium ............ } & \multicolumn{2}{|c|}{$1.04-1.30 \mathrm{~mm}$. } & \multicolumn{2}{|c|}{$1.09 \mathrm{~mm}$. } \\
\hline & $\mathrm{Lz}$ & $\ldots \ldots \ldots \ldots \ldots \ldots \ldots \ldots$ & $0.47-0.73$ & - & 0.55 & - \\
\hline & lz & $\ldots \ldots \ldots \ldots \ldots \ldots \ldots \ldots$ & $0.23-0.31$ & - & 0.28 & - \\
\hline & ho & (opercular portion) ........ & $0.05-0.08$ & - & 0.06 & - \\
\hline & 10 & $(-\quad-) \ldots \ldots \ldots$ & $0.10-0.13$ & - & 0.11 & - \\
\hline
\end{tabular}

\section{Material.}

Thorslunde -3 specimens; Faxe -7 specimens; Faxe II - 11 specimens; Saltholm, Bryozoan Limestone - 1 specimen; Saltholm - 5 specimens; Copenhagen, the South Harbour - 2 specimens; Herfølge, Bryozoan Limestone 125 specimens. 
Remarks.

Floridina pulchella (KADE) habitually bears great resemblance to $F$. tubulosa Vorgt. This especially applies to the specimens without union of the opesial processes so that the opesium is trifoliate. The opesium, however, is larger in F. tubulosa than in $F$. pulchella (ho: $0.21-0.26 \mathrm{~mm}$. as against $0.16 \mathrm{~mm}$.).

\section{Distribution.}

Germany: Erratic Danian blocks at Anhalt. Denmark: Upper Danian: Kagstrup, Thorslunde, Faxe, Saltholm, Copenhagen, Herfølge, and Klintholm.

\section{Floridina levinseni n.sp.}

Plate 12, Figs. 2-4.

Diagnosis.

A Floridina species with bifoliate, discoidal zoarium, consisting of elongated, hexagonal zooecia in quincunx. Zooecium with an elongated cryptocyst, two circular opesiules and a semi-elliptical transversal opercular portion of the opesium. Long, tapering onychocellarium with an acute-angled, roof-like process above the pyriform opesium.

\section{Description.}

The zoarium consists of thin, bifoliate plates with the zooecia in regular quincunx, separated by narrow furrows.

The zooecia are elongated, hexagonal. In the posterior part of the zooecium the mural rim is separated from the elongated, convex, slightly sloping cryptocyst by two slightly marked longitudinal furrows issuing from the opesiules. The anterior part of the cryptocyst is embedded and perforated by two circular opesiules, which are anteriorly separated from the terminal, semi-elliptical, transverse opercular region of the opesium by a union of the opesial processes. On zooecia where this union not exists, the opesium has a trifoliate shape.

The ovicells belong to the same type as those in Onychocella pulchella (KADE); they form convex, roof-like processes, which almost cover the opesia. The highly curved anterior margin merges smoothly into the lateral rims of the zooecium.

The onychocellaria are larger, particularly longer than the zooecia. The posterior half is demarcated by concave lateral rims, which encircle an area the proximal part of which is convex, while the area behind the opesium slopes smoothly down towards this. The anterior part of the onychocellarium is demarcated by convex lateral lines which above the opesium form a rounded, acute-angled, roof-like process. The opesium is large, pyriform. 


\begin{tabular}{|c|c|c|c|c|c|c|}
\hline \multicolumn{3}{|c|}{ Measurements. } & \multicolumn{2}{|l|}{ Range } & \multicolumn{2}{|c|}{ Average } \\
\hline \multirow[t]{8}{*}{ Herfølge. } & $\mathrm{Lz}$ & $\ldots \ldots$ & $0.47-0.62$ & $\mathrm{~mm}$. & 0.55 & $\mathrm{~mm}$. \\
\hline & $1 z$ & $\ldots \ldots$ & $0.26-0.36$ & - & 0.31 & - \\
\hline & ho & $\ldots \ldots \ldots \ldots \ldots \ldots \ldots \ldots$ & 0.16 & - & 0.16 & - \\
\hline & lo & $\ldots \ldots \ldots \ldots \ldots \ldots \ldots$ & $0.13-0.16$ & - & 0.16 & - \\
\hline & ho & (opercular portion) ........ & 0.08 & - & 0.08 & - \\
\hline & 10 & $(-\quad-\quad) \ldots \ldots \ldots$ & 0.10 & - & 0.10 & - \\
\hline & Lon & $\ldots \ldots \ldots \ldots \ldots \ldots \ldots$ & $0.78-0.83$ & - & 0.81 & - \\
\hline & lon & $\ldots \ldots \ldots \ldots \ldots \ldots \ldots \ldots$ & 0.34 & - & & \\
\hline
\end{tabular}

Material.

Herfølge, Bryozoan Limestone - 90 specimens; Herfølge, Calcarenite - 4 specimens; Klintholm - 1 specimen.

Holotype. Pl. 12, Fig. 2. Herfølge, Bryozoan Limestone.

Paratypes. Pl. 12, Figs. 3-4. Herfølge, Bryozoan Limestone.

\section{Remarks.}

The species is dedicated to the memory of the late Dr. G. M. R. LEVINSEN (18501914 ) in appreciation of his investigations into fossil and recent Bryozoa.

Floridina levinseni n.sp. seems, together with $F$. pulchella (KADE) and the Senonian form F. impressipora (MARSSON), to form a natural group within the genus Floridina, characterized by the demarcated opesiular indentations and the shape of the onychocellaria.

Habitually $F$. levinseni bears a great resemblance to $F$. voigti (BASSLER), first of all by having the same shape of colony, the thin, bilamellar plates. Among differences we should especially emphasize the opesial size and shape, as the opesium in $F$. voigti is more tapering and generally larger (ho: $0.18 \mathrm{~mm}$.) than that of F. levinseni (ho: $0.16 \mathrm{~mm}$.). Furthermore, the wide, low lip on the inferior margin of the opesium is a characteristic feature in F. voigti.

In his description of $F$. voigti $(1930$, p. 468) VoIGT states that on well-preserved fragments it is possible to observe a line of demarcation between the opercular region of the opesium and the opesiular indentations, an observation which probably is based on examinations of material belonging to F. levinseni.

Distribution. Denmark: Upper Danian, Herfølge and Klintholm.

\section{Floridina fragilis n.sp.}

Plate 28, Figs. 2, 3 and 6.

Diagnosis.

A Floridina species with thin, unilamellar, discoidal zoaria consisting of roundedhexagonal zooecia in regular quincunx. The zooecial rim has a narrow, prominent 
outer zone and a broader, sloping inner zone, which surrounds the elongated, rounded-rectangular or trapezohedral opesium. The cryptocyst is convex, slightly sloping.

\section{Description.}

The zoarium forms thin unilamellar, sometimes curved plates with the zooecia in regular quincunx, separated by narrow furrows. The back consists of rhombic, imbricate scales.

The zooecia are rounded-hexagonal. The mural rim as a rule has a prominent narrow outer zone and a broader inner zone, which distally slopes towards the embedded opesium, and which proximally passes smoothly into the convex, slightly sloping cryptocyst. The opesium is elongated, rounded-rectangular or trapezohedral, with a straight or slightly curved posterior edge. The opesiular indentations are not distinctly marked, and as the lateral opesial processes are not particularly prominent, either, the outline of the opesium is not really trifoliate. Sometimes there are calcified zooecia in which the opesium is covered by a thin olocyst with an oval pore.

Ovicells or onychocellaria have not been observed.

\begin{tabular}{|c|c|c|c|c|}
\hline \multicolumn{3}{|c|}{ Measurements. } & \multirow{2}{*}{$\begin{array}{l}\text { Range } \\
0.47-0.57 \mathrm{~mm} \text {. }\end{array}$} & \multirow{2}{*}{$\begin{array}{l}\text { Average } \\
0.51 \mathrm{~mm}\end{array}$} \\
\hline Kagstrup. & $\mathrm{Lz}$ & $\cdots$ & & \\
\hline & $1 z$ & $\ldots \ldots$ & $0.31-0.42-$ & $0.36-$ \\
\hline & ho & $\ldots \ldots \ldots \ldots \ldots \ldots \ldots \ldots \ldots$ & $0.16-0.21-$ & 0.18 \\
\hline & lo & $\ldots \ldots \ldots \ldots \ldots \ldots \ldots$ & $0.10-0.16$ & 0.14 \\
\hline
\end{tabular}

\section{Material.}

Kagstrup, Sample Ba (the Tylocidaris abildgaardi zone) - 345 specimens; Kagstrup, Sample Ca (the T. brünnichi zone) - 228 specimens; Stevns, Boesdal, Sample Ma - 258 specimens, Mb - 494 specimens, Mc -500 specimens, $\mathrm{Md}-$ 482 specimens, Me - 272 specimens, Mf - 56 specimens; Faxe, Hvedeland, Sample D - 68 specimens; Faxe, North wall, Sample $\mathrm{Na}-10$ specimens, $\mathrm{Nb}-$ 12 specimens, Nc - 36 specimens, Nd -2 specimens; Saltholm, Bryozoan Limestone, Sample E - 3 specimens, and Sample Fc -1 specimen.

Holotype. Pl. 28, Fig. 2. Kagstrup. T. abildgaardi zone.

\section{Remarks.}

The trivial name refers to the fragility of the fragments, which is the cause of these mostly consisting of a few zooecia only.

Floridina fragilis has the same shape of colony as the Senonian species $F$. canui Brydone and the Danian species, F. trifolioides n.sp. and F. brydonei Vorgt. The former two species have distinctly trifoliate opesia, F. canui furthermore large onychocellaria, and F. brydonei has large zooecia with wide, triangular opesia. There is also a certain habitual similarity to $F$. assimilis LE- 
VINSEN and $F$. tubulosa VOIGT, both of these species having tubular colonies, and $F$. assimilis is furthermore characterized by having a wide, trifoliate opesium and 5 apertural spines. In $F$. tubulosa the posterior rim forms a wide, low, labial process, while the lateral rims are provided with small dentiform opesial processes.

Distribution. Danian: Stevns, Kagstrup, Faxe, and Saltholm.

\section{Floridina excavata Voigt}

Plate 13, Fig. 5.

1930 Floridina scutata LeVInsen var. excavata Vorgt. Leopoldina. VI, p. 471, Pl. 21, Figs. 4-6.

\section{Description.}

The zoarium forms unilamellar, tubular stems with dichotomous ramification. The zooecia are placed in alternating longitudinal rows and separated by narrow, but distinct furrows.

The zooecia are rounded-hexagonal. The mural rim is distally and laterally somewhat prominent, convex. Proximally it passes evenly into the slightly embedded cryptocyst; in the area immediately below the opesium it is separated from the cryptocyst by two faint longitudinal furrows issuing from the proximal corners of the opesium. This is trifoliate, with small opesiular indentations; on old fragments these have disappeared and the shape of the opesium then is semi- or subcircular. Calcified zooecia occur in the bifurcation area. The olocyst is provided with a median oval or circular pore.

Ovicells have only been observed as cup-shaped depressions above a few opesia. The outline is rounded-quadrangular and the length is a little greater than the width.

Onychocellaria have not been observed.

\begin{tabular}{|c|c|c|c|c|c|c|}
\hline \multicolumn{3}{|c|}{ Measurements. } & \multicolumn{2}{|l|}{ Range } & \multicolumn{2}{|c|}{ Average } \\
\hline Herfølge. & Wid & of zoarium ............ & $0.73-1.14$ & $\mathrm{~mm}$. & 0.94 & $\mathrm{~nm}$. \\
\hline & $\mathrm{Lz}$ & $\ldots \ldots \ldots \ldots \ldots \ldots \ldots$ & $0.31-0.42$ & - & 0.38 & - \\
\hline & $1 z$ & $\ldots \ldots \ldots$ & $0.26-0.36$ & - & 0.29 & - \\
\hline & ho & $\ldots \ldots \ldots \ldots \ldots \ldots \ldots \ldots$ & $0.08-0.10$ & - & 0.09 & - \\
\hline & 10 & $\ldots \ldots \ldots \ldots \ldots \ldots \ldots \ldots$ & $0.10-0.13$ & - & 0.11 & - \\
\hline & hov & 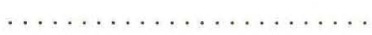 & $0.13-0.16$ & - & & \\
\hline & lov & $\ldots \ldots \ldots \ldots \ldots$ & 0.13 & - & & \\
\hline
\end{tabular}

Material. Herfølge, Bryozoan Limestone, 9 specimens. 
Distribution.

Germany: Erratic Danian blocks at Köthen (Anhalt). Denmark: Upper Danian: Herfølge and Klintholm.

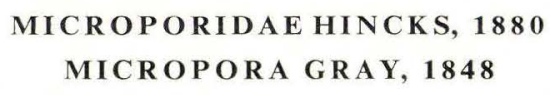

\section{Micropora angulata Levinsen}

Plate 13, Fig. 6.

1925 Micropora angulata Levinsen. Vidensk. Selsk. Skr. 8. Ser. VII, 3, p. 363, PI. IV, Fig. 51.

1930 Micropora angulata Levinsen. Voigt. Leopoldina. VI, p. 473, Pl. 21, Fig. 19.

\section{Description.}

The zoarium forms cylindrical or slightly compressed stems with 6-9 alternating rows of zooecia. The zooecia are separated by distinct furrows or narrow depressions.

The zooecia are elongated, rounded-hexagonal. The posterior half has concave lateral rims and a straight posterior edge, the anterior part having convex lateral margins and an evenly rounded anterior edge. The lateral zooecial rims are wide, very convex, falling off outwards towards the adjoining zooecia as well as inwards towards the cryptocyst; the width decreases gradually towards the proximal part of the zooecium. The width of the carinate, convex cryptocyst amounts to only about half of that of the zooecium, and between the cryptocyst and the lateral rims there are two pronounced elongated depressions which increase in width in the distal direction. Below the aperture the lateral rims are connected with a transversal ridge, so that the small, semielliptical aperture in all directions is surrounded by prominent, convex rims. In the widest part of the two longitudinal furrows there are two symmetrical, oval opesiules.

Ovicells and avicularia have not been observed.

\begin{tabular}{|c|c|c|c|c|}
\hline \multicolumn{3}{|c|}{ Measurements. } & \multirow{2}{*}{$\begin{array}{l}\text { Range } \\
0.78-1.20 \mathrm{~mm} \text {. }\end{array}$} & \multirow{2}{*}{$\begin{array}{l}\text { Average } \\
0.93 \mathrm{~mm}\end{array}$} \\
\hline Herfølge. & Wic & of zoarium $\ldots \ldots \ldots \ldots$ & & \\
\hline & $\mathrm{Lz}$ & $\ldots \ldots \ldots \ldots \ldots \ldots \ldots \ldots$ & $0.68-0.88-$ & $0.74-$ \\
\hline & $1 z$ & $\ldots \ldots \ldots \ldots$ & $0.29-0.47$ & 0.38 \\
\hline & ha & $\ldots \ldots \ldots \ldots$ & $0.08-0.13$ & 0.10 \\
\hline & la & $\ldots \ldots \ldots \ldots \ldots \ldots \ldots$ & $0.08-0.10$ & 0.10 \\
\hline
\end{tabular}

\section{Material.}

Thorslunde - 6 specimens; Faxe - 42 specimens; Faxe XI - 8 specimens; Herfølge, Bryozoan Limestone - 70 specimens; Herfølge, Calcarenite - 1 specimen. 


\section{Distribution.}

In LEVINSEN's collection of types there are four fragments marked Møn, i.e. Senonian. Considering that the species is not known from other Senonian localities we undoubtedly ought to call in question this indication of locality. Otherwise the species is connected with Upper Danian, Thorslunde, Faxe, Saltholm, Herfølge, and Klintholm; furthermore it has been found in erratic Danian blocks in Germany.

\section{Micropora erratica (Voigt)}

Plate 15, Figs. 2-3.

1924 Homalostega erratica VoIGT. Pal. Zeitschr. VI. 1, p. 9, Pl. I, Fig. 27.

1925 Micropora gracilis Levinsen. Vidensk. Selsk. Skr. 8. Ser. VII. 3, p. 365, Pl. IV, Fig. 52.

1930 Micropora erratica (VOIGT). Leopoldina, VI, p. 474, Pl. 22, Fig. 11.

\section{Description.}

The zoarium is encrusting, with the zooecia in regular quincunx, separated by furrows and depressions.

The zooecia are oval or rounded-hexagonal. The cryptocyst is plane or slightly convex, pierced by two circular or elliptical opesiules, which are placed below the opesium, near the lateral rims of the zooecium. The aperture is terminal, semi-elliptical, transverse, with a curved anterior edge and a straight posterior edge, which sometimes has a broad labial process. Calcified zooecia with an oval median pore are common.

The ovicells form broad, convex roof-like processes above a few opesia.

Avicularia have not been observed.

\begin{tabular}{|c|c|c|c|c|}
\hline \multicolumn{3}{|c|}{ Measurements. } & \multirow{2}{*}{$\begin{array}{l}\text { Range } \\
0.36-0.52 \mathrm{~mm} \text {. }\end{array}$} & \multirow{2}{*}{$\begin{array}{l}\text { Average } \\
0.45 \mathrm{~mm}\end{array}$} \\
\hline Stevns, & $\mathrm{Lz}$ & & & \\
\hline Kagstrup, & $\mathrm{lz}$ & $\ldots$ & $0.23-0.36-$ & $0.30-$ \\
\hline Faxe, & ha & $\ldots \ldots \ldots \ldots \ldots \ldots$ & $0.05-0.08$ & 0.06 \\
\hline \multirow[t]{3}{*}{ Herfølge. } & la & $\ldots \ldots \ldots \ldots \ldots \ldots \ldots$ & $0.10-0.13$ & 0.11 \\
\hline & hov & $\ldots \ldots \ldots \ldots \ldots \ldots \ldots \ldots$ & 0.10 & 0.10 \\
\hline & lov & $\ldots \ldots \ldots \ldots \ldots \ldots \ldots$ & $0.16-0.18$ & 0.17 \\
\hline VoIGT, & $\mathrm{Lz}$ & $\ldots \ldots$ & $0.23-0.33 \mathrm{~mm}$. & \\
\hline 1924, p. 9. & $\mathrm{lz}$ & $\ldots \ldots \ldots$ & $0.22-0.30-$ & \\
\hline
\end{tabular}

\section{Material.}

Stevns, Bryozoan Limestone - 11 specimens; Kagstrup - 9 specimens; Faxe 1 specimen; Faxe II - 4 specimens; Herfølge, Bryozoan Limestone -8 specimens. 
Remarks.

According to Voigt (1930, p. 474) this species is known from the Santonian deposits on Ifö in Sweden and from the Danian at Faxe, whereas it has not been found in the Baltic Senonian Chalk. This extraordinary distribution suggests that we have to do with two species, a point of view which is supported by the fact that the zooecial length in the Ifö material is smaller than that of the Danian specimens $(0.25-0.30 \mathrm{~mm}$. as against $0.36-0.52 \mathrm{~mm}$.).

\title{
Distribution .
}

Danian: Stevns, Kagstrup, Faxe, Saltholm, Herfølge, and Klintholm.

\section{Micropora hennigiana n.sp.}

\author{
Plate 13, Figs. 7-8.
}

1892 ?Steganoporella nobilis (EsPer) HenNIG. Lunds Univ. Årsskr. XXVIII, p. 35, Pl. 2, Figs. 25-26.

1930 Micropora sp. Voigt. Leopoldina. VI, p. 474, Pl. 22, Fig. 15.

Diagnosis.

A Micropora species with encrusting zoaria consisting of wide, rounded-hexagonal zooecia in irregular quincunx. The terminal, semi-elliptical, transverse aperture and the anterior, laterally embedded, medianly convex, part of the cryptocyst is demarcated by a wide, plane rim, which below the aperture is connected with a plane transversal band. The opesiules are oblong-elliptical, marginal, embedded.

\section{Description.}

The zoarium is encrusting, with the zooecia in irregular quincunx and separated by furrows and depressions.

The zooecia are wide, rounded-hexagonal, each with a terminal, semielliptical, transverse aperture. The mural rim is wide, plane, and prominent round the aperture and the anterior, laterally embedded part of the cryptocyst, while it proximally passes smoothly into the posterior, plane, or slightly convex cryptocystal area. Below the aperture the rims are connected by a projecting transversal band. The opesiules are oblong-elliptical, placed in the embedded parts at the foot of the zooecial rim, separated by a convex part of the cryptocyst.

The ovicells appear as large convex processes above the opesia and covering these. The bottom of the ovicell forms a cup-shaped depression. The fertile zooecia have wider apertures than the sterile ones.

Avicularia have not been observed. 


\begin{tabular}{|c|c|c|c|c|c|}
\hline \multicolumn{3}{|c|}{ Measurements. } & \multicolumn{2}{|l|}{ Range } & Average \\
\hline Faxe, & $\mathrm{Lz}$ & $\ldots \ldots$ & $0.42-0.55$ & $\mathrm{~mm}$. & $0.48 \mathrm{~mm}$. \\
\hline Herfølge. & $1 z$ & $\ldots \ldots$ & $0.31-0.47$ & - & $0.40-$ \\
\hline & ha & $\ldots \ldots \ldots \ldots \ldots \ldots \ldots \ldots$ & $0.05-0.08$ & - & 0.07 \\
\hline & la & $\ldots \ldots \ldots \ldots \ldots \ldots \ldots$ & $0.05-0.10$ & - & 0.10 \\
\hline & la & (fertile zooecium) ....... & 0.16 & - & \\
\hline & hov, & lov $\ldots \ldots \ldots \ldots \ldots \ldots$ & 0.26 & - & \\
\hline
\end{tabular}

\section{Material.}

Faxe - 5 specimens; Faxe XI - 2 specimens; Herfølge, Bryozoan Limestone 2 specimens.

Holotype. Pl. 13, Fig. 7. Herfølge, Bryozoan Limestone.

\section{Remarks.}

Micropora hennigiana n.sp. is dedicated to the memory of the Swedish paleontologist Anders Hennig, Ph.D., who in 1892-94 published his investigations into Swedish cretaceous Bryozoa.

HenNiG's species Steganoporella nobilis (ESPER) is given with a question mark against it in the list of synonyms. This uncertainty is due to the fact that HENNIG in his description of the species states the presence of tapering, transverse avicularia above the opesia, formulating his statement in the way that such avicularia are found in large numbers on some specimens, while they are absent on others. HenNIG's pictures show partly a specimen without avicularia (Fig. 25), partly a fragment with avicularia (Fig. 26). The present material of $M$. hennigiana agrees with the former illustration, whereas the pictured specimen bearing avicularia has a deviating appearance. It is probable that HENNIG's figures 25 and 26 are pictures of two different species.

Distribution. Sweden: Danian at Annetorp. Denmark: Faxe, Herfølge, i.e. Upper Danian.

\section{Micropora stevensis Levinsen}

Plate 14, Fig. 1.

1925 Micropora stevensis Levinsen. Vidensk. Selsk. Skr. 8. Ser. VII. 3, p. 366, Pl. V, Fig. 53.

1930 Micropora stevensis LeVInsen. Vorgt. Leopoldina. VI, p. 474, PI. 22, Fig. 9.

\section{Description.}

The zoarium is encrusting, with the zooecia in fairly regular quincunx, separated by narrow, mostly indistinct furrows, sometimes imbricate.

The zooecia are rhombically or hexagonally rounded. The cryptocyst is generally slightly convex, surrounded by narrow, straight and very erect rims. 
The aperture is terminal, semi-elliptical, transverse. The proximal, straight edge is provided with a wide, low, thickened, dentiform process.

The ovicells form wide, convex, roof-like processes above some of the apertures. The fertile zooecia have wider apertures than the sterile ones.

Avicularia are very rare. They are extremely small, of a rounded-triangular form, and generally placed above the zooecia.

\begin{tabular}{|c|c|c|c|c|c|c|}
\hline \multicolumn{3}{|c|}{ Measurements. } & \multicolumn{2}{|l|}{ Range } & \multicolumn{2}{|c|}{ Average } \\
\hline Kagstrup, & $\mathrm{Lz}$ & $\ldots \ldots \ldots \ldots \ldots \ldots \ldots \ldots$ & $0.36-0.57$ & $\mathrm{~mm}$. & 0.48 & $\mathrm{~mm}$. \\
\hline Faxe, & $\mathrm{lz}$ & $\ldots \ldots \ldots \ldots \ldots \ldots \ldots \ldots$ & $0.29-0.47$ & & 0.36 & - \\
\hline \multirow[t]{5}{*}{ Herfølge. } & ha & $\ldots \ldots \ldots \ldots \ldots \ldots \ldots \ldots$ & $0.05-0.08$ & - & 0.07 & - \\
\hline & la & $\ldots \ldots \ldots \ldots \ldots \ldots \ldots \ldots$ & $0.10-0.13$ & - & 0.10 & - \\
\hline & la & (fertile zooecium) $\ldots \ldots \ldots$ & 0.16 & - & & \\
\hline & hov & $\ldots \ldots \ldots \ldots \ldots \ldots \ldots \ldots$ & $0.21-0.26$ & - & 0.23 & - \\
\hline & lov & $\ldots \ldots \ldots \ldots \ldots \ldots \ldots \ldots$ & $0.23-0.29$ & - & 0.24 & - \\
\hline
\end{tabular}

Material.

Kagstrup, Bryozoan Limestone - 1 specimen; Faxe -8 specimens; Faxe XI 4 specimens; Herfølge, Bryozoan Limestone - 29 specimens.

Neotype.

Pl. 14, Fig. 1. Faxe, Bryozoan Limestone. The species is missing from LevinSEN's type collection.

Remarks.

This species occupies a place apart within the genus Micropora as it is not, like the other species mentioned, in possession of visible opesiules.

\section{Distribution .}

Germany: Erratic Danian blocks at Köthen. Denmark: Kagstrup, Stevns, Faxe, and Herfølge.

\section{SEMIESCHARIN ELLA d' ORBIG NY, 1852}

\section{Semiescharinella complanata d'Orbigny}

Plate 14, Figs. 2-3.

1846 Cellepora ricata v. Hagenow. In H.B. Geinitz, Grundriss der Versteinerungskunde, p. 616.

1852 Semiescharinella complanata D’Orbigny. Pal. Franç. Terr. Crét. 5, p. 427, P1. 714, Figs. 1-4.

1887 Semieschara subgranulata (v. Hag.). Marsson. Pal. Abh. IV. 1, p. 75. 
1925 Membranipora (?) subgranulata (v. HaG.). LeVinsen. Vidensk. Selsk. Skr. 8. Ser. VII. 3, p. 348.

1930 Micropora subgranulata (v. HAG.) [partim]. Voigt. Leopoldina. VI, p. 476, Pl. 24, Fig. 18.

1959 Semiescharinella complanata d’Orbigny. Voigt. Geologie. Beiheft 25, p. 54, Pl. VI, Fig. 1.

\section{Description.}

The zoarium is encrusting or forms free, unilamellar, thin plates. Sometimes there are also tubular colonies. The zooecia are placed in more or less regular quincunx and separated by narrow, mostly indistinct furrows.

The zooecia are variable in size and shape, most frequently rounded-hexagonal or rhombic, more rarely oval. The zooecial margin forms a narrow rim, which posteriorly is slightly elevated, in the anterior half more prominent. The cryptocyst may be slightly convex, plane, or slightly concave, sometimes with two longitudinal furrows issuing from the proximal corners of the aperture. In the encrusting material the aperture is semi-circular or semi-elliptical, transverse, small, about one fifth of the zooecial length. In the unilamellar specimens the aperture is generally larger, with a maximum of one third of the length of the zooecium. The outline is pyriform or rounded-quadrangular. Between these two types of apertures there are gradual transitions. The posterior edge of the aperture is provided with a wide, low, labial process.

As to the shape and size of the ovicells there is also as a rule a difference between the encrusting and the unilamellar material. On the encrusting colonies the ovicells form small, wide, convex roof-like processes above the opesia. The distal margin of the ovicell is mostly distinctly issuing from the cryptocyst of the distal zooecium. On the unilamellar plates the ovicells on the whole are larger, particularly longer, and the distal part of the convex ovicell passes more or less smoothly into the cryptocyst placed anteriorly to it.

Small, triangular avicularia occur above all zooecia with the exception of those bearing ovicells. The base of the triangle is formed by the distal zooecial rim, and the two other sides of the triangle consist of elevated narrow bands, which surround a circular or oval pore. On the discoidal colonies LEVINSEN could observe that the pore continues in a long, somewhat bent, highly tapering groove. I have not been able to demonstrate this development on the Danian specimens examined. Unfortunately LEvINSEN's material of discoidal zoaria are missing from his type collection.

\section{Measurements.}

\begin{tabular}{|c|c|c|c|c|c|}
\hline \multicolumn{3}{|c|}{ Encrusting colonies: } & \multirow{2}{*}{\multicolumn{2}{|c|}{$\begin{array}{l}\text { Range } \\
0.31-0.52 \mathrm{~mm} .\end{array}$}} & \multirow{2}{*}{$\begin{array}{l}\text { Average } \\
0.43 \mathrm{~mm}\end{array}$} \\
\hline Herfølge. & $\mathrm{Lz}$ & & & & \\
\hline & $1 z$ & & $0.21-0.36$ & - & $0.30-$ \\
\hline & ha & & $0.08-0.10$ & - & 0.09 \\
\hline & la & & $0.10-0.18$ & - & 0.15 \\
\hline
\end{tabular}




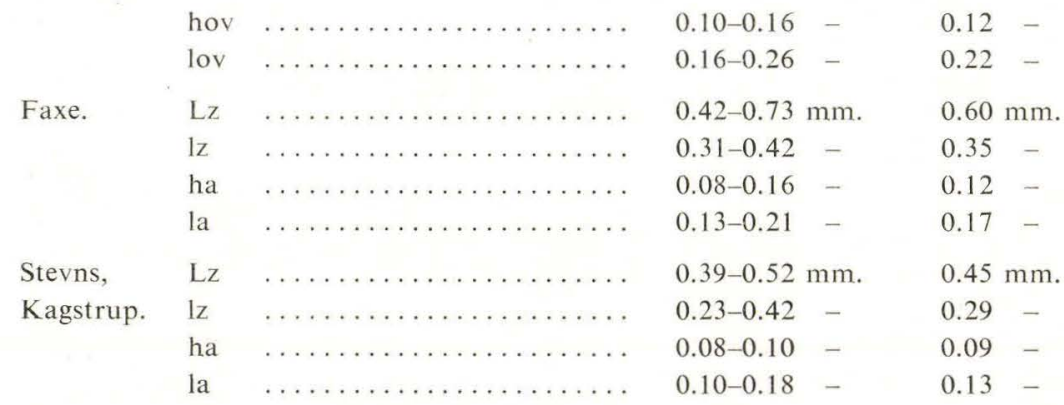

Unilamellar colonies:

\begin{tabular}{|c|c|c|c|c|}
\hline \multirow[t]{6}{*}{ Herfølge. } & $\mathrm{Lz}$ & & $0.62-1.04 \mathrm{~mm}$. & $0.76 \mathrm{~mm}$. \\
\hline & lz & $\ldots \ldots \ldots \ldots \ldots \ldots \ldots \ldots \ldots$ & $0.31-0.42-$ & $0.34-$ \\
\hline & ha & $\ldots \ldots \ldots \ldots \ldots \ldots \ldots \ldots$ & $0.18-0.29$ & 0.24 \\
\hline & la & $\ldots \ldots \ldots \ldots \ldots \ldots \ldots \ldots$ & $0.18-0.26$ & 0.22 \\
\hline & hov & $\ldots \ldots \ldots \ldots \ldots \ldots \ldots \ldots$ & $0.23-0.26$ & 0.25 \\
\hline & lov & $\ldots \ldots \ldots \ldots \ldots \ldots \ldots \ldots \ldots$ & $0.26-0.29$ & 0.28 \\
\hline \multirow[t]{6}{*}{ Faxe. } & $\mathrm{Lz}$ & . & $0.62-1.04 \mathrm{~mm}$. & $0.75 \mathrm{~mm}$. \\
\hline & $\mathrm{lz}$ & $\ldots \ldots \ldots \ldots \ldots \ldots \ldots \ldots$ & $0.31-0.52-$ & $0.39-$ \\
\hline & ha & $\ldots \ldots \ldots \ldots \ldots \ldots \ldots \ldots$ & $0.16-0.31$ & 0.22 \\
\hline & la & $\ldots \ldots \ldots \ldots \ldots \ldots \ldots \ldots$ & $0.18-0.31$ & 0.24 \\
\hline & hov & $\ldots \ldots \ldots \ldots \ldots \ldots \ldots \ldots \ldots$ & 0.26 & \\
\hline & lov & $\ldots \ldots \ldots \ldots \ldots \ldots \ldots$ & 0.31 & \\
\hline
\end{tabular}

The measurements show that apart from the above-mentioned variation in the ratio of the length of zooecium to the length of aperture, there is an appreciable difference between the zooecial length in the encrusting colonies and that in the unilamellar ones, the latter having considerably longer zooecia than the encrusting specimens.

\section{Material.}

As regards shapes of colonies and localities, the material examined is distributed as follows:

$\begin{array}{ccc}\begin{array}{c}\text { Encrusting } \\ \text { specimens }\end{array} & \begin{array}{c}\text { Tubular } \\ \text { specimens }\end{array} & \begin{array}{c}\text { Discoidal } \\ \text { specimens }\end{array}\end{array}$

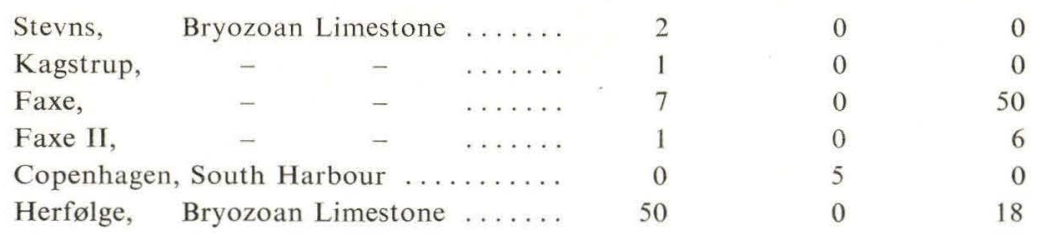

\section{Remarks.}

VoIGT (1959, p. 54) had an opportunity to examine D'ORBIGNY's original material of Semiescharinella complanata and has been able to show that the specimens. of Micropora subgranulata v. HAGENOw from Rügen agree with 
D'ORBIGNY's species, while the Maastricht material of M. subgranulata clearly differs from $S$. complanata.

Voigt at the same time revived D'Orbigny's genus Semiescharinella, characterized by the presence of a small avicularium above the opesium and the absence of opesiules and interzooecial avicularia.

The Danian material naturally attaches itself to $S$. complanata. The largecelled, discoidal colonies perhaps ought to be referred to a subspecies of $S$. complanata. The reason why such a placing has not been practised here, is in the first place lack of knowledge of the range of variations in encrusting and discoidal colonies from the Senonian.

\title{
Distribution.
}

Senonian: France: Cotentin. Germany: Rügen. Sweden: Ifö. Denmark: Ålborg, Gudumlund.

Danian: Sweden (Volgt, 1930, p. 476). Germany: Erratic Danian blocks. Denmark: Stevns, Kagstrup, Faxe, Saltholm, Copenhagen, Herfølge, and Klintholm.

\section{Semiescharinella pulchra (Ulrich and Bassler)}

\author{
Plate 28, Fig. 4.
}

1907 Micropora pulchra Ulrich and Bassler. In Weller, Geol. Surv. New Jersey. Paleontology. Vol. 4, p. 347, Pl. 25, Fig. 3.

1930 Micropora ef. pulchra Ulrich and Bassler. Voigt. Leopoldina. Vol. 6, p. 476, PI. 24, Fig. 20.

1933 Micropora (?) pulchra Ulrich and Bassler. Canu and Bassler. U.S. Nat. Mus. Bull. 165, p. 36, Pl. 8, Fig. 5.

1959 Semiescharinella pulchra (Ulrich and Bassler). Voigt. Geologie. Beiheft 25, p. 55.

\section{Description.}

The zoarium forms free, slender, cylindrical or bilamellar stems with dichotomous ramification. The zooecia are arranged in alternating longitudinal rows and are separated by narrow furrows.

The zooecia are elongated, hexagonal, with almost parallel, prominent, rounded lateral rims. The anterior end of the zooecium is tapering, rounded at the tip. The proximal part is generally concealed under the zooecium below. The cryptocyst is plane or slightly convex. It is demarcated from the lateral rims by two parallel longitudinal furrows issuing from the proximal apertural corners. The aperture is terminal, semi-elliptical, transverse, and proximally demarcated by a narrow, concave lip.

Ovicells have not been observed, but according to CANU and BASSLER they are endozooecial, very small, convex, and smooth.

Above the opesia there are small, triangular, oblique avicularia. 
Measurements.

Range Average

Saltholm. Width of zoarium .......... $0.57-0.73 \mathrm{~mm} . \quad 0.62 \mathrm{~mm}$.

Lz $\quad \ldots \ldots \ldots \ldots \ldots \ldots \ldots, 0.68-0.78-0.73-$

lz $\quad \ldots \ldots \ldots \ldots \ldots \ldots \ldots \ldots, 0.26-0.29-0.27 \quad-$

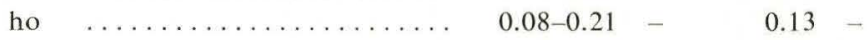

lo $\ldots \ldots \ldots \ldots \ldots \ldots \ldots \ldots$. $0.10-0.16-0.15$ -

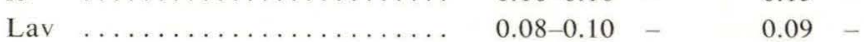

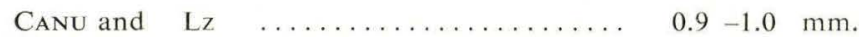

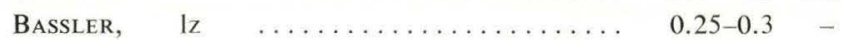

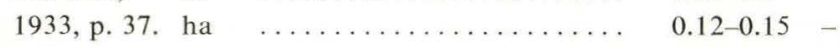

la $\quad \ldots \ldots \ldots \ldots \ldots \ldots \ldots \ldots, 0.15-0.17 \quad-$

Material.

Saltholm, Sandy-limestone, Sample Fa - 3 specimens, Sample Fb - 2 specimens; Herfølge, Bryozoan Limestone, Sample Ge - 1 specimen; Klintholm, Sample I- 1 specimen.

Distribution.

Upper Danian: Saltholm, Herfølge, and Klintholm. Paleocene: Vincentown, New Jersey, U.S.A.

AECHMELLA CANU AND BASSLER, 1917

\section{Aechmella pindborgi n.sp.}

Plate 14, Figs. 4-5.

1924 Aechmella hippocrepis (non Goldfuss) [partim] VoIgT. Pal. Zeitschr. VI. 1, p. 9, Pl. I, Figs. 35-36.

1925 Micropora hippocrepis (non Goldfuss) [partim] LeVInsen. Vidensk.Selsk. Skr. 8. Ser. VII. 3, p. 367.

1930 Aechmella clio (D’OrbignY) [partim]. Voigt. Leopoldina. VI, p. 477.

Diagnosis.

An Aechmella species with encrusting zoaria consisting of rounded-hexagonal zooecia in regular quincunx. The cryptocyst and the embedded, semi-elliptical, transverse opesium is surrounded by a narrow rim, which distally becomes gradually more prominent, and which above the opesium forms a roof at right angles to the frontal. The ovicells form convex processes above a few opesia. The proximal part of the avicularium is rhombic or pyriform. The distal part tapers into a long narrow tip. 


\section{Description.}

The zoarium is encrusting, with the zooecia in regular quincunx, often imbricate.

The zooecia are rounded-hexagonal, more rarely oval. The cryptocyst, which is plane or slightly convex, slopes smoothly towards the embedded opesium; it is surrounded by a narrow rim, which in the posterior half of the zooecium is level with the cryptocystal area or slightly elevated above it. In the anterior part of the zooecium the lateral rims gradually become more prominent and culminate at the distal zooecial end, where the two rims join in a roof-like process stretching over the opesium at right angles to the frontal. The opesium is semi-elliptical, transverse, with curved anterior and lateral borders and straight or slightly curved posterior edge, which may be bandshaped and thickened or form a wide, low, labial process.

The ovicells belong to the endozooecial type. They form wide, convex, sloping roof-like processes, which completely or partly cover the opesium. The ovicell distally passes smoothly into the cryptocyst of the zooecium in front. The anterior margin is greatly curved. The fertile zooecia have wider opesia than the sterile ones.

The avicularia occur interzooecially. They are rhombic or pyriform, with the embedded, oval, comparatively large opesium shifted a little forward. The anterior part is drawn out into a shorter or longer, thin tip with almost parallel lateral margins along a narrow, slightly tapering canal.

\begin{tabular}{|c|c|c|c|c|c|c|}
\hline Measure & nts. & & Range & & Aver: & \\
\hline Herfølge. & $\mathrm{Lz}$ & $\ldots \ldots \ldots \ldots \ldots+\ldots, \ldots$ & $0.34-0.47$ & $\mathrm{~nm}$. & 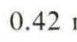 & $\mathrm{nm}$. \\
\hline & $\mathrm{Iz}$ & 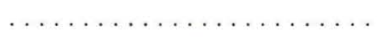 & $0.26-0.31$ & - & 0.29 & - \\
\hline & ho & 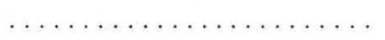 & $0.08-0.10$ & - & 0.09 & - \\
\hline & lo & 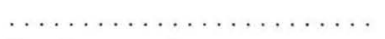 & $0.10-0.18$ & - & 0.14 & - \\
\hline & lo & (fertile zooecium) $\ldots \ldots \ldots$ & 0.21 & - & & \\
\hline & hov & 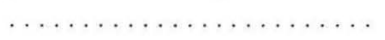 & 0.10 & - & & \\
\hline & lov & 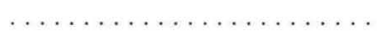 & $0.13-0.16$ & - & & \\
\hline & Lav & 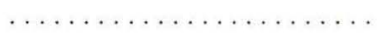 & $0.26-0.31$ & - & 0.27 & - \\
\hline & lav & 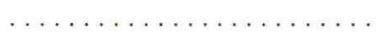 & $0.10-0.26$ & - & 0.12 & - \\
\hline Faxe, & $\mathrm{Lz}$ & $\cdots \ldots \ldots$ & $0.34-0.52$ & $\mathrm{~nm}$. & 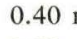 & $\mathrm{nm}$. \\
\hline Saltholm, & 17. & 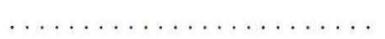 & $0.23-0.36$ & - & 0.29 & - \\
\hline Kagstrup, & ho & 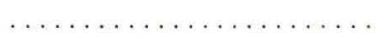 & $0.05-0.10$ & - & 0.08 & - \\
\hline Stevns. & lo & 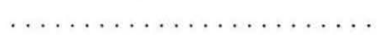 & $0.10-0.18$ & - & 0.14 & - \\
\hline & Lav & & $0.21-0.26$ & - & 0.23 & - \\
\hline & lav & 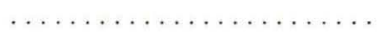 & 0.10 & - & 0.10 & - \\
\hline Aechmella & lio: & & & & & \\
\hline Møn. & $\mathrm{Lz}$ & $\ldots \ldots \ldots \ldots \ldots \ldots \ldots \ldots$ & $0.34-0.52$ & nm. & 0.42 & $\mathrm{~nm}$ \\
\hline & $1 z$ & $\ldots \ldots \ldots, \ldots, \ldots, \ldots, \ldots$ & $0.26-0.36$ & - & 0.33 & - \\
\hline & ho & & $0.05-0.10$ & - & 0.08 & - \\
\hline & lo & $\ldots \ldots \ldots \ldots \ldots \ldots+\ldots, \ldots$ & $0.13-0.21$ & - & 0.15 & - \\
\hline & Lav & 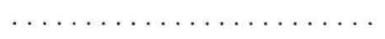 & $0.16-0.18$ & - & 0.16 & - \\
\hline & lav & $\ldots \ldots$ & $0.08-0.10$ & - & 0.09 & - \\
\hline
\end{tabular}




\section{Material.}

Stevns, Bryozoan Limestone - 131 specimens; Kagstrup - 34 specimens; Thorslunde - 2 specimens; Faxe - 134 specimens; Faxe II - 8 specimens; Faxe XI - 9 specimens; Saltholm - 6 specimens; Herfølge, Bryozoan Limestone -208 specimens.

Holotype. Pl. 14, Fig. 4. Herfølge, Bryozoan Limestone.

\section{Remarks.}

Aechmella pindborgi is dedicated to the memory of the late S.J. PINDBorG (1850-1921), teacher, who alongside of his teaching occupied himself with the study of cretaceous Bryozoa, thus determinations of species in the material of Bryozoa from the South Harbour of Copenhagen (Rosenkrantz, 1920, p. 28).

A. pindborgi differs from A. clio D'Orbigny (Pl. 14, Fig. 6) in the delimitation made by Volgt (1930, p. 477) -on the following points:

(1) The shape of zooecium in A. pindborgi is mainly rounded-hexagonal, whereas oval zooecia are the dominant type in $A$. clio. (2) In $A$. pindborgi there is above the opesium a roof-like process formed by ramification of the distal parts of the prominent rims of the zooecium. Such a process is rarely-and if so, more slightly-developed in A. clio. (3) A. pindborgi has comparatively large rhombic or pyriform avicularia with correspondingly large opesia. The anterior part of the avicularium is protracted into a narrow tip. A. clio has small, oval avicularia (cf. the measurements as above) with small opesia.

LEVINSEN's characterization of Micropora hippocrepis (1925, p. 367) is mainly based on colonies from Faxe. An examination of this material has shown that most specimens belong to $A$. pindborgi, while the remaining fragments may be referred to Aechmella latistoma n.sp.

Correspondingly VoIGT's description of A. hippocrepis (VoIGT, 1924, p. 9) is apparently based on a mixed material of specimens of $A$. pindborgi and A. latistoma from erratic Danian blozks from Köthen and Rosslau in Germany. VorGT's Figs. 35 and 36 show fragments of $A$. pindborgi, while Fig. 34 seems to picture A.latistoma. The description in the text of the shape of the opesium and the corresponding measurements fit to a greater extent with A. latistoma than with $A$. pindborgi, whereas VoIGT's characterization of the shape of the avicularium seems to be based on avicularia of the $A$. pindborgi type.

In Hennig's description of Periteichisma hippocrepis (1892, p. 26) the Swedish Danian locality Annetorp is mentioned as one of the habitats of this species. Therefore it is an obvious idea that $A$. pindborgi should be represented in the Bryozoan fauna of Swedish Danian, but it is not possible to have this point of view corroborated on the basis of HENNIG's description of species.

From the English Senonian Brydone (1930, p. 74, Pl. XXXVI, Figs. 2-4) has described and pictured a form, Rhagasostoma vectense, which habitually bears a certain resemblance to $A$. pindborgi. It is, however, characterized by 
the narrow, tapering part of the avicularium being very long, longer than the rest of the avicularium, so that this has the same, or approximately the same, length as the zooecium.

\section{Distribution.}

Danian: Germany: Erratic blocks at Köthen and Rosslau. Denmark: Stevns, Kagstrup, Thorslunde, Faxe, Saltholm, Herfølge, and Klintholm.

\section{Aechmella latistoma n.sp.}

Plate 14, Fig. 7.

Plate 15, Fig. 1.

1924 Aechmella hippocrepis (non Goldfuss) [partim]. Vorgt. Leopoldina, Pal. Zeitschr. VI. 1, p. 9, Pl. 1, Fig. 34.

1925 Aechmella hippocrepis (non Goldfuss) [partim]. LeVInsen. Vidensk. Selsk. Skr. 8. Ser. VII. 3, p. 367.

\section{Diagnosis.}

An Aechmella species with encrusting zoaria consisting of hexagonal zooecia in quincunx. Mural rim increasing in width towards the middle of the zooecium and stretching over the adjoining zooecia. Opesium terminal, semi-elliptical, transverse with a wide, thickened proximal lip. Fertile zooecia with a median bulge. Avicularia interzooecial, oval, with opesial slit.

\section{Description.}

The zooarium is encrusting, with the zooecia in fairly regular quincunx.

The zooecia are rounded-hexagonal. The mural rim at the posterior end of the cell is narrow, but increases gradually in width towards the middle of the zooecium and at the same time grows plane, with smoothly rounded outer margins; where the rim has its greatest width it stretches over the proximal corners of the adjoining zooecia. Anteriorly it again grows gradually narrower and above the opesium has its original width. The cryptocyst is convex, sloping slightly towards the opesium and demarcated from the mural rim by two distinct longitudinal furrows issuing from the proximal corners of the opesium. This is terminal, wide, semi-elliptical, transverse, with a greatly curved anterior margin and a more slightly curved posterior edge which forms a thickened, wide, low, labial process. In the proximal corners there are two symmetrical notches, which must be interpreted as opesiular indentations. The opesial shape of the fertile zooecium is mentioned under the description of the ovicells.

The endozooecial ovicells present themselves by a slight raising of the posterior part of the cryptocyst on the distal zooecium. The aperture is very narrow and demarcated by a highly curved margin which generally is merged 
with the anterior margin of the opesium, which thus obtains a small, distally directed bulge.

Avicularia appear interzooecially, but are rare. They are oblong-oval with a smoothly rounded posterior part and a tapering anterior part. The opesium, which is embedded, with a rhombic outline, is proximally provided with a long narrow slit. This is anteriorly barred by a transversal ridge, which has arisen by merging of two symmetrical processes placed laterally to the slit. The transversal ridge divides the anterior part of the opesium into three small, elongated areas.

\begin{tabular}{|c|c|c|c|c|c|c|}
\hline \multicolumn{3}{|c|}{ Measurements. } & \multicolumn{2}{|l|}{ Range } & \multicolumn{2}{|c|}{ Average } \\
\hline Faxe, & $\mathrm{Lz}$ & $\ldots \ldots \ldots \ldots \ldots$ & $0.34-0.52$ & $\mathrm{~mm}$. & 0.42 & $\mathrm{~mm}$. \\
\hline Herfølge. & $1 z$ & 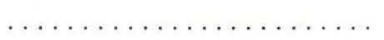 & $0.26-0.36$ & - & 0.31 & - \\
\hline & ho & $\ldots \ldots \ldots, \ldots, \cdots$, & $0.05-0.10$ & - & 0.07 & - \\
\hline & lo & 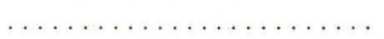 & $0.16-0.21$ & - & 0.18 & - \\
\hline & hov & $\ldots \ldots \ldots \ldots \ldots \ldots \ldots \ldots$ & 0.10 & - & & \\
\hline & lov & 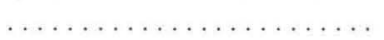 & 0.10 & - & & \\
\hline & Lav & 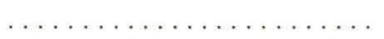 & $0.26-0.36$ & - & 0.31 & - \\
\hline & lav & $\ldots \ldots \ldots \ldots \ldots \ldots \ldots \ldots$ & $0.13-0.16$ & - & 0.15 & - \\
\hline
\end{tabular}

\section{Material.}

Thorslunde - 6 specimens; Faxe - 6 specimens; Herfølge, Bryozoan Limestone 61 specimens.

Holotype. Pl. 14, Fig. 7. Herfølge, Bryozoan Limestone.

\section{Remarks.}

The trivial name refers to the wide, semi-elliptical, transverse opesium.

As mentioned in my remarks in connexion with the description of Aechmella pindborgi n.sp., some of LEVINSEN's material, marked Micropora hippocrepis, belongs to that species. Similarly, some of the Danian material on which VorgT's description and pictures of Aechmella hippocrepis has been based (VoIGT, 1924, p. 9), probably should be referred to A. latistoma. This is indicated partly by VoIGT's Fig. 34, partly by his statements of measurements in the text (ho: 0.04-0.07 mm., lo: 0.15-0.17 mm.).

Aechmella latistoma by virtue of its special type of avicularium occupies a place apart within the genus Aechmella. In Rhagastoma anglicum BRYDONE (1936, p. 76, Pl. XXXVII, Figs. 2-4) from Trimingham in England the avicularia have a similar shape.

\section{Distribution.}

Danian: Germany: Erratic blocks at Köthen and Rosslau. Denmark: Upper Danian: Thorslunde, Faxe, Herfølge, and Klintholm. 


\section{Aechmella microstoma (Marsson)}

Plate 14, Fig. 8.

1887 Vincularia microstoma Marsson. Pal. Abh. IV. 1, p. 65, PI. VI, Fig. 9.

1925 Micropora hippocrepis microstoma MARsson. Levinsen. Vidensk. Selsk. Skr. 8. Ser. VII. 3, p. 368.

1930 Aechmella microstoma Marsson. Vorgt. Leopoldina. VI, p. 478, Pl. 24, Figs. 5-6.

\section{Description.}

The zoarium forms slender, hexagonal stems with dichotomous ramification and with the zooecia in regularly alternating longitudinal rows.

The zooecia are oblong-hexagonal with a tapering proximal part. The mural rim, which is comparatively narrow, somewhat prominent, rounded, is demarcated from the plane or slightly convex, sloping cryptocyst by two longitudinal furrows. The opesium is terminal, semi-elliptical, transverse. The posterior margin is provided with a broad, low lip.

The ovicells form slightly convex processes above the various opesia. In the fertile zooecia the opesium is a little larger than in the sterile ones.

The avicularia are interzooecial. They are lanceolate with a smoothly rounded posterior end and a tapering anterior part. The opesium is oval with a short, narrow, median slit on the proximal lip.

Measurements.

Herfølge, Width of zoarium ...........

Saltholm.

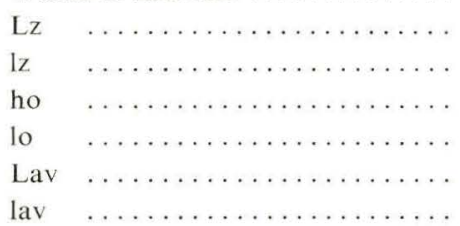

Range

Average

$0.52-0.68 \mathrm{~mm}$. $\quad 0.60 \mathrm{~mm}$.

$\begin{array}{lll}0.44-0.52 & - & 0.47\end{array}$

$0.21-0.31-0.27$

$0.05-0.10-0.08$

$0.10-0.13-0.10-$

$0.31-0.34-$

$0.10 \quad-$

Faxe.

\begin{tabular}{|c|c|c|c|}
\hline Wid & of zoarium $\ldots \ldots$. & $0.62-0.83$ & $\mathrm{~mm}$ \\
\hline $\mathrm{Lz}$ & $\ldots \ldots \ldots \ldots \ldots \ldots \ldots \ldots$ & $0.42-0.57$ & - \\
\hline lz & $\ldots \ldots$ & $0.23-0.31$ & - \\
\hline ho & $\cdots$ & $0.05-0.10$ & - \\
\hline lo & $\ldots \ldots \ldots \ldots \ldots \ldots$ & $0.10-0.13$ & - \\
\hline Lav & $\ldots \ldots \ldots \ldots \ldots \ldots \ldots \ldots$ & $0.21-0.26$ & - \\
\hline lav & $\ldots \ldots \ldots \ldots \ldots \ldots \ldots$ & 0.10 & - \\
\hline
\end{tabular}

$0.75 \mathrm{~mm}$.

0.48

0.26

$0.08-$

$0.11-$

\section{Material.}

Thorslunde - 1 specimen; Faxe - 18 specimens; Faxe II - 2 specimens; Saltholm, Bryozoan Limestone - 1 specimen; Saltholm - 3 specimens; Herfølge, Bryozoan Limestone - 18 specimens. 
Distribution.

Senonian: Germany: Rügen. Denmark: Møn.

Danian: Sweden: Skåne (VoIGT, 1930, p. 469). Germany: Erratic blocks. Denmark: Stevns, Kagstrup, Thorslunde, Faxe, Saltholm, Herfølge, and Klintholm.

\section{Aechmella tenuis n.sp.}

Plate 28, Fig 5.

Diagnosis.

Slender, quadrangular to octagonal stems consisting of elongated zooecia in alternating longitudinal rows. The anterior part of the zooecium is semi-elliptical and demarcated by a narrow prominent margin, while the posterior part is smoothly tapering and is terminated by a straight posterior margin. The opesium is semi-elliptical, terminal. The avicularium is rhombic or pyriform, with the distal end drawn out into a long, narrow tip.

\section{Description .}

The zoarium forms slender, quadrangular to octagonal, dichotomous stems consisting of regularly alternating longitudinal rows of zooecia, which are separated by narrow, almost invisible furrows.

The anterior part of the zooecium is semi-elliptical and provided with a narrow, prominent rim, which sometimes forms a roof-like process above the opesium. The proximal part is smoothly tapering towards the posterior end and is terminated by a straight or slightly curved posterior margin. The cryptocyst is plane and often slightly embedded. It is sometimes provided with two narrow longitudinal furrows issuing from the proximal corners of the opesium. This is terminal, semi-elliptical or, more rarely, rounded-rectangular with a straight posterior margin.

Ovicells have not been observed.

The avicularia occur interzooecially. They are rounded-rhombic or pyriform, with the embedded oval opesium shifted forward. The anterior part of the avicularium is drawn out into a long tip with almost parallel lateral rims along a narrow, slightly tapering canal.

\begin{tabular}{|c|c|c|c|c|c|c|}
\hline \multicolumn{3}{|c|}{ Measurements. } & \multirow{2}{*}{\multicolumn{2}{|c|}{$\begin{array}{l}\text { Range } \\
0.42-0.57 \mathrm{~mm} \text {. }\end{array}$}} & \multirow{2}{*}{\multicolumn{2}{|c|}{$\begin{array}{l}\text { Average } \\
0.49 \mathrm{~mm}\end{array}$}} \\
\hline Kagstrup, & Widt & n of zoarium ............ & & & & \\
\hline Faxe, & $\mathrm{Lz}$ & $\ldots \ldots \ldots \ldots \ldots \ldots \ldots \ldots$ & $0.47-0.57$ & - & 0.50 & - \\
\hline \multirow[t]{5}{*}{ Klintholm. } & $\mathrm{lz}$ & $\ldots \ldots \ldots \ldots \ldots \ldots \ldots \ldots$ & $0.21-0.31$ & - & 0.24 & - \\
\hline & ho & $\ldots \ldots \ldots \ldots \ldots \ldots \ldots \ldots$ & $0.05-0.10$ & - & 0.08 & - \\
\hline & 10 & $\ldots \ldots \ldots \ldots \ldots \ldots \ldots \ldots$ & $0.08-0.10$ & - & 0.09 & - \\
\hline & Lav & $\ldots \ldots \ldots \ldots \ldots \ldots \ldots \ldots$ & $0.26-0.36$ & - & & \\
\hline & lav & $\ldots \ldots \ldots \ldots \ldots \ldots \ldots \ldots$ & $0.10-0.16$ & - & & \\
\hline
\end{tabular}


Material.

Kagstrup, Sample Ca (the T. brünnichi zone- 833 specimens. Faxe, Hvedeland, Sample Da - 48 specimens; Faxe, northern wall, Sample $\mathrm{Na}-24$ specimens, Sample Nb - 10 specimens, Sample Nc - 6 specimens; Saltholm, Bryozoan Limestone, Sample E - 55 specimens, Sample Fc - 36 specimens; Saltholm, Sandy-limestone, Sample Fb - 3 specimens; Herfølge, Sample Gd (5.80 m.) 3 specimens, Sample Ge $(6.75$ m.) - 11 specimens, Sample Gf $(7.15$ m.) 26 specimens; Klintholm, Sample $\mathrm{Ha}-16$ specimens, Sample $\mathrm{Hb}-93$ specimens, Sample I - 37 specimens.

\section{Holotype.}

Pl. 28, Fig. 5. Faxe, north wall of the quarry, about $4 \mathrm{~m}$. below ground level, Bryozoan Limestone.

\section{Remarks.}

The trivial name refers to the thin stems. Aechmella tenuis n.sp. habitually bears great resemblance to A. microstoma MARsson, which on the whole has slightly thicker stems and which, furthermore, is characterized by having a broad, low lip on the posterior edge of the opesium.

Floridina gothica D'OrBIGNy has the same shape of colony as A. tenuis, but differs from it as regards (1) the zooecial shape, the zooecium in $F$. gothica laterally being demarcated by parallel rims, (2) the shape of the opesial area, which in F. gothica is either composed of two circular opesiules and a trapezohedral opercular portion or trifoliate.

Apart from the features mentioned Aechmella tenuis differs from the two species by having narrow prominent rims which demarcate the anterior part of the zooecium.

\section{Distribution.}

Upper Danian: Kagstrup, Faxe, Saltholm, Herfølge, and Klintholm.

\section{H O PLIT A ECHMELLA V OIGT, 1949}

\section{Hoplitaechmella smitti (Hennig)}

Plate 15, Fig. 4.

1892 Periteichisma Smittii HennIG. Lunds Univ. Årsskr. XXVIII, p. 25, Pl. 1, Figs. 10-11.

1925 Membranipora (?) vespertilio var. Smitti Hennig. Levinsen. Vidensk. Selsk. Skr. 8. Ser. VII. 3, p. 349.

1930 Aechmella smitti Hennig. Voigt. Leopoldina. VI, p. 481, Pl. 23, Fig. 3. 


\section{Description.}

The zoarium is encrusting with the zooecia in irregularly alternating longitudinal rows and separated by deep depressions.

The zooecia are rounded-hexagonal. In the distal part of the zooecium the rim is narrow, prominent, set with 6-8 apertural spines, which appear as small, wart-like processes with a circular pore at the top. The cryptocyst is well-developed, convex, with two longitudinal furrows issuing from the proximal corners of the opesium. This is semi-elliptical or rounded-triangular with a straight posterior margin, which laterally is provided with two small, symmetrical notches, opesiular indentations.

Ovicells have not been observed in the material examined. According to HeNNIG they are globular.

There are two types of avicularia: frontal and interzooecial ones. The former appear in pairs above the distal corners of the zooecium. They are lanceolate with an oblong-oval opesium. The latter are found in the depressions between the zooecia. They have a rounded-rhombical posterior part and a smoothly tapering anterior part. On the surface of the avicularium there is a grooveshaped depression issuing from the tip of the avicularium and amounting to about two thirds of the length of the avicularium. In the middle of this groove there is a small oval or circular opesium. The groove is laterally demarcated by narrow, prominent lateral rims, which off the opesium are provided with a concavity so that the groove in this place seems to have a constriction.

\section{Measurements.}

\begin{tabular}{|c|c|c|c|c|c|c|}
\hline \multirow{3}{*}{$\begin{array}{l}\text { Faxe, } \\
\text { Herfølge. }\end{array}$} & \multirow{3}{*}{$\begin{array}{l}\mathrm{Lz} \\
\mathrm{lz}\end{array}$} & & \multicolumn{2}{|l|}{ Range } & \multicolumn{2}{|c|}{ Average } \\
\hline & & $\ldots \ldots \ldots \ldots \ldots$ & $0.42-0.62$ & $\mathrm{~mm}$. & 0.49 & $\mathrm{~mm}$. \\
\hline & & $\ldots \ldots \ldots \ldots \ldots \ldots$ & $0.26-0.42$ & - & 0.34 & - \\
\hline & ho & $\ldots \ldots \ldots \ldots \ldots \ldots$ & $0.10-0.16$ & - & 0.12 & - \\
\hline & lo & $\ldots \ldots \ldots \ldots \ldots \ldots \ldots \ldots$ & $0.10-0.18$ & - & 0.15 & - \\
\hline & hov & $\ldots \ldots \ldots \ldots \ldots \ldots$ & 0.16 & - & & \\
\hline & lov & $\ldots \ldots \ldots \ldots \ldots \ldots \ldots$ & 0.26 & - & & \\
\hline & Lav & (frontal) $\ldots \ldots \ldots \ldots \ldots$ & 0.10 & - & 0.10 & - \\
\hline & lav & $(-) \ldots \ldots \ldots \ldots \ldots$ & 0.08 & - & 0.08 & - \\
\hline & Lav & (interzooecial) $\ldots \ldots \ldots \ldots$ & 0.42 & - & & \\
\hline & lav & $(\quad-\quad) \ldots \ldots \ldots \ldots$ & 0.16 & - & & \\
\hline
\end{tabular}

Material. Faxe -2 specimens; Herfølge -8 specimens.

\section{Remarks.}

The presence of apertural spines and dimorphic avicularia refers this species to VoigT's genus, Hoplitaechmella.

LeVInSEn viewed Hennig's species as a variety of the Senonian form, Aechmella vespertillo v. HAGENOW. Apart from the difference in stratigraphic 
placement, $A$. vespertilio differs from $A$. smitti i.a. by having larger zooecia (Lz: 0.68-1.04 mm.), more prominent opesiular indentations (see Pl. 14, Fig. 6), and a different shape of the avicularium.

Distribution. Danian: Sweden: Annetorp. Denmark: Faxe and Herfølge.

\section{Hoplitaechmella vespertilioides n.sp.}

Plate 15, Fig. 5.

Diagnosis.

A Hoplitaechmella species with encrusting zoaria consisting of irregularlysometimes flabelliformly - arranged, imbricate, hexagonal or rhombic zooecia. The zooecium is provided with 6 apertural spines, semi-elliptical, transverse opesium with a broad labial posterior margin and obliquely backwards directed, circular opesiular indentations. The mural rim increases in width towards the middle of the zooecium and is separated from the convex cryptocyst by two longitudinal furrows. The surface is marbled. Small convex ovicells are of common occurrence above the opesia. Two types of avicularia: (1) Two small, lanceolate ones placed symmetrically above the distal corners of the zooecium; (2) Interzooecial large ones with a rhombic proximal area and a groove-like depression in the distal part.

\section{Description .}

The zoarium is encrusting, with imbricate, irregularly-sometimes flabelliformly-arranged zooecia, which are separated by deep depressions and furrows.

The zooecia are rounded-hexagonal or rhombic. The rim round the aperture is comparatively narrow, rounded, prominent. It is provided with 6 circular pores, traces of apertural spines. Off the posterior margin of the opesium the mural rim expands into a wide, plane frame, which sometimes stretches beyond the proximal corners of the adjoining zooecia and which has its greatest width off the middle of the zooecium. Proximally the frame decreases gradually and has completely disappeared at the posterior margin of the zooecium. It is separated from the plane, greatly convex cryptocyst by two distinct longitudinal furrows. The opesium is terminal, semi-elliptical, transverse. In the proximal corners the opesiular indentations form two symmetrical, circular bulges, which are directed obliquely backwards so that the posterior margin becomes a broad, low, slightly thickened, labial process. The frontal has a characteristic marbled surface.

Ovicells are very common. They form small, convex processes above the opesia.

There are two types of avicularia: (1) Above the distal corners of the zooecium $10 *$ 
there are two symmetrical lanceolate avicularia with oblong-oval opesia. The avicularia are often as if squeezed into the cryptocyst of the zooecium in front. (2) Interzooecial avicularia, which may be nearly as long as zooecia. The proximal area is large, rhombic; the opesium is placed in the anterior part of the avicularium and in continuation of the opesium there is a groove-like depression laterally demarcated by narrow, prominent, rims, which medianly have a concavity. The distal end of the avicularium is straight.

\begin{tabular}{|c|c|c|c|c|c|c|}
\hline \multicolumn{3}{|c|}{ Measurements. } & \multicolumn{2}{|l|}{ Range } & \multicolumn{2}{|c|}{ Average } \\
\hline \multirow[t]{10}{*}{ Saltholm. } & $\mathrm{Lz}$ & 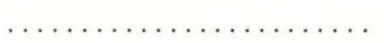 & $0.57-0.78$ & $\mathrm{~mm}$. & & \\
\hline & $\mathrm{lz}$ & $\ldots \ldots \ldots \ldots \ldots \ldots \ldots \ldots$ & $0.36-0.52$ & - & 0.42 & - \\
\hline & ho & 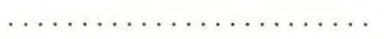 & $0.10-0.13$ & - & 0.10 & - \\
\hline & lo & 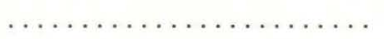 & $0.10-0.18$ & - & 0.15 & - \\
\hline & lov & 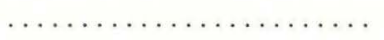 & 0.23 & - & & \\
\hline & hov & 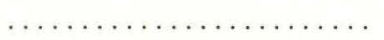 & 0.21 & - & & \\
\hline & Lav & 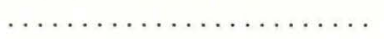 & $0.16-0.21$ & - & 0.20 & - \\
\hline & lav & 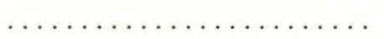 & 0.10 & - & 0.10 & - \\
\hline & Lav & (interzooecial) $\ldots \ldots \ldots \ldots$ & $0.57-0.70$ & - & 0.61 & - \\
\hline & lav & $(\quad-\quad) \ldots \ldots \ldots \ldots$ & $0.31-0.42$ & - & 0.38 & - \\
\hline \multirow[t]{4}{*}{ Faxe. } & $\mathrm{Lz}$ & & $0.42-0.57$ & $\mathrm{~nm}$. & 0.51 & $\mathrm{~mm}$. \\
\hline & $\mathrm{lz}$ & 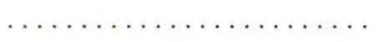 & $0.36-0.42$ & - & 0.40 & - \\
\hline & ho & & 0.08 & - & 0.08 & - \\
\hline & lo & $\ldots \ldots \ldots \ldots \ldots \ldots \ldots \ldots$ & $0.10-0.16$ & - & 0.13 & - \\
\hline \multicolumn{7}{|c|}{ Hoplitaechmella vespertilio v. HAGENOW. } \\
\hline \multirow[t]{6}{*}{ Hemmoor. } & $\mathrm{Lz}$ & & $0.68-1.04$ & $\mathrm{~nm}$. & 0.81 & $\mathrm{~mm}$. \\
\hline & $1 \mathrm{z}$ & 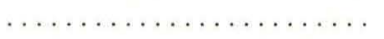 & $0.42-0.68$ & - & 0.54 & - \\
\hline & ho & & $0.10-0.13$ & - & 0.11 & - \\
\hline & lo & & $0.18-0.26$ & - & 0.22 & - \\
\hline & Lav & $\ldots \ldots \ldots \ldots \ldots \ldots$ & $0.10-0.16$ & - & 0.12 & - \\
\hline & lav & & $0.08-0.10$ & - & 0.09 & \\
\hline
\end{tabular}

\section{Material.}

Faxe - 1 specimen; Faxe II - 1 specimen; Saltholm - 2 specimens; Saltholm, Sandy-limestone -2 specimens.

Holotype. P1. 15, Fig. 5. Saltholm.

\section{Remarks.}

The trivial name refers to the great similarity to the Senonian species $H$. vespertilio v. Hagenow ( $\mathrm{Pl}$. 15, Fig. 6). The latter species has larger zooecia, but smaller avicularia (cf. the measures above). The opesium is rounded-triangular with a straight posterior margin. This form is due to the fact that the opesiular indentations are placed laterally. Ovicells are rarer in this species than in $H$. vespertilioides.

Distribution. Upper Danian, Faxe and Saltholm. 


\section{G A R G A N T A JULLIEN, 1888}

\section{Gargantua parvicella (Voigt)}

Plate 15, Fig. 7.

1924 Homalostega parvicella VoIGT. Pal. Zeitschr. VI. 1, p. 9, PI. I, Figs. 28-31.

1925 Onychocella parvicella (VoIGt). LeVinsen. Vidensk. Selsk. Skr. 8. Ser. VII. 3, p. 356.

1925 Micropora minuta Levinsen. Vidensk. Selsk. Skr. 8. Ser. VII. 3, p. 366, Pl. V, Fig. 54

1930 Gargantua parvicella Voigt. Leopoldina. VI, p. 477, Pl. 22, Figs. 23-24.

\section{Description.}

The zoarium is encrusting, with irregularly arranged zooecia, which are separated by depressions or furrows.

The zooecia are small, rounded-hexagonal or oval. The plane, sometimes embedded cryptocyst and the terminal, semi-elliptical, transverse opesium are surrounded by a comparatively broad, plane rim. The posterior margin of the opesium generally has a low, broad lip.

Ovicells and avicularia have not been observed.

\begin{tabular}{|c|c|c|c|c|}
\hline \multicolumn{2}{|c|}{ Measurements. } & & Range & Average \\
\hline Faxe. & $\mathrm{Lz}$ & $\ldots \ldots \ldots \ldots$ & $0.23-0.31 \mathrm{~mm}$ & $0.27 \mathrm{~mm}$. \\
\hline & $\mathrm{lz}$ & $\ldots \ldots \ldots \ldots \ldots \ldots \ldots \ldots$ & $0.21-0.29-$ & $0.24-$ \\
\hline & ho & $\ldots \ldots \ldots \ldots \ldots \ldots$ & $0.05-0.08$ & 0.06 \\
\hline & 10 & $\ldots \ldots \ldots \ldots \ldots \ldots \ldots \ldots$ & $0.08-0.10$ & 0.09 \\
\hline VOIGT, & $\mathrm{Lz}$ & & $0.22-0.30 \mathrm{~mm}$ & \\
\hline 1924, p. 9. & $1 z$ & $\ldots \ldots \ldots \ldots \ldots \ldots \ldots \ldots$ & $0.18-0.23-$ & \\
\hline & ho & $\ldots \ldots \ldots \ldots \ldots \ldots \ldots$ & $0.04-0.06$ & \\
\hline & lo & $\ldots \ldots \ldots \ldots \ldots \ldots$ & $0.06-0.10$ & \\
\hline
\end{tabular}

\section{Material.}

Thorslunde -3 specimens; Faxe -20 specimens; Faxe II -2 specimens; Saltholm - 1 specimen.

\section{Remarks.}

In his mention of Onychocella parvicella, LeVINSEN (p. 356) has given a characterization of the avicularia of this species. In his type collection at the Zoological Museum of Copenhagen there is under this specific name only one specimen with avicularia and this fragment does not belong to Gargantua parvicella, but is a small Onychocella form. The state of preservation of the specimen does not permit a closer identification. The same applies to the ovicells in Micropora minuta (LEVINSEN, p. 366). In this case, too, the description is based on a single specimen bearing ovicells, a specimen which does not belong to Gargantua parvicella, but is an unidentifiable Onychocella form. 
Distribution.

Senonian: ? Germany, Gr. Bülten.

Danian: Germany: Erratic blocks. Denmark: Thorslunde, Faxe, Saltholm, and Klintholm. The species in its occurrence seems to be attached to Upper Danian.

\section{B R Y DONELLA n.g.}

Dedicated to the memory of the English bryozoologist R.M. BRYDONE, after whom the so far only representative of this genus, Brydonella vulcani has been named.

\section{Diagnosis.}

Encrusting or free, uni- or multilamellar colonies consisting of zooecia without marginal delimitation. The opesium is rounded-quadrangular-heel-shaped-, surrounded by an irregular whorl of small, oval avicularia with a central pivot. Interzooecial, large, oblong-oval avicularia with a proximally placed pivot are frequent on a few colonies, but are missing on most.

\section{Remarks.}

The establishment of this new genus is a natural consequence of BASSLER's choice of Cellepora convexa v. Hagenow as type of the genus Homalostega (BASSLER 1935, p. 129; 1953, p. G 170). Among other things, this species is characterized by having well-demarcated, hexagonal, highly convex zooecia with small, distally placed, semi-circular opesia and by having no avicularia.

The systematic position of Brydonella is most uncertain. The thick cell-walls and the absence of marginal delimitations of the zooecia might suggest that there is a certain relationship to forms within the sub-order Ascophora, e.g. Acanthionella CANU and BASSLER. On the other hand, zoaria with a thick olocyst and lack of demarcations of zooecia also occur within the sub-order Anasca, e.g. in Frurionella CANU and BAssler. The position chosen is determined by the shape of the aperture, as in the majority of the opesia it is possible to observe slight circular bulges from the proximal corners, which probably should be interpreted as opesiular indentations.

\section{Brydonella vulcani (Brydone)}

Plate 15, Fig. 8.

1839 Cellepora filograna v. Hagenow. N. Jahrb. f. Min., p. 278.

1913 Homalostega vulcani Brydone. Geol. Mag. Dec. V. Vol. X, p. 98, Pl. IV, Fig. 7. 
1925 Monoporella confusa Levinsen. Vidensk. Selsk. Skr. 8. Ser. VII. 3, p. 402, Pl. VII, Fig. 80.

1930 Homalostega vulcani Brydone. Voigt. Leopoldina. VI, p. 531, Pl. 35, Figs. 17-18. 1959 "Homalostega" vulcani Brydone. Voigt. Geologie. Beiheft 25, p. 32.

\section{Description .}

The zoarium is encrusting or forms free, uni- or multilamellar colonies with irregularly arranged zooecia without marginal delimitations on the surface of the zoarium. The back of the colony, on the other hand shows a division into rhombic or hexagonal areas separated by narrow furrows.

The opesia of the zooecia are rounded-quadrangular, heel-shaped. In the proximal corners there are faint, circular bulges, which probably should be interpreted as opesiular indentations.

Ovicells have not been observed.

Of avicularia there are two types: (1) Round the opesia there is an irregular whorl of small oval avicularia, the largest of which are provided with a central -or approximately central-pivot. (2) Scattered over the frontal there are large, oblong-oval-sometimes almost finger-shaped-avicularia with a proximally placed pivot. This type is found in rather large numbers on a few fragments of colonies, but are missing on most.

\begin{tabular}{|c|c|c|c|c|c|}
\hline \multicolumn{3}{|c|}{ Measurements. } & \multicolumn{2}{|l|}{ Range } & Average \\
\hline \multirow[t]{6}{*}{ Herfølge. } & ho & $\ldots \ldots \ldots \ldots \ldots \ldots \ldots$ & $0.13-0.16$ & $\mathrm{~mm}$. & $0.15 \mathrm{~mm}$. \\
\hline & lo & $\ldots \ldots \ldots \ldots \ldots \ldots$ & 0.16 & - & $0.16-$ \\
\hline & Lav & $\ldots \ldots \ldots \ldots \ldots \ldots \ldots \ldots$ & 0.10 & - & 0.10 \\
\hline & lav & $\ldots \ldots \ldots \ldots \ldots \ldots$ & $0.08-0.10$ & - & 0.08 \\
\hline & Lav & (interzooecial) $\ldots \ldots \ldots \ldots$ & $0.31-0.34$ & - & \\
\hline & lav & ) $\ldots \ldots \ldots$ & 0.10 & - & \\
\hline \multirow[t]{6}{*}{ Møn. } & ho & $\ldots \ldots$ & $0.16-0.21$ & $\mathrm{~mm}$. & $0.17 \mathrm{~mm}$. \\
\hline & lo & $\ldots \ldots \ldots \ldots \ldots \ldots$ & $0.16-0.19$ & - & $0.18-$ \\
\hline & Lav & $\ldots \ldots \ldots \ldots \ldots \ldots$ & 0.10 & - & $0.10-$ \\
\hline & lav & $\ldots \ldots \ldots \ldots \ldots \ldots$ & $0.08-0.10$ & - & $0.08-$ \\
\hline & Lav & (interzooecial) $\ldots \ldots \ldots \ldots$ & $0.68-0.78$ & - & \\
\hline & lav & $(\quad-\quad) \ldots \ldots \ldots \ldots$ & $0.21-0.26$ & - & \\
\hline $\begin{array}{l}\text { VoIGT, } \\
1930 \text {, p. } 53\end{array}$ & Lav & (interzooecial) $\ldots \ldots \ldots \ldots$ & $0.50-0.70$ & $\mathrm{~mm}$. & \\
\hline
\end{tabular}

\section{Material.}

Faxe - 2 specimens; Faxe II - 4 specimens; Herfølge, Bryozoan Limestone 45 specimens; Herfølge, Calcarenite -5 specimens.

\section{Distribution.}

Senonian: England: Trimingham. Holland: Maastricht. Germany: Rügen. Sweden: Balsberg. Denmark: Møn.

Danian: Only known from Upper Danian: Faxe, Herfølge, and Klintholm. 
LUNULITIDAE LAGAAIJ, 1952

LUNULITES LAMARCK, 1816

66. Lunulites faxensis (Levinsen)

Plate 16, Figs. 1-2.

1925 Onychocella faxensis LeVInSEN. Vidensk. Selsk. Skr. 8. Ser. VII. 3, p. 354, Pl. VIII, Fig. 4.

1930 Lunularia faxensis LeVinsen. Vorgt. Leopoldina. VI, p. 484, Pl. 21, Fig. 25.

\section{Description .}

The zoarium forms free, slightly convex, rounded plates. The convex surface consists of radial rows of zooecia, while the concave side is divided into irregular, elongated areas of radial and transverse furrows.

The zooecia are hexagonal. They are provided with a narrow, projecting mural rim, which surrounds the embedded, plane cryptocyst and the terminal, rounded-quadrangular opesium, the rims of which may be slightly projecting.

Ovicells have not been observed.

Vibracula appear scattered among the zooecia, each row of zooecia beginning with a vibraculum. They are elongated, narrow, hexagonal or oval, with embedded opesia, which as a rule are oval or pyriform with a tapering proximal part. Sometimes the opesium proximally ends with a narrow slit, thus being formed like a mushroom.

\begin{tabular}{|c|c|c|c|c|c|}
\hline \multicolumn{3}{|l|}{ Measurements. } & Range & \multicolumn{2}{|c|}{ Average } \\
\hline Herfølge, & $\mathrm{Lz}$ & $\ldots \ldots \ldots \ldots \ldots$ & $0.62-0.78 \mathrm{~mm}$ & 0.67 & $\mathrm{~mm}$. \\
\hline \multirow{5}{*}{$\begin{array}{l}\text { Bryozoan Limestone } \\
\text { and Calcarenite. }\end{array}$} & $\mathrm{lz}$ & $\ldots \ldots \ldots \ldots \ldots \ldots$ & $0.36-0.78-$ & 0.49 & - \\
\hline & ho & $\ldots \ldots \ldots \ldots \ldots \ldots$ & $0.24-0.36$ & 0.30 & - \\
\hline & 10 & $\ldots \ldots \ldots \ldots \ldots$ & $0.21-0.36$ & 0.26 & - \\
\hline & Lv & $\ldots \ldots \ldots \ldots \ldots$ & $0.73-0.78$ & 0.76 & - \\
\hline & lv & $\ldots \ldots \ldots \ldots \ldots \ldots$ & $0.26-0.31$ & 0.29 & - \\
\hline \multirow{6}{*}{$\begin{array}{l}\text { Kagstrup, } \\
\text { Thorslunde, Faxe. }\end{array}$} & $\mathrm{Lz}$ & $\ldots \ldots \ldots \ldots \ldots$ & $0.47-0.57 \mathrm{~mm}$ & 0.54 & $\mathrm{~mm}$. \\
\hline & $1 z$ & & $0.31-0.57-$ & 0.44 & - \\
\hline & ho & $\ldots \ldots \ldots \ldots \ldots$ & $0.16-0.26$ & 0.20 & - \\
\hline & 10 & $\ldots \ldots \ldots \ldots \ldots$ & $0.18-0.26$ & 0.21 & - \\
\hline & Lv & $\ldots \ldots \ldots \ldots \ldots \ldots$ & $0.57-0.68$ & 0.60 & - \\
\hline & lv & $\ldots \ldots \ldots \ldots \ldots \ldots$ & $0.16-0.26-$ & 0.20 & \\
\hline
\end{tabular}

\section{Material.}

Stevns, Bryozoan Limestone - 2 specimens; Kagstrup - 16 specimens; Thorslunde - 57 specimens; Faxe - 33 specimens; Faxe XI - 1 specimen; Saltholm 17 specimens; Copenhagen, the South Harbour - 2 specimens; Copenhagen, Svanemøllen - 2 specimens; Herfølge, Bryozoan Limestone - 91 specimens; Herfølge, Calcarenite - 16 specimens. 
Neotype. Pl. 16, Fig. 1, Bryozoan Limestone, Faxe.

\section{Remarks.}

The material examined mainly includes small fragments of a size of one fourth to a half $\mathrm{cm}$. The specimens from the Calcarenite at Herfølge, however, on the whole are one to one and a half $\mathrm{cm}$. in size.

\section{Distribution.}

Danian: Stevns, Kagstrup, Thorslunde, Faxe, Saltholm, Copenhagen, Herfølge, and Klintholm. This species thus occurs in Lower as well as Upper Danian.

\section{Lunulites saltholmensis n.sp.}

Plate 16, Figs. 3-5.

1925 Onychocella Goldfussii (v. Hagenow) [partim]. Levinsen. Vidensk. Selsk. Skr. 8. Ser. VII. 3, p. 352.

Diagnosis.

Free, cup-shaped colonies with alternating rows of zooecia and vibracula on the convex side of the zoarium. The outermost four to five circular rows consist of rounded-quadrangular polypidian zooecia with a terminal, semi-elliptical opesium and an embedded cryptocyst. The hydrostatic zooecia are found in the central part of the colony. They have a more or less convex cryptocyst and a sealed or small, mostly oval opesium. The vibracula are lanceolate with lateral condyles.

\section{Description.}

The zoarium forms free, circular or oval, cup-shaped colonies. The cups may vary in shape from wide, flat to semi-globular. The zooecia are placed on the convex outer surface in radial and circular rows alternating with radial rows of vibracula. The outermost four to five circular rows consist of polypidian zooecia, while the central section-round the ancestrula-is developed to have a hydrostatic function. The inner side of the zoarium is divided into irregular areas of narrow, deep furrows, radially directed, often combined with a dichotomous ramification. The furrows may be absent in the central part of the colony, i.e. within the area with the hydrostatic zooecia. The areas between the furrows are provided with irregularly scattered, circular, pore-shaped depressions.

Zooecia: as mentioned above, there are two types of zooecia in the present species. The polypidian zooecia are quadrangularly rounded. The embedded, slightly sloping or plane cryptocyst and the terminal, semi-elliptical or roundedquadrangular opesium is surrounded by a projecting, comparatively broad, 
rounded margin. The hydrostatic zooecia are irregularly arranged, compressed. The individual zooecia have a more or less convex surface. The opesia may be sealed or restricted to a circular or oval, transverse pore.

Ovicells have not been observed.

The vibracula are arranged in radial rows alternating with the rows of zooecia so that each vibraculum is surrounded by four zooecia. They are lanceolate with a rounded posterior part and a tapering anterior part. Medianly two small, symmetrical, rounded, dentiform condyles issue from the lateral rims.

\begin{tabular}{|c|c|c|c|c|c|c|}
\hline \multicolumn{3}{|c|}{ Measurements. } & \multicolumn{2}{|l|}{ Range } & \multicolumn{2}{|c|}{ Average } \\
\hline Saltholm. & Wic & h of zoarium ....... & $3.12-7.28$ & $\mathrm{~nm}$. & 4.21 & $\mathrm{~mm}$. \\
\hline & $\mathrm{Lz}$ & $\ldots \ldots \ldots \ldots \ldots \ldots \ldots \ldots$ & $0.26-0.31$ & - & 0.29 & - \\
\hline & $1 z$ & $\ldots \ldots \ldots \ldots \ldots \ldots \ldots \ldots$ & $0.26-0.36$ & - & 0.30 & - \\
\hline & ho & 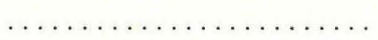 & $0.08-0.16$ & - & 0.12 & - \\
\hline & lo & $\ldots \ldots \ldots \ldots \ldots \ldots \ldots \ldots$ & $0.10-0.16$ & - & 0.12 & - \\
\hline & Lv & 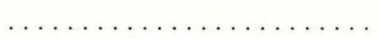 & $0.08-0.16$ & - & 0.11 & - \\
\hline & lv & $\ldots \ldots \ldots \ldots \ldots \ldots \ldots \ldots$ & $0.05-0.08$ & - & 0.08 & - \\
\hline
\end{tabular}

\section{Material.}

Saltholm - 64 specimens; Copenhagen, Sundkrogen - 56 specimens (small fragments).

Holotype. Pl. 16, Fig. 3. Saltholm.

\section{Remarks.}

LEVINSEN (1925, p. 352) in his description of Lunulites goldfussi (v. HaGENow) states that this species-apart from the Senonian habitats-occurs in the limestone on Saltholm. Unfortunately the Saltholm specimens are missing from LEVINSEN's type collection, but there is reason to assume that the specimens in question belong to L. saltholmensis and not to L. goldfussi. The two species have certain features in common, among others regarding the shape and size of the zooecia and the shape of the vibracula. In L. goldfussi the vibracula are not, however, arranged in radial rows; as a rule they occur as first cell in a row of zooecia. Furthermore, the opesium is not placed terminally in the zooecium; its position is more central. Judging from the Senonian specimens in LEVINSEN's collection L. goldfussi seems to lack hydrostatic zooecia in the central section of the colony.

L. saltholmensis also bears a habitual resemblance to L. cretacea (DEFRANCE). In the first place this is due to agreement in respect of the structure of the colony, as L cretacea also has radial rows of zooecia alternating with radial rows of vibracula, and a central area consisting of hydrostatic zooecia. The individual zooecia in $L$. cretacea are nearly square, and the quadrangular 
opesium is often placed almost centrally. Furthermore, the vibracula are smaller and narrower in L. cretacea than in L. saltholmensis.

Among North American Early Tertiary Bryozoa there are a number of Lunulites species which on various points have features in common with $L$. saltholmensis (see CANU and BASSLER, 1920).

\title{
Distribution.
}

Upper Danian of Kagstrup, Faxe, Saltholm, and Copenhagen (Sundkrogen).

\section{THALA M O PORELLID AE LEVINSEN, 1902}

PUNCTURIELLA LEVINSEN, 1925

\section{Puncturiella sculpta (d'Orbigny)}

\author{
Plate 17, Figs. 1-2.
}

1839 Glauconome spiralis v. Hagenow. N. Jahrb. f. Min., p. 292, Pl. V, Fig. 13a-b. 1851 Vincularia sculpta D'OrbignY. Pal. Franç. Terr. Crét. V, p. 72, Pl. 655, Figs. 16-18.

1886 Vincularia sculpta D'Orbigny. Pergens and Meunier. Ann. Soc. Malac. Belg. XXI, p. 231.

1887 Vincularia exsculpta Marsson. Pal. Abh. IV. 1, p. 67, Pl. VI, Fig. 14.

1892 Steganoporella? sculpta D’Orbigny. Hennig. Lunds Univ. Årsskr. XXVIII, p. 35, Pl. 1, Fig. 20.

1925 Micropora exsculpta Marsson. Levinsen. Vidensk. Selsk. Skr. 8. Ser. VII. 3, p. 364.

1930 Puncturiella exsculpta Marsson. Vorgt. Leopoldina. VI, p. 488, PI. 24, Fig. 15.

1959 Puncturiella sculpta (D’Orbigny) Voigt. Geologie. Beiheft 25, p. 44.

\section{Description.}

The zoarium forms either free, slender, cylindrical stems consisting of six to eight alternating rows of zooecia, or bilamellarly compressed, sometimes flabelliform plates. The zooecia are separated by narrow, mostly indistinct furrows.

The zooecia are very elongate, rounded-rectangular with almost parallel, very sharply indicated lateral margins. The cryptocyst is slightly embedded, plane, apart from a steeply ascending area immediately below the aperture. The surface of the cryptocyst is perforated by fine, dense pores, the largest and most constant of which are placed in a more or less distinct row along and immediately inside each lateral margin. The aperture is small, oval, transverse, terminal.

Ovicells have not been observed.

Immediately above each aperture there is a small, rounded-triangular avicularium with a triangular or semi-circular opesium. 


\begin{tabular}{|c|c|c|c|}
\hline \multicolumn{2}{|c|}{ Measurements. } & \multirow{2}{*}{$\begin{array}{l}\text { Range } \\
0.73-2.44 \mathrm{~mm} \text {. }\end{array}$} & \multirow{2}{*}{$\begin{array}{l}\text { Average } \\
1.51 \mathrm{~mm} .\end{array}$} \\
\hline Herfølge, & Width of zoarium $\ldots \ldots \ldots \ldots$ & & \\
\hline Bryozoan & $\mathrm{Lz} \quad \ldots \ldots \ldots \ldots \ldots \ldots \ldots \ldots \ldots \ldots \ldots$ & $0.62-1.09-$ & $0.88-$ \\
\hline Limestone. & $\ldots \ldots \ldots \ldots \ldots \ldots \ldots \ldots$ & $0.16-0.26$ & 0.23 \\
\hline & $\ldots \ldots \ldots \ldots \ldots \ldots \ldots$ & $0.08-0.10$ & 0.08 \\
\hline & la $\quad \ldots \ldots \ldots \ldots \ldots$ & $0.10-0.16$ & 0.15 \\
\hline & 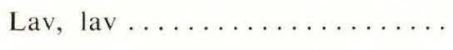 & 0.05 & \\
\hline \multirow[t]{6}{*}{ Faxe. } & Width of zoarium & $0.52-0.68 \mathrm{~mm}$. & $0.60 \mathrm{~mm}$. \\
\hline & $\mathrm{Lz} \quad \ldots \ldots \ldots \ldots \ldots \ldots \ldots \ldots \ldots \ldots$ & $0.73-0.83-$ & $0.78-$ \\
\hline & $\ldots \ldots$ & $0.24-0.29$ & $0.26-$ \\
\hline & ha & $0.08-0.10$ & 0.08 \\
\hline & la $\quad \ldots \ldots \ldots \ldots \ldots \ldots \ldots \ldots \ldots \ldots$ & $0.10-0.13$ & 0.12 \\
\hline & Lav, lav $\ldots \ldots \ldots \ldots \ldots \ldots$ & 0.05 & \\
\hline
\end{tabular}

Apart from the difference in zoarial width in the material from the two localities examined, - a fact which will be discussed in detail below-, there is reason to note that the zooecia in the specimens from Herfølge are longer and narrower than those in the colonies from Faxe.

\section{Material.}

Apart from the Herfølge material the specimens examined have slender cylindrical stems. As to Herfølge, the material includes 17 fragments with cylindrical stems and 11 specimens with a bilamellar, compressed shape of colony. Otherwise the material is distributed as follows: Stevns, Bryozoan Limestone - 1 specimen; Faxe - 3 specimens; Faxe II - 3 specimens; Faxe XI 1 specimen; Saltholm - 1 specimen; Herfølge, Bryozoan Limestone - 28 specimens.

\section{Distribution.}

Senonian: Germany: Rügen. France: Cotentin. Denmark: Møn.

Danian: Sweden: Annetorp. Denmark: Stevns, Kagstrup, Faxe, Saltholm, Herfølge, and Klintholm. The species thus seems to be of general occurrence within the Danian.

\section{Puncturiella tenera (Voigt)}

Plate 17, Fig. 3.

1924 Homalostega tenera Voigt. Pal. Zeitschr. VI. 1, p. 8, PI. I, Figs. 32-33.

1930 Micropora tenera Voigt. Leopoldina. VI, p. 476, PI. 22, Fig. 22.

\section{Description.}

The zoarium is encrusting or forms free, thin, unilamellar plates, with the zooecia in fairly regular quincunx. 
The zooecia are variable in shape and size, elongate, with more or less parallel marginal rims and a rounded tapering anterior end. The posterior rim of the zooecium and the lateral rims are comparatively broad, plane, rounded; a correspondingly broad, curved, prominent band forms the posterior apertural lip and connects the two lateral rims, while the rim round the rest of the aperture is narrower and little prominent. The avicularium at the top and the aperture are separated only by a thin band. The cryptocyst is convex, distinctly issuing from the lateral rims and perforated by $40-50$ small, circular pores. Sometimes these pores seem to be placed in transversal rows, but as a rule their position apparently is irregular. The aperture is terminal, oval, transverse.

Ovicells have not been observed.

Above each aperture there is a small, rounded, triangular avicularium with a circular or oval, transverse pore.

Measurements.

\begin{tabular}{|c|c|c|c|c|}
\hline \multirow{6}{*}{ Herfølge. } & \multirow{3}{*}{$\begin{array}{l}\mathrm{Lz} \\
\mathrm{lz}\end{array}$} & & Range & Average \\
\hline & & $\ldots \ldots \ldots \ldots \ldots \ldots \ldots \ldots$ & $0.62-0.99 \mathrm{~mm}$ & $0.79 \mathrm{~mm}$ \\
\hline & & $\ldots \ldots \ldots \ldots \ldots \ldots \ldots$ & $0.26-0.42-$ & $0.35-$ \\
\hline & ho & $\ldots \ldots \ldots \ldots \ldots \ldots \ldots$ & $0.08-0.10$ & 0.09 \\
\hline & lo & $\ldots \ldots \ldots \ldots \ldots \ldots \ldots$ & $0.13-0.18$ & 0.16 \\
\hline & Lav & $\ldots \ldots \ldots \ldots \ldots \ldots \ldots$ & 0.05 & 0.05 \\
\hline & lav & $\ldots \ldots \ldots \ldots \ldots \ldots \ldots \ldots$ & 0.08 & 0.08 \\
\hline \multirow{4}{*}{$\begin{array}{l}\text { VoIGT, } \\
1924 \text {, p. } 9 .\end{array}$} & $\mathrm{Lz}$ & $\ldots \ldots \ldots \ldots \ldots \ldots \ldots \ldots$ & $0.70-0.80 \mathrm{~mm}$ & \\
\hline & lz & $\ldots \ldots \ldots \ldots \ldots \ldots \ldots \ldots$ & $0.22-0.30-$ & \\
\hline & ho & $\ldots \ldots \ldots \ldots \ldots \ldots \ldots$ & $0.10-0.12$ & \\
\hline & lo & $\ldots \ldots \ldots \ldots \ldots \ldots \ldots$ & $0.12-0.13$ & \\
\hline
\end{tabular}

Material. Herfølge, Bryozoan Limestone - 3 specimens.

\section{Remarks.}

From the English Senonian White Chalk (Trimingham) BRydone (1936, p. 84, Pl. XL, Fig. 17) examined and described a form, Puncturiella norviciensis spinulata BRYDONE, which seems to be closely related to $P$. tenera. Unfortunately it is not possible on the basis of BRYDONE's incomplete description to decide whether the two forms are identical.

\section{Distribution}

Danian: Germany: Erratic blocks at Rosslau. Denmark: Faxe, Herfølge, and Klintholm. 
Zoaria erect, cylindrical or bilamellar. Zooecia in longitudinal series, frontal area formed by an imperforate depressed cryptocyst. Hydrostatic system external, confined to the hypostege (cavity between ectocyst and cryptocyst of each zooecium). Avicularia vicarious, replacing zooecia in the series. Spines and pores wanting. Ovicell embedded in distal zooecium.

\author{
COSCINOPLEURIDAE CANU, 1913
}

COSCINOPLEURA MARSSON, 1887

\title{
70. Coscinopleura angusta angusta Berthelsen
}

Plate 17, Figs. 4-7.

1925 Rhagosostoma elegans (v. Hagenow) var. a. Levinsen. Vidensk. Selsk. Skr. 8. Ser. VII. 3, p. 368.

1930 Coscinopleura elegans v. Hagenow [partim]. Voigt. Leopoldina. VI, p. 490.

1948 Coscinopleura angusta Berthelsen. Geol. Survey Denmark. IV Series. Vol. 3. No. 3, pp. 1-13, Fig. 4.

1956 Coscinopleura angusta angusta Berthelsen. Voigt. Mitt. Geol. Staatsinst. Hamb. H. 25, p. 48 , Pl. 5, Figs. 1-8.

\section{Description.}

The zoarium forms free, bilamellar, dichotomous stems with the zooecia in regularly alternating longitudinal rows. The zooecia are separated by narrow, but distinct furrows. The marginal zone of the colony consists of vibracula (= coscinozooecia in VoIGT, 1956, p. 39), alternating with kenozooecia.

The zooecia are elongate, pyriform, with a wide, smoothly rounded anterior part, which is demarcated by convex lateral lines and a tapering posterior part with concave lateral lines. The proximal edge is straight. The convex, smooth cryptocyst completely surrounds the aperture, which is semi-elliptical, a little elongate, with a slightly thickened proximal lip, which bears two small, symmetrical opesiular indentations. In the zooecia bearing ovicells the aperture is wider and more angular than in the normal ones (cf. VoIGT, 1956, p. 31).

The ovicells are hyperstomial, shaped like a flat helmet, terminated laterally by two symmetrically arranged horns.

As mentioned above, vibracula are placed along the margin of the zoarium. The individual vibracula (= coscinozooecia) have a convex surface, which is perforated by circular pores (coscinospores in VoIGT, 1956, p. 30), of which, as a rule, there are four along each rim and two or three on the central part of the frontal. The semicircular aperture is terminal; it may be partly sealed by a salient, oblique denticulum (VoIGT, 1956, p. 39).

Kenozooecia appear partly singly on the margin of the zoarium, where they 
fill in the intervals between the vibracula, so that each kenozooecium is surrounded by four vibracula (see Plate 17, Fig. 5), partly in groups in the basal parts of the colonies between more or less calcified zooecia. Such collections of kenozooecia are seen to be especially developed on $5-6.5 \mathrm{~mm}$. broad stems from the Calcarenite at Herfølge (Plate 17, Fig. 6). The shape of the kenozooecia is very variable, apparently dependent on conditions of space in the colony. In the centre they have a circular pore.

\begin{tabular}{|c|c|c|c|c|c|c|}
\hline \multicolumn{3}{|c|}{ Measurements. } & \multicolumn{2}{|c|}{ Rance } & \multicolumn{2}{|c|}{ Average } \\
\hline \multirow[t]{11}{*}{ Herfølge. } & Width & h of zoarium ............ & $1.41-1.83$ & $\mathrm{~mm}$. & 1.58 & $\mathrm{~mm}$. \\
\hline & $\mathrm{Lz}$ & $\ldots \ldots \ldots \ldots \ldots \ldots \ldots$ & $0.52-0.65$ & - & 0.60 & - \\
\hline & lz & $\ldots \ldots \ldots \ldots \ldots \ldots$ & $0.29-0.42$ & - & 0.36 & - \\
\hline & ha & $\ldots \ldots \ldots \ldots \ldots \ldots$ & $0.10-0.16$ & - & 0.13 & - \\
\hline & la & $\ldots \ldots \ldots \ldots \ldots \ldots \ldots$ & $0.10-0.16$ & - & 0.12 & - \\
\hline & hov & $\ldots \ldots \ldots \ldots \ldots \ldots \ldots \ldots$ & $0.23-0.26$ & - & & \\
\hline & low & $\ldots \ldots \ldots \ldots \ldots \ldots \ldots$ & 0.26 & - & & \\
\hline & $\mathrm{Lv}$ & $\ldots \ldots \ldots \ldots \ldots \ldots \ldots$ & $0.52-0.68$ & - & 0.56 & - \\
\hline & lv & $\ldots \ldots \ldots \ldots \ldots \ldots \ldots \ldots$ & $0.31-0.42$ & - & 0.36 & - \\
\hline & Lengt & th of kenozooecium....... & $0.13-0.18$ & - & 0.16 & - \\
\hline & Width & $h-\quad-\quad \ldots \ldots$ & $0.13-0.18$ & - & 0.15 & - \\
\hline \multirow[t]{7}{*}{ Kagstrup. } & Width & 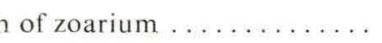 & $1.50-1.66$ & $\mathrm{~mm}$. & 1.60 & $\mathrm{~mm}$. \\
\hline & $\mathrm{Lz}$ & $\ldots \ldots \ldots \ldots \ldots \ldots \ldots \ldots$ & $0.52-0.57$ & - & 0.55 & - \\
\hline & lz & $\ldots \ldots \ldots \ldots \ldots \ldots \ldots$ & $0.31-0.36$ & - & 0.35 & - \\
\hline & ha & $\ldots \ldots \ldots \ldots \ldots \ldots \ldots \ldots$ & 0.10 & - & 0.10 & - \\
\hline & la & $\ldots \ldots \ldots \ldots \ldots \ldots \ldots \ldots$ & $0.10-0.13$ & - & 0.11 & - \\
\hline & Lv & $\ldots \ldots \ldots \ldots \ldots \ldots \ldots \ldots$ & $0.57-0.62$ & - & & \\
\hline & IV & $\ldots \ldots \ldots \ldots \ldots \ldots \ldots$ & $0.34-0.36$ & - & & \\
\hline
\end{tabular}

The values stated show the variation within material from the lowermost and the uppermost Danian. For supplementary information reference must be made to my paper from 1948 (p. 6) and VoIGT's investigations (VOIGT, 1956, p. 49 and pp. 62-63).

\section{Material.}

Stevns, Bryozoan Limestone - 26 specimens; Kagstrup - 187 specimens; Thorslunde - 48 specimens; Faxe - 128 specimens; Faxe II - 33 specimens; Saltholm - 875 specimens; Copenhagen, Svanemøllebugten - 516 specimens; Herfølge, Bryozoan Limestone - 1645 specimens; Herfølge, Calcarenite 94 specimens; Klintholm - 22 specimens.

\section{Holotype.}

Berthelsen, 1948, Fig. 4 (p. 12), Bryozoan Limestone, Herfølge.

\section{Remarks.}

VOIGT (1956) in monographic form has given an excellent characterization of the species within the genera Coscinopleura, Acoscinopleura, and Tremoscino- 
pleura. Only two of these species will be mentioned here, viz. Coscinopleura angusta minor VOIGT and Coscinopleura digitata MORTON. The former is a subspecies of $C$. angusta BERTHELSEN established by VoIGT on the basis of material from Tuffeau de Ciply, Lower Montian. It differs from the main species by having smaller zooecia and narrower stems. Furthermore the aperture in the zooecia bearing ovicells is only a little greater than in the normal ones, and the number of coscinopores is on the whole higher (9-15) than in C. angusta angusta. C. digitata Morton (Pl. 18, Fig. 1) is one of the commonest species in the paleocene? Vincentown formation in New Jersey. It differs from the European forms by having hexagonal zooecia and 10-18 very large coscinopores.

\section{Distribution.}

Danian: Germany: Erratic blocks. Russia: The Crimea. Sweden: Limhamn and Östra Torp. Denmark: Stevns, Kagstrup, Thorslunde, Faxe, Saltholm, Copenhagen, Herfølge, and Klintholm. The species thus is known from all East Danish Danian localities.

\section{SUBORDER CRIBRIMORPHA LANG, 1916}

Zooecia with more or less of front membranous, protected by a roof formed of fused overarching circumareal spines.

Fig. 27 is a schematic diagram of a Cribrimorph Bryozoa with statement of the particular terms used for the characterization of species within this group.

\section{FIS S UR I C ELLA V OIG T, 1959}

\section{Fissuricella fissa (Voigt)}

Plate 18, Fig. 2.

1930 Andriopora fissa Voigt. Leopoldina. VI, p. 496, Pl. 26, Figs. 22-23.

1959 Fissuricella fissa Voigt. Neues Jb. Geol. u. Paläont. Abh. 108. 3, p. 260, PI. 26, Figs. 4-7.

\section{Description.}

The zoarium forms encrusting, uniserial, small colonies.

The zooecia are elongate, pyriform or oval, greatly convex, almost bladdershaped. Medianly on the frontal there is a narrow, elongate, groove-like depression, which according to VoIGT $(1959$, p. 264) has arisen by coalescence of a wide, median cleft. At the anterior end of the zooecium, rather much embedded, there is a small, round aperture and distally to this a circular 


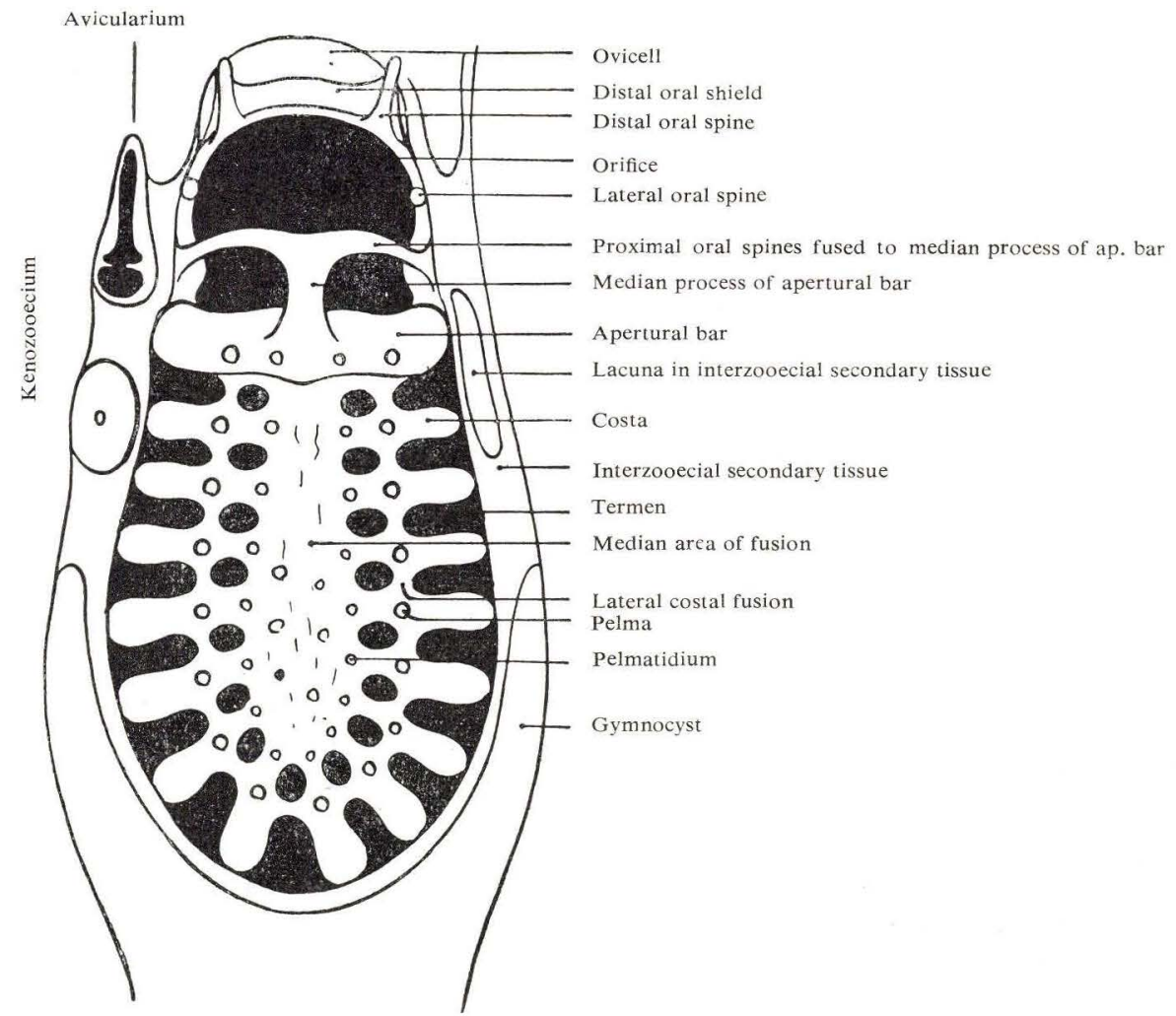

Fig. 27. Schematic diagram of a Cribrimorph Bryozoa to show the terms. (LANG, 1921).

communication pore, which is larger than the aperture. Circular communication pores also occur in the lateral walls of the zooecium. These pores, however, are smaller than the distal communication pore.

Ovicells and avicularia have not been observed.

\begin{tabular}{|c|c|c|c|c|}
\hline \multicolumn{3}{|c|}{ Measurements. } & Range & Average \\
\hline \multirow[t]{2}{*}{ Herfølge. } & $\mathrm{Lz}$ & . & $0.68-1.09 \mathrm{~mm}$. & $0.79 \mathrm{~mm}$. \\
\hline & $\mathrm{lz}$ & $\ldots \ldots \ldots \ldots \ldots$ & $0.26-0.47-$ & $0.36-$ \\
\hline VOIGT, & $\mathrm{Lz}$ & $\ldots \ldots \ldots \ldots \ldots \ldots \ldots \ldots$ & $0.75-0.90 \mathrm{~mm}$ & \\
\hline 1930 , p. 49 & & $\ldots \ldots{ }_{1} \ldots \mu_{1}$ & $0.30-0.35-$ & \\
\hline
\end{tabular}

\section{Material.}

Stevns, Bryozoan Limestone - 1 specimen; Saltholm - 1 specimen; Herfølge, Bryozoan Limestone -6 specimens.

Remarks.

VorgT originally (1930, p. 496) referred F. fissa to the genus Andriopora, as he thought that the particular development of the median region was due to a 
fusion of costae. Examinations of new material and comparison with Fissuricella vermiculata VoigT from Upper Maastrichtian in Holland, however, convinced VoIGT that this interpretation cannot be retained and that the two species belong together in a special genus which probably has nothing to do with the Cribrimorpha. On the other hand, it has not been possible for Vorgt to decide to what family this genus belongs. Perhaps a particular family ought to be established for Fissuricella, but Vorgt has preferred so far to let the genus remain as a genus incertae sedis.

\section{Distribution.}

Danian: Germany: Erratic blocks, i.a. at Daerstorf near Harburg. Denmark: Stevns, Saltholm, Herfølge, and Faxe (Voigt, 1930, p. 496).

CRIBRILINIDAE HIN CKS, 1880

MEMBRANIPORELLA SMITT, 1873

\section{Membraniporella squamulosa (v. Hagenow)}

Plate 18, Fig. 3.

1839 Cellepora squamulosa v. Hagenow. N. Jahrb. f. Min., p. 270.

1959 Membraniporella squamulosa v. Hagenow. Voigt. Geologie. Beiheft 25, p. 16, Pl. IV, Fig. 3.

\section{Description.}

The zoarium forms encrusting, uni- or multilamellar colonies, which are often composed of subcolonies. The zooecia are arranged in irregular, radial rows. They may be dense, only separated by a narrow furrow, or have greater intervals between the cells.

The zooecia are oblong-elliptical, with a narrow, knotty rim round the large elliptical area. On well-preserved specimens there is a frontal shield composed of 7-10 extremely delicate costae, but as a rule these are missing. In such cases the area is frequently sealed by a thin calcium lamella.

The ovicells are hyperstomial, helmet-shaped.

Small, oval, elliptical avicularia are of frequent occurrence, as a rule in the intervals between the zooecia.

\begin{tabular}{|c|c|c|c|c|}
\hline \multicolumn{3}{|l|}{ Measurements. } & \multirow{2}{*}{$\begin{array}{l}\text { Range } \\
0.34-0.42 \mathrm{~mm} .\end{array}$} & \multirow{2}{*}{$\begin{array}{l}\text { Average } \\
0.36 \mathrm{~mm} .\end{array}$} \\
\hline Herfølge, & $\mathrm{Lz}$ & & & \\
\hline Bryozoan Limestone. & $\mathrm{lz}$ & $\ldots \ldots \ldots \ldots \ldots$ & $0.23-0.26-$ & $0.25-$ \\
\hline Stevns, & $\mathrm{Lz}$ & $\cdots \cdots$ & $0.26-0.39 \mathrm{~mm}$. & $0.33 \mathrm{~mm}$. \\
\hline Bryozoan Limestone. & $\mathrm{lz}$ & $\ldots \ldots \ldots \ldots \ldots$ & $0.18-0.23-$ & $0.21-$ \\
\hline & Lav & 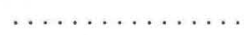 & $0.10-0.13$ & 0.12 \\
\hline & lav & $\ldots \ldots \ldots \ldots \ldots$ & $0.08-0.10-$ & 0.09 \\
\hline
\end{tabular}


Material.

Stevns, Bryozoan Limestone - 1 specimen; Kagstrup - 52 specimens; Faxe 1 specimen; Faxe II - 1 specimen; Saltholm - 9 specimens; Herfølge, Bryozoan Limestone -5 specimens.

\section{Distribution.}

Senonian: Germany: Rügen.

Danian: Denmark: Stevns, Bryozoan Limestone, Kagstrup, Faxe, Saltholm, Herfølge, and Klintholm, besides Voldum and Grenå in Jutland (VoIGT, 1959, p. 16).

LA GYNOPORIDAE LANG, 1916

LEP T OCHEILOP ORA LANG, 1916

\section{Leptocheilopora laticostata n.sp.}

Plate 18, Fig. 4

Diagnosis.

A Leptocheilopora species characterized by wide, elliptical zooecia with a welldeveloped gymnocyst and a frontal shield consisting of 12-16 wide, flat costae and an oblong-oval area of fusion provided with a median longitudinal row of rimmed pores. Apertural bar with proximal bend. Orifice divided into a large semi-circular anter and a small oval transverse poster.

\section{Description}

The zoarium is encrusting, unilamellar, with irregularly arranged zooecia separated by deep depressions or furrows.

The zooecia are elliptical, wide, greatly convex, with a well-developed gymnocyst. The frontal shield consists of 12-16 wide, flat, dense costae without visible lateral fusions. The costae are medianly united in an oblong-oval area of fusion, which along the longitudinal median line is provided with fine, rimmed pores. At low magnification this row of pores seems to form a slight carina. The apertural bar has the same width as the costae and a sharp proximal bend. Medianly there is a small knob-shaped process. Two small lateral cardelles near the proximal margin of the orifice divide this into a large semicircular anter and a small oval, transverse poster. On a single zooecium two oral spines were observed. The position of these suggests that originally there were four such spines.

The ovicells are hyperstomial; on the fragments examined they only occur in the shape of elongate, rounded scars with greatly curved lateral margins.

Avicularia have not been observed. 


\begin{tabular}{|c|c|c|c|c|c|c|}
\hline \multicolumn{3}{|c|}{ Measurements. } & \multicolumn{2}{|l|}{ Range } & \multicolumn{2}{|c|}{ Average } \\
\hline \multirow[t]{8}{*}{ Faxe. } & $\mathrm{Lz}$ & $\ldots \ldots \ldots$ & $0.52-0.62$ & $\mathrm{~mm}$. & 0.56 & $\mathrm{~nm}$. \\
\hline & $\mathrm{lz}$ & 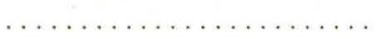 & $0.31-0.42$ & - & 0.34 & - \\
\hline & $\mathrm{hr}$ & 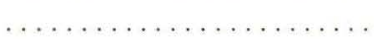 & $0.08-0.10$ & - & 0.10 & - \\
\hline & Ir & $\ldots \ldots \ldots \ldots \ldots \ldots \ldots \ldots$ & 0.10 & - & & \\
\hline & Lengtl & h of frontal shield.......... & $0.26-0.47$ & - & 0.33 & - \\
\hline & Width & $a-\quad-\quad-\ldots \ldots \ldots$ & $0.21-0.26$ & - & 0.23 & - \\
\hline & hov & $(\mathrm{scar}) \ldots \ldots \ldots \ldots \ldots$ & 0.26 & - & & \\
\hline & lov & $(-) \ldots \ldots \ldots \ldots \ldots \ldots \ldots$ & 0.21 & - & & \\
\hline
\end{tabular}

Material. Faxe -4 specimens.

Holotype. Pl. 18, Fig. 4. Faxe, Bryozoan Limestone.

\section{Remarks.}

The trivial name refers to the wide costae.

This species occupies a place apart within Leptocheilopora as a consequence of the well-developed gymnocyst. As regards the shape of the zooecia and the size and number of the costae L. laticostata bears the greatest resemblance to L. tenuilabrosa LANG from the English Santonian, from which, however, it differs by having oral spines and by the presence of a median row of pores.

Distribution. Danian: Faxe and Herfølge.

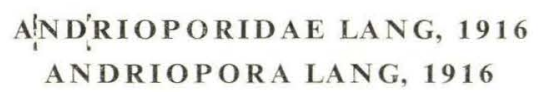

\section{Andriopora daniensis Voigt}

Plate 18, Fig. 5.

1930 Andriopora daniensis Volgt. Leopoldina. VI, p. 497, Pl. 26, Fig. 19.

\section{Description.}

The zoarium is encrusting, uniserial, with a short cauda.

The zooecia are elongate-elliptical. The frontal shield, which occupies the whole frontal of the zooecia, consists of 12 wide, flat costae separated by narrow furrows. Medianly the costae are fused and form a long narrow carina. The apertural bar has the same width as the costae and has a proximal bend. The distal part of the orifice is circular, the proximal part is tapering. According to VorgT each zooecium has four oral spines.

Ovicells and avicularia have not been observed. 


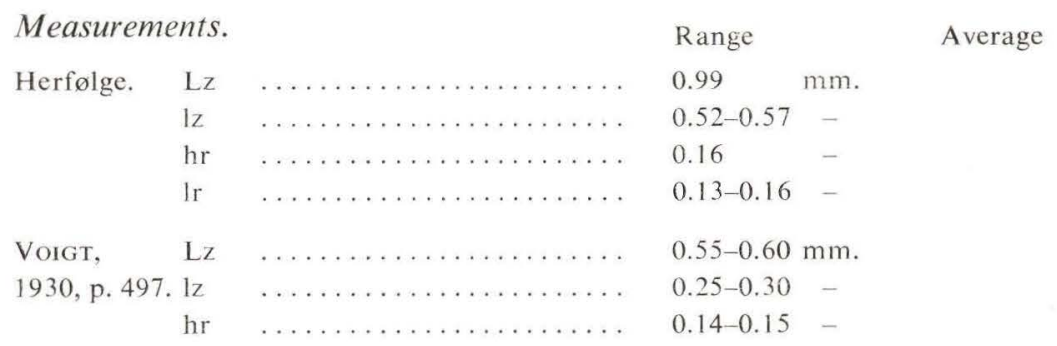

Material. Herfølge, Bryozoan Limestone - 5 specimens.

\section{Distribution.}

Danian: Germany: Erratic blocks at Köthen (Anhalt). Denmark: Faxe and Herfølge.

PLiOPHLOEA GABB AND HORN, 1862

\section{Pliophloea subcornuta n.sp.}

Plate 18, Fig. 6.

1925 Barroisina cornuta (v. Hagenow) [partim]. LeVInSEN. Vidensk. Selsk. Skr. 8. Ser. VII. 3, p. 384, Pl. VI, Fig. 66b?

\section{Diagnosis.}

An encrusting Pliophloea species with elongate, tapering zooecia, hyperstomial ovicells, small symmetrical avicularia above the distal corners of the zooecium and numerous kenozooecia. Zooecium with 16-18 wide costae and orifice with a large trapezohedral anter and a small, oval transverse poster.

\section{Description.}

The zoarium forms encrusting, unilamellar colonies with irregularly arranged, sometimes imbricate zooecia, which are separated by furrows or broad depressions filled in by kenozooecia.

The zooecia are very variable in shape and size. Elongate, proximally tapering cells are the commonest type. The convex frontal shield consists of 16-18 wide, flat costae, which are separated by rows of pores, as the costae are interconnected by lateral fusions. The apertural bar is a little wider than the costae, slightly projecting, rounded, with a proximal bend. The orifice is by small proximally placed cardelles divided into a large rounded-trapezohedral anter and a small, oval, transverse poster. The poster is about half as wide as the anter. Oral spines have not been observed.

The ovicells are hyperstomial, helmet-shaped, with a narrow median carina. 
Each zooecium bears two, small, symmetrical avicularia placed on the distal corners ("shoulders") of the zooecium, laterally to the ovicell. The shape is oblong-oval, the opesium is terminal, elongate, and narrow.

In the depressions between the normal zooecia there are kenozooecia of variable shape and size. In the largest ones there are slight traces of costae. An aperture occurs but exceptionally and if so, only in the form of a circular or oval pore.

\begin{tabular}{|c|c|c|}
\hline \multirow[t]{8}{*}{ Faxe. } & $\mathrm{Lz}$ & $\ldots \ldots \ldots \ldots \ldots$ \\
\hline & $\mathrm{lz}$ & $\ldots \ldots \ldots \ldots \ldots \ldots \ldots \ldots$ \\
\hline & $\mathrm{hr}$ & $\ldots \ldots \ldots \ldots \ldots \ldots \ldots \ldots$ \\
\hline & Ir & $\ldots \ldots \ldots \ldots \ldots \ldots \ldots \ldots \ldots$ \\
\hline & hov & $\ldots \ldots \ldots \ldots \ldots \ldots \ldots \ldots$ \\
\hline & lov & $\ldots \ldots \ldots \ldots \ldots \ldots \ldots \ldots$ \\
\hline & Lav & $\ldots \ldots \ldots \ldots \ldots \ldots \ldots \ldots$ \\
\hline & lav & $\ldots \ldots \ldots \ldots \ldots \ldots \ldots \ldots \ldots$ \\
\hline
\end{tabular}

\begin{tabular}{|c|c|c|c|}
\hline Range & & Aver & age \\
\hline $0.36-0.52$ & $\mathrm{~nm}$. & 0.42 & $\mathrm{~mm}$ \\
\hline $0.23-0.36$ & - & 0.29 & - \\
\hline 0.08 & - & 0.08 & - \\
\hline 0.08 & - & 0.08 & - \\
\hline $0.21-0.23$ & - & & \\
\hline 0.18 & - & & \\
\hline 0.10 & - & & \\
\hline 0.08 & - & & \\
\hline
\end{tabular}

Stevns, $\quad \mathrm{Lz} \quad \ldots \ldots \ldots \ldots \ldots \ldots \ldots \ldots$

$0.47 \mathrm{~mm}$.

Kagstrup. $1 z \quad \ldots \ldots \ldots \ldots \ldots \ldots \ldots \ldots \ldots .0 .26-0.36 \quad-$

$0.31-$

hr $\ldots \ldots \ldots \ldots \ldots \ldots \ldots \ldots \ldots 0.0 .04 \quad-$

lr

0.08

$0.08-$

Pliophloea cornuta.

Vorgt, $\quad \mathrm{Lz} \quad \ldots \ldots \ldots \ldots \ldots \ldots \ldots \ldots . \ldots . \ldots .45-0.50 \mathrm{~mm}$.

1930, p. 499.

Material.

Stevns, Bryozoan Limestone -8 specimens; Kagstrup - 7 specimens; Faxe 13 specimens; Faxe II -4 specimens; Faxe XI - 3 specimens.

Holotype. Pl. 18, Fig. 6. Faxe, Bryozoan Limestone.

Remarks.

The trivial name refers to the similarity of $P$. subcornuta to the Senonian species $P$. cornuta V. Hagenow. Both species are encrusting, have wide, flat costae and two small symmetrical avicularia above the distal corners of the zooecium. P. cornuta, however, has more oval zooecia with fewer (12-14) costae, and the orifice has more prominent cardelles and a slit-shaped poster. Furthermore, the opesia of the avicularia are larger and are placed medianly. Kenozooecia seem to occur more frequently in $P$. subcornuta than in $P$. cornuta. Probably Levinsen's picture of a $P$. cormuta colony (1925, Pl. VI, Fig. 66b) with kenozooecia is a rendering of a specimen of $P$. subcornuta. In his collection there is only one fragment with so many kenozooecia. This specimen originates from Faxe and belongs to $P$. subcornuta. 


\section{Distribution.}

Danian: Stevns, Kagstrup, Faxe, and Saltholm. The distribution of the species thus seems to be restricted to Zones B and C according to ØDuM's classification of the Danian.

\section{Pliophloea cf. P. gluma Lang \\ Plate 19, Fig. 1.}

1916 Pliophloea gluma LANG. Ann. \& Mag. Nat. Hist. 8. Ser. Vol. 18, p. 392.

1921 Pliophloea gluma LANG. Cat. of Cret. Bryozoa, Vol. III, p. 188, Fig. 88, P1. VI, Fig. 3.

1930 Pliophloea gluma LANG. Voigt. Leopoldina. VI, p. 501, Pl. 27, Fig. 21.

\section{Description.}

The zoarium is encrusting, unilamellar, with irregular arranged zooecia, which are separated by narrow, but distinct furrows.

The zooecia are oblong-oval. The gymnocyst is slightly developed and in part covered by the avicularia. The frontal shield is plane, composed of 12-13 wide, flat costae, which are interconnected by lateral fusions and medianly are united in a band-shaped area of fusion. The apertural bar has a proximal bend, but otherwise has the same appearance as the normal costae. Welldeveloped cardelles divide the orifice into a large, subcircular anter and a small, oval, transverse poster. Small oral spines are present.

The ovicells are hyperstomial, large, helmet-shaped, without any median carina.

Avicularia are common, occurring either singly near the orifice or in pairs above the distal corners of the zooecia, laterally to the orifice. Sometimes they may appear in a fairly large number in depressions between the zooecia. They are variable in shape and size, generally elongate, with a terminal narrow opesium.

\begin{tabular}{|c|c|c|c|c|c|c|}
\hline \multicolumn{3}{|c|}{ Measurements. } & \multicolumn{2}{|l|}{ Range } & \multicolumn{2}{|c|}{ Average } \\
\hline \multirow[t]{6}{*}{ Faxe. } & $\mathrm{Lz}$ & $\ldots \ldots \ldots \ldots \ldots \ldots \ldots \ldots \ldots$ & $0.52-0.57$ & $\mathrm{~mm}$. & 0.55 & $\mathrm{~mm}$. \\
\hline & $\mathrm{lz}$ & $\ldots \ldots \ldots \ldots \ldots \ldots \ldots \ldots$ & $0.26-0.31$ & - & 0.29 & - \\
\hline & $\mathrm{hr}$ & $\ldots \ldots \ldots \ldots \ldots \ldots \ldots \ldots$ & 0.10 & - & 0.10 & - \\
\hline & Ir & $\ldots \ldots \ldots \ldots \ldots \ldots$ & 0.08 & - & 0.08 & - \\
\hline & hov & $\ldots \ldots \ldots \ldots \ldots \ldots \ldots \ldots$ & $0.23-0.26$ & - & & \\
\hline & lov & $\ldots \ldots \ldots \ldots \ldots \ldots \ldots \ldots$ & 0.26 & - & & \\
\hline \multirow[t]{2}{*}{ LANG, 1921.} & $\mathrm{Lz}$ & $\cdots$ & 0.40 & $\mathrm{~mm}$. & & \\
\hline & $1 \mathrm{z}$ & $\ldots \ldots \ldots \ldots \ldots \ldots \ldots \ldots \ldots$ & 0.25 & - & & \\
\hline
\end{tabular}

Material.

Faxe - 10 specimens; Herfølge, Bryozoan Limestone - 2 specimens. 


\title{
Remarks.
}

The specific name is indicated with cf. because this form-in spite of the specific characters mentioned-is extremely difficult to distinguish from Pliophloea gluma LANG. Such a distinction presupposes a very fine state of preservation, and my material cannot satisfy this demand. Future investigations perhaps will result in a merging of the two species in question.

\section{Distribution:}

Danian: Germany: Erratic blocks at Köthen. Denmark: Upper Danian: Faxe and Herfølge.

\section{Pliophloea cf. P. palea Lang}

\author{
Plate 19, Fig. 2.
}

1916 Pliophloea palea Lang. Ann. Mag. Nat. Hist. 8. Ser. Vol. 18, p. 391.

1921 Pliophloea palea LANG. Cat. of Cret. Bryozoa. Vol. III, p. 187, Fig. 87, Pl. VI, Fig. 2.

1930 Pliophloea palea Lang. Voigt. Leopoldina. VI, p. 501, Pl. 27, Fig. 21.

\section{Description .}

The zoarium is encrusting, unilamellar with irregularly arranged zooecia, which are separated by furrows and deep depressions.

The zooecia are oval, with slightly developed gymnocyst, which as a rule are concealed by avicularia and kenozooecia. The frontal shield consists of 16-20 dense, rather thin costae with numerous, but rather distinct lateral fusions. The costae are medianly united in a narrow, band-shaped area of fusion. The apertural bar bends in a proximally directed curve. The orifice consists of a large subcircular anter and a small, oval, transverse or roundedtrapezohedral poster. According to LANG the rim round the orifice is set with about six small oral spines.

The ovicells are hyperstomial, helmet-shaped, with a narrow median carina.

The avicularia mainly occur in pairs above the distal corners of the zooecium. They are small, elongate, with terminal, narrow opesia.

In the depressions between the normal zooecia there are frequently small, irregular kenozooecia medianly provided with a circular pore.

\begin{tabular}{|c|c|c|c|c|c|c|}
\hline \multicolumn{2}{|c|}{ Measurements. } & & \multicolumn{2}{|l|}{ Range } & \multicolumn{2}{|c|}{ Average } \\
\hline Faxe. & $\mathrm{Lz}$ & $\ldots \ldots \ldots \ldots \ldots \ldots \ldots \ldots$ & $0.36-0.52$ & nm. & 0.42 & $\mathrm{~nm}$. \\
\hline & Iz & $\ldots \ldots \ldots \ldots \ldots \ldots \ldots \ldots$ & $0.23-0.26$ & - & 0.26 & - \\
\hline & $\mathrm{hr}$ & $\ldots \ldots \ldots \ldots \ldots \ldots \ldots \ldots$ & 0.08 & - & 0.08 & - \\
\hline & Ir & $\ldots \ldots \ldots \ldots \ldots \ldots \ldots \ldots$ & 0.08 & - & 0.08 & - \\
\hline & hov & $\ldots \ldots \ldots \ldots \ldots \ldots \ldots \ldots$ & 0.21 & - & & \\
\hline & lov & $\ldots \ldots \ldots \ldots \ldots \ldots \ldots \ldots$ & 0.21 & - & & \\
\hline
\end{tabular}




\begin{tabular}{|c|c|c|c|c|c|}
\hline & Lav & $\ldots \ldots \ldots \ldots \ldots \ldots \ldots \ldots \ldots \ldots$ & $0.16-0.21$ & - & 0.17 \\
\hline & lav & $\ldots \ldots \ldots \ldots \ldots \ldots \ldots \ldots$ & $0.08-0.13$ & - & 0.10 \\
\hline LANG, & $\mathrm{Lz}$ & & 0.40 & $\mathrm{~mm}$. & \\
\hline 1921, p. 187. & 1z & 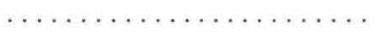 & 0.26 & - & \\
\hline
\end{tabular}

\section{Material.}

Faxe - 12 specimens; Herfølge, Bryozoan Limestone - 10 specimens; Herfølge, Calcarenite -6 specimens.

\section{Remarks.}

As mentioned under $P$. gluma (p. 167), it is very difficult to keep specimens of $P$. gluma and $P$. palea apart, especially if the state of preservation is not particularly good. My material of $P$. palea mainly includes small and poorly preserved fragments, and the uncertainty thus arising regarding the determination of species has necessitated the indication cf. against the specific name.

Distribution. Upper Danian: Faxe and Herfølge.

\section{Pliophloea vincularioides Voigt}

Plate 18, Fig. 7.

1924 Pliophloea vincularioides Voigt. Pal. Zeitschr. VI. 1, p. 11, Pl. I, Figs. 38-39.

1930 Pliophloea vincularioides VoIgt. Leopoldina. VI, p. 502, Pl. 27, Fig. 22.

\section{Description .}

The zoarium forms slender, cylindrical stems with dichotomous ramification and the zooecia in 5-7 alternating longitudinal rows. The zooecia are separated by narrow, almost invisible furrows.

The zooecia are elongate, narrow, plane, little prominent. The frontal shield consists of 15-25 flat costae, which are separated by indistinct rows of pores. The apertural bar has a sharp proximal bend. The orifice is provided with welldeveloped cardelles, which separate a comparatively large, subcircular anter and a small, narrow poster.

The ovicells are hyperstomial, large, globular.

The avicularia appear in pairs, symmetrically placed above the distal corners of the zooecium. They are small, elongate, directed obliquely forwards, with small, narrow opesia.

\begin{tabular}{|c|c|c|c|}
\hline \multicolumn{2}{|c|}{ Measurements. } & \multirow{2}{*}{$\begin{array}{l}\text { Range } \\
0.57-0.78 \mathrm{~mm} .\end{array}$} & \multirow{2}{*}{$\begin{array}{l}\text { Average } \\
0.68 \mathrm{~mm}\end{array}$} \\
\hline Faxe. & Width of zoarium . . . . . . . & & \\
\hline & $\mathrm{Lz} \quad \ldots \ldots \ldots \ldots \ldots \ldots \ldots \ldots$ & $0.47-0.68-$ & $0.61-$ \\
\hline & $\ldots \ldots \ldots \ldots \ldots \ldots$ & $0.18-0.26-$ & 0.23 \\
\hline
\end{tabular}




\begin{tabular}{|c|c|c|c|c|c|}
\hline & $\mathrm{hr}$ & $\ldots \ldots \ldots \ldots \ldots \ldots \ldots \ldots \ldots$ & 0.10 & - & 0.10 \\
\hline & $1 \mathrm{r}$ & 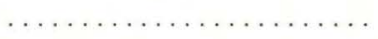 & 0.08 & - & 0.08 \\
\hline & hov & 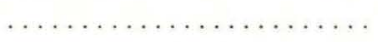 & 0.10 & - & \\
\hline & lov & $\ldots \ldots+\ldots \ldots+\ldots, \ldots+\ldots$ & 0.10 & - & \\
\hline & $\mathrm{Lz}$ & …........ & 0.60 & $\mathrm{~mm}$. & \\
\hline 1924, p. 11. & $1 \mathrm{z}$ & 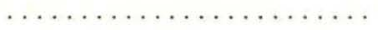 & $0.20-0.25$ & - & \\
\hline
\end{tabular}

Material.

Thorslunde -7 specimens; Faxe II -7 specimens; Saltholm -1 specimen.

Distribution .

Danian: Germany: Erratic blocks at Köthen. Denmark: Upper Danian, Faxe, Thorslunde, Saltholm, Herfølge, and Klintholm.

\section{Pliophloea brünnichi n.sp.}

Plate 19, Figs. 3-4.

Diagnosis.

A Pliophloea species with bi- or multilamellar, discoid or stem-shaped colonies consisting of elongate, elliptical zooecia in irregular quincunx. Frontal shield with 16-24 flat, dense costae separated by rows of small lacunae. Orifice with well-developed cardelles, large subcircular anter and a small oval, transverse poster. Ovicells hyperstomial, helmet-shaped, with a median carina. Small oval avicularia above the distal corners of the zooecium.

\section{Description .}

The zoarium constitutes free, bilamellar or multilamellar colonies, which sometimes form lobed plates, sometimes compressed stems with dichotomous ramification. The zooecia are arranged in irregular quincunx and separated by narrow, but distinct furrows.

The zooecia are very elongate, elliptical, more rarely rhombic. The frontal shield is plane or slightly convex, consisting of 16-24 dense costae, which are separated by very small lacunae. The costae are flat, irregular in width. The apertural bar is little prominent. It has the same width as the widest costae and bends proximally. The orifice is provided with well-developed cardelles so that a constriction arises between a large, subcircular anter and a small, oval poster. Oral spines have not been observed.

The ovicells are hyperstomial, helmet-shaped, with a narrow median carina.

Above the distal corners ("shoulders") of the zooecium there are two symmetrical, small, oblong-oval avicularia with an elongate, narrow opesium. 


\begin{tabular}{|c|c|c|c|c|c|}
\hline Measurements. & & & Range & & Average \\
\hline Herfølge, & $\mathrm{Lz}$ & $\ldots \ldots \ldots \ldots \ldots$ & $0.52-0.78$ & $\mathrm{~mm}$. & $0.61 \mathrm{~mm}$. \\
\hline Bryozoan Limestone, & $1 z$ & $\ldots \ldots \ldots \ldots \ldots \ldots$ & $0.18-0.31$ & - & $0.23-$ \\
\hline thin, bilamellar plates. & hr & $\ldots \ldots \ldots \ldots \ldots$ & 0.10 & - & 0.10 \\
\hline & $\operatorname{lr}$ & $\ldots \ldots \ldots \ldots \ldots$ & 0.08 & - & 0.08 \\
\hline & hov & $\ldots \ldots \ldots \ldots \ldots$ & $0.18-0.21$ & - & 0.20 \\
\hline & lov & $\ldots \ldots \ldots \ldots \ldots$ & $0.18-0.21$ & - & 0.19 \\
\hline & Lav & $\ldots \ldots \ldots \ldots \ldots$ & $0.08-0.10$ & - & 0.09 \\
\hline & lav & $\ldots \ldots \ldots \ldots \ldots$ & 0.05 & - & 0.05 \\
\hline Herfølge, & $\mathrm{Lz}$ & $\cdots$ & $0.47-0.62$ & $\mathrm{~mm}$. & $0.54 \mathrm{~mm}$. \\
\hline ultilamellar plates. & $1 z$ & $\ldots \ldots \ldots \ldots \ldots \ldots$ & $0.18-0.31$ & - & $0.24-$ \\
\hline & $\mathrm{hr}$ & $\ldots \ldots \ldots \ldots \ldots$ & $0.08-0.10$ & - & 0.10 \\
\hline & Ir & $\ldots \ldots \ldots \ldots \ldots$ & $0.05-0.08$ & - & 0.07 \\
\hline
\end{tabular}

The measurements show that the bilamellar zoaria have larger zooecia than the multilamellar ones.

\section{Material.}

Herfølge, Bryozoan Limestone - 1208 specimens; Herfølge, Calcarenite 51 specimens; Klintholm -3 specimens.

Holotype. Pl. 19, Fig. 3. Herfølge, Bryozoan Limestone.

Paratype. Pl. 19, Fig. 4.

Remarks.

P. brünnichi is dedicated to the memory of the late Dr. K. BRÜNNICH NIELSEN (1872-1942), physician and paleontologist, who is the author of a number of papers about invertebrate fossils in the Danian (cf. the List of Literature, p. 284).

Bilamellar and multilamellar colonies are also found in Pliophloea arborea Voigt and Pliophloea sagena Morton. The Senonian form, P. arborea (VoIgt, 1930, p. 501, Pl. 27, Figs. 16-17), has shorter zooecia (Lz: $0.45 \mathrm{~mm}$.) with 12-14 costae. The orifice is shaped like a figure eight, the poster having nearly the same width as the anter. A characteristic feature of this species is the position of the avicularia, which form connected rows (bands) between the rows of zooecia. $P$. arborea is identical with LEVINSEN's form $P$. cornuta var. b. (LeVInsen, 1925, p. 384, Pl. VI, Fig. 66 c).

P. sagena Morton (CANu and Bassler, 1933, p. 49, Pl. 11, Figs. 1-5) (Pl. 19, Fig. 5) from the Paleocene (?) Vincentown formation in New Jersey probably is the species which is most closely related to $P$. brünnichi. $P$. sagena generally has shorter, but wider zooecia (Lz: 0.54-0.63 mm., 1z: 0.25-0.29 mm.) and fewer costae (12-14) than P. brünnichi. Furthermore, P. sagena has a semi- 
circular orifice with little prominent cardelles and the same width of anter and poster. CANU and BASSLER have observed that the bilamellar zoaria have the largest zooecia and that the zooecia decrease in size the more the lamellae increase in number. As mentioned in connexion with the measurements, a corresponding development has also been established in the case of $P$. brünnichi.

Distribution. Upper Danian: Herfølge and Klintholm.

MONOCERATOPORA LANG, 1916

\section{Monoceratopora quadrisulcata (Hennig)}

Plate 19, Figs. 6-7.

1892 Cribrilina quadrisulcata Hennig. Lunds Univ. Årsskr. XXVIII, p. 38, Pl. 2, Figs. $31-32$.

1925 Barroisina quadrisulcata (Hennig). Levinsen. Vidensk. Selsk. Skr. 8. Ser. VII. 3, p. 390 , Pl. VI, Fig. 70.

1930 Monoceratopora quadrisulcata Hennig. Vorgt. Leopoldina VI, p. 499, PI. 27, Fig. 8.

\section{Description.}

The zoarium is encrusting, with irregularly arranged zooecia separated by furrows and depressions.

The zooecia are rhombically oval, with a convex frontal shield consisting of about 10 wide, rounded, dense costae which are separated by narrow furrows. Medianly the costae are united in a small, oval area of fusion. The apertural bar is wide, rounded, prominent. The orifice is small, rounded-quadrangular, with a straight posterior margin.

The ovicells are hyperstomial, large, helmet-shaped, with a median carina.

On top of each zooecium - with the exception of those bearing ovicellsthere is a small oblique, trilateral, pyramidal avicularium, the opesium of which is turned obliquely upwards.

\begin{tabular}{|c|c|c|c|c|c|c|}
\hline \multicolumn{2}{|c|}{ Measurements. } & & \multicolumn{2}{|l|}{ Range } & \multicolumn{2}{|c|}{ Average } \\
\hline Faxe. & $\mathrm{Lz}$ & $\ldots \ldots \ldots \ldots \ldots \ldots \ldots \ldots$ & $0.42-0.52$ & $\mathrm{~mm}$. & 0.46 & $\mathrm{~mm}$. \\
\hline & $1 z$ & $\ldots \ldots \ldots \ldots \ldots \ldots$ & $0.26-0.36$ & - & 0.32 & - \\
\hline & $\mathrm{hr}$ & $\ldots \ldots \ldots \ldots \ldots \ldots \ldots$ & 0.05 & - & 0.05 & - \\
\hline & lr & $\ldots \ldots \ldots \ldots \ldots \ldots \ldots$ & 0.05 & - & 0.05 & - \\
\hline & hov & $\ldots \ldots \ldots \ldots \ldots \ldots$ & 0.21 & - & & \\
\hline & lov & $\ldots \ldots \ldots \ldots \ldots \ldots \ldots$ & $0.21-0.23$ & - & & \\
\hline
\end{tabular}

Material.

Kagstrup - 4 specimens; Faxe - 16 specimens; Faxe II - 2 specimens; Faxe XI 8 specimens; Herfølge, Bryozoan Limestone - 8 specimens; Klintholm 1 specimen. 
Distribution.

Danian: Sweden: Annetorp. Denmark: Kagstrup, Faxe, Herfølge, and Klintholm. The species thus seems to be a general form within the series of Bryozoan Limestone of the Danian. According to LevinSEN (1925, p. 390) M.quadrisulcata also occurs in the Senonian White Chalk in Stevns.

\section{PELMAT OPORIDAE LANG, 1916 \\ PELMATOPORA LANG, 1916}

\section{Pelmatopora daniensis Voigt}

Plate 19, Fig. 8.

1925 Pelmatopora daniensis Voigt. Zeitschr. f. Geschiebe-forsch. Bd. 1. H. 3, p. 100, Text-fig. 2, Pl. 3, Figs. 4-6.

1930 Pelmatopora daniensis VoIgt. Leopoldina. VI, p. 514, Pl. 31, Fig. 11.

\section{Description .}

The zoarium forms free, unilamellar, thin plates with the zooecia in fairly regular quincunx.

The zooecia are elongate, wide, elliptical. The slightly convex frontal shield consists of 18-22 wide costae, which are mutually connected by regular costal fusions. Each costa bears four small pores, pelmata. The apertural bar is comparatively narrow, rounded, slightly curved. The orifice is semi-circular, and above this there are four oral spines.

Ovicells have not been observed.

The avicularia in my material are poorly preserved, but according to VoIGT (1925, p. 101) they are large, elongate-elliptical or rectangular, mostly tapering downwards. In the posterior part of the opesium there is a narrow pivot.

\begin{tabular}{|c|c|c|c|c|}
\hline \multirow[t]{5}{*}{ Measurements. } & & & Range & Average \\
\hline & $\mathrm{Lz}$ & & $0.78-0.83 \mathrm{~mm}$. & $0.81 \mathrm{~mm}$. \\
\hline & $1 z$ & $\ldots \ldots$ & $0.31-0.34-$ & $0.32-$ \\
\hline & hr & $\ldots \ldots \ldots \ldots \ldots \ldots \ldots$ & 0.10 & 0.10 \\
\hline & $\operatorname{lr}$ & $\ldots \ldots \ldots \ldots \ldots \ldots$ & $0.10-0.13-$ & 0.11 \\
\hline \multirow{4}{*}{$\begin{array}{l}\text { VoIGT, } 1925 \text {, } \\
\text { p. } 101 .\end{array}$} & $\mathrm{Lz}$ & . & $0.75-1.05 \mathrm{~mm}$. & \\
\hline & $1 z$ & $\ldots \ldots \ldots \ldots \ldots \ldots \ldots$ & $0.36-0.44-$ & \\
\hline & Lav & $\ldots \ldots \ldots \ldots \ldots \ldots$ & $0.21-0.24$ & \\
\hline & lav & $\ldots . . . . . . .$. & $008-0-12$ & \\
\hline
\end{tabular}

Material. Herfølge, Bryozoan Limestone - 1 specimen.

Distribution .

Danian: Germany: Erratic blocks at Köthen (Anhalt). Denmark: Herfølge. 


\section{Pachydera densa Lang}

Plate 20, Fig. 1.

1916 Pachydera densa Lang. Ann. Mag. Nat. Hist. 8. Ser. Vol. 18, p. 112.

1922 Pachydera densa Lang. Cat. Cret. Bryozoa. Vol. IV, p. 383, Text-fig. 122, Pl. VIII, Fig. 7.

1925 Pachydera grandis Marsson [partim]. Levinsen. Vidensk. Selsk. Skr. 8. Ser. VII. 3, p. 395.

1930 Pachydera densa Lang. Volgt. Leopoldina VI, p. 516, Pl. 32, Fig. 5.

\section{Description .}

The zoarium is unilamellar, encrusting or free. The free colonies have a semiglobular shape with spike-like prominent zooecia, which are irregularly arranged and separated by deep depressions.

The structure of the zooecia is very complicated. The gymnocyst is mostly invisible, but may sometimes be observed as a narrow rounded border at the base of the zooecium. The frontal shield has peripherically a steeply ascending zone consisting of $8-10$ rounded costae separated by spaces of the same width as the costae. The median region of the zooecium is plane, circular, separated from the marginal costal zone by a rounded, slightly prominent, circular rim. Immediately inside this there is a whorl of radial, slender, and short costules, separated by small, triangular intervals. The individual costules are often, but not always, placed off one of the costae of the outer zone. Towards the centre of the zooecium the costular zone is demarcated by a broad, circular rim which encircles an area of fusion with irregularly arranged, circular or cleft-shaped pores.

The orifice of the zooecium is sealed by a rounded-quadrangular, tubular peristomie with a terminal peristomice. The peristomie is at almost right angles with the rest of the surface of the zooecium. On each of its four sides the wall is penetrated by three fenestrae, the lowest and biggest one of which is oval, transverse and its lower margin formed by the wide, rounded apertural bar. The two other fenestrae are circular, the middle one generally being twice as big as the uppermost one.

The ovicells are mostly covered by the peristomies; they are wide, slightly convex.

Avicularia have not been observed in my material, but according to LANG (1922, p. 382) avicularia enter in pairs in the peristomie between the fenestrae.

\begin{tabular}{|c|c|c|c|c|c|}
\hline \multicolumn{3}{|c|}{ Measurements. } & \multirow{2}{*}{\multicolumn{2}{|c|}{$\begin{array}{l}\text { Range } \\
0.52-0.94 \mathrm{~mm} .\end{array}$}} & \multirow{2}{*}{$\begin{array}{l}\text { Average } \\
0.75 \mathrm{~mm}\end{array}$} \\
\hline Faxe. & $\mathrm{Lz}$ & . & & & \\
\hline & $\mathrm{lz}$ & $\ldots \ldots \ldots \ldots \ldots \ldots \ldots \ldots$ & 0.52 & - & $0.52-$ \\
\hline & Per & tomice, diameter ......... & 0.21 & - & 0.21 \\
\hline
\end{tabular}


Material.

Stevns, Bryozoan Limestone - 7 specimens; Kagstrup - 1 specimen; Faxe 8 specimens; Faxe XI - 1 specimen.

Remarks.

LEVINSEN's material from Faxe marked Pachydera grandis MARsson belongs to $P$. densa LANG.

\section{Distribution.}

Stevns, Kagstrup, Faxe. The species thus in a biostratigraphical respect seems to be attached to the Tylocidaris abildgaardi and brünnichi zones.

\section{Pachydera fissa n.sp.}

Plate 20, Figs. 2-4.

Diagnosis.

A Pachydera species with unilamellar, free, or encrusting zoaria consisting of irregularly arranged, scutiform zooecia. The frontal shield consists of a level or steeply rising outer zone with 10-12 curved costae and a plane or slightly convex inner zone, in which the costae are mutually connected with 2-3 circular rings of fusion with knob-like elevations. The peristomie is smoothly ascending, rounded-quadrangular, without dorsal and frontal fenestrae, but laterally provided with oblique slits.

\section{Description.}

The zoarium is unilamellar, encrusting or free, with irregularly arranged zooecia, which are separated by deep depressions.

The zooecia are scutiform. The gymnocyst can be observed on a few zooecia as a narrow rounded border along the base of the zooecium. The frontal shield consists of an outer zone consisting of 10-12, smoothly or steeply ascending, curved, wide costae, separated by oblong-triangular or slit-shaped spaces, - and a plane or slightly convex inner zone. The boundary between the two zones is formed by a slightly prominent, rounded, circular rim, which connects the costae and off these bear knob-like elevations. The area within this circle can be differently shaped within the same colony. As a rule the costae continue, although in a slenderer shape (costules) towards the central part of the zooecium, but is delimited from the latter by an inner ring of fusion, which is slenderer than the outer ring and with smaller, knob-like elevations. The area of fusion within the inner ring is mostly perforated by irregularly arranged pores, but such pores may be absent. On a few zooecia it is possible further to observe a ring of fusion, which surrounds a small area of 
fusion, so that the costae can be traced almost to the centre of the zooecium.

The orifice is covered by a rounded-quadrangular peristomie forming an obtuse angle with the rest of the surface of the zooecium. The frontal and dorsal walls are without fenestrae, whereas the lateral walls are provided with oblique fissures so that the lateral parts of the peristomie seem to form a continuation of the outer costal area. The peristomice is terminal, roundedquadrangular.

Ovicells are observed only on a single zooecium. It is hyperstomial with a free, convex posterior wall.

Avicularia have not been observed.

\begin{tabular}{|c|c|c|c|c|c|}
\hline \multicolumn{3}{|c|}{ Measurements. } & \multicolumn{2}{|l|}{ Range } & \multirow{2}{*}{$\begin{array}{l}\text { Average } \\
0.64 \mathrm{~mm} .\end{array}$} \\
\hline Faxe. & $\mathrm{Lz}$ & & $0.52-0.83$ & $\mathrm{~nm}$. & \\
\hline & $\mathrm{lz}$ & $\ldots \ldots \ldots \ldots \ldots \ldots \ldots \ldots$ & $0.35-0.57$ & - & $0.52-$ \\
\hline & \multicolumn{2}{|c|}{ Peristomice, diameter......... } & 0.10 & - & 0.10 \\
\hline & ho & $\ldots \ldots \ldots \ldots \ldots \ldots \ldots \ldots$ & 0.16 & - & \\
\hline & lov & $\ldots \ldots \ldots \ldots \ldots \ldots \ldots \ldots$ & 0.13 & - & \\
\hline
\end{tabular}

Material.

Faxe - 1 specimen; Daersdorf near Hamburg (erratic Danian block) - 3 specimens.

Holotype. P1. 20, Fig. 4. Type locality: Daersdorf.

Paratype. Pl. 20, Fig. 3. Type locality: Daersdorf.

Remarks.

The trivial name refers to the slit-shaped fenestrae of the lateral walls of the peristomie.

The material from Daersdorf has kindly been submitted to me by Professor VoIGT, Hamburg.

Pachydera fissa n.sp. differs from the other species within the genus Pachydera, $P$. grandis MARsson and $P$. densa LANG, by having no frontal or dorsal fenestrae on the peristomie. The new species furthermore differs from $P$. grandis as regards size, as the zooecial length of the Senonian form is $1.25-1.50 \mathrm{~mm}$; $P$. fissa can be distinguished from $P$. densa by the curved costae of the outer zone and the size of the angle between the peristomie and the rest of the frontal wall, this angle being almost right in $P$. densa, but obtuse in $P$. fissa.

\section{Distribution.}

Danian: Germany: Daersdorf near Hamburg (erratic block). Denmark: Faxe. The modest material does not permit an evaluation of the regional and stratigraphical distribution of the species. 
TRICEPHALOPORA LA NG, 1916

\section{Tricephalopora cerberus Lang}

Plate 20, Fig. 5.

1916 Tricephalopora cerberus LANG. Ann. Mag. Nat. Hist. 8. Ser. Vol. 18, p. 89.

1919 Tricephalopora cerberus LANG. Proc. Geol. Assoc. Vol. XXX, p. 106, Fig. 19d.

1922 Tricephalopora cerberus LANG. Cat. Cret. Bryozoa. Vol. IV, p. 86, Text-fig. 24-25, P1. I, Fig. 9.

1925 Kelestoma umbilicatum Levinsen. Vidensk. Selsk. Skr. 8. Ser. VII. 3, p. 392, Pl. VI, Fig. 73.

1930 Tricephalopora cerberus Lang. Vorgt. Leopoldina. VI, p. 507, P1. 29, Fig. 21.

1955 Tricephalopora cerberus Lang. Balavoine. Bull. Soc. Geol. France. 6. Ser. 5, p. 62, Pl. IV, Fig. 4.

\section{Description.}

The zoarium is encrusting or free (VOIGT), uni- or multilamellar (LANG), with irregularly arranged zooecia, which are separated by deep depressions.

The zooecia, which are highly convex, have rounded-quadrangular outlines. The posterior half of the zooecium laterally and proximally consists of the gymnocyst, which encircles a central subcircular fenestra, through which a small, depressed, circular costal area is observed, composed of 10-12 slender costules, the outer sections of which are free, whereas the inner parts are fused. The anterior half of the zooecium consists of a wide, steeply ascending peristomie, which forms an almost right angle with the rest of the zooecium. The peristomice is terminal, elliptical, transverse. Above the distal corners of the fenestra, nearly at the base of the peristomie, there are two small, circular pores.

The ovicells (according to LeVINSEN) are large, greatly convex, almost globular, retroflexed.

The avicularia appear in pairs, laterally to the peristomie. They form tubular processes, which are fused with the lateral walls of the peristomie. The opesium is placed at the top, rising obliquely, oblong-triangular, with the tapering anterior end turned towards the peristomice. In the posterior part of the opesium there is a distinct pivot.

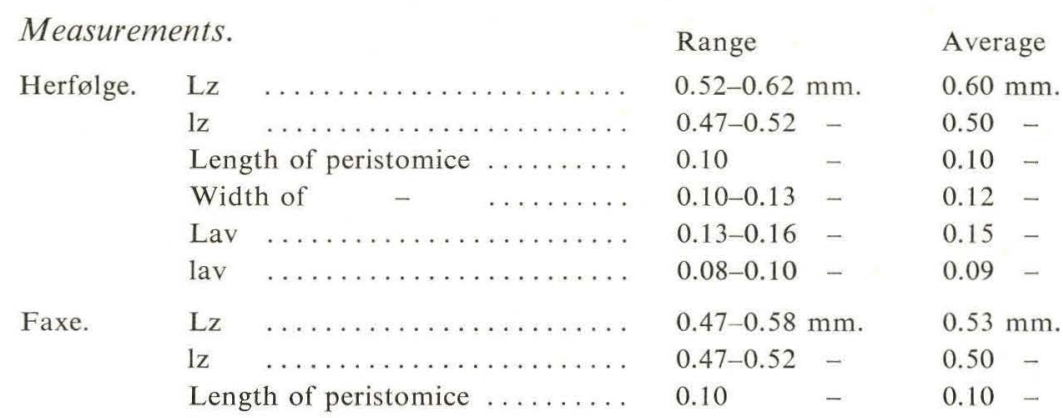




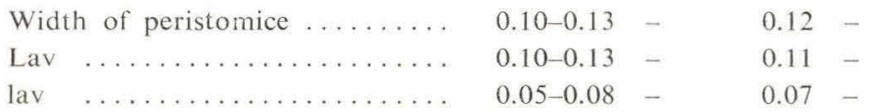

Material.

Faxe - 33 specimens; Faxe II - 1 specimen; Faxe XI - 7 specimens; Herfølge, Bryozoan Limestone - 26 specimens; Herfølge, Calcarenite - 2 specimens.

Distribution .

Danian: France: Vigny. Germany: Köthen (erratic blocks). Denmark: Stevns, Faxe, Saltholm, and Herfølge.

\section{Tricephalopora subtriceps n.sp.}

Plate 20, Fig. 6.

Diagnosis.

Encrusting zoarium consisting of rounded-triangular to -quadrangular zooecia. The proximally tapering gymnocyst surrounds a horseshoe-shaped costal area composed of 12 costae. At the base of the wide, compressed, steeply ascending peristomie there is a median circular pore and two lateral oval pores. The peristomice is oval, transverse.

\section{Description .}

The zoarium is encrusting, with more or less regularly arranged zooecia, which are separated by deep depressions.

The zooecia are rounded-triangular, sometimes very elongate. The posterior half of the zooecium laterally and proximally has a well-developed gymnocyst. The proximal portion may be long and very tapering, sometimes covered by the projecting part of the proximal zooecium. The gymnocyst surrounds an elongate horseshoe-shaped costal area consisting of 12 costae, which are fused in an oblong-oval area of fusion. The anterior half of the zooecium forms a wide, compressed, steeply ascending peristomie with an oval, transverse peristomice. At the base of the peristomie there are three pores, the lateral ones, which are placed on the border of the costal area, are small, oval, transverse, while the median one, which is larger and circular, is found a little closer to the distal end of the zooecium.

Ovicells have not been observed.

The avicularia appear in pairs, laterally to the peristomie. They form tubular processes, which are fused with the lateral walls of the peristomie. The opesium is placed at the top, rising obliquely, rounded-triangular, tapering, with the tip turned towards the anterior or central part of the peristomice. 


\begin{tabular}{|c|c|c|c|c|}
\hline \multicolumn{3}{|c|}{ Measurements. } & Range & Average \\
\hline \multirow[t]{6}{*}{ Faxe. } & $\mathrm{Lz}$ & & $0.57-0.62 \mathrm{~mm}$ & $0.59 \mathrm{~mm}$. \\
\hline & $1 z \quad \ldots \ldots \ldots \ldots \ldots$ & $\ldots \ldots \ldots$ & $0.42-0.52-$ & $0.48-$ \\
\hline & Length of peristomice & $\ldots \ldots \ldots$ & 0.10 & 0.10 \\
\hline & Width of $\quad-$ & $\ldots \ldots \ldots$ & $0.10-0.13$ & 0.12 \\
\hline & Lav $\ldots \ldots$. & $\ldots \ldots \ldots$ & 0.10 & 0.10 \\
\hline & $\ldots \ldots \ldots \ldots$ & $\ldots \ldots \ldots$ & $0.05-0.08$ & 0.08 \\
\hline \multirow[t]{4}{*}{ Kagstrup. } & $\mathrm{Lz}$ & $\ldots \ldots$ & $0.47-0.52 \mathrm{~mm}$ & $0.48 \mathrm{~mm}$. \\
\hline & $\mathrm{lz} \quad \ldots \ldots \ldots \ldots \ldots$ & $\ldots \ldots \ldots$ & $0.26 \quad-$ & $0.26-$ \\
\hline & Length of peristomice & $\ldots \ldots \ldots$ & $0.08-0.10$ & 0.09 \\
\hline & Width of $\quad-$ & $\ldots \ldots \ldots$ & $0.10-0.13$ & 0.12 \\
\hline \multicolumn{5}{|c|}{ Tricephalopora triceps (MARssON). } \\
\hline \multirow[t]{4}{*}{ Møn. } & $\mathrm{Lz} \quad \ldots \ldots \ldots \ldots \ldots$ & $\ldots \ldots \ldots$ & $0.78-0.88 \mathrm{~mm}$. & $0.84 \mathrm{~mm}$. \\
\hline & Iz $\quad \ldots \ldots \ldots \ldots \ldots$ & $\ldots \ldots \ldots \ldots$ & $0.36-0.39-$ & $0.37-$ \\
\hline & Length of peristomice & $\ldots \ldots \ldots$ & 0.21 & 0.21 \\
\hline & Width of $\quad-$ & $\ldots \ldots \ldots$ & $0.10-0.13-$ & 0.12 \\
\hline
\end{tabular}

Material.

Kagstrup - 1 specimen; Faxe -5 specimens; Faxe II - 1 specimen; Faxe XI 1 specimen.

Holotype. Pl. 20, Fig. 6. Faxe, Bryozoan Limestone.

Remarks.

The trivial name refers to the great similarity to Tricephalopora triceps (MARSSON, 1887, p. 98, Pl. X, Fig. 12). Apart from the difference in stratigraphical distribution $T$. subtriceps differs from $T$. triceps by having shorter and comparatively wider zooecia. Furthermore, the peristomice in $T$. subtriceps is comparatively small - about one sixth of the zooecial length - and oval, transverse, while in $T$. triceps it is longer than wide, and its size is about one fourth of the length of zooecium.

Distribution. Danian: Kagstrup and Faxe.

\section{Tricephalopora circumvallata (Levinsen)}

Plate 20, Fig. 7.

1925 Membraniporella circumvallata LeVINSEN. Vidensk. Selsk. Skr. 8. Ser. VII. 3, p. 382, Pl. VIII, Fig. 5.

\section{Description.}

The zoarium is encrusting, with fairly regularly arranged zooecia.

The zooecia are oblong-oval, slightly convex. The frontal shield consists of 14-18 costae, which medianly are fused in an oblong-oval area of fusion. The $12^{*}$ 
costae are separated by narrow, but distinct furrows. On young specimens there are two larger and two smaller breaches between the orifice and the apertural bar, separated by two median processes from the apertural bar, which are mutually connected by a narrow transversal band. On older colonies these breaches seem to be sealed. The frontal shield is surrounded by an originally narrow, wall-shaped, rounded rim, which in younger colonies by a distinct depression is separated from the corresponding rim in the adjoining zooecia. Gradually these rims are fused and in time become wider and higher, so that in the older zooaria a greatly prominent network is formed, the depressed spaces of meshes containing the costal areas.

The orifice is covered by a ring- or collar-shaped peristomie, which with increasing age increases in height and thickness, as it becomes enclosed by the same glistening, knotty-wrinkled mass of calcium that surrounds the costal areas of ribs like a wall. In old colonies the peristomice therefore is placed on top of a crater-shaped peristomie projecting vertically from the surface of the zooecium. The peristomice varies in shape between semi-elliptical, semicircular, and subcircular.

The ovicells are small, rather wide, spherically convex, retroflexed.

The avicularia appear in pairs, laterally to the peristomice, off the proximal part of this. They are small, oval, ascending obliquely.

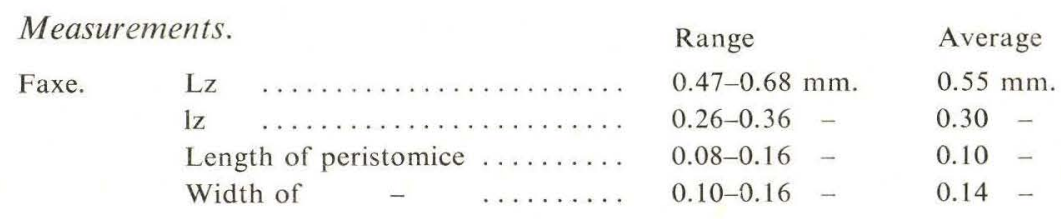

Material.

Faxe - 6 specimens; Herfølge, Bryozoan Limestone - 2 specimens.

Lectotype.

Pl. VIII, Fig. 5 in Vidensk. Selsk. Skr. 8. Ser. VII, 3. The type specimen is found in Levinsen's collection in the Zoological Museum of Copenhagen. Type locality: Faxe: Bryozoan Limestone.

Distribution. Danian: Faxe, Herfølge, and Klintholm.

\section{Tricephalopora robusta n.sp.}

Plate 21, Fig. 1.

Diagnosis.

A Tricephalopora species with encrusting or free, uni- or multilamellar colonies consisting of irregularly arranged, large, oval zooecia. The furrows between the 
zooecia may be covered by a band of secondary tissue. The frontal shield is composed of 8-10 vigorous costae separated by slit-shaped intervals. The area of fusion is oblong-oval with a central depression. The wide, straight apertural bar bears a wide, concave median process, which separates two oval, transverse breaches. The peristomie is crater-shaped with a subcircular peristomice. Small oval avicularia occur laterally to the peristomice.

\section{Description .}

The zoarium is encrusting or forms free, uni- or multilamellar colonics, with irregularly arranged zooecia separated by deep furrows, often filled in by irregular bands of secondary tissue, which may also cover parts of the outer regions of the frontal shield.

The zooecia are large, oval. The well-developed, convex, frontal shield consists of $8-10$ robust rounded costae, which decrease in width towards the middle of the zooecium. They are separated by narrow, slit-like intervals. The costae are fused medianly in an oblong-oval area of fusion, which centrally has an oblong depression. The apertural bar is wide, straight, rounded. It is provided with a wide, concave median process without breaches, but with a narrow, median longitudinal furrow. Laterally to the median process there are two oval, transverse fenestrae.

The orifice is covered by a crater-shaped peristomie, which forms an almost right angle to the rest of the surface of the zooecium. The peristomice is subcircular.

The ovicells are broad, almost globular, retroflexed.

The avicularia appear in pairs, laterally to the peristomice. They are small, oval, obliquely ascending, with a slender pivot.

\begin{tabular}{|c|c|c|c|c|c|c|}
\hline \multicolumn{3}{|c|}{ Measurements. } & \multicolumn{2}{|l|}{ Range } & \multicolumn{2}{|c|}{ Average } \\
\hline \multirow[t]{6}{*}{ Faxe. } & Length of frontal shiel & $\mathrm{d} \ldots \ldots \ldots$ & $0.62-0.83$ & $\mathrm{~mm}$. & 0.69 & $\mathrm{~nm}$. \\
\hline & Width of - - & $\ldots \ldots$ & $0.36-0.47$ & - & 0.43 & - \\
\hline & Length of peristomice & $\ldots \ldots \ldots$ & $0.13-0.21$ & - & 0.17 & - \\
\hline & Width of $\quad-$ & $\ldots \ldots \ldots$ & $0.13-0.16$ & - & 0.15 & - \\
\hline & Lav $\ldots \ldots \ldots \ldots$ & $\ldots \ldots \ldots$ & 0.13 & - & & \\
\hline & $\ldots \ldots \ldots \ldots$ & $\ldots \ldots \ldots$ & 0.10 & - & & \\
\hline
\end{tabular}

Material. Faxe -7 specimens; Faxe XI - 2 specimens.

Holotype. P1. 21, Fig. 1. Faxe, Bryozoan Limestone.

\section{Remarks.}

The trivial name refers to the well-developed, robust frontal shield and the general robust character of the species.

Tricephalopora robusta n.sp. differs from other species within the genus 
Tricephalopora by the robust frontal shield, which is surrounded by bandshaped secondary tissue, and by the wide median process of the apertural bar.

Distribution. Danian: Faxe.

HAPLOCEPHALOPORA LANG, 1916

88. Haplocephalopora uniceps Lang

Plate 20, Fig. 8.

1916 Haplocephalopora uniceps LANG. Ann. Mag. Nat. Hist. 8. Ser. Vol. 18, p. 89.

1922 Haplocephalopora uniceps Lang. Cat. Cret. Bryozoa. Vol. IV, p. 95, Text-fig. 28, Pl. II, Fig. 1.

1925 Kelestoma distomum Levinsen. Vidensk. Selsk. Skr. 8. Ser. VII. 3, p. 394, Pl. VIII, Fig. 9.

1930 Haplocephalopora uniceps LANG. VoIGT. Leopoldina. VI, p. 508, PI. 30, Fig. 1.

\section{Description.}

The zoarium is encrusting, with irregularly arranged zooecia. The intercellular spaces are in part filled in by secondary tissue, which also covers the surface of the zooecia.

The zooecia are bottle- or jar-shaped with a freely ascending peristomie. In the middle of the frontal wall there is a subcircular or elliptical, transverse fenestra, which is sometimes surrounded by a swollen border zone. Within the fenestra an embedded costal area may be observed, consisting of eight to ten slender, rather wide-spaced costae, which medianly are fused into a narrow band of fusion. This is more or less covered with secondary tissue rising pillarwise at the distal end of the fenestra. The orifice is covered by a tubular peristomie with a terminal, subcircular peristomice. This secondary aperture is surrounded by a thickened rim.

Ovicells have not been observed.

The avicularia are small, rounded, tapering. They occur in pairs on the swollen rim of the peristomie, with one on each side of the peristomice, directed obliquely towards the median line of it.

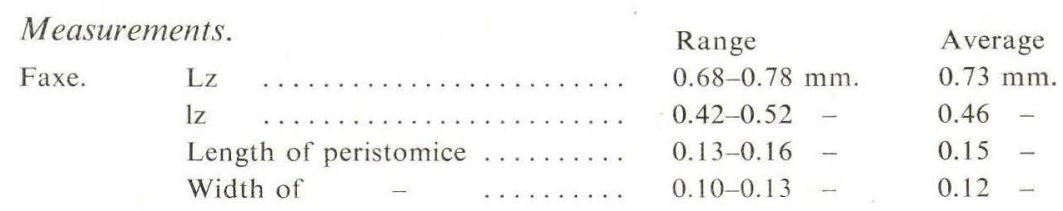

Material.

Thorslunde - 1 specimen; Faxe - 9 specimens; Faxe XI - 3 specimens; Herfølge, Bryozoan Limestone - 5 specimens. 


\section{Distribution.}

Danian: Germany: Erratic blocks at Köthen. Denmark: Thorslunde, Faxe, and Herfølge.

PHRACTOPORELLA LANG, 1917

\section{Phractoporella cordiformis (Levinsen)}

Plate 21, Fig. 2.

1925 Kelestoma cordiforme Levinsen. Vidensk. Selsk. Skr. 8. Ser. VII. 3, p. 393, P1. VI, Fig. $74 \mathrm{a}-\mathrm{b}$.

1930 Phractoporella cordiformis Levinsen. Voigt. Leopoldina. VI, p. 508, Pl. 30, Fig. 5.

\section{Description.}

The zoarium is encrusting, with irregularly arranged zooecia without marginal delimitations, as the intercellular spaces are filled in by secondary tissue, which also covers a great part of the surface of the zooecium.

The zooecia seem to be wide, rounded-rhombical. In the proximal half there is an embedded, wide, heart-shaped costal area, consisting of ten to twelve slender costae, which medianly are fused into an oblong-oval area of fusion. This band of fusion is more or less covered by a tongue of secondary tissue, which projects from the neighbourhood of the apertural bar. Sometimes this tongue stretches through the whole of the costal area, dividing this into two parts, the sizes of which depend on the breadth of the bridge of calcium. The anterior half of the zooecium is occupied by a tubular or crater-shaped, more or less steeply ascending peristomie with a terminal, circular or subcircular peristomice.

Ovicells have not been observed.

On the anterior side of the peristomie there are two oblique, steeply ascending, oblong-oval avicularia. The opesium is oblong-soleshaped, the almost parallel lateral rims having a slight indentation.

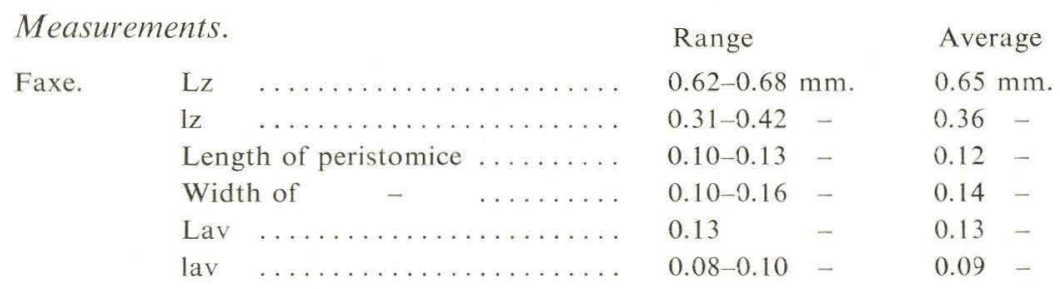

Material.

Stevns, Bryozoan Limestone - 4 specimens; Kagstrup - 2 specimens; Thorslunde -1 specimen; Faxe -21 specimens; Saltholm - 3 specimens. 
Distribution.

Danian: Germany: Erratic blocks at Köthen. Denmark: Stevns, Kagstrup, Thorslunde, Faxe, Saltholm, and Karleby Klint (Levinsen).

\section{DIACANTHOPORA LA NG, 1916}

\section{Diacanthopora bispinosa Lang}

Plate 21, Figs. 3-4.

1916 Diacanthopora bispinosa LANG. Ann. Mag. Nat. Hist. 8. Ser. Vol. 18, p. 101.

1922 Diacanthopora bispinosa LANG. Cat. Cret. Bryozoa. Vol. IV, p. 231, Text-fig. 71, Pl. V, Fig. 4.

1925 Diacanthopora bispinosa Lang. Volgt. Zeitschr. f. Geschiebeforsch. Bd. I, Pl. I, Fig. 19.

1930 Diacanthopora cf. bispinosa LANG. VoIGT. Leopoldina. VI, p. 514, P1. 31, Fig. 8.

\section{Description .}

The zoarium is unilamellar, encrusting or forms free, thin plates consisting of zooecia in regular quincunx. The original depressions between zooecia is in part filled in by secondary tissue, which also covers the gymnocyst. The back of the discoidal colonies displays a division into irregular elongate figures.

The frontal shield of the zooecium and the aperture are surrounded by secondary tissue. Sometimes this is penetrated by a narrow, uneven furrow proximally to the frontal shield. The costal area is plane or slightly convex. In the free colonies it is composed of 12-17 costae, while the zooecia of the encrusting colonies have 9-11 costae, only. The individual costae are rather wide and plane, and are provided with a proximal pelma and a distal pelmatidium. The costae are separated by narrow, but distinct furrows, but are medianly fused into an elongate, carinate area of fusion. The apertural bar is wide, rounded and curved, a little more prominent than the rest of the frontal. The orifice is large and subcircular, laterally and distally surrounded by a salient rim (peristome).

Ovicells have not been observed.

The avicularia are rounded-triangular or oval, with a slender, curved pivot. They occur in pairs, often laterally and distally to the orifice with an oblique direction, or - although more rarely-laterally to the apertural bar.

\begin{tabular}{|c|c|c|c|c|c|c|}
\hline \multicolumn{3}{|c|}{ Measurements. } & \multicolumn{2}{|l|}{ Range } & \multicolumn{2}{|c|}{ Average } \\
\hline Herfølge. & $\mathrm{Lz}$ & $\ldots \ldots$ & $0.75-1.04$ & $\mathrm{~mm}$. & 0.84 & $\mathrm{~mm}$. \\
\hline & $\mathrm{lz}$ & $\ldots \ldots \ldots \ldots \ldots \ldots \ldots$ & $0.42-0.49$ & - & 0.45 & - \\
\hline & $\mathrm{hr}$ & $\ldots \ldots \ldots \ldots \ldots \ldots \ldots$ & $0.18-0.28$ & - & 0.19 & - \\
\hline & $\operatorname{lr}$ & $\ldots \ldots \ldots \ldots \ldots \ldots$ & $0.13-0.18$ & - & 0.15 & - \\
\hline & Lav & $\ldots \ldots \ldots \ldots \ldots \ldots \ldots$ & 0.10 & - & & \\
\hline & lav & $\ldots \ldots \ldots \ldots \ldots \ldots \ldots$ & 0.08 & - & & \\
\hline
\end{tabular}


Material.

Faxe -3 specimens; Herfølge, Bryozoan Limestone - 22 specimens.

\section{Distribution.}

Danian: Germany: Köthen (erratic blocks). Denmark: Upper Danian: Kagstrup, Faxe, Saltholm, and Herfølge.

\section{Diacanthopora reticulata n.sp.}

Plate 21, Fig. 5.

Diagnosis.

A Diacanthopora species with tubular or discoid colonies. The spaces between the zooecia and the gymnocystal portions of these are covered by an irregular, robust network of secondary tissue with scattered pores of varying size and shape. The costal area of the zooecium is deep-lying, narrow, consisting of 7-8 short, slender costules, which medianly are united in a carinate area of fusion. The orifice is subcircular, embedded.

\section{Description.}

The zoaria form unilamellar, free, discoid or tubular colonies, with the zooecia in fairly regular quincunx. The intercellular spaces are covered by an irregular, strongly developed network of secondary tissue, which often stretches over the outer parts of the frontal shield. The "threads" of the network are robust, rounded, convex bands of varying breadth and thickness, set with scattered, circular or elongate pores of varying size.

The zooecia appear as low-lying, narrow costal areas and embedded orifices in the meshes of the reticulate epicalcification. The frontal shield is composed of 7-8 short, slender costules, which are mutually separated by narrow, slitshaped furrows and which medianly are united in a narrow, elongate, carinate area of fusion. The apertural bar is straight, rounded, slightly prominent, mostly wider than the costules. The orifice is large and subcircular.

Ovicells have not been observed.

Where the intense calcification does not cover the original surface, a rimmed, circular perforation, which probably represents an avicularium, is seen laterally to the orifice, off the middle of it.

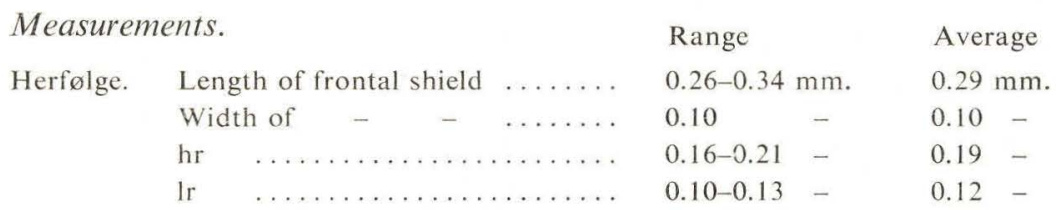


Material. Herfølge, Bryozoan Limestone - 2 specimens.

Holotype. Pl. 21, Fig. 5. Herfølge, Bryozoan Limestone.

\section{Remarks.}

The trivial name refers to the reticulate epicalcification.

Diacanthopora reticulata n.sp. differs from other species of the genus Diacanthopora by the strong secondary calcification and by the structure of the costal area, this-as mentioned above-consisting of 7-8 costules only. As mentioned on p. 184, the number of costules in D. bispinosa LANG varies in the encrusting specimens between 9 and 11 and in the free colonies between 12 and 17, while the Senonian species D. impressa LeVINSEN (1925, p. 388, Pl. VIII, Fig. 7) has about 20 costules. The American Diacanthopora species from the Paleocene (?) Vincentown formation, D. abbotti GABB and HoRn, D. distans GABB and Horn, D. convexa CANU and BASSLER, and D. marginata GabB and Horn (see CANU and BASsLer, 1933, pp. 65-70) have 10-20, 8-10, 14-16, and 10-20 costules, respectively.

Distribution. Upper Danian: Herfølge and Klintholm.

\section{ANORNITHOPORA LANG, 1916}

\section{Anornithopora minuta Voigt}

Plate 22, Fig. 1.

1925 Anornithopora ?) minuta VoIGT. Zeitschr. f. Geschiebeforsch. Bd. 1. H. 3, p. 102, Fig. 3, Pl. 3, Figs. 1-3.

1925 Cribilina intermixta Levinsen. Vidensk. Selsk. Skr. 8. Ser. VII. 3, p. 378, Pl. V, Fig. 60.

1930 Anornithopora minuta Voigt. Leopoldina. VI, p. 510, Pl. 30, Fig. 10.

Description.

The zoarium is encrusting, with irregularly arranged zooecia, which are separated by narrow, deep depressions.

The zooecia are broadly oval or rhombically rounded. The convex frontal shield consists of 15-18 convex costae, which medianly are joined in a narrow, elongated area of fusion. The costae are connected by slight lateral fusions, the intercostal spaces thus being subdivided into series of pores, each consisting of 6-8 oval pores. At high magnification it is possible on each costa to observe 6-8 pelmatidia, which frequently are fused into an irregular groove-like depression. The orifice is semi-circularly transverse. It is proximally delimited by a swollen, angular apertural bar, which medianly bears a small tubular process. The distal rim is provided with 5-6 knobby impressions after apertural spines. 
The ovicells are hyperstomial, large, and highly convex, with a slightly developed median carina.

Avicularia occur irregularly scattered between or on the zooecia. Sometimes they appear in interzooecial groups in a number which varies between two and eight cells. Their shape is oval or slightly tapering. The opesium is small, circular, and connected with the anterior end of the avicularium with a narrow, groove-shaped embedment.

Among the normal zooecia there are sometimes small kenozooecia with a more or less well-developed costal area, but without an orifice.

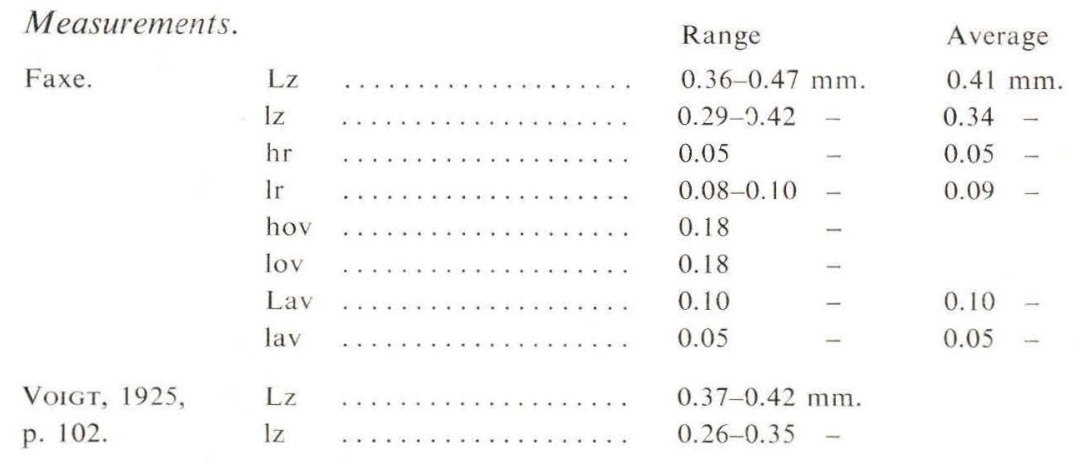

Material.

Faxe - 26 specimens; Faxe II - 1 specimen; Faxe XI - 2 specimens; Herfølge, Bryozoan Limestone - 14 specimens.

Distribution.

Senonian: Holland: Maastricht. Denmark: Stevns, Hillerslev.

Danian: Germany: Erratic blocks in Anhalt. Denmark: Stevns (LevinSEN), Faxe, Karleby Klint, Herfølge.

\section{Anornithopora polygona Voigt}

Plate 21, Fig. 6.

1930 Anornithopora polygona VoIGT. Leopoldina. VI, p. 510, P1. 30, Figs. 11-12.

Description .

The zoarium is unilamellar, free or encrusting, with irregularly arranged zooecia, which are separated by narrow, but distinct furrows.

The outlines of the zooecia are irregularly hexagonal or polygonal. The plane or slightly convex frontal shield is composed of 15-20 wide flat costae, which medianly are joined into an oblong-oval area of fusion. The costae are 
interconnected by numerous fine lateral fusions, the intercostal spaces thus being subdivided into more or less distinct rows of pores. According to VoIGT the costae are provided with pelmata and pelmatidia. It has not been possible to establish the presence of such ornaments on my material. The apertural bar is slightly curved, rather vigorous, swollen. The orifice is semi-circular, transverse. The distal apertural rim bears traces of four spines.

Ovicells and avicularia have not been observed.

\begin{tabular}{|c|c|c|c|c|}
\hline \multicolumn{3}{|l|}{ Measurements. } & Range & \multirow{2}{*}{$\begin{array}{l}\text { Average } \\
0.72 \mathrm{~mm} .\end{array}$} \\
\hline Faxe. & $\mathrm{Lz}$ & $\ldots \ldots+\cdots, \ldots$ & $0.68-0.83 \mathrm{~mm}$. & \\
\hline & $\mathrm{lz}$ & $\ldots \ldots \ldots \ldots \ldots \ldots \ldots$ & $0.42-0.62-$ & $0.54-$ \\
\hline & $\mathrm{hr}$ & $\ldots \ldots \ldots \ldots \ldots \ldots \ldots$ & $0.13-0.18 \quad-$ & $0.13-$ \\
\hline & Ir & $\ldots \ldots \ldots \ldots \ldots \ldots \ldots$ & $0.18-0.21-$ & 0.19 \\
\hline $\begin{array}{l}\text { VolGt, } 1930, \\
\text { p. } 510\end{array}$ & $\mathrm{lz}$ & & $0.80-0.90 \mathrm{~mm}$. & \\
\hline
\end{tabular}

Material. Faxe - 5 specimens; Faxe II - 1 specimen.

Distribution. Danian: Faxe and Klintholm.

\section{Anornithopora circulata n.sp.}

Plate 22, Figs. 2-3.

Diagnosis.

An Anornithopora species with oblong- or widely oval zooecia. The costal area consists of 12-15 wide, convex costae. The apertural bar is wide, prominent, with a narrow median process and two lateral, knob-shaped traces of spines. The orifice is semi-elliptical, transverse. The distal rim has 4 large, circular traces of oral spines.

\section{Description.}

The zoarium is encrusting, with irregularly arranged zooecia, which are separated by deep furrows.

The zooecia are oblong- or widely oval. The gymnocyst forms a low, almost vertical margin on which the plane or slightly convex frontal shield is supported. The costal area consists of 12-15 wide, convex costae, which are provided with pelmata and perhaps pelmatidia as well. The costae are united medianly into an oblong-oval area of fusion and are laterally interconnected by fusions, which subdivide each of the intercostal spaces into 4 pores. The apertural bar is comparatively wide, prominent, with a straight or slightly curved posterior margin. It is provided with a narrow, elongated median process and two knob- 
shaped traces of spines placed off the proximal corners of the orifice. This is semi-elliptical, transverse; its distal rim is curved, with 4 large, circular traces of oral spines.

The ovicells are hyperstomial, large, greatly convex.

Avicularia have not been observed.

\begin{tabular}{|c|c|c|c|c|}
\hline \multicolumn{2}{|c|}{ Measurements. } & & \multirow{2}{*}{$\begin{array}{l}\text { Range } \\
0.62-0.83 \mathrm{~mm} .\end{array}$} & \multirow{2}{*}{$\begin{array}{l}\text { Average } \\
0.74 \mathrm{~mm}\end{array}$} \\
\hline Faxe, & $\mathrm{Lz}$ & & & \\
\hline Herfølge. & $1 z$ & & $0.52-0.73-$ & $0.62-$ \\
\hline & $\mathrm{hr}$ & $\ldots \ldots \ldots$ & $0.10-0.16-$ & $0.13-$ \\
\hline & lr & $\ldots \ldots \ldots \ldots \ldots \ldots \ldots \ldots$ & $0.16-0.21-$ & $0.17-$ \\
\hline
\end{tabular}

\section{Material.}

Faxe - 2 specimens; Herfølge, Bryozoan Limestone - 9 specimens.

Holotype. Pl. 22, Fig. 2. Faxe, Bryozoan Limestone.

\section{Remarks.}

The trivial name refers to the large, circular traces of oral spines.

A. circulata n.sp. as regards size of the zooecium agrees with $A$. polygona VoIGT (see p. 188). On this point these two species occupy a position apart within the genus Anornithopora, the other species of which are characterized by having comparatively small zooecia. A circulata differs from $A$. polygona by having a smaller number of costae (12-15 as against 15-20) and fewer pores in the intercostal rows of pores, and finally by the size of the traces of oral spines.

Distribution. Faxe and Herfølge.

\section{Anornithopora isolata n.sp.}

Plate 22, Fig. 4.

Diagnosis.

An Anornithopora species with free, uniserial colonies consisting of large, oval or rounded-hexagonal zooecia. The costal area includes 18-22 costae, the outermost part of which is steeply ascending, while the central part is slightly convex and provided with 3-5 concentric rings of lateral fusions. The apertural bar is widely rounded, L-shaped. The orifice is semi-elliptical or subcircular, transverse. The distal rim has 4 traces of oral spines. 
Description.

The zoarium is free, uniserial, perhaps ramified.

The zooecia are large, oval or rounded-hexagonal. The frontal shield consists of 18-22 comparatively wide, rounded costae. In the outermost part of the costal area the costae are steeply ascending and mutually separated by slitshaped spaces. The central part of the frontal is slightly convex, and there 3-5 concentric rings of lateral fusions subdivide the intercostal spaces into rows of pores. The apertural bar is wide, rounded, L-shaped. The orifice is semi-elliptical or subcircular, transverse. The poor state of preservation of the apertural area in the material examined does not with certainty permit an establishment of the number of spines; but as far as can be judged, the distal rim bears 4-5 knob-shaped traces of oral spines.

Ovicells and avicularia have not been observed.

\begin{tabular}{|c|c|c|c|c|}
\hline \multicolumn{3}{|c|}{ Measurements. } & Range & Average \\
\hline Saltholm. & $\begin{array}{l}\mathrm{Lz} \\
\mathrm{lz}\end{array}$ & ${ }^{2}$ & $\begin{array}{l}1.09-1.30 \mathrm{~mm} . \\
0.83-0.93\end{array}$ & $\begin{array}{l}1.21 \mathrm{~mm} \text {. } \\
0.92-\end{array}$ \\
\hline & $\mathrm{hr}$ & $\ldots \ldots \ldots+\cdots, \cdots, \ldots$ & $0.16-0.21-$ & $0.17-$ \\
\hline & $\operatorname{lr}$ & & $0.29-0.31$ & $0.30-$ \\
\hline
\end{tabular}

Material. Saltholm, 12 zooecia.

Holotype. Pl. 22, Fig. 4. Saltholm.

Remarks.

The trivial name refers to the uniserial habit.

This species is anornithoporine except for its very great size, which is more reminiscent of Rhiniopora. Until more material is available the species is, however, placed in Anornithopora.

Dr. BRÜNNICH Nielsen at his mounting of the 12 zooecia from Saltholm marked a tendency towards ramification in this species. It is not possible to decide whether this placing of the zooecia is correct or whether it is chosen e.g. from an aesthetic point of view.

Distribution. Upper Danian: Saltholm, Faxe, Herfølge, and Klintholm.

RHINIOPORA LANG, 1916

\section{Rhiniopora globulosa n.sp.}

Plate 21, Fig. 7.

Diagnosis.

A Rhiniopora species with globular zooecia, the outlines of which are widely oval or subcircular. The frontal shield consists of 18 wide, convex costae. The 
semi-elliptical, transverse orifice is encircled by a rounded, swollen collar formed by a slightly curved apertural bar and a more curved lateral and distal rim, which bears 4-5 oral spines. The apertural bar is provided with two traces of spines.

\section{Description.}

The zoarium is encrusting; the zooecia are separated by narrow, deep depressions.

The zooecia are large, widely oval or subcircular. The gymnocyst rises almost vertically from its base. The slightly convex frontal shield consists of about 18 wide, slightly convex costae, which medianly form an elongated area of fusion. The costae, which are provided with pelmata and perhaps pelmatidia as well, are interconnected by comparatively strong, flat transversal bridges, the intercostal spaces thus being subdivided into rows of pores, each row consisting of 5-7 oval pores. The slightly curved apertural bar together with the rest of the more curved apertural rim forms a rounded, swollen collar round the semi-elliptical, transverse orifice. On the distal margin there are 4-5 traces of spines in the form of knob-shaped processes. Furthermore, the apertural bar has traces of a pair of oral spines placed off the proximal corners of the orifice. In the middle of the apertural bar there is a small knob-shaped elevation.

Ovicells and avicularia have not been observed.

\begin{tabular}{|c|c|c|c|}
\hline \multicolumn{3}{|c|}{ Measurements. } & Range \\
\hline Herfølge. & $\mathrm{Lz}$ & . & $1.09-1.14 \mathrm{~mm}$. \\
\hline & $\mathrm{lz}$ & $\ldots \ldots \ldots \ldots \ldots \ldots \ldots$ & $0.83-1.04-$ \\
\hline & $\mathrm{hr}$ & $\ldots \ldots \ldots \ldots \ldots \ldots \ldots \ldots$ & $0.10-0.13$ \\
\hline & Ir & $\ldots \ldots \ldots \ldots \ldots \ldots \ldots$ & $0.23-0.26$ \\
\hline
\end{tabular}

Material. Herfølge, Bryozoan Limestone - 1 specimen.

Holotype. Pl. 21, Fig. 7. Herfølge, Bryozoan Limestone.

\section{Remarks.}

The trivial name refers to the shape of the zooecium, the vertical, gymnocystal, frontal wall in combination with the convex costal area imparting a globular shape to the zooecium.

The reference of the species to the genus Rhiniopora is due partly to the large size of the zooecia, partly to the comparatively large number of costae. Perhaps $R$. globulosa ought to be referred to Anornithopora, as it bears a habitual resemblance to forms within this genus. Probably a revision of the genera Rhiniopora and Anornithopora will result in an amalgamation of the two genera 
or-perhaps rather-a change of the distribution of the species within the genera.

R. globulosa n.sp. differs from the other Rhiniopora species by its globular shape of the zooecia and by its stratigraphical distribution, as the other species occur in Senonian deposits.

Distribution. Danian: Bryozoan Limestone, Herfølge.

\section{STICHOCADOS MARSSON, 1887}

\section{Stichocados subbrachiata n.sp.}

Plate 22, Fig. 5.

Diagnosis.

Zoarium encrusting. Zooecia oval or rounded-triangular, separated by deep depressions, in part filled in by secondary tissue; frontal shield with 10-14 wide, rounded costae, wide lateral fusions and small, circular, interjacent pores; apertural bar salient, rounded with irregular lobes on the proximal rim. Two oblong-oval traces of lateral oral spines (-or avicularia?-) present. Ovicell large, convex.

\section{Description.}

The zoarium is encrusting, with irregularly arranged, often imbricate zooecia, which are separated by deep depressions, in part filled in by secondary tissue.

The zooecia are oval or rounded-triangular. The frontal shield consists of 10-14 wide, rounded costae. In the outermost part of the costal area the costae are obliquely ascending and separated by large pores. This area is often covered by secondary tissue or by the adjoining zooecia. The rest of the costal area is concave, plane, or slightly convex. In this area the intercostal lateral fusions are arranged in 3-4 concentric rings. The fusions as a rule have the same width as the costae, and the interjacent pores are small and circular. The apertural bar is salient, rounded, with a straight or slightly curved distal rim, while the proximal margin is provided with small irregular lobes, which in part encircle the pores in the distal row of pores. The orifice is semi-elliptical, transverse. Two oblong-oval traces of lateral oral spines (-or avicularia?-) are present.

The ovicells are hyperstomial, large, convex.

Avicularia: See above.

\begin{tabular}{|c|c|c|c|c|}
\hline \multicolumn{3}{|c|}{ Measurements. } & \multirow{2}{*}{$\begin{array}{l}\text { Range } \\
0.62-0.83 \mathrm{~mm} .\end{array}$} & \multirow{2}{*}{$\begin{array}{l}\text { Average } \\
0.71 \mathrm{~mm}\end{array}$} \\
\hline Faxe. & $\mathrm{Lz}$ & $\ldots \ldots \ldots \ldots \ldots \ldots \ldots \ldots$ & & \\
\hline & $\mathrm{lz}$ & $\ldots \ldots \ldots \ldots \ldots \ldots \ldots \ldots$ & $0.36-0.52-$ & $0.47-$ \\
\hline & $\mathrm{hr}$ & $\ldots \ldots \ldots \ldots \ldots \ldots \ldots$ & $0.10-0.13$ & 0.11 \\
\hline & Ir & $\ldots \ldots \ldots \ldots \ldots \ldots \ldots \ldots$ & $0.16-0.21$ & 0.18 \\
\hline
\end{tabular}


Material. Stevns, Bryozoan Limestone - 2 specimens; Faxe -1 specimen.

Holotype. Pl. 22, Fig. 5, Bryozoan Limestone, Faxe.

Remarks.

The trivial name has reference to the habitual similarity of this species to Cribrilina brachiata Levinsen (1925, p. 377, Pl. VIII, Fig. 24) = Stichocados ordinatus LANG (Vorgt, 1930, p. 510, Pl. 30, Fig. 14). S. subbrachiata differs from this species i.a. by having larger zooecia and smaller traces of lateral oral spines; further, there is a deviation in stratigraphical distribution, S. ordinatus being a Senonian form.

Among the rest of species within Stichocados Lang (1922, pp. 174-180), S. verruculosus MARSSON and $S$. compositus LANG are i.a. characterized by having fewer costae (6-7 and about 9, respectively); S. moeniensis LANG is not pictured by LANG, but according to his description this species is provided with a secondary tubular aperture with lateral fenestrae and with small avicularia occurring at the base of the apertural ring.

Distribution. Danian: Denmark: Stevns and Faxe.

\section{SUBORDER ASCOPHORA LEVINSEN, 1909}

This group is characterized by zooecia with a calcified frontal surface, beneath which a compensation sac (compensatrix) serves as hydrostatic system for protusion or withdrawal of the tentacles. This sac generally opens at the proximal border of the aperture, but a more proximally placed special pore-ascopore-may constitute an opening for the sac.

\section{FAMILY PORINIDAE D'ORBIGNY, 1852 PORINA D'ORBIGNY, 1852}

\section{Porina cylindrica Voigt}

Plate 22, Figs. 6-7.

1924 Porina cylindrica Vorgt. Pal. Zeitschr. VI. 1, p. 10, Pl. 1, Fig. 37. 1930 Porina cylindrica Vorgt. Leopoldina. VI, p. 527, Pl. 35, Fig. 19.

\section{Description.}

The zoarium forms slender, smooth, cylindrical, sometimes somewhat compressed stems with dichotomous ramification. The zooecia have no marginal delimitations. The apertures are placed in alternating longitudinal rows. In some colonies there are small, circular or oval pores irregularly spread over the frontal. 
The apertures are variable in form, circular, oblong-oval or sole-shaped with a straight proximal rim. Sometimes the lateral rims in the latter type are introflexed, the aperture thus assuming the form as a key-hole (see e.g. Plate 22, Fig. 6).

Ovicells have not been observed.

Between the two apertures in the same longitudinal row, there is a slightly prominent, oval avicularium with a distinct pivot. Sometimes the avicularium is placed immediately below the proximal margin of the aperture.

\begin{tabular}{|c|c|c|c|}
\hline Measurer & its. & Range & Average \\
\hline $\begin{array}{l}\text { Stevns, } \\
\text { Kagstrup. }\end{array}$ & $\begin{array}{l}\text { Distance between apertures, } \\
\text { vertical } \ldots \ldots \ldots \ldots \ldots \ldots \ldots \ldots\end{array}$ & $0.42-0.57 \mathrm{~mm}$ & $0.50 \mathrm{~mm}$. \\
\hline & horizontal $\ldots \ldots \ldots \ldots \ldots \ldots$ & $0.42-0.47-$ & $0.44-$ \\
\hline & ha $\quad \ldots \ldots \ldots \ldots \ldots \ldots \ldots \ldots \ldots$ & $0.10-0.23$ & $0.16-$ \\
\hline & la $\quad \ldots \ldots \ldots \ldots \ldots \ldots \ldots \ldots \ldots \ldots \ldots \ldots \ldots$ & $0.10-0.13$ & $0.11-$ \\
\hline & Width of zoarium $\ldots \ldots \ldots \ldots$ & $0.88-1.04$ & 0.96 \\
\hline Saltholm. & $\begin{array}{l}\text { Distance between apertures, } \\
\text { vertical } \ldots \ldots \ldots \ldots \ldots \ldots \ldots \ldots\end{array}$ & $0.42-0.52 \mathrm{~mm}$ & $0.48 \mathrm{~mm}$. \\
\hline & horizontal $\ldots \ldots \ldots \ldots \ldots \ldots$ & $0.25-0.31-$ & $0.30-$ \\
\hline & ha $\quad \ldots \ldots \ldots \ldots \ldots \ldots \ldots \ldots$ & $0.10-0.18$ & 0.15 \\
\hline & $\ldots \ldots \ldots \ldots \ldots \ldots \ldots$ & 0.10 & 0.10 \\
\hline & $\ldots \ldots \ldots \ldots \ldots \ldots \ldots$ & 0.08 & 0.08 \\
\hline & 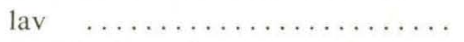 & 0.05 & 0.05 \\
\hline & Width of zoarium $\ldots \ldots \ldots \ldots$ & $0.88-1.04$ & 0.98 \\
\hline Faxe. & $\begin{array}{l}\text { Distance between apertures, } \\
\text { vertical } \ldots \ldots \ldots \ldots \ldots \ldots \ldots \ldots \ldots\end{array}$ & $0.42-0.55 \mathrm{~mm}$. & $0.50 \mathrm{~mm}$. \\
\hline & horizontal $\ldots \ldots \ldots \ldots \ldots \ldots$ & $0.31-0.44-$ & $0.38-$ \\
\hline & 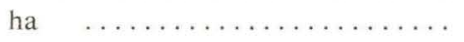 & $0.10-0.16$ & 0.14 \\
\hline & $\ldots \ldots \ldots \ldots \ldots \ldots \ldots$ & $0.10-0.13$ & 0.11 \\
\hline & $\ldots \ldots \ldots \ldots \ldots \ldots \ldots$ & 0.08 & 0.08 \\
\hline & lav $\quad \ldots \ldots \ldots \ldots \ldots \ldots \ldots \ldots \ldots$ & 0.05 & 0.05 \\
\hline & Width of zoarium $\ldots \ldots \ldots \ldots$ & $0.88-1.14$ & 0.98 \\
\hline $\begin{array}{l}\text { Herfølge, } \\
\text { Bryozoan }\end{array}$ & $\begin{array}{l}\text { Distance between apertures, } \\
\text { vertical } \ldots \ldots \ldots \ldots \ldots \ldots \ldots \ldots \ldots\end{array}$ & $0.31-0.52 \mathrm{~mm}$ & $0.43 \mathrm{~mm}$. \\
\hline Limestone. & horizontal $\ldots \ldots \ldots \ldots \ldots \ldots$ & $0.36-0.52-$ & $0.42-$ \\
\hline & ha $\quad \ldots \ldots \ldots \ldots \ldots \ldots \ldots \ldots \ldots$ & $0.18-0.26$ & 0.22 \\
\hline & $\ldots \ldots \ldots \ldots \ldots \ldots \ldots \ldots$ & $0.10-0.18$ & 0.13 \\
\hline & $\ldots \ldots \ldots \ldots \ldots \ldots \ldots \ldots$ & $0.08-0.13$ & 0.09 \\
\hline & lav $\ldots \ldots \ldots \ldots \ldots \ldots \ldots \ldots \ldots$ & 0.08 & 0.08 \\
\hline & Width of zoarium $\ldots \ldots \ldots \ldots$ & $1.04-1.09$ & 1.05 \\
\hline
\end{tabular}

\section{Material.}

Stevns, Bryozoan Limestone - 38 specimens; Kagstrup - 2 specimens; Thorslunde - 2 specimens; Faxe -7 specimens; Faxe I - 3 specimens; Faxe II 41 specimens; Saltholm, Bryozoan Limestone - 1 specimen; Saltholm 160 specimens; Herfølge, Bryozoan Limestone - 151 specimens; Herfølge, Calcarenite - 1 specimen. 


\section{Remarks.}

As mentioned in the description of Frurionella daniensis n.sp. (p. 107), F. daniensis, Porina cylindrica, and Pachythecella anhaltina have so many morphological features in common that the mutual relationship between these species deserves more detailed investigations.

\section{Distribution.}

Senonian: Germany: Erratic blocks at Bräsen (Anhalt).

Danian: Germany: Erratic blocks at Köthen and Bräsen (Anhalt). Denmark: Stevns, Kagstrup, Thorslunde, Faxe, Saltholm, Herfølge, and Klintholm, i.e. all Danian zones.

\section{Porina salebrosa Marsson}

Plate 23, Figs. 1-4.

1887 Porina salebrosa Marsson. Pal. Abh. IV. 1, p. 86, Pl. VIII, Fig. 10.

1913 Acropora salebrosa Marsson. Canu. Bull. Soc. Géol. France. 4e Ser. XIII, p. 137, Fig. 3.

1925 Porina salebrosa Marsson. Levinsen. Vidensk. Selsk. Skr. 8. Ser. VII. 3, p. 407, P1. VII, Fig. 84.

1925 Porina salebrosa Marsson var. faxensis. LeVInsen. Vidensk. Selsk. Skr. 8. Ser. VII. 3, p. 407.

1930 Acropora salebrosa Marsson. Voigt. Leopoldina. VI, p. 519, Pl. 33, Fig. 17.

\section{Description.}

Zoarium and Zooecia: Free, cylindrical or compressed, dichotomous stems consisting of zooecia without marginal delimitations. The surface of the colony is unevenly undulate, which to some degree is due to alternating longitudinal rows of dome- or wart-shaped processes, on the top of which the circular apertures are placed. Unevenly spread over the surface of the colony there are pores of varying shape and size. Between two apertures in the same longitudinal row there is a circular ascopore which is larger than the other pores.

The ovicells are deeply immersed, invisible exteriorly (see CANU, 1913, p. 137, Fig. 3).

In this species there are two types of avicularia: small, oval ones and large, rounded-triangular, tapering ones. The small avicularia as a rule appear in large numbers, partly in whorls, consisting of 3-7 specimens, round the apertures on top of the domes, partly unevenly distributed over the surface of the colony. The large avicularia as a rule are steeply ascending towards the tapering anterior end, which often is bent like a spout. They frequently occur on the slope of the domes with the pointed anterior end wedged in between the small, verticillate avicularia. In other cases they appear irregularly scattered over the surface of the colony without any immediate connexion with the apertures. $13 *$ 
Sometimes the number of avicularia is larger near the rim of the zoarium than on the rest of the colony. In the small, oval avicularia the pivot is found immediately behind the middle of the avicularium, while in the large, triangular avicularia it is situated near the posterior margin of the opesium.

Measurements.

Herfølge, Diameter of aperture . .

Faxe.

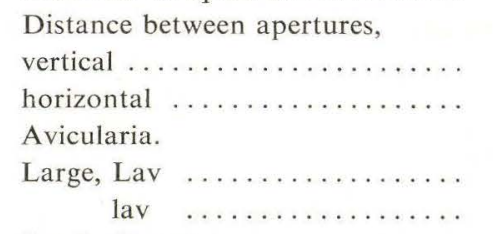

\begin{tabular}{|c|c|c|}
\hline Range & & Average \\
\hline 0.10 & $\mathrm{~mm}$. & \\
\hline $0.42-0.52$ & - & $0.46 \mathrm{mn}$ \\
\hline $0.31-0.42$ & - & $0.37-$ \\
\hline $0.26-0.31$ & - & $0.30-$ \\
\hline $0.10-0.13$ & - & $0.11-$ \\
\hline 0.05 & - & \\
\hline $1.14-1.87$ & - & $1.44-$ \\
\hline
\end{tabular}

Saltholm. Distance between apertures,

vertical ......................................

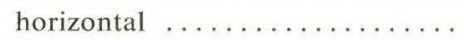

$\begin{array}{ll}0.52-0.62 \mathrm{~mm} . & 0.56 \mathrm{~mm} . \\ 0.26-0.47- & 0.39- \\ 0.08-0.10- & 0.09- \\ 0.88-1.46- & 1.26- \\ 0.10- & \end{array}$

Stevns, Aperture, diameter $\ldots \ldots \ldots \ldots \ldots$
Width of zoarium $\ldots \ldots \ldots \ldots$

$0.10 \mathrm{~mm}$.

$0.10 \mathrm{~mm}$.

Kagstrup. Distance between apertures,

\begin{tabular}{|c|c|c|c|c|}
\hline vert & $0.47-0.52$ & - & 0.51 & - \\
\hline horizontal ... & $0.36-0.42$ & - & 0.39 & - \\
\hline \multicolumn{5}{|l|}{ Avicularia. } \\
\hline Large, Lav & 0.21 & - & & \\
\hline & 0.10 & - & & \\
\hline Width of zoarium $\ldots \ldots \ldots \ldots$ & $0.88-1.35$ & - & 1.07 & - \\
\hline Diameter of aperture $\ldots . . . \ldots \ldots$ & 0.10 & $\mathrm{~mm}$. & 0.10 & $\mathrm{~mm}$. \\
\hline $\begin{array}{l}\text { Distance between apertures, } \\
\text { vertical } \ldots \ldots \ldots \ldots \ldots \ldots \ldots\end{array}$ & $0.39-0.57$ & - & 0.45 & - \\
\hline $\begin{array}{l}\text { horizontal } \ldots \ldots \ldots \ldots \ldots \ldots \ldots \\
\text { Avicularia. }\end{array}$ & \multicolumn{3}{|c|}{ Avicularia. } & - \\
\hline Large, Lav & $0.23-0.26$ & - & 0.25 & - \\
\hline lav $\ldots . .$. & $0.10-0.13$ & - & 0.11 & - \\
\hline Width of zoarium & $1.20-2.08$ & - & 1.53 & \\
\hline
\end{tabular}

Material.

Stevns, Bryozoan Limestone - 102 specimens; Kagstrup - 37 specimens; Thorslunde - 21 specimens; Faxe - 255 specimens; Faxe I - 61 specimens; Faxe II - 520 specimens; Faxe XI - 52 specimens; Saltholm, Bryozoan Limestone - 18 specimens; Saltholm - 105 specimens; the South Harbour of Copenhagen - 2 specimens; Herfølge, Bryozoan Limestone - 54 specimens.

\section{Remarks.}

LEVINSEN (1925, p. 407) established a variety, faxensis, which was said to be characteristic of the Danian and marked by having greatly prominent "aper- 
tural domes" and few large avicularia. It has not, however, been possible to maintain var. faxensis, as there is a smooth transition between this and the main species. The extremes of the variation of the species are formed by two types, one of which is characterized by having numerous, dense pores and many large, obliquely placed avicularia, but few and little prominent domes bearing apertures. The other type forms slender, smooth stems with greatly prominent domes. Large avicularia seem to be missing from this type.

\section{Distribution.}

Senonian: Germany: Rügen and in erratic blocks at Köthen. Denmark: Møn, Ålborg, Hillerslev, and Stevns.

Danian: Stevns, Kagstrup, Thorslunde, Faxe, Saltholm, the South Harbour of Copenhagen, Herfølge, Klintholm, and Karleby Klint.

\section{BEISSELINA CANU, 1913}

\section{Beisselina nobilis (Levinsen)}

Plate 23, Figs. 5-7.

1925 Monoporella nobilis Levinsen. Vidensk. Selsk. Skr. 8. Ser. VIII. 3, p. 403, PI. VII, Fig. 81 .

1930 Beisselina nobilis Levinsen. Voigt. Leopoldina. VI, p. 525, P1. 33, Figs. 21-22.

\section{Description.}

The zoarium forms free, bilamellar or, more rarely, cylindrical stems with dichotomous ramification. The zooecia are without marginal delimitations. The apertures are arranged in two systems of oblique rows intersecting each other at acute angles.

Zooecia and avicularia: As regards the shape of the apertures and the appearance and position of the avicularia, it is possible to distinguish two types in this species. One type (Pl. 23, Fig. 7) is characterized by having a large, circular or elliptical aperture, a correspondingly large or larger distal avicularium and a proximal avicularian area with two pairs of avicularia. The distal, sometimes obliquely ascending avicularium has farthest out a narrow, rounded rim surrounding a circular or elliptical opesium with a plane, crescent-shaped area behind it. The avicularium has a slender pivot in the distal half. A corresponding narrow frame encircles the aperture and the proximal avicularian area, which is rounded-triangular or trapezohedral and slightly embedded and consists of two pairs of oval avicularia, of which the anterior pair is the larger one. Both pairs of avicularia are oblique, with the anterior part turned towards the median line of the area. In the triangular avicularian areas there is proximally a narrow, transverse pore. 
In the other type (Pl. 23, Fig. 5) the aperture is generally elliptical, transverse. It is surrounded by a broad, rounded frame, which distally encircles a small, elliptical avicularium. The proximal avicularian area also in this form consists of two pairs of avicularia, of which the foremost ones, which are oblong-oval or cleft-shaped are oriented so that the anterior end points upwards and outwards, i.e. away from the median line of the area, while the anterior end of the hindmost, oval avicularia is turned towards this line.

Laterally to the distal rim of the aperture there is in both types a pair of oval avicularia. The two types are connected through transitional forms, which show different combinations regarding the shape of the aperture and the apertural frame, and regarding appearance and position of the avicularia. The majority of the specimens examined have an elliptical transverse aperture and in that respect are similar to Type Two.

Ovicells have not been observed.

\section{Measurements.}

\begin{tabular}{|c|c|c|c|c|c|}
\hline Type 1. & & & Range & & Average \\
\hline Herfølge, & Aperture, ha $\ldots \ldots \ldots$ & $\ldots \ldots$ & $0.10-0.21$ & $\mathrm{~mm}$. & $0.12 \mathrm{~mm}$. \\
\hline Thorslunde. & la $\quad \ldots \ldots \ldots$ & $\ldots \ldots$ & $0.13-0.18$ & - & $0.15-$ \\
\hline & Distal avicularium, Lav & $\ldots \ldots$ & $0.13-0.29$ & - & 0.19 \\
\hline & lav & $\ldots \ldots$ & $0.10-0.26$ & - & 0.17 \\
\hline ype 2 and & transitional forms. & & & & \\
\hline lerfølge, & Aperture, ha $\quad \ldots \ldots \ldots$ & $\ldots \ldots$ & $0.08-0.13$ & $\mathrm{~mm}$. & $0.10 \mathrm{~mm}$. \\
\hline Faxe, & la $\quad \ldots \ldots \ldots$ & $\ldots \ldots$ & $0.10-0.16$ & - & $0.13-$ \\
\hline Saltholm. & Distal avicularium, Lav & $\ldots \ldots$ & 0.10 & - & 0.10 \\
\hline & lav & $\ldots \ldots$ & 0.08 & - & 0.08 \\
\hline idth of $\mathrm{z}$ & aria. & & & & \\
\hline lerfølge. & $\ldots \ldots \ldots$ & $\ldots \ldots$ & $1.40-2.60$ & $\mathrm{~mm}$. & $1.88 \mathrm{~mm}$. \\
\hline Faxe. & $\ldots \ldots \ldots \ldots \ldots$ & $\ldots \ldots$ & $1.04-2.08$ & - & $1.46-$ \\
\hline altholm. & Bryozoan Limestone. & $\ldots \ldots \ldots$ & $0.94-1.87$ & - & 1.40 \\
\hline & Sandy-limestone ...... & $\ldots \ldots \ldots$ & $0.88-1.40$ & - & 1.09 \\
\hline
\end{tabular}

\section{Material.}

Thorslunde - 12 specimens; Faxe - 7 specimens; Faxe I - 1 specimen; Saltholm, Bryozoan Limestone - 3 specimens; Saltholm - 21 specimens; Copenhagen, the South Harbour - 2 specimens; Herfølge, Bryozoan Limestone 236 specimens.

\section{Lectotype.}

The best preserved specimen in LEVINSEN's collection in the Zoological Museum of Copenhagen has been selected as the type. Type locality: Faxe.

\section{Distribution.}

Senonian: Møn? (Levinsen, p. 404).

Upper Danian: Thorslunde, Faxe, Saltholm, Copenhagen, Herfølge, and Klintholm. 
Unfortunately LEVINSEN's specimen from Møn is missing from his collection, so that a checking of the determination of the species is not possible.

\section{Beisselina celleporoides (Voigt)}

Plate 24, Figs. 3-5.

1930 Kleidionella celleporoides Vorgt. Leopoldina. VI, p. 529, Pl. 37, Fig. 4.

1959 Beisselina celleporoides (VorGT). Bull. Soc. Geol. France, 7e sér. I, p. 701, Pl. XXXI, Figs. 10-12.

\section{Description.}

Zoarium and zooecia: The colony consists of free, bilamellar stems with rounded margins and elliptical cross-sections. In this species occur two generations (?) of zooecia. The primary zooecia are arranged in two systems of oblique rows intersecting at acute angles. The zooecia have no marginal delimitations. The circular aperture is placed on top of a slightly convex dome and surrounded by a narrow, slightly prominent rim. Round the dome there is a ring of small, circular pores. At this stage the species bears a great resemblance to other species within the genus Beisselina. The original structure is gradually veiled by a cover of irregular, celleporoid zooecia, which project in various places on the surface of the colony. These secondary zooecia as a rule are oval, globular, smooth. The aperture is terminal, rounded-quadrangular, and behind it there is a circular or oval, transverse pore.

Ovicells have not been observed.

In the rings of pores round the apertures there are sometimes small, oval avicularia. Such may also appear on the sides of the domes. On the narrow, rounded zoarial margins there are long, sole-shaped avicularia.

\section{Measurements.}

Range Average

Thorslunde, Distance between apertures

Faxe, in first generation.

Saltholm, vertical .............

Herfølge.

horizontal

Aperture, 1. gen. diam. ........

2. - ha $\ldots \ldots \ldots$.

2. - la $\quad \ldots \ldots \ldots$.

Avicularium, Lav ............

lav $\ldots \ldots \ldots \ldots$.

Width of zoarium.

Faxe.

Saltholm.

Herfølge.

$\ldots \ldots \ldots \ldots$
$\ldots \ldots \ldots \ldots$
Bryozoan Limestone $\ldots \ldots \ldots \ldots$
Calcarenite $\ldots \ldots \ldots \ldots \ldots$

$\begin{array}{lll}0.47-0.52 \mathrm{~mm} . & 0.50 \mathrm{~mm} . \\ 0.31-0.42- & 0.37- \\ 0.10-0.13- & 0.11- \\ 0.10 & - & 0.10- \\ 0.10-0.13- & 0.12- \\ 0.10 & - & \end{array}$

$0.08-$
$1.56-2.87 \mathrm{~mm}$.

$2.18 \mathrm{~mm}$.

$1.67-3.64-2.50-$

$1.82-3.85$ - 2.76 -

$1.61-3.12-2.52-$

$1.76-4.60-2.68-$ 
Material.

Thorslunde - 137 specimens; Faxe - 50 specimens; Faxe I - 1 specimen; Faxe II - 3 specimens; Faxe XI - 7 specimens; Saltholm - 44 specimens; Herfølge, Bryozoan Limestone - 204 specimens; Herfølge, Calcarenite - 29 specimens; Klintholm - 1 specimen.

\section{Distribution}

Danian: Germany: Erratic blocks at Köthen. Denmark: Thorslunde, Faxe, Saltholm, Herfølge, and Klintholm. The species seems to occur only in Upper Danian.

\section{BEISSELINOPSIS VOIGT, 1951}

\section{Beisselinopsis tubulifera n.sp.}

Plate 24, Figs. 1-2.

Diagnosis.

A Beisselinopsis species with a bilamellar stem and a tapering, cylindrical basal part. Tubular peristomies in alternating longitudinal rows alternate with pores of varying shape and size. At the foot of the peristomie or on the sides of this there are 2-5 oval avicularia.

\section{Description .}

The zoarium has free, bilamellar stems with a tapering, cylindrical basal part. The zooecia have no marginal delimitations. The apertures (peristomices) are placed in alternating longitudinal rows. Between these there is an irregular network formed of pores of varying shape and size. (Tremopores according to VoIGT, 1951, p. 66).

Zooecia: The peristomices are circular and placed on top of tubular, thinwalled peristomies. On a few fragments the peristomies are but little prominent, collar-shaped, thick-walled.

Ovicells have not been observed.

The avicularia occur in a number of 2-5 round the base of the peristomie or oblique ascending on the sides of this. As a rule they are oval, with a slender pivot. On the colonies which bear collar-shaped peristomies, two proximal avicularia are frequently particularly prominent. They are obliquely ascending and as if dug into the wall of the peristomie.

Measurements.

\begin{tabular}{|c|c|c|c|c|}
\hline \multirow{4}{*}{$\begin{array}{l}\text { Faxe, } \\
\text { Herfølge. }\end{array}$} & & & Range & Average \\
\hline & ha & & $0.10-0.16 \mathrm{~mm}$. & $0.13 \mathrm{~mm}$ \\
\hline & la & $\ldots \ldots \ldots \ldots \ldots \ldots \ldots \ldots$ & $0.13-0.16-$ & $0.15-$ \\
\hline & Wic & $\mathrm{h}$ of zoarium $\ldots \ldots \ldots \ldots$ & $0.88-192$ & 1.38 \\
\hline
\end{tabular}


Material.

Faxe - 19 specimens; Herfølge, Bryozoan Limestone - 2 specimens.

Holotype. Pl. 24, Fig. 1. Faxe, Bryozoan Limestone.

Remarks.

The trivial name refers to the tubular peristomies.

B. tubulifera differs from the other Beisselinopsis species by having (1) tubular peristomies, (2) an irregular network of pores, and (3) 2-5 avicularia at the base of the peristomie or on the sides of it.

\section{Distribution.}

Danian: Faxe, Herfølge, and Klintholm. Thus the species seems to be attached to the Upper Danian.

\section{Beisselinopsis oblita (Kade) \\ Plate 24, Fig. 6.}

1852 Eschara oblita KADE. Die losen Versteinerungen des Schan zenberges bei Meseritz, p. 29, Pl. 1, Fig. 18.

1925 Porina flabellata (D'Orbigny) [partim]. Levinsen. Vidensk. Selsk. Skr. 8. Ser. VII. 3, p. 405, Pl. VII, Fig. 83 a-c.

1930 Beisselina flabellata (D’ORBIGNY) [partim]. VoIgt, Leopoldina. VI, p. 525, Pl. 34, Fig. 11.

1959 Beisselinopsis oblita (KADE). Voigt. Geologie. Beiheft 25, p. 11.

\section{Description.}

The zoarium consists of free, bilamellar, flabelliform stems with a tapering basal part. The zooecia have no marginal delimitations. The apertures are arranged in regular quincunx and are separated by narrow diagonal furrows pitted with large circular or oval pores, as a rule 2 to 3 off each aperture.

The circular or subcircular apertures are encircled by a rounded, slightly prominent peristome.

Ovicells have not been observed.

In the system of pores in the diagonal furrows there are a few small, oval avicularia with a central pivot.

\begin{tabular}{|c|c|c|c|}
\hline \multicolumn{2}{|c|}{ Measurements. } & Range & Average \\
\hline Kagstrup, & Distance between apertures, & & \\
\hline Stevns. & vertical $\ldots \ldots \ldots \ldots \ldots \ldots$ & $0.31-0.52 \mathrm{~mm}$ & $0.45 \mathrm{~mm}$. \\
\hline & horizontal $\ldots \ldots \ldots \ldots$. & $0.34-0.52-$ & $0.39-$ \\
\hline & ha $\quad \ldots \ldots \ldots \ldots \ldots \ldots \ldots \ldots$ & $0.10-0.18$ & 0.15 \\
\hline & $\ldots \ldots \ldots \ldots \ldots \ldots \ldots$ & $0.13-0.18$ & 0.15 \\
\hline
\end{tabular}




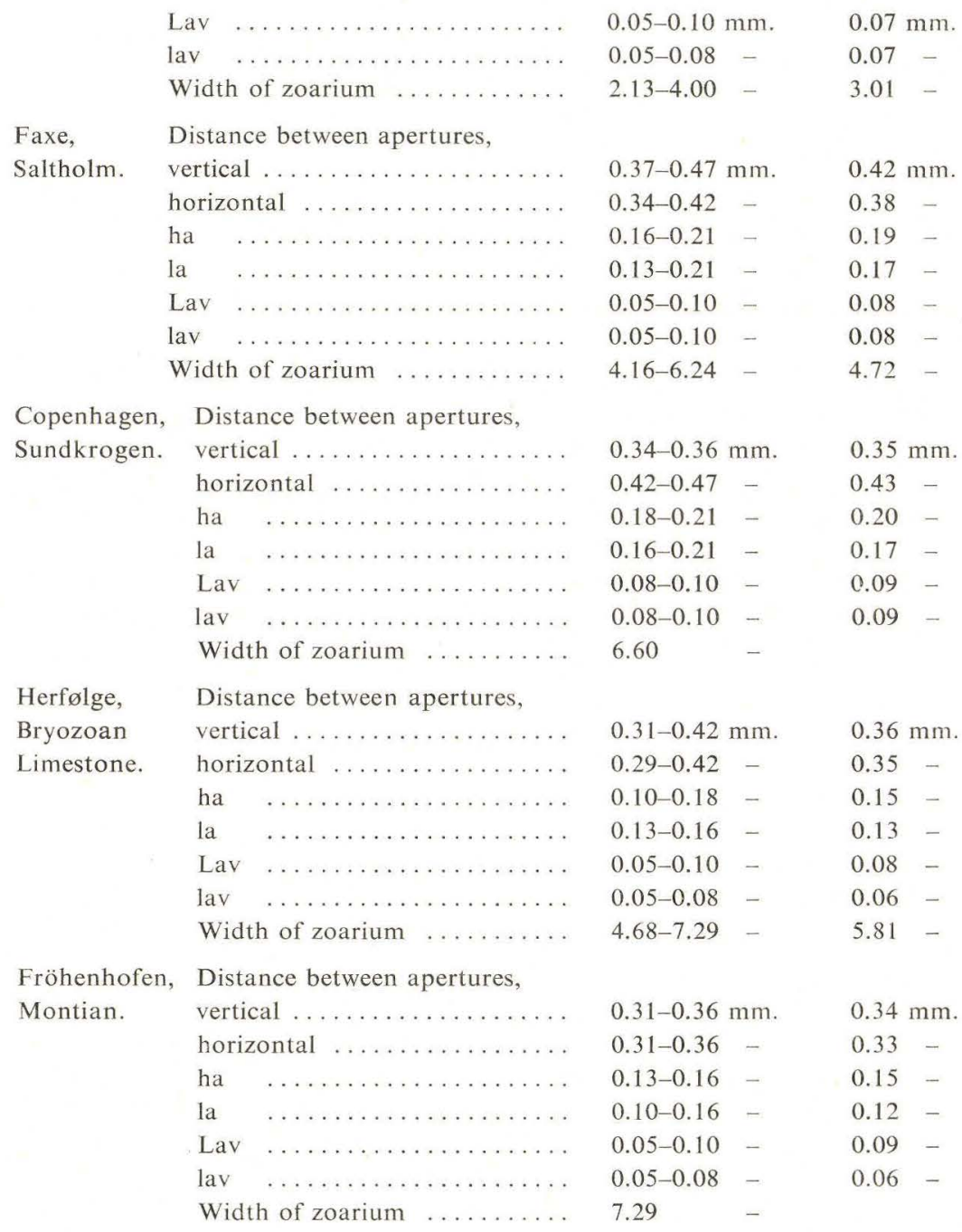

\section{Material.}

Stevns, Bryozoan Limestone - 12 specimens; Kagstrup - 6 specimens; Thorslunde - 21 specimens; Faxe - 170 specimens; Faxe XI - 3 specimens; Saltholm 29 specimens; Copenhagen, the South. Harbour - 7 specimens; Copenhagen, Sundkrogen - 81 specimens; Herfølge, Bryozoan Limestone - 92 specimens; Herfølge, Calcarenite -5 specimens.

\section{Remarks.}

The Montian specimen from the Albert Canal at Fröhenhofen in Belgium has kindly been submitted to me by Professor VoIGT.

VoIGT has shown $(1959$, p. 11) that the specific name of Beisselinopsis 
flabellata D'ORBIGNY actually covers three species, viz. Beisselinopsis flabellata (D'Orbigny) from the French Upper Maastrichtian, Beisselinopsis marginata (v. Hagenow), which occurs in the Senonian Chalk on Rügen, and Beisselinopsis oblita (KADE) from deposits belonging to the Danian and Montian. It is probable that LEvinSEN's material from Møn stated to belong to B. flabellata actually belongs to $B$. marginata, but unfortunately the fragments in question are missing from his collection. There does not seem to be any doubt that his description and picture are based on Danian colonies of $B$. oblita.

\section{Distribution.}

Danian: Stevns, Kagstrup, Thorslunde, Faxe, Saltholm, Copenhagen, Herfølge, and Klintholm.

Montian: Belgium.

PACHYTHECELLA BASSLER, 1934

\section{Pachythecella anhaltina (Voigt)}

Plate 25, Figs. 1-3.

1930 Pachytheca anhaltina VoIGT. Leopoldina. VI, p. 521, Pl. 33, Fig. 12.

\section{Description.}

The zoarium forms free, cylindrical or compressed, bilamellar, sometimes flabelliform stems with dichotomous ramification. The zooecia have no marginal delimitation. The apertures are arranged in alternating longitudinal rows. In the flabelliform colonies the arrangement is rather irregular. Between the apertures the cylindrical and bilamellar stems are irregularly pitted with comparatively few, small circular pores. In the flabelliform colonies the number of pores is increased, and besides the cylindrical pores there are large, oblongoval perforations.

The apertures are ovi- or pyriform with a tapering, proximal part, which in the cylindrical and bilamellar stems appears as an unsymmetrical, slit-shaped cut. The aperture is encircled by a rounded, prominent peristome.

Ovicells have not been observed.

In the cylindrical and bilamellar stems there is immediately beside the slitshaped cut a circular or oval avicularium, the opesium of which is sometimes turned towards the slit. In the majority of the flabelliform fragments the avicularium is withdrawn from the apertural area and placed at the base of the peristome or between the apertures.

\begin{tabular}{|c|c|c|c|c|}
\hline \multicolumn{3}{|c|}{ Measurements. } & Range & Average \\
\hline Stevns, & Aperture, ha & $\ldots \ldots \ldots \ldots \ldots$ & $0.13-0.18 \mathrm{~mm}$. & $0.16 \mathrm{~mm}$. \\
\hline $\begin{array}{l}\text { Bryozoan } \\
\text { Limestone. }\end{array}$ & la & $\cdots \cdots \cdots \cdots \cdots \cdots$ & $0.10-0.18-$ & $0.16-$ \\
\hline
\end{tabular}




\begin{tabular}{|c|c|c|c|}
\hline & $\begin{array}{l}\text { Avicularium, diameter } \ldots \ldots \ldots \\
\text { Width of zoarium } \ldots \ldots \ldots \ldots\end{array}$ & $\begin{array}{l}0.05-0.10 \mathrm{~mm} . \\
0.73-1.56-\end{array}$ & $\begin{array}{l}0.08 \mathrm{~mm} . \\
1.09-\end{array}$ \\
\hline Faxe. & $\begin{array}{l}\text { Aperture, ha } \ldots \ldots \ldots \ldots \ldots \\
\text { la } \ldots \ldots \ldots \ldots \ldots \\
\text { Avicularium, diameter } \ldots \ldots \ldots \\
\text { Width of zoarium } \ldots \ldots \ldots \ldots\end{array}$ & $\begin{array}{l}0.13-0.26 \mathrm{~mm} . \\
0.10-0.20- \\
0.08-0.10- \\
1.04-2.60-\end{array}$ & $\begin{array}{l}0.20 \mathrm{~mm} . \\
0.15- \\
0.09- \\
1.66-\end{array}$ \\
\hline $\begin{array}{l}\text { Herfølge, } \\
\text { Bryozoan } \\
\text { Limestone. }\end{array}$ & $\begin{array}{l}\text { Aperture, ha } \ldots \ldots \ldots \ldots \ldots \\
\text { la } \ldots \ldots \ldots \ldots \ldots \\
\text { Avicularium, diameter } \ldots \ldots \ldots \ldots \\
\text { Width of zoarium } \ldots \ldots \ldots \ldots \ldots\end{array}$ & $\begin{array}{l}0.13-0.18 \mathrm{~mm} . \\
0.13-0.18- \\
0.05-0.13- \\
1.66-5.62-\end{array}$ & $\begin{array}{l}0.15 \mathrm{~mm} . \\
0.16- \\
0.08- \\
2.55-\end{array}$ \\
\hline
\end{tabular}

\section{Material.}

Stevns, Bryozoan Limestone - 10 specimens; Kagstrup - 1 specimen; Thorslunde -6 specimens; Faxe - 103 specimens; Faxe I - 7 specimens; Faxe II 1 specimen; Faxe XI - 3 specimens; Saltholm - 1 specimen; Herfølge, Bryozoan Limestone -67 specimens.

\section{Remarks.}

BASSLER (1934, p. 408) has introduced the generic name of Pachythecella to replace Pachytheca CANU, 1913, as the latter name proved to have been preoccupied by SCHLÜTER, 1885.

All the fragments from Stevns and Kagstrup have cylindrical stems, whereas the material from Faxe, Thorslunde, and Saltholm has either cylindrical colonies or bilamellar zoaria with parallel lateral margins. The majority of the Herfølge fragments have flabelliform zoaria while the remaining ones have a bilamellar habit.

\section{Distribution.}

Danian: Germany: Erratic blocks at Köthen. Denmark: Stevns, Kagstrup, Thorslunde, Faxe, Saltholm, Herfølge, and Klintholm.

\section{Pachythecella filiformis (d'Orbigny)}

Plate 25, Fig. 4.

1852 Porina filiformis D'Orbigny. Pai. Franç. Terr. Crét. V, p. 438, PL 714, Figs. 11-13. 1865 ? Entalophora Bosqueti BeIssel. Nat. Verh. holl. Maatsch. Wet. Ser. 2. Vol. XXII, p. 78, Pl. IX, Figs. 107-115.

1887 Acropora filiformis d'Orbigny. Marsson. Pal. Abh. IV. 1, p. 83, Pl. VIII, Fig. 2.

1900 Porina filiformis D’Orbigny. Canu. Bull. Soc. Géol. France. 3. Ser. XXVIII, p. 461.

1913 Pachytheca filiformis D'Orbigny. Canu. Bull. Soc. Géol. France. 4. Ser. XIII, p. 142, Fig. 8 .

1920 Pachytheca filiformis D'Orbigny. Canu. Bull. Soc. Géol. France. 4. Ser. XIX, p. 199, Pl. V, Fig. 13.

1925 Porina filiformis d'Orbigny. Levinsen. Vidensk. Selsk. Skr. 8. Ser. Vil. 3, p. 408. 
1925 Monoporella dubiosa LeVInsen. Vidensk. Selsk. Skr. 8. Ser. VII. 3, p. 403, Pl. VIII, Fig. 11.

1925 Monoporella Bosqueti (Beissel). Levinsen. Vidensk. Selsk. Skr. 8. Ser. VII. 3, p. 403. 1930 Pachytheca filiformis D'Orbigny. Voigt. Leopoldina. VI, p. 520, Pl. 33, Figs. 4-7.

\section{Description .}

The zoarium consists of free, cylindrical stems with dichotomous ramification. The zooecia have no marginal delimitations. The apertures are placed in alternating longitudinal rows. Irregularly scattered over the surface of the colony there are small, circular pores.

The apertures are circular or elliptical, transverse; they are placed on top of short, broad, cylindrical, or conical peristomies.

Ovicells have not been observed.

Halfway between two apertures in the same longitudinal rows there is a circular pore, which, as a rule, is encircled by a narrow, elevated rim. This pore originally was considered an ascopore, but VoIGT's investigations (1930, p. 520) have made it clear that it is an avicularium. According to CANU (1913, p. 143 , and 1920 , p. 200) there are two small avicularia immediately above the distal corners of the aperture. Such avicularia have not been found in my material. Nor has Voigt been able to demonstrate their presence (VOIGT, 1930, p. 520).

\begin{tabular}{|c|c|c|c|}
\hline \multicolumn{2}{|c|}{ 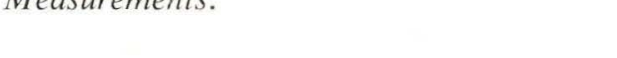 } & Range & Average \\
\hline $\begin{array}{l}\text { Faxe, } \\
\text { Thorslunde, }\end{array}$ & $\begin{array}{l}\text { Distance between apertures, } \\
\text { vertical } \ldots \ldots \ldots \ldots \ldots \ldots \ldots\end{array}$ & $0.36-0.62 \mathrm{~mm}$. & $0.51 \mathrm{~mm}$ \\
\hline Saltholm. & horizontal $\ldots \ldots \ldots \ldots \ldots \ldots$ & $0.52-0.78-$ & $0.60-$ \\
\hline & Aperture, ha $\ldots \ldots \ldots \ldots \ldots$ & $0.10-0.16$ & 0.13 \\
\hline & $\ldots \ldots \ldots \ldots \ldots$ & $0.10-0.21$ & 0.15 \\
\hline & Width of zoarium & $0.88-1.67-$ & 1.20 \\
\hline
\end{tabular}

\section{Material.}

Thorslunde - 19 specimens; Faxe - 12 specimens; Saltholm - 4 specimens.

\section{Remarks.}

LeVInSEN in his description of the avicularia in Porina filiformis (1925, p. 408) states that these "are fastened to the prominent part of the zooecia which bears apertures, and their anterior end extends right to the free rim of the aperture." This characterization suggests that his evaluation is based on a mixed material of $P$. filiformis and $P$. lundgreni, the position of the avicularia indicated being typical of the latter species. This assertion cannot, however, be proved, as in LEVINSEN's collection in the Zoological Museum of Copenhagen, there are only two fragments from Møn under the name of $P$. filiformis and these specimens actually belong to this species. 


\section{Distribution.}

Senonian: Germany: Rügen; erratic blocks. Holland: Aachen. France: Royan, Saint Palais, and Saint-Goudens. Denmark: Møn.

Upper Danian: Kagstrup, Thorslunde, Faxe, Saltholm, Herfølge, and Klintholm.

\section{Pachythecella lundgreni (Pergens and Meunier)}

Plate 25, Figs. 5-6.

1886 Foveolaria Lundgreni Pergens and Meunier. Ann. Soc. Malac. Belg. XXI, p. 242, Pl. XI, Fig. 3.

1892 Foveolaria Lundgreni Pergens and Meunier. Hennig. Lunds Univ. Årsskr. XXVIII, p. 37.

1925 Monoporella Lundgreni (Pergens and Meunier). Levinsen. Vidensk. Selsk. Skr. 8. Ser. VII. 3, p. 400, Text-fig. 27.

1930 Pachytheca lundgreni (Pergens and Meunier). Voigt. Leopoldina. VI, p. 520, Pl. 33, Figs. 8-9.

\section{Description .}

The zoarium forms free, cylindrical, smooth stems with dichotomous ramification. The zooecia show no marginal delimitations. The apertures are arranged in alternating longitudinal rows.

The apertures are bean-shaped, transverse, with a prominent, convex lower lip.

Ovicells have not been observed.

Immediately below the aperture there is a prominent, short, compressed, tubular avicularium with an oblong-oval opesium.

\section{Measurements.}

\begin{tabular}{|c|c|c|c|}
\hline & & Range & Average \\
\hline Stevns, Faxe, & ha & $0.10-0.21 \mathrm{~mm}$. & $0.15 \mathrm{~mm}$. \\
\hline Saltholm, & $\ldots \ldots \ldots \ldots \ldots \ldots$ & $0.13-0.26-$ & $0.20-$ \\
\hline Svanemøllen, & Lav $\ldots \ldots \ldots \ldots \ldots \ldots$ & $0.08-0.10$ & $0.10-$ \\
\hline Herfølge. & lav $\ldots \ldots \ldots \ldots \ldots \ldots$ & $0.05-0.08$ & 0.07 \\
\hline \multicolumn{4}{|l|}{ Width of zoaria. } \\
\hline Stevns, Herfølge. & . & $0.57-1.30 \mathrm{~mm}$ & $0.81 \mathrm{~mm}$. \\
\hline Faxe. & . & $0.73-1.14-$ & $0.94-$ \\
\hline Saltholm. & $\ldots \ldots \ldots \ldots \ldots \ldots$ & $0.73-1.30$ & 0.99 \\
\hline Svanemøllen. & $\ldots \ldots \ldots \ldots \ldots \ldots \ldots \ldots \ldots$ & $0.68-1.14$ & 0.88 \\
\hline
\end{tabular}

\section{Material.}

Stevns, Bryozoan Limestone - 58 specimens; Kagstrup - 3 specimens; Thorslunde -17 specimens; Faxe - 54 specimens; Faxe II - 2 specimens; Faxe XI 2 specimens; Saltholm, Bryozoan Limestone - 3 specimens; Saltholm - 14 specimens; Copenhagen, the South Harbour - 97 specimens; Copenhagen, 
Svanemøllen - 37 specimens; Copenhagen, Sundkrogen - 12 specimens; Herfølge, Bryozoan Limestone - 89 specimens; Herfølge, Calcarenite - 5 specimens.

\section{Distribution.}

Danian: Germany: Erratic blocks in Anhalt. Sweden: Limhamn. Denmark: Stevns, Kagstrup, Thorslunde, Faxe, Saltholm, Copenhagen, Herfølge, and Klintholm.

\section{COLUMNOTHECA MARSSON, 1887}

\section{Columnotheca cribrosa Marsson}

Plate 24, Fig. 7.

1840 Ceriopora? echinata v. Hagenow. N. Jahrb. f. Min., p. 647.

1852 ? Eschara cricoporacea (v. Hagenow). KADE. Die losen Versteinerungen des Schanzenberges bei Meseritz, p. 29.

1885 Pustulipora circulata Quenstedt. Petrefaktenkunde Deutschlands. Bd. VI. Korallen, PI. 155, Fig. $17 \mathrm{c}$.

1886 Spiropora vertebralis Pergens and Meunier [non StoliczKa]. Ann. Soc. Malac. Belg. XXI, p. 210, Pl. XI, Fig. 2.

1887 Columnotheca cribrosa Marsson. Pal. Abl. IV, 1, p. 82, Pl. VIII, Fig. 1.

1892 Columnotheca cribrosa Marsson. Hennig. Lunds Univ. Årsskr. XXVIII, p. 42.

1894 ? Spiropora vertebralis (non Stoliczka). Hennig. Lunds Univ. Årsskr. XXX, p. 18.

1925 Monoporella cribrosa (Marsson). Levinsen. Vidensk. Selsk. Skr. 8. Ser. VII. 3, p. 405 , Pl. VII, Fig. $82 \mathrm{a}-\mathrm{b}$.

1930 Columnotheca cribrosa Marsson. Voigt. Leopoldina. VI, p. 519, Pl. 33, Fig. 13.

1959 Columnotheca cribrosa Marsson. Voigt. Geologie. Beiheft 25, p. 49.

\section{Description.}

The zoarium consists of free, cylindrical, bifurcate stems with apertures arranged in circles, each circle being composed of 6-10 apertures. The distance between these circles as a rule is somewhat smaller than the thickness of the stem. The surface of the colony is provided with numerous irregular pores, which are often covered by a thin calcium membrane.

The zooecia have no marginal delimitation. The circular peristomices are placed on the ends of tubular peristomies.

Ovicells have not been observed.

Avicularia are of fairly rare occurrence. They are small, oval, and are placed on or in immediate proximity of the peristomies.

\section{Measurements.}

\begin{tabular}{|c|c|c|c|}
\hline & & Range & Average \\
\hline $\begin{array}{l}\text { Faxe, } \\
\text { Saltholm, }\end{array}$ & $\begin{array}{l}\text { Diameter of apertures } \ldots \ldots \ldots \ldots \\
\text { Distance between circles }\end{array}$ & 0.08 & $0.08 \mathrm{~mm}$. \\
\hline Herfølge. & of apertures .......... & $0.68-0.83$ & 0.78 \\
\hline
\end{tabular}




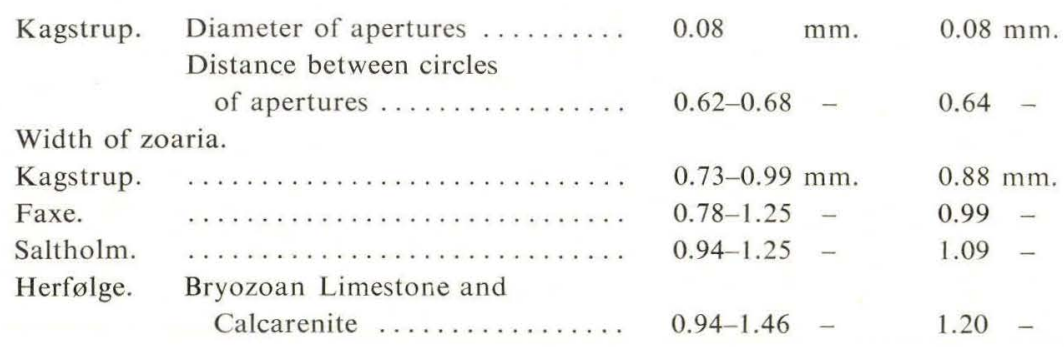

\section{Material.}

Stevns, Bryozoan Limestone - 5 specimens; Kagstrup - 398 specimens; Thorslunde - 5 specimens; Faxe - 19 specimens; Saltholm - 26 specimens; Herfølge, Bryozoan Limestone - 1421 specimens; Herfølge, Calcarenite - 70 specimens; Klintholm -7 specimens.

Distribution.

Senonian: Germany: Rügen. Denmark: Gudumlund, Stevns.

Danian: Stevns, Kagstrup, Thorslunde, Faxe, Saltholm, Herfølge, Klintholm, and Karleby Klint.

\section{CYCLICOPORIDAE HINCKS, 1884}

TAENIOPORINA MARSSON, 1887

\section{Taenioporina articulata Voigt}

Plate 26, Fig. 1.

1886 Vincularia areolata Pergens and Meunier. Ann. Soc. Malac. Belg. XXI, p. 232, Pl. XIII, Fig. 1.

1930 Taenioporina articulata VoIgt. Leopoldina. VI, p. 534, P1. 37, Figs. 17-19.

\section{Description.}

The zoarium consists of free, cylindrical stems with dichotomous ramification. No marginal delimitations of the zooecia can be observed. The apertures are placed in alternating longitudinal rows. On the surface of the colony there are some peculiar threads that demarcate irregular, hexagonal, slightly embedded areas. These appear by a transverse thread below an aperture by means of diagonal threads being connected with longitudinal threads which run along the lateral margins of the apertural areas in adjoining longitudinal rows, and which, again, are connected with a lower transverse thread placed above the underlying aperture. Sometimes the longitudinal threads do not pass along the sides of the apertures, but through these, the apertures in question thus being divided into two halves. The embedded area is provided with pores, most of which are situated along the threads.

The apertures are elongate-elliptical, little prominent.

Ovicells and avicularia have not been observed. 


\section{Measurements.}

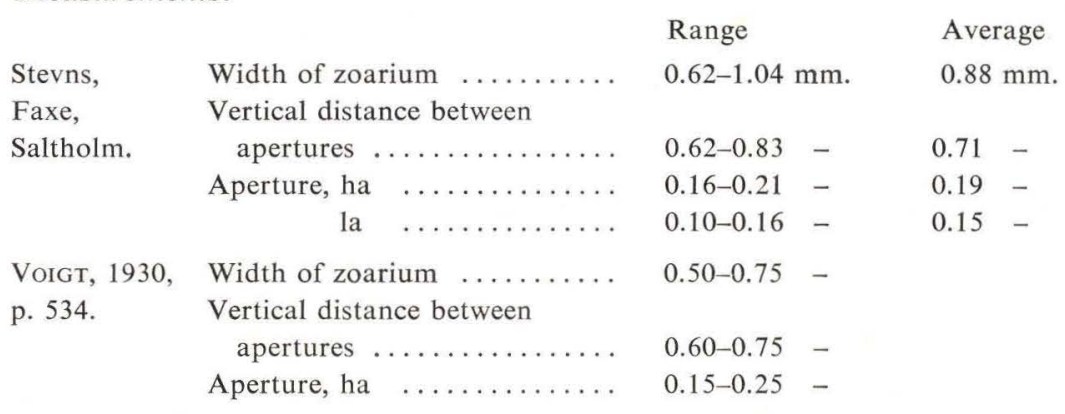

\section{Material.}

Stevns, Bryozoan Limestone - 6 specimens; Thorslunde -2 specimens; Faxe 23 specimens; Faxe II - 4 specimens; Saltholm - 9 specimens; Copenhagen, the South Harbour - 7 specimens; Herfølge, Bryozoan Limestone - 1 specimen.

\section{Distribution.}

Senonian: Germany: Rügen.

Danian: Germany: Erratic blocks. Sweden: Annetorp (according to VoIGT). Denmark: Stevns, Kagstrup, Thorslunde, Faxe, Saltholm, Copenhagen, Herfølge, and Klintholm.

\section{HI P POTHOIDAE LEVINSEN, 1909 \\ DIPLOTRESIS CANU AND BASSLER, 1934}

109. Diplotresis europaea n.sp.

Diagnosis.

Plate 26, Figs. 2-4.

A Diplotresis species with encrusting zoarium, composed of oblong-oval, distinct zooecia. The frontal wall is perforated by fine pores in regular transverse rows and two larger, circular (asco-?)pores. The aperture is semi-elliptical, transverse, terminal, surrounded by a narrow, slightly prominent peristome. The ovicell is hyperstomial, large, globular, finely punctate. A few interzooecial avicularia are present.

\section{Description.}

The zoarium is encrusting, with irregularly arranged, sometimes imbricate zooecia, which are separated by deep, narrow furrows.

The zooecia are variable in shape, but as a rule oblong-oval. The frontal wall is plane or slightly convex and perforated by numerous fine pores, which are arranged in transverse rows. At a slight distance below the aperture there are two distinct, circular pores, which perhaps have been formed by a division 
of the ascopore. The aperture is semi-elliptical, transverse, terminal. It is surrounded by a narrow, plane, slightly prominent peristome.

The ovicells are hyperstomial, large, globular. The surface is very finely punctate.

In the interzooecial furrows there are a few elongate, tapering avicularia (or zooeciules? - CANU and BASSLER, 1933, p. 72) with narrow opesia.

Measurements.

\begin{tabular}{|c|c|c|c|c|c|c|}
\hline \multirow{9}{*}{ Herfølge. } & & & \multicolumn{2}{|l|}{ Range } & \multicolumn{2}{|c|}{ Average } \\
\hline & $\mathrm{Lz}$ & $\ldots \ldots \ldots \ldots \ldots \ldots \ldots \ldots$ & $0.42-0.62$ & $\mathrm{~nm}$ & 0.53 & $\mathrm{~mm}$. \\
\hline & $1 z$ & $\ldots \ldots \ldots \ldots \ldots \ldots \ldots$ & $0.26-0.36$ & - & 0.29 & - \\
\hline & ha & $\ldots \ldots \ldots \ldots \ldots \ldots \ldots \ldots$ & 0.08 & - & 0.08 & - \\
\hline & la & $\ldots \ldots \ldots \ldots \ldots \ldots \ldots \ldots$ & 0.10 & - & 0.10 & - \\
\hline & hov & $\ldots \ldots \ldots \ldots \ldots \ldots \ldots$ & $0.29-0.31$ & - & 0.30 & - \\
\hline & lov & $\ldots \ldots \ldots \ldots \ldots \ldots \ldots \ldots$ & 0.31 & - & 0.31 & - \\
\hline & Lav & $\ldots \ldots \ldots \ldots \ldots \ldots \ldots$ & 0.16 & - & & \\
\hline & lav & $\ldots \ldots \ldots \ldots \ldots \ldots \ldots \ldots$ & 0.10 & - & & \\
\hline
\end{tabular}

For comparison the measures of the American species Diplotresis sparsiporosa CANU and BASSLER may be adduced:

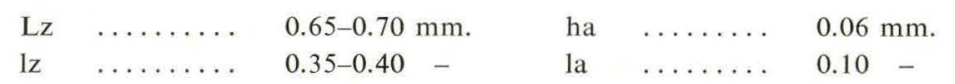

Material. Herfølge, Bryozoan Limestone - 70 specimens.

Holotype. Pl. 26, Fig. 3. Herfølge, Bryozoan Limestone.

\section{Remarks.}

The trivial name has been chosen in order to mark that this species is so far the only representative of the genus of Diplotresis in European deposits.

Apart from D. europaea the genus only comprises D. sparsiporosa CANU and BASSLER, which occurs in the deposits of limesand of the Paleocene (?) Vincentown formation in New Jersey (CANU and BASsLer, 1933, p. 72, Pl. 17, Figs. 6-7). The above-mentioned measures show that the zooecia in D. europaea on the whole are shorter and narrower than in D. sparsiporosa. Amongst other distinctive features it may be stated that the number of avicularia (zooeciules?) is considerably larger in $D$. sparsiporosa than in $D$. europaea, and that between the two circular (asco-?)pores in D. sparsiporosa there is a small median tuberosity. Such a tuberosity does not seem to occur in D. europaea.

Distribution. Danian: Herfølge. 
STOMACHETOSELLIDAE CANU AND BASSLER, 1917

OCHETOSELLINA n.g.

Diagnosis.

The zoarium consists of free, rounded-quadrangular, dichotomous stems, composed of four alternating rows of elongated, hexagonal zooecia separated by salient threads. The terminal aperture is by two lateral teeth divided into a large, circular portion and a smaller, transverse, oval part (rimule). The frontal wall is provided with 7-10 mainly lateral pores and an oval (oral) avicularium.

\section{Ochetosellina areolata n.sp.}

Plate 25, Figs. 7-8.

Diagnosis. Like the generic diagnosis.

\section{Description.}

The zoarium forms rounded-quadrangular, dichotomous stems composed of four alternating rows of zooecia, which are separated by salient, sinuous threads.

The zooecia are elongated, hexagonal, with a terminal aperture. The frontal wall is convex in a transverse direction, concave at the proximal end and smoothly ascending towards the posterior margin of the aperture, while the apertural area itself slopes down towards the anterior margin of the zooecium. The surface is perforated by $7-10$ small, circular pores, which are mainly placed along the zooecial margins. The aperture is of the same form as that of Pliophloea, two small lateral processes dividing it into an upper, circular or subcircular part and a lower, smaller, transverse, oval area, which is obliquely projecting and which perhaps is to be interpreted as a rimule, serving as an opening to the compensatrix.

Ovicells have not been observed.

Laterally to the aperture, as a rule on its proximal margin, there is a single, small, oval avicularium.

\section{Measurements.}

\begin{tabular}{|c|c|c|c|c|}
\hline \multirow[b]{2}{*}{ Herfølge. } & & & Range & Average \\
\hline & $\mathrm{Lz}$ & $\ldots \ldots \ldots \ldots \ldots \ldots \ldots \ldots$ & $0.78-1.25 \mathrm{~mm}$. & $1.00 \mathrm{~mm}$ \\
\hline & $\mathrm{lz}$ & $\ldots \ldots \ldots \ldots \ldots \ldots \ldots$ & $0.52-0.60-$ & $0.54-$ \\
\hline & ha & $\ldots \ldots \ldots \ldots \ldots \ldots$ & $0.16-0.26$ & 0.19 \\
\hline & la & $\ldots \ldots \ldots \ldots \ldots \ldots \ldots$ & $0.10-0.21$ & 0.11 \\
\hline & Lav & $\ldots \ldots \ldots \ldots \ldots \ldots \ldots$ & 0.08 & \\
\hline & lav & $\ldots \ldots \ldots \ldots \ldots \ldots \ldots \ldots$ & 0.05 & \\
\hline & Widt & h of zoarium $\ldots \ldots \ldots \ldots$ & $0.62-1.25$ & 0.83 \\
\hline
\end{tabular}


Material. Herfølge, Bryozoan Limestone - 23 specimens.

Holotype. P1. 25, Fig. 7. Herfølge, Bryozoan Limestone.

Remarks.

The reference of Ochetosellina to the Stomachetosellidae is owing to the features which the genus has in common with other genera within this family, especially Ochetosella CANU and BASSLER (see e.g. O.jacksonica CANU and BASSLER, 1920, p. 452, Pl. 15, Figs. 1-10). This applies to the shape of the colony, the salient threads between the zooecia, the shape of the zooecia, and the distribution of the pores. Ochetosellina differs from Ochetosella with regard to the rimule, which in the latter genus is replaced by a small canal supported by a peristomial projection.

A corresponding distribution of pores is also found in Psilosecos (see Pl. 27, Figs. 3-4) within the family Reteporidae. This genus, however, is characterized by having a lyrule on the proximal lip of the aperture.

Distribution. Upper Danian: Faxe, Herfølge, and Klintholm.

$$
\begin{aligned}
& \text { SCHIZOPORELLIDAE JULLIEN, } 1903 \\
& \text { SYSTENOSTOMA MARSSON, } 1887
\end{aligned}
$$

\section{Systenostoma verticillata Levinsen}

Plate 26, Fig. 5.

1925 Systenostoma verticillata LeVInsEn. Vidensk. Selsk. Skr. 8. Ser. VII. 3, p. 410, PI. VII, Fig. $86 \mathrm{a}-\mathrm{b}$.

1930 Systenostoma verticillata LeVInSEn. Vorgt. Leopoldina. VI, p. 526, Pl. 33, Fig. 26.

\section{Description .}

The colonies form free, cylindrical or subcylindrical stems with dichotomous ramification. The zooecia are arranged in more or less regular verticils and are separated by fine furrows.

The zooecia are elongated, rounded-quadrangular or slightly pyriform, as they generally decrease in width downwards. The aperture is oblong-oval and it is laterally and distally surrounded by a very prominent, semi-circular or horseshoe-shaped, rounded ridge provided with 2-6 circular or oval pores. On well-preserved specimens a transverse, slit-shaped pore (rimule or avicularium ?), separated from the aperture by a thin crossbeam, is seen below the aperture. Mostly only fragments of it are preserved as two small, lateral, dentiform processes in the aperture.

Ovicells have not been observed.

Avicularia: Perhaps the transverse pore below the aperture is the remnant of an avicularium. 


\section{Measurements.}

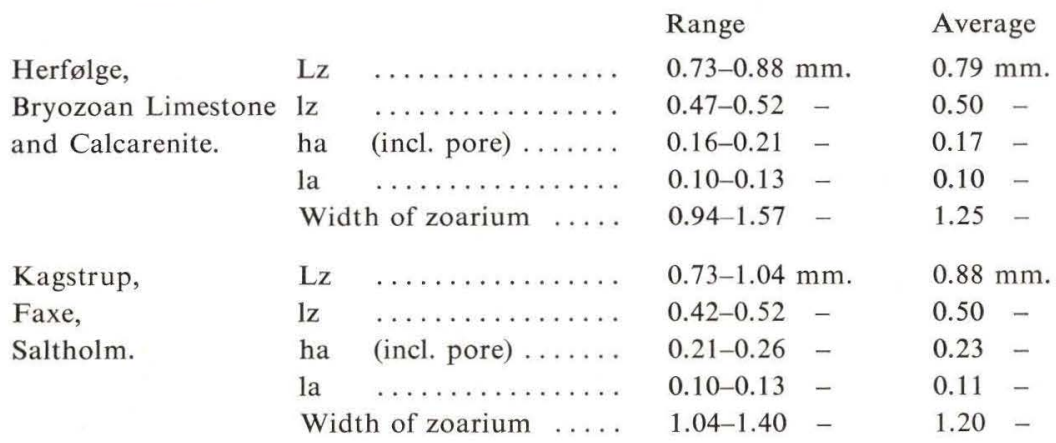

\section{Material.}

Stevns, Bryozoan Limestone - 7 specimens; Kagstrup - 36 specimens; Thorslunde - 47 specimens; Faxe - 58 specimens; Faxe I - 4 specimens; Saltholm 37 specimens; Herfølge, Bryozoan Limestone - 189 specimens; Herfølge, Calcarenite -3 specimens.

Lectotype.

The type specimen is found in LeVINSEN's collection in the Zoological Museum of Copenhagen. Type locality: Faxe.

\section{Distribution.}

Senonian: Germany: "Obersenongeschiebe im Limstenfazies von Lubmin (Pommern)" (Voigt, 1930, p. 526).

Danian: Stevns, Kagstrup, Thorslunde, Faxe, Saltholm, Herfølge, and Klintholm.

\section{Systenostoma pontifera n.sp.}

Plate 26, Figs. 6-7.

Diagnosis.

A Systenostoma species with thick, bilamellar, compressed stems composed of rhombic or pyriform zooecia in regular quincunx. The aperture is semi-elliptical, transverse, surrounded by a horseshoe-shaped ridge set with mostly 3, sometimes up to 7 pores. Below the aperture there is an oval, transverse pore, separated from the aperture by a narrow crossbeam.

\section{Description.}

The zoarium consists of free, thick, bilamellar, compressed stems with rounded edges and an elliptical cross-section. The zooecia are arranged in regular quincunx and separated by fine, often indistinct furrows. 
The zooecia are rounded-rhombic or pyriform, as a rule decreasing in width downwards. The aperture is semi-elliptical with a straight posterior edge, embedded. It is laterally and distally surrounded by a broad, horseshoe-shaped, rounded ridge. Below the aperture there is a transverse, oval pore (rimule or avicularium?), the width of which is somewhat smaller than the apertural width. Aperture and pore are separated by a narrow crossbeam. On the ridge above the aperture there are three distinct pores, the two lateral ones of which are circular, tubular, and projecting, while the median pore is transverse, oval or triangular, slightly embedded. On the lateral parts of the ridge there may be $2-4$ pores of varying distinctness. Sometimes the frontal wall below the aperture as well is provided with a few pores. In some of the specimens examined the wall is very thick, and the apertures consequently are embedded at the bottom of deep crates (peristomes); the surface of these fragments is perforated by numerous pores (tremopores).

Ovicells have not been observed.

Perhaps the transverse pore below the aperture should be considered the remnant of an avicularium.

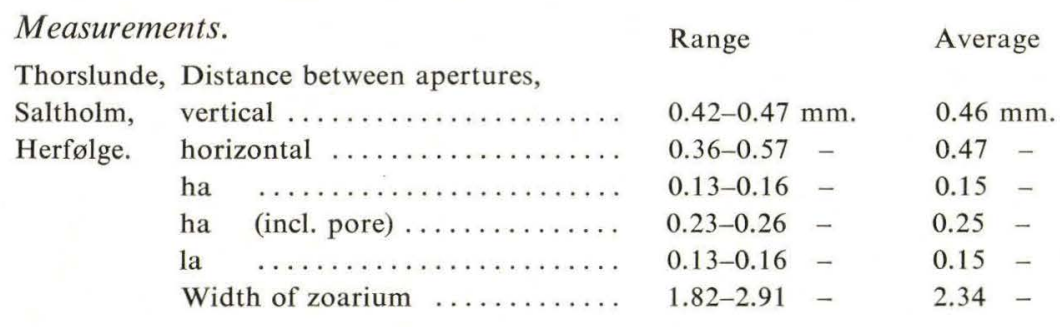

Material.

Thorslunde - 2 specimens; Saltholm - 3 specimens; Herfølge - 40 specimens.

Holotype. P1. 26, Fig. 6. Herfølge, Bryozoan Limestone.

\section{Remarks.}

The trivial name refers to the small bridge that separates aperture and pore.

Systenostoma pontifera differs from S. verticillata LEVINSEN (see p. 212) as regards the shape of colonies, the latter species having cylindrical stems with verticillate zooecia. Furthermore, $S$. verticillata has oblong-oval apertures and 2-6 pores on the prominent apertural ridge.

The Senonian species S. asperulum Marsson (1887, p. 89, Pl. IX, Fig. 2) has the same shape of colony as $S$. pontifera, but differs from it by having a more compressed ridge area laterally to the aperture, whereas the distal ridge area often seems to be missing. The apertural area in S. asperulum is hourglassshaped, as the oblong-oval aperture and the underlying pore have the same width. As regards the distribution of pores there is also a difference between the two species. 
Distribution.

Upper Danian: Thorslunde, Faxe, Saltholm, and Herfølge.

\section{MUCRONELLIDAE LEVINSEN, 1902 \\ MUCRONELLA HINCKS, 1880}

\section{Mucronella hians Hennig}

Plate 26, Fig. 8.

1892 Mucronella hians Hennig. Lunds Univ. Årsskr. XXVIII, p. 44, Pl. 2, Fig. 42.

1925 Lepralia hians (Hennig). Levinsen. Vidensk. Selsk. Skr. 8. Ser. VII. 3, p. 411, PI. VII, Fig. 87.

1930 Mucronella hians Hennig. Voigt. Leopoldina. VI, p. 536, P1. 36, Fig. 18.

\section{Description .}

The zoarium is encrusting, with irregularly arranged zooecia, which are separated by deep, narrow depressions.

The zooecia are urceolate, greatly convex, tapering towards both ends and more or less steeply ascending towards the anterior end. The peristomice, which is bean-shaped, transverse, is placed on top of a semi-globular peristomie, the proximal rim of which bears a dentiform lyrule. The distal oral rim is provided with four traces of spines.

The ovicells are hyperstomial, greatly convex.

Avicularia have not been observed.

\section{Measurements.}

\begin{tabular}{|c|c|c|c|c|}
\hline \multirow{7}{*}{ Faxe. } & & & Range & Average \\
\hline & $\mathrm{Lz}$ & $\ldots \ldots$ & $0.47-0.52 \mathrm{~mm}$. & $0.50 \mathrm{~mm}$ \\
\hline & $1 z$ & $\ldots \ldots \ldots \ldots \ldots \ldots \ldots \ldots$ & $0.31-0.36-$ & $0.36-$ \\
\hline & ha & $\ldots \ldots \ldots \ldots \ldots \ldots \ldots$ & $0.08-0.10$ & 0.10 \\
\hline & la & $\ldots \ldots \ldots \ldots \ldots \ldots \ldots \ldots$ & $0.10-0.16$ & 0.12 \\
\hline & hov & $\ldots \ldots \ldots \ldots \ldots \ldots \ldots \ldots$ & $0.16-0.18$ & 0.17 \\
\hline & lov & $\ldots \ldots \ldots \ldots \ldots \ldots \ldots$ & $0.21-0.23$ & 0.22 \\
\hline
\end{tabular}

\section{Material.}

Stevns, Bryozoan Limestone - 3 specimens; Faxe - 129 specimens; Faxe II 5 specimens; Herfølge, Bryozoan Limestone -8 specimens; Saltholm -1 specimen.

\section{Remarks.}

HENNIG's reference of this species to the genus Mucronella seems in the first place to be owing to the presence of a lyrule on the peristomie and in the occurrence of apertural spines. It is, however, doubtful whether this reference can be maintained, as other, essential, generic characters, such as e.g. marginal 
areolar pores, are missing from Mucronella hians. According to BASSLER (1953, p. G. 207) the oldest representatives of Mucronella occur in Eocene deposits.

\section{Distribution .}

Danian: Sweden: Annetorp. Denmark: Stevns, Kagstrup, Faxe, Saltholm, and Herfølge.

\section{CRYPTOSTOMELLA BASSLER, 1953}

\section{Cryptostomella pectinata n.sp.}

Plate 27, Figs. 1-2.

Diagnosis.

A Cryptostomella species with unilamellar, encrusting or free colonies composed of oval, rounded-triangular or -hexagonal zooecia with large peristomices. The peristomie is oblique, crater-shaped, provided with a pectinate process from the proximal wall. Oval, tubular avicularia (?) occur in the peristomie, on its margin, or on the zooecial rim.

\section{Description.}

The zoarium consists of unilamellar, encrusting or-more rarely-free colonies composed of irregularly arranged zooecia, which are separated by fine furrows. Sometimes fusions have subdivided the furrows into elongated pores.

The zooecia are oval, rounded-triangular or -hexagonal. The peristomice is of the same shape as the zooecium and is encircled by a comparatively narrow, rounded rim. The peristomie is crater-shaped, oblique. A little down the inner side of its proximal wall there is a horizontal, pectinate projection formed by one or two dichotomous processes. Between the two processes there is a narrow, deep incision, and the two short teeth that form the end of each process are separated by a V-shaped cleft.

Ovicells have not been observed.

Above the pectinate projection on the proximal wall of the peristomie there are one or two low, tubular cells which presumably are to be interpreted as avicularia. In this position the oval opesium is placed vertically. Sometimes the avicularia have moved higher up and been placed at the entrance to the peristomie, the opesia consequently being oblique. More rarely an avicularium is placed on the rim of the zooecium and the opesium then is turned into the horizontal plane.

Measurements.

\begin{tabular}{|c|c|c|c|c|}
\hline & & & Range & Average \\
\hline & $\begin{array}{l}\mathrm{Lz} \\
\mathrm{lz}\end{array}$ & $\ldots \ldots \ldots \ldots \ldots \ldots \ldots \ldots \ldots \ldots \ldots$ & $\begin{array}{l}0.42-0.55 \mathrm{~mm} . \\
0.34-0.52-\end{array}$ & $\begin{array}{l}0.49 \mathrm{~mm} . \\
0.44-\end{array}$ \\
\hline
\end{tabular}




\begin{tabular}{|c|c|c|}
\hline ha & $0.29-0.42 \mathrm{~mm}$ & $0.36 \mathrm{~mm}$. \\
\hline жю, & $0.26-0.31-$ & $0.29-$ \\
\hline 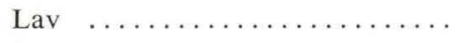 & 0.16 & 0.16 \\
\hline . & 0.10 & 0.10 \\
\hline
\end{tabular}

For comparison the measures of the Senonian species Cryptostomella gastroporum MARSSON may be adduced:

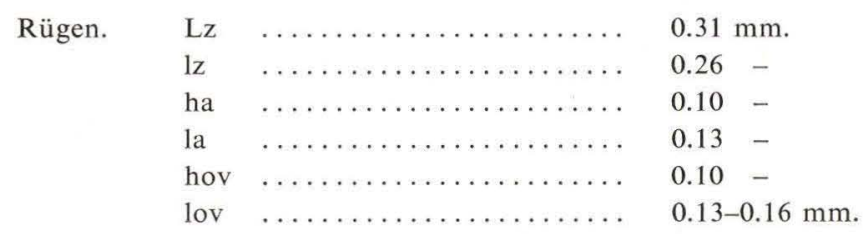

Material.

Stevns, Bryozoan Limestone - 3 specimens; Kagstrup - 1 specimen; Thorslunde - 2 specimens; Faxe - 10 specimens; Faxe XI - 2 specimens.

Holotype. Pl. 27, Fig. 1. Faxe, Bryozoan Limestone.

\section{Remarks.}

The trivial name refers to the pectinate projection from the peristomie.

The genus Cryptostomella only comprises two species, viz. C. pectinata n.sp. and C. gastroporum Marsson (1887, p. 96, Pl. X, Fig. 6), which are both pictured on Plate 27 (Figs. 1-2). The measures given above show that the zooecia of $C$. pectinata are considerably larger than those of $C$. gastroporum. Furthermore, the latter species differs from the Danian species by having a wide, crescent-shaped aperture, a tongue-shaped projection in the peristomie and a small pore in the middle of the frontal wall.

Distribution. Danian: Stevns, Kagstrup, Thorslunde, and Faxe.

RETEPORIDAE SMITT, 1867

PSILOSECOS CANU AND BASSLER, 1933

\section{Psilosecos angustidens (Levinsen)}

Plate 27, Figs. 3-4.

1925 Monoporella (?) angustidens LeVInSEn. Vidensk. Selsk. Skr. 8. Ser. VII. 3, p. 397, P1. VII, Fig. 75.

1930 Achanthionella angustidens Levinsen. Voigt. Leopoldina. VI, p. 529, P1. 37, Fig. 5. 1933 Psilosecos angustidens Levinsen. CANU and Bassler. U.S. Nat. Mus., Bull. 65, p. 83.

\section{Description.}

The zoarium is composed of free, bilamellar plates of varying width. The zooecia are arranged in fairly regular quincunx. They are sometimes separated 
by narrow furrows, but mostly the external demarcations cannot be observed.

The zooecia are rounded-rhombic or -hexagonal. The frontal wall is slightly convex or plane and provided with 4-6 sublateral pores. The aperture is semielliptical or rounded-quadrangular, and the lateral rims are often indented in the middle or a little below it. The proximal lip medianly bears a process in the shape of a small rectangular tooth.

Ovicells have not been observed, but presumably they are of the same type as those of Psilosecos muralis (GABB and HoRN) from the Vincentown formation, i.e. a hyperstomial ovicell which is completely embedded into the frontal wall of the distal zooecium and therefore invisible exteriorly.

In LEVINSEN's opinion the frontal pores are traces of avicularia, as it is sometimes possible to find a few small, oval avicularia preserved in the places of the pores. According to CANU and BASSLER these pores should rather be interpreted as areolar pores. Avicularia may also occur near the aperture, either laterally or distally to it.

\section{Measurements.}

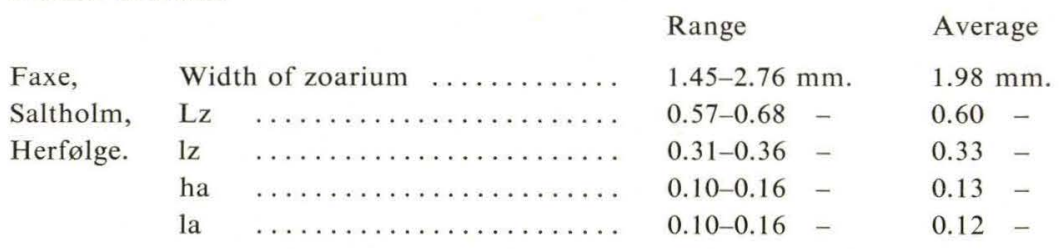

For comparison the measures of Psilosecos muralis (according to CANU and BASSLER, 1933, p. 83) may be adduced:

$\begin{array}{lllllll}\mathrm{Lz} & \ldots \ldots & 0.6-0.7 \mathrm{~mm} . & \text { ha } & \ldots \ldots & 0.12 \mathrm{~mm} . \\ \mathrm{lz} & \ldots \ldots & 0.35 & - & \text { la } & \ldots \ldots & 0.1\end{array}$

\section{Material.}

Thorslunde - 1 specimen; Faxe - 32 specimens; Faxe I - 1 specimen; Faxe II 6 specimens; Saltholm, Bryozoan Limestone - 2 specimens; Saltholm - 12 specimens; Herfølge, Bryozoan Limestone - 15 specimens; Herfølge, Calcarenite -2 specimens.

\section{Lectotype.}

The type specimen occurs in Levinsen's collection in the Zoological Museum of Copenhagen. Type locality: Faxe.

\section{Remarks.}

The genus Psilosecos comprises two species, only, viz. P. angustidens and $P$. muralis GABB and HorN from the Paleocene (?) Vincentown formation in 
New Jersey (see CAnu and Bassler, 1933, p. 83, Pl. 15, Figs. 2-7). The American species has more distinct zooecia and a larger number of avicularia, as a rule found near the aperture.

\section{Distribution.}

Danian: Germany: Erratic blocks at Köthen. Denmark: Thorslunde, Faxe, Saltholm, Herfølge, and Klintholm. The species seems to occur only in Upper Danian.

\section{CELLEPORIDAE BUSK, 1852 \\ CELLEPORA LINNÉ, 1767}

\section{Cellepora daniensis Voigt}

Plate 27, Fig. 5.

1930 Cellepora daniensis Voigt. Leopoldina. VI, p. 528, Pl. 36, Fig. 17.

\section{Description .}

The zoarium is unilamellar, free or encrusting, with the zooecia arranged in irregular quincunx.

The zooecia forms long, tubular processes with circular apertures placed at the top and surrounded by an uneven, undulate rim.

Ovicells have not been observed.

Between the zooecial tubes there are small, globular avicularia.

Measurements.

\begin{tabular}{|c|c|c|c|}
\hline \multirow{4}{*}{$\begin{array}{l}\text { Kagstrup, } \\
\text { Stevns. }\end{array}$} & & Range & Average \\
\hline & $\mathrm{Lz}$ & 0.52 & $0.32 \mathrm{~mm}$. \\
\hline & $\mathrm{lz}$ & $0.36-0.42-$ & $0.42-$ \\
\hline & Aperture, diameter . & $0.18-0.21$ & 0.20 \\
\hline
\end{tabular}

\section{Material.}

Stevns, Bryozoan Limestone - 13 specimens; Kagstrup - 2 specimens.

Distribution.

Danian: Germany: Erratic blocks at Blauen Berge near Rosslau. Denmark: Stevns, Kagstrup, Faxe, and Saltholm.

Diagnosis.

CRAS SICELLEPORA n. g.

Thick, more or less cylindrical, smooth stems composed of zooecia without marginal delimitations. The apertures are large, rounded-quadrangular or oval. The ovicells 
are hyperstomial, embedded in the wall of the distal zooecium. The avicularia have large circular or oval opesia, which mostly are placed on top of crater-like elevations.

\section{Crassicellepora voigti n.sp.}

Plate 27, Figs. 6-8.

Diagnosis. Like the generic one.

\section{Description.}

The most frequent form of the colonies is thick, more or less cylindrical, smooth stems. Of rarer occurrence are free, uni- or multilamellar plates. The zooecia have no marginal delimitations. The apertures are placed in fairly regular quincunx.

The apertures are large, rounded-quadrangular or circular. They are sometimes surrounded by a vallate, thickened rim.

The ovicell is hyperstomial, large, embedded in the wall of the distal zooecium, and on the surface of the colony appears only as a slight convexity above the aperture.

The avicularia appear as large, circular or oval pores, which partly occur on top of crater-like elevations between the apertures of the zooecia, partly as depressions immediately below these.

\section{Measurements.}

\begin{tabular}{|c|c|c|c|c|c|}
\hline \multirow{3}{*}{$\begin{array}{l}\text { Faxe, } \\
\text { Herfølge. }\end{array}$} & \multirow[b]{2}{*}{ ha } & & \multicolumn{2}{|l|}{ Range } & Average \\
\hline & & & $0.23-0.31$ & $\mathrm{~nm}$. & $0.26 \mathrm{~mm}$. \\
\hline & & & $0.23-0.26$ & - & $0.26-$ \\
\hline & hov & $\ldots \ldots \ldots, \cdots, \cdots, \ldots$ & 0.26 & - & 0.26 \\
\hline & lov & & 0.31 & - & 0.31 \\
\hline & Lav & 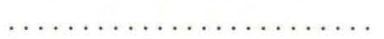 & $0.13-0.16$ & - & 0.15 \\
\hline & lav & $\ldots \ldots \ldots \ldots$ & $0.10-0.13$ & - & 0.11 \\
\hline
\end{tabular}

Material.

Faxe - 25 specimens; Faxe XI - 4 specimens; Herfølge, Bryozoan Limestone 17 specimens; Herfølge, Calcarenite -1 specimen; Klintholm -1 specimen.

Holotype. P1. 27, Fig. 8. Bryozoan Limestone, Herfølge.

Remarks.

The species is dedicated to Professor ErH. Voigt, Ph.D., of Hamburg in admiration of his great contributions to the study of Bryozoa.

Distribution. Upper Danian: Faxe, Herfølge, and Klintholm. 
Table 1. Survey of the number of fragments in the museum material

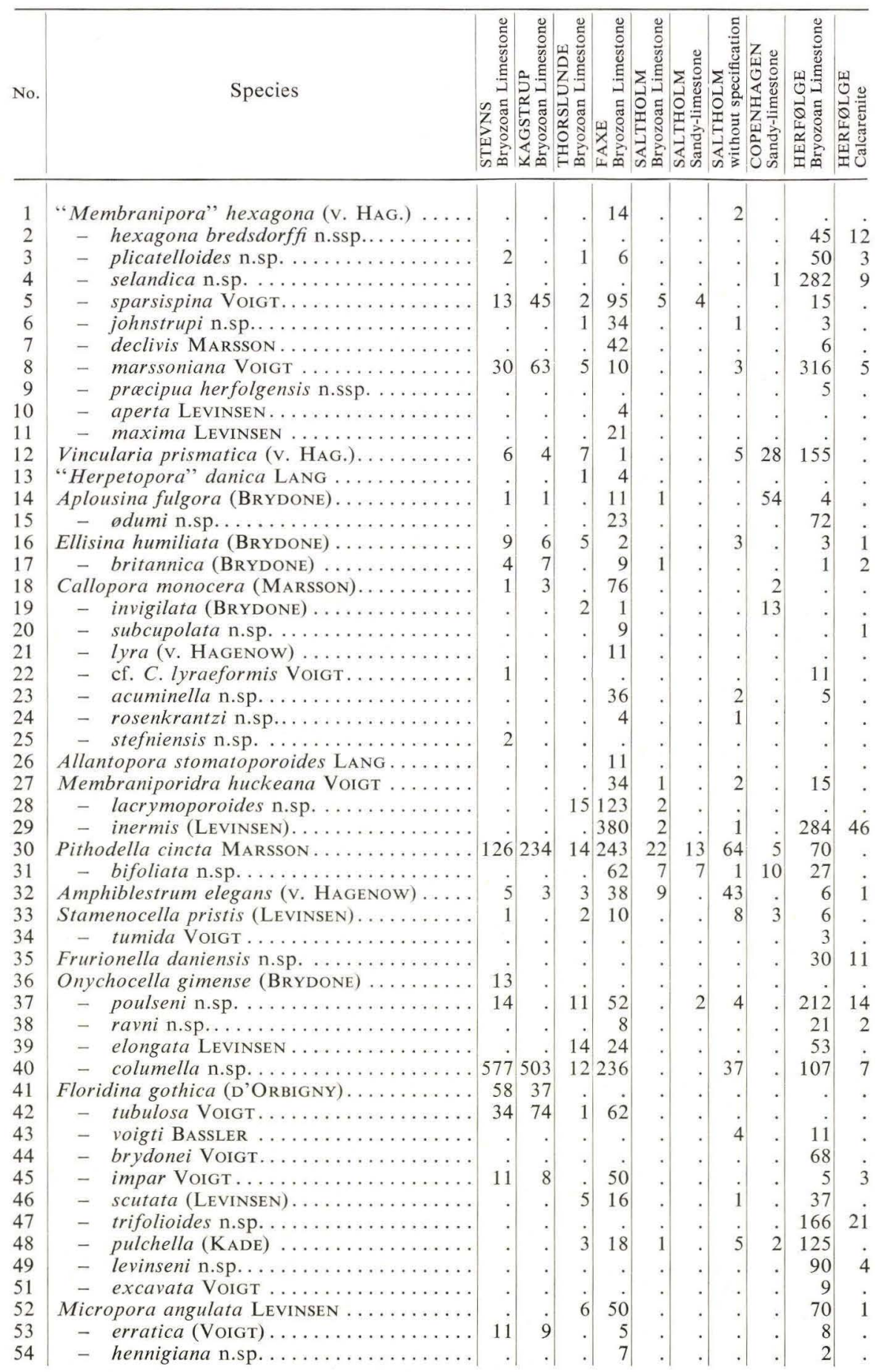


Table 1 (continued)

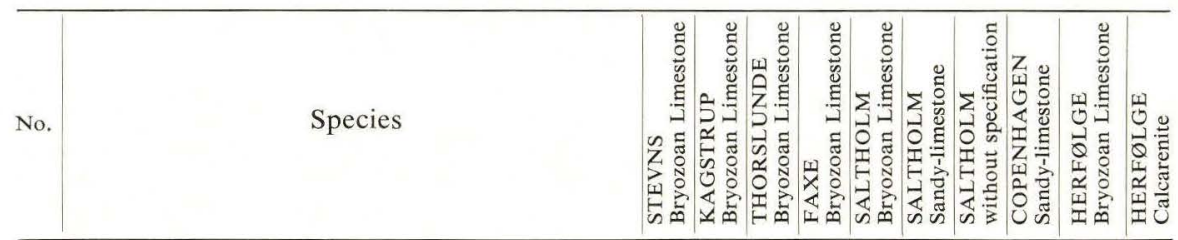

\begin{tabular}{|c|c|c|c|c|c|c|c|c|c|c|c|}
\hline 55 & Micropora stevensis LEVINSEN . . . . . . . . . & & 1 & & 12 & - & & & & 29 & \\
\hline 0 & Semiescharinella complanata D'ORBIGNY ... & 2 & 1 & & 64 & & & & 5 & 68 & \\
\hline 8 & Aechmella pindborgi n.sp............. & 131 & 34 & 2 & 151 & & & 6 & . & 208 & \\
\hline 2 & 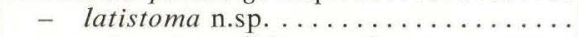 & . & & 6 & 6 & . & & . & . & 61 & \\
\hline 6 & - microstoma (MARsSON) .......... & . & . & 1 & 20 & 1 & . & 3 & . & 18 & \\
\hline 02 & Hoplitaechmella smitti (HENNIG) . . . . . . . & . & . & . & 2 & . & & . & . & 8 & . \\
\hline 63 & - vespertilioides n.sp. . . . . . . . . . & . & . & . & 2 & . & 2 & 2 & . & . & . \\
\hline 64 & Gargantua parvicella (VoIGT) ............ & . & . & 3 & 22 & & & 1 & & & \\
\hline 63 & Brydonella vulcani (BRYDONE) . . . . . . . . . & . & . & & 6 & & & . & . & 45 & 5 \\
\hline 66 & Lunulites faxensis (LEVINSEN). . . . . . . . . & 2 & 16 & 57 & 34 & . & . & 17 & 4 & 91 & 16 \\
\hline 7 & - saltholmensis n.sp.............. & - & 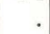 & &. & . & . & 64 & 56 & & . \\
\hline 68 & Puncturiella sculpta (D'ORBIGNY)......... & 1 & . & . & 7 & . & . & 1 &. & 28 & . \\
\hline & VOIGT) $\ldots \ldots \ldots \ldots \ldots \ldots$ & $\cdot$ & . & & $\cdot$ & . & . & $\cdot$ & $\cdot$ & 3 & . \\
\hline 70 & ta BERTHELSEN. . . . . . . & 26 & 187 & 48 & 161 & & . & 875 & 516 & 1645 & 94 \\
\hline 71 & Fissuricella fissa (VoIGT). . . . . . . . . . . & 1 & & & . & . & & 1 & . & 6 & . \\
\hline 72 & Membraniporella squamulosa (v. HAG.) . . . . & 1 & 52 & . & 2 & . & . & 9 & . & 5 & . \\
\hline 73 & ostata n.sp. ........ & - & & • & 4 & & . & . & . & . & . \\
\hline 14 & is Voigt ........... & . & . & . & . & & . & - & . & 5 & . \\
\hline 75 & Pliophloea subcornuta n.sp. . . . . . . . . & 8 & 7 & . & 20 & & . & & & & . \\
\hline 16 & - cf. P. gluma LANG............. & . & . & . & 10 & . & . & - & . & 2 & . \\
\hline 77 & - cf. P. palea LA & . & . & . & 12 & & . & - & . & 10 & 6 \\
\hline 78 & - vincularioides VorGT . ............ & . & . & 7 & 7 & . & . & 1 & . & & . \\
\hline 79 & - brünnichi $\mathrm{n}$ & . & . & . & . & & . & - & . & 1208 & 51 \\
\hline 80 & Monoceratopora quadrisulcata (HENNIG) ... & - & 4 & . & 26 & & & & & 8 & . \\
\hline & Pelmatopora daniensis VoIGT . . . . . . . . . & . & . & . & . & . & . & . & . & 1 & . \\
\hline 2 & Pachydera densa LANG . . . . . . . . . . . . . . & 7 & 1 & & 9 & & & • & . & . & . \\
\hline & p. $\ldots \ldots \ldots \ldots \ldots \ldots \ldots$ & . & . & . & 1 & & & . & . & & . \\
\hline & cerberus LANG. . . . . . . . . . . . & . & . & . & 41 & $\cdot$ & . & - & . & 26 & 2 \\
\hline & - subtriceps n.sp................ & . & 1 & . & 7 & . & . & - & . & $\cdot$ & . \\
\hline & allata (LEVINSEN) . . . . . . . . & . & . & . & 6 & $\cdot$ & . & . & . & 2 & . \\
\hline & $\ldots \ldots \ldots \ldots \ldots \ldots \ldots$ & - & . & - & 9 & ${ }^{\circ}$ & & . & . & $\cdot$ & . \\
\hline & Haplocephalopora uniceps LANG . . . . . . . . & . & . & 1 & 12 & . & s. & . & . & 5 & . \\
\hline & Phractoporella cordiformis (LEVINSEN) ..... & 4 & 2 & 1 & 21 & r. & . & 3 & . & $\cdot$ & . \\
\hline 0 & Diacanthopora bispinosa LANG . . . . . . . . . & . & . & . & 3 & . & . & . & . & 22 & . \\
\hline & 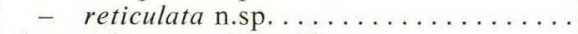 & . & . & . & . & . & s. & . & . & 2 & . \\
\hline 2 & Anornithopora minuta VoIGT ......... & . & . & . & 29 & . & s. & - & . & 14 & . \\
\hline & - polygona VoIGT .............. & - & . & . & 6 & - & s. & . & . & 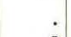 & . \\
\hline & 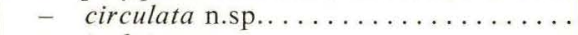 & . & . & . & 2 & - & . & . & . & 9 & . \\
\hline & $\ldots \ldots \ldots \ldots \ldots \ldots$ & . & . & . &. & . & . & 1 & . & . & . \\
\hline & Rhiniopor & & & . & . & - & & . & . & 1 & . \\
\hline & achiata n.sp.......... & 2 & & & 1 & & . & & . & & . \\
\hline & Porina cylindrica VoIGT . . . . . . . . . . . & 38 & 2 & 2 & 51 & & . & 160 & . & 151 & 1 \\
\hline & - salebro & 102 & 37 & 21 & 888 & 18 & . & 105 & 2 & 54 & . \\
\hline 10 & Beisselina no & . & . & 12 & 8 & 3 & . & 21 & 2 & 236 & \\
\hline & poroides (VoIGT) .. & . & . & 137 & 61 & . & . & 44 & . & 204 & 29 \\
\hline & abulifera n.sp....... & & & & 19 & . & . & & . & 2 & \\
\hline & & 12 & 6 & 21 & 173 & . & . & 29 & 88 & 92 & 3 \\
\hline & Pachythecella anhaltina (VoIGT).. & 10 & 1 & 6 & 114 & . & & 1 & . & 67 & . \\
\hline & - filiformis (D'ORBIGNY)......... & & & 19 & 12 & & & 4 & & & \\
\hline & - lundgreni (PERG. and MeUN.) .. & 58 & 3 & 17 & 58 & 5 & & 14 & 146 & 89 & \\
\hline & inotheca cribrosa MARSSON......... & 5 & 398 & 5 & 19 & . & . & 26 & 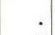 & 1421 & 70 \\
\hline & Taenioporina articulata VoIGT ......... & 6 & & 2 & 27 & . & & 9 & 7 & 1 & . \\
\hline 09 & Diplotresis europaea n.sp.............. & $\cdot$ & & . & & . & • & $\cdot$ & . & 70 & \\
\hline
\end{tabular}


Table 1 (continued)

\begin{tabular}{|c|c|c|c|c|c|c|c|c|c|c|c|}
\hline No. & Species & 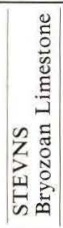 & 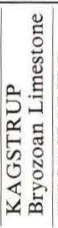 & 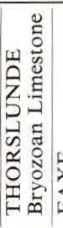 & 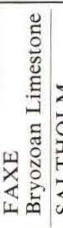 & 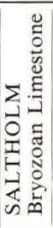 & 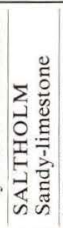 & 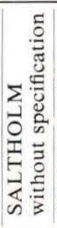 & 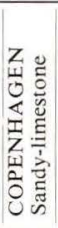 & 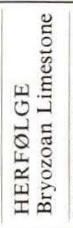 & 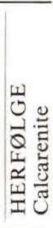 \\
\hline 110 & Ochetosellina areolata n.sp. ........... & & & & & & & & & 23 & \\
\hline 111 & Systenostoma verticillata LEV............ & 7 & 36 & 47 & 62 & . & & 37 & . & 189 & 3 \\
\hline 112 & 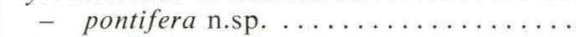 & & & 2 & & & & 3 & . & 40 & \\
\hline 113 & Mucronella hians HeNnIG. . . . . . . . . . & 3 & & & 134 & . & & 1 & . & 8 & \\
\hline 114 & Cryptostomella pectinata n.sp........ & 3 & 1 & 2 & 12 & & & & & & \\
\hline 115 & Psilosecos angustidens (LEVINSEN) . . . . . & & & 1 & 39 & 2 & 2 & 12 & . & 15 & \\
\hline 116 & Cellepora daniensis VoIGt ............. & 13 & 2 & & & . & & & . & & \\
\hline 117 & Crassicellepora voigti n.sp.............. & & . & & 29 & . & 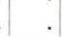 & & . & 17 & \\
\hline
\end{tabular}




\title{
IV. STRATIGRAPHICAL INVESTIGATIONS
}

\author{
1. Purpose.
}

As mentioned in the Introduction the main purpose of the supplementary stratigraphical investigations was that of obtaining a more reliable basis of comparison by taking fresh samples from the localities selected. Besides, I have made it my concern partly to try to elucidate the extent to which the Bryozoa have participated in the formation of the various Danian limestones, partly to have cleared up the composition of the Bryozoan assemblages within the various zones of the Danian, with special regard to the possible influence of the environment.

\section{Method and Results.}

For use at the solution of these tasks 18 samples were introductorily taken from Kagstrup, Faxe, Saltholm, Copenhagen, Herfølge, and Klintholm. This material was later supplemented by 10 samples from Stevns and Faxe. Particulars about places where samples were taken, etc., have been communicated in the chapter of descriptions of localities (pp. 11-38) and in Tables 2 and 3.

The samples taken were dried and weighed and then by washing and sifting divided into three fractions comprising material of fragments below $0.5 \mathrm{~mm}$., material of fragments between 0.5 and $1.5 \mathrm{~mm}$., and finally material of fragments above $1.5 \mathrm{~mm}$. in size of grains, respectively. These boundaries of fractions were selected in order to have all Bryozoan fragments collected within one fraction, viz. $0.5-1.5 \mathrm{~mm}$. After weighing the material in the three categories, 10 grammes of the fraction containing Bryozoa were taken (of the supplementary samples from Faxe and Stevns, however, only 5 grammes), which were sorted out in the groups (1) fragments of Cheilostome Bryozoa, (2) Cyclostome fragments, (3) other fossils, and (4) limestone and flint fragments. During the sorting out the species of the Cheilostome colonies were determined and the number of fragments within the two groups of Bryozoa was registered. After the sorting out had been completed, the material in the four groups was weighed.

The results of these processes of fractionation and weighing are indicated in Tables 2 and 3 (pp. 229 and 230), while Table 6 (p. 240) shows the number of fragments of the various Cheilostome species in the samples examined.

For a comment on the results of the analyses see p. 227. Before this comment is given a short survey will be made of the development of the terminology and there will be a characterization of the rocks of the Danian. 


\section{Development of the Terminology.}

In 1835 FORCHHAMMER (pp. 76-84) made the first classification of the limestones of the Danian. He divided them into Faxekalk, Saltholmskalk, Limsten and Blegekridt (the latter two names are early Jutland terms for types of limestone). JoHnstrup (1882, pp. 49-50) replaced the term of Faxekalk with that of Koralkalk (Coral-reef Limestone) and established Bryozokalk (Bryozoan Limestone) as a second main type, as he considered Saltholmskalk, Limsten and Blegekridt as being varieties of Bryozoan Limestone.

RøRDAM (1897, pp. 48-55, Résumé pp. 136-144) supplied the first consistent classification on the basis of petrographical investigations. He distinguished the following types: (1) Coral-reef Limestone, (2) Bryozoan Limestone, (3) Foraminiferal Limestone, (4) Coccolith-limestone, and (5) Spongia-limestone. These names of rocks were not quite recognized by other geologists. Thus, GröNWALL (1898, p. 1) used FORCHHAMMER's terms, which he supplemented by the Crania tuberculata zone, including a series of rocks with a faunal relationship. RAVN (1903, p. 413) used a combination of ForCHHAMmer's and JoHnStRup's names: Coral-reef Limestone, Bryozoan Limestone, Saltholm Limestone, and Blegekridt. As a new term he introduced Crania-limestone to replace GröNWALL's Crania tuberculata zone.

ROSENKRANTZ (1920, pp. 12-14) subdivided the Crania-limestone into a Lower and an Upper Crania-limestone, the Lower one corresponding to RøRDAM's Foraminiferal Limestone, while the Upper Crania-limestone was identified with the Spongia-limestone. In a later paper (1924a, 1, p. 5) Rosenkrantz replaced Lower Crania-limestone by Kalksandskalk (Sandy-limestone), while the term of Upper Crania-limestone was dropped. In 1908 (p. 57) Milthers introduced the term of Gruskalk ("gravel-lime" = Calcarenite) for the upper layers of limestone at Herfølge.

Instead of the term of Kalksandskalk Troelsen (1957, p. 126) and BerGGREN (1960, p. 187) use the name of Calcarenite, whereas SorGENFreI (1957, p. 11) uses this term about Gruskalk at Herfølge. The latter rock is termed Calcirudite by BERGGREN.

\section{Characterization of the Rocks of the Danian.}

Bryozoan Limestone. Johnstrup (1882, p. 51) defines Bryozoan Limestone as a limestone "the chief mass of which consists of Bryozoa broken more or less by water movement, and which therefore if anything can be considered a limestone similar to sandstone." RøRDAM (1897, p. 50) adds to this characterization that "the Bryozoan Limestone is composed of a great many irregularly deposited Bryozoa, which are surrounded by very small-grained crystals of calcite, which do not show any signs of having been rolled or of being fragments of organized or unorganized large-sized pieces, but must have been crystallized 
in the place where they are found. Single specimens of Foraminifera are seen to occur among the branches of the Bryozoa, but these animal forms are fairly rare in this rock in contrast to the Bryozoa, which must be said to constitute the bulk of the rock."

HeNNIG (1899, pp. 38-39) demonstrated that the Bryozoa originally lived where their fragments now have gathered to form Bryozoan Limestone. The disintegration of the colonies into fragments is not due to water movement, but has been caused by the bryozoophilous fauna, among them Crustacea. In HeNNIG's opinion the calcareous silt between the Bryozoan fragments mainly consists of fragments of walls of zooecia and has arisen by crushing of large fragments of colonies.

The Foraminiferal Limestone according to RøRDAM (1897, p. 70) mainly consists of Foraminifera embedded in a microcrystalline mass of calcite which fills in all cavities and pores, including the chambers of the Foraminifera. Furthermore there are large, limpid parts of calcite and small, clear, sharp grains of quartz and a few needles from spongia. The rock is grey, hard, and highly ringing. According to GRY (1935, p. 23) the Foraminiferal Limestone is "built up of fine or coarse calcareous sand, consisting of foraminiferal and bryozoan fragments and other lime fragments of sand-grain size, subangular or rounded, cemented by a fine or coarse calcite aggregate."

The Coccolith-limestone according to RøRDAM's description (1897, p. 75) is composed of accumulated, circular, elliptical, or bean-shaped Coccoliths and very small crystals of calcite. Foraminifera also occur, but "seem to constitute only a small part of the mass." HADDING (1933, p. 24) finds this term for the rock infelicitous, partly because Coccoliths also appear in other rocks (e.g. White Chalk), partly because the Coccoliths are not the dominant element, being less frequent than e. g. Foraminifera. The chief constituent of the limestone, however, in HADDING's opinion is "a microcrystalline, formless calcitic mass. This has obviously undergone a recrystallization after the deposition, and for that reason it is difficult to give an opinion of its primary character. It is not improbable that it has in part been deposited under the influence of bacteria. Part of it consists of redeposited calcareous mud."

Saltholm Limestone is a hard, ringing limestone, which according to RøRDAM, RAVN (1903, p. 419), BROTZEN (1959, p. 28), and others has arisen by secondary hardening of Coccolith-limestone, while other authors use this rock term to denote all hard Danian limestones without regard to their origin.

Sandy-limestone (kalksandskalk). This term was introduced by ROSENKRANTZ (1924a, p. 5) for the more or less hardened deposits of calcareous sand which constitute the substratum of the Paleocene in the Copenhagen area and with this demarcation is identical with RøRDAM's Foraminiferal Limestone and Rosenkrantz's Lower Crania-limestone. Later (1937, p. 201) RosEnkRANTZ extended this term to include also the Coccolith-limestone on Saltholm.

Brotzen (1959, p. 27) writes about the Sandy-limestone: "It seems that 
inorganic elements are more characteristic than coccoliths for the Upper Danian limestones. The loose limestones contain mainly small needles of calcite. In the softer limestones which intercalate the hard beds, these loose crystals give the impression that the limestone is a fine sand in which calcite grains occur instead of quartz grains. Therefore Rosenkrantz in 1938 and Brotzen in the same year used the term "limestone sand", which is not quite correct, but the term sand can also be used as foraminiferal sand or mollusc sand. It is difficult to find a correct term for this rock. A great number of foraminifera and small shell fragments are embedded between the calcite crystals and the fine grained ooze of small crystals and coccoliths among the larger crystals."

About the Calcarenite (gruskalk = "gravel-lime") at Herfølge Milthers (1908, p. 57) states that the lowest layers are constituted by a grey limestone of fine, sugar-grained appearance. It consists largely of small fragments of fossils, which are very loosely cemented by crystalline calcite. Higher in the layer the limestone is more coarse-grained and at the top passes into "gravel-lime" proper. This character especially manifests itself through the high contents of round or angular quartz grains or glauconite grains up to a size of $2 \mathrm{~mm}$. Furthermore there are fragments of fossils and of calcite, besides a great many light-brown, glistening, oval coproliths up to a size of $0.5 \mathrm{~mm}$.

The structure of the Coral-reef limestone is briefly mentioned in the section about Faxe in the description of localities. A more detailed description of this rock is found in JoHNSTRUP (1864) and RøRDAM (1897) as well as in BRÜNNICH Nielsen (1919 and 1922) and HAdDing (1941, p. 120).

Fish-clay and Cerithium-limestone. These rocks are briefly described in the section on Stevns (above, p. 14). See furthermore papers by Rosenkrantz (1924b, and 1937) and ØDUM (1928).

The Conglomerates on Saltholm and at Herfølge have been dealt with on p. 259.

\section{Lithological Evaluation.}

Introductorily the following remarks are to be made on the results of the analyses, Tables 2 and 3 .

The samples examined have for the sake of washing and sifting been taken from the loosest material in the sites, so that the actual ratio between calcareous silt and hardened limestone in the respective localities are not clearly expressed in the tables. The degree of hardening of the limestone, however, had no influence on the solution of the tasks mentioned above. In this connexion it should be mentioned that the contents of fragments of Bryozoa have also been examined in the case of the hard limestone.

The group of "other fossils" mainly includes members of Crinoids, fragments of Asteroids and Brachiopods and a few large Foraminifera, while the other 
Foraminifera have been washed away together with the calcareous silt. This material is, however, to be preserved for later microfaunistic investigations.

As mentioned above, Bryozoan fragments have previously been considered the dominant constituent of Bryozoan Limestone. The results of the analyses, however, suggest that this assumption has attributed too great importance to the Bryozoa. The contents of Bryozoa did not in any of the samples examined exceed 40 per cent., and in most of the samples the Bryozoa constitute a considerably lower percentage. It may be difficult to obtain a clear impression of these conditions by looking at Table 3 , because the varying contents of fragments of limestone and flint in the fraction containing Bryozoa to some degree veil the picture. A better basis of valuation is obtained if, on the basis of the weight of the Bryozoan fragments in the various 10 and $5 \mathrm{~g}$ samples, the weight of the colonies in the Bryozoan fraction of the initial material is calculated and this value is expressed as a percentage of the total weight of the initial material. (Such a procedure must be considered warrantable considering that at the taking of the small samples, the aim was just that of making these representative). The results of these percentage calculations are shown in Table 4 and in diagrammatic form in Fig. 28.

It is seen here that the contents of Bryozoa in the sample from Hvedeland in the quarry of Faxe, which, as regards weight, contains the largest amount of Bryozoa, only constitute 36 per cent. Bryozoan Limestone, while the other samples from Faxe show contents of Bryozoa varying between 5 and 15 per cent. In the case of the other samples of Bryozoan Limestone, the contents of Bryozoa vary as follows: Kastrup 13.5-27 per cent., Stevns 7-18 per cent., Saltholm 7-15 per cent., Herfølge 7-9 per cent. and Klintholm 8-11 per cent.

The contents of Bryozoa in the Sandy-limestone are only between 0 and 2 per cent. Of the samples of Calcarenite from Herfølge only the lowermost one (Gd: $5.85 \mathrm{~m}$.) contains Bryozoa (2.7 per cent.).

The mechanical analyses have also revealed another interesting fact, as the Cyclostome Bryozoa to a greater extent than the Cheilostome ones proved to have contributed to the formation of the rock. This manifests itself whether, as in Table 4 and fig. 28, the distribution according to weight or the number of Bryozoan fragments forms the basis of valuation. The latter solution is shown in a particular column in Table 3.

LARSEN (1961) has instituted a quantitative petrographic investigation of some limestone samples. The material examined comprises 1 sample of the Cerithium-limestone from Stevns Klint and 4 samples of Bryozoan Limestone, two of them originating from Herfølge (from depths of $6.10 \mathrm{~m}$. and $7.15 \mathrm{~m}$.), while the other two samples were taken at Stevns and Faxe. Furthermore, 1 sample of the Sandy-limestone from Copenhagen (Hyttehusvej) and 2 samples of the Calcarenite of Herfølge $(2.15 \mathrm{~m}$. and $5.00 \mathrm{~m}$.). From these samples thin sections have been made which have been examined by means of a polarizing microscope. 
Table 2. Division of the stratigraphical material according to size of grains

\begin{tabular}{|c|c|c|c|c|c|c|c|c|c|}
\hline \multirow{2}{*}{ Locality } & \multirow{2}{*}{$\begin{array}{c}\text { Symbols } \\
\text { on maps } \\
\text { etc. }\end{array}$} & \multirow{2}{*}{$\begin{array}{l}\text { Depths and characterization } \\
\text { (indications of depths in rela- } \\
\text { tion to ground level) }\end{array}$} & \multirow{2}{*}{$\begin{array}{l}\text { Weight in } \\
\text { grammes of } \\
\text { initial } \\
\text { material }\end{array}$} & \multicolumn{2}{|c|}{$\begin{array}{c}\text { Contents of silt and } \\
\text { fragments less than } \\
0.5 \mathrm{~mm} .\end{array}$} & \multicolumn{2}{|c|}{$\begin{array}{l}\text { Contents of Bryozoa and } \\
\text { fragments of limestone } \\
\text { between } 0.5 \text { and } 1.5 \mathrm{~mm} \text {. }\end{array}$} & \multicolumn{2}{|c|}{$\begin{array}{l}\text { Contents of fragments } \\
\text { of limestone and flint of } \\
\text { more than } 1.5 \mathrm{~mm} \text {. }\end{array}$} \\
\hline & & & & $\begin{array}{l}\text { Weight } \\
\text { in } \\
\text { grammes }\end{array}$ & $\begin{array}{l}\text { Percentage } \\
\text { of initial } \\
\text { material }\end{array}$ & $\begin{array}{l}\text { Weight } \\
\text { in } \\
\text { grammes }\end{array}$ & $\begin{array}{l}\text { Percentage } \\
\text { of initial } \\
\text { material }\end{array}$ & $\begin{array}{l}\text { Weight } \\
\text { in } \\
\text { grammes }\end{array}$ & $\begin{array}{l}\text { Percentage } \\
\text { of initial } \\
\text { material }\end{array}$ \\
\hline Kagstrup & $\begin{array}{l}\mathrm{Aa} \\
\mathrm{Ba} \\
\mathrm{Ca}\end{array}$ & $\begin{array}{l}\text { Bryozoan Limestone between flint layers } \\
\text { Nos. } 4 \text { and } 5 \ldots \ldots \ldots \ldots \ldots \ldots \ldots \ldots \ldots \ldots \ldots \ldots \ldots \\
\quad-10 \text { and } 11 \ldots \ldots \ldots \ldots \ldots \ldots \ldots \ldots \ldots\end{array}$ & $\begin{array}{l}292.8 \\
292.8 \\
242.2\end{array}$ & $\begin{array}{l}167.7 \\
124.1 \\
150.1\end{array}$ & $\begin{array}{l}57.3 \\
42.4 \\
61.9\end{array}$ & $\begin{array}{l}64.0 \\
74.4 \\
77.7\end{array}$ & $\begin{array}{l}21.8 \\
25.4 \\
32.1\end{array}$ & $\begin{array}{l}61.1 \\
94.3 \\
14.4\end{array}$ & $\begin{array}{r}20.9 \\
32.2 \\
6.0\end{array}$ \\
\hline Faxe & $\mathrm{Da}$ & Hvedeland, Bryozoan Limestone .......... & 214.4 & 81.7 & 38.1 & 88.5 & 41.3 & 44.2 & 20.6 \\
\hline Saltholm & $\begin{array}{l}\mathrm{E} \\
\mathrm{Fc} \\
\mathrm{Fa} \\
\mathrm{Fb}\end{array}$ & 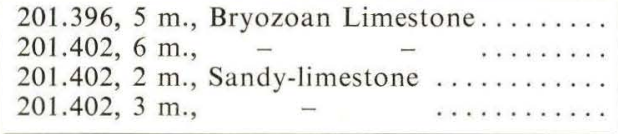 & $\begin{array}{l}189.0 \\
165.3 \\
148.0 \\
107.0\end{array}$ & $\begin{array}{r}79.7 \\
44.5 \\
68.5 \\
7.9\end{array}$ & $\begin{array}{r}42.2 \\
26.9 \\
46.3 \\
7.4\end{array}$ & $\begin{array}{r}108.6 \\
96.3 \\
32.2 \\
30.6\end{array}$ & $\begin{array}{l}57.5 \\
58.3 \\
21.8 \\
28.6\end{array}$ & $\begin{array}{r}0.7 \\
24.5 \\
47.3 \\
68.5\end{array}$ & $\begin{array}{r}0.3 \\
14.8 \\
31.9 \\
64.0\end{array}$ \\
\hline Herfølge & $\begin{array}{l}\mathrm{Ga} \\
\mathrm{Gb} \\
\mathrm{Gc} \\
\mathrm{Gd} \\
\mathrm{Ge} \\
\mathrm{Gf}\end{array}$ & 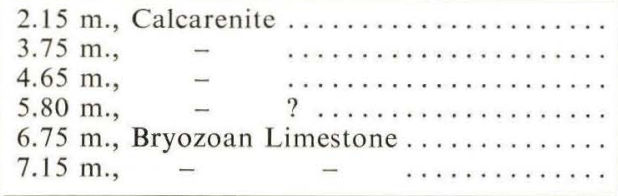 & $\begin{array}{l}196.1 \\
100.0 \\
196.0 \\
176.0 \\
257.0 \\
228.1\end{array}$ & $\begin{array}{r}173.9 \\
83.6 \\
185.7 \\
156.9 \\
223.8 \\
179.7\end{array}$ & $\begin{array}{l}88.7 \\
83.6 \\
94.7 \\
89.1 \\
87.1 \\
78.8\end{array}$ & $\begin{array}{r}21.1 \\
15.2 \\
9.2 \\
14.7 \\
29.9 \\
34.7\end{array}$ & $\begin{array}{r}10.8 \\
15.2 \\
4.7 \\
8.4 \\
11.6 \\
15.2\end{array}$ & $\begin{array}{r}1.1 \\
1.2 \\
1.1 \\
4.4 \\
3.3 \\
13.7\end{array}$ & $\begin{array}{l}0.5 \\
1.2 \\
0.6 \\
2.5 \\
0.3 \\
6.0\end{array}$ \\
\hline Klintholm & $\begin{array}{l}\mathrm{Ha} \\
\mathrm{Hb} \\
\mathrm{I}\end{array}$ & $\begin{array}{l}2.7 \text { m., Glauconitic Bryozoan Limestone } \ldots \ldots \\
3.1 \mathrm{~m} . \text {, Bryozoan Limestone } \ldots \ldots \ldots \ldots \ldots \ldots \\
\text { Heap of Bryozoan Limestone . . . . . }\end{array}$ & $\begin{array}{l}108.0 \\
160.3 \\
120.0\end{array}$ & $\begin{array}{l}23.8 \\
88.6 \\
91.9\end{array}$ & $\begin{array}{l}22.0 \\
55.3 \\
76.6\end{array}$ & $\begin{array}{l}29.9 \\
48.1 \\
19.9\end{array}$ & $\begin{array}{l}27.7 \\
30.0 \\
16.6\end{array}$ & $\begin{array}{r}54.3 \\
23.6 \\
8.2\end{array}$ & $\begin{array}{r}50.3 \\
14.7 \\
6.8\end{array}$ \\
\hline Copenhagen & $\mathrm{K}$ & Hyttehusvej, 7 m., Sandy-limestone........ & 300.0 & 205.9 & 68.6 & 11.6 & 3.9 & 82.5 & 27.5 \\
\hline $\begin{array}{l}\text { Stevns } \\
\text { (Boesdal } \\
\text { quarry) }\end{array}$ & $\begin{array}{l}\mathrm{La} \\
\mathrm{Lb} \\
\mathrm{Lc} \\
\mathrm{Ld} \\
\mathrm{Le} \\
\mathrm{Lf}\end{array}$ & 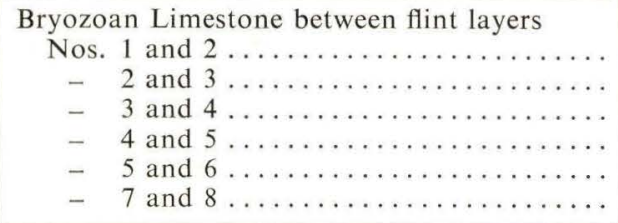 & $\begin{array}{l}162.7 \\
126.6 \\
167.9 \\
160.1 \\
159.1 \\
184.9\end{array}$ & $\begin{array}{r}138.2 \\
90.9 \\
124.6 \\
112.5 \\
109.6 \\
146.3\end{array}$ & $\begin{array}{l}84.9 \\
71.8 \\
74.2 \\
70.3 \\
68.9 \\
79.1\end{array}$ & $\begin{array}{l}20.6 \\
30.2 \\
32.2 \\
33.8 \\
37.6 \\
32.9\end{array}$ & $\begin{array}{l}12.7 \\
23.9 \\
19.2 \\
21.1 \\
23.6 \\
17.8\end{array}$ & $\begin{array}{r}3.9 \\
5.5 \\
11.1 \\
13.8 \\
11.9 \\
5.7\end{array}$ & $\begin{array}{l}2.4 \\
4.3 \\
6.6 \\
8.6 \\
7.5 \\
3.1\end{array}$ \\
\hline $\begin{array}{l}\text { Faxe } \\
\text { (North wall) }\end{array}$ & $\begin{array}{l}\mathrm{Ma} \\
\mathrm{Mb} \\
\mathrm{Mc} \\
\mathrm{Md}\end{array}$ & 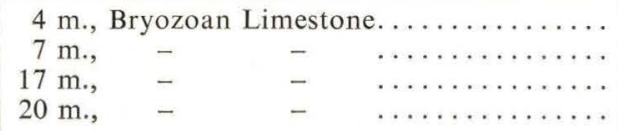 & $\begin{array}{l}187.0 \\
153.6 \\
195.6 \\
191.0\end{array}$ & $\begin{array}{l}158.6 \\
108.3 \\
132.1 \\
119.3\end{array}$ & $\begin{array}{l}84.8 \\
70.5 \\
67.5 \\
62.5\end{array}$ & $\begin{array}{l}21.9 \\
31.6 \\
25.7 \\
35.4\end{array}$ & $\begin{array}{l}11.7 \\
20.5 \\
13.1 \\
18.5\end{array}$ & $\begin{array}{r}6.5 \\
13.7 \\
37.8 \\
36.3\end{array}$ & $\begin{array}{r}3.5 \\
9.0 \\
19.3 \\
18.9\end{array}$ \\
\hline
\end{tabular}


Table 3. Analysis of the material

\begin{tabular}{|c|c|c|c|c|c|}
\hline \multirow{2}{*}{ Locality } & \multirow{2}{*}{$\begin{array}{c}\text { Symbols } \\
\text { on maps } \\
\text { etc. }\end{array}$} & \multirow{2}{*}{$\begin{array}{l}\text { Depths and characterization } \\
\text { (indications of depths in relation } \\
\text { to ground level) }\end{array}$} & \multirow{2}{*}{$\begin{array}{l}\text { Weight in } \\
\text { grammes } \\
\text { of initial } \\
\text { material }\end{array}$} & \multicolumn{2}{|c|}{$\begin{array}{l}\text { Contents of frag- } \\
\text { ments of limestone } \\
\text { and flint }\end{array}$} \\
\hline & & & & $\begin{array}{l}\text { Weight } \\
\text { in } \\
\text { grammes }\end{array}$ & $\begin{array}{l}\text { Percentage } \\
\text { of initial } \\
\text { material }\end{array}$ \\
\hline Kagstrup & $\begin{array}{l}\mathrm{Aa} \\
\mathrm{Ba} \\
\mathrm{Ca}\end{array}$ & $\begin{array}{l}\text { Bryozoan Limestone between flint layers } \\
\text { Nos. } 4 \text { and } 5 \ldots \ldots \ldots \ldots \ldots \ldots \ldots \ldots \ldots \ldots \ldots \ldots \ldots \ldots \ldots \ldots \ldots \ldots \ldots \ldots \ldots \ldots\end{array}$ & $\begin{array}{l}10 \\
10 \\
10\end{array}$ & $\begin{array}{l}3.66 \\
2.17 \\
1.48\end{array}$ & $\begin{array}{l}36.6 \\
21.7 \\
14.8\end{array}$ \\
\hline Faxe & $\mathrm{Da}$ & Hvedeland, Bryozoan Limestone .......... & 10 & 1.09 & 10.9 \\
\hline Saltholm & $\begin{array}{l}\mathrm{E} \\
\mathrm{Fc} \\
\mathrm{Fa} \\
\mathrm{Fb}\end{array}$ & $\begin{array}{l}\text { 201.396, } 5 \text { m., Bryozoan Limestone. . } \ldots \ldots \ldots \\
\text { 201.402, } 6 \text { m., }-\quad-\quad \ldots \ldots \ldots \ldots \\
\text { 201.402, } 2 \text { m., Sandy-limestone. } \ldots \ldots \ldots \ldots \ldots \\
\text { 201.402, } 3 \text { m., } \quad-\quad \ldots \ldots \ldots \ldots\end{array}$ & $\begin{array}{l}10 \\
10 \\
10 \\
10\end{array}$ & $\begin{array}{l}7.38 \\
8.83 \\
9.42 \\
9.30\end{array}$ & $\begin{array}{l}73.8 \\
88.3 \\
94.2 \\
93.0\end{array}$ \\
\hline Herfølge & $\begin{array}{l}\mathrm{Ga} \\
\mathrm{Gb} \\
\mathrm{Gc} \\
\mathrm{Gd} \\
\mathrm{Ge} \\
\mathrm{Gf}\end{array}$ & 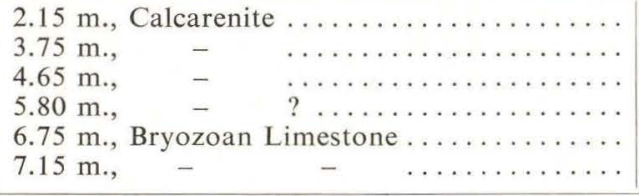 & $\begin{array}{c}10 \\
10 \\
9.2 \\
10 \\
10 \\
10\end{array}$ & $\begin{array}{r}10 \\
10 \\
6.96^{9} \\
2.70 \\
4.95\end{array}$ & $\begin{array}{l}\mathrm{g} \\
\mathrm{g} \\
18 \mathrm{~g} \\
\quad 69.6 \\
27.0 \\
49.5\end{array}$ \\
\hline Klintholm & $\begin{array}{l}\mathrm{Ha} \\
\mathrm{Hb} \\
\mathrm{I}\end{array}$ & $\begin{array}{l}2.7 \mathrm{~m} . \text {, Glauconitic Bryozoan Limestone . . . . } \\
3.1 \mathrm{~m} . \text {, Bryozoan Limestone } \ldots \ldots \ldots \ldots \ldots \ldots \\
\text { Heap of Bryozoan Limestone . . . . . . . . }\end{array}$ & $\begin{array}{l}10 \\
10 \\
10\end{array}$ & $\begin{array}{l}9.28 \\
6.47 \\
5.38\end{array}$ & $\begin{array}{l}92.8 \\
64.7 \\
53.8\end{array}$ \\
\hline Copenhagen & K & Hyttehusvej, 7 m., Sandy-limestone........ & 10 & 9.15 & 91.5 \\
\hline $\begin{array}{l}\text { Stevns } \\
\text { (Boesdal } \\
\text { quarry) }\end{array}$ & $\begin{array}{l}\mathrm{La} \\
\mathrm{Lb} \\
\mathrm{Lc} \\
\mathrm{Ld} \\
\mathrm{Le} \\
\mathrm{Lf}\end{array}$ & 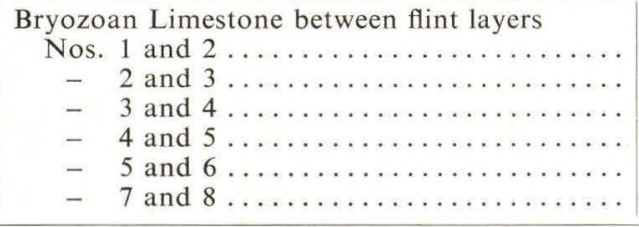 & $\begin{array}{l}5 \\
5 \\
5 \\
5 \\
5 \\
5\end{array}$ & $\begin{array}{l}0.77 \\
1.06 \\
1.27 \\
1.42 \\
1.77 \\
1.16\end{array}$ & $\begin{array}{l}15.4 \\
21.0 \\
25.4 \\
28.4 \\
35.4 \\
23.2\end{array}$ \\
\hline $\begin{array}{l}\text { Faxe } \\
\text { (North wall) }\end{array}$ & $\begin{array}{l}\mathrm{Ma} \\
\mathrm{Mb} \\
\mathrm{Mc} \\
\mathrm{Md}\end{array}$ & 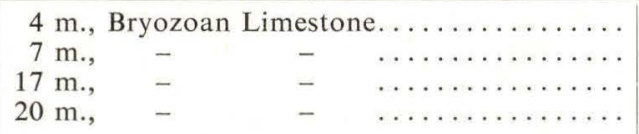 & $\begin{array}{l}5 \\
5 \\
5 \\
5\end{array}$ & $\begin{array}{l}1.16 \\
0.94 \\
2.77 \\
3.34\end{array}$ & $\begin{array}{l}23.2 \\
18.8 \\
55.4 \\
66.8\end{array}$ \\
\hline
\end{tabular}

The analysis comprises (1) identification and description of the components of rocks, (2) determination of the percentage of the components and (3) determination of grain-size distribution.

LARSEN subdivides the lime material in the following 3 categories:

(1) Matrix, i. e. limestone components, the particle size of which is smaller than $20 \mu$.

(2) Organisms larger than $20 \mu$.

(3) Inorganic grains, the size of which exceeds $20 \mu$.

On the basis of this principle of classification the samples examined may be characterized as follows: 
between 0.5 and $1.5 \mathrm{~mm}$.

\begin{tabular}{|c|c|c|c|c|c|c|c|c|}
\hline \multicolumn{2}{|c|}{$\begin{array}{l}\text { Contents of } \\
\text { other fossils }\end{array}$} & \multicolumn{3}{|c|}{$\begin{array}{c}\text { Contents of } \\
\text { Cyclostome Bryozoa }\end{array}$} & \multicolumn{3}{|c|}{$\begin{array}{c}\text { Contents of } \\
\text { Cheilostome Bryozoa }\end{array}$} & \multirow{2}{*}{$\begin{array}{l}\text { Percentage } \\
\text { share of frag- } \\
\text { ments of Cheilo- } \\
\text { stome Bryozoa } \\
\text { in the total } \\
\text { number of } \\
\text { fragments }\end{array}$} \\
\hline $\begin{array}{l}\text { Weight } \\
\text { in } \\
\text { grammes }\end{array}$ & $\begin{array}{l}\text { Percentage } \\
\text { of initial } \\
\text { material }\end{array}$ & $\begin{array}{l}\text { Weight } \\
\text { in } \\
\text { grammes }\end{array}$ & $\begin{array}{l}\text { Percentage } \\
\text { of initial } \\
\text { material }\end{array}$ & $\begin{array}{c}\text { Number } \\
\text { of } \\
\text { fragments }\end{array}$ & $\begin{array}{c}\text { Weight } \\
\text { in } \\
\text { grammes }\end{array}$ & $\begin{array}{l}\text { Percentage } \\
\text { of initial } \\
\text { material }\end{array}$ & $\begin{array}{l}\text { Number } \\
\text { of } \\
\text { fragments }\end{array}$ & \\
\hline 0 & 0 & 6.14 & 61.4 & 15213 & 0.20 & 2.0 & 328 & 2.1 \\
\hline 0.04 & 0.4 & 7.04 & 70.4 & 12940 & 0.75 & 7.5 & 1435 & 10.0 \\
\hline 0.26 & 2.6 & 7.11 & 71.1 & 11850 & 1.15 & 11.5 & 3385 & 22.2 \\
\hline 0.05 & 0.5 & 7.39 & 73.9 & 8310 & 1.47 & 14.7 & 2183 & 20.8 \\
\hline 0 & 0 & 2.44 & 24.4 & 4569 & 0.18 & 1.8 & 589 & 11.4 \\
\hline 0 & 0 & 1.00 & 10.0 & 2458 & 0.17 & 1.7 & 286 & 10.4 \\
\hline 0.04 & 0.4 & 0.40 & 4.0 & 275 & 0.14 & 1.4 & 108 & 28.2 \\
\hline 0.01 & 0.1 & 0.49 & 4.9 & 293 & 0.20 & 2.0 & 147 & 33.4 \\
\hline \multirow{2}{*}{\multicolumn{2}{|c|}{$\begin{array}{c}100 \% \\
100 \% \\
99.8 \%\end{array}$}} & & & $\begin{array}{l}0 \\
0\end{array}$ & & & $\begin{array}{l}0 \\
0\end{array}$ & \\
\hline & & 0.01 & 0.1 & 9 & 0.01 & 0.1 & 13 & 59.1 \\
\hline 0.02 & 0.2 & 2.16 & 21.6 & 2239 & 0.86 & 8.6 & 701 & 23.8 \\
\hline 0.04 & 0.4 & 5.78 & 57.8 & 4929 & 1.48 & 14.8 & 1266 & 20.4 \\
\hline 0.35 & 3.5 & 3.82 & 38.2 & 2961 & 0.88 & 8.8 & 970 & 24.7 \\
\hline 0 & 0 & 0.48 & 4.8 & 607 & 0.24 & 2.4 & 261 & 30.1 \\
\hline 0.02 & 0.2 & 2.63 & 26.3 & 3560 & 0.88 & 8.8 & 1053 & 22.9 \\
\hline 0.02 & 0.2 & 3.48 & 34.8 & 3625 & 1.12 & 11.2 & 1284 & 26.2 \\
\hline 0.66 & 6.6 & 0.03 & 0.3 & 62 & 0.04 & 0.4 & 41 & 39.8 \\
\hline 0.46 & 9.2 & 2.43 & 48.6 & 3488 & 1.34 & 26.8 & 1551 & 30.8 \\
\hline 0.10 & 2.0 & 2.41 & 48.2 & 4280 & 1.43 & 28.6 & 1650 & 27.8 \\
\hline 0.18 & 3.6 & 2.06 & 41.2 & 3085 & 1.49 & 29.8 & 2052 & 39.9 \\
\hline 0.10 & 2.0 & 1.76 & 35.2 & 2620 & 1.72 & 34.4 & 1532 & 35.3 \\
\hline 0.12 & 2.4 & 1.10 & 22.0 & 1363 & 2.01 & 40.2 & 1735 & 56.0 \\
\hline 1.98 & 39.6 & 1.04 & 20.8 & 1485 & 0.82 & 16.4 & 770 & 34.1 \\
\hline 0.56 & 11.2 & 2.36 & 47.2 & 2910 & 0.92 & 18.4 & 920 & 24.0 \\
\hline 0.30 & 6.0 & 2.42 & 48.4 & 2745 & 1.34 & 26.8 & 1171 & 29.9 \\
\hline 0.29 & 5.8 & 1.28 & 25.6 & 965 & 0.66 & 13.2 & 468 & 32.7 \\
\hline 0.31 & 6.2 & 1.22 & 24.4 & 885 & 0.13 & 2.6 & 50 & 4.4 \\
\hline
\end{tabular}

(a) The Bryozoan limestone from Faxe and Stevns and the Cerithium-limestone consist of about one third of matrix and two thirds of organisms.

(b) The Bryozoan Limestone from Herfølge consists of three fourths of matrix and one fourth of organisms.

(c) The Sandy-limestone is composed of about one third of matrix and one fourth of inorganic grains, while the rest is constituted by organisms.

(d) Calcarenite is characterized by a content of matrix of less than 10 per cent. and besides that equal amounts of inorganic grains and organisms.

The size distribution of particles larger than $20 \mu$ is shown on the graph, Fig. 29. 

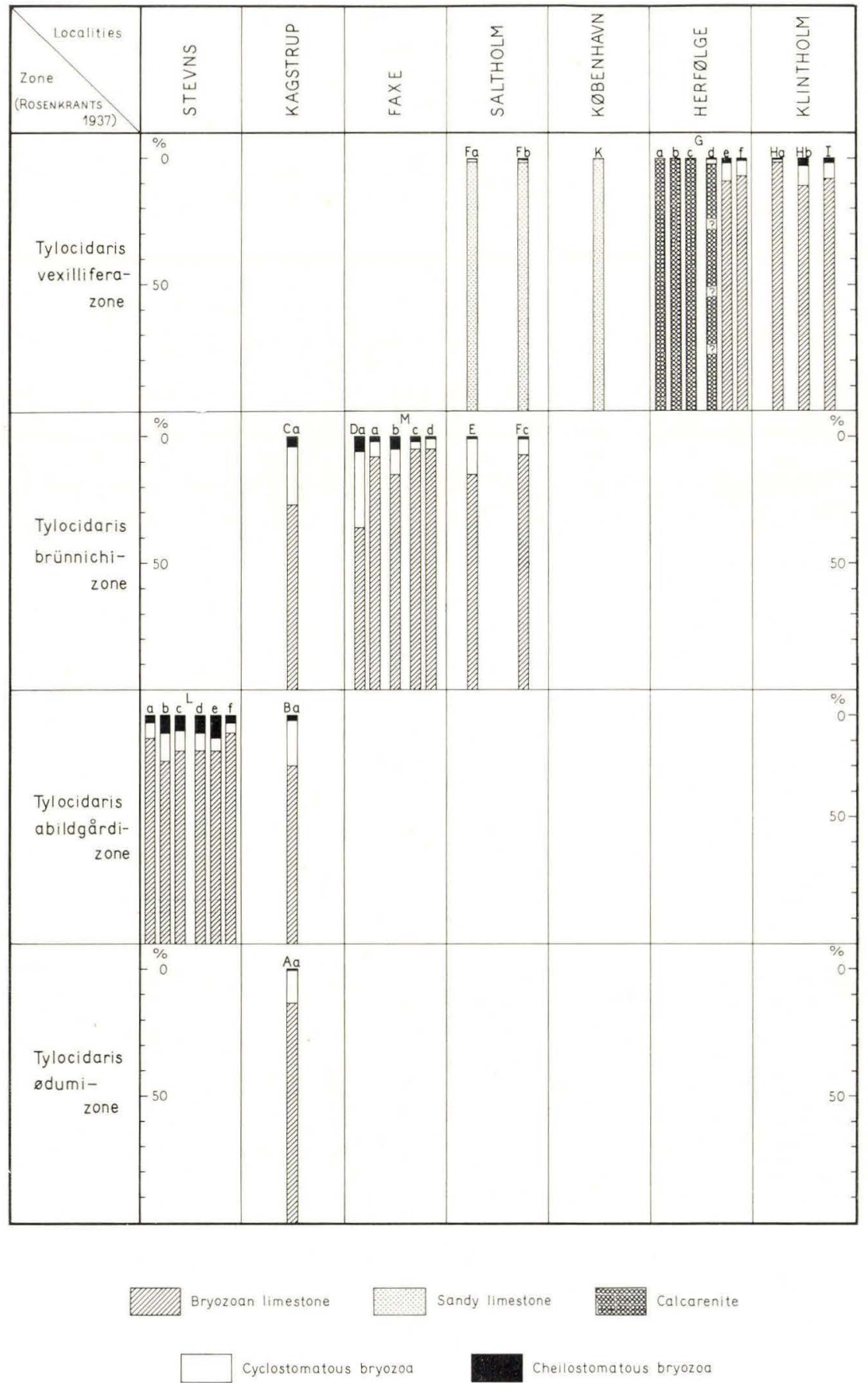

Fig. 28. Percentage distribution of limestone material, Cyclostome and Cheilostome Bryozoa in relation to localities and biostratigraphical zones. 
Table 4. Percentage distribution of limestone- and Bryozoan material

\begin{tabular}{|c|c|c|c|c|c|c|}
\hline & \multirow[b]{2}{*}{ Symbol } & \multirow{2}{*}{\multicolumn{2}{|c|}{ Rock }} & \multicolumn{3}{|c|}{ Weight per cent. } \\
\hline & & & & $\begin{array}{l}\text { Limestone } \\
\text { and } \\
\text { silt }\end{array}$ & $\begin{array}{l}\text { Cyclo- } \\
\text { stome } \\
\text { fragments }\end{array}$ & $\begin{array}{l}\text { Cheilo- } \\
\text { stome } \\
\text { fragments }\end{array}$ \\
\hline $\mathrm{Aa}$ & Kagstrup & Bryozoan Limestone & $\ldots \ldots \ldots \ldots$ & 86.5 & 13 & 0.5 \\
\hline $\mathrm{Ba}$ & - & $-\quad-$ & $\ldots \ldots \ldots$ & 80 & 18 & 2 \\
\hline $\mathrm{Ca}$ & - & - & $\ldots \ldots \ldots \ldots$ & 73 & 23 & 4 \\
\hline $\mathrm{Da}$ & Faxe, Hvedeland & - & $\ldots \ldots \ldots \ldots$ & 64 & 30 & 6 \\
\hline E & Saltholm & - & $\ldots \ldots \ldots$ & 85 & 14 & 1 \\
\hline $\mathrm{Fc}$ & - & $\begin{array}{ll}- & -\end{array}$ & $\ldots \ldots \ldots$ & 93 & 6 & 1 \\
\hline $\mathrm{Fa}$ & - & Sandy-limestone .... & $\ldots \ldots \ldots \ldots$ & 98.8 & 0.9 & 0.3 \\
\hline $\mathrm{Fb}$ & - & $-\quad \ldots \ldots$ & $\ldots \ldots \ldots$ & 98.4 & 1.0 & 0.6 \\
\hline $\mathrm{Ga}$ & Herfølge & Calcarenite........ & $\ldots \ldots \ldots$ & 100 & 0 & 0 \\
\hline $\mathrm{Gb}$ & - & $-\quad \ldots \ldots \ldots$ & $\ldots \ldots \ldots \ldots$ & 100 & 0 & 0 \\
\hline Gc & - & $\ldots \ldots \ldots$ & $\ldots \ldots \ldots$ & 100 & 0 & 0 \\
\hline $\mathrm{Gd}$ & - & $? \ldots \ldots$ & $\ldots \ldots \ldots \ldots$ & 97.3 & 2.0 & 0.7 \\
\hline $\mathrm{Ge}$ & - & Bryozoan Limestone & $\ldots \ldots \ldots$ & 91 & 7 & 2 \\
\hline Gf & - & $\begin{array}{ll}- & -\end{array}$ & $\ldots \ldots \ldots \ldots$ & 93 & 6 & 1 \\
\hline $\mathrm{Ha}$ & Klintholm & Glauconitic Bryozoan & Limestone. & 98.4 & 1 & 0.6 \\
\hline $\mathrm{Hb}$ & - & Bryozoan Limestone & $\ldots \ldots \ldots$ & 89 & 8 & 3 \\
\hline I & - & $-\quad-$ & $\ldots \ldots \ldots \ldots$ & 92 & 6 & 2 \\
\hline $\mathrm{K}$ & Copenhagen & Sandy-limestone .... & $\ldots \ldots \ldots \ldots$ & 99.98 & 0.01 & 0.01 \\
\hline $\mathrm{La}$ & Stevns & Bryozoan Limestone & $\ldots \ldots \ldots \ldots$ & 91 & 6 & 3 \\
\hline $\mathrm{Lb}$ & - & $-\quad-$ & $\ldots \ldots \ldots \ldots$ & 82 & 11 & 7 \\
\hline $\mathrm{Lc}$ & - & - & $\ldots \ldots \ldots \ldots$ & 86 & 8 & 6 \\
\hline $\mathrm{Ld}$ & - & - & $\ldots \ldots \ldots$ & 86 & 7 & 7 \\
\hline $\mathrm{Le}$ & - & - & $\ldots \ldots \ldots \ldots$ & 86 & 5 & 9 \\
\hline $\mathrm{Lf}$ & - & - & $\ldots \ldots \ldots$ & 93 & 4 & 3 \\
\hline $\mathrm{Ma}$ & Faxe & - & $\ldots \ldots \ldots$ & 92 & 6 & 2 \\
\hline $\mathrm{Mb}$ & - & - & $\ldots \ldots \ldots \ldots$ & 85 & 10 & 5 \\
\hline Mc & - & - & $\ldots \ldots \ldots$ & 95 & 3 & 2 \\
\hline $\mathrm{Md}$ & - & - & $\ldots \ldots \ldots \ldots$ & 95 & 4 & 1 \\
\hline
\end{tabular}

As a result of the investigation LARSEN concludes that the Bryozoan Limestone may be classified as an autochthonous sediment, while the Calcarenite and the Sandy-limestone are obviously clastic limestones. The sample of the Cerithium-limestone represents a transition type between the autochthonous limestones and the clastic limestones.

As shown in Table 2, the contents of silt in the Bryozoan Limestone from Herfølge are higher than those in the Bryozoan Limestone from Stevns. LARSEN's analyses has shown that the material of silt in the former limestone is the most fine-grained one. From this information it might be immediately concluded that the Herfølge limestone must have been deposited in deeper water than the limestone of Stevns. Amongst other things the distribution of the various zoarial types (see p. 240) decisively tell against such an interpretation. There can be no doubt that the assemblage of Bryozoa that lived at Herfølge developed in shallower water than the corresponding faunal assemblage at Stevns. Under these circumstances it must be supposed that the fine- 


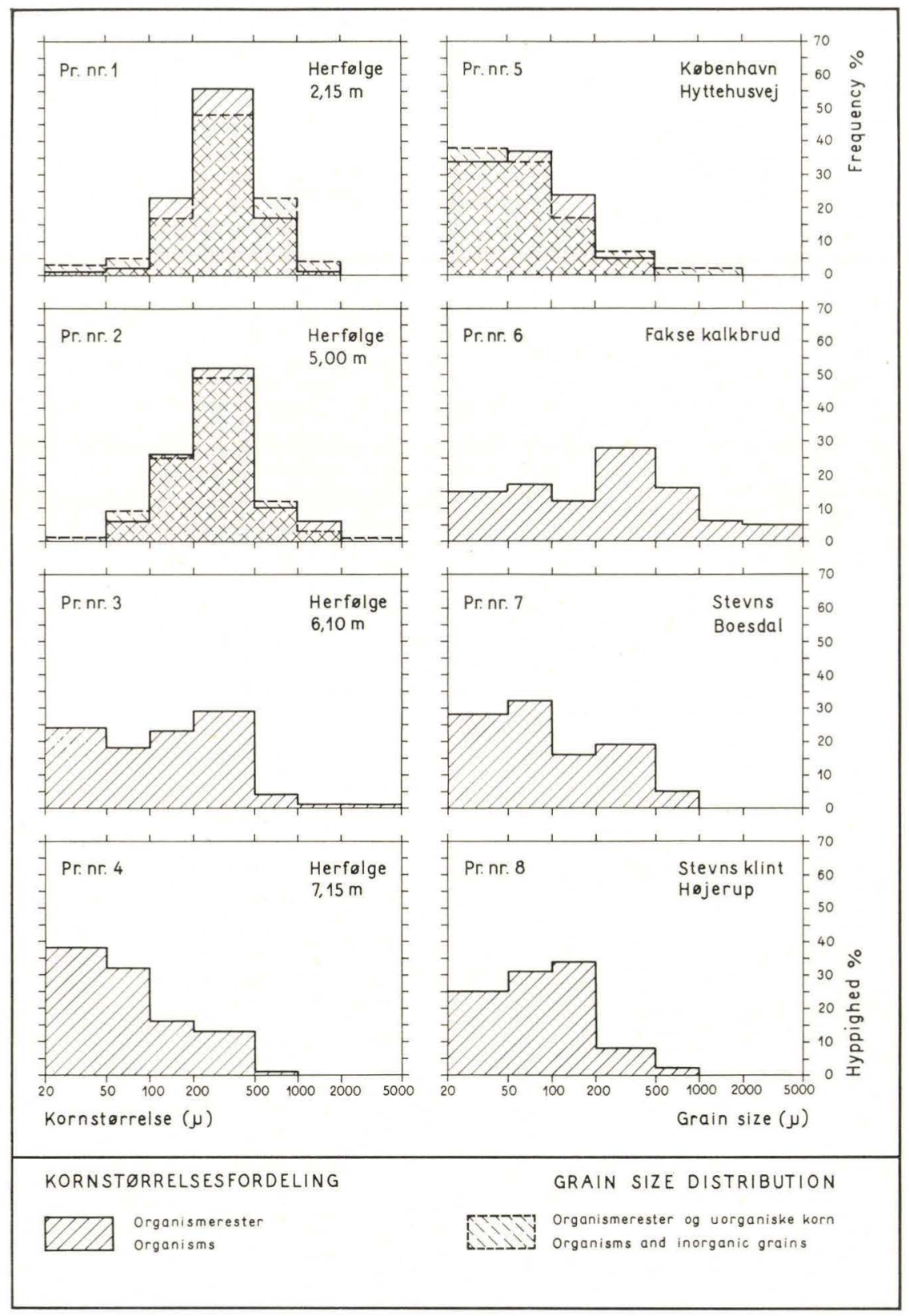

Fig. 29. The size distribution of organisms and inorganic grains larger than $20 \mu$ (LARSEN, 1961). 
grained calcareous silt was developed by chemical liberation in the uppermost layers of the water in the sea, perhaps with the co-operation of Bacteria (cf. TARR, 1925, p. 252, and HAdDING, 1933, p. 24). From ØDum's investigations into the limestone deposits in Jutland (1926, p. 221) we know that in Upper Danian there, a corresponding increase in the supply of silt took place - in ØDUM's opinion under the influence of the two factors mentioned.

BRotzen (1959, p. 19) uses the term of bioherms about the bank structures characteristic of the Bryozoan Limestone in Limhamn and Stevns. In the present writer's opinion the term of biostromes for these structures would be more correct (cf. Link, 1950, p. 263, and Pettijohn, 1949, p. 294); but the term of bioherm can advantageously be used about the Coral bank at Faxe.

To judge from the sifting analyses (Table 2), the Calcarenite at Herfølge contains only 1-2 per cent. with a grain size of more than $1.5 \mathrm{~mm}$., and according to Fig. 29 the average grain size in this limestone amounts to 200-500 $\mu$. The term of "gruskalk" ("gravel-lime") under these circumstances must be characterized as somewhat misleading. The same applies to the term of "Calcirudite" used by BERGGREN (1960, p. 188), as this name, too, refers to a coarse-grained rock. In my opinion the term of "Calcarenite" is the best substitute for "gruskalk" (cf. Sorgenfrei, 1957, p. 11). Troelsen (1957, p. 126) and BergGren (1960, p. 188) use the term of "Calcarenite" instead of Sandy-limestone ("kalksandskalk"); the term of "kalksandskalk", however, has gradually obtained a footing in Scandinavian geological literature, for which reason I do not feel called upon to make a change. It is a different matter that we perhaps through sediment-petrographical investigations ought to try to have it substantiated whether the term of "Sandy-limestone" ("kalksandskalk") perhaps may cover several rocks, especially whether the limestone on Saltholm, which, as mentioned above, was previously (by RøRDAM and others) termed "Coccolith-limestone", is identical with the limestone in the Copenhagen area (RøRDAM’s Foraminiferal Limestone). The contents of Bryozoa in the limestone on Saltholm seems to be higher than those in the Sandy-limestone under Copenhagen.

\section{Paleo-ecological Evaluation.}

The conditions under which the paleo-ecological research of Bryozoa work, can best be illustrated by means of a quotation from HELEN DUNCAN (1957, p. 783):

"The student who attempts to utilize the bryozoa for paleo-ecologic interpretations is immediately struck by the dearth of concrete information that would be generally applicable and essential lack of detailed observations on environmental factors and biological associations that should be provided by careful stratigraphic studies. The farther one goes back in the geologic record, the more meager reliable information becomes."

Within this sphere one must mainly extend one's knowledge on the basis of 
the information that can be obtained through comparisons with the habits and distribution of recent Bryozoa, but here, too, there are difficulties, because so far little attention has been given to the ecology of this animal group (cf. OSBURN, 1957, p. 1109).

Under such circumstances there are of course limits to the extent to which conclusions can be drawn regarding the environmental conditions in the Danian sea in which the Bryozoa lived, but a few clues concerning their vital conditions can be mentioned.

Bottom conditions. The chief basis of the formation of Bryozoan colonies is that bottom conditions make it possible for the Bryozoan larvae after the free stage to fasten to the bottom or to fixed objects on it and start the development of the colony. The optimal biotope has a irregular bottom relief, a well-developed vegetation of algae and/or a rich benthonic macrofauna. As an example of such an ideal station the Coral bank at Faxe can be mentioned. A muddy or sandy bottom does not offer the Bryozoan larvae the necessary possibilities of fastening, which is no doubt the explanation of the fact that neither the Cerithium-limestone nor the Calcarenite contains an appreciable number of Bryozoan fragments, and that the fauna in the Sandy-limestone is characterized by scarcity of individuals and species. According to STACH $(1937$, p. 8) larvae of the lunulitiform species are capable of encrusting sand grains. An example of this is the cupshaped Lunulites saltholmensis n.sp., which especially seems to be connected with deposits of Sandy-limestone. As mentioned above, the rich Bryozoan fauna at Faxe suggests that there were particularly good conditions of growth for the Bryozoa there. This fact, in so far, is remarkable as in the seas of the present time Bryozoa are extremely rarely found on the same biotope as Corals and Hydrocorals, partly because the corals eat the freeswimming Bryozoan larvae, partly because the animal groups mentioned are competitors for nourishment. The explanation of this is perhaps that there may be an alternation in the growth of Corals and Bryozoa, so that the Bryozoan larvae have been able to utilize the dead Coral stems as objects on which to fasten. This is, however, a problem requiring closer investigations.

Conditions of depth. The bathymetrical conditions of the Danian sea are a subject which has occupied Danish and Swedish geologists for many years.

In RøRDAM's opinion (1897, p. 85) the Coral-reef Limestone was deposited at a low depth near the land or on a shallow in the sea, while the Coccolithlimestone developed at great depths ("on the bottom of the open sea"). Bryozoan Limestone and Foraminiferal Limestone developed at intermediary depths so that the former was deposited at lower water than the latter.

HeNnig (1899, p. 116) compares the Bryozoan Limestone with recent Bryozoan banks off Florida and Prince Edward's Island, and on this basis deems that the Bryozoa of the Danian lived at a depth of 100-150 fathoms.

In RAVN's opinion (1903, p. 421) the "Blegekridt" and typical Saltholm Limestone were deposited in comparatively deep water, whereas it may be 
difficult to decide the conditions of depths on which the Bryozoan Limestone and the Coral-reef limestone were formed. The Crania-limestone must have been deposited in shallow water, - must perhaps even be considered a beach formation.

Milthers (1908, p. 60) shares RAvN's view as regards the Crania-limestone, as he thinks that he has observed a distinct stratification which may be the result of ripple activities. The Bryozoan Limestone was deposited at depths between 200 and $600 \mathrm{~m}$.

Rosenkrantz (1920, p. 61) also characterizes the Crania-limestone as a shallow-water formation. This view is supported by the unhardened layers of limestone sand alternating with indurated layers.

Troedsson (1923, p. 560) has described a crocodile, Thoracosaurus scanicus Troedsson, from the Bryozoan Limestone at Limhamn. On the basis of the placing of the skeletal parts in the limestone and the presence of gastroliths Troedsson concluded that the Bryozoan Limestone in which the fossil was embedded, was deposited in shallow water, perhaps even as a littoral formation.

Voigt $(1925$, p. 85$)$ estimates the depth of the Danian sea at 80 to $150 \mathrm{~m}$. on the basis of the frequent occurrence of a Cyclostome species, Mecynoecia proboscidea M. EDw., which in the seas of the present time lives within this depth range.

ØDum (1926, p. 223) was the first to view the conditions of depth of the Danian sea in a stratigraphical perspective. In his opinion the depth of the sea was greatest in Lower Danian, while at the beginning of Zone $\mathrm{C}$ an upheaval of the sea bottom set in which culminated at the end of the Danian period. In ØDum's view the Coccolith-limestone was deposited in shallower water than the Bryozoan Limestone.

In certain respects the Vincentown formation in New Jersey has features in common with Upper Danian in Denmark. On the basis of the Bryozoan fauna (especially representatives of the genus Allantopora) CANU and BASSLER (1933, p. 24) estimate that the fossils in this formation must have been deposited at a depth of at least $90 \mathrm{~m}$.

About the evidence of the Corals HadDing says (1941, p. 126): "The Danian reefs have considerably greater connection with Tertiary and Quaternary reefs than with Paleozoic ones, and they have their nearest recent analogy in coral beds at a depth of 100-300 m."

According to OsBuRn (1957, p. 1109) Bryozoa may occur at all depths from the coast down to a depth of more than $5000 \mathrm{~m}$., but the great majority of species are restricted to the comparatively shallow water of the Continental shelf between the tidal limit and 200-300 m. (the sublittoral zone). According to MARcus (1921) the great majority of recent Bryozoan species occur above the $60 \mathrm{~m}$. curve.

STACH (1936, pp. 60-65, and 1937, pp. 80-83) has examined the zoarial forms of the Cheilostome Bryozoa. He has succeeded in distinguishing 9 zoarial types 
and to demonstrate a distinct connexion between the various types and their environment, so that these zoarial types can be used as an aid at the evaluation of the bathymetrical conditions.

STACH divides the nine types into two groups:
A. Stable forms
1. Petraliform
B. Unstable forms
2. Reteporiform
7. Membraniform
3. Cellariform
8. Vinculariform
4. Catenicelliform
9. Eschariform
5. Flustriform
6. Lunulitiform

The stable zoarial forms "are restricted to definite habitats," whereas the unstable zoarial types "are capable of modifying their zoarial form to suit the conditions imposed upon them by their environment. The nature of the substratum is the principal factor that controls the occurrence of the stable forms. Depth and degree of agitation of the water are the factors that affect the development of different forms of zoaria in the unstable group."

Types 1-5 are littoral forms and are completely missing from the deposits of the Danian. StACH characterizes the other types as follows:

6. Lunulitiform. Zoarium free, hollow-conical, the zooecia opening on the outer face; from their present-day occurrences they are restricted to sandy bottoms where current action is strong, their upper limit being about 15 fathoms ( $35 \mathrm{~m}$.).

7. Membraniform. Unilaminate zoaria whose entire basal lamina is attached to the substratum. They are mainly limited to the littoral and sublittoral zones.

8. Vinculariform. Zoarium attached, consisting of erect, rigid, subcylindrical branches. The narrow branches of the non-articulate colony are adapted for life in deep or sheltered waters where wave action is absent and currents scarcely are active. This group typifies growth in quiet waters.

9. Eschariform. Zoarium bilaminate, foliaceous; attached to the substratum either by radicles or direct adherence. This type is adapted for life in sublittoral zones of at least 10 fathoms $(20 \mathrm{~m}$.). The Zoarium is strongly calcified and usually has a rigid basis of attachment. It may extend to deeper water, but not to the littoral zone.

The genus Lunulites is represented by two species in the Danian, viz. $L$. faxensis LEv. and L. saltholmensis n.sp., but only the latter is lunulitiform. It mainly occurs in Sandy-limestone, where, however, it is fairly rare, while the discoidal $L$. faxensis is common in the Bryozoan Limestone.

Thus it is the representatives of the unstable group, i. e. the membraniform, vinculariform, and eschariform zoarial types which characterize the Danian. The percentage distribution of these forms in the samples examined is shown 
in Table 5. From this table it appears that the eschariform type is almost completely absent from Lower Danian, while it plays a more significant part in Upper Danian, - evidence of the fact that the sea depth was greatest during the depositing of the Bryozoan Limestone of Lower Danian. In the two uppermost samples from Herfølge, in the sample of Sandy-limestone from Copenhagen, and in the lowermost sample from the north wall in the quarry at Faxe, the eschariform type dominates over the vinculariform one, which presumably indicates that the limestones represented by these samples were deposited in comparatively shallow water.

Among the Bryozoa of the Danian there are also instances of different zoarial types in the same species. In Pachythecella anhaltina Voigt (Plate 25, Figs. 1-3) the colonies in the Stevns and Kagstrup material are vinculariform, the zoaria from Faxe and Thorslunde are eschariform, while the fragments from Herfølge have "flabelliform" zoaria. Correspondingly the colonies from Stevns of Puncturiella sculpta D'ORB. are vinculariform, while the specimens from Herfølge are "flabelliform" (Plate 17, Figs. 1-2). The "flabelliform" type perhaps indicates a smaller depth of water than the eschariform type.

The maximum depth in the Danian sea perhaps was $100-150 \mathrm{~m}$. This is suggested by the wealth of fragments of Mecynoecia proboscidea M. EDw. in the material from the $T$. odumi zone. According to Vorgt $(1925$, p. 85) this species in the seas of the present time occurs at a depth of $80-150 \mathrm{~m}$.

Conditions of temperature. The Bryozoa are rather tolerant as regards temperature variations and therefore have been unable to contribute to the solution of the problem of conditions of temperature in the Danian sea. In this connexion it should, however, be mentioned that it has been tried to elucidate this problem by different means.

HeNNIG $(1899$, p. 126) fastened upon the great wealth of Coccoliths in the Danian deposits. In the present time Coccoliths only occur in marine areas the lowest surface temperature of which is about $8^{\circ} \mathrm{C}$. Another characteristic feature in the order of strata of the Danian is the absence of Rhabdoliths in the calcareous sediments. In our time Rhabdoliths are found in warm seas in which the temperature does not fall below $18^{\circ} \mathrm{C}$. From these facts Hennig concluded that the Danian rocks were deposited in a sea the surface temperature of which was between 8 and $18^{\circ} \mathrm{C}$.

In ØDuM's opinion (1926, p. 221) the Danian sea was a tropical or subtropical inland sea.

CANU and BASSLER (1933, p. 25) state that the temperature in the sea in which the fauna of the Vincentown formation lived, was about $20^{\circ} \mathrm{C}$. As mentioned above, this deposit has many points in common with the layers of Upper Danian in Denmark.

LOWENSTAM and EPSTEIN (1954, p. 246) used the oxygen isotope method for temperature measurings of i.a. fossils from Faxe. They conclude that the Danian climate presumably was very similar to that prevailing during the 
Table 5. Percentage distribution of zoarial types

\begin{tabular}{|c|c|c|c|c|c|c|c|c|c|c|c|}
\hline \multirow[b]{2}{*}{ Zone } & \multirow{2}{*}{\multicolumn{2}{|c|}{ Symbol }} & \multirow{2}{*}{\multicolumn{2}{|c|}{ Rock }} & \multirow{2}{*}{$\begin{array}{l}\text { Number of } \\
\text { Cheilostome } \\
\text { fragments }\end{array}$} & \multicolumn{2}{|c|}{ Membraniform } & \multicolumn{2}{|c|}{ Vinculariform } & \multicolumn{2}{|c|}{ Eschariform } \\
\hline & & & & & & $\begin{array}{c}\text { Number } \\
\text { of } \\
\text { fragments }\end{array}$ & Percentage & $\begin{array}{l}\text { Number } \\
\text { of } \\
\text { fragments }\end{array}$ & Percentage & $\begin{array}{l}\text { Number } \\
\text { of } \\
\text { fragments }\end{array}$ & Percentage \\
\hline $\begin{array}{l}\text { The Tylocidaris } \\
\text { vexillifera } \\
\text { zone }\end{array}$ & $\begin{array}{l}\mathrm{Gd} \\
\mathrm{Ge} \\
\mathrm{Gf} \\
\mathrm{Ha} \\
\mathrm{Hb} \\
\mathrm{I} \\
\mathrm{K} \\
\mathrm{Fa} \\
\mathrm{Fb}\end{array}$ & $\begin{array}{l}\text { Herfølge } \\
\quad- \\
- \\
\text { Klintholm } \\
- \\
- \\
\text { Copenhagen } \\
\text { Saltholm } \\
\text { - }\end{array}$ & 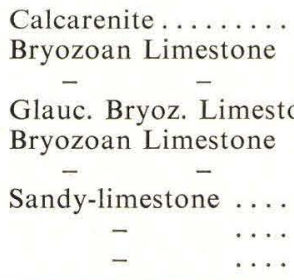 & $\begin{array}{l}\ldots \ldots \ldots \\
\ldots \ldots \ldots \\
\ldots \ldots \ldots \\
\text { one } \ldots \ldots \\
\ldots \ldots \ldots \\
\ldots \ldots \ldots \\
\ldots \ldots \ldots \\
\ldots \ldots \ldots\end{array}$ & $\begin{array}{r}701 \\
1266 \\
970 \\
261 \\
1053 \\
1284 \\
41 \\
108 \\
147\end{array}$ & $\begin{array}{r}66 \\
202 \\
113 \\
53 \\
226 \\
349 \\
0 \\
5 \\
15\end{array}$ & $\begin{array}{r}9 \\
16 \\
12 \\
20 \\
21 \\
27 \\
0 \\
5 \\
10\end{array}$ & $\begin{array}{r}301 \\
460 \\
496 \\
139 \\
702 \\
528 \\
18 \\
68 \\
103\end{array}$ & $\begin{array}{l}43 \\
36 \\
51 \\
53 \\
67 \\
41 \\
44 \\
63 \\
70\end{array}$ & $\begin{array}{r}334 \\
604 \\
361 \\
69 \\
125 \\
407 \\
23 \\
35 \\
29\end{array}$ & $\begin{array}{l}48 \\
48 \\
37 \\
27 \\
12 \\
32 \\
56 \\
32 \\
20\end{array}$ \\
\hline $\begin{array}{l}\text { The Tylocidaris } \\
\text { brünnichi } \\
\text { zone }\end{array}$ & $\begin{array}{l}\mathrm{E} \\
\mathrm{Fc} \\
\mathrm{Da} \\
\mathrm{Ma} \\
\mathrm{Mb} \\
\mathrm{Mc} \\
\mathrm{Md} \\
\mathrm{Ca}\end{array}$ & $\begin{array}{l}\text { Saltholm } \\
- \\
\text { Faxe } \\
- \\
- \\
- \\
- \\
\text { Kagstrup }\end{array}$ & 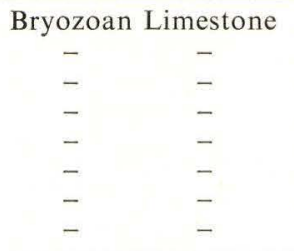 & $\begin{array}{l}\ldots \ldots \ldots \\
\ldots \ldots \ldots \\
\ldots \ldots \ldots \\
\ldots \ldots \ldots \\
\ldots \ldots \ldots \\
\ldots \ldots \ldots \\
\ldots \ldots \ldots \\
\ldots \ldots \ldots\end{array}$ & $\begin{array}{r}589 \\
286 \\
2183 \\
920 \\
1171 \\
468 \\
50 \\
3385\end{array}$ & $\begin{array}{r}59 \\
31 \\
363 \\
158 \\
142 \\
151 \\
17 \\
354\end{array}$ & $\begin{array}{l}10 \\
11 \\
17 \\
17 \\
11 \\
33 \\
34 \\
10\end{array}$ & $\begin{array}{r}475 \\
232 \\
1570 \\
611 \\
717 \\
184 \\
13 \\
2995\end{array}$ & $\begin{array}{l}81 \\
81 \\
72 \\
67 \\
62 \\
39 \\
26 \\
89\end{array}$ & $\begin{array}{r}55 \\
23 \\
250 \\
149 \\
312 \\
133 \\
20 \\
33\end{array}$ & $\begin{array}{r}9 \\
8 \\
11 \\
16 \\
27 \\
28 \\
40 \\
1\end{array}$ \\
\hline $\begin{array}{l}\text { The Tylocidaris } \\
\text { abildgaardi } \\
\text { zone }\end{array}$ & $\begin{array}{l}\mathrm{Ba} \\
\mathrm{La} \\
\mathrm{Lb} \\
\mathrm{Lc} \\
\mathrm{Ld} \\
\mathrm{Le} \\
\mathrm{Lf}\end{array}$ & $\begin{array}{l}\text { Kagstrup } \\
\text { Stevns } \\
- \\
- \\
- \\
- \\
-\end{array}$ & $\begin{array}{cc}\text { Bryozoan } & \text { Limestone } \\
- & - \\
- & - \\
- & - \\
- & - \\
- & - \\
- & -\end{array}$ & $\begin{array}{l}\ldots \ldots \ldots \\
\ldots \ldots \ldots \\
\ldots \ldots \ldots \\
\ldots \ldots \ldots \\
\ldots \ldots \ldots \\
\ldots \ldots \ldots\end{array}$ & $\begin{array}{r}1435 \\
1551 \\
1650 \\
2052 \\
1532 \\
1735 \\
770\end{array}$ & $\begin{array}{l}651 \\
307 \\
585 \\
562 \\
467 \\
383 \\
132\end{array}$ & $\begin{array}{l}46 \\
20 \\
36 \\
28 \\
30 \\
22 \\
18\end{array}$ & $\begin{array}{r}780 \\
1243 \\
1064 \\
1490 \\
1064 \\
1352 \\
631\end{array}$ & $\begin{array}{l}54 \\
80 \\
64 \\
72 \\
70 \\
78 \\
81\end{array}$ & $\begin{array}{l}4 \\
1 \\
1 \\
0 \\
1 \\
0 \\
7\end{array}$ & $\begin{array}{l}0.2 \\
0.06 \\
0.06 \\
0 \\
0.06 \\
0 \\
1\end{array}$ \\
\hline $\begin{array}{l}\text { The Tylocidaris } \\
\text { odumi zone }\end{array}$ & Aa & Kagstrup & Bryozoan Limestone & $\ldots \ldots \ldots$ & 328 & 38 & 12 & 290 & 88 & 0 & 0 \\
\hline
\end{tabular}


Maastrichtian period, and that the sea temperature, if this interpretation is correct, was close to HenNiG's upper limit, i. e. about $18^{\circ} \mathrm{C}$.

Conditions of current and supply of nourishment. According to HENNIG (1899, p. 119) a sea current rich in nutrients, a "Gulf Stream", which was constant for a prolonged period, flowed over Faxe in the Danian period. This theory was rejected by RAVN (1903, p. 421), but has recently been resumed by RoSENKRANTZ $(1960$, p. 197) to explain the sudden invasion in Middle Danian of Cephalopods and Tertiary Gastropod genera.

According to CANU and BASSLER (1933, p. 78) the avicularia increase in number and size in deep and calm water. The task of these avicularia is that of providing for a constant renewal of the water so that sufficient quantities of nourishment can be supplied. It has not been possible to demonstrate any differences in the number and size of avicularia within the Bryozoan fauna of Lower and Upper Danian, perhaps because the variations in depth were too small.

Salinity. On this point Bryozoa are rather tolerant. A salinity of 3.5 per cent. seems to be the normal for the development of most Bryozoa. Below 2.0 per cent. the number of genera and species soon decreases.

Measurements. As an element of the investigations the sizes of the cells have also been taken up for evaluation, from a wish to elucidate possible variations in the measures of the species occurring either (1) in the Senonian as well as the Danian, or (2) in Lower as well as Upper Danian. Unfortunately the Senonian material is rather slight, comprising exclusively specimens from the White Chalk of Møn.

The zoarial width in the vinculariform and eschariform colonies is subject to some variation. A comparison of the width of the stems in the species occurring in the Senonian as well as the Danian, shows that the zoarial width is smaller in the Senonian specimens of "Membranipora" marssoniana VorgT and Pithodella cincta Marsson than in the Danian specimens of these species, while the inverse ratio is found in Porina salebrosa Marsson. Regarding a comparison of the zoarial width of the species occurring in all the zones of the Danian, it may as the principal rule be said that the specimens from Herfølge have the greatest width of stems, while the slenderest stems are found among the material from Kagstrup. An exception from this rule is a group of species, including Coscinopleura angusta BERTHELSEN and Beisselinopsis oblita KADE, which in the Sandy-limestone have developed particularly vigorous stems. Voigt (1956, p. 48) has demonstrated a corresponding development in forms from the Sandy-limestone of Voldum in Jutland. In his opinion the coarse stems are expressive of particularly favourable conditions of life. I am, however, rather inclined to believe that the environmental conditions during the depositing of the Sandy-limestone have impeded the possibilities of development of the Bryozoa, and that especially an increased water movement necessitated the formation of more vigorous stems.

16 
A comparison of the lengths of zooecia in species appearing both in the Senonian and in the Danian shows that the length of zooecium as a rule is greatest in the Senonian specimens. Among the species found only in the Danian measurements have been made on 56 occurring in more than one locality. 11 of these species had stable measures, while in the case of the remaining species there might be rather great variations regarding the measures of the different cell types and apertures. As a principal rule it may be inferred from this numerical material that cells and apertures are largest in the specimens from Upper Danian. An examination of 16 species common to all localities thus yielded the following results:

Longest zooecia :

Herfølge .... 7 species

Herfølge-Faxe.. 3 -

Faxe........ 4 -

Faxe-Stevns.... 1 -

Stevns ...... 1 -
Shortest zooecia :

Kagstrup-Stevns . 6 species

Stevns-Faxe .... 3 -

Stevns-Herfølge . . 1 -

Faxe......... 1 -

Saltholm ....... 1 -

Faxe-Herfølge ... 1 -

Herfølge ...... 3 -

Thus there seems to be a tendency towards increase in size of cells and aperturcs by decreasing depth of water.

\section{Faunistic Evaluation.}

As mentioned above, the stratigraphical investigations also included specific determination of the fragments of Cheilostome Bryozoa in the samples taken and the registration of the number of colonies of the species identified. The results of this section of the stratigraphical analysis are grouped in Table 6 . The localities are arranged in stratigraphical succession, beginning with Kagstrup and with Klintholm as the last locality.

The next step was that of trying to find the characterizing species of the localities and biozones. To elucidate this problem the percentage share of the number of fragments in the total number of fragments in the samples was calculated for each species. The dominant species, i.e. the forms which in one of the samples examined constituted at least 10 per cent. of the total number of Cheilostome colonies in the sample are arranged in Table 7 . The table furthermore shows the number of Cheilostome species in the samples.

The Tylocidaris odumi zone. The fauna includes twenty species, four of which are absolutely dominant, viz. Floridina gothica D'OrB., Onychocella columella n.sp., Membranipora sparsispina VoIGT, and Columnotheca cribrosa MARSS. 


\section{Table 6}

\section{Kagstrup.}

Numbers of Bryozoan fragments in $10 \mathrm{~g}$ material.

$$
\begin{aligned}
& \mathrm{Aa}=\text { Sample of Bryozoan Limestone between flint layers Nos. } 4 \text { and } 5 \text { ( } T \text {. odumi zone) }
\end{aligned}
$$

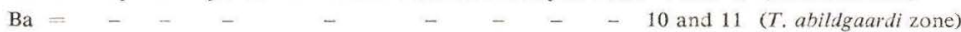

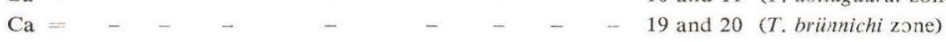

\begin{tabular}{|c|c|c|c|c|}
\hline No. & Species & Aa & $\mathrm{Ba}$ & $\mathrm{Ca}$ \\
\hline 1 & "Membranipora" hexagona (v. HaGENOW) ......... & . & . & 6 \\
\hline 3 & - plicatelloides n.sp. .................... & $\dot{0}$ & 5 & . \\
\hline 5 & - sparsispina VorGT. . . . . . . . . . . . . . . & 52 & . & . \\
\hline 8 & - marssoniana Vorgt ................... & 9 & 9 & 23 \\
\hline 12 & Vincularia prismatica (v. HaGenow) $\ldots \ldots \ldots \ldots$ & 1 & 78 & 40 \\
\hline 13 & "Herpetopora" danica LANG .................. & $\cdot$ & 5 & . \\
\hline 17 & 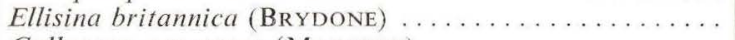 & 12 & 8 & 1 \\
\hline 18 & Callopora monocera (MARSSON) . . . . . . . . . . . . & 6 & 10 & 10 \\
\hline 23 & 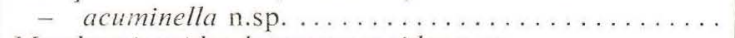 & $\cdot$ & . & 4 \\
\hline 28 & 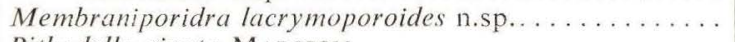 & $\dot{2}$ & 1 & 1 \\
\hline 30 & Pithodella cincta MARSSON . . . . . . . . . . . . . . . & 3 & 97 & 89 \\
\hline 32 & Amphiblestrum elegans faxensis (LEVINSEN) . . . . . . . . . & . & $\cdot$ & 631 \\
\hline 32 & - elegans (v. HAG.), discoidal form ............ & . & 61 & 7 \\
\hline 33 & Stamenocella pristis (LEVINSEN) . . . . . . . . . . . . & . & 2 & 5 \\
\hline 36 & Onychocella gimense (BRYDONE) $\ldots \ldots \ldots \ldots \ldots$ & . & 1 & ; \\
\hline 37 & 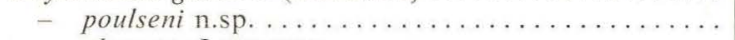 & . & . & 1 \\
\hline 39 & 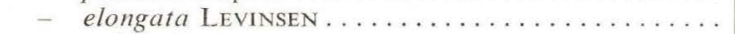 & . & . & 1 \\
\hline 40 & 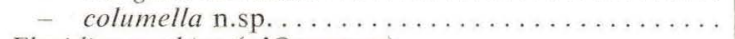 & 72 & 121 & 193 \\
\hline 41 & 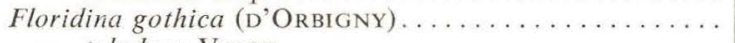 & 78 & 90 & 56 \\
\hline 42 & 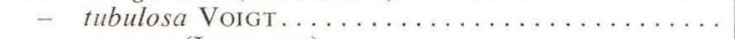 & 1 & . & 18 \\
\hline 46 & $-\operatorname{scutata}($ LEVINSEN) $\ldots \ldots \ldots \ldots \ldots \ldots \ldots$ & . & . & 3 \\
\hline 48 & 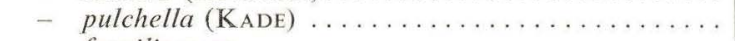 & . & $\cdot$ & 2 \\
\hline 50 & 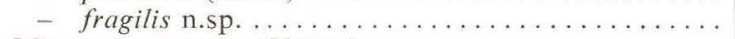 & . & 345 & 228 \\
\hline 53 & 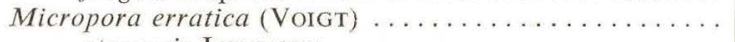 & 2 & 21 & 18 \\
\hline 55 & 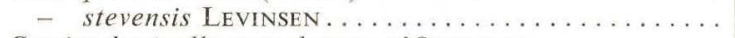 & 1 & 7 & 1 \\
\hline 56 & Semiescharinella complanata D'ORBIGNY ........... & 2 & 97 & 34 \\
\hline 58 & 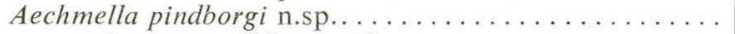 & 8 & 83 & 11 \\
\hline 60 & - microstoma (MARSSON) $\ldots \ldots \ldots \ldots \ldots \ldots \ldots \ldots$ & 2 & 31 & 612 \\
\hline 61 & 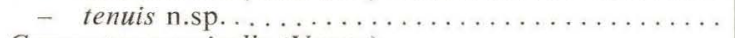 & . & . & 833 \\
\hline 64 & Gargantua parvicella (VoIGT) $\ldots \ldots \ldots \ldots \ldots \ldots$ & . & 1 & 2 \\
\hline 67 & 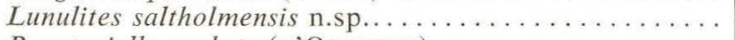 & $\dot{s}$ & $\therefore$ & 3 \\
\hline 68 & Puncturiella sculpta (D'ORBIGNY) . . . . . . . . . . . & 2 & 59 & 7 \\
\hline 70 & Coscinopleura angusta angusta BertheLSEN. . . . . . . . & . & 3 & 12 \\
\hline 75 & Pliophloea subcornuta n.sp. . . . . . . . . . . . . . . & . & 1 & . \\
\hline 80 & Monoceratopora quadrisulcata (HenNIG) ............ & ; & 2 & . \\
\hline 82 & 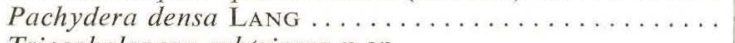 & 1 & $\dot{s}$ & . \\
\hline 85 & Tricephalopora subtriceps n.sp. ............... & . & 2 & : \\
\hline 90 & Diacanthopora bispinosa LANG . . . . . . . . . . . . & . & . & 1 \\
\hline 98 & 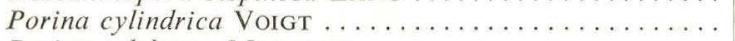 & $\dot{s}$ & 10 & 11 \\
\hline 99 & Porina salebrosa MARSSON .................. & 7 & 37 & 44 \\
\hline 104 & Pachythecella anhaltina (VorGT) ............... & . & 16 & 19 \\
\hline 105 & 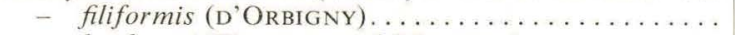 & . & . & 1 \\
\hline 106 & - lundgreni (Pergens and Meunier) . . . . . . . . . & 16 & 46 & 148 \\
\hline 107 & 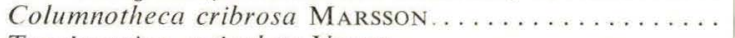 & 48 & 38 & 36 \\
\hline 108 & Taenioporina articulata VorGT . . . . . . . . . . . . . & . & 35 & 23 \\
\hline 111 & Systenostoma verticillata LEVINSEN . . . . . . . . . . . . & . & 2 & 1 \\
\hline 113 & Mucronella hians HenNig. .................. & . & 1 & . \\
\hline 116 & Cellepora daniensis VoIGT . . . . . . . . . . . . . . & 1 & 1 & 2 \\
\hline
\end{tabular}


Table 6 (continued).

\section{Boesdal, Stevns.}

Numbers of Bryozoan fragments in $5 \mathrm{~g}$ material.

$$
\begin{array}{llllllll}
\mathrm{La} & = & \text { Bryozoan Limestone between flint layers Nos. } 1 \text { and } 2 \\
\mathrm{Lb}= & - & - & - & - & - & - & 2 \text { and } 3 \\
\mathrm{Lc}= & - & - & - & - & - & - & 3 \text { and } 4 \\
\mathrm{Ld}= & - & - & - & - & - & - & 4 \text { and } 5 \\
\mathrm{Le}= & - & - & - & - & - & - & 5 \text { and } 6 \\
\mathrm{Lf} & = & - & - & - & - & - & -
\end{array}
$$

\begin{tabular}{|c|c|c|c|c|c|c|c|}
\hline No. & Species & $\mathrm{La}$ & $\mathbf{L b}$ & Lc & Ld & Le & Lf \\
\hline 3 & "Membranipora" plicatelloides n.sp......... & . & 3 & . & 3 & 1 & 2 \\
\hline 5 & - sparsispina VoIGT. . . . . . . . . . . . & 48 & 45 & 90 & 68 & 93 & 29 \\
\hline 8 & - marssoniana VoIGT .............. & 3 & 8 & 4 & 15 & 20 & 3 \\
\hline 12 & Vincularia prismatica (v. HAG.). . . . . . . & 126 & 109 & 173 & 129 & 132 & 19 \\
\hline 14 & Aplousina fulgora (BRYD.) . . . . . . . . & 2 & 2 & 5 & 2 & 4 & . \\
\hline 15 & 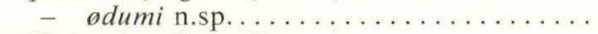 & . & . & . & . & 3 & 1 \\
\hline 16 & Ellisina humiliata (BRYD.). . . . . . . . & . & . & . & 2 & . & . \\
\hline 17 & - britannica (BRYD.).............. & 12 & 11 & 9 & 9 & 13 & 4 \\
\hline 18 & Callopora monocera MARs.............. & 1 & 4 & 1 & 4 & 3 & . \\
\hline 23 & - acuminella n.sp................. & 5 & 6 & 7 & 9 & 7 & 1 \\
\hline 30 & Pithodella cincta (MARs.) . . . . . . . . . & 223 & 97 & 134 & 139 & 99 & 66 \\
\hline 32 & Amphiblestrum elegans (v. HAG.) ......... & 44 & 51 & 81 & 30 & 23 & 12 \\
\hline 33 & Stamenocella pristis (LEv.) . . . . . . . . . & . & . & 1 & . & . & . \\
\hline 36 & Onychocella gimense (BRYD.) .......... & . & . & 2 & 1 & 2 & . \\
\hline 40 & 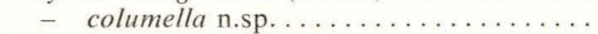 & 302 & 126 & 146 & 162 & 164 & 263 \\
\hline 41 & Floridina gothica (D'ORs.). . . . . . . . . & 285 & 420 & 624 & 169 & 177 & 121 \\
\hline 42 & - tubulosa Vorgr.................. & 61 & 121 & 133 & 75 & 58 & 35 \\
\hline 45 & 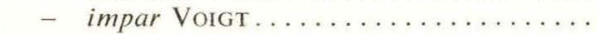 & 3 & 7 & 2 & 2 & 2 & 3 \\
\hline 50 & 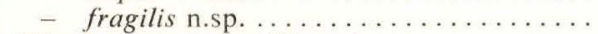 & 129 & 247 & 250 & 241 & 136 & 28 \\
\hline 53 & Micropora erratica (Voigt) . . . . . . . . & 9 & 7 & 21 & 8 & 4 & 1 \\
\hline 55 & - stevensis LEV. . . . . . . . . . . . . & . & . & . & 5 & . & . \\
\hline 56 & Semiescharinella complanata (D'ORB.) . . . . . & 9 & 131 & 67 & 41 & 42 & 10 \\
\hline 58 & Aechmella pindborgi n.sp............. & 64 & 38 & 50 & 56 & 55 & 39 \\
\hline 60 & - microstoma (MARs.) ............ & 19 & 1 & 1 & 2 & 1 & . \\
\hline 64 & Gargantua parvicella (VoIGT) ........... & 3 & 2 & 1 & 1 & . & . \\
\hline 68 & Puncturiella sculpta (D'ORB.) ............ & 2 & 9 & 39 & 14 & 16 & 5 \\
\hline 70 & Coscinopleura angusta BERтн. . . . . . . . . & 1 & 1 & . & 1 & . & 7 \\
\hline 72 & Membraniporella squamulosa (v. HAG.) ..... & . & . & . & 2 & 1 & 1 \\
\hline 75 & Phliophloea subcornuta n.sp. ........... & 6 & 4 & 10 & 6 & 10 & 5 \\
\hline 84 & Tricephalopora cerberus LANG........... & . & . & . & . & . & 2 \\
\hline 98 & Porina cylindrica VoIGt . . . . . . . . . . . & 5 & . & 5 & . & 1 & 1 \\
\hline 99 & 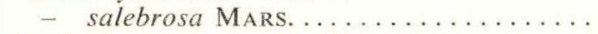 & 18 & 35 & 41 & 199 & 432 & 60 \\
\hline 104 & Pachythecella anhaltina (VoIGT) .......... & 9 & 2 & 26 & 3 & 8 & 2 \\
\hline 106 & - lundgreni (P. and M.) ............. & 54 & 19 & 25 & 12 & 9 & 1 \\
\hline 107 & Columnotheca cribrosa MARs. ........... & 88 & 115 & 65 & 108 & 110 & 38 \\
\hline 108 & Taenioporina articulata VoIGT . . . . . . . . . & 17 & 25 & 35 & 11 & 9 & 11 \\
\hline 113 & Mucronella hians HenNIG............. & 3 & 2 & 4 & 1 & . & . \\
\hline
\end{tabular}


3. Faxe.

Table 6 (continued).

Numbers of Bryozoan fragments in $10 \mathrm{~g}$ material: D. Hvedeland.

Numbers of Bryozoan fragments in $5 \mathrm{~g}$ material: M. The North Wall.

$\mathrm{Ma}=4 \mathrm{~m}$. below ground level

$\mathrm{Mb}=7 \mathrm{~m}$.
$\mathrm{Mc}=17 \mathrm{~m}$. below ground leve $\mathrm{Md}=20 \mathrm{~m}$.

\begin{tabular}{|c|c|c|c|c|c|c|}
\hline No. & Species & $\mathrm{Da}$ & $\mathrm{Ma}$ & $\mathrm{Mb}$ & Mc & Md \\
\hline 1 & "Membranipora" hexagona (v. HAG.) ........... & 6 & 1 & 3 & . & . \\
\hline 3 & 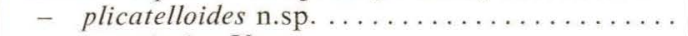 & . & 2 & 3 & . & . \\
\hline 5 & - sparsispina VorGT. ................... & 134 & 54 & 70 & 7 & 1 \\
\hline 7 & 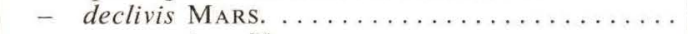 & . & 2 & 1 & . & . \\
\hline 8 & - marssoniana VoIGT .................. & 28 & 13 & 10 & 4 & . \\
\hline 11 & - maxima LeV. . . . . . . . . . . . . . . . & 1 & $\dot{1}$ & $\dot{1}$ & 6 & 1 \\
\hline 12 & Vincularia prismatica (v. HAG.). . . . . . . . . & 37 & 9 & 29 & 9 & 0 \\
\hline 13 & "Herpetopora" danica LANG ................ & 8 & . & 1 & . & . \\
\hline 14 & Aplousina fulgora (BRYD.) $\ldots \ldots \ldots \ldots \ldots \ldots$ & 6 & 4 & 4 & 1 & 1 \\
\hline 15 & 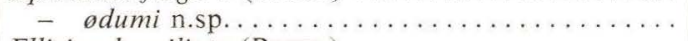 & 2 & 8 & 4 & 2 & . \\
\hline 16 & Ellisina humiliata (BRYD.). .............. & 1 & $\dot{s}$ & $\dot{s}$ & 1 & . \\
\hline 17 & - britannica (BRYD.) ................ & 7 & 3 & 3 & 3 & . \\
\hline 18 & Callopora monocera (MARs.) ............... & 8 & . & 2 & . & . \\
\hline 19 & - invigilata (BRYD.) . . . . . . . . . . . . . & . & 2 & . & . & . \\
\hline 21 & 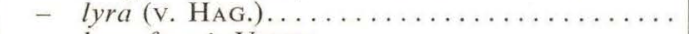 & . & . & . & 1 & . \\
\hline 22 & 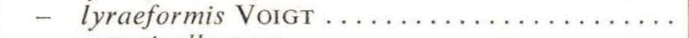 & $\dot{0}$ & $\therefore$ & ; & 2 & . \\
\hline 23 & 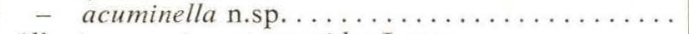 & 5 & 14 & 4 & 3 & . \\
\hline 26 & 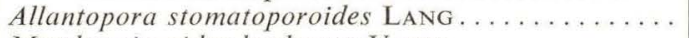 & 2 & $\cdot$ & . & 3 & $\dot{0}$ \\
\hline 27 & Membraniporidra huckeana VorGT ............ & 12 & 8 & 8 & 12 & 3 \\
\hline 28 & 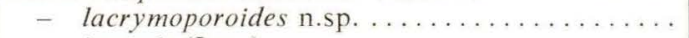 & 28 & 15 & 23 & 8 & . \\
\hline 29 & 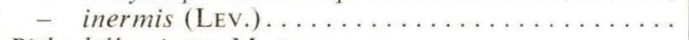 & 10 & 11 & 24 & 4 & . \\
\hline 30 & Pithodella cincta MARs. . . . . . . . . . . . . . & 300 & 154 & 163 & 27 & . \\
\hline 31 & 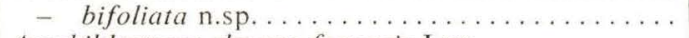 & 5 & 3 & 6 & 2 & 1 \\
\hline 32 & Amphiblestrum elegans faxensis LEV. . . . . . . . . . & 44 & 48 & 49 & 28 & . \\
\hline 32 & - elegans (v. HAG.), discoidal form .......... & 22 & $\dot{0}$ & $\cdot$ & ; & . \\
\hline 33 & 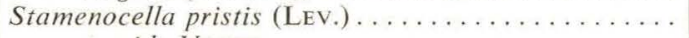 & 47 & 13 & 6 & 1 & . \\
\hline 34 & 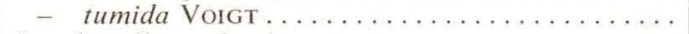 & . & 1 & . & . & . \\
\hline 37 & 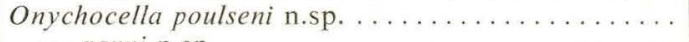 & 1 & 1 & 1 & . & . \\
\hline 38 & 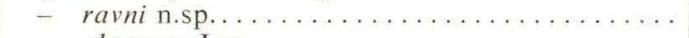 & $\dot{\theta}$ & 2 & 3 & $\dot{s}$ & . \\
\hline 39 & 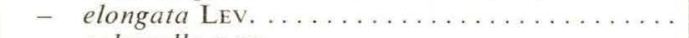 & 8 & 1 & 5 & 3 & . \\
\hline 40 & 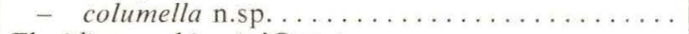 & 22 & 7 & 7 & . & . \\
\hline 41 & 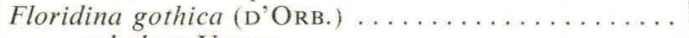 & 184 & 4 & 5 & 2 & . \\
\hline 42 & - tubulosa VoIGt....................... & 5 & 4 & 1 & 1 & . \\
\hline 43 & - voigti BASSLER $\ldots \ldots \ldots \ldots \ldots \ldots \ldots \ldots$ & 3 & $\dot{2}$ & $\dot{s}$ & $\dot{s}$ & : \\
\hline 45 & 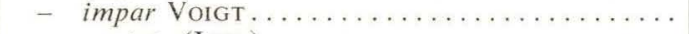 & $\dot{.}$ & 3 & 2 & 2 & 1 \\
\hline 46 & 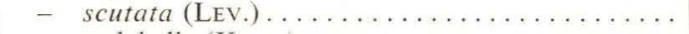 & 7 & 3 & 6 & 6 & . \\
\hline 48 & 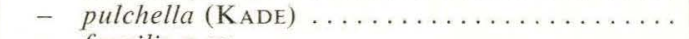 & 65 & 30 & 25 & 9 & 1 \\
\hline 50 & 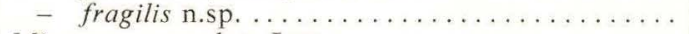 & 68 & 5 & 6 & 18 & 1 \\
\hline 52 & 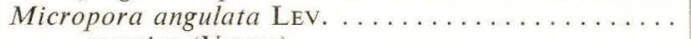 & 23 & 8 & 35 & 11 & . \\
\hline 53 & 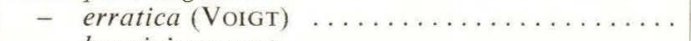 & 26 & 2 & $\cdot$ & 1 & : \\
\hline 54 & 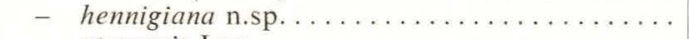 & $\cdot$ & 1 & $\dot{0}$ & 6 & 1 \\
\hline 55 & 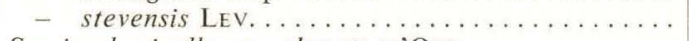 & 1 & 3 & 2 & ; & . \\
\hline 56 & Semiescharinella complanata D'ORB............. & 58 & 15 & 13 & 6 & . \\
\hline 57 & - pulchra (UlLr. and BASSL.) . . . . . . . . . . & $\dot{0}$ & 11 & 3 & 3 & $\dot{0}$ \\
\hline 58 & 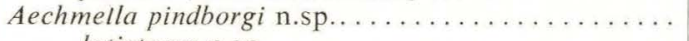 & 23 & 9 & 10 & 29 & 2 \\
\hline 59 & 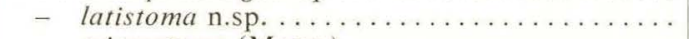 & $\cdot$ & $\therefore$ & 2 & 1 & : \\
\hline 60 & - microstoma (MARS.) $\ldots \ldots \ldots \ldots \ldots \ldots \ldots$ & 290 & 74 & 94 & 23 & 1 \\
\hline 61 & 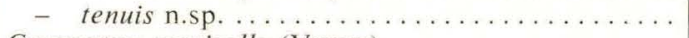 & 48 & 24 & 10 & 6 & : \\
\hline 64 & Gargantua parvicella (VoIGt) ................ & 7 & 5 & 6 & 7 & 1 \\
\hline 65 & Brydonella vulcani (BRYD.) . . . . . . . . . . . & 1 & 10 & $\cdot$ & 43 & . \\
\hline 67 & 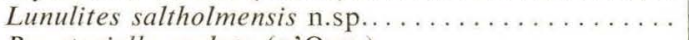 & 1 & 2 & $\therefore$ & $\dot{3}$ & . \\
\hline 68 & Puncturiella sculpta (D'ORB.) ............... & 98 & 10 & 11 & 2 & \\
\hline 69 & 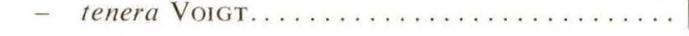 & $\cdot$ & 2 & $\cdot$ & . & \\
\hline
\end{tabular}


Table 6 (Faxe, continued).

\begin{tabular}{|c|c|c|c|c|c|c|}
\hline No. & Species & $\mathrm{Da}$ & Ma & $\mathrm{Mb}$ & Mc & Md \\
\hline 70 & 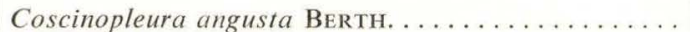 & 49 & 31 & 104 & 21 & \\
\hline 72 & Membraniporella squamulosa (v. HAG.) . . . . . . . . . & 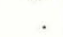 & & 2 & . & \\
\hline 74 & Andriopora daniensis VoIGT $\ldots \ldots \ldots \ldots \ldots \ldots \ldots$ & & 1 & & & \\
\hline 75 & Pliophloea subcornuta n.sp. . . . . . . . . . . . . . & 5 & 2 & 6 & 4 & \\
\hline 76 & 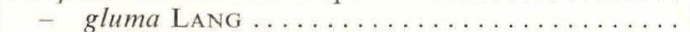 & & & 1 & & \\
\hline 78 & - vincularioides LANG. . . . . . . . . . . . . & 12 & 5 & 32 & 8 & . \\
\hline 82 & Pachydera densa LANG ................... & . & 2 & & . & . \\
\hline 83 & 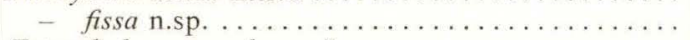 & . & & 1 & & \\
\hline 84 & Tricephalopora cerberus LANG............... & . & 3 & 2 & 5 & 1 \\
\hline 88 & Haplocephalopora uniceps LANG ............. & . & 1 & 2 & . & . \\
\hline 90 & Diacanthopora bispinosa LANG . . . . . . . . . . . & . & 1 & & . & . \\
\hline 95 & Anomithopora isolata $\mathrm{n} . \mathrm{sp} \ldots \ldots \ldots \ldots \ldots \ldots \ldots$ & & 2 & 1 & & . \\
\hline 98 & Porina cylindrica Vorgt $\ldots \ldots \ldots \ldots \ldots \ldots \ldots$ & 19 & 38 & 20 & 8 & \\
\hline 99 & - salebrosa Mars.................... & 83 & 44 & 111 & 39 & 18 \\
\hline 100 & Beisselina nobilis (LEV.) $\ldots \ldots \ldots \ldots \ldots \ldots \ldots \ldots$ & 35 & 11 & 27 & 2 & 1 \\
\hline 101 & - celleporoides (VoIGT) . . . . . . . . . . . . & 3 & 4 & 1 & 1 & . \\
\hline 103 & 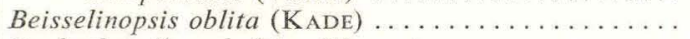 & 1 & & . & & . \\
\hline 104 & Pachythecella anhaltina (VoIGT) $\ldots \ldots \ldots \ldots \ldots \ldots$ & 11 & 7 & 4 & . & . \\
\hline 105 & 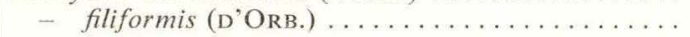 & 1 & 8 & 1 & & \\
\hline 106 & 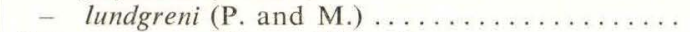 & 220 & 104 & 107 & 26 & 0 \\
\hline 107 & Columnotheca cribrosa (MARs.) . . . . . . . . . . & 72 & 1 & 52 & 15 & 11 \\
\hline 108 & 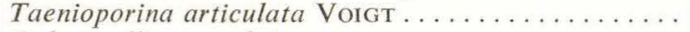 & 19 & 14 & 12 & 3 & . \\
\hline 110 & Ochetosellina areolata $\mathrm{n} . \mathrm{sp} . \ldots \ldots \ldots \ldots \ldots \ldots$ & & 1 & & & . \\
\hline 111 & Systenostoma verticillata LEV. . . . . . . . . . . . & 1 & 1 & 2 & 1 & \\
\hline 113 & Mucronella hians HenNIG................... & 5 & 12 & 7 & 11 & 1 \\
\hline 114 & nella pectinata $\mathrm{n} . \mathrm{sp} \ldots \ldots \ldots \ldots \ldots \ldots \ldots$ & & 2 & 4 & & 1 \\
\hline 115 & gustidens LEV. . . . . . . . . . . . . & 6 & 8 & 7 & 3 & . \\
\hline 116 & Cellepora daniensis VoIGT $\ldots \ldots \ldots \ldots \ldots \ldots \ldots$ & 1 & & 1 & 2 & \\
\hline 117 & Crassicellepora voigti & 1 & 4 & 5 & 8 & \\
\hline
\end{tabular}

\section{Saltholm.}

Numbers of fragments in 10 g. material.

$\mathrm{E}=$ File no. 201.396, 5 m., Bryozoan Limestone

$\mathrm{Fa}=$ File no. 201.402, $2 \mathrm{~m}$., Sandy-limestone

$\mathrm{Fc}=$ File no. 201.402, $6 \mathrm{~m}$.

$\mathrm{Fb}=$ File no, 201.402, $3 \mathrm{~m}$.,

\begin{tabular}{|c|c|c|c|c|c|}
\hline No. & Species & E & Fc & $\mathrm{Fa}$ & $\mathrm{Fb}$ \\
\hline 5 & "Membranipora" sparsispina VoIGT ............ & 8 & 5 & 3 & 3 \\
\hline 8 & - marssoniana VoIGT ................. & 6 & 4 & . & 1 \\
\hline 12 & Vincularia prismatica (v. HAG.) . . . . . . . . & 6 & 5 & 2 & 1 \\
\hline 13 & "Herpetopora" danica LANG . . . . . . . . . . . . & 1 & . & . & . \\
\hline 14 & Aplousina fulgora (BRYD.) $\ldots \ldots \ldots \ldots \ldots \ldots$ & . & 1 & . & 1 \\
\hline 17 & Ellisina britannica (BRYD.) . . . . . . . . . . & 2 & . & . & . \\
\hline 18 & Callopora monocera (MARs.) . . . . . . . . . . & 1 & 3 & . & . \\
\hline 23 & 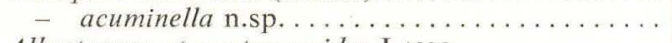 & $\dot{2}$ & 1 & . & . \\
\hline 26 & Allantopora stomatoporoides LANG . . . . . . . . . & 2 & . & . & . \\
\hline 27 & Membraniporidra huckeana VoIGT ........... & . & 1 & . & $\dot{0}$ \\
\hline 28 & 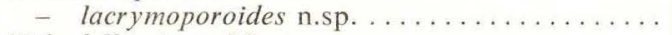 & . & . & . & 2 \\
\hline 30 & 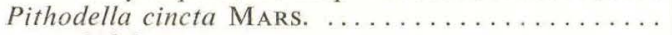 & 55 & 29 & 7 & 17 \\
\hline 31 & 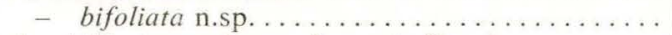 & 1 & . & . & . \\
\hline 32 & Amphiblestrum elegans faxensis (LEv.) . . . . . . . . . & 23 & 24 & 9 & 17 \\
\hline 32 & - elegans (v. HAG.), tubular form .......... & 19 & 5 & 1 & 1 \\
\hline 32 & - elegans (v. HAG,), discoidal form ....... & . & 5 & . & . \\
\hline 33 & Stamenocella pristis (LEv.) . . . . . . . . . . . & 12 & . & 1 & 1 \\
\hline 37 & 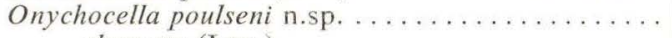 & $\cdot$ & . & : & 1 \\
\hline 39 & 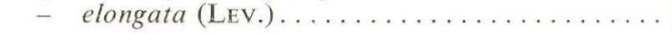 & . & . & 1 & 2 \\
\hline
\end{tabular}


Table 6 (Saltholm, continued).

\begin{tabular}{|c|c|c|c|c|c|}
\hline No. & Species & $\mathrm{E}$ & $\mathrm{Fc}$ & $\mathrm{Fa}$ & $\mathrm{Fb}$ \\
\hline 40 & Onychocella columella n.sp............... & 3 & 1 & 1 & . \\
\hline 41 & 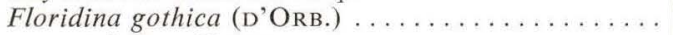 & 1 & . & . & . \\
\hline 42 & - tubulosa Voigt. . . . . . . . . . . . . . . & 2 & . & . & . \\
\hline 45 & 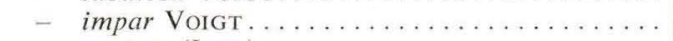 & . & 1 & . & : \\
\hline 46 & 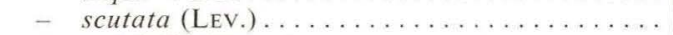 & . & . & . & 1 \\
\hline 48 & - pulchella (KADE) $\ldots \ldots \ldots \ldots \ldots \ldots$ & 16 & 6 & 2 & 1 \\
\hline 50 & 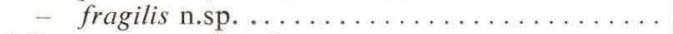 & 3 & 1 & . & . \\
\hline 52 & Micropora angulata LEV. . . . . . . . . . . . . . & 1 & 1 & . & . \\
\hline 53 & 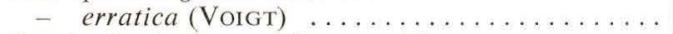 & 9 & 4 & . & . \\
\hline 56 & Semiescharinella complanata D'OrB............. & 1 & 1 & . & . \\
\hline 57 & 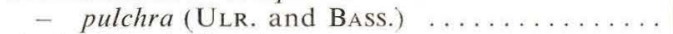 & 40 & 19 & 3 & 2 \\
\hline 58 & 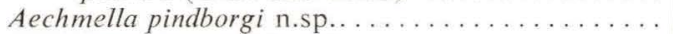 & 1 & 1 & 1 & 5 \\
\hline 60 & - microstoma (MARs.) ............... & 137 & 47 & 11 & 24 \\
\hline 61 & 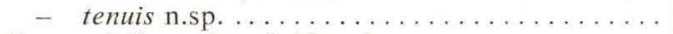 & 55 & 36 & . & 3 \\
\hline 68 & Puncturiella sculpta (D'ORB.) . .............. & 26 & 11 & . & . \\
\hline 70 & Coscinopleura angusta BERTH. . . . . . . . . . . . . & 33 & 8 & . & . \\
\hline 75 & 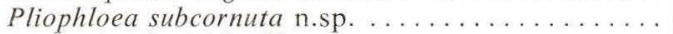 & 1 & 1 & . & . \\
\hline 78 & 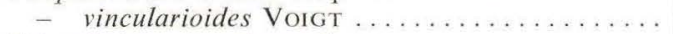 & 14 & 14 & 1 & 8 \\
\hline 84 & Tricephalopora cerberus LANG ............... & 1 & . & . & . \\
\hline 98 & 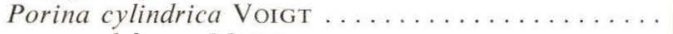 & . & . & 2 & 3 \\
\hline 99 & 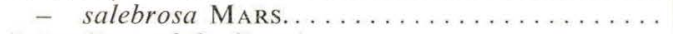 & 6 & 8 & 6 & 2 \\
\hline 100 & Beisselina nobilis (LEV.). . . . . . . . . . . . . & 7 & 4 & 3 & 2 \\
\hline 104 & Pachythecella anhaltina (VoIGT) .............. & 1 & . & . & . \\
\hline 106 & - lundgreni (P. and M.) ............... & 44 & 13 & 8 & 4 \\
\hline 107 & Columnotheca cribrosa MARs. . . . . . . . . . . . & 34 & 17 & 16 & 14 \\
\hline 108 & Taenioporina articulata VoIGT . . . . . . . . . . . . & 7 & 2 & . & 1 \\
\hline 111 & Systenostoma verticillata LEV................ & 3 & 4 & 2 & 7 \\
\hline 115 & Psilosecos angustidens (LEv.) . .............. & . & . & . & 3 \\
\hline
\end{tabular}

\section{Copenhagen.}

Numbers of fragments in $10 \mathrm{~g}$ material from Hyttehusvej, $7 \mathrm{~m}$., Sandy-limestone.

\begin{tabular}{|c|c|c|}
\hline No. & Species & K \\
\hline 70 & 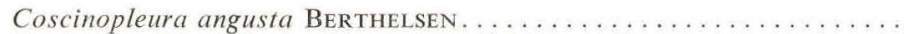 & 23 \\
\hline 106 & Pachythecella lundgreni (Pergens and Meunier) . . . . . . . . . . . . & 18 \\
\hline
\end{tabular}

\section{Herfolge.}

Numbers of Bryozoan fragments in $10 \mathrm{~g}$ material.

$\mathrm{Gd}=$ Sample of Calcarenite, at a depth of $5.8 \mathrm{~m}$.
$\mathrm{Ge}=-\quad-$ Bryozoan Limestone taken at a depth of $6.75 \mathrm{~m}$.
$\mathrm{Gf}=-\ldots+\ldots-15 \mathrm{~m}$.

\begin{tabular}{|c|c|c|c|c|}
\hline No. & Species & Gd & $\mathrm{Ge}$ & Gf \\
\hline 1 & "Membranipora" hexagona (v. HAG.) .............. & . & 15 & 5 \\
\hline 2 & 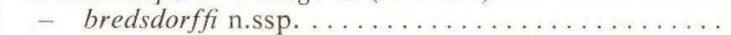 & . & . & . \\
\hline 3 & - plicatelloides n.sp. .................. & 6 & 35 & 11 \\
\hline 5 & - sparsispina VoIGT. . . . . . . . . . . . . . & 11 & 59 & 56 \\
\hline 8 & 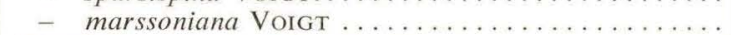 & . & 35 & 46 \\
\hline 12 & Vincularia prismatica (v. HAG.)................ & 66 & 38 & 44 \\
\hline 14 & Aplousina fulgora (BRYD.) . . . . . . . . . . . . . . & . & 2 & 1 \\
\hline
\end{tabular}


Table 6 (Herfølge, continued).

\begin{tabular}{|c|c|c|c|c|}
\hline No. & Species & $\mathrm{Gd}$ & $\mathrm{Ge}$ & Gf \\
\hline 15 & Aplousina odumi n.sp...................... & 3 & 4 & 10 \\
\hline 17 & 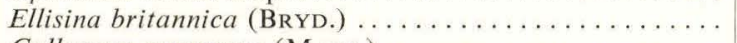 & . & . & 1 \\
\hline 18 & Callopora monocera (MARs.) . . . . . . . . . . . . & . & . & 3 \\
\hline 19 & 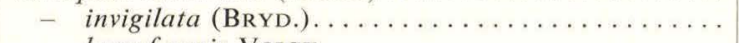 & . & $\dot{7}$ & 1 \\
\hline 22 & - lyraeformis VoIGT $\ldots \ldots \ldots \ldots \ldots \ldots \ldots \ldots$ & . & 7 & . \\
\hline 23 & 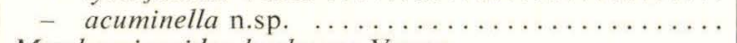 & . & 3 & . \\
\hline 27 & Membraniporidra huckeana VoIGT ............. & : & 1 & 2 \\
\hline 29 & 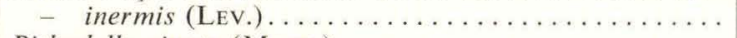 & 1 & 33 & 13 \\
\hline 30 & 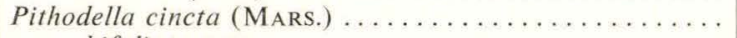 & 17 & 11 & 120 \\
\hline 31 & 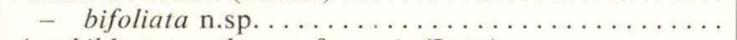 & 13 & 8 & $\dot{0}$ \\
\hline 32 & Amphiblestrum elegans faxensis (LEV.) ............. & 1 & 24 & 12 \\
\hline 32 & - elegans (v. HAG.), tubular form ............. & . & 15 & 17 \\
\hline 33 & 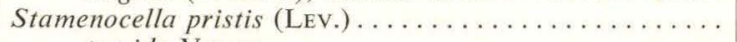 & 2 & 11 & 3 \\
\hline 34 & - tumida Vorgt ..................... & - & 1 & 1 \\
\hline 35 & Frurionella daniensis n.sp. . . . . . . . . . . . . . & . & 2 & 3 \\
\hline 37 & 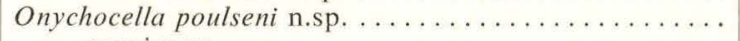 & . & 12 & 2 \\
\hline 38 & 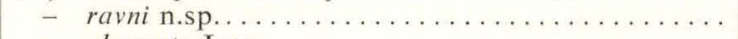 & . & 1 & . \\
\hline 39 & - elongata Lev. . . . . . . . . . . . . . . . . . . . . . & 1 & 3 & 4 \\
\hline 40 & 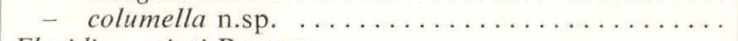 & 25 & 10 & 3 \\
\hline 43 & 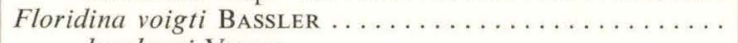 & 13 & 37 & 17 \\
\hline 44 & 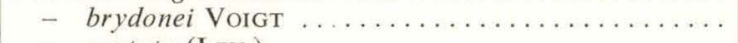 & $\dot{2}$ & ; & 1 \\
\hline 46 & 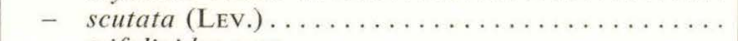 & 2 & 3 & . \\
\hline 47 & 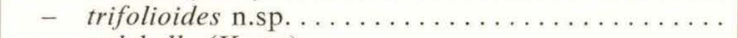 & 1 & 45 & 8 \\
\hline 48 & 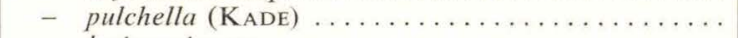 & 45 & 25 & 17 \\
\hline 49 & 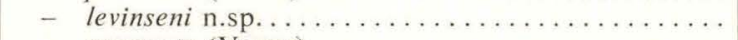 & 29 & 59 & 7 \\
\hline 51 & $-\operatorname{excavata(\text {VoIgt})\ldots \ldots \ldots \ldots \ldots \ldots \ldots \ldots \ldots \ldots \ldots \ldots \ldots \ldots }$ & . & 5 & $\therefore$ \\
\hline 52 & Micropora angulata LEv. ................. & 1 & 4 & 10 \\
\hline 53 & - erratica VoIGT $\ldots \ldots \ldots \ldots \ldots \ldots \ldots \ldots \ldots \ldots$ & . & 2 & 2 \\
\hline 56 & Semiescharinella complanata D'ORB.............. & 6 & 22 & 21 \\
\hline 57 & - pulchra (ULR. and BASSL.) ............... & $\dot{-}$ & 1 & . \\
\hline 60 & Aechmella microstoma (MARs.) . . . . . . . . . . & 7 & 18 & 32 \\
\hline 65 & 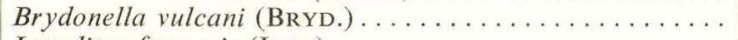 & 1 & 7 & 21 \\
\hline 66 & 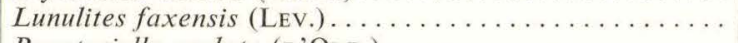 & 1 & 7 & 10 \\
\hline 68 & Puncturiella sculpta (D'ORB.) ................ & 6 & 8 & 6 \\
\hline 69 & 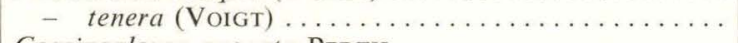 & $\dot{0}$ & 2 & $\cdot$ \\
\hline 70 & Coscinopleura angusta BERTH. . . . . . . . . . . . & 180 & 163 & 98 \\
\hline 71 & 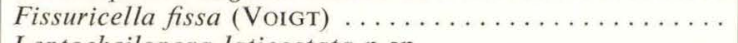 & $\cdot$ & . & 2 \\
\hline 73 & 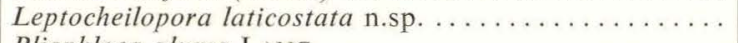 & . & . & 1 \\
\hline 76 & Pliophloea gluma LANG. . . . . . . . . . . . . . . . & 2 & 2 & 2 \\
\hline 78 & - vincularioides Vorgt $\ldots \ldots \ldots \ldots \ldots \ldots \ldots \ldots$ & 4 & 22 & 30 \\
\hline 79 & 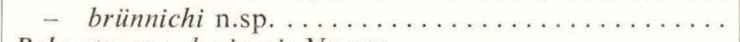 & 20 & 188 & 110 \\
\hline 81 & Pelmatopora daniensis VoIGT . . . . . . . . . . . . & $\cdot$ & 1 & 1 \\
\hline 90 & Diacanthopora bispinosa LANG . . . . . . . . . . . . . & . & 6 & 8 \\
\hline 91 & 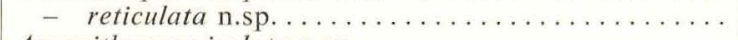 & . & 5 & . \\
\hline 95 & 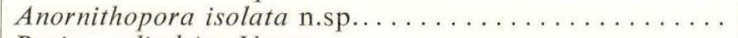 & $\dot{0}$ & 1 & . \\
\hline 98 & 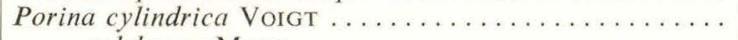 & 33 & 32 & 9 \\
\hline 99 & 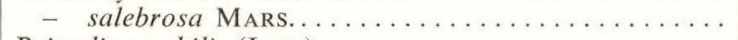 & 2 & $\cdot$ & 1 \\
\hline 100 & 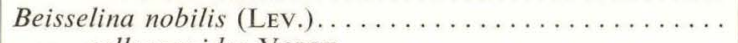 & 9 & 9 & 17 \\
\hline 101 & 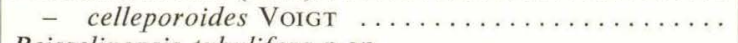 & 8 & 28 & 2 \\
\hline 102 & Beisselinopsis tubulifera n.sp................ & $\dot{s}$ & : & 1 \\
\hline 103 & 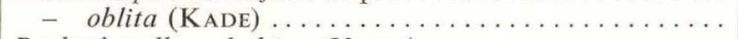 & 2 & 1 & 1 \\
\hline 104 & Pachythecella anhaltina (VorGT) $\ldots \ldots \ldots \ldots \ldots$ & 4 & 7 & 5 \\
\hline 105 & 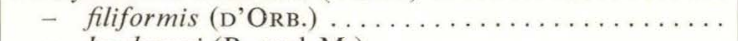 & 2 & 3 & . \\
\hline 106 & 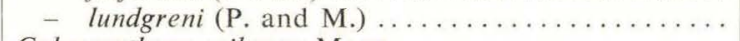 & 39 & 37 & 36 \\
\hline 107 & 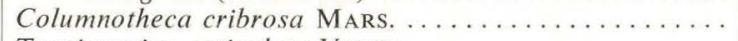 & 64 & 121 & 49 \\
\hline 108 & Taenioporina articulata VoIGT . . . . . . . . . . . . & 9 & 7 & 5 \\
\hline 110 & 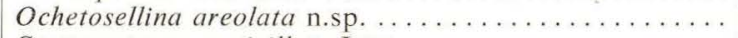 & 1 & 2 & 1 \\
\hline 111 & Systenostoma verticillata LEV. . . . . . . . . . . . . . & 8 & 8 & 5 \\
\hline 115 & Psilosecos angustidens (LEv.) . . . . . . . . . . . . . . & . & 3 & 5 \\
\hline
\end{tabular}


Table 6 (continued).

\section{Klintholm.}

Numbers of Bryozoan fragments in $10 \mathrm{~g}$ material.

$\mathrm{Ha}=$ Sample of glauconitic Limestone, Pit H, at a depth of $2.7 \mathrm{~m}$.

$\mathrm{Hb}=\quad-\quad$ Bryozoan Limestone, Pit H, at a depth of $3.1 \mathrm{~m}$.

$\mathrm{I}=\ldots+\ldots \quad-\quad$ from the heaps of limestone beside the southernmost pit

\begin{tabular}{|c|c|c|c|c|}
\hline No. & Species & $\mathrm{Ha}$ & $\mathrm{Hb}$ & $\mathrm{I}$ \\
\hline 1 & "Membranipora" hexagona (v. HAG.) ............. & . & . & 3 \\
\hline 3 & 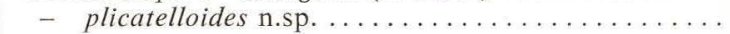 & . & 5 & 11 \\
\hline 5 & - sparsispina VorGt..................... & 4 & 4 & 48 \\
\hline 8 & - marssoniana VoIGT ..................... & 3 & 38 & 28 \\
\hline 12 & 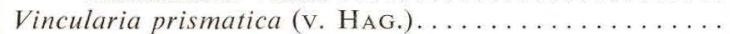 & 21 & 130 & 104 \\
\hline 13 & "Herpetopora" danica LANG ................... & . & 2 & 2 \\
\hline 14 & 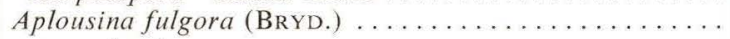 & . & 1 & 2 \\
\hline 15 & 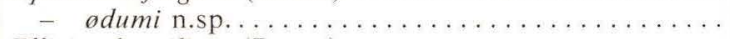 & 5 & 11 & 12 \\
\hline 16 & Ellisina humiliata (BRYD.) . . . . . . . . . . . . . & . & . & 1 \\
\hline 17 & 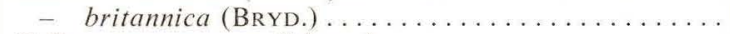 & 2 & 2 & 3 \\
\hline 18 & Callopora monocera (MARs.) . . . . . . . . . . . . & . & 5 & 1 \\
\hline 19 & 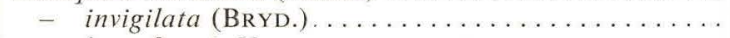 & . & 1 & . \\
\hline 22 & - lyraeformis VoIGT ...................... & . & . & 7 \\
\hline 23 & 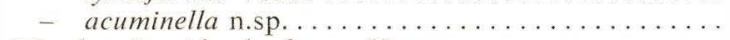 & . & 1 & 3 \\
\hline 27 & Membraniporidra huckeana VoIGT ............. & . & . & 16 \\
\hline 28 & 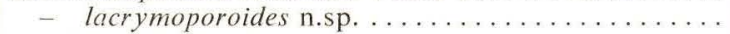 & . & 2 & . \\
\hline 29 & 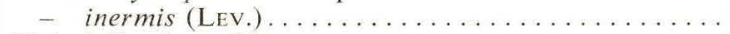 & . & 1 & 14 \\
\hline 30 & 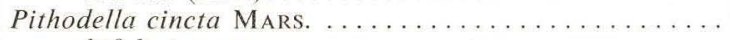 & 8 & 88 & 50 \\
\hline 31 & 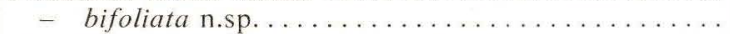 & . & . & 6 \\
\hline 32 & Amphiblestrum elegans faxensis (LEV.).............. & . & 2 & 4 \\
\hline 32 & - elegans (v. HAG.), tubular form .............. & 9 & 74 & 49 \\
\hline 33 & Stamenocella pristis (LEV.) . . . . . . . . . . . . . . & 1 & 9 & 5 \\
\hline 35 & Frurionella daniensis n.sp. . . . . . . . . . . . . & . & . & 1 \\
\hline 37 & 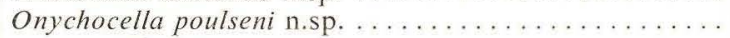 & 4 & 9 & 7 \\
\hline 38 & 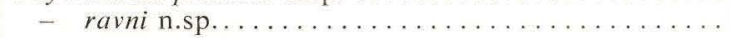 & . & 2 & 10 \\
\hline 39 & - elongata Lev. ........................ & 4 & 9 & 14 \\
\hline 40 & - columella n.sp........................ & 2 & . & 2 \\
\hline 43 & 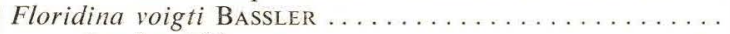 & 1 & . & 34 \\
\hline 44 & 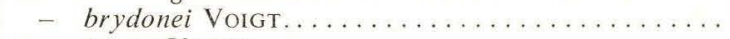 & 2 & 1 & 45 \\
\hline 45 & 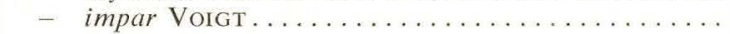 & . & . & 1 \\
\hline 46 & - scutata (LEV.) . . . . . . . . . . . . . . . . & . & 5 & 5 \\
\hline 47 & - trifolioides n.sp. ................... & 9 & 2 & 44 \\
\hline 48 & 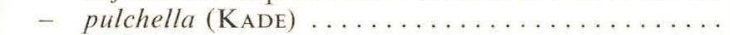 & 6 & 15 & 30 \\
\hline 49 & 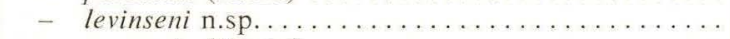 & . & 1 & 3 \\
\hline 51 & 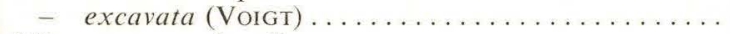 & 1 & . & 18 \\
\hline 52 & Micropora angulata LEV. . . . . . . . . . . . . . . . & . & 11 & 20 \\
\hline 53 & 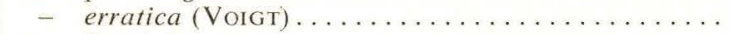 & 2 & 10 & 3 \\
\hline 54 & 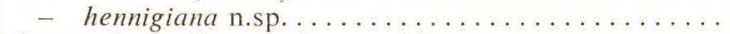 & . & . & 6 \\
\hline 56 & Semiescharinella complanata D'ORв............... & 3 & 66 & 16 \\
\hline 57 & 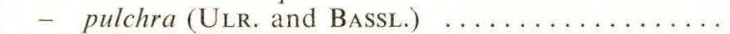 & . & . & 1 \\
\hline 58 & 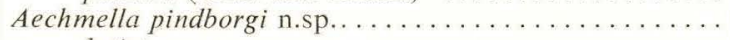 & 1 & 1 & 19 \\
\hline 59 & 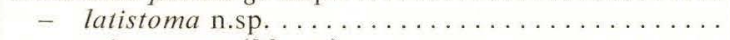 & . & . & 6 \\
\hline 60 & 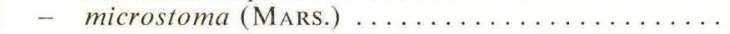 & 43 & 182 & 89 \\
\hline 61 & 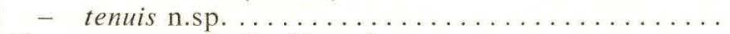 & 16 & 93 & 37 \\
\hline 64 & Gargantua parvicella (Vorgt) ................. & 1 & 1 & 5 \\
\hline 65 & Brydonella vulcani (BRYD.) . . . . . . . . . . . . & 1 & . & 14 \\
\hline 66 & 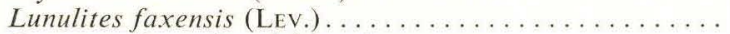 & . & . & 10 \\
\hline 68 & 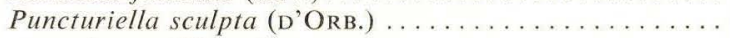 & 5 & 25 & 5 \\
\hline 69 & 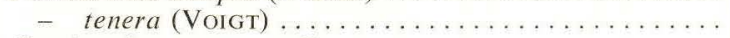 & . & 年 & 1 \\
\hline 70 & 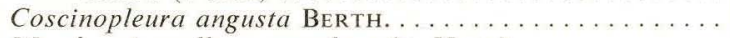 & 53 & 95 & 217 \\
\hline 72 & Membraniporella squamulosa (v. HAG.) . . . . . . . . . . & . & . & 1 \\
\hline 78 & Pliophloea vincularioides LANG ................. & 1 & 12 & 14 \\
\hline 79 & 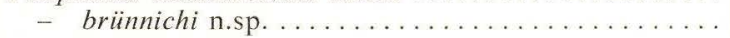 & 2 & 1 & 9 \\
\hline
\end{tabular}


Table 6 (Klintholm, continued).

\begin{tabular}{|c|c|c|c|c|}
\hline No. & Species & $\mathrm{Ha}$ & $\mathrm{Hb}$ & I \\
\hline 86 & Tricephalopora circumvallata (LEv.) . . . . . . . . . . . & 1 & . & \\
\hline 91 & Diacanthopora reticulata $\mathrm{n} . \mathrm{sp} \ldots \ldots \ldots \ldots \ldots \ldots \ldots$ & . & & 2 \\
\hline 93 & 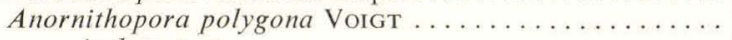 & & 1 & . \\
\hline 95 & 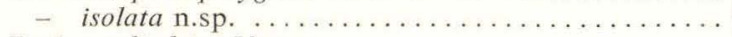 & 2 & & \\
\hline 98 & Porina cylindrica Vorgt $\ldots \ldots \ldots \ldots \ldots \ldots \ldots \ldots$ & 1 & 9 & 8 \\
\hline 99 & 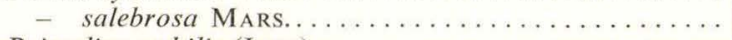 & 1 & 7 & 34 \\
\hline 100 & 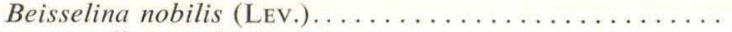 & . & 11 & 11 \\
\hline 101 & - celleporoides VoIGT $\ldots \ldots \ldots \ldots \ldots \ldots \ldots \ldots \ldots$ & . & 5 & . \\
\hline 102 & 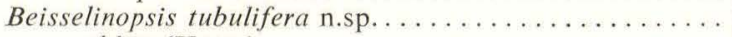 & . & 3 & 1 \\
\hline 103 & - oblita $_{(\mathrm{KADE})} \ldots \ldots \ldots \ldots \ldots \ldots \ldots \ldots \ldots \ldots$ & & 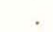 & 4 \\
\hline 104 & Pachythecella anhaltina VoIGt................. & 6 & 1 & 10 \\
\hline 105 & 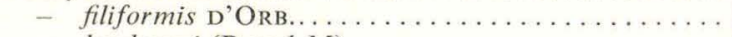 & & 1 & 1 \\
\hline 106 & - lundgreni $(\mathrm{P}$ and $\mathrm{M}) \ldots \ldots \ldots \ldots \ldots \ldots \ldots$ & 5 & 34 & 29 \\
\hline 107 & 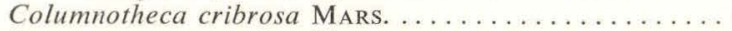 & 24 & 60 & 60 \\
\hline 108 & 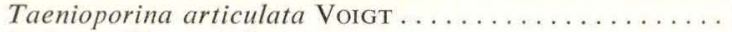 & 3 & 3 & 12 \\
\hline 110 & Ochetosellina areolata $\mathrm{n} . \mathrm{sp} . \ldots \ldots \ldots \ldots \ldots \ldots \ldots$ & 1 & . & 4 \\
\hline 111 & Systenostoma verticillata LEV. . . . . . . . . . . . . & . & 1 & 11 \\
\hline 115 & Psilosecos angustidens (LEV.) $\ldots \ldots \ldots \ldots \ldots \ldots \ldots \ldots$ & 1 & - & 14 \\
\hline 117 & 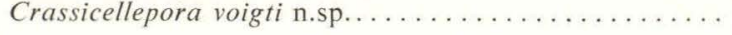 & 1 & 3 & 18 \\
\hline
\end{tabular}

The T. abildgaardi zone. Presumably the greater part of the museum material marked "Kagstrup" originates from this zone. As shown in Tables 6 and 7, 34 species were found in the sample from this locality, while the number of species from Stevns amounts to 37. If to these are added the species only found in the museum material and Membraniporidra gigantea (Lev.), which according to the author occurs in the Bryozoan Limestone in Stevns, the number of species known comes to 42 for Kagstrup and 50 for Stevns.

The dominant species in this zone are the four mentioned from the T. odumi zone and Pithodella cincta MARsS., Vincularia prismatica v. HAG., Floridina fragilis n.sp., and Porina salebrosa Marss.

The $T$. brünnichi zone. Within this zone there is a considerable difference between Faxe and the other localities, viz. Kagstrup and Saltholm. As shown in Table 7, the Kagstrup material includes 39 species. Dominant species are Aechmella tenuis n.sp., Amphiblestrum elegans (v. HAG.), and Aechmella microstoma (MARSS.).

In the samples of Bryozoan Limestone from Saltholm 41 species have been found. The museum material, marked "Bryozokalk, Saltholm", furthermore comprises 3 species, i.e. a total of 44 species. To these should perhaps be added some of the 15 species which in the collection of Bryozoa in the Museum are marked "Saltholm" without indication of rock. Dominant forms are Aechmella microstoma Marss., Aechmella tenuis n.sp., Pithodella cincta Marss., and Amphiblestrum elegans v. HaG.

In the stratigraphical test material from Faxe 82 species were found. From the museum material another 18 species are known, and from the literature (VorGT, 
1930, and LEVINSEN, 1925) the following 19 species, which were not found again during the paleontological investigations: "Membranipora" ravni VoIGT, M. diluvii Vorgt, $M$. galeifera Voigt, M. tecta Voigt, M. brünnichi Voigt, Herpetopora faxensis VoIGT, Marssonopora catenularia VoIGT, Floridina piriformis Volgt, Dimorphostylus tetrasticus VoIGT, Quadricellaria excavata D'Orb., Auchenopora guttur LAng, Trilophopora trifida LAng, Beisselina seriata MARSSON, and Membraniporidra gigantea (LEVINSEN), Membraniporella rapax LEV., M. stylifera Lev., and Cribilina sparsiporis Lev. A total of 115 species of Cheilostome Bryozoa is now known from Faxe. Between the museum material and the stratigraphical material from the Danian there is a characteristic difference, the museum material to a great extent including whole specimens or fragments of macrofossils with encrusting Bryozoa, while these in the stratigraphical material recede into the background in favour of the free zoarial types. The museum material suggests that the encrusting forms play a greater part than is actually the case. This general evaluation especially proves justified at Faxe, where the luxuriant benthonic fauna gave particularly favourabie possibilities of fastening for Bryozoan larvae and suitable conditions of growth to the encrusting forms. On this background it is natural that 31 of the 39 species which are "absent" from the stratigraphical material should be encrusting. The Cribrimorph Bryozoa, which, indeed, are mainly encrusting, had extremely favourable conditions of growth at Faxe. 24 out of the 29 Cribrimorph Bryozoan species known from the Danian deposits occur at Faxe.

The dominant forms in the Bryozoan Limestone of Faxe are Pithodella cincta Marsson, Aechmella microstoma MARsson, Porina salebrosa MARsson, Columnotheca cribrosa MARsson, and Pachythecella lundgreni PerG. and Meun. Presumably Membraniporidra inermis (LEV.), which is very common in the museum material, should be added here.

The $T$. vexillifera zone.

1. The Sandy-limestone on Saltholm. From there 29 species are known, 27 of which were found in the samples examined, while 2 species were known from the museum material only. The number of species should probably be supplemented by some of the 15 species found in the collection of Bryozoa in the Mineralogical Museum which are marked "Saltholm" without indication of rock. Dominant forms are Coscinopleura angusta Berthelsen, Aechmella microstoma Marsson, Columnotheca cribrosa MARsson, Amphiblestrum elegans v. HAG., Pithodella cincta MARsson, and Pachythecella lundgreni (Pergens and Meunier).

2. Sandy-limestone from the Copenhagen area.

The sample examined from Hyttehusvej in Copenhagen contained 41 Cheilostome fragments only, distributed by 23 specimens on Coscinopleura 
Table 7. Survey of the percentage frequency of the dominant

- indicates that the species is present in the sample,

\begin{tabular}{|c|c|c|c|c|c|c|c|c|c|}
\hline \multirow{3}{*}{\multicolumn{2}{|c|}{ Species }} & \multirow{3}{*}{$\begin{array}{c}\begin{array}{c}\text { Tyl. odumi } \\
\text { zone }\end{array} \\
\text { Kagstrup } \\
\text { Aa }\end{array}$} & \multicolumn{7}{|c|}{ Tyl. abildgaardi zone } \\
\hline & & & \multicolumn{6}{|c|}{ Stevns } & \multirow{2}{*}{$\begin{array}{c}\text { Kagstrup } \\
\mathrm{Ba}\end{array}$} \\
\hline & & & La & $\mathrm{Lb}$ & Lc & Ld & $\mathrm{Le}$ & Lf & \\
\hline 41 & Floridina gothica D'ORв.............. & $\begin{array}{l}\% \\
23\end{array}$ & $\begin{array}{l}\% \\
18\end{array}$ & $\begin{array}{l}\% \\
25\end{array}$ & $\begin{array}{l}\% \\
30\end{array}$ & $\begin{array}{l}\% \\
12\end{array}$ & $\begin{array}{l}\% \\
10\end{array}$ & $\%$ & $\%$ \\
\hline 40 & Onychocella columella n.sp................. & 22 & 19 & 8 & 7 & 11 & 10 & 34 & 9 \\
\hline 5 & Membranipora sparsispina VoIGT . . . . . . . . & 16 & 3 & 3 & 4 & 5 & 6 & 4 & 8 \\
\hline 107 & Columnotheca cribrosa MARss. . . . . . . . . . & 15 & 6 & 7 & 3 & 8 & 7 & 5 & 3 \\
\hline 106 & Pachythecella lundgreni (P. and M.) ........ & 5 & 4 & 1 & 2 & 1 & - & - & 3 \\
\hline 30 & Pithodella cincta Marss.................. & - & 14 & 6 & 7 & 10 & 6 & 9 & 7 \\
\hline 12 & Vincularia prismatica (v. HAG.). . . . . . . . & - & 8 & 7 & 8 & 9 & 8 & 2 & 5 \\
\hline 50 & 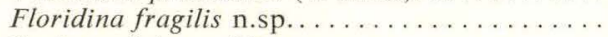 & . & 8 & 15 & 12 & 17 & 8 & 4 & 24 \\
\hline 99 & Porina salebrosa Marss............... & . & 1 & 2 & 2 & 13 & 28 & 9 & 2 \\
\hline 32 & Amphiblestrum elegans (v. HAG.) .......... & . & 3 & 3 & 4 & 2 & 1 & 2 & 4 \\
\hline 60 & Aechmella microstoma (MARss.) ........... & . & 1 & & & . & . & . & 2 \\
\hline 61 & Aechmella tenuis n.sp.................. & . & . & & & . & . & . & \\
\hline 70 & Coscinopleura angusta BERTH. . . . . . . . . . & . & - & - & . & - & . & - & - \\
\hline 79 & Pliophloea brünnichi n.sp................ & . & . & . & . & . & . & . & . \\
\hline \multicolumn{2}{|r|}{ Percentage number } & 81 & 85 & 77 & 79 & 88 & 84 & 85 & 73 \\
\hline \multicolumn{2}{|r|}{ Number of Cheilostome species $\ldots \ldots \ldots \ldots \ldots \ldots$} & 20 & 29 & 29 & 30 & 33 & 30 & 28 & 34 \\
\hline
\end{tabular}

angusta Berthelsen and 18 on Pachythecella lundgreni (Pergens and Meunier). This material is of course too slight to serve as a basis of a faunistic evaluation, which must be postponed until further material has been examined. The composition of the museum material suggests that such forms as Aplousina fulgora (BRYDONE), Beisselinopsis oblita (KADE), and Lunulites saltholmensis n.sp. also characterized the assemblage of Bryozoa.

3. The Bryozoan Limestone of Herfølge and Klintholm.

In the samples of Bryozoan Limestone from Herfølge 66 Cheilsostome species were found, to which should be added 22 species known from the museum material only and 3 species which by VoIGT are stated to occur at Herfølge: Membranipora diluvii VoIgt, M. orbavicularia VoIGT, and Membraniporidra gigantea (LEVINSEN), i. e. a total of 91 spesies.

According to the samples, which indeed are the only basis of evaluation in the case of this locality, the fauna in the Bryozoan Limestone of Klintholm contains 70 species. Further investigations will probably raise the number of species.

The dominant Herfølge species are Pliophloea brünnichi n.sp., Coscinopleura angusta BERTHelsen, Columnotheca cribrosa MARsson, and Pithodella cincta MARSSON, while the fauna at Klintholm is characterized by Coscinopleura angusta BeRTHELSEN, Aechmella microstoma (MARSSON), and 
species and the number of species in the test series A-M

but that the number of fragments is below $1 \%$.

\begin{tabular}{|c|c|c|c|c|c|c|c|c|c|c|c|c|c|c|c|c|}
\hline \multicolumn{8}{|c|}{ Tyl. trünnichi zone } & \multicolumn{9}{|c|}{$T y l$ vexillifera zone } \\
\hline Kagstrup & \multicolumn{5}{|c|}{ Faxe } & \multicolumn{4}{|c|}{ Saltholm } & \multirow{2}{*}{$\frac{\text { Copenhagen }}{\mathrm{K}}$} & \multicolumn{3}{|c|}{ Herfølge } & \multicolumn{3}{|c|}{ Klintholm } \\
\hline $\mathrm{Ca}$ & $\mathrm{Da}$ & $\mathrm{Ma}$ & $\mathrm{Mb}$ & $\mathrm{Mc}$ & $\mathrm{Md}$ & E & $\mathrm{Fc}$ & $\mathrm{Fa}$ & $\mathrm{Fb}$ & & Gd & $\mathrm{Ge}$ & Gf & $\mathrm{Ha}$ & $\mathrm{Hb}$ & I \\
\hline$\%$ & $\%$ & $\%$ & $\%$ & $\%$ & $\%$ & $\%$ & $\%$ & $\%$ & $\%$ & $\%$ & $\%$ & $\%$ & $\%$ & $\%$ & $\%$ & $\%$ \\
\hline 2 & 9 & - & - & - & - & - & . & . & . & . & . & . & . & . & . & . \\
\hline 6 & 1 & 1 & - & . & . & - & - & 1 & . & . & 3 & 1 & - & - & . & - \\
\hline 8 & 6 & 6 & 6 & 2 & . & 1 & 2 & 3 & 2 & . & 2 & 5 & 6 & 1 & - & 4 \\
\hline 1 & 3 & 1 & 5 & 4 & 28 & 6 & 6 & 15 & 9 & & 9 & 10 & 5 & 9 & 6 & 5 \\
\hline 4 & 10 & 11 & 9 & 5 & . & 7 & 5 & 8 & 3 & 44 & 6 & 3 & 4 & 2 & 3 & 2 \\
\hline 2 & 14 & 17 & 14 & 6 & . & 9 & 10 & 7 & 12 & . & 2 & 1 & 12 & 3 & 8 & 4 \\
\hline 1 & 2 & 1 & 2 & 2 & . & 1 & 2 & 2 & - & . & 9 & 3 & 5 & 8 & 12 & 8 \\
\hline 7 & 3 & 1 & - & 4 & - & - & - & . & . & . & . & . & . & . & . & . \\
\hline 1 & 4 & 5 & 9 & 8 & 45 & 1 & 3 & 6 & - & . & 8 & 2 & 4 & - & 1 & 3 \\
\hline 19 & 3 & 5 & 4 & 6 & . & 7 & 11 & 10 & 12 & - & - & 3 & 3 & 3 & 7 & 4 \\
\hline 18 & 13 & 8 & 8 & 5 & - & 23 & 16 & 10 & 16 & . & 1 & 1 & 3 & 17 & 17 & 7 \\
\hline 25 & 2 & 3 & 1 & 1 & . & 9 & 13 & . & 2 & & - & - & 3 & 7 & 9 & 3 \\
\hline- & 2 & 3 & 9 & 5 & . & 6 & 3 & 24 & 14 & 56 & 26 & 13 & 10 & 20 & 9 & 17 \\
\hline . & . & . & . & . & . & . & . & . & . & . & 3 & 15 & 11 & 1 & - & 1 \\
\hline 94 & 72 & 62 & 67 & 48 & 73 & 70 & 71 & 86 & 70 & 100 & 69 & 57 & 66 & 71 & 72 & 58 \\
\hline 39 & 39 & 60 & 67 & 63 & 55 & 18 & 32 & 22 & 27 & 2 & 45 & 59 & 57 & 40 & 47 & 68 \\
\hline
\end{tabular}

Vincularia prismatica (v. HAG.). The large number of fragments of "Membranipora" selandica n.sp., Membraniporidra inermis (LEvINSEN), Beisselina nobilis (LEVINSEN), and Beisselina celleporoides (VOIGT) in the museum material suggests that these species, too, have contributed to characterizing the Bryozoan fauna at Herfølge.

4. Calcarenite at Herfølge and glauconitic Bryozoan Limestone at Klintholm.

45 Cheilostome species have been shown to occur in the sample of Calcarenite. By the paleontological examinations of the museum material a further 13 species were found. Dominant forms are Coscinopleura angusta Berthelsen, Vincularia prismatica (v. HAG.), Columnotheca cribrosa MARSSON, and Porina salebrosa MARsson.

The sample of glauconitic Bryozoan Limestone from Klintholm contained 40 species, of which Coscinopleura angusta BERTHELSEn, Aechmella microstoma Marsson, Columnotheca cribrosa Marsson were those of the most frequent occurrence.

The fauna in the two sediments (- and in the Sandy-limestone) can be characterized as a "watered-down" fauna of Bryozoan Limestone composed of the forms of the assemblage of Bryozoa of the underlying limestone which were able to adapt themselves to the changed environmental conditions. 


\section{Biostratigraphical Evaluation.}

Table 8 shows the biostratigraphical distribution of the species of Cheilostome Bryozoa in the Danian. The table is prepared on the basis of the information in Tables 1 and 6 about the distribution of the species within the museum material and the stratigraphical material, respectively. In the table the species are omitted which occur in all zones, besides the forms occurring with less than 5 specimens in the same locality.

Table 8. The stratigraphical distribution of the Cheilostome Bryozoa in the Danian

$+=$ Stratigraphical material

$-=$ Museum material

\begin{tabular}{|c|c|c|c|c|c|c|c|c|c|c|c|c|c|c|c|}
\hline \multirow[b]{2}{*}{ No. } & \multirow[b]{2}{*}{ Names of species } & \multirow[b]{2}{*}{ 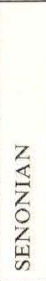 } & \multirow{2}{*}{ 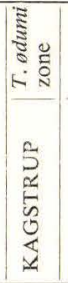 } & \multicolumn{2}{|c|}{ 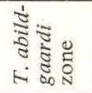 } & \multicolumn{4}{|c|}{$\begin{array}{l}\text { T. brünnichi } \\
\text { zone }\end{array}$} & \multirow[b]{2}{*}{ 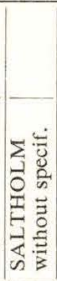 } & \multicolumn{5}{|c|}{$\begin{array}{l}T . \text { vexillifera } \\
\text { zone }\end{array}$} \\
\hline & & & & 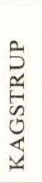 & 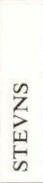 & 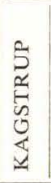 & 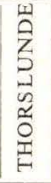 & $\begin{array}{l}\text { 岁 } \\
\frac{x}{4} \\
4\end{array}$ & 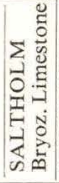 & & 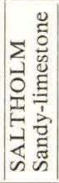 & $\begin{array}{l}Z \\
\text { 至 } \\
0 \\
\vdots \\
\mathbb{Z} \\
z \\
01 \\
0 \\
0 \\
0\end{array}$ & 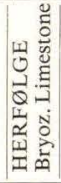 & 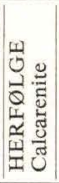 & 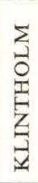 \\
\hline 36 & Onychocella gimense (BRYD.)..... & - & . & + & \pm & . & . & . & • & . & . & . & . & . & . \\
\hline 41 & Floridina gothica (D'ORB.) ....... & - & + & + & \pm & \pm & . & + & + & . & . & . & . & . & . \\
\hline 82 & Pachydera densa LANG .......... & . & + & - & - & . & . & - & . & . & . & . & . & . & . \\
\hline 116 & Cellepora danienses VorGT ........ & . & + & \pm & \pm & + & . & + & . & . & . & . & . & . & . \\
\hline 42 & Floridina tubulosa VoIGT ........ & . & + & - & \pm & + & - & \pm & + & . & . & . & . & . & . \\
\hline 50 & Floridina fragilis n.sp........... & . & . & + & + & + & . & + & + & . & . & . & . & . & . \\
\hline 75 & Pliophloea subcornuta n.sp. ....... & . & . & \pm & \pm & . & . & \pm & + & . & . & . & . & . & . \\
\hline 114 & Cryptostomella pectinata n.sp..... & . & . & - & - & . & - & \pm & $\cdot$ & . & . & . & . & . & . \\
\hline 89 & Phractoporella cordiformis (LEV.). & . & . & - & - & . & - & - & . & - & . & . & . & . & . \\
\hline 11 & Membranipora maxima LEV. ...... & · & . & - & . & · & · & \pm & . & . & · & . & . & . & . \\
\hline 26 & Allantopora stomatoporoides LANG & . & . & - & . & . & . & \pm & . & . & . & . & . & . & . \\
\hline 67 & Lunulites saltholmensis n.sp...... & . & . & . & . & + & . & + & . & - & . & - & . & . & . \\
\hline 6 & "Membranipora" johnstrupi n.sp. . & . & . & . & . & . & - & - & . & - & . & - & . & . & . \\
\hline 27 & Membraniporidra huckeana VoIGT. & . & . & . & . & . & . & \pm & \pm & - & . & . & \pm & . & + \\
\hline 29 & - inermis (LEV.). . . . . . . . . . & . & . & . & . & . & . & \pm & - & - & . & . & \pm & + & . \\
\hline 31 & Pithodella bifoliata n.sp......... & . & . & . & . & . & . & \pm & \pm & - & - & - & \pm & + & + \\
\hline 38 & Onychocella ravni n.sp........... & . & . & . & . & $\cdot$ & . & \pm & . & . & $\cdot$ & - & \pm & - & + \\
\hline 39 & - elongata LEV.............. & . & . & . & . & + & - & \pm & . & . & + & . & \pm & + & + \\
\hline 43 & Floridina voigti BASSLER . . . . . . . & . & . & . & . & . & . & + & . & - & . & . & \pm & + & + \\
\hline 46 & - scutata (LEV.)............ & . & . & . & . & + & - & \pm & . & - & + & . & \pm & + & + \\
\hline 48 & - pulchella (KADE) .......... & . & . & . & . & + & - & \pm & \pm & - & + & - & \pm & + & + \\
\hline 52 & Micropora angulata LEV. ......... & . & . & . & . & - & - & \pm & + & - & · & . & \pm & \pm & + \\
\hline 54 & - hennigiana n.sp. ........... & . & . & . & . & . & . & \pm & . & . & . & . & - & $\cdot$ & + \\
\hline 59 & Aechmella latistoma n.sp........ & . & . & . & . & . & - & \pm & . & . & . & . & 一 & $\cdot$ & + \\
\hline 61 & - tenuis n.sp.............. & - & . & . & . & + & . & + & + & . & + & . & $\cdot$ & $\cdot$ & + \\
\hline 62 & Hoplitaechmella smitti (HENNIG).. & . & . & . & . & $\cdot$ & . & - & . & . & . & . & - & $\cdot$ & . \\
\hline 76 & Pliophloea gluma LANG.......... & & . & . & . & . & . & \pm & . & . & . & . & \pm & + & . \\
\hline 77 & - palea LANG............... & . & . & . & . & . & . & - & $\cdot$ & . & . & . & - & - & . \\
\hline 78 & - vincularioides VorGT ....... & - & . & . & . & . & - & \pm & + & - & + & . & + & + & + \\
\hline 88 & Haplocephalopora uniceps LANG .. & . & . & . & . & . & - & \pm & . & . & . & . & - & $\cdot$ & . \\
\hline 90 & Diacanthopora bispinosa LANG ... & & . & . & . & . & . & \pm & . & . & . & . & \pm & . & . \\
\hline 92 & Anornithopora minuta VoIGT ..... & . & . & . & . & . & . & - & . & . & . & . & - & $\cdot$ & . \\
\hline
\end{tabular}


Table 8 (continued).

\begin{tabular}{|c|c|c|c|c|c|c|c|c|c|c|c|c|c|c|c|}
\hline \multirow[b]{2}{*}{ No. } & \multirow[b]{2}{*}{ Names of species } & \multirow[b]{2}{*}{ 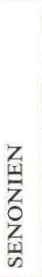 } & \multirow{2}{*}{ 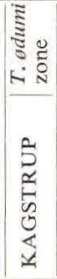 } & \multicolumn{2}{|c|}{ 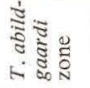 } & \multicolumn{4}{|c|}{$\begin{array}{l}\text { T. brïnnichi } \\
\text { zone }\end{array}$} & \multirow[b]{2}{*}{ 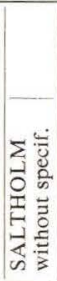 } & \multicolumn{5}{|c|}{$\begin{array}{l}T . \text { vexillifera } \\
\text { zone }\end{array}$} \\
\hline & & & & 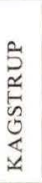 & $\frac{n}{z}$ & 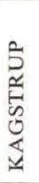 & 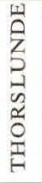 & $\underset{\leftarrow}{\infty}$ & 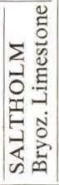 & & 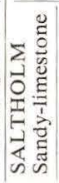 & $\begin{array}{l}Z \\
\text { 岁 } \\
0 \\
1 \\
\frac{1}{Z} \\
0 \\
0 \\
0\end{array}$ & 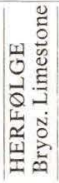 & 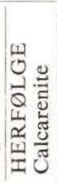 & 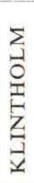 \\
\hline 93 & Anornithopora polygona VoIGT ... & . & . & . & - & . & . & - & . & - & . & . & . & . & + \\
\hline 94 & - circulata n.sp............ & . & . & . & . & . & . & - & . & . & . & . & - & . & . \\
\hline 95 & - isolata n.sp. ............ & . & . & . & . & . & . & + & . & - & . & . & + & . & + \\
\hline 100 & Beisselina nobilis (LEv.). . . . . . . & . & . & . & . & . & - & \pm & \pm & - & \pm & & \pm & + & + \\
\hline 101 & - celleporoides (VoIGT) ...... & . & . & . & . & . & - & \pm & . & - & . & . & \pm & \pm & + \\
\hline 102 & Beisselinopsis tubulifera n.sp..... & . & . & . & . & . & . & - & . & . & . & . & \pm & . & + \\
\hline 112 & Systenostoma pontifera n.sp. .... & . & . & . & . & . & - & - & . & . & . & . & - & . & . \\
\hline 115 & Psilosecos angustidens (LEV.) ..... & . & . & . & . & . & - & \pm & - & - & + & . & \pm & - & + \\
\hline 117 & Crassicellopora voigti n.sp........ & . & . & . & . & . & . & \pm & . & . & . & . & - & - & . \\
\hline 2 & $\begin{array}{l}\text { "Membranipora" hexagona } \\
\text { bredsdorffi n.sp........... }\end{array}$ & & & . & & & & & & & & & + & - & \\
\hline 4 & 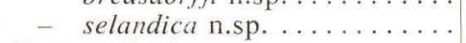 & . & . & . & - & . & . & . & . & . & . & $\dot{-}$ & \pm & - & . \\
\hline 35 & Frurionella daniensis n.sp........ & . & . & . & . & . & . & . & . & . & . & . & - & - & . \\
\hline 44 & Floridina brydonei VoIGT . . . . . . . & . & . & . & . & . & . & . & . & . & . & . & \pm & - & \pm \\
\hline 47 & - trifolioides n.sp........... & . & . & . & . & . & . & . & . & . & . & . & \pm & \pm & - \\
\hline 49 & - levinseni n.sp............ & . & . & . & . & . & . & . & . & . & . & . & \pm & + & + \\
\hline 51 & - excavata VorGT........... & . & . & . & - & . & . & . & . & . & . & . & \pm & . & t \\
\hline 79 & Pliophloea brünnichi n.sp........ & . & - & . & - & . & . & . & . & . & . & . & \pm & \pm & t \\
\hline 109 & Diplotresis europaea n.sp........ & . & . & . & - & . & . & . & . & . & . & . & - & $\therefore$ & $\therefore$ \\
\hline 110 & Ochetosellina areolata n.sp. ...... & . & . & . & . & . & . & . & . & . & . & . & \pm & + & + \\
\hline
\end{tabular}

As appears from the table, the Bryozoa seem to be an excellent aid at the biostratigraphical classification of the Danian. The species are naturally divided into four groups, corresponding to the four Tylocidaris zones, and the stratigraphical placing of the localities on the basis of the occurrence of the Bryozoa agrees with the experiences obtained through the study of the distribution of other animal groups, - with one exception:

Saltholm. If on the basis of the Bryozoa alone the limestones on Saltholm should be placed in the stratigraphical diagram, both Bryozoan Limestone and Sandy-limestone should be referred to the T. brünnichi zone.

This deviation from the current view has made it necessary to discuss the arguments which have been adduced in the documentation of the reference of the Sandy-limestone to the $T$. vexillifera zone. Such a revision has been made in the last chapter of this work.

Species of the genus Floridina have proved to be particularly suitable as an implement to be used at the biostratigraphical classification, because they, apart from the difference in stratigraphical placing, in the case of most species are of rather common occurrence and are easy to identify as regards species (in contrast to e.g. the Cribrimorph species of Bryozoa). The stratigraphical distribution of the Floridina species appears from the diagram Fig. 30. 


\begin{tabular}{|c|c|c|c|c|}
\hline Species & $\begin{array}{l}\text { T. odumi } \\
\text { zone }\end{array}$ & $\begin{array}{c}T \text {.abildgaardi } \\
\text { zone }\end{array}$ & $\begin{array}{l}T . \text { brünnichi } \\
\text { zone }\end{array}$ & $\begin{array}{c}\text { T. vexillifera } \\
\text { zone }\end{array}$ \\
\hline 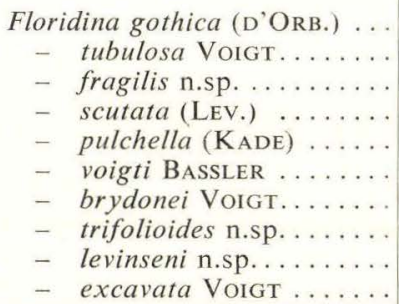 & & & & \\
\hline
\end{tabular}

Fig. 30. Stratigraphical distribution of the Floridina species. 


\section{STRATIGRAPHICAL POSITION OF THE SANDY-LIMESTONE ON SALTHOLM}

The order of strata on Saltholm is known from pits on the north end of the island and from wells. The pits have been water-logged for a number of years. During a short draining of the northernmost pit in 1935 RosENKRANTZ (1935, p. 547) measured a section $6 \mathrm{~m}$. in height, including at the bottom $2 \mathrm{~m}$. Bryozoan Limestone, above this a conglomerate with head-sized pebbles covered with glauconite and embedded in a argillaceous groundmass, and at the top alternating layers of calcareous sand and indurated Sandy-limestone.

The series of Sandy-limestone, as mentioned above, has so far been referred to the Tylocidaris vexillifera zone. This placing is partly based on the faunal relationship with the Sandy-limestone at Copenhagen, partly on features which the locality has in common with Herfølge and Limhamn regarding the lithological development.

\section{Faunistic Arguments.}

According to RoSENKRANTZ (1920, p. 49) the following forms are particularly characteristic of the Sandy-limestone in the Copenhagen area: Graphularia grönwalli Br. Nielsen, Ditrupula schlotheimi Rosenkrantz, Crania posselti Rosenkrantz, Crania tuberculata Nilsson (C. brattenburgicus Schlotheim in CARLSSON 1958, p. 27), Argyrotheca scabricula V. KoEnen, Lima bisulcata Ravn, Lima testis Grönwall, Pecten sericeus Grönwall, Plicatula ravni Rosenkrantz, Modiola hauniensis Rosenkrantz, Scalpellum steenstrupi Br. Nielsen, and Cestracion danicus Rosenkrantz. This list of fossils has later been supplemented by Echinocorys obliquus RAvN (1927, p. 338), and Chatwinothyris lens (NILSSON) (ROSENKRANTZ 1944b, p. 448). The following ten of these fourteen species have also been found in the Sandy-limestone on Saltholm (Rosenkrantz and BrüNNich NielSEN (1926)): Graphularia grönwalli, Echinocorys obliquus, Ditrupula schlotheimi, Crania posselti, Crania tuberculata, Chatwinothyris lens, Argyrotheca scabricula, Pecten sericeus, Scalpellum steenstrupi, and Cestracion danicus. On the occurrence of these species the following remarks should be made:

Graphularia grönwalli according to BrüNNICH NIELSEN (1913, p. 8) also occurs in the limestone at Faxe. The species is by ØDUM (1926, p. 224) characterized as a form of silty bottom. 
Echinocorys obliquus is by BROTZEN (1959, p. 22) stated to occur in the T. brünnichi zone in the limestone quarry of Limhamn.

Ditrupula schlotheimi according to BRÜNNICH NIELSEN (1931, p. 95) is connected with the facies of Sandy-limestone, whereas ØDum (1926, p. 225) characterizes it as a form of silty bottom.

Crania posselti according to BrüNNICH NiELSEN (1909, p. 149) also occurs in the Bryozoan Limestone in Stevns.

Crania tuberculata especially seems to occur in deposits of Sandy-limestone, where it is very common, while the variety transversa is generally distributed in Sandy-limestone as well as Bryozoan Limestone. In ØDum's opinion (1926, p. 225) C. tuberculata transversa as to its distribution is independent of depth, while $C$. tuberculata seems to have preferred shallow water.

Argyrotheca scabricula according to BRÜNNICH NIELSEN (1928, p. 223) also occurs in the Bryozoan Limestone of Faxe.

Pecten sericeus has been found in Paleocene deposits of marl and greensand. (GRÖNWALL and HARDER, 1907, p. 28).

Scalpellum steenstrupi is known from the Bryozoan Limestone of Faxe (BRÜNNICH NIELSEN 1912, p. 16). The species is characterized by ØDUM (1926, p. 226) as a form occurring both in Coccolith-limestone, Sandy-limestone and Bryozoan Limestone, but which hardly lived in very deep water.

Cestracion danicus has been found at Aggersborg (in Jutland) in Bryozoan Limestone belonging to the Lower Danian (ØDum 1926, p. 192).

Terebratula lens is still left. In East Denmark this species is known from the Sandy-limestone in the Copenhagen area and on Saltholm, while in Jutland it occurs in Coccolith-limestone belonging to the $T$. vexillifera zone. To all appearances the species thus would seem an excellent guiding fossil for this zone; but apparently it does not occur in the T. vexillifera zone at Herfølge, neither in the Bryozoan Limestone nor in the Calcarenite. According to information received from the specialist in Brachiopods Miss Ulla AsGaARD, the other representatives of the genus Chatwinothyris (with the exception of $C h$. pseudocarnea and its subspecies) are characterized by only occurring in the Coccolith-limestone, while species of the genus Gryphus mark the fauna of Brachiopods in the Bryozoan Limestone. Against this background it cannot be considered precluded that the distribution of Chatwinothyris lens is first of all dictated by ecological factors.

If a conclusion is to be drawn on the basis of this discussion of the characterizing species of Sandy-limestone, it must be that the apparent relationship between the fauna in the Sandy-limestone on Saltholm and that of the Copenhagen area need not absolutely exist because the two assemblages have lived at the same time. The correct explanation perhaps may be that the two assemblages developed at different times, but under uniform environmental conditions.

In this connexion there might be reason to adduce a form more, viz. Tyloci- 
daris vexillifera SCHLÜTER var. typica $\mathrm{RAVN}(1928$, p. 32) (=T. pomifer herupensis and T. pomifer vexillifera in WIND (1954, p. 483) and T. herupensis in BROTZEN (1959, p. 51)). Indeed, this species is a guiding fossil for the $T$. vexillifera zone and consequently also ought to occur in the Sandy-limestone on Saltholm. However, there seems to be some confusion on this point. RAvN (1928, p. 34) states that the collection in the Mineralogical Museum of spines of this form amongst others contains 15 specimens from the Saltholm Limestone (= the Sandy-limestone) on Saltholm, but that the great majority of spines in this limestone (about 260 specimens) belong to Tyl. brünnichi. Six T. brünnichi spines from the Sandy-limestone on Saltholm are pictured in RAVN's Plate IV. BROTZEN (1959, p. 50) makes a reference to these pictures of T. brünnichi spines in RAVN, maintaining that the spines in question cannot originate from the Sandy-limestone, but must have come from the underlying Bryozoan Limestone, as this form ought not to occur in the Sandy-limestone. At the same time he calls attention to the fact (p. 52) that in the Sandy-limestone at Östratorp it is possible to find spines of $T$. brünnichi as well as T. herupensis. Furthermore, he states (p. 31) that on Saltholm in the Sandy-limestone a few metres above Middle Danian it is possible to collect spines of $T$. herupensis which look like spines of $T$. brünnichi, as they are of the same size as these and have corresponding, slightly developed wings. Furthermore (according to BRoTZEN), there are transitional types between $T$. brünnichi and T. herupensis in the Sandylimestone on Saltholm.

The typical $T$. vexillifera ( $T$. herupensis) has not been found in the limestone quarry at Limhamn. Spines of a type which WIND (1954, p. 483) has described under the name of $T y l$. pomifer vexillifera are known from the limestone of Klagshamn. This is a form which also occurs at Faxe and which in WIND's opinion is characteristic of the upper part of Middle Danian.

\section{Lithological Arguments.}

In the argumentation for the reference of the Sandy-limestone of Saltholm to the $T$. vexillifera zone especially the Conglomerate between Bryozoan Limestone and Sandy-limestone has played a part, as this Conglomerate by RosENKRANTZ (1931, p. 139) was considered to be of the same age as the Conglomerates from Herfølge and Limhamn, because "the overlying layers contain the same fauna in all the three localities."

The Conglomerate on Saltholm is composed of pebbles which are often covered with glauconite and in some cases are head-sized. The mass enclosing the pebbles is often dark and argillaceous, and above the Conglomerate or in places where this is not developed, there is a layer of clay $2 \mathrm{~cm}$. thick and in a moist state quite black (RosenKRANTZ, 1935, p. 548).

The Conglomerate above the Bryozoan Limestone at Herfølge has only $17^{*}$ 
been cursorily mentioned in reports of excursions and summaries of lectures (Medd. Dansk Geol. Foren. 1924, p. 28, and Rosenkrantz 1931, p. 138). In the section in the north wall of the quarry excavated in 1951 (see p. 33) the Conglomerate was found at a depth of $5.94 \mathrm{~m}$. to a depth of $6.28 \mathrm{~m}$. and consisted of slightly rounded, fist-sized clods of comparatively hard Bryozoan Limestone in a groundmass of calcareous silt. Under the Conglomerate there was a very silty Bryozoan Limestone with scattered flint nodules, and immediately above the Conglomerate there was a $4 \mathrm{~mm}$. thick yellowish brown layer of clay, which was superposed by a soft silty limestone. This rock, which during the excavation was interpreted as Calcarenite, is in the stratigraphical material represented by a sample from a depth of $5.80 \mathrm{~m}$. The contents of Bryozoa in this sample of limestone proved to be of approximately the same order of magnitude as those in the underlying Bryozoan Limestone (see Table 3), whereas the overlying layers of limestone contained very few Bryozoan fragments. The sample in question is in the various diagrams characterized as Calcarenite; but it is doubtful whether it should not rather be termed Bryozoan Limestone containing silt. The reason why this has not been done is partly that previous examinations of the locality tell against such an interpretation, partly that there is no sediment-petrographical analysis of the sample available. If such an examination proves to support my view, the consequence will be that the lower margin of the Calcarenite is moved from a depth of $5.94 \mathrm{~m}$. to somewhere between 5.00 and $5.80 \mathrm{~m}$. below ground level, and that the Conglomerate enters as part of the series of Bryozoan Limestone.

Rosenkrantz (1931, p. 138) states about the Conglomerate in the limestone at Limhamn that in 1929 it was possible to observe a section in the north wall of the quarry comprising at the bottom $15 \mathrm{~m}$. Bryozoan Limestone and Coralreef Limestone with a cover of Coccolith-limestone. This series was discordantly overlain by a $30-40 \mathrm{~cm}$. thick Conglomerate consisting of pebbles up to head-size, more or less phosphoritic and covered with glauconite, in a groundmass of calcareous sand. Above this there was 1-6 m. grey calcareous sand with bands of flint, covered with glacial deposits. According to BROTZEN (1940, p. 17, and 1959 , p. 29) the Conglomerate in the south wall of the quarry has developed as a greenish argilliferous horizon with secondarily deposited fossils.

On the face of it there seems to be a greater similarity between the Conglomerates on Saltholm and at Limhamn than between these and the Conglomerate at Herfølge. This difference is further stressed by a consideration of the stratigraphical conditions. As mentioned above, the Conglomerate on Saltholm rests on Bryozoan Limestone belonging to the T. brünnichi zone, as is also the case at Limhamn. At Herfølge the Conglomerate is underlain by Bryozoan Limestone belonging to the $T$. vexillifera zone. If the Conglomerates in the three localities should have been formed at the same time, it must be assumed that there was a break in the sedimentation of longer duration on Saltholm and at Limhamn than at Herfølge, and such a development at any rate does not manifest itself in the case of the Bryozoa. 
The above-mentioned faunal relationship between Herfølge and Saltholm comprises the following characterizing species: Ditrupula schlotheimi, Crania posselti, Crania tuberculata, Argyrotheca scabricula, Scalpellum steenstrupi, and Cestracion danicus. Under the faunistic considerations in the present chapter an account of the conditions of distribution of these species has already been given. Here it is only to be stressed that the species in question are either known from localities belonging to Lower Danian deposits or their occurrence is restricted to silty or sandy bottom.

The conglomerates must be characterized as intraformational regression conglomerates (Pettionon 1949, p. 210, and Hadding 1927, pp. 148 and 159). Such conglomerates as a rule are formed in shallow water (perhaps outside the littoral zone) and mostly mark a break in the sedimentation of short duration. A regression will give rise to changes in the ecological situation, which presumably will cause the benthonic fauna to seek an area where the environmental conditions have not changed characters. If the subsequent transgression does not re-create the original environs, the result will faunistically be that an animal assemblage will be created which is composed of the species from the original assemblage which are capable of adapting themselves to the changed ecological conditions, - and a group of species which have better possibilities of development in the new environs than in the original ones.

Such a development is reflected in conditions on Saltholm as well as those at Herfølge. During the transgression, changes take place in both places as regards conditions of the bottom, the depth, and the current, which, again, is of importance for the temperature, supply of nourishment, etc. In the case of the Bryozoa these changes cause that the number of species within the assemblage of Bryozoa is considerably reduced, presumably especially as the changed bottom conditions decrease the possibilities of fastening to the larvae. On the other hand such a form as Lumulites saltholmensis n.sp. seems to have obtained better conditions of development because the larvae of this species are capable of fastening on the sandy bottom. Similarly there must in other animal groups in the changed environs be a "sorting-out" of the species into "suitable" and "unsuitable" forms. The above-mentioned characterizing species for the Sandy-limestone therefore need not occur in this deposit "because their time has come" biostratigraphically. The explanation of their presence perhaps may be that the changed ecological conditions just satisfy their demands on environs, or, in other words, "the presence or absence of a species is not only a function of time. Paleoenvironments may play a more important part in controlling the distribution of species" (SorGENFREI, 1958, p. 18).

The conclusion of these considerations must be that in the geological literature on Saltholm there is no information available which decisively tells against referring the Sandy-limestone on Saltholm to the T. brünnichi zone.

My evaluation of the lithological development of the Danian appears from Fig. 31. Future research will decide whether this assumption is true or whether the interpretation previously advanced should stand. 


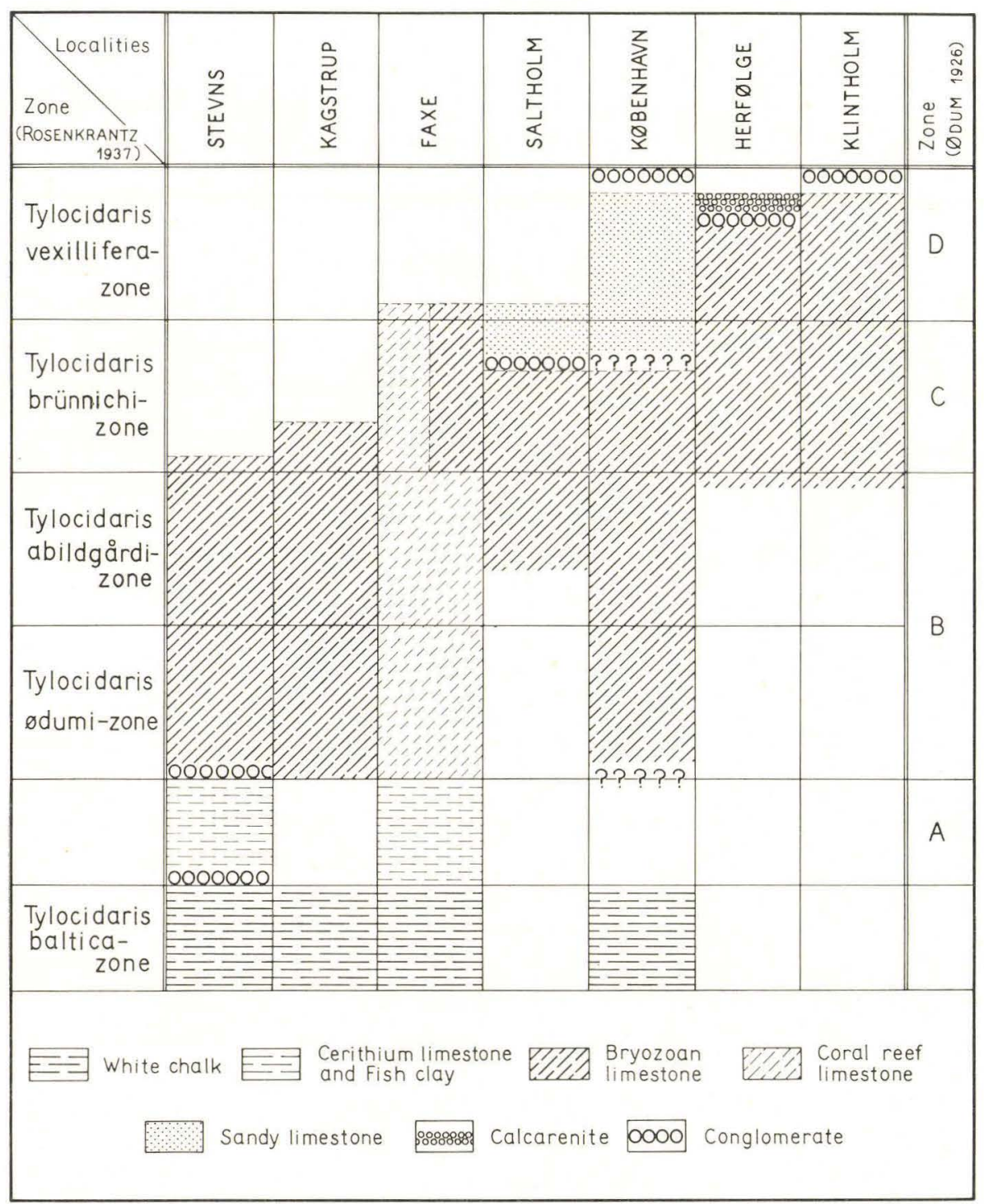

Fig. 31. Survey of the lithological development of the Danian in East Denmark. 
DANSK SAMMENDRAG

\title{
CHEILOSTOME BRYOZOER I ØSTDANMARKS DANIENAFLEJRINGER
}

\author{
I. Indledning.
}

I dette arbejde forelægges resultaterne af nogle undersøgelser vedrørende de cheilostome bryozoers palæontologi og udbredelse inden for Danienaflejringerne i Østdanmark. Disse studier blev påbegyndt i 1950, og som udgangspunkt valgtes materiale fra bryozokalken ved Herfølge. Mineralogisk Museums fossilsamlinger fra denne lokalitet er meget omfangsrige, men valget var yderligere motiveret i Herfølge-bryozoernes bevaringstilstand, som gjorde dem særlig velegnet for palæontologiske undersøgelser.

Det viste sig imidlertid at være temmelig vanskeligt at artsbestemme en stor del af kolonifragmenterne på basis af den existerende bryozolitteratur, som fortrinsvis bygger på undersøgelser af materiale fra Faxe og Danien-blokke i kvartærlagene samt de senone aflejringer. Forklaringen herpå kunne være, at de facielle forhold ved Herfølge var anderledes end f. eks. ved Faxe, men man kunne også tænke sig den mulighed, at identifikationsvanskelighederne var et udtryk for en forskel i de to nævnte lokaliteters stratigrafiske placering inden for Danienet - eller sagt med andre ord, at bryozoerne var et egnet hjælpemiddel i den stratigrafiske vurdering af Danienaflejringerne. LANG (1921-22) og VoIGT (1930) har påvist denne dyregruppes anvendelighed inden for Senonstratigrafien, det var derfor en nærliggende tanke at foretage en tilsvarende analyse af bryozoernes optræden inden for Danienet.

I konsekvens heraf blev undersøgelserne udvidet til at omfatte bryozomateriale fra en række andre forekomster, således at alle Danienets zoner var repræsenteret ved mindst to lokaliteter. På nedenstående oversigt er vist zoneinddelingen efter ØDum (1926) og RosEnKRANTZ (1937), samt de lokaliteter, hvorfra bryozomateriale blev udtaget.

De indledende stratigrafiske undersøgelser byggede udelukkende på museumsmateriale, idet der i Mineralogisk Museum findes en omfattende samling af udsorterede bryozoer, indsamlede, undersøgte og i nogen grad slægts-eller artsbestemte af Dr. BRÜNNICH NiELSEN. For at opnå et mere ensartet og i stratigrafisk henseende mere pålideligt sammenligningsgrundlag suppleredes dette materiale senere med bryozomateriale fra kalkprøver, indsamlet og behandlet af forfatteren. Denne samling af bryozoer betegnes i det følgende som det stratigrafiske materiale til adskillelse fra museumsmaterialet. 


\begin{tabular}{|c|c|c|c|}
\hline & ROSENKRANTZ & $\varnothing_{\text {DUM }}$ & Lokaliteter \\
\hline \multirow[t]{2}{*}{ Yngre Danien } & Tylocidaris vexillifera-zonen............ & Zone D & $\begin{array}{l}\text { Saltholm } \\
\text { København } \\
\text { Herfølge } \\
\text { Klintholm }\end{array}$ \\
\hline & Tylocidaris brünnichi-zonen . ........... & Zone C & $\begin{array}{l}\text { Thorslunde } \\
\text { Faxe }\end{array}$ \\
\hline \multirow[t]{2}{*}{ Aldre Danien } & $\begin{array}{l}\text { Tylocidaris abildgaardi-zonen. . . . . . . . . . } \\
\text { Tylocidaris odumi-zonen } \ldots \ldots \ldots \ldots\end{array}$ & Zone B & $\begin{array}{l}\text { Kagstrup } \\
\text { Stevns }\end{array}$ \\
\hline & Cerithiumkalk ............... & Zone A & \\
\hline
\end{tabular}

\section{Lokalitetsbeskrivelser.}

Det geologiske kort, fig. 1 (side 12), viser beliggenheden af de undersøgte Danienlokaliteter, som i dette kapitel er beskrevet i følgende rækkefølge: Stevns (side 11), Kagstrup (side 15), Thorslunde (side 19), Faxe (side 21), København (side 25), Saltholm (side 29), Herfølge (side 32) og Klintholm (side 35). Kapitlet indledes med en oversigt over afhandlinger, som refererer ældre undersøgelser (d.v.s. før 1908), og som bringer udførlige litteraturhenvisninger.

De enkelte lokaliteter behandles efter følgende retningslinier: Der indledes med en kort anvisning på lokalitetens beliggenhed, som sammen med det ledsagende kortudsnit skulle gøre det muligt - også for udenlandske geologer at finde frem til lokaliteten. Dernæst gives en fortegnelse over afhandlinger, som specielt beskæftiger sig med den pågældende lokalitet. Den efterfølgende karakteristik af lagserien bygger fortrinsvis på nævnte litteratur, suppleret med egne iagttagelser. I et særligt underafsnit behandles dernæst lokalitetens biostratigrafiske placering og som afslutning på beskrivelsen af de enkelte lokaliteter gøres der rede for bryozomaterialets oprindelse.

Museumsmaterialet fra Stev n s er mærket bryozokalk, Stevns eller Danien, Stevns. Det stratigrafiske materiale omfatter 6 prøver, som er udtaget i sydvæggen i Boesdal kalkgrav; udtagningsstederne er afmærket med a-f på fig. 4 (side 16).

Museumsmaterialet fra K a g s tr u p bærer betegnelsen bryozokalk, Kagstrup. Det stratigrafiske materiale omfatter 3 prøver udtaget henholdsvis i den nedre del af østvæggen ( $T$. ødumi-zonen), i nordvæggen ( $T$. abildgaardi-zonen) og i den øvre del af vestvæggen (T. brünnichi-zonen). Udtagningsstederne er angivet på fig. 6 (side 18) med A, B og C.

Fra Thorslunde foreligger der kun museumsmateriale, da kalkgraven ikke mere er tilgængelig.

Med hensyn til Faxe er der ved undersøgelserne anvendt museumsmateriale mærket Faxe, samt bryozoer udsorteret af BRÜNNICH NIELSEN fra prøver, som 
denne i 1909 indsamlede i kalkgraven på de på fig. 13 (side 25) med I-XIII afmærkede steder (BRÜNNICH NIELSEN, 1911). Det stratigrafiske materiale omfatter en prøve udtaget i gravens vestlige ende (Hvedeland); udtagningsstedet er afmærket med Da på fig. 9 (side 21). Endvidere fire prøver fra gravens nordvæg (ved M på fig. 9), udtaget henholdsvis 4 m, 7 m, 17 m, og 20 m under terræn.

Fra København er der undersøgt bryozoer fra 4 lokaliteter, som på kortudsnittet fig. 14 (side 26) er afmærket som Sydhavnen, Sundkrogen, Svanemøllen og Hyttehusvej. Materialet fra Sydhavnen stammer fra to udgravninger, som blev udført i 1917-19 (fig. 15 og 16, side 27 og 28) og undersøgt og beskrevet af Rosenkrantz (1920). Bryozoerne fra Sundkrogen er udtaget af Harder (1922), som har sammenstillet sine iagttagelser i et skematisk profil, som er vist på fig. 17 (side 28); bryozomaterialet stammer fra det lerede grønsandslag over grønsandskalken. Mellem Svanemøllen og Middelgrunden er der i kalklagene udbygget en tunnel til bortledning af spildevand; professor ROSENKRANTZ har velvilligst overladt mig bryozomateriale, mærket Svanemølleskakten, fra denne lokalitet. Det stratigrafiske materiale stammer fra en prøve af kalksandskalk udtaget i $7 \mathrm{~m}$ dybde i en udgravning til en pumpestation på Hyttehusvej; lokaliteten er afmærket med K på fig. 14.

Om materialet fra Saltholm kan følgende oplyses: I Mineralogisk Museums samlinger findes bryozomateriale mrk. 1) Saltholm (eller Saltholmen) og 2) bryozokalk, Saltholm. Det førstnævnte materiale stammer sandsynligvis fra de opgravede kalkdynger ved bruddet og ved havnemolen. Denne kalk hidhører efter RosENKRANTZ's opfattelse (1935) i overvejende grad fra lagene omkring grænsen mellem bryozokalk og kalksand. Hertil må også henregnes de bryozoarter, som er opført i BRÜNNICH NIELSEN's fossilliste (1926). I materialefortegnelserne inden for de respektive artsbeskrivelser er dette bryozomateriale betegnet som Saltholm, d.v.s. uden bjergartsangivelse. Bryozoerne fra bryozokalken kan være udtaget af den faststående kalk øst for bruddet, men kan også stamme fra bryozokalkbrokker i dyngerne. Bryozomaterialet fra denne kategori er betegnet bryozokalk, Saltholm, i artsbeskrivelserne.

I Mineralogisk Museum findes endvidere en mindre bryozosamling, mærket General Madsens Skanse. Denne samling stammer fra et mindre, mere sydligt beliggende brud i kalksandskalk (afmærket med X på fig. 18, side 30). Bryozoer fra denne forekomst figurerer i materialeoversigterne med betegnelsen kalksandskalk, Saltholm.

Det stratigrafiske materiale er udtaget af prøveserierne fra to kalkboringer, som er udført på det nordlige Saltholm. Ved boring 1 (D.G.U. arkiv nr. 201.396 - afmærket med E på fig. 18) traf man følgende lagserie:

Terrænhøjde: $+1 \mathrm{~m}$. $0-0,3 \mathrm{~m}$ Tørv

0,3-5,1 m Vekslende lag af hård og blød bryozokalk

Fra denne boring er der undersøgt en prøve fra $5 \mathrm{~m}$ dybde. 
Boring 2 (D.G.U. arkiv nr. 201.402 - på fig. 18 afmærket med F) blev ført gennem følgende lagserie:

Terrænhøjde: $+1 \mathrm{~m}$.

$$
\begin{array}{ccl}
0- & 0,2 \mathrm{~m} & \text { Sandblandet muld } \\
0,2-\mathrm{ca} 4 & \mathrm{~m} & \text { Kalksandskalk } \\
\text { ca 4-20,2 m } & \text { Bryozokalk. }
\end{array}
$$

Fra denne serie er analyseret en bryozokalkprøve fra $6 \mathrm{~m}$ dybde (prøve Fc) og 2 prøver af kalksandskalk (Fa og Fb) fra 2 og 3 m dybde.

Museumsmaterialet fra Herfølge er mærket bryozokalk eller craniakalk. Det stratigrafiske materiale er udtaget i 1951 under rengravningen af et $2 \mathrm{~m}$ bredt og ca. $8 \mathrm{~m}$ højt profil i kalkgravens nordvæg. Profilet, fig. 21 (side 34), kan beskrives således:

Terrænkote: $+22,5 \mathrm{~m}$.

0-1,5 m Moræneler, hvis nederste del har karakter af lokalmoræne, stærkt opblandet med brudstykker af gruskalk, (kalkarenit).

1,5-5,94 m Gruskalk (kalkarenit), i vekslende bænke af blød kalk og hård kalksten, afbrudt $\mathrm{af}$ lag af flintknolde og pladeflint. Kalkkornenes størrelse er aftagende ned igennem serien.

ved $5,94 \mathrm{~m}$ Lerlag, gulligt, ca. 4 mm tykt.

5,94-6,28 m Konglomerat, bestående af håndstore knolde af bryozokalk i en grundmasse opbygget af gruskalk (kalkarenit).

6,28-6,73 m Overgangslag, blød kalk (bryozokalk?) med spredte flintknolde.

6,73-7,15 m Bryozokalk, gullig slamholdig.

7,15-7,35 m Bryozokalk, gullig, med en del forsteninger.

Materialet omfatter 6 prøver, udtaget i dybderne 2,15 m, 3,75 m, 4,65 m, $5,80 \mathrm{~m}, 6,75 \mathrm{~m}$ og $7,15 \mathrm{~m}$.

Fra Klintholm forefindes der intet udsorteret museumsmateriale. Det stratigrafiske materiale omfatter 3 prøver, hvoraf de 2 er udtaget i vestvæggen i den største af gravene (afmærket med H på fig. 22, side 36). Fig. 23 på samme side viser et af TH. Sorgenfrei i 1946 opmålt profil af denne væg, som nu er bortgravet. Kalken er en gullig-hvid, slamholdig, blød bryozokalk, hvis øverste ca. $30 \mathrm{~cm}$ er brokket og ret stærkt imprægneret med glaukonit. Kalken overlejres af et 5-10 cm tykt paleocænt bundkonglomerat, fortrinsvis opbygget af rullede Tylocidaris-pigge i en mørk, leret grundmasse. Den øverste af de udtagne prøver repræsenterer den glaukonitrige zone (kote $+3,5)$, medens den anden prøve (udtaget i kote $+3,1$ ) består af gullig-hvid bryozokalk. Prøve 3, som velvilligst er overladt mig af præparator KR. SKov, stammer fra kalkdyngerne ved den sydligste af gravene; udtagningsstedet er afmærket med I på fig. 22. 


\section{Palæontologi.}

\section{Klassifikation.}

Den systematiske inddeling af det undersøgte bryozomateriale følger - med enkelte undtagelser - BASSLER's klassifikation, således som den er udformet i Treatise on Invertebrate Paleontology, part G, Bryozoa (1953).

Det har vist sig umuligt at indordne en del "Membranipora"-former i BASSLER's system. BASSLER's opdeling af Membranipora-arterne i 4 familier (Membraniporidae, Electrinidae, Hincksinidae og Calloporidae) er baseret på recente arter; disse arter repræsenterer imidlertid kun resterne af en bryozogruppe, der havde sin kulmination i Senonien. Indplaceringen af de kretaciske Membranipora-arter i BASSLER's system kan under disse betingelser ikke undgå at blive en skematisk og utilfredsstillende løsning (jfr. VoIGT, 1957). En revision af Membranipora-gruppens systematik på grundlag af senont bryozomateriale er hårdt tiltrængt.

Danienets repræsentanter for denne gruppe er - i mangel af anden udvejhenført til slægten "Membranipora", idet slægtsnavnet er sat i anførselstegn for at markere den midlertidige løsning.

\section{Bemærkninger til artsbeskrivelserne.}

Beskrivelserne er udarbejdet på grundlag af bryozomateriale fra samlingerne i Mineralogisk Museum i København, idet dette materiales bevaringstilstand har gjort det særlig velegnet til formålet. Tre af de behandlede arter (Floridina fragilis n.sp., Semiescharinella pulchra CANU og BASsLER og Aechmella tenuis n.sp.) blev først opdaget ved undersøgelserne af det stratigrafiske materiale.

For alle arters vedkommende er der udarbejdet en karakteristik, som med hensyn til tidligere offentliggjorte arter bygger på de publicerede oplysninger, suppleret med egne iagttagelser; denne forholdsvis udførlige omtale er motiveret med, at en stor del af de pågældende arter er publiceret $\mathrm{i}$ vanskeligt tilgængelige tidsskrifter 0.1 . Ud fra samme betragtning er alle behandlede arter afbildet på tavlerne bagest i bogen.

Målingerne, som ledsager artsbeskrivelserne, er foretaget således, at der af de forskellige celletyper hos hver art såvidt muligt er målt mindst 20 normale celler på forskellige kolonier fra alle de lokaliteter, hvor arten optræder. Disse målinger er anvendt til at angive celletypernes variationsintervaller, og gennemsnittet af disse værdier er placeret $i$ en særlig rubrik som middelværdier. Middelværdierne bygger således på et temmelig spinkelt grundlag, set fra et statistisk synspunkt, men deres opgave er kun at tjene som et hjælpemiddel ved sammenligninger, dels af samme arts størrelsesforhold inden for de forskellige lokaliteter, dels af arterne indbyrdes. Hvor der ved enkelte målinger kun er anført én værdi i rubrikken for variationsintervallet, og dette tal er gentaget som middelværdi, markerer dette, at der ikke er konstateret variationer i målene 
hos de pågældende celletyper. Såfremt rubrikken for middelværdier ikke er udfyldt, er dette udtryk for, at der ikke har været 20 celler til rådighed for gennemsnitsberegninger.

Følgende forkortelser er anvendt:

$\begin{array}{ll}\text { Lz: længde af zoøcium } & \text { hov: længde af ovicell } \\ \text { lz: bredde af zoøcium } & \text { lov: bredde af ovicell } \\ \text { ho: længde af opesium } & \text { Lav: længde af avicularium } \\ \text { lo: bredde af opesium } & \text { lav: bredde af avicularium } \\ \text { hr: længde af orificium } & \text { Lon: længde af onychocellarium } \\ \text { lr: bredde af orificium } & \text { lon: bredde af onychocellarium } \\ \text { ha: længde af apertura } & \text { Lv: længde af vibraculum } \\ \text { la: bredde af apertura } & \text { lv: bredde af vibraculum }\end{array}$

I rubrikken materiale er kun anført det museumsmateriale, som har været inddraget $\mathrm{i}$ undersøgelserne; denne bryozosamling er sorteret i arter og forefindes i Mineralogisk Museum i København.

Bryozomaterialet fra de supplerende stratigrafiske undersøgelser er ikke artssorteret; antallet af fragmenter af de forskellige arter er opført i tabel 6, side 243-250. Materialet beror i samlingerne på Danmarks Geologiske Undersøgelse, Charlottenlund.

Hvad angår typer, opereres der i det palæontologiske afsnit med 3 typer: Lectotyper, holotyper og paratyper. Lectotyperne er udvalgt blandt eksemplarerne i LEVINSEN's samling af bryozoer som typer for de arter, som er opstillet af Levinsen. Dette materiale findes i Zoologisk Museum i København. Holotyper og de supplerende paratyper er udvalgt blandt de undersøgte kolonier fra Mineralogisk Museums samlinger og forefindes i overensstemmelse hermed i dette museums typesamling.

Angivelser af de enkelte arters udbredelse er baseret på såvel museumsmateriale som det stratigrafiske materiale.

\section{Terminologi.}

I det terminologiske afsnit forklares betydningen af en række specielle betegnelser, som anvendes ved beskrivelsen af bryozoer.

\section{Bibliografi.}

I dette afsnit bringes en kronologisk ordnet oversigt over afhandlinger omhandlende cheilostome Danienbryozoer i Danmark og Sverige samt i løse blokke i Nordtyskland. For hver afhandling anføres de arter, som er beskrevet, afbildet eller nævnt $i$ det pågældende arbejde samt de gyldige artsnavne for disse arter. 


\section{Artsbeskrivelser.}

I det systematiske afsnit, side 50-220, beskrives 117 cheilostome arter og underarter, hvoraf 42 ikke tidligere er blevet behandlet. Afsnittet slutter med en tabellarisk oversigt over antallet af fragmenter af de beskrevne arter i museumsmaterialet fra de undersøgte lokaliteter (tabel 1, side 221).

\section{De stratigrafiske undersøgelser.}

\section{Formål.}

Som næunt i indledningen har hovedformålet med de supplerende stratigrafiske undersøgelser været at nå frem til et mere pålideligt sammenligningsgrundlag gennem udtagelse af nye prøver fra de udvalgte lokaliteter. Jeg har derudover set det som min opgave dels at søge klarlagt, i hvilket omfang bryozoerne har taget del i dannelsen af de forskellige kalkbjergarter dels for at få klarhed over sammensætningen af bryozoselskaberne inden for de enkelte zoner af Danienet - under særlig hensyntagen til miljøforholdenes eventuelle indflydelse.

\section{Metode og resultater.}

Til brug ved løsningen af disse opgaver blev der til indledning udtaget 18 prøver fra Kagstrup, Faxe, Saltholm, København, Herfølge og Klintholm. Dette materiale blev senere suppleret med 10 prøver fra Stevns og Faxe. Nærmere oplysninger om udtagninsgsteder m.v. er meddelt ovenfor samt $\mathrm{i}$ afsnittet med lokalitetsbeskrivelser (side 11-38) og i tabellerne 2 og 3.

De udtagne prøver blev tørret og vejet og derefter ved slæmning og sigtning opdelt i 3 fraktioner omfattende henholdsvis materiale mindre end $0,5 \mathrm{~mm}$, materiale mellem $0,5 \mathrm{og} 1,5 \mathrm{~mm}$ samt materiale over $1,5 \mathrm{~mm}$ i kornstørrelse. Disse fraktionsgrænser valgtes for at få alle bryozofragmenterne samlet inden for én fraktion, 0,5-1,5 mm. Efter vejning af materialet i de tre kategorier, blev der af den bryozoholdige fraktion udtaget $10 \mathrm{~g}$ ( - af de supplerende prøver fra Faxe og Stevns dog kun $5 \mathrm{~g}-$ ), som udsorteredes i grupperne 1) cheilostome bryozofragmenter, 2) cyclostome fragmenter, 3) andre forsteninger og 4) kalkog flintbrokker. Samtidig med sorteringsarbejdet blev der foretaget artsbestemmelse af de cheilostome kolonier, ligesom antallet af fragmenter inden for de to bryozogrupper blev registreret. Efter fuldendt udsortering blev materialet $\mathrm{i}$ de fire grupper gjort til genstand for vejning.

Resultaterne af disse fraktionerings- og vejningsprocesser er indført på tabellerne 2 og 3 (side 229 og 230), medens tabel 6 (side 243) viser antallet af fragmenter af de forskellige cheilostome arter i de undersøgte prøver. 


\section{Terminologiens udvikling.}

De fleste danske og svenske afhandlinger, som beskæftiger sig med Danienet, har som fællestræk, at de mangler et résumé på engelsk. Det kan derfor være svært for udenlandske læsere at holde rede på de forskellige kalkstensbetegnelser. For at afhjælpe dette forhold bringes der i dette afsnit en kortfattet oversigt over udviklingen i navngivningen af bjergarterne inden for Danienserien.

\section{Karakteristik af Danienets kalkaflejringer.}

I dette afsnit refereres danske og svenske afhandlinger, hvori kalksedimenternes sammensætning og opbygning er taget op til behandling.

\section{Lithologisk vurdering.}

Man har hidtil anset bryozofragmenter for at være den dominerende bestanddel af bryozokalken; analyseresultaterne (tabel 2-3) tyder imidlertid på, at man med denne antagelse har tillagt bryozoerne en for stor betydning. I ingen af de undersøgte prøver har bryozoindholdet oversteget $40 \%$, og i de fleste af prøverne udgør bryozoerne en betydelig mindre procentdel. Det kan være vanskeligt at få et klart indtryk af dette forhold ved betragtning af tabel 3, fordi det varierende indhold af kalk- og flintbrokker i den bryozoholdige fraktion i nogen grad tilslører billedet. Man opnår et bedre vurderingsgrundlag, hvis man på basis af bryozofragmenternes vægt i de enkelte 10 og 5 g prøver udregner vægten af kolonierne i udgangsmaterialets bryozoholdige fraktion og udtrykker denne værdi som procentdel i udgangsmaterialets totalvægt. Resultaterne af disse procentiske beregninger er sammenstillet i tabel 4 (side 233) og i grafisk form på fig. 28 (side 232).

Analyserne har også afsløret et andet interessant forhold, idet det har vist sig, at de cyclostome bryozoer i højere grad end de cheilostome former har medvirket ved bjergartsdannelsen; dette kommer til udtryk, hvad enten man, som i tabel $4 \mathrm{og}$ fig. 28, 1ægger vægtfordelingen til grund, eller lader antallet af bryozofragmenter danne vurderingsgrundlaget; den sidste løsning er vist i en særlig rubrik i tabel 3.

GUNNAR LARSEN (1961) har udført en petrografisk undersøgelse af nogle kalkprøver. Prøveserien omfatter 1 prøve af cerithiumkalken fra Stevns Klint og 4 prøver af bryozokalk, hvoraf de to stammer fra Herfølge (- fra 6,10 m og 7,15 m's dybde), medens de to andre prøver er udtaget ved Stevns og Faxe; endvidere 1 prøve af kalksandskalken fra København (Hyttehusvej) samt 2 prøver af gruskalken (kalkarenitten) ved Herfølge (2,15 m og 5,00 m). Af disse prøver er der fremstillet tyndslib, som er blevet undersøgt under polarisationsmikroskop; der er bl. a. foretaget en udmåling af den relative hyppighed af følgende komponentgrupper:

1. Kalkmatrix, d.v.s. kalkbestanddele, hvis kornstørrelse er mindre end $20 \mu$. 
2. Uorganiske kalkkorn, d.v.s. kalkbestanddele, hvis kornstørrelse overstiger $20 \mu$.

3. Kalkorganismer større end $20 \mu$.

Man kan på grundlag af dette inddelingsprincip karakterisere de undersøgte prøver således:

a. Bryozokalken fra Faxe og Stevns samt cerithiumkalken er sammensat af ca. 1/3 kalkmatrix og 2/3 kalkorganismer.

b. Bryozokalken fra Herfølge består af $3 / 4$ kalkmatrix og $1 / 4$ kalkorganismer.

c. Kalksandskalken er opbygget af ca. $1 / 3$ kalkmatrix og $1 / 4$ uorganiske kalkkorn, medens resten udgøres af kalkorganismer.

d. Gruskalken (Kalkarenitten) er kendetegnet ved et indhold af kalkmatrix på mindre end $10 \%$ og derudover lige mængder uorganiske kalkkorn og kalkorganismer.

LARSEN har endvidere undersøgt kornstørrelsesfordelingen af materiale større end $20 \mu$. Resultaterne af disse undersøgelser er afbildet i grafisk form på fig. 29 (side 234). Efter hans opfattelse må gruskalken (kalkarenitten) og kalksandskalken karakteriseres som allochthone aflejringer, medens bryozokalken i alt fald i overvejende grad - er autochthon i sin oprindelse; cerithiumkalken er sandsynligvis sammensat af såvel autochthont som allochthont materiale.

Som vist på tabel 2 er slamindholdet i bryozokalken ved Herfølge større end i bryozokalken fra Stevns; LARSEN har kunnet påvise, at slammaterialet i førstnævnte kalksten er det mest finkornede. Man ville umiddelbart af disse oplysninger drage den konklusion, at Herfølge-kalken må være afsat på dybere vand end kalken på Stevns. Mod en sådan tolkning taler blandt andet fordelingen af de forskellige zoarietyper (se side 240) på afgørende vis; der kan ikke herske tvivl om, at det bryozoselskab, som har levet ved Herfølge, har udviklet sig på lavere vand end det tilsvarende faunaselskab ved Stevns. Man må under disse omstændigheder formode, at det finkornede kalkslam er dannet ved kemisk udskillelse i de øverste vandlag i havet, muligvis under medvirkning af bakterier (jfr. TARR, 1925 og HADDING, 1933). Fra ØDum's undersøgelser af kalkaflejringerne i Jylland (1926) er det kendt, at der her i yngre Danien skete en tilsvarende forøgelse i slamtilførslen - efter ØDUM's opfattelse under indflydelse af de to nævnte faktorer.

Gruskalken ved Herfølge indeholder - at dømme efter sigteanalyserne (tabel 2) - kun 1-2\% med en kornstørrelse over 1,5 mm; ifølge LARSEN's undersøgelser forekommer over $50 \%$ af materialet inden for intervallet $200-500 \mu$. Benævnelsen gruskalk må under disse omstændigheder betegnes som i nogen grad vildledende; det samme gælder udtrykket kalcirudit, som BERGGREN anvender (1960), idet også dette navn refererer til en grovkornet bjergart. Efter min mening er benævnelsen kalkarenit den bedste erstatning for gruskalk (jft. Sorgenfrei, 1957). Troelsen (1957) og BergGren (1960, p. 188) bruger kalkarenit i stedet for kalksandskalk. Betegnelsen kalksandskalk har imidlertid efterhånden vundet indpas i den skandinaviske, geologiske litteratur, hvorfor jeg ikke finder anledning til at foretage en ændring. Man bør imidlertid gennem 
petrografiske undersøgelser søge klarlagt, om benævnelsen kalksandskalk eventuelt dækker over flere bjergarter, specielt om kalken på Saltholm, som jo tidligere (af RøRDAM m. fl.) betegnedes som Coccolithkalk, er identisk med kalken i Københavnsområdet (RøRDAM's foraminiferkalk); bryozoindholdet i kalken på Saltholm synes at være større end i kalksandskalken under København.

\section{Palæoøkologisk vurdering.}

I dette afsnit gennemgås de miljøfaktorer, som skønnes at have haft indflydelse på Danienbryozoernes udbredelse. Dette skøn er fortrinsvis baseret på tilsvarende undersøgelser af de recente bryozoers levevilkår, men desværie har man ikke hidtil vist denne dyregruppes økologi særlig megen opmærksomhed (jfr. Duncan, 1957 og Osburn, 1957).

Det er under disse omstændigheder begrænset hvor vidtgående slutninger man kan tillade sig at drage med hensyn til miljøforholdene i det Danien-hav, hvori bryozoerne har levet.

Bundforhold. Den vigtigste forudsætning for dannelsen af en bryozokoloni er, at bundforholdene gør det muligt for bryozolarverne efter det frie stadium at fæstne sig til bunden eller faste genstande pa denne og påbegynde koloniudviklingen. Den optimale biotop har et uroligt bundrelief, en veludviklet algevækst og/eller en rig benthogen makrofauna; som eksempel på en sådan ideel vokseplads kan nævnes koralbanken ved Faxe. En mudret eller sandet bund byder ikke bryozolarverne de nødvendige fasthæftningsmuligheder, og man skal sikkert her søge forklaringen på, at hverken cerithiumkalken eller kalkarenitten indeholder bryozofragmenter i nævneværdigt antal, samt at faunaen i kalksandskalken er præget af individ- og artsfattigdom.

Dybdeforhold. Dette underafsnit indledes med en kronologisk ordnet oversigt over danske og svenske geologers vurdering af dybdeforholdene i det hav, hvori de forskellige danienbjergarter er afsat. Dernæst anføres efter OsBURN (1957) og MARCus (1921) nogle generelle betragtninger vedrørende de recente bryozoers udbredelse i relation til havdybde. To afhandlinger af STACH (1936 og 1937) behandles mere indgående. Ved at undersøge zoarieformerne hos de cheilostome bryozoer har STACH kunnet adskille 9 zoarietyper. Han har endvidere kunnet påvise en tydelig forbindelse mellem de enkelte typer og deres miljø, specielt med hensyn til de bathymetriske forhold.

STACH fordeler de ni typer i to grupper:
A. Stabile former
B. Ustabile former
1. Petraliform
7. Membraniform
2. Reteporiform
8. Vinculariform
3. Cellariform
9. Eschariform
4. Catenicelliform
5. Flustriform
6. Lunulitiform 
De stabile zoarieformers udbredelse er begrænset til bestemt voksepladser med underlagets natur som den adskillende faktor. Den "ustabile" gruppes repræsentanter er i stand til at tilpasse zoarieformen efter miljøet, specielt havdybden og vandbevægelsens styrke.

Typerne 1-5 er littorale former og mangler fuldstændig i Danienet aflejringer. De øvrige typer karakteriserer STACH således:

6. Lunulitiform. Skålformede zoarier med zoøcieåbningerne på skålens yderside. Denne type er knyttet til et miljø med sandet bund og stærk strøm. Mindste dybde ca. $35 \mathrm{~m}$.

7. Membraniform. Eenlagede incrusterende zoarier, som fortrinsvis forekommer i de littorale og sublittorale zoner.

8. Vinculariform. Kolonien er opbygget af stive, subcylindriske grene uden leddeling. Denne type er tilpasset livet i dybt eller beskyttet vand uden bølgebevægelse og strømvirksomhed.

9. Eschariform. Zoarierne er hos denne type udformet som bilaminære, oftest kraftige stammer. Denne form er knyttet til den sublittorale zone på mindst $20 \mathrm{~m}$ vand.

Den lunulitiforme type er kun repræsenteret ved en enkelt art i Danienet, Lunulites saltholmensis n.sp., som fortrinsvis forekommer i kalksandskalk, hvor den dog er temmelig sjælden.

Det bliver således den ustabile gruppes repræsentanter, de membraniforme, vinculariforme og eschariforme zoarietyper, som præger Danienet. Den procentiske fordeling af disse former i de undersøgte prøver er vist på tabel 5 , side 240. Det vil at dette skema fremgå, at den eschariforme type mangler næsten fuldstændigt i ældre Danien, medens den spiller en mere betydende rolle i yngre Danien - et vidnesbyrd om, at havdybden har været størst under aflejringen af ældre bryozokalk. I de to øverste prøver fra Herfølge, i prøven af kalksandskalk fra København samt $\mathrm{i}$ den nederste prøve fra nordvæggen i Faxe kalkbrud dominerer den eschariforme type over den vinculariforme, hvilket antagelig er et udtryk for, at de kalkbjergarter, som disse prøver repræsenterer, er afsat på forholdsvis lavt vand.

Også inden for Danienets bryozoer kendes eksempler på forskellige zoarietyper hos samme art. Hos Pachythecella anhaltina VoIgT (Tavle 25, fig. 1-3) er kolonierne i Stevns-Kagstrupmaterialet vinculariforme, zoarierne fra Faxe og Thorslunde er eschariforme, medens fragmenterne fra Herfølge har "flabelliforme" zoarier; tilsvarende er kolonierne fra Stevns af Puncturiella sculpta D'ORB. vinculariforme, medens eksemplarerne fra Herfølge er "flabelliforme" (tavle 17, fig. 1-2). Den "flabelliforme" type markerer sandsynligvis en mindre vanddybde end den eschariforme.

Den maximale dybde i Danienhavet har muligvis været 100-150 m. Herpå tyder de talrige fragmenter af Mecynoecia proboscidea M. EDw. i materialet fra ødumi-zonen; denne art forekommer ifølge Voigt (1925) i nutidens have på 80-150 m dybde. 
Temperaturforhold. Bryozoerne synes at være temmelig tolerante med hensyn til temperaturvariationer og har derfor ikke kunnet bidrage til løsningen af spørgsmålet om Danienhavets temperaturforhold. Da forskellige forfattere har været inde på dette problem, er deres synspunkter medtaget i en kort oversigt.

Man kan heller ikke på grundlag af Danien bryozoernes udbredelse drage nogen slutninger med hensyn til strømforhold og saltindhold i Danienhavet. Der har tidligere i den geologiske litteratur været en del diskussion om tilstedeværelsen af en havstrøm i Danientiden, hvorfor de forskellige synspunkter kort er refereret.

Målinger. Som et led i undersøgelserne er også cellernes størrelse taget op til vurdering, ud fra ønsket om at klarlægge eventuelle variationer i målene hos de arter, som forekommer enten 1) i både Senonienct og Danienet eller 2) i såvel ældre som yngre Danien. Det senone materiale er desværre temmelig spinkelt og omfatter udelukkende eksemplarer fra skrivekridtet på Møn.

Zoariebredden hos de vinculariforme og eschariforme kolonier er underkastet en del variation. En sammenligning af stammebredderne hos de arter, som optræder i såvel Senonien som Danien, viser, at zoariebredden er mindre hos de senone eksemplarer af "Membranipora" marssoniana Voigt og Pithodella cincta MARsson end hos Danien-eksemplarer af disse arter, medens det omvendte forhold findes hos Porina salebrosa MARsson. Hvis man sammenligner zoariebredden hos de arter, som optræder i alle Danienets zoner, kan man som hovedregel sige, at eksemplarerne fra Herfølge har den største stammebredde, medens de spinkleste stammer findes blandt materialet fra Kagstrup. En undtagelse fra denne regel danner en gruppe af arter - hvortil bl. a. hører Coscinopleura angusta BERTHELSEN og Beisselinopsis oblita KADE - som i kalksandskalken har udviklet særlig kraftige stammer. VoIGT (1956) har kunnet påvise en tilsvarende udvikling hos former i kalksandskalken ved Voldum i Jylland; efter hans opfattelse er de grove stammer et udtryk for særlig gunstige levevilkår; jeg vil dog snarere tro, at miljøforholdene under aflejringen af kalksandskalken, specielt en forøget vandbevægelse, har nødvendiggjort dannelsen af kraftigere stammer.

En sammenligning af zoøcie-længden hos arter, som optræder både i Senonienet og Danienet, viser at zoøcielængden i reglen er størst hos de senone eksemplarer. Blandt de arter, der kun findes i Danienet, er der udført målinger på 56 arter, som forekommer på mere end én lokalitet; af disse havde 11 arter stabile mål, medens der for de resterende arters vedkommende kunne være ret store variationer med hensyn til målene på de forskellige celletyper og åbninger. Som hovedregel kan man af dette talmateriale udlede, at celler og åbninger er størst hos eksemplarerne fra Yngre Danien; en undersøgelse af 16 "gennemgående" arter gav således følgende resultater: 
Længste zoøcier:

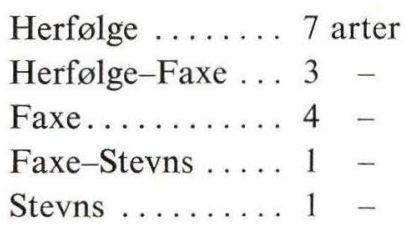

Korteste zoøcier :

\begin{tabular}{|c|c|}
\hline Kagstrup-Stevns. . . & 6 arte \\
\hline Stevns-Faxe ...... & 3 \\
\hline Stevns-Herfølge. . . & \\
\hline Faxe........... & \\
\hline Saltholm .......... & 1 \\
\hline Faxe-Herfølge ..... & 1 \\
\hline Herfølge ......... & 3 \\
\hline
\end{tabular}

Der synes således at være en tendens til forøgelse af størrelsen af celler og åbninger med aftagende vanddybde.

\section{Faunistisk vurdering.}

Som tidligere nævnt har de stratigrafiske undersøgelser også omfattet artsbestemmelse af de cheilostome bryozofragmenter i de udtagne prøver samt registrering af antallet af kolonier af de påviste arter. Resultaterne af dette afsnit af den stratigrafiske analyse er sammenstillet i tabel 6.

Det næste skridt har været at finde frem til lokaliteternes og bio-zonernes karakterformer. For at få dette spørgsmål belyst er der for hver art udregnet fragmentantallets procentiske andel i det samlede fragmentantal. I tabel 7 (side 252) er samlet de dominerende arter, d.v.s. de former, som i én af de undersøgte prøver har udgjort mindst $10 \%$ af det totale antal af cheilostome kolonier i prøven. På skemaet er endvidere anført antallet af cheilostome arter i prøverne.

De dominerende arter fordeler sig således:

Tyl. ødumi-zonen:

Floridina gothica (D'ORB.)

Onychocella columella n.sp.

Membranipora sparsispina VOIGT

Columnotheca cribrosa MARSSON

Tyl. abildgårdi-zonen:

Floridina gothica (D'ORB.)

Onychocella columella n.sp.

Membranipora sparsispina VoIGT

Columnotheca cribrosa MARSSON

Pithodella cincta MARsson

Vincularia prismatica (v. HAG.)

Floridina fragilis n.sp.

Porina salebrosa MARSSON

Tyl. brünnichi-zonen:

Kagstrup

Amphiblestrum elegans (v. HAG.)

Aechmella tenuis n.sp.

- microstoma (MARSSON) 
Saltholm

Amphiblestrum elegans (v. HAG.)

Aechmella tenuis n.sp.

- microstoma (MARSSON)

Pithodella cincta MARSSON

Faxe

\author{
Aechmella microstoma (MARsSON) \\ Pithodella cincta MARSSON \\ Porina salebrosa MARsson \\ Columnotheca cribrosa MARSSON \\ Pachythecella lundgreni (PERG. og MeUn.)
}

Tyl. vexillifera-zonen:

\begin{tabular}{|c|c|}
\hline Saltholm & $\begin{array}{l}\text { Coscinopleura angusta BERTHELSEN } \\
\text { Aechmella microstoma (MARSSON) } \\
\text { Columnotheca cribrosa MARSSON } \\
\text { Amphiblestrum elegans (V. HAG.) } \\
\text { Pithodella cincta MARSSON } \\
\text { Pachythecella lundgreni (PERG. og MEUN.) }\end{array}$ \\
\hline København & $\begin{array}{l}\text { Coscinopleura angusta BERTHELSEN } \\
\text { Pachythecella lundgreni (PERG. og MEUN.) }\end{array}$ \\
\hline $\begin{array}{l}\text { Herfølge } \\
\text { (Bryozokalk) }\end{array}$ & $\begin{array}{l}\text { Phiophloea brïnnichi } \mathrm{n} . \mathrm{sp} . \\
\text { Coscinopleura angusta BERTHELSEN } \\
\text { Aechmella microstoma (MARSSON) } \\
\text { Vincularia prismatica (v. HAG.) }\end{array}$ \\
\hline $\begin{array}{l}\text { Herfølge } \\
\text { (Kalkarenit) }\end{array}$ & $\begin{array}{l}\text { Coscinopleura angusta BERTHELSEN } \\
\text { Vincularia prismatica (v. HAG.) } \\
\text { Columnotheca cribrosa MARSSON } \\
\text { Porina salebrosa MARSSON }\end{array}$ \\
\hline $\begin{array}{l}\text { Klintholm } \\
\text { (Bryozokalk) }\end{array}$ & $\begin{array}{l}\text { Coscinopleura angusta BERTHELSEN } \\
\text { Aechmella microstoma (MARSSON) } \\
\text { Vincularia prismatica (v. HAG.) }\end{array}$ \\
\hline $\begin{array}{l}\text { Klintholm } \\
\text { (Glaukonit-zone) }\end{array}$ & $\begin{array}{l}\text { Coscinopleura angusta BERTHELSEN } \\
\text { Aechmella microstoma (MARSSON) } \\
\text { Columnotheca cribrosa MARSSON }\end{array}$ \\
\hline
\end{tabular}

8. Biostratigrafisk vurdering.

Tabel 8 (side 254) viser den biostratigrafiske udbredelse af Danienets cheilostome bryozoarter. Skemaet er udarbejdet på grundlag af oplysningerne i tabellerne $1 \mathrm{og} 6 \mathrm{om}$ arternes fordeling inden for henholdsvis museumsmaterialet og det stratigrafiske materiale. I tabellen er udeladt de arter, som optræder i alle zoner, samt de former, som forekommer i mindre end 5 eksemplarer på samme lokalitet.

Som det fremgår af skemaet synes bryozoerne at være et udmærket hjælpemiddel ved den biostratigrafiske inddeling af Danienet. Arterne fordeler sig naturligt i fire grupper, svarende til de fire Tylocidaris-zoner, og den stratigrafiske placering af lokaliteterne på grundlag af bryozoernes forekomst 
stemmer overens med de erfaringer, som er indvundet gennem studiet af andre dyregruppers udbredelse - med én undtagelse:

Saltholm. Hvis man på grundlag af bryozoerne alene skulle placere kalken på Saltholm $i$ det stratigrafiske skema, måtte saivel bryozokalk som kalksandskalk henføres til T. brünnichi-zonen.

Denne afvigelse fra den gældende opfattelse har gjort det nødvendigt at gennemgå de argumenter, som har været bragt i anvendelse i dokumentationen for kalksandskalkens henføring til $T$. vexillifera-zonen. En sådan revision er foretaget $\mathrm{i}$ afhandlingens sidste kapitel.

Det har vist sig, at arter af slægten Floridina er særligt velegnede som redskab ved den biostratigrafiske zoneinddeling, fordi de - udover forskellen i den stratigrafiske placering - for de fleste arters vedkommende er temmelig almindeligt forekommende og lette at artsbestemme (- i modsætning til f. ex. de cribrimorfe bryozoarter). På fig. 32 er vist Floridina-arternes stratigrafiske udbredelse.

\begin{tabular}{|c|c|c|c|c|}
\hline Species & $\begin{array}{l}T . \text { edumi } \\
\text { zone }\end{array}$ & $\begin{array}{l}T \text {, abildgaardi } \\
\text { zone }\end{array}$ & $\begin{array}{l}\text { T. brünnichi } \\
\text { zone }\end{array}$ & $\begin{array}{l}\text { T. vexillifera } \\
\text { zone }\end{array}$ \\
\hline \multicolumn{5}{|l|}{ Floridina gothica (D'ORB.) ... } \\
\hline \multicolumn{5}{|l|}{ - tubulosa VoIGT........ } \\
\hline \multicolumn{5}{|l|}{ - fragilis n.sp. ......... } \\
\hline \multicolumn{5}{|l|}{ - pulchella (KADE) ....... } \\
\hline \multirow{2}{*}{\multicolumn{5}{|c|}{ - voigti BASSLER . . . . . . . }} \\
\hline & & & & \\
\hline - trifolioides n.sp........ & & & & \\
\hline - levinseni n.sp............ & & & & \\
\hline - excavata VOIGT ...... & & & & \\
\hline
\end{tabular}

Fig. 32. Floridina-arternes stratigrafiske udbredelse.

\section{Den stratigrafiske placering af kalksandskalken på Saltholm.}

Lagserien på Saltholm er kendt fra kalkbrud på øens nordende samt fra boringer. Kalkbruddene har været vandfyldte gennem en årrække; under en kortvarig tørlægning i 1935 af den nordligste kalkgrav opmålte ROSENKRANTZ (1935) et $6 \mathrm{~m}$ højt profil, omfattende nederst $2 \mathrm{~m}$ bryozokalk, herover et konglomerat med glaukonitbeklædte hovedstore rullesten i en leret grundmasse og øverst vekslende lag af kalksand og hærdnet kalksandskalk.

Kalksandsserien har - som foran nævnt - hidtil været henført til Tyl. vexillifera-zonen. Denne placering er dels baseret på et faunafællesskab med kalksandskalken ved København, dels på fællestræk med Herfølge og Limhamn med hensyn til den lithologiske udvikling. 


\section{Faunistiske argumenter.}

Ifølge RosEnKRANTz (1920) er følgende arter karakteristiske for kalksandskalken i Københavns-området: Graphularia grönwalli Br. NIELSEN, Ditrupula schlotheimi Rosenkrantz, Crania posselti Rosenkrantz, Crania tuberculata Nilsson (C. brattenburgicus Schlotheim hos CARLsson, 1958), Argyrotheca scabricula V. Koenen, Lima bisulcata Ravn, Lima testis Grönwall, Pecten sericeus Grönwall, Plicatula ravni Rosenkrantz, Modiola hauniensis RosenKRANTZ, Scalpellum steenstrupi BR. NIELSEN og Cestracion danicus RosenKRANTZ. Denne faunaliste er senere blevet suppleret med Echinocorys obliquus Ravn (1927) og Chatwinothyris lens (NiLsson) (Rosenkrantz 1944). Af disse fjorten arter er følgende ti også fundet i kalksandskalken på Saltholm (Rosenkrantz og BRÜNNICH NielSEN (1926)): Graphularia grönwalli, Echinocorys obliquus, Ditrupula schlotheimi, Crania posselti, Crania tuberculata, Chatwinothyris lens, Argyrotheca scabricula, Pecten sericeus, Scalpellum steenstrupi og Cestracion danicus.

Hvis man nu på grundlag af litteraturangivelser gennemgår disse ti arters forekomst inden for Danienet (se side 257-259), viser det sig, at de pågældende arter enten kendes fra andre Danien-zoner eller i deres udbredelse er begrænset til slam eller sandbund. Det tilsyneladende fællesskab, som består mellem faunaen i kalksandskalken på Saltholm og i Københavnsområdet, behøver derfor ikke absolut at eksistere, fordi de to faunaselskaber har levet på samme tid. Den rigtige forklaring kan muligvis være, at de to selskaber er udviklede til forskellig tid, men under ensartede miljøforhold.

Tylocidaris vexillifera Schlüter $f$. typica RAVN (1928) (=T. pomifer herupensis og T. pomifer vexillifera hos WIND (1954) og T. herupensis hos BROTZEN (1959)) er ledefossil for T. vexillifera-zonen og skulle i konsekvens heraf også forekomme i kalksandskalken på Saltholm; der synes imidlertid at herske nogen uklarhed på dette punkt. RAvN (1928) oplyser, at Mineralogisk Museums samling af pigge af denne form bl. a. omfatter 15 eksemplarer fra saltholmskalken (= kalksandskalken) på Saltholm, men at det langt overvejende antal pigge i denne kalksten (ca. 260 eksemplarer) tilhører Tyl. brünnichi. Seks T. brünnichi-pigge fra kalksandskalken på Saltholm er afbildet på RavN's tavle IV. BROTZEN (1959, p. 50) refererer til disse afbildninger hos RAvN, idet han gør gældende, at de pågældende pigge ikke kan stamme fra kalksandskalken, men må hidrøre fra den underliggende bryozokalk, idet denne form ikke bør forekomme i kalksandskalken. Imidlertid gør han samtidig opmærksom på (p. 52), at man i kalksandskalken ved Östratorp kan finde pigge af såvel $T$. brünnichi som T. herupensis. Endvidere oplyser han (p. 31), at man på Saltholm i kalksandskalken nogle få meter over Mellem-Danien kan indsamle pigge af T. herupensis, som ligner $T$. brünnichi-pigge, idet de har samme størrelse som disse og tilsvarende, svagt udviklede vinger; desuden forekommer der i kalksandskalken på Saltholm (ifølge BrotzeN) transitionstyper mellem T. brünnichi og T. herupensis. 
Den typiske $T$. vexillifera ( $T$. herupensis) er ikke fundet i kalkbruddet ved Limhamn; fra kalken ved Klagshamn kendes pigge af en type, som WIND har beskrevet under navnet Tyl. pomifer vexillifera (1954) - en form, som også forekommer ved Faxe, og som efter WIND's opfattelse er karakteristisk for den øvre del af Mellem-Danien.

\section{Lithologiske argumenter.}

I bevisførelsen for henføringen af Saltholm's kalksandskalk til $T$. vexilliferazonen har især konglomeratet mellem bryozokalk og kalksandskalk spillet en rolle, idet dette konglomerat af RoSENKRANTZ (1931) er blevet anset for at være jævnaldrende med konglomeraterne fra Hetfølge og Limhamn, fordi "de overliggende lag rummer samme fauna på alle 3 lokaliteter".

Konglomeratet på Saltholm er opbygget af rullesten, der ofte er beklædte med glaukonit og kan opnå hovedstørrelse. Massen mellem rullestenene er ofte mørk og leret, og over konglomeratet, eller på steder, hvor dette ikke er udviklet, findes et $2 \mathrm{~cm}$ tykt, i fugtig tilstand helt sort lerlag (ROSENKRANTz, 1935).

Konglomeratet over bryozokalken ved Herfølge er kun flygtigt omtalt i ekskursions- og foredragsreferater (Medd. Dansk Geol. Foren. 1924 og RosenKRANTZ 1931). I det i 1951 rengravede profil i kalkbruddets nordvæg (se p. 32) fandtes konglomeratet fra 5,94 til 6,28 m's dybde, og det bestod af svagt afrundede, knytnæve-store knolde af en forholdsvis hård bryozokalk i en grundmasse af kalkslam. Under konglomeratet fandtes en meget slamholdig bryozokalk med spredte flintknolde, og umiddelbart over konglomeratet forekom et $4 \mathrm{~mm}$ gulbrunt lerlag, som overlejredes af en blød, slamrig kalksten; denne bjergart, som under udgravningsarbejdet blev fortolket som gruskalk (kalkarenit), er i det stratigrafiske materiale repræsenteret ved en prøve fra 5,80 m dybde. Bryozoindholdet i denne kalkprøve har vist sig at være af omtrent samme størrelsesorden som i den underliggende bryozokalk (se tabel 3), hvorimod de overliggende kalklag kun indeholdt ganske få bryozofragmenter. Den pågældende prøve er i de forskellige skemaer karakteriseret som kalkarenit, men det er et spørgsmål, om man ikke snarere burde benævne den som slamholdig bryozokalk. Når dette ikke er sket, skyldes det dels, at tidligere undersøgelser af lokaliteten taler imod en sådan fortolkning, dels at der ikke foreligger en petrografisk analyse af prøven. Såfremt en sådan undersøgelse viser sig at støtte min vurdering, bliver konsekvensen, at kalkarenittens underkant flyttes fra 5,94 $\mathrm{m}$ dybde til et sted mellem 5,00 og 5,80 m under terræn, samt at konglomeratet indgår som en del af bryozokalkserien.

Om konglomeratet i kalkgraven ved Limhamn oplyser RosENKRANTz (1931), at man i 1929 kunne iagttage et profil i bruddets nordvæg omfattende nederst $15 \mathrm{~m}$ bryozokalk med et dække af coccolithkalk; denne serie blev diskordant overlejret af et $30-40 \mathrm{~cm}$ tykt konglomerat, bestående af indtil hovedstore, $18 *$ 
mere eller mindre fosforritiserede og glaukonitbeklædte rullesten i en mellemmasse af kalksand; herover fulgte 1-6 m gråt kalksand med flintlag, dækket af morænedannelser. Ifølge BROTZEN (1940 og 1959) er konglomeratet i gravens sydvæg udviklet som en grønlig, lerholdig horisont med sekundært aflejret fossiler.

Der synes umiddelbart at være større lighed mellem konglomeraterne på Saltholm og ved Limhamn end mellem disse og konglomeratet ved Herfølge. Denne forskel bliver yderligere understreget ved en betragtning af de stratigrafiske forhold. Som tidligere nævnt hviler konglomeratet på Saltholm på bryozokalk tilhørende $T$. brünnichi-zonen, og det samme er tilfældet med konglomeratet ved Limhamn; ved Herfølge underlejres konglomeratet af bryozokalk tilhørende $T$. vexillifera-zonen. Hvis konglomeraterne på de tre lokaliteter skal være dannet på samme tid, må man forudsætte, at der har været en mere langvarig sedimentationsafbrydelse på Saltholm og ved Limhamn end ved Herfølge, og en sådan udvikling kommer i alt fald ikke til udtryk for bryozoernes vedkommende.

Konglomeraterne må karakteriseres som intraformationale regressionskonglomerater (PettiJohn, 1949 og HAdDING, 1927); sådanne er i reglen dannet på lavt vand (- muligvis uden for littoralzonen -) og markerer som oftest en kortvarig sedimentationsafbrydelse. En regression vil give anledning til ændringer i den økologiske situation, hvilket formodentlig vil medføre, at en del af den benthogene fauna vil søge til områder, hvor miljøforholdene ikke har ændret karakter. Hvis en påfølgende transgression ikke genskaber det oprindelige miljø, vil resultatet i faunistisk henseende blive, at der skabes et dyresamfund, sammensat af de arter fra det oprindelige selskab, som er i stand til at tilpasse sig de ændrede økologiske forhold plus en kreds af arter, som har bedre udviklingsmuligheder i det nye miljø end i det oprindelige.

En sådan udvikling afspejler sig såvel i forholdene på Saltholm som ved Herfølge; begge steder sker der med transgressionen ændringer i bundforhold, dybdeforhold og strømforhold, hvilket igen har betydning for temperatur, næringstilførsel o.s.v. For bryozoernes vedkommende bevirker disse forandringer, at bryozoselskabets artsantal indskrænkes betydeligt, antagelig specielt fordi de ændrede bundforhold nedsætter fasthæftningsmulighederne for larverne; derimod synes en form som Lunulites saltholmensis n.sp. at have fået bedre udviklingsbetingelser, fordi larven hos denne art er i stand til at fæstne sig på den sandede bund. På tilsvarende måde må der hos andre dyregrupper i det ændrede miljø ske en "sortering" af arterne i "egnede" og "uegnede" former. De ovenfor nævnte karakterformer for kalksandskalken behøver derfor ikke at forekomme i denne aflejring "fordi deres tid er inde" i biostratigrafisk henseende; forklaringen på deres tilstedeværelse kan muligvis være, at de ændrede økologiske forhold netop honorerer deres krav til miljøet - eller sagt med andre ord: "palæomiljøforholdenes indflydelse kan ofte være mere afgørende for en arts udbredelse end tidsfaktoren” (SORGENFreI, 1958). 
Konklusionen af disse betragtninger må blive, at der ikke i den geologiske litteratur om Saltholm foreligger oplysninger, som på afgørende måde taler imod at henføre kalksandskalken på Saltholm til T. brünnichi-zonen.

Min vurdering af Danienets lithologiske udvikling er vist på fig. 31, p. 262. Fremtidige undersøgelser må afgøre, om denne antagelse er rigtig, eller om den hidtidige fortolkning bør stå ved magt. 


\section{BIBLIOGRAPHY}

Balavorne, P., 1955. Description de quelques Bryozoaires des Calcaires de Montainville et de Vigny (Seine-et-Oise). Bull. Soc. Géol. France. 6e Sér. Tom. V. Fasc. 1-3, p. 59. Paris.

Barroso, M. G., 1944. Briozoos del maestrichtiense de Olazagutia (Navarra). Bol. Real Soc. Espaňola de Hist. Nat. Tome XLII. Num. 3-4, p. 287. Madrid.

Bassler, R. S., 1922. The Bryozoa or Moss Animals. Ann. Smithsonian Inst. Washington.

- 1934. Notes on fossil and recent Bryozoa. Journ. Wash. Acad. Sci. Vol. 24. No. 9, p. 404. Washington.

- 1934. Fossilium Catalogus. 1: Animalia. Edit. a W. Quenstedt. Pars 67. Bryozoa. 's-Gravenhage.

- 1936. Notes on Fossil and Recent Bryozoa. Journ. Wash. Acad. Sci. Vol. 26. No. 26. Washington.

- 1953. Treatise on Invertebrate Paleontology, edit. by R. C. Moore. Part G. Bryozoa. Kansas.

Beissel, I., 1865. Ueber die Bryozoen der Aachner Kreidebildung. Nat. Verh.holl. Maatsch. Wet. Ser. 2, Vol. XXII. Haarlem.

Berggren, W. A., 1960. Biostratigraphy, Planktonic Foraminifera and the CretaceousTertiary Boundary in Denmark and Southern Sweden. Intern. Geol. Congr. XXI Sess. Part V, p. 181. København.

Berthelsen, O., 1948. Studies on the Bryozoan Species Coscinopleura elegans and Coscinopleura angusta n.sp. from the Senonian and Danian Deposits of Denmark. Danmarks Geol. Unders. IV. R. Bd. 3. Nr. 3. København.

Bonnesen, E. P., O. B. BøgGild og J. P. J. Ravn, 1913. Carlsbergfondets Dybdeboring i Grøndals Eng ved København 1894-1907 og dens videnskabelige Resultater. Mus. Min. et Geol. l'Univ. Copenhaque. Communic. géol. No. 3. København.

BredsdorfF, J. H., 1824. Om Kalkstensbrudet ved Herfølge. Tidskr. f. Naturvidensk. 3. Bd., p. 171. København.

Brown, D. A., 1952. The Tertiary Cheilostomatous Polyzoa of New Zealand. Br. Mus. Nat. Hist. London.

Brotzen, F., 1938. Der postkimmeriche Bau des südlichsten Schwedens. Geol. Fören. Förh. Stockholm. Bd. 60, p. 73. Stockholm.

- 1940. Flintrännans och Trindelrännans geologi (Zusammenfassung: Geologie der Flintund Trindelrinne.) Sveriges Geol. Unders. Ser. C. No. 435. Stockholm.

- 1945. De geologiske resultaten från borrningarna vid Höllviken. (Summary and Description of Foraminifera). Sveriges Geol. Unders. Ser. C. No. 465. Stockholm.

- 1959. On Tylocidaris Species (Echinoidea) and the Stratigraphy of the Danian of Sweden. Sveriges Geol. Unders. Ser. C. No. 571. Stockholm.

Brydone, R. M., 1909-1918. Notes on New or Imperfectly Known Chalk Polyzoa. Geol. Mag. 1909: Dec. V. Vol. VI, pp. 337-339, 398-400. 1910: Dec. V. VII, pp. 4-5, 76-77, 145-147, 258-260, 390-392, 481-483. 1911: Dec. V. Vol. VIII, pp. 153-156. 1912: Dec. V. Vol. IX, pp. 7-8, 145-147, 294-296, 433-435. 1913: Dec. V, Vol. X, pp. 97-99, 196-199, 248-250, 436-438. 1914: Dec. VI. Vol. I, pp. 97-99, 345-347, 481-483. 1916: Dec. VI. Vol. III, pp. 97-100, 241-243, 337-339, 433-435. 1917: Dec. VI. Vol. IV, pp. 49-53, 145-148, 492-496. 1918: Dec. VI, Vol. V, pp. 1-4, 97-100. London. 
Brydone, R. M., 1929-1936. Further Notes on New or Imperfectly Known Chalk Polyzoa. Part I: 1929, Part II: 1930, Part III: 1936. London.

Buge, E., 1957. Les Bryozoaires du Néogène de l'Ouest de la France et leur signification stratigraphique et paléobiologique. Mém. Mus. Nat. d'Hist. Nat. Nouv. Sér. C. Tome VI. Paris.

Canu, F., 1900. Revision des Bryozoaires du Crétacé figurés par d'Orbigny. Part II. Cheilostomata. Bull. Soc. Geol. France. 3e Sér. Tome XXVIII, p. 334. Paris.

- 1913. Etudes morphologiques sur trois nouvelles familles de Bryozoaires. Bull. Soc. Geol. France. $4^{\mathrm{e}}$ Sér. Tome XIII, p. 132. Paris.

- and R. S. Bassler, 1920. North American Early Tertiary Bryozoa. U.S. Nat. Mus. Bull. 106. Washington.

- and R. S. BAssler, 1923. North American Later Tertiary and Quaternary Bryozoa. U.S. Nat. Mus. Bull. 125. Washington.

- and R. S. BASSLER, 1926. In B. WADE: The Fauna of the Ripley Formation on Coon Creek, Tennessee. U.S. Geol. Surv. Prof. Paper 137.

- and R. S. Bassler, 1927. Classification of the Cheilostomatous Bryozoa. Proc. U.S. Nat. Mus. Vol. 69. Art. 14. Washington.

- and R. S. Bassler, 1928. Fossil and Recent Bryozoa of the Gulf of Mexico Region. Proc. U.S. Nat. Mus. Vol. 72. Art 14. Washington.

- and R. S. Bassler, 1933. The Bryozoan Fauna of the Vincentown Limesand. U.S. Nat. Mus. Bull. 165. Washington.

Carlsson, I. G., 1958. Le genre Crania du Terrain Crétacé de la Suède. Publ. Inst. Min. Pal. and Quat. Geol. Univ. Lund. Nr. 45.

Cumings, E. R., 1932. Reefs or Bioherms? Bull. Geol. Soc. Amer. Vol. 43, p. 331. Washington.

Dartevelle, E. 1933. Contributions a l'étude des Bryozoaires fossiles de l'Éocène de la Belgique. Ann. Soc. Roy. Zool. Belgique. Vol. 63, p. 55. Bruxelles.

Duncan, H., 1957. Bryozoans. In Treatise on Marine Ecology and Paleoecology. Vol. 2. Paleoecology (Edit H. LADd). Geol. Soc. Amer. Mem. 67, p. 783. Washingtom.

Forchiammer, G., 1835. Danmarks geognostiske Forhold. København.

GrY, H., 1935. Petrology of the Paleocene Sedimentary Rocks of Denmark. Danmarks Geol. Unders. II. R. Nr. 61. København.

Grönwall, K. A., 1898. Danmarks yngste krit-och äldsta tertiäraflagringar. Förh. 15. Skand. Naturforsk. Stockholm 1898, p. 223. Stockholm.

- og P. Harder, 1907. Paleocæn ved Rugaard i Jylland og dets Fauna. (Résumé: Paléocene près de Rugaard en Jutland). Danmarks Geol. Unders. II. R. Nr. 18. København.

Hadding, A., 1927. The Pre-Quaternary Sedimentary Rocks of Sweden. II. The Paleozoic and Mesozoic Conglomerates of Sweden. Medd. Lunds Geol.-Min. Inst. Nr. 32, Lund.

- 1933. The Pre-Quaternary Sedimentary Rocks of Sweden. V. On the Organic Remains of the Limestones. Lunds Geol.-Min. Inst. Nr. 55. Lund.

- 1941. The Pre-Quaternary Sedimentary Rocks of Sweden. VI. Reef Limestones. Lunds Univ. Årsskr. N.F. Avd. 2. Bd. 37. Nr. 10. Lund.

Hagenow, F. V., 1839. Monographie der Rügen'schen Kreide-Versteinerungen. Abt. I. Phytolithen und Polyparien. N. Jahrb. f. Min., Geogn., Geol. und Petrefactenkunde. Von LeOnhard und Bronn, 1839, p. 253. Stuttgart.

- 1851. Die Bryozoen der Maastrichter Kreidebildung. Cassel.

Harder, P., 1922. Om Grænsen mellem Saltholmskalk og Lellinge Grønsand og nogle Bemærkninger om Inddelingen af Danmarks ældre Tertiær. (Résumé: Sur la limite entre le Calcaire de Saltholm et le Sable vert de Lellinge avec quelques remarques sur la division du Tertiaire inférieur du Danemark). Danmarks Geol. Unders. II. R. Nr. 38. København. 
Hennig, A., 1892. Studier öfver Bryozoerna i Sveriges Kritsystem. I. Cheilostomata. Lunds Univ. Årskr. Tom. XXVIII. Lund.

- 1894. Studier öfver Bryozoerna i Sveriges Kritsystem. II. Cyclostomata. Lunds Univ. Årskr. Tom. XXX. Lund.

- 1899. Studier öfver den baltiska yngre kritans bildningshistoria. Geol. Fören. Förh. Stockholm. Bd. 21, p. 19. Stockholm.

Johnstrup, F., 1864. Faxekalkens Dannelse og senere undergaaede Forandringer. Vid. Selsk. Forh. Bd. 7, p. 29. København.

- 1882. Oversigt over de geognostiske Forhold i Danmark. I. Falbe Hansen og ScharLING: Danmarks Statistik, 1. Bd. København.

KADE, A., 1852. Die losen Versteinerungen des Schanzenberges bei Meseritz. Ber. d. Oberrealschule zu Meseritz. Meseritz.

LagaAis, R., 1952. The Pliocene Bryozoa of the Low Countries and Their Bearing on the Marine Stratigraphy of the North Sea Region. Med. Geol. Sticht., Ser. C.V. No. 5. Maastricht.

LANG, W. D., 1914. On Herpetopora, a New Genus Containing Three New Species of Cretaceous Cheilostome Polyzoa. Geol. Mag. Dec. VI. Vol. I, p. 5.

- 1914. Some New Genera and Species of Cretaceous Cheilostome Polyzoa. Geol. Mag. Dec. VI. Vol. I, p. 436. London.

- 1916. A Revision of the "Cribrimorph" Cretaceous Polyzoa. Ann. and Mag. of Nat. Hist. 8. Ser. Vol. 18., pp. 81-112, 381-410. London.

- 1919. Old Age and Extinction in Fossils. Proc. Geol. Assoc. Vol. XXX, p. 102. London.

- 1920. The Pelmatoporinæ, an Essay on the Evolution of a Group of Cretaceous Polyzoa. Phil. Trans. Royal Soc. of London. Ser. B. Vol. 209, p. 191. London.

- 1921-22. Catalogue of the Fossil Bryozoa in the Department of Geology. British Museum. The Cretaceous Bryozoa. Vols. III-IV. London.

LARSEN, G., 1961. Kvantitativ petrografisk undersøgelse af nogle sjællandske Danienkalksten. (Summary: Quantitative Petrographic Investigation of some Danian Limestones from Sjælland (Denmark)). Danmarks Geol. Unders. IV. R. Bd. 4. Nr. 7. København.

Levinsen, G. M. R., 1909. Morphological and Systematic Studies on the Cheilostomatous Bryozoa. København.

- 1925. Undersøgelser over Bryozoerne i den danske Kridtformation. D. Kgl. Danske Vid. Selsk. Skr. nat. og mat. Afd. 8. R. VII. 3. København.

Link, TH. A., 1950. Theory of Transgressive and Regressive Reef (Bioherm) Development and Origin of Oil. Bull. Amer. Ass. Petr. Geol. Vol. 34. No. 2, p. 263. Tulsa, Oklahoma.

Lowenstam, H. A. and S. Epstein, 1954. Paleotemperatures of the Post-Aptian Cretaceous as Determined by the Oxygen Isotope Method. Journ. Geol. Vol. 62, no. 3, p. 207. Chicago.

Marcus, E., 1921. Über die Verbreitung der Meeresbryozoen. Zool. Anzeiger LIII. Berlin.

Marsson, Th., 1887. Die Bryozoen der weissen Schreibkreide der Insel Rügen. Pal. Abhandl. von W. Dames und E. Kayser. Bd. IV. H. 1. Berlin.

Milthers, K., 1949. Ekskursion til Sydfyn og Langeland. Medd. Dansk Geol. Foren. Bd. 11, p. 495. København.

Milthers, V., 1908. Kortbladene Faxe og Stevns Klint. (Résumé en français). Danmarks Geol. Unders. I. R. Nr. 11. København.

- 1935. Nordøstsjællands Geologi. Danmarks Geol. Unders. V. R. Nr. 3, 2. edit. København.

Nielsen, K. BrünniCh, 1909. Brachiopoderne i Danmarks Kridtaflejringer. D. Kgl. Danske Vid. Selsk. Skr. 7. R. nat. og mat. Afd. VI. 4. København.

- 1910. Om det i Københavns Havn ved Knippelsbro fundne yngste Danien. Medd. Dansk Geol. Foren. Bd. 3. Nr. 16. København. 
Nielsen, K. Brünnich, 1911. Brachiopoderne i Faxe. Medd. Dansk Geol. Foren. Bd. 3. Nr. 17. København.

- 1912. Cirripedierne i Danmarks Danienaflejringer. Medd. Dansk Geol. Foren. Bd. 4, p. 19. København.

- 1913. Moltkia Isis, Steenstrup og andre Octocorallia fra Danmarks Kridttidsaflejringer. Mindeskrift for Japetus Steenstrup. København.

- 1917. Cerithiumkalken i Stevns Klint. Danmarks Geol. Unders. IV. Rk. Bd. 1. Nr. 7. København.

- 1919. En Hydrocoralfauna fra Faxe og Bemærkninger om Danien'ets geologiske Stilling. Danmarks Geol. Unders. IV R. Bd. 1. Nr. 10. København.

- 1920. Inddelingen af Danien'et i Danmark og Skåne. Medd. Dansk Geol. Foren. Bd. 5. Nr. 19. København.

- 1922. Zoantharia from Senone and Paleocene Deposits in Denmark and Skaane. D. Kgl. Danske Vid. Selsk. Skr. 8. Rk. nat. og mat. Afd. V. 3. København.

- 1926. Kalken paa Saltholm (Summary: The Limestone of the Isle of Saltholm in the Sound). Danmarks Geol. Unders. IV. R. Bd. 1. Nr. 20. København.

- 1928. Argiope-Arterne i Danmarks senone, daniske og paleocæne Aflejringer. Medd. Dansk. Geol. Foren. Bd. 7, p. 215. København.

- 1931. Serpulidae from the Senonian and Danian Deposits of Denmark. Medd. Dansk Geol. Foren. Bd. 8, p. 71. København.

- 1937. Faunaen i Ældre Danium ved Korporalskroen. Medd. Dansk Geol. Foren. Bd. 9., p. 117. København.

Pergens, E., and A. Meunier, 1886. La Faune des Bryozoaires gamruniens de Faxe. Ann. Soc. Roy. Malac. Belgique. Tome XXI, p. 187. Bruxelles.

D'Orbigny, A., 1850-52. Paléontologie Française. Terrains Crétacés. Tome V. Bryozoaires. Paris.

Osburn, R. C., 1957. Marine Bryozoa. In Treatise on Marine Ecology and Paleoecology Vol. 1. Ecology (Edit. I. W. Hedgreth). Geol. Soc. Amer. Mem. 67. p. 1109. Washington.

Pettionn, F. J., 1949. Sedimentary Rocks. New York.

Quenstedt, F. A., 1885. Petrefaktenkunde Deutschlands. Bd. VI. Korallen.

RAvN, J. P. J., 1903. Molluskerne i Danmarks Kridtaflejringer. III. Stratigrafiske Undersøgelser. (Résumé: Recherches sur la stratigraphie du Crétacé en Danemark). D. Kgl. Danske Vid. Selsk. Skr. 6. Rk. nat. og mat. Afd. XI. 6. København.

- 1927. De irregulære Echinider i Danmarks Kridtaflejringer. D. Kgl. Danske Vid. Selsk. Skr. 8. Rk. nat. og mat. Afd. XI. 4. København.

- 1928. De regulære Echinider i Danmarks Kridtaflejringer. D. Kgl. Danske Vid. Selsk. Skr. 9. Rk. nat. og mat. Afd. I. 1. København.

Rosenkrantz, A., 1920. En ny københavnsk Lokalitet for forsteningsførende Paleocæn. Medd. Dansk Geol. Foren. Bd. 5. Nr. 20. København.

- 1920. Craniakalk fra Kjøbenhavns Sydhavn. (Résumé: Calcaire à Crania du port sud de Copenhague). Danmarks Geol. Unders. II. R. Nr. 36. København.

- 1924a. De københavnske Grønsandslag og deres Placering i den danske Lagrække. Medd. Dansk Geol. Foren. Bd. 6. Nr. 23. København.

- 1924b. Nye Iagttagelser over Cerithiumkalken i Stevns Klint med Bemærkninger om Grænsen mellem Kridt og Tertiær. Medd. Dansk Geol. Foren. Bd. 6. p. 28. København.

- 1925. Undergrundens tektoniske Forhold i København. Medd. Dansk Geol. Foren. Bd. 6. Nr. 26. København.

- 1931. Jordskorpebevægelser i Yngre Danien-Tid inden for Øresundsomraadet. Medd. Dansk Geol. Foren. Bd. 8 p. 138. København.

- 1935. Ekskursion til Saltholm. Medd. Dansk Geol. Foren. Bd. 8, p. 547. København. 
Rosenkrantz, A., 1937. Bemærkninger om det østsjællandske Daniens Stratigrafi og Tektonik. Medd. Dansk Geol. Foren. Bd. 9, p. 199. København.

- 1941. Ekskursion til Tunnelanlægget Svanemøllen-Middelgrund. Medd. Dansk Geol. Foren. Bd. 10, p. 64. København.

- 1944 a. Smaabidrag til Danmarks Geologi. Nr. 3. Oversigt over Nautilerne i vort yngste Senon, Danien og Paleocæn. Medd. Dansk Geol. Foren. Bd. 10, p. 442. København.

- 1944b. Smaabidrag til Danmarks Geologi. Nr. 4. Slægten Chatwinothyris og andre Terebratler fra Danmarks Senon og Danien. Medd. Dansk Geol. Foren. Bd. 10, p. 446. København.

- 1955. Københavns klippegrund og trafikproblemer. Salmonsens Leksikon-Tidsskrift, p. 653. København.

- 1960. Danian Mollusca from Denmark. Intern. Geol. Congr. XXI Sess. Part V, p. 193. København.

Rørdam, K., 1897. Kridtformationen i Sjælland i Terrænet mellem København og Køge, og paa Saltholm. (Résumé: La Système crétacique en Séeland, dans le terrain situé entre Copenhague et Køge, et dans l'île de Saltholm). Danmarks Geol. Unders. II. R. Nr. 6. København.

- 1899. Kortbladene Kjøbenhavn og Roskilde. (Résumé en français). Danmarks Geol. Unders. I. R. Nr. 6. København.

Scenk, E., T. and J. H. McMasters., 1948. Procedure in Taxonomy. Revised edition by A. M. KeEn and S. W. Muller. Stanford, California.

Sorgenfrei, Th., 1949. Nyere undersøgelser over Fyns undergrund. Medd. Dansk Geol. Foren. Bd. 11, p. 490. København.

- 1957. Formations of Denmark. Lexique Stratigraphique International. Vol. I. Fasc. 2 d, Danemark. Paris.

- 1958. Molluscan Assemblages from the Marine Middle Miocene of South Jutland and Their Environments. Danmarks Geol. Unders. II. R. Nr. 79. København.

- 1959. Dybgrundens geologi. I. J. P. TraP: Danmark. Vol. I., 2. Storkøbenhavn I, p. 354. København.

- , and O. Berthelsen, 1954. Geologi og Vandboring (Engl. Abstr. Geology and Water Well Boring). Danmarks Geol. Unders. III. R. Nr. 31. København.

StaCH, L.W., 1936. Correlation of Zoarial Form with Habitat. Journ. Geology. Vol. 44, p. 60. Chicago.

- 1937. The Application of the Bryozoa in Cainozoic Stratigraphy. Australian and New Zealand Assoc. Adv. Sci., Rept of 23rd meeting, Auckland, p. 80. Auckland.

TARr, W. A., 1925. Is the Chalk a Chemical Deposit? Geol. Mag. Vol. LXII, p. 252, London.

Thomas, H. D., and G. P. Larwood, 1956. Some "Uniserial" Membraniporine Polyzoan Genera and a New American Albian Species. Geol. Mag. Vol. XCIII. No. 5, p. 369. London.

- and G. P. LARwood, 1960. The Cretaceous Species of Pyripora d'Orbigny and Rhammatopora Lang. Palaeontology. Vol. 3. Part 3, p. 370. London.

Troedsson, G. T., 1923. Om krokodilfynden i Skånes yngsta krita. Geol. Fören. Förh. Bd. 45. H. 6-7, p. 546. Stockholm.

Troelsen, J. C., 1957. Some Planktonic Foraminifera of the Type Danian and their Stratigraphic Importance. U.S. Nat. Mus. Bull. 215. p. 126. Washington.

Ulrich, E. O., and R. S. Bassler, 1907. Bryozoa. In S. Weller: A Report on the Cretaceous Paleontology of New Jersey. Geol. Surv. New Jersey. Paleontology. Vol. IV. Trenton.

WIND, J., 1954. Tylocidaris Piggene som Ledeforsteninger i vort øvre Senon og Danien. Medd. Dansk Geol. Foren. Bd. 12, p. 481. København. 
WIND, J., 1959. Echinocorys-formerne og deres stratigrafiske Udbredelse i det øverste Kridt i Danmark. Medd. Dansk Geol. Foren. Bd. 14, p. 122. København.

VoIGt, E., 1923. Über einige neue und wenig bekannte Bryozoen der Gattung Floridina aus dem Danien von Faxe. Medd. Dansk Geol. Foren. Bd. 6. Nr. 20. København.

- 1924. Über neue Bryozoen aus Daniengeschieben Anhalts. Pal. Zeitschr. Bd. VI. H. 1. Berlin.

- 1924. Beiträge zur Kenntnis der Bryozoenfauna der subherzynen Kreidemulde. Pal. Zeitschr. Bd. VI. H. 2, p. 94. Berlin.

- 1925. Neue cribrimorphe Bryozoen aus der Familie der Pelmatoporidae in Kreidegeschieben Anhalts. Zeitschr. f. Geschiebeforsch. Bd. I. H. 3, p. 97. Berlin.

- 1925. Über das Vorkommen von Bryozoen in Diluvialgeschieben und die Grundzüge ihrer Systematik. Zeitschr. f. Geschiebeforsch. Bd. I. p. 14. Berlin.

- 1929. Die Lithogenese der Flach- und Tiefwassersedimente des jüngeren Oberkreidemeeres. Jhrb. d. Halleschen Verb. f. Erdforsch. d. mitteldeutschen Bodenschätze u. ihrer Verwertung. Bd. 8. N. F. Dessau.

- 1930. Morphologische und stratigraphische Untersuchungen über die Bryozoenfauna der oberen Kreide. Ber. Kaiserl. Leopoldin. Deutsch. Akad. d. Naturforscher. zu Halle. Bd. VI, p. 379. Halle.

- 1949. Cheilostome Bryozoen aus der Quadratenkreide Nordwestdeutschlands. Mitt. Geol. Staatsinst. Hamburg. H. 19. Hamburg.

- 1951. Das Maastricht-Vorkommen von Ilten bei Hannover und seine Fauna. Mitt. Geol. Staatsinst. Hamburg. H. 20, p. 15. Hamburg.

- 1956. Untersuchungen über Coscinopleura MARSSON und verwandte Gattungen. Mitt. Geol. Staatsinst. Hamburg. H. 25, p. 26. Hamburg.

- 1957. Bryozoen aus dem Kreidetuff von St. Symphorien bei Ciply. Inst. royald. Sciences nat. d. Belgique. Tome XXXIII, Bull. no. 43. Bruxelles.

- 1959. Über Fissuricella n.g. Neues Jb. Geol. und Paläont., Abh. Bd. 108. H. 3, p. 260. Stuttgart.

- 1959. Revision der von F. v. HaGenow 1839-1850 aus der Schreibkreide von Rügen veröffentlichten Bryozoen. Geologie. 8. Jahrg. Beih. 25. Berlin.

- 1959. Sur les difrérénts stades de l'astogénèse de certains Bryozoaires cheilostomes. Bull. Soc. Géol. France. 7e Serie, tome I, p. 697. Paris.

ØDum, H., 1926. Studier over Daniet i Jylland og på Fyn. (Summary: Studies on the Danian in Jutland and Funen). Danmarks Geol. Unders. II. R. Nr. 45. København.

- 1928. The Cretaceous Deposits of Denmark. In "Summary of the Geology of Denmark". Danmarks Geol. Unders. V. R. Nr. 4, p. 51. København. 


\section{INDEX OF BRYOZOA}

The names of species and genera used in the present paper are printed in italics; all synonyms in Roman types.

\begin{tabular}{|c|c|}
\hline Page & \\
\hline iminella, Callopora ............ & circulata, Anornithopora.......... \\
\hline echmella................. 138 & irculata, Pustulipora............ \\
\hline Allantopora................ 9 & ircumvallata, Membraniporella.... \\
\hline mphiblestrum... & ircumvallata, Tricephalopora....... 179 \\
\hline ndriopora .............. 164 & lavata, Membranipora ........ 71 \\
\hline ngulata, Micropora ........... 130 & 138 \\
\hline nopleura ..... 158 & olumella, Onychocella ......... 113 \\
\hline a ...... 217 & Columnotheca.............. 207 \\
\hline & miescharinella...... 134 \\
\hline$\ldots \ldots \ldots \ldots 217$ & a.......... \\
\hline$\ldots \ldots \ldots 20$ & 1а........ 183 \\
\hline$\ldots \ldots 20$ & oporella........ 183 \\
\hline$\ldots \ldots \ldots \ldots 186$ & $\sin a \ldots \ldots \ldots \ldots 165$ \\
\hline$\ldots \ldots \ldots \ldots 65$ & $\ldots \ldots \ldots \ldots \ldots 158$ \\
\hline$\ldots \ldots \ldots \ldots$ & sicellepora............. 219 \\
\hline$\ldots \ldots \ldots 211$ & olumnotheca........... \\
\hline & \\
\hline 20 & ra......... 207 \\
\hline$\ldots \ldots 11$ & $\ldots \ldots \ldots \ldots \ldots 216$ \\
\hline$\ldots \ldots .19$ & $n a \ldots \ldots \ldots \ldots \ldots 193$ \\
\hline .. 200 & opora........... \\
\hline$\ldots \ldots 11$ & opora......... 164 \\
\hline$\ldots \ldots \ldots \ldots$ & $\ldots \ldots \ldots 219$ \\
\hline$\ldots \ldots \ldots \ldots$ & $l a \ldots \ldots \ldots \ldots 105$ \\
\hline ora ........ 18 & ora ....... 173 \\
\hline & ora $\ldots \ldots \ldots 60,61$ \\
\hline$\ldots \ldots \ldots 204$ & $\ldots \ldots \ldots \ldots 174$ \\
\hline . 20 & $\ldots \ldots \ldots \ldots \ldots 184$ \\
\hline$\ldots \ldots 7$ & $\ldots \ldots \ldots \ldots \ldots 209$ \\
\hline$\ldots \ldots \ldots \ldots$ & nа........ 182 \\
\hline & ora $\ldots \ldots \ldots 83$ \\
\hline . 170 & lla......... 205 \\
\hline . 11 & ora.........207 \\
\hline . 150 & trum......... 100 \\
\hline Callopora. & opleura ........ 158 \\
\hline & pora ........ 100 \\
\hline 21 & oma $\ldots \ldots \ldots \ldots 158$ \\
\hline . 19 & $11 a \ldots \ldots \ldots \ldots 100$ \\
\hline . 19 & elliptica faxensis, Membranipora ... 58 \\
\hline cerberus, Tricephalopora & Ellisina . . . . . . . . . . . . . \\
\hline cincta, Pithodella ...... & elongata, Onychocella ........... \\
\hline
\end{tabular}


erratica, Homalostega............ 131

erratica, Micropora........... 131

eurita, Eschara............... 94

europaea, Diplotresis............ 209

excavata, Floridina............. 129

exsculpta, Micropora .......... 155

exsculpta, Puncturiella ......... 155

exsculpta, Vincularia........... 155

faxensis, Lunularia ............ 152

faxensis, Lunulites . . . . . . . . . 152

faxensis, Onychocella .......... 152

filiformis, Acropora..... . . . . . . 204

filiformis, Pachytheca............ 204

filiformis, Pachythecella.......... 204

filiformis, Porina. . . . . . . . . . . . 204

filograna, Cellepora........... 150

fissa, Andriopora............. 160

fissa, Fissuricella ............. 160

fissa, Pachydera ............. 175

Fissuricella ............... 160

flabellata, Beisselina .......... 201

flabellata, Porina .............. 201

Floridina ............... 115

fragilis, Floridina............ 127

Frurionella................ 105

fulgora, Aplousina ........... 71

fulgora, Membranipora ........ 71

Gartantua ................. 149

gimense, Onychocella.......... 108

Gimense, Rhagasostoma ........ 108

globulosa, Rhiniopora .......... 190

gluma, Pliophloea............. 167

Goldfussii, Onychocella......... 153

gothica, Floridina ............ 115

gothica, Vincularia ............ 115

gracilis, Micropora ........... 131

grandis, Pachydera ............ 174

Haplocephalopora............. 182

hennigiana, Micropora......... 132

Herpetopora ............... 69

hexagona bredsdorffi, Membranipora 53

hexagona, Cellepora........... 51

hexagona, Membranipora........ 51

hians, Lepralia.............. 215

hians, Mucronella............ 215

hippocrepis, Aechmella......... 138

hippocrepis, Micropora ........ 138

Hoplitaechmella............. 145

Huckeana, Membranipora....... 92

huckeana, Membraniporidra...... 92

humiliata, Ellisina............. 74

humiliata, Membranipora ....... 74
Page

impar, Floridina............ 120

impressipora faxensis, Thalamopo-

rella................... 125

inermis, Membranipora .......... 94

inermis, Membraniporidra........ 94

intermixta, Cribilina.......... 186

invigilata, Callopora........... 80

invigilata, Membranipora........ 80

irregularis faxensis, Onychocella... 109

irregularis, Onychocella ......... 108

isolata, Anornithopora........... 189

johnstrupi, Membranipora........ 58

lacrymopora, Membranipora...... 93

lacrymoporoides, Membraniporidra . 93

laticostata, Leptocheilopora ....... 163

latistoma, Aechmella........... 141

laximaculata, Ellisina ......... 76

laximaculata, Membranipora...... 76

Leptocheilopora ............. 163

levinseni, Floridina ............ 126

Lundgreni, Foveolaria . . . . . . . . 206

Lundgreni, Monoporella ......... 206

lundgreni, Pachytheca........... 206

lundgreni, Pachythecella ......... 206

Lunulites ................... 152

lyra, Callopora............. 83

lyra, Cellepora.............. 83

lyra, Membranipora ......... 83, 84

lyraeformis, Callopora.......... 84

lyraeformis, Membranipora...... 84

marssoniana, Membranipora...... 61

maxima, Membranipora ........ 66

Membranipora ............. 51

Membraniporella ......................... 162

Membraniporidra............ 92

Micropora................. 130

microstoma, Aechmella......... 143

microstoma, Vincularia ......... 143

minuta, Anornithopora......... 186

minuta, Micropora ............. 149

monocera, Callopora........... 78

monocera, Membranipora ....... 78

Monoceratopora............ 172

Mucronella ................ 215

nobilis, Beisselina ............ 197

nobilis, Monoporella............ 197

nobilis, Steganoporella ......... 132

Nysti, Rhagasostoma ........... 113

oblita, Beisselinopsis............ 201

oblita, Eschara.............. 201

Ochetosellina.............. 211

oculata cincta, Membranipora .... 95 


\begin{tabular}{|c|c|}
\hline & \\
\hline culata lyra, Membranipora...... 84 & cutata, Membranipora .......... \\
\hline culata, Membranipora ........ 84 & elandica, Membranipora ......... \\
\hline Onychocella................ 108 & Semiescharinella.............. \\
\hline Pachydera................ 174 & mitti, Aechmella............. 145 \\
\hline achythecella ............... 203 & mitti, Hoplitaechmella.......... 14 \\
\hline$\ldots \ldots \ldots 168$ & Smittii, Periteichisma .......... 14 \\
\hline argantua.......... 149 & sparsispina, Membranipora....... \\
\hline malostega......... 149 & spiralis, Glauconome .......... \\
\hline la........ 149 & pora......... \\
\hline Cryptostomella....... 216 & raniporella ..... 16 \\
\hline ora $\ldots \ldots \ldots \ldots \ldots \ldots \ldots \ldots$ & cella............ 10 \\
\hline$\ldots \ldots \ldots \ldots 183$ & stefniensis, Callopora........... \\
\hline$\ldots \ldots \ldots \ldots 138$ & stevensis, Micropora ............ \\
\hline$\ldots \ldots \ldots \ldots \ldots \ldots \ldots$ & Stichocados................ 19 \\
\hline plicatelloides, Membranipora ...... 54 & stomatoporoides, Allantopora ...... 9 \\
\hline Pliophloea................. 165 & subbrachiata, Stichocados......... 19 \\
\hline ora....... 187 & subcornuta, Pliophlea ........... Ic \\
\hline$\ldots \ldots \ldots \ldots 213$ & subcupolata, Callopora ......... 8 \\
\hline$\ldots \ldots \ldots \ldots 193$ & subfulgora, Membranipora ....... \\
\hline$\ldots \ldots \ldots 109$ & ranipora ..... 13 \\
\hline auconome........ 67 & ata, Semieschara....... 13 \\
\hline ncularia.......... 67 & ricephalopora ....... 178 \\
\hline$\ldots \ldots \ldots \ldots 103$ & $m a \ldots \ldots \ldots \ldots \ldots \ldots 212$ \\
\hline$\ldots \ldots \ldots 103$ & $n a \ldots \ldots \ldots \ldots \ldots \ldots$ \\
\hline pracipua herfolgensis, Membranipora 63 & ga......... 15 \\
\hline prcecipua, Membranipora......... 63 & \\
\hline$s \ldots \ldots \ldots \ldots \ldots \ldots 217$ & iella ............ 15 \\
\hline$\ldots \ldots \ldots \ldots 124$ & $\| l a \ldots \ldots \ldots \ldots \ldots 14$ \\
\hline$\ldots \ldots \ldots \ldots 124$ & $\ldots \ldots \ldots \ldots \ldots \ldots 17$ \\
\hline$\ldots \ldots 137$ & loridina.......... 12 \\
\hline$\ldots 137$ & linopsis ........ 20 \\
\hline$\ldots 155$ & t. \\
\hline$\ldots \ldots \ldots 172$ & $\ldots \ldots 10$ \\
\hline$\ldots \ldots \ldots 172$ & $\ldots \ldots 17$ \\
\hline ratopora .... 172 & phalopora........ 18 \\
\hline$\ldots \ldots \ldots \ldots 111$ & Austra ........... 6 \\
\hline$\ldots 185$ & na........... \\
\hline$\ldots 74$ & pora ... 12 \\
\hline , Membranipora .... & ipora $\ldots \ldots \ldots .5$ \\
\hline$\ldots 190$ & ra........ 20 \\
\hline$\ldots 134$ & stoma........21 \\
\hline$\ldots 180$ & Iioides, Hoplitaechmella..... 147 \\
\hline rosenkrantzi, Callopora...... & ilio Smitti, Membranipora... 14 \\
\hline salebrosa, Acropora ........ & Vincularia $\ldots \ldots \ldots \ldots \ldots \ldots$ \\
\hline$\ldots 195$ & ides, Pliophloea ... \\
\hline saltholmensis, Lunulites..... & voigti, Crassicellepora........ \\
\hline sculpta, Puncturiella....... & voigti, Floridina . ......... \\
\hline$\ldots 15$ & vulcani, Brydenella.......... \\
\hline$\ldots 155$ & vulcani, Homalostega ........ \\
\hline . . 12 & dumi, Aplousina .......... \\
\hline
\end{tabular}



Denne bog er sat med Monotype Times og trykt i 1500 eksemplarer på Andelsbogtrykkeriet i Odense. Papir: ekstraglittet 605, $125 \mathrm{~g}$, fra De forenede Papirfabrikker. 
PLATES 


\section{Plate 1}

All magnifications $\times 20$.

Fig. 1. "Membranipora" hexagona (v. Hagenow). Faxe. Page 51.

Fig. 2. "Membranipora" hexagona (v. HAGENow). Back of zoarium.

Fig. 3. "Membranipora" hexagona bredsdorffi n.subsp. Herfølge. Page 53.

Fig. 4. "Membranipora" hexagona bredsdorffi. Back of zoarium.

Fig. 5. "Membranipora" plicatelloides n.sp. Faxe. Page 54.

Fig. 6. "Membranipora" plicatelloides. Back of colony.

Fig. 7. "Membranipora" plicatella (v. HAG.). Wulmstorf. (Page 55).

Phot. Chr. WestergaArd 
Plate 1
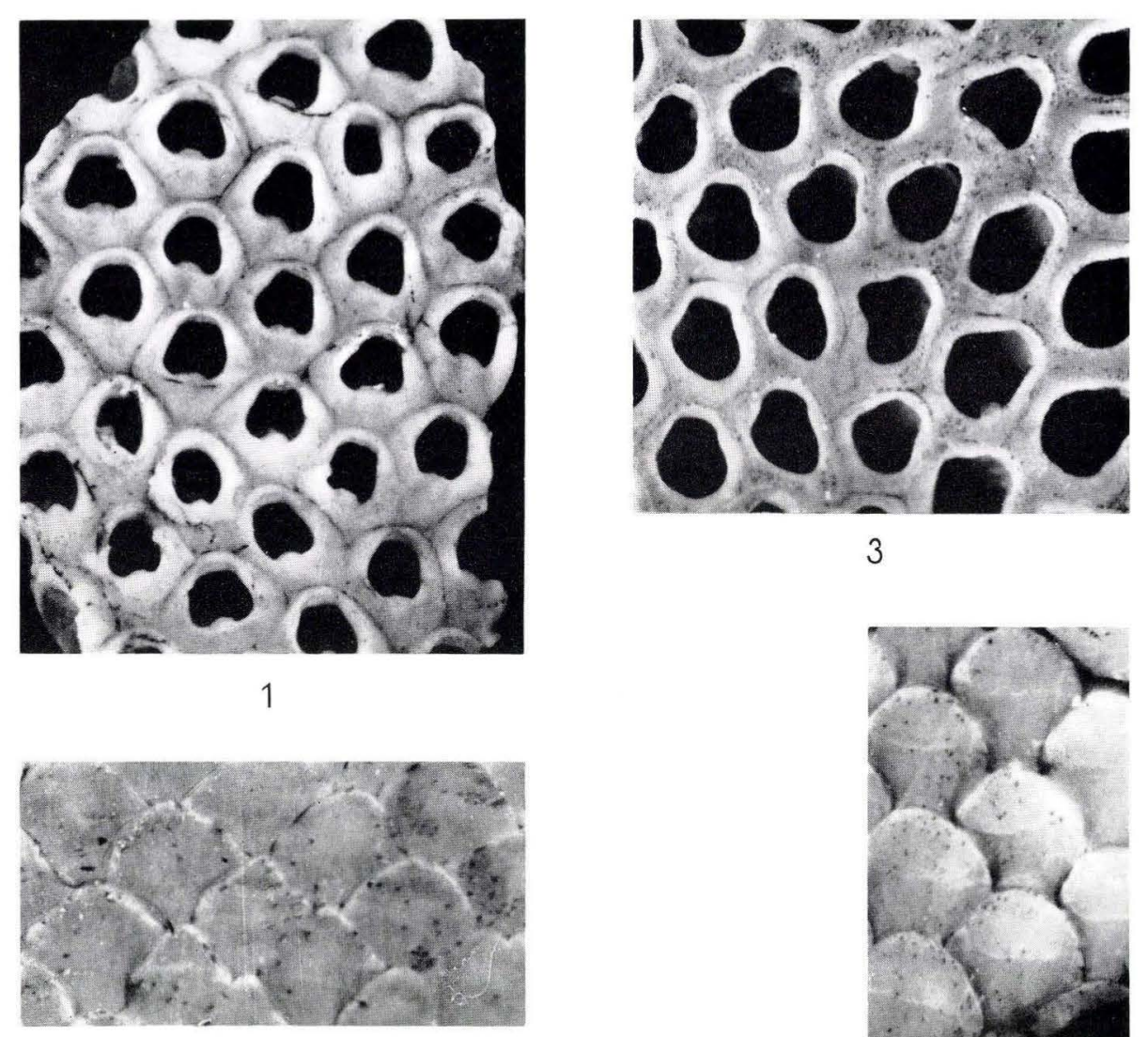

4

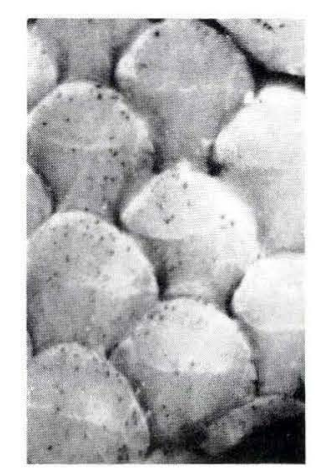

2

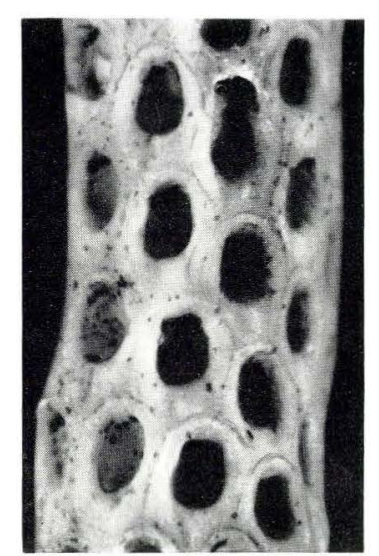

5

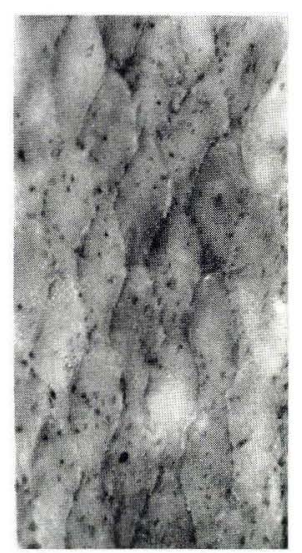

6

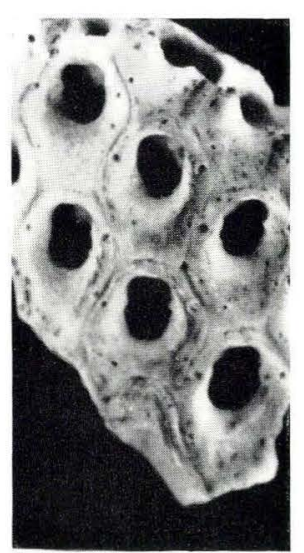

7

I*

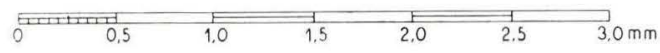




\section{Plate 2}

All magnifications $\times 20$.

Fig. 1. "Membranipora" plicatelloides n.sp. Herfølge. Page 54.

Figs. 2-5. "Membranipora" selandica n.sp. Herfølge. Page 55.

Fig. 2. Normal and sealed zooecia.

Fig. 3. Sealed and normal zooecia, proximally set with pores.

Fig. 4. Two layers of zooecia with different orientation. The lower layer consists of regenerated zooecia.

Fig. 5. Segment of colony with avicularium.

Figs. 6-7. "Membranipora" sparsispina VoIGt. Page 57.

Fig. 6. Columnar (vinculariform) colony, Stevns.

Fig. 7. Bilamellar (eschariform) colony, Faxe.

Phot. Chr. Westergaard 
Plate 2

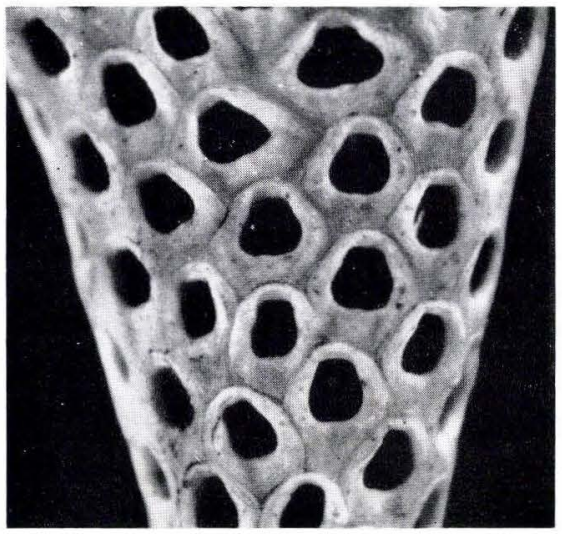

1

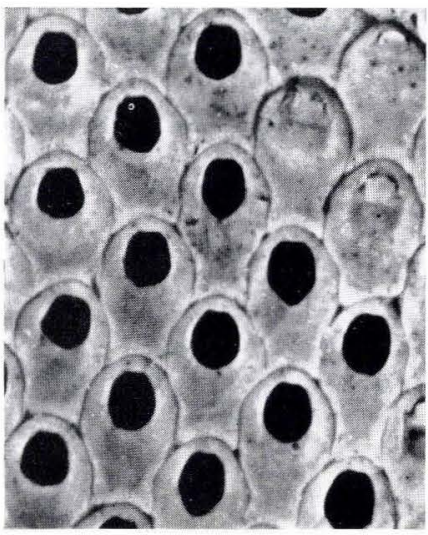

2

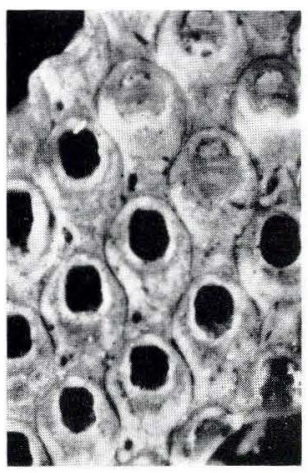

3

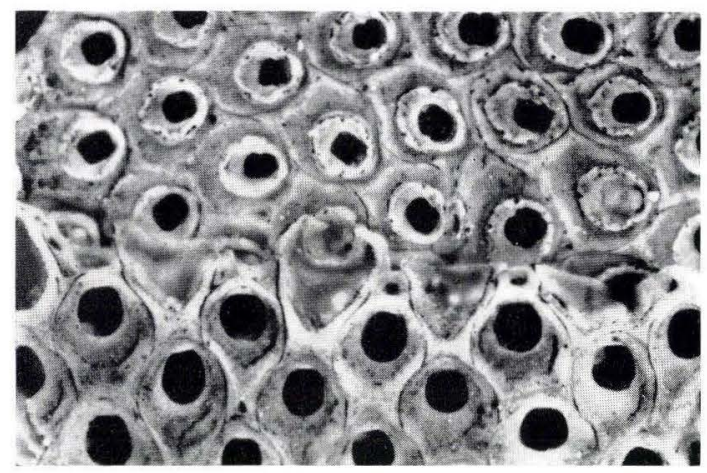

4

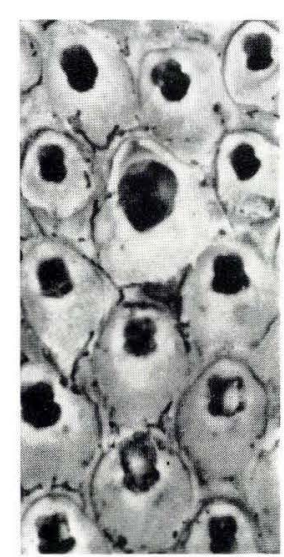

5

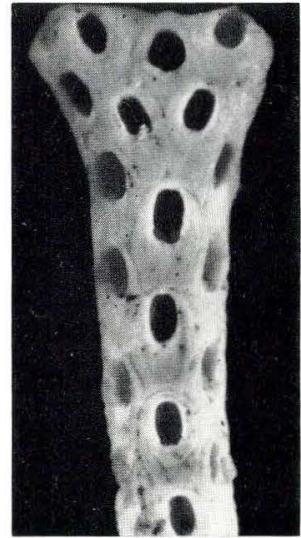

6

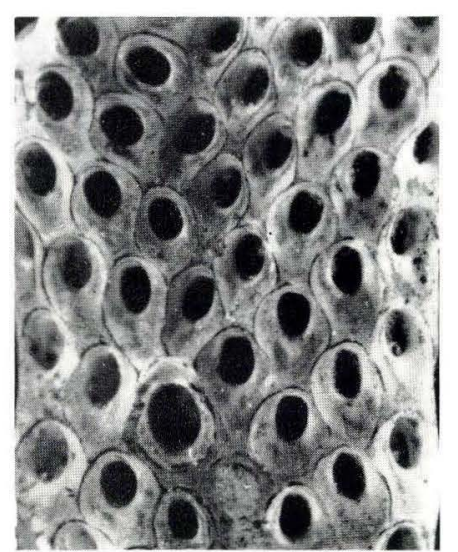

7

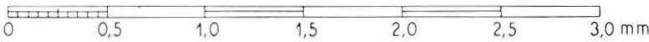




\section{Plate 3}

All magnifications $\times 20$.

Fig. 1. "Membranipora" declivis Marsson. Faxe. Page 60.

Figs. 2-3. "Membranipora" marssoniana VoIGT. Herfølge. Page 61.

Fig. 2. Colony with well-preserved avicularium.

Fig. 3. Colony with remnants of ovicells.

Fig. 4. "Membranipora" aperta Lev. Faxe. Page 65.

Figs. 5-6. "Membranipora" maxima Lev. Faxe. Page 66.

Fig. 5. Colony with avicularium and scars of ovicells.

Fig. 6. Colony with avicularium.

Phot. Chr. WestergaArd 
Plate 3

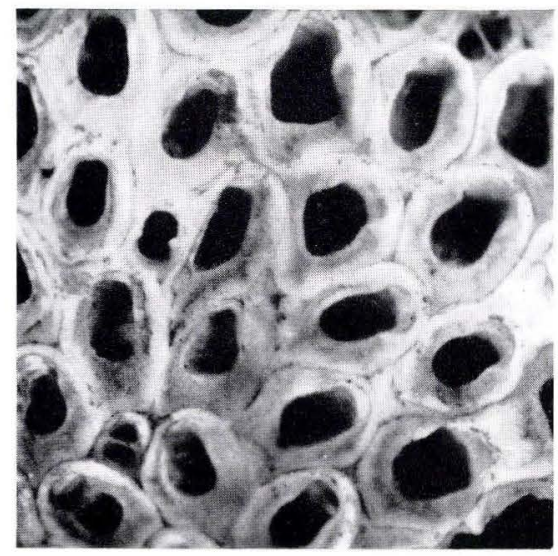

1

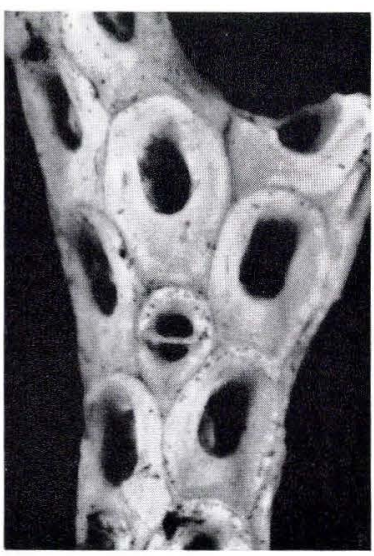

2
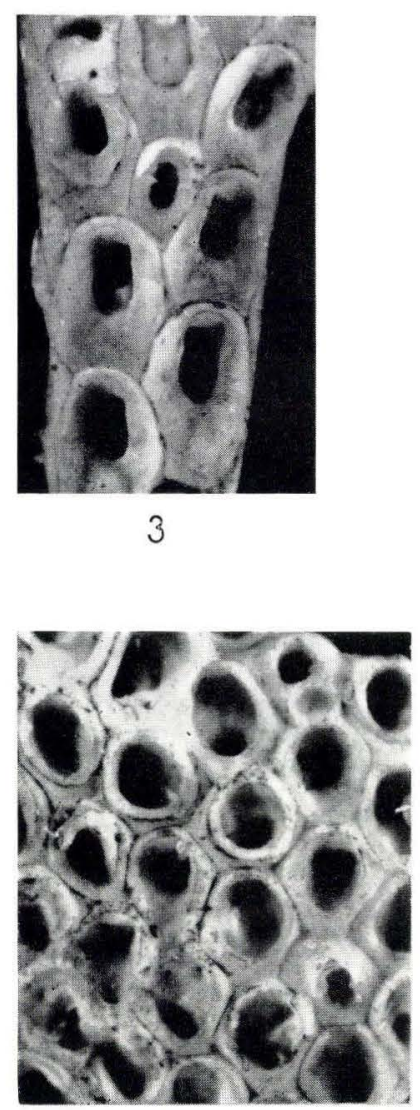

4

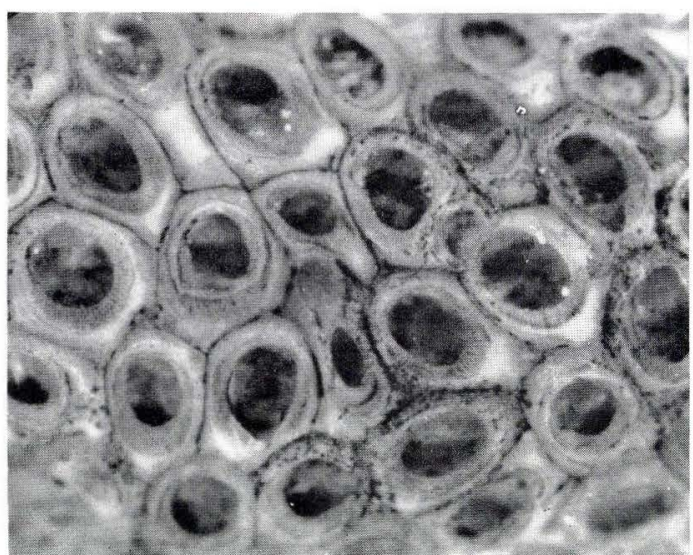

5

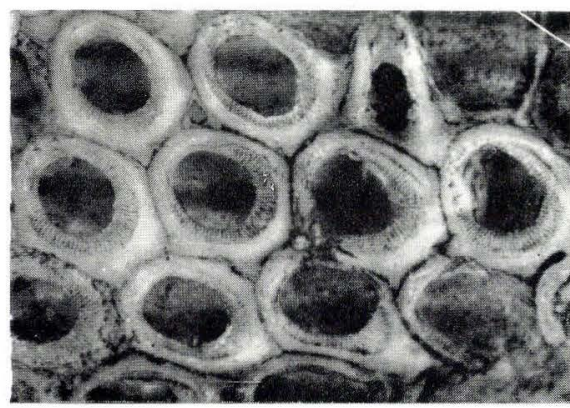

6
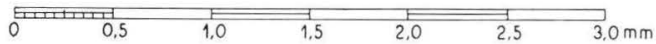


\section{Plate 4}

All magnifications $\times 20$.

Figs. 1-2. "Membranipora" johnstrupi n.sp. Faxe. Page 58.

Fig. 1. Colony with avicularia and sealed zooecium.

Fig. 2. Zoarium with scars of ovicells.

Figs. 3-4. "Membranipora" pracipua herfolgensis n.subsp. Herfølge. Page 63.

Fig. 3. Colony with vicarious avicularium.

Fig. 4. Colony with interstitial avicularium and scars of hyperstomial ovicells.

Fig. 5. Vincularia prismatica (v. HAG.) Herfølge. Page 67.

Fig. 6. "Herpetopora" danica LANG. Page 69.

Fig. 7. Aplousina fulgora (BRydone). Wulmstorf. Page 71.

Fig. 8. Aplousina fulgora (BRYDONE). Faxe.

Phot. Chr. WestergaArd 

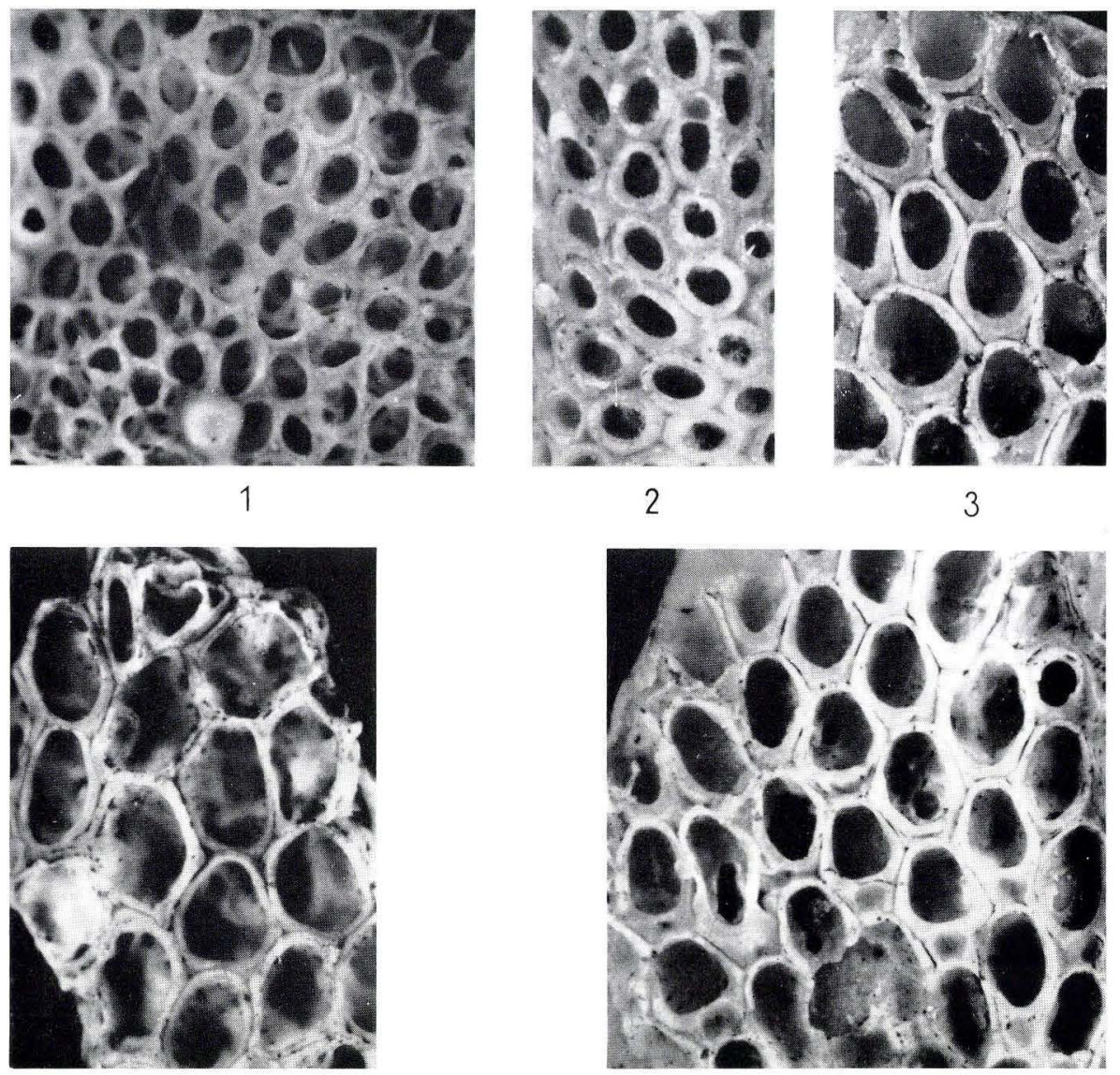

7

4

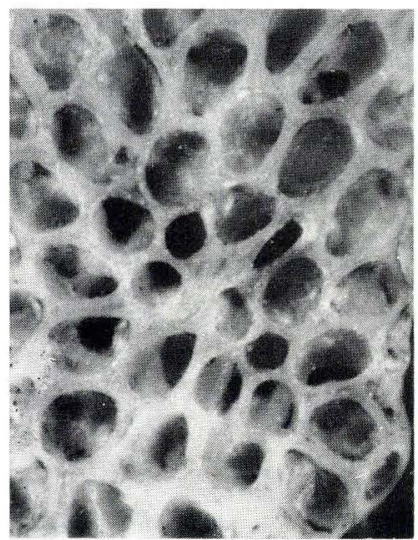

8

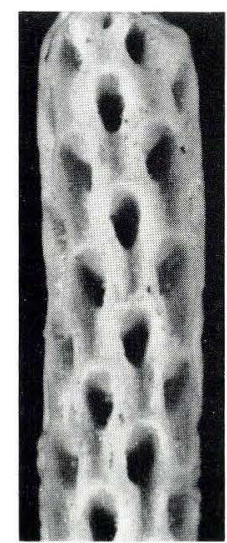

5

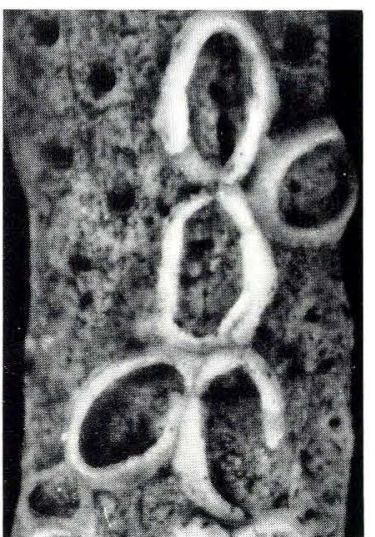

6

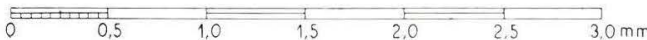




\section{Plate 5}

All magnifications $\times 20$.

Figs. 1-2. Aplousina ødumi n.sp. Herfølge. Page 73.

Fig. 2. Fragment with regenerated zooecium and ovicell.

Fig. 3. Ellisina humiliata (BRydone). Herfølge. Page 74.

Fig. 4. Ellisina britannica (BRydone). Faxe. Page 76.

Figs. 5-6. Callopora monocera (MArsson). Faxe. Page 78.

Fig. 6. Back of zoarium.

Fig. 7. Callopora subcupolata n.sp. Faxe. Page 81.

Phot. Chr. Westergated 
Plate 5

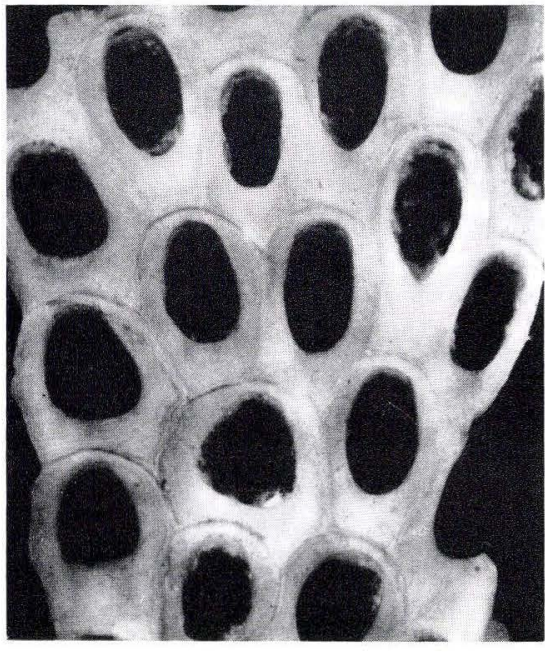

1

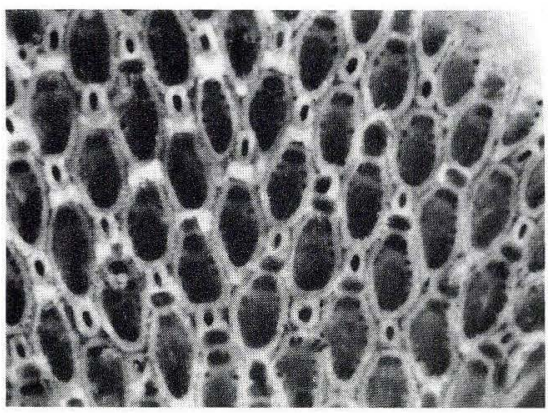

3
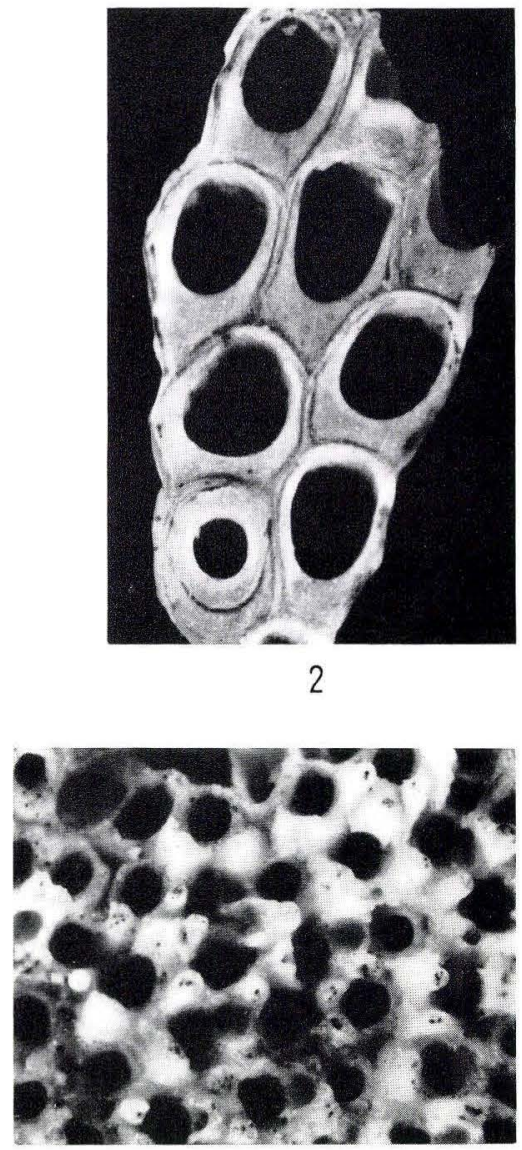

7

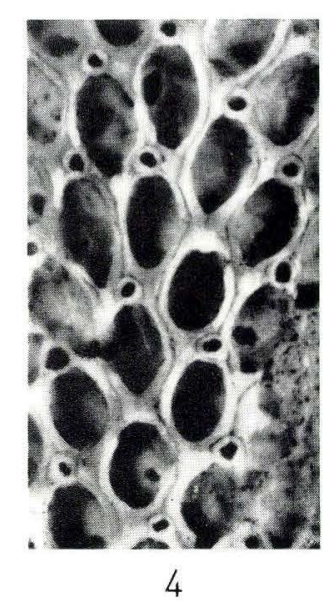

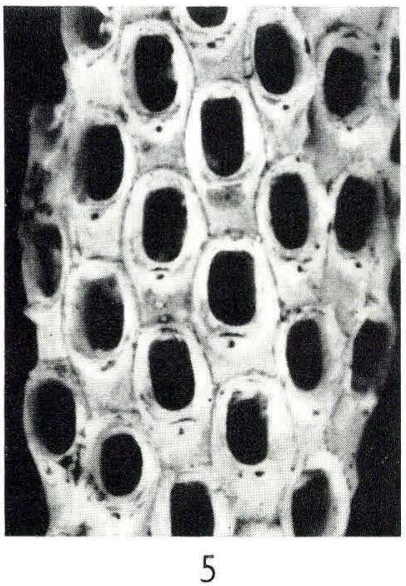
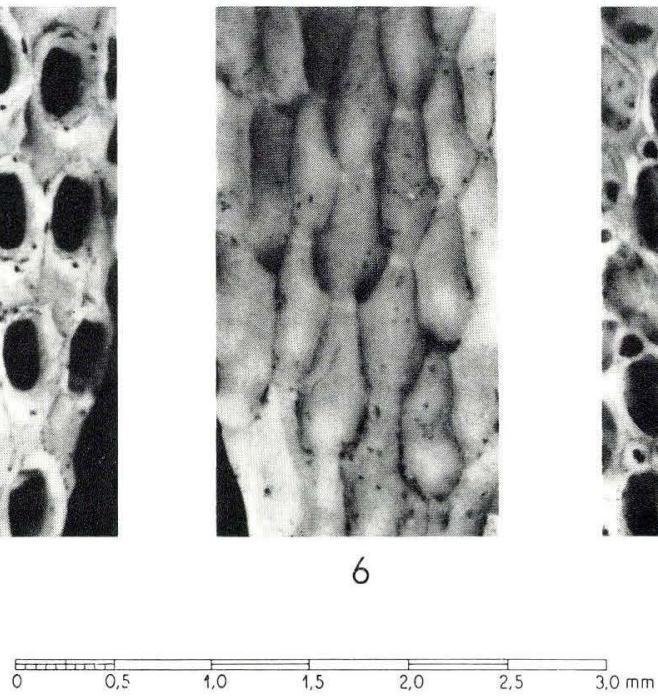


\section{Plate 6}

All magnifications $\times 20$.

Fig. 1. Callopora invigilata (BRydone). Herfølge. Page 80.

Figs. 2-3. Callopora acuminella n.sp. Faxe. Page 86.

Fig. 2. Fragment with avicularia in regenerated zooecia.

Fig. 3. Fragment with ovicells.

Fig. 4 Callopora coronata Levinsen. Havighorst. (Page 87).

Figs. 5-6. Callopora rosenkrantzi n.sp. Faxe. Page 88.

Figs. 7-8. Callopora stefniensis n.sp. Stevns. Page 89.

Phot. Chr. WestergaArd 


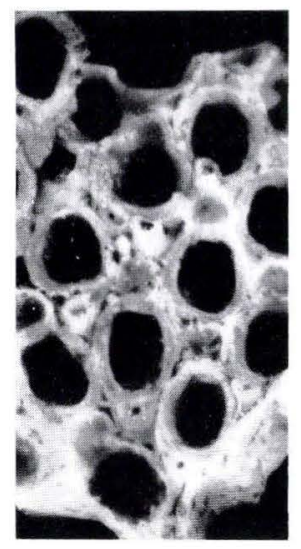

1

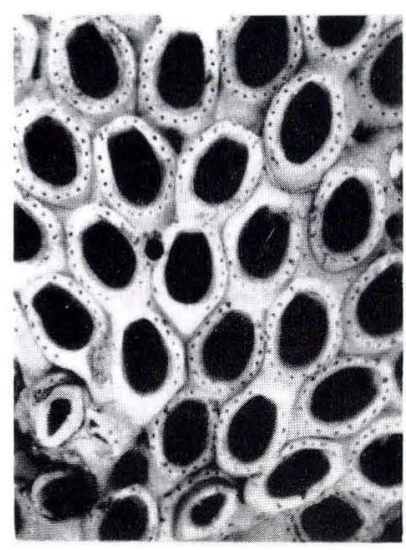

2

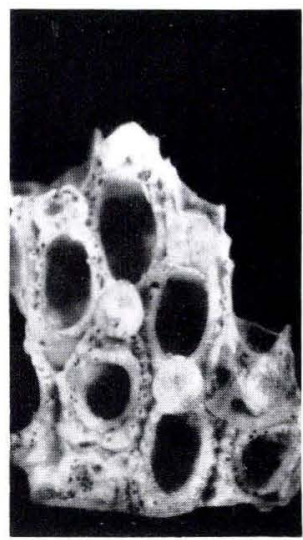

4

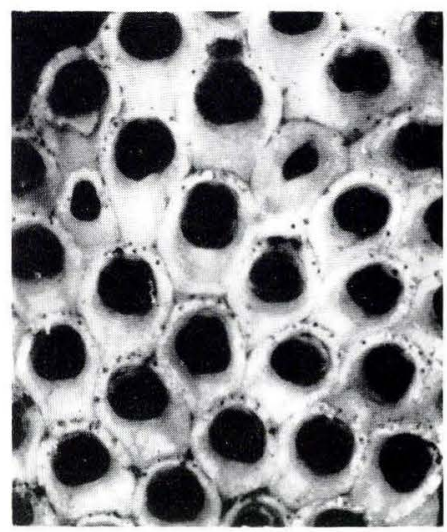

7

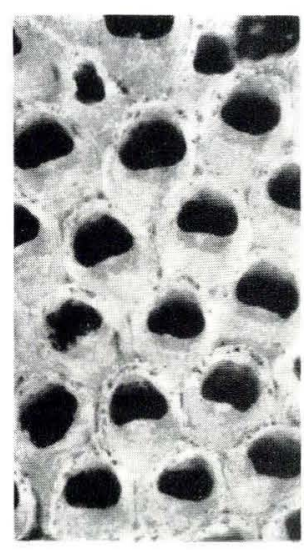

8

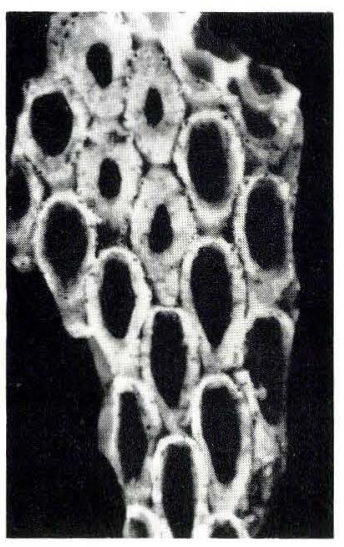

5

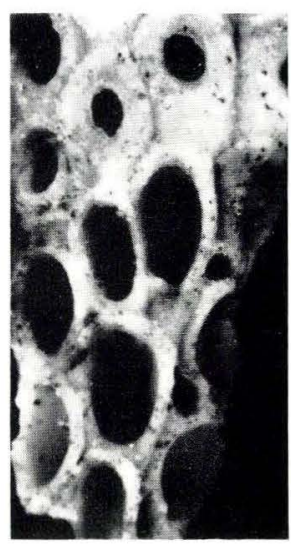

6 


\section{Plate 7}

All magnifications $\times 20$.

Fig. 1. Callopora lyra (v. Hagenow). Faxe. Page 83.

Fig. 2. Callopora ef. C. lyraeformis Voigt. Herfølge. Page 84.

Fig. 3. Allantopora stomatoporoides Lang. Faxe. Page 91.

Figs. 4-5. Membraniporidra huckeana Voigt. Faxe. Page 92.

Fig. 6. Membraniporidra inermis (Levinsen). Faxe. Page 94.

Phot. Chr. Westergatrd 
Plate 7
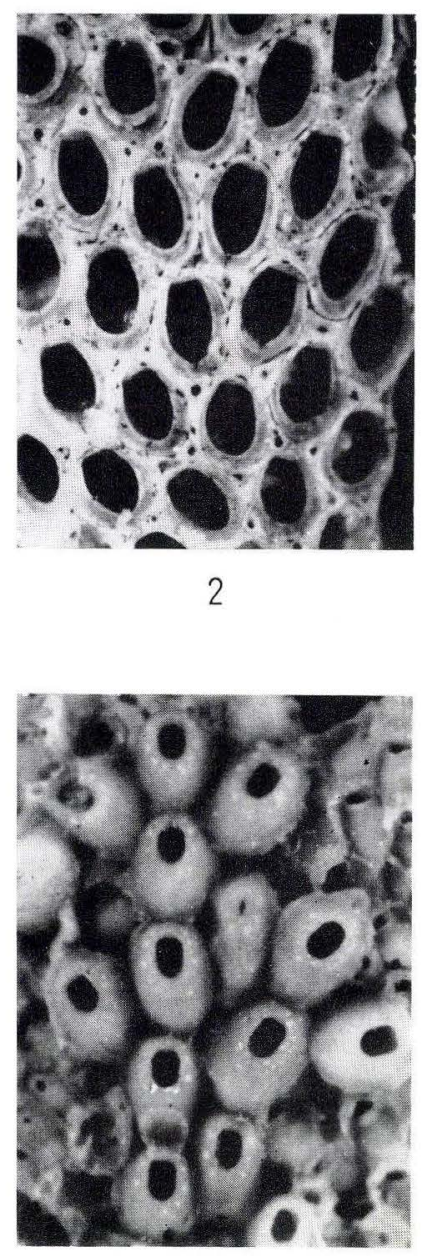

3

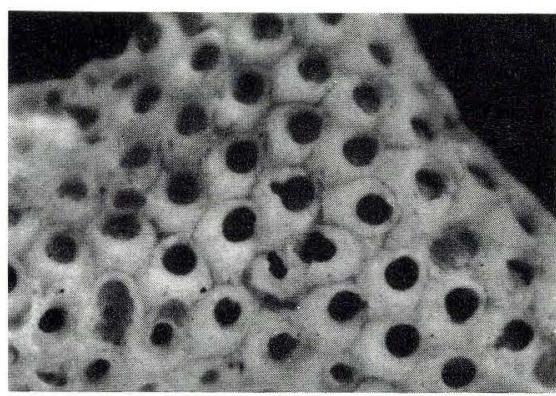

4

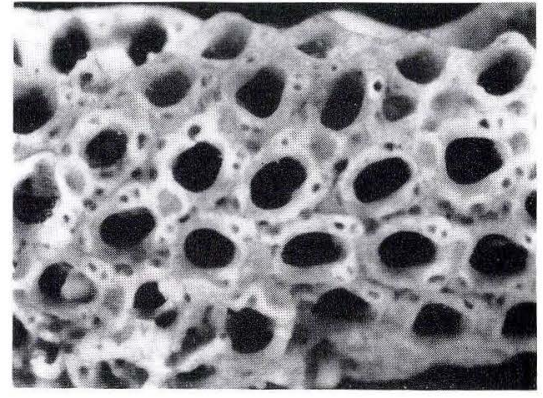

1

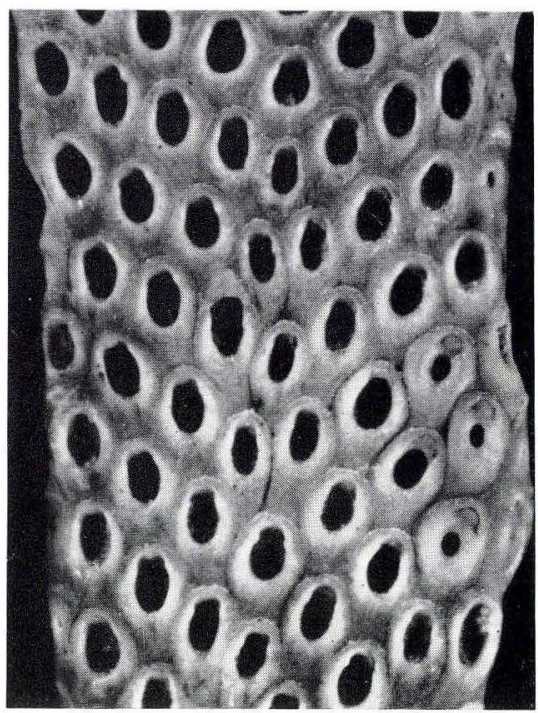

6

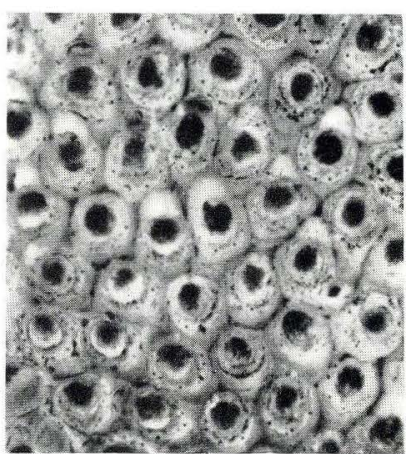

5

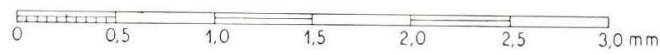




\section{Plate 8}

All magnification $\times 20$.

Fig. 1. Membraniporidra lacrymoporoides n.sp. Faxe. Page 93.

Figs. 2-3. Pithodella cincta Marsson. Faxe. Page 95.

Figs. 4-7. Pithodella bifoliata n.sp. Faxe. Page 98.

Phot. Chr. Westergaard 
Plate 8
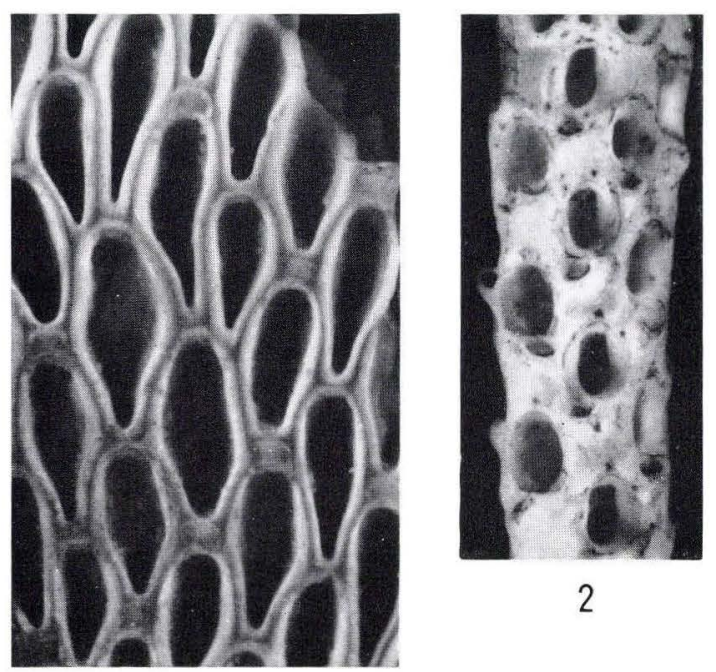

1

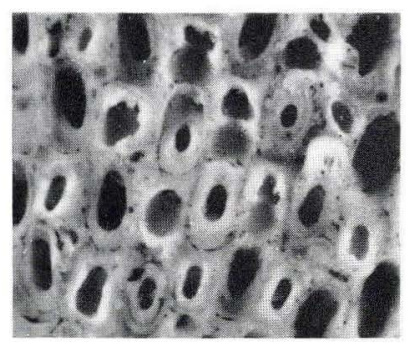

5

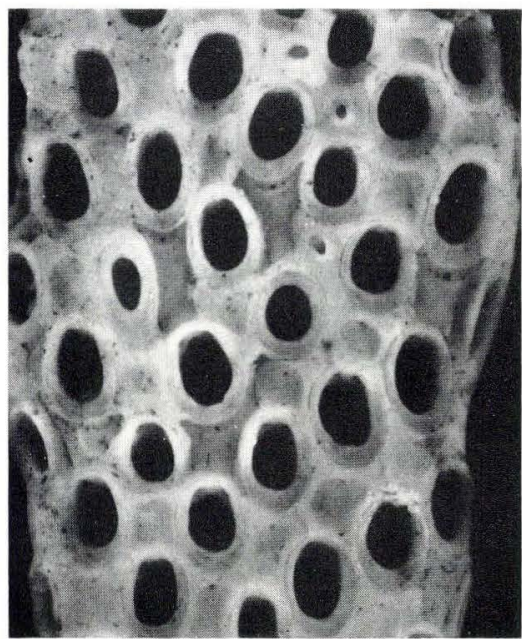

6

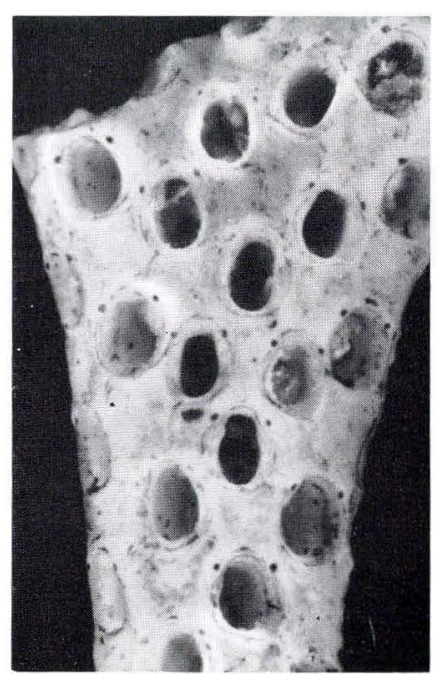

3

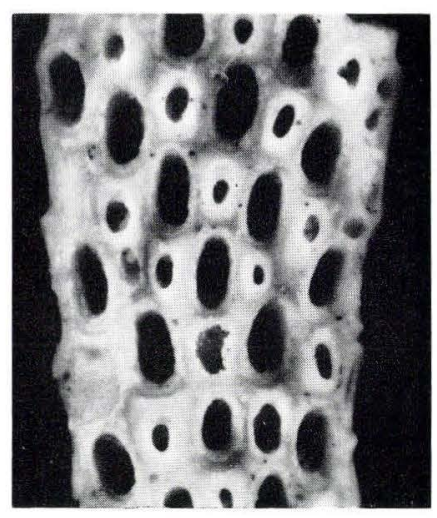

4

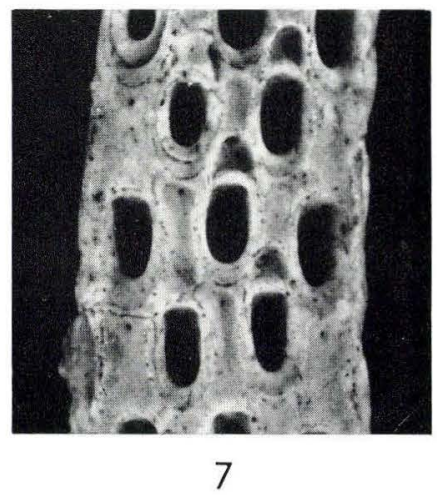

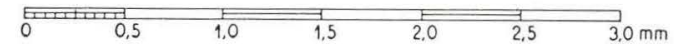




\section{Plate 9}

All magnifications $\times 20$.

Figs. 1-5. Amphiblestrum elegans (v. Hagenow). Page 100.

Fig. 1. Amphiblestrum elegans. Møn.

Fig. 2. Amphiblestrum elegans faxensis Lev. Faxe.

Fig. 3. Amphiblestrum elegans. Coarse, tubular colony. Herfølge.

Fig. 4. Amphiblestrum elegans. Encrusting colony. Stevns.

Fig. 5. Amphiblestrum elegans. Free, unilamellar colony. Faxe.

Fig. 6. Stamenocella pristis (Levinsen). Saltholm. Page 103.

Fig. 7. Stamenocella tumida VoIGT. Herfølge. Page 104.

Figs. 8-9. Frurionella daniensis n.sp. Herfølge. Page 105.

Fig. 9. Marginal avicularia.

Phot. Chr. Westergaard 
Plate 9

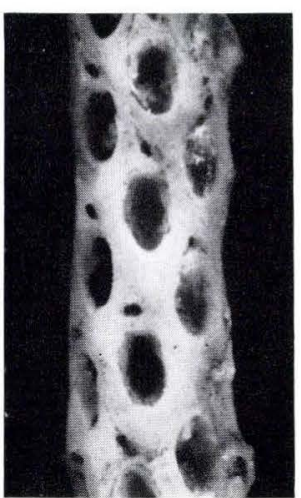

1

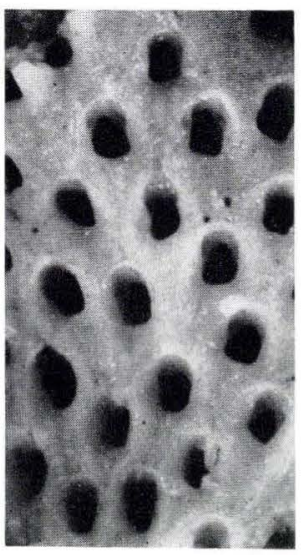

4

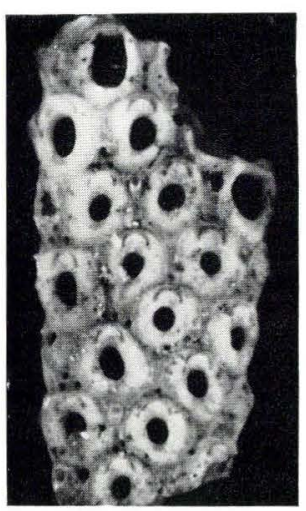

7

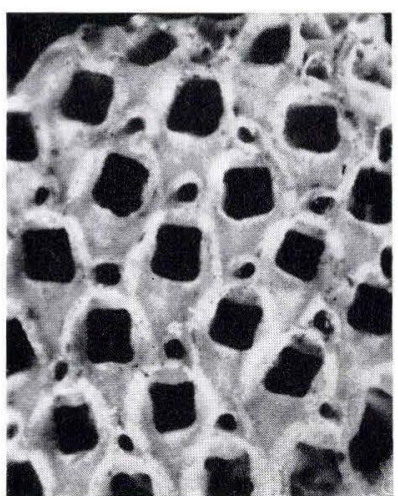

3

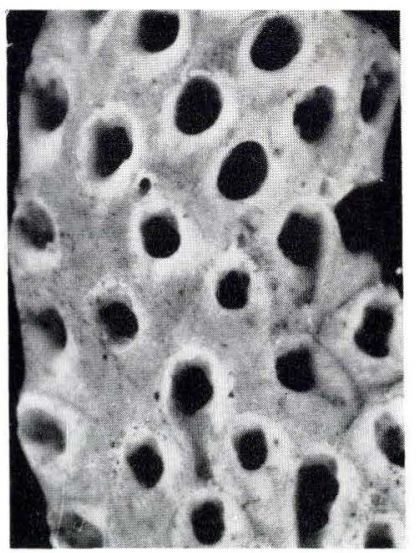

5

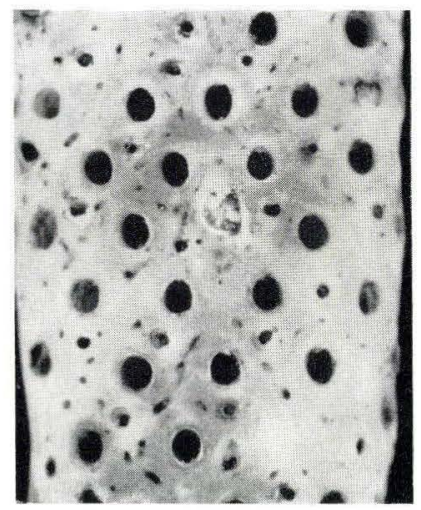

8

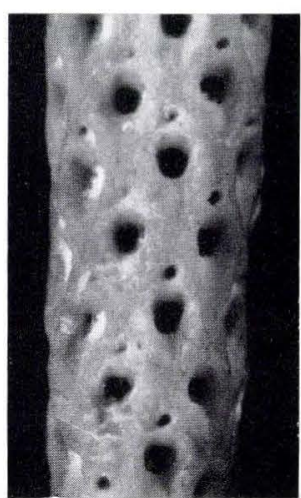

2

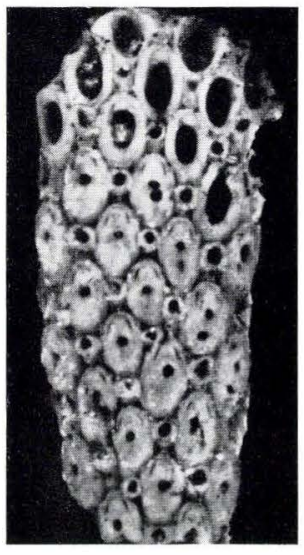

6

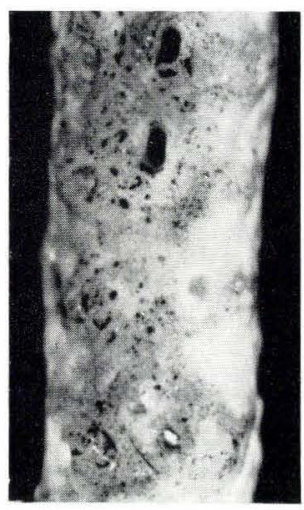

9 


\section{Plate 10}

All magnifications $\times 20$.

Fig. 1. Frurionella daniensis n.sp. Herfølge. Page 105.

Fig. 2. Onychocella gimense (BRydone) Stevns. Page 108.

Fig. 3. Onychocella poulseni n.sp. Herfølge. Page 109.

Figs. 4-5. Onychocella elongata Levinsen. Herfølge. Page 112. Fig. 5. Back of colony.

Fig. 6. Onychocella nysti (v. HaG.). Møn (Page 115).

Figs. 7-8. Onychocella columella n.sp. Faxe. Page 113.

Phot. Chr. WestergaArd 
Plate 10
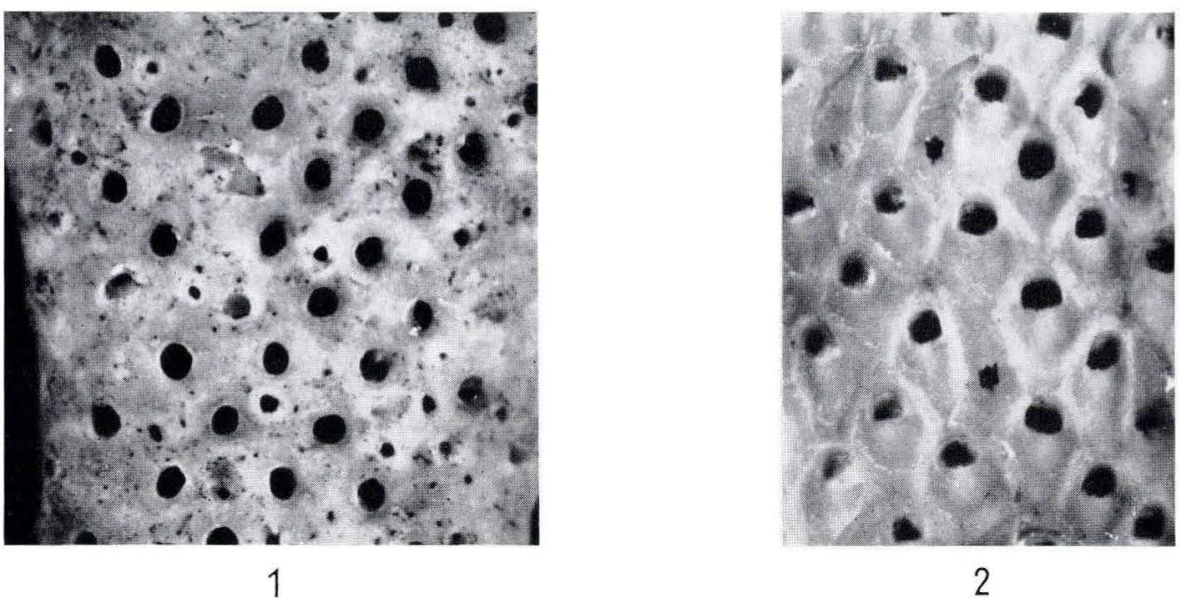

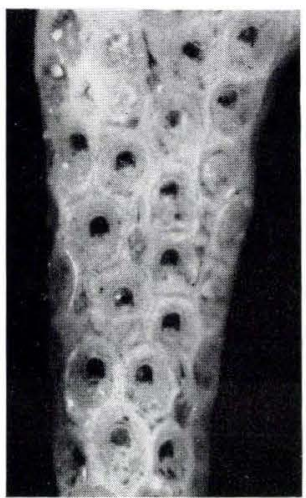

6

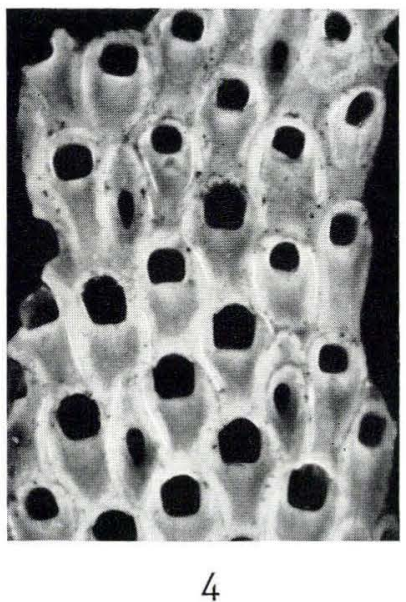

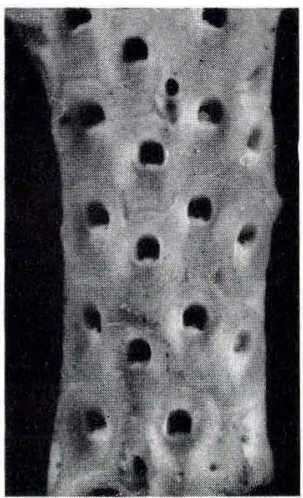

7

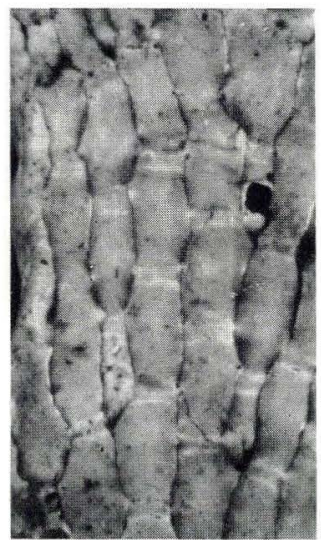

5

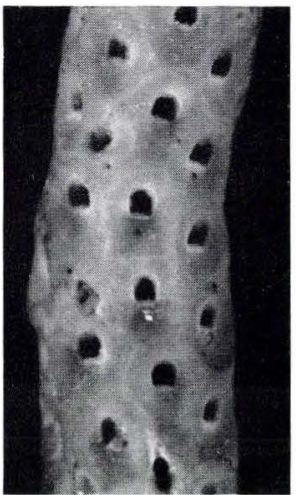

8

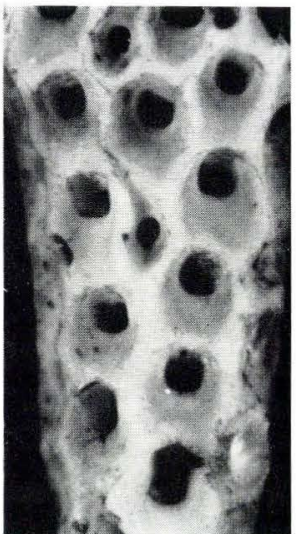

3

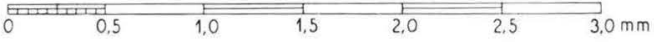




\section{Plate 11}

All magnifications $\times 20$.

Figs. 1-3. Onychocella ravni n.sp. Herfølge. Page 111. Fig. 3. Back of colony.

Fig. 4. Floridina gothica (D'OrBIGNY). Kagstrup. Page 115.

Fig. 5. Floridina tubulosa Voigt. Kagstrup. Page 117.

Figs. 6-7. Floridina pulchella (KADE). Herfølge. Page 124.

Fig. 8. Floridina scutata (Levinsen). Faxe. Page 121.

Phot. Chr. WestergaArd 
Plate 11

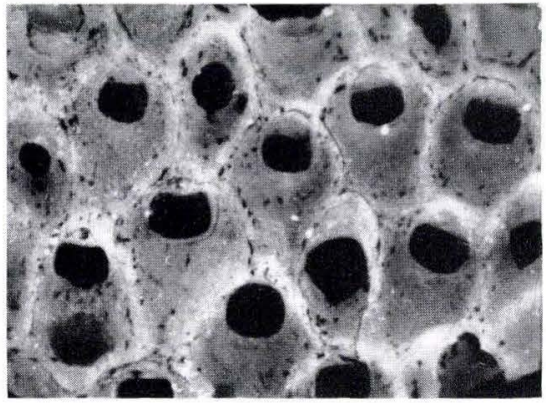

1

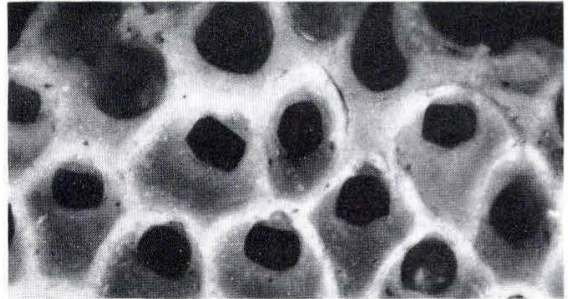

2

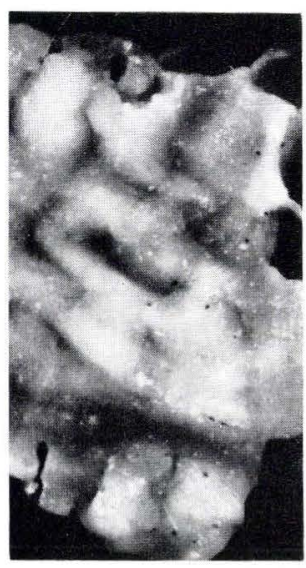

3

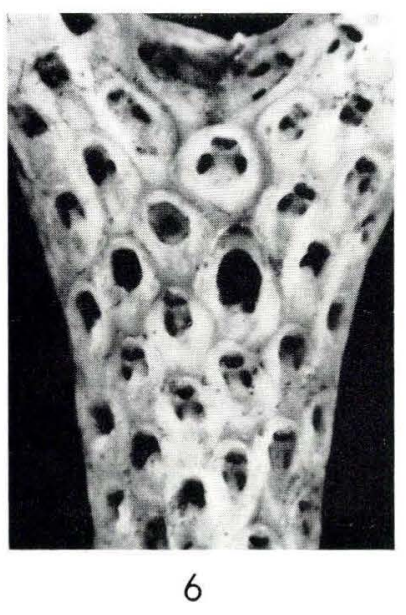

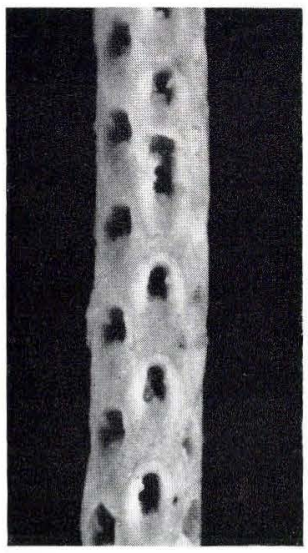

4

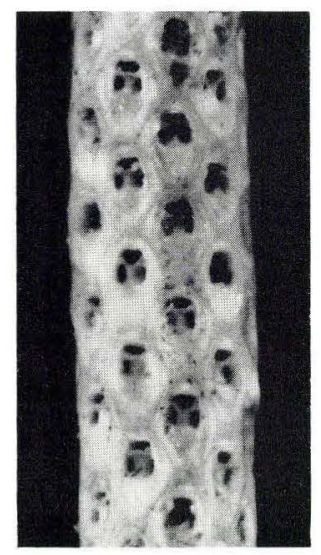

7

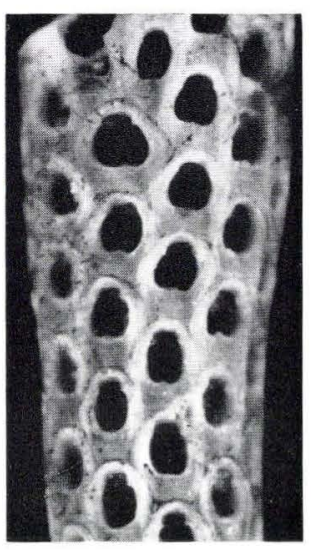

5

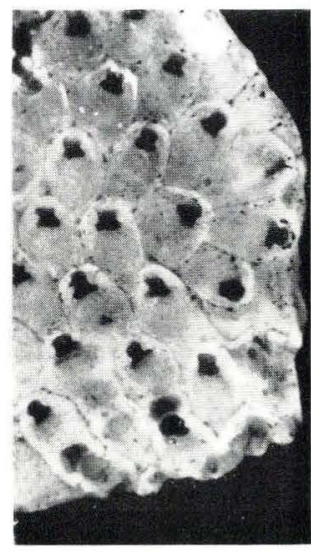

8

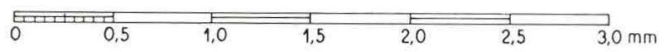




\section{Plate 12}

All magnifications $\times 20$

Fig. 1. Floridina voigti BASSLER. Herfølge. Page 118.

Figs. 2-4. Floridina levinseni n.sp. Herfølge. Page 126.

Fig. 3. Fragment with ovicells.

Fig. 4. Colony with avicularia.

Figs. 5-6. Floridina brydonei VoIGt. Herfølge. Page 119.

Fig. 6. Back of zoarium.

Fig. 7. Floridina impar Volgt. Faxe. Page 120.

Phot. Chr. WestergaArd 
Plate 12
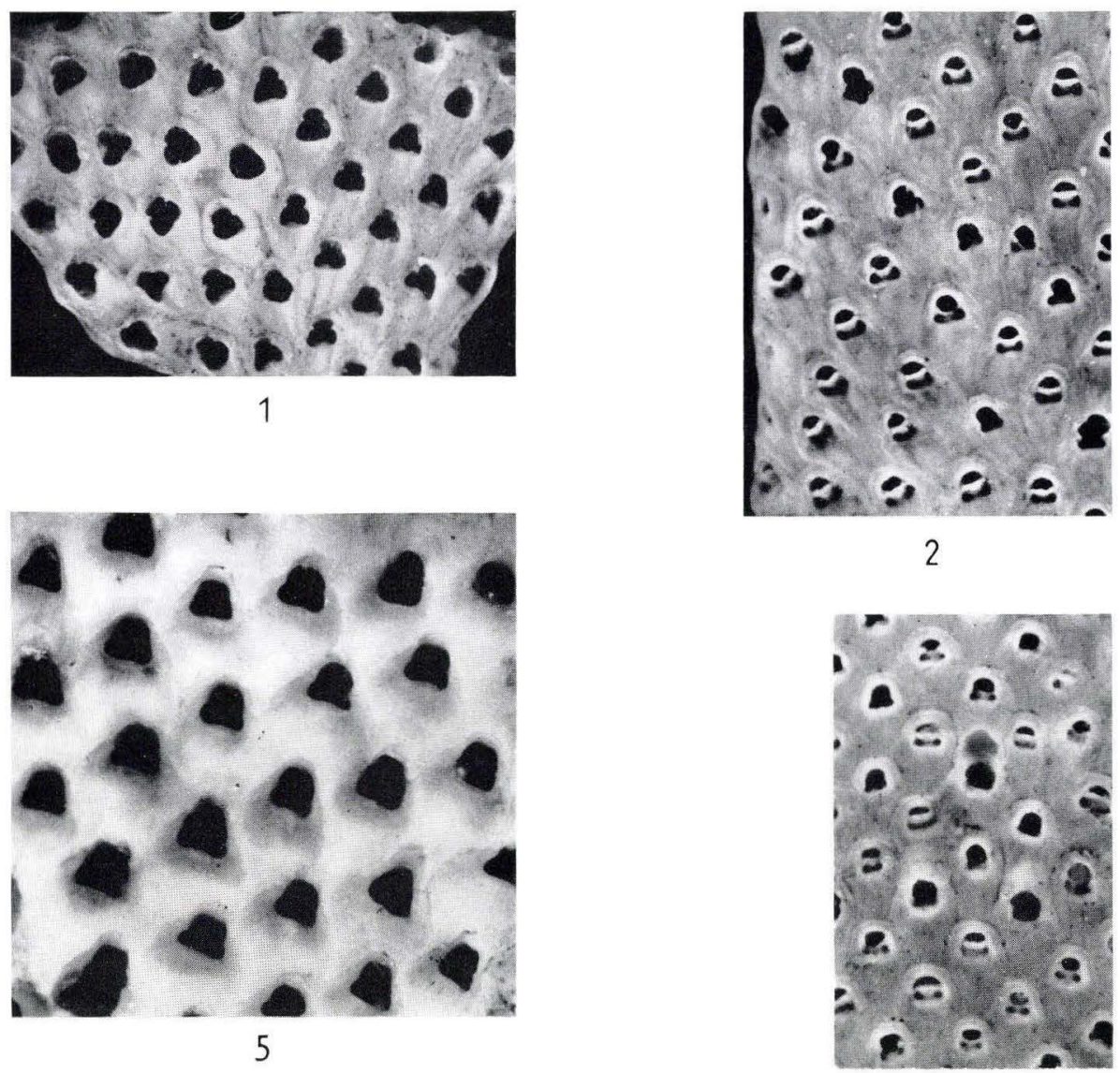

3

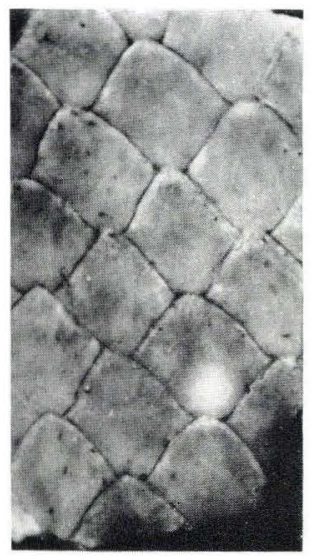

6

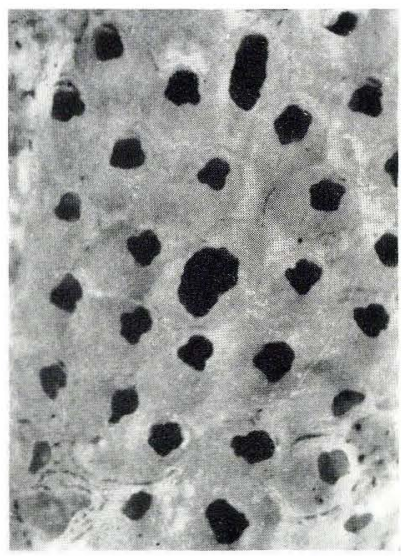

7

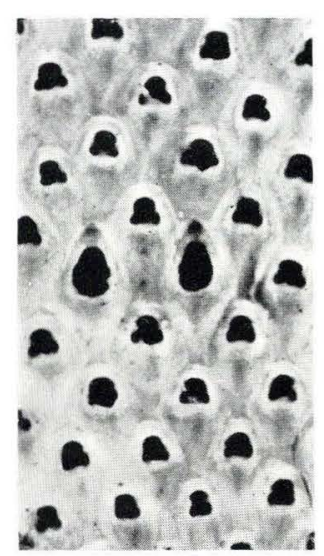

4

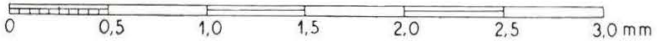




\section{Plate 13}

All magnifications $\times 20$.

Fig. 1. Floridina impar Volgt. Herfølge. Page 120.

Figs. 2-4. Floridina trifolioides n.sp. Herfølge. Page 123.

Fig. 3. Fertile zooecia with larger opesia than the sterile ones.

Fig. 4. Back of colony.

Fig. 5. Floridina excavata Voigt. Herfølge. Page 129.

Fig. 6. Micropora angulata LevinSEN. Herfølge. Page 130.

Figs. 7-8. Micropora hennigiana n.sp. Herfølge. Page 132.

Fig. 7. Zoarium with ovicells.

Phot. Chr. WestergaArd 
Plate 13
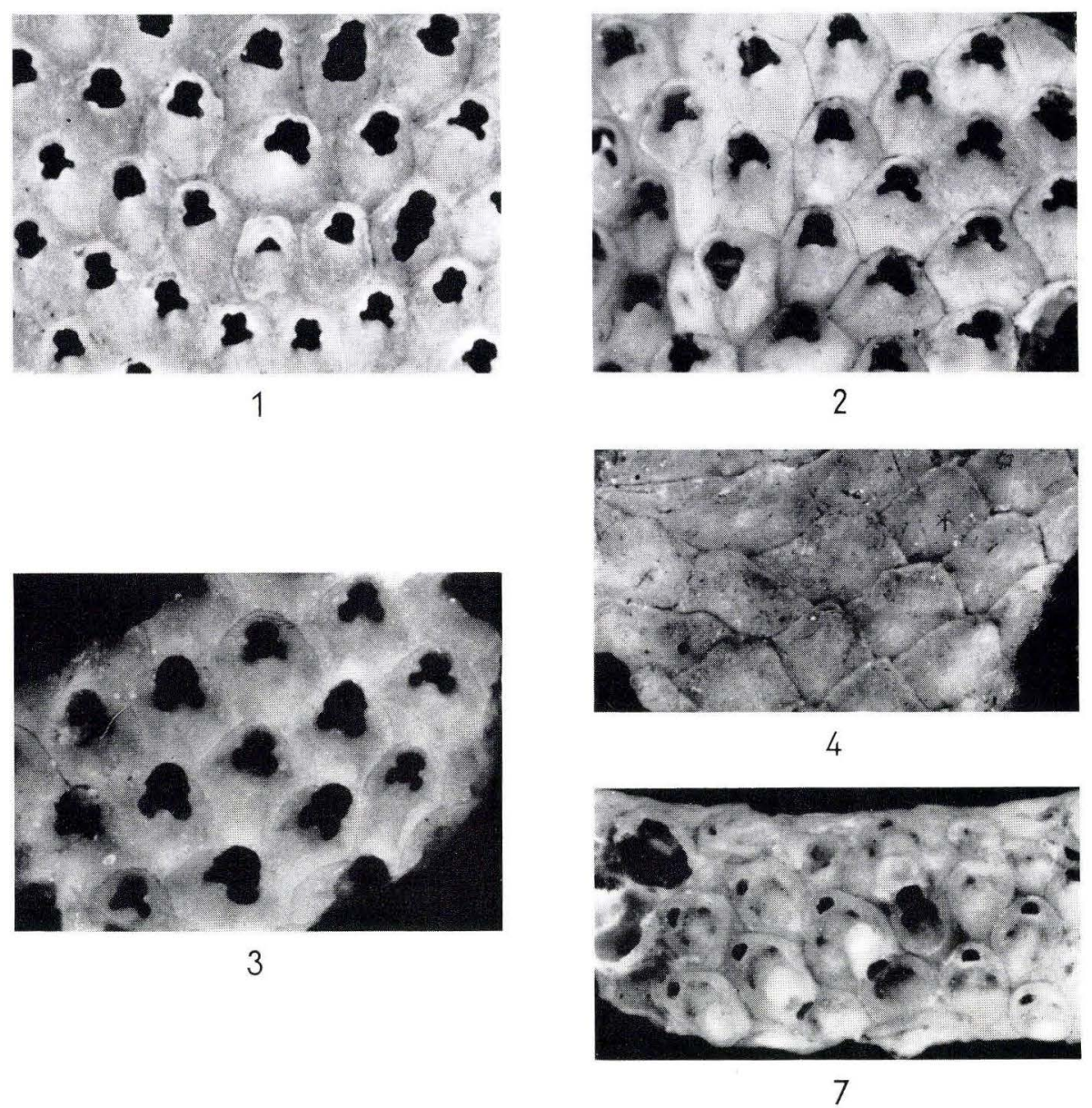

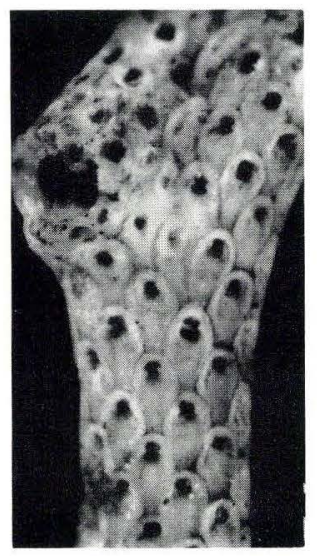

5

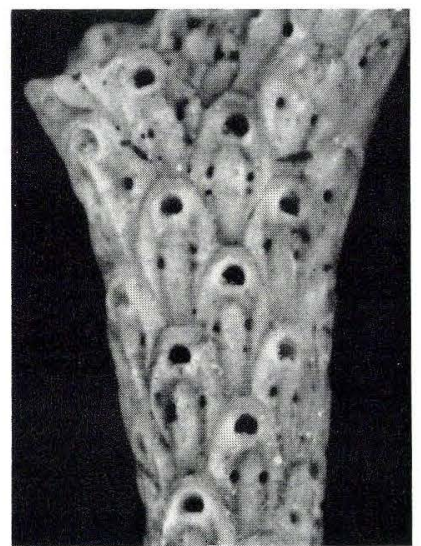

6

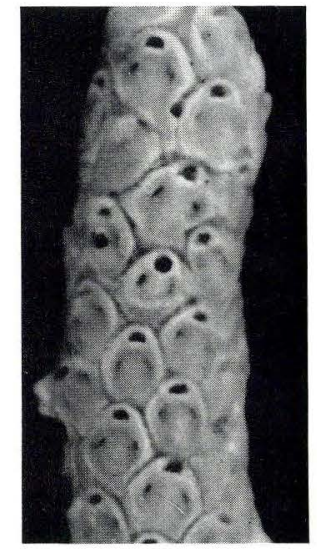

8

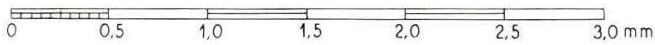




\section{Plate 14}

All magnifications $\times 20$

Fig. 1. Micropora stevensis Levinsen. Kagstrup. Page 133.

Figs. 2-3. Semiescharinella complanata D’Orb. Herfølge. Page 134. Fig. 3. Back of colony.

Figs. 4-5. Aechmella pindborgi n.sp. Herfølge. Page 138.

Fig. 6. Aechmella clio (D’OrB.). Møn. (Page 140).

Fig. 7. Aechmella latistoma n.sp. Herfølge. Page 141.

Fig. 8. Aechmella microstoma (Marsson). Faxe. Page 143.

Phot. Chr. WestergaArd 
Plate 14

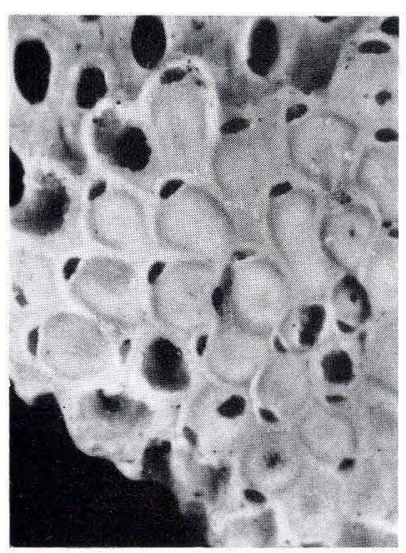

1

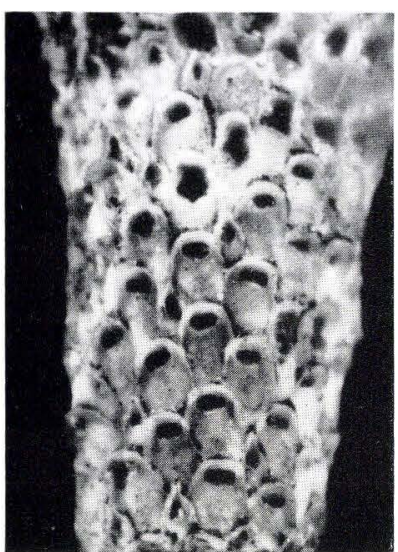

4

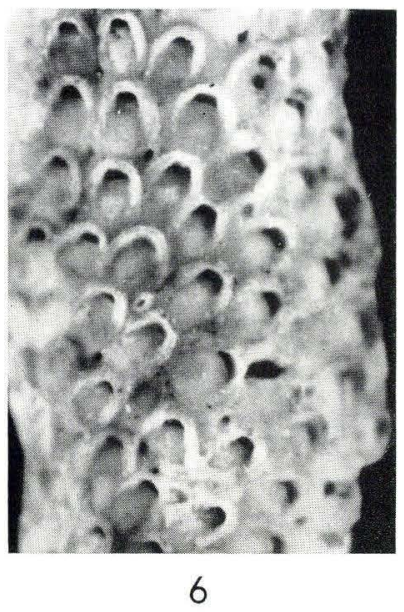

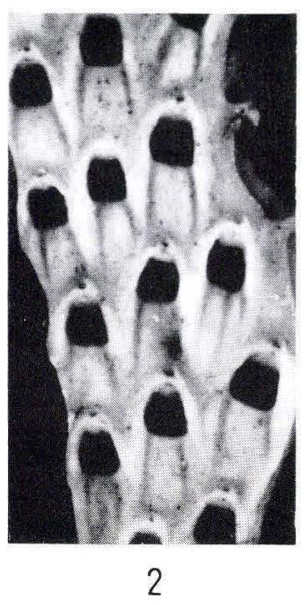

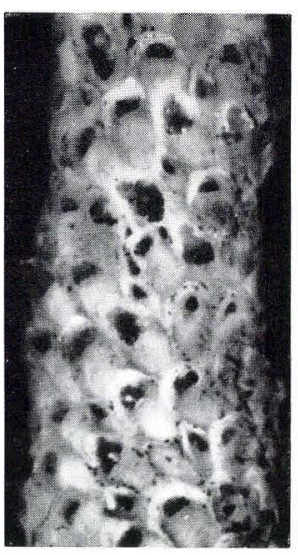

5
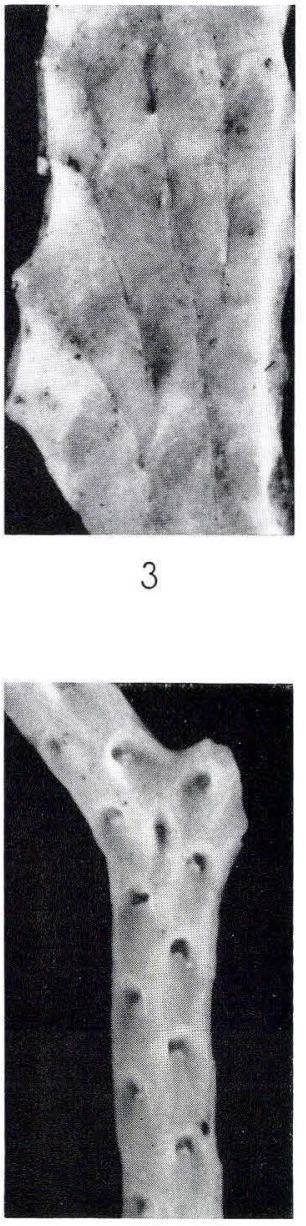

8
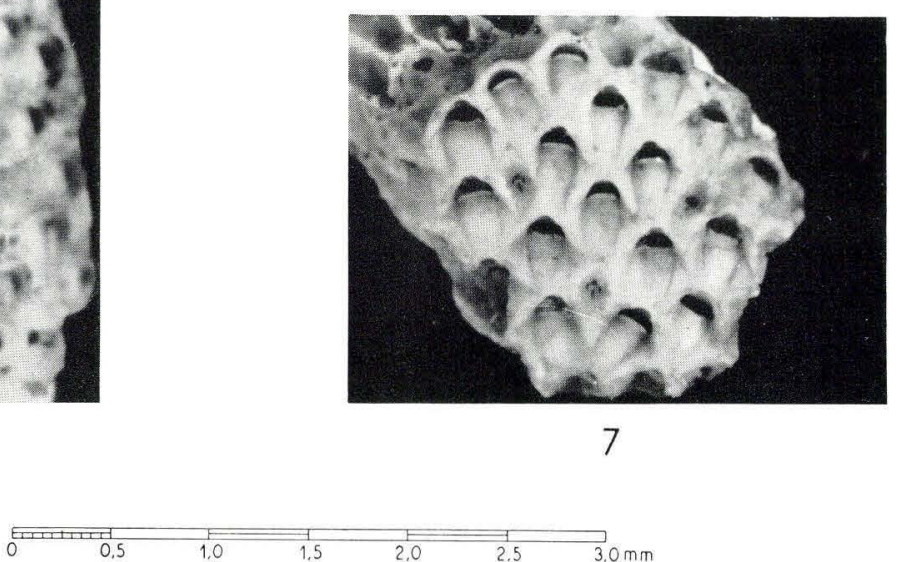


\section{Plate 15}

All magnifications $\times 20$.

Fig. 1. Aechmella latistoma n.sp. Herfølge. Page 141.

Figs. 2-3. Micropora erratica (VoIGT). Kagstrup. Page 131.

Fig. 4. Hoplitaechmella smitti (Hennig). Herfølge. Page 145.

Fig. 5. Hoplitaechmella vespertilioides n.sp. Saltholm. Page 147. (Without number in the plate).

Fig. 6. Hoplitaechmella vespertilio (v. HaG.). Hemmoor. (Page 148).

Fig. 7. Gargantua parvicella Voigt. Faxe. Page 149.

Fig. 8. Brydonella vulcani (BRYdone). Herfølge. Page 150.

Phot. Chr. Westerganid 


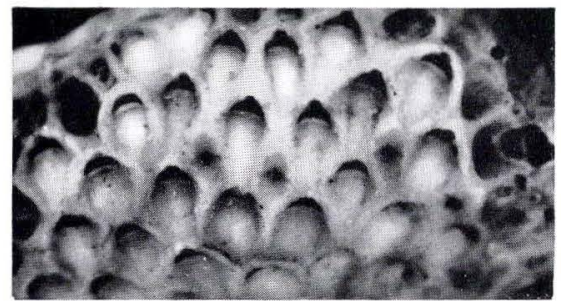

1

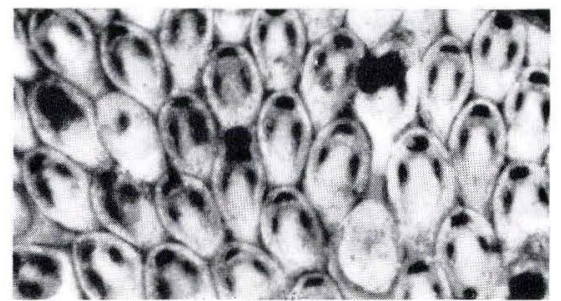

2

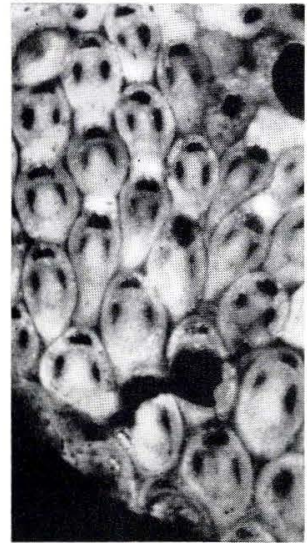

3

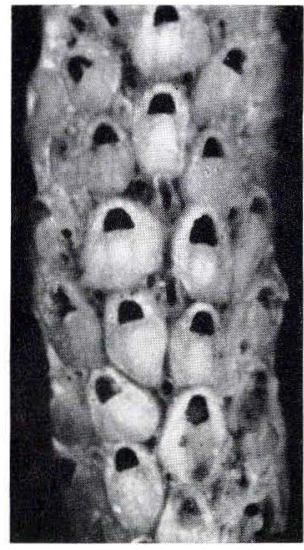

4

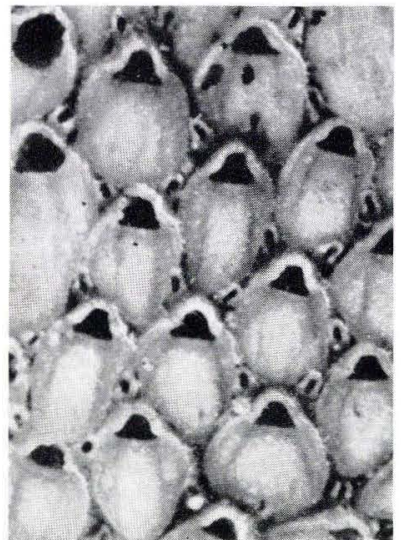

6

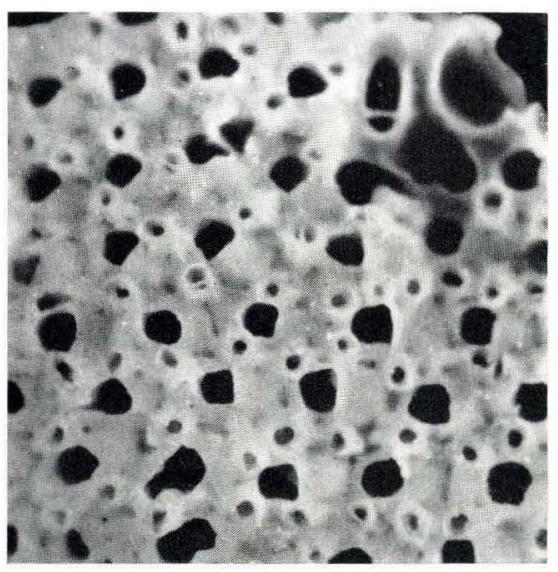

8
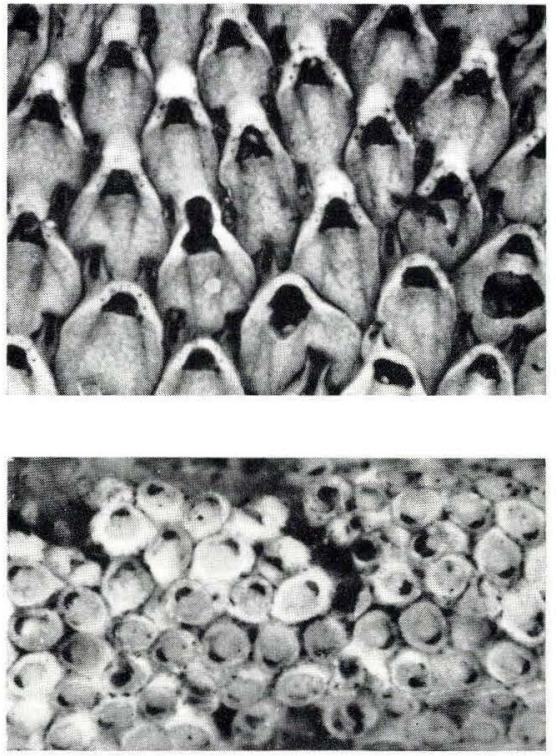

7

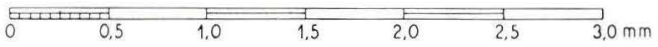




\section{Plate 16}

All magnifications $\times 20$.

Figs. 1-2. Lunulites faxensis (LevinSen). Herfølge. Page 152.

Fig. 2. The concave side of the zoarium.

Figs. 3-5. Lunulites saltholmensis n.sp. Saltholm. Page 153.

Fig. 5. Segment of the inside of the colony.

Phot. Chr. WestergaArd 


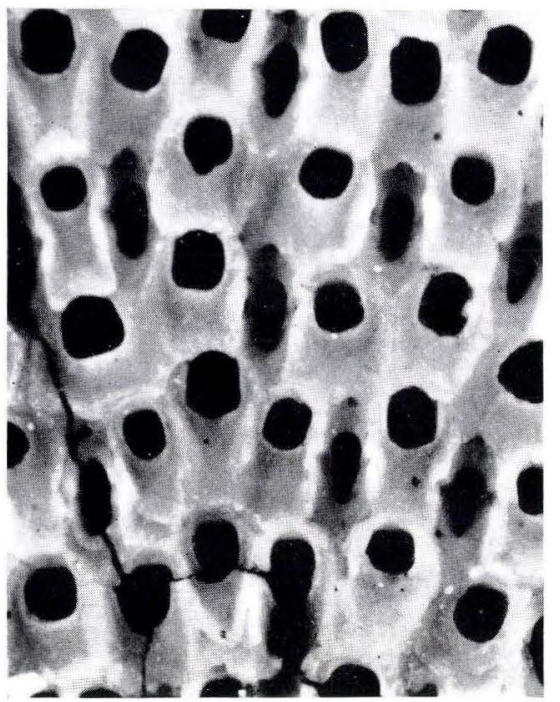

1

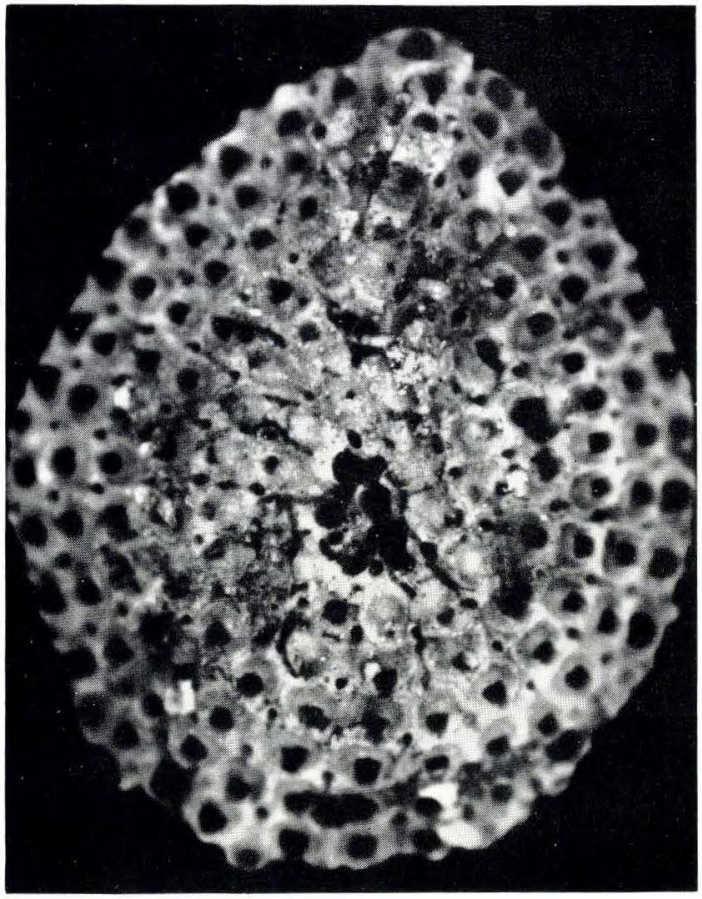

3
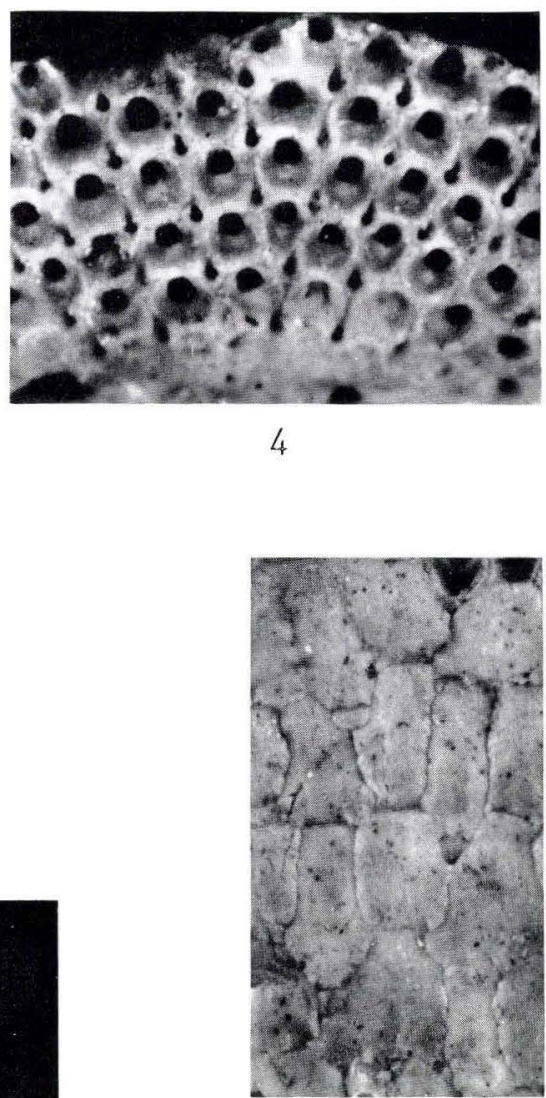

2

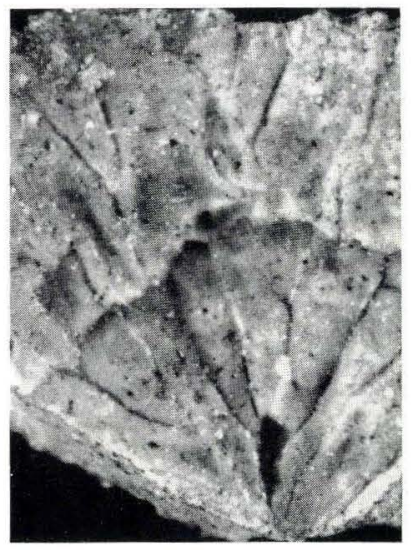

5

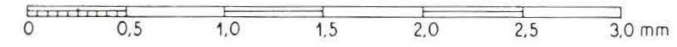




\section{Plate 17}

All magnifications $\times 20$.

Figs. 1-2. Puncturiella sculpta (D’OrB.). Page 155.

Fig. 1. "Flabelliform" colony. Herfølge.

Fig. 2. Vinculariform colony. Faxe.

Fig. 3. Puncturiella tenera (VoIGT). Faxe. Page 156.

Figs. 4-7. Coscinopleura angusta angusta Berthelsen. Herfølge. Page 158.

Fig. 5. Marginal zone of colony with vibracula alternating with kenozooecia.

Fig. 6. Basal part of stem from the calcarenite at Herfølge. Calcified zooecia alternating with groups of kenozooecia.

Fig. 7. Colony with ovicells.

Phot. Chr. WestergaArd 


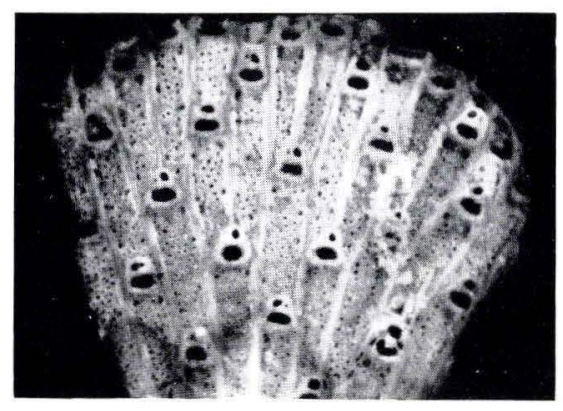

1
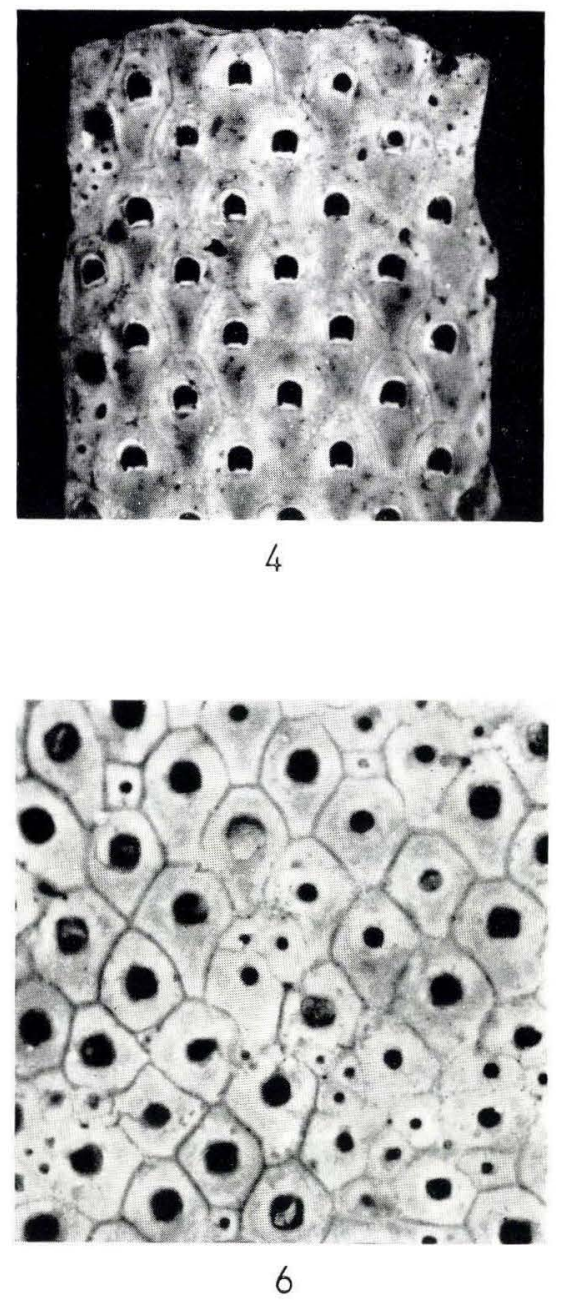

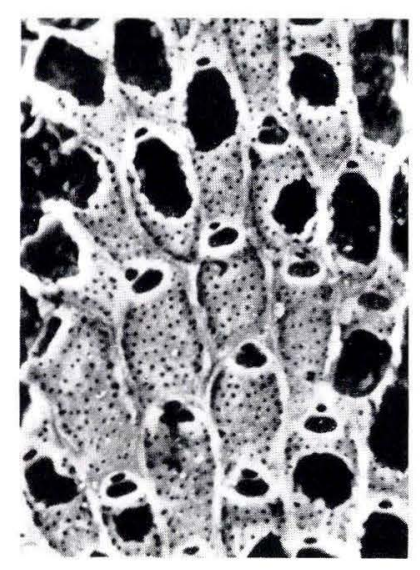

3

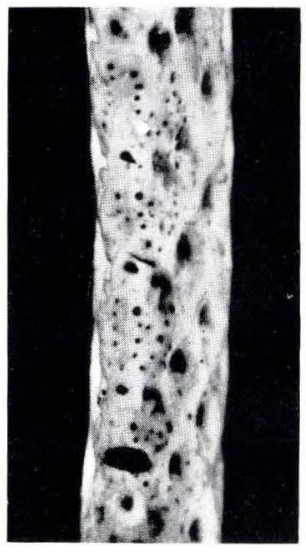

5

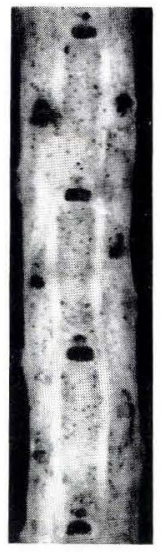

2

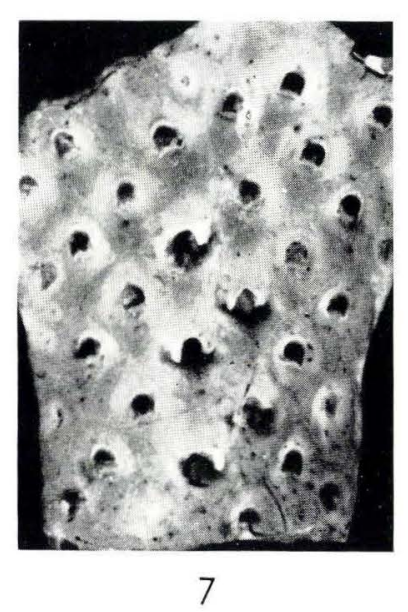

III*

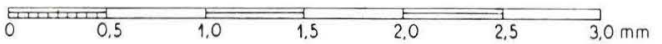




\section{Plate 18}

All magnifications $\times 20$.

Fig. 1. Coscinopleura digitata Morton. Vincentown. (Page 160).

Fig. 2. Fissuricella fissa Voigt. Herfølge. Page 160.

Fig. 3. Membraniporella squamulosa (v. Hag.) Stevns. Page 162.

Fig. 4. Leptocheilopora laticostata n.sp. Faxe. Page 163.

Fig. 5. Andriopora daniensis Voigt. Herfølge. Page 164.

Fig. 6. Pliophloea subcornuta n.sp. Faxe. Page 165.

Fig. 7. Pliophloea vincularioides Voigt. Faxe. Page 169.

Phot. Chr. WestergaArd 
Plate 18

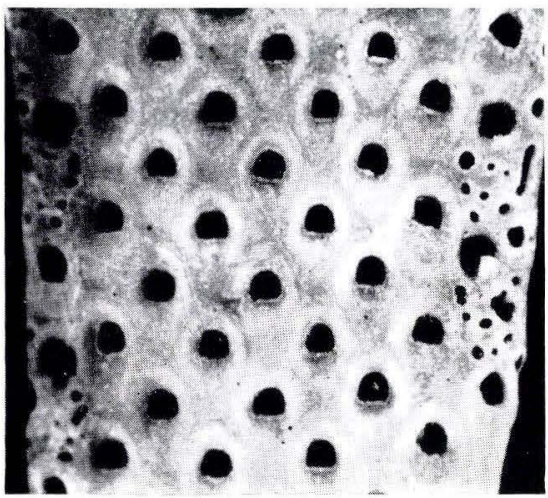

1

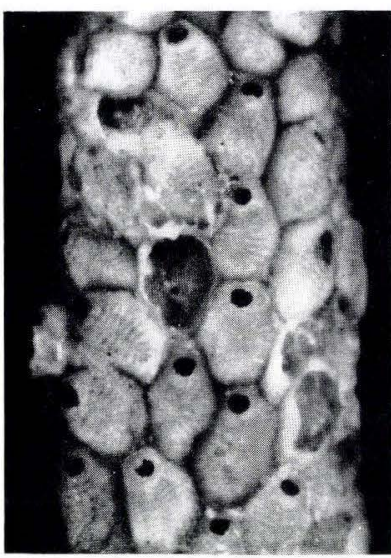

4

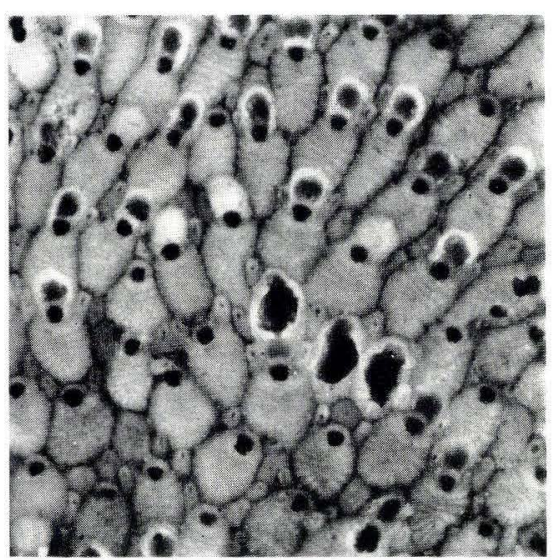

6

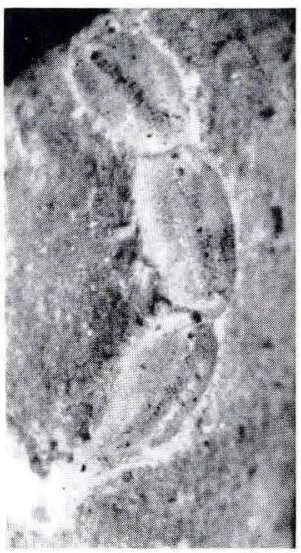

2

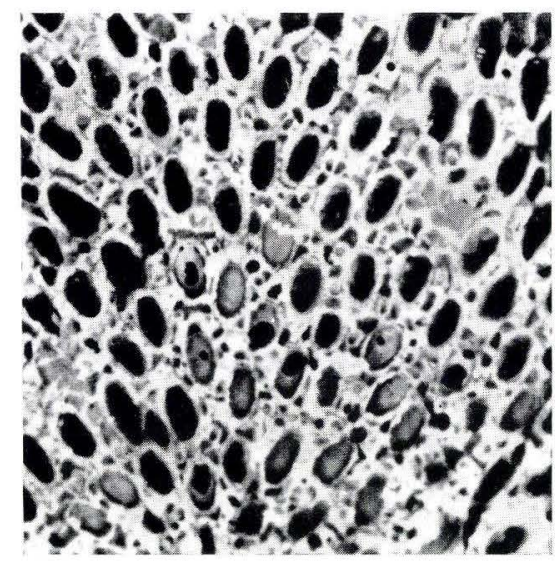

3

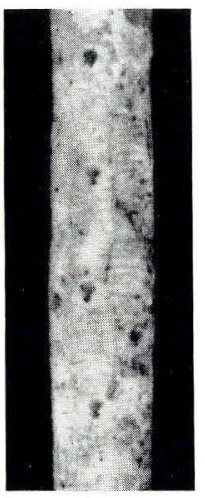

7

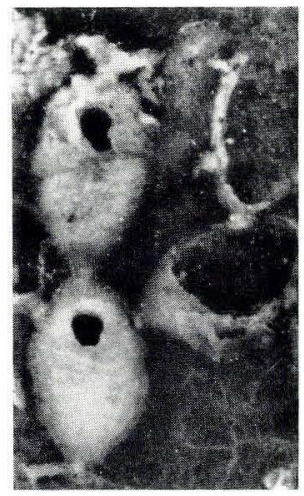

5

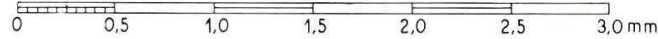




\section{Plate 19}

All magnifications $\times 20$

Fig. 1. Pliophloea cf. P. gluma LANG. Herfølge. Page 167.

Fig. 2. Pliophloea cf. P. palea LANG. Herfølge. Page 168.

Figs. 3-4. Pliophloea brünnichi n.sp. Herfølge. Page 170.

Fig. 5. Pliophloea sagena Morton. Vincentown. (Page 171).

Figs. 6-7. Monoceratopora quadrisulcata (Hennig). Faxe. Page 172.

Fig. 8. Pelmatopora daniensis VoIGT. Herfølge. Page 173.

Phot. Chr. WestergaArd 


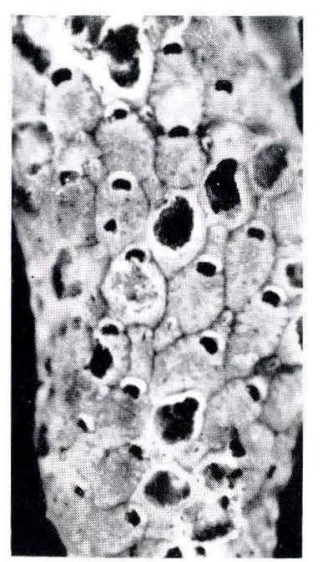

1

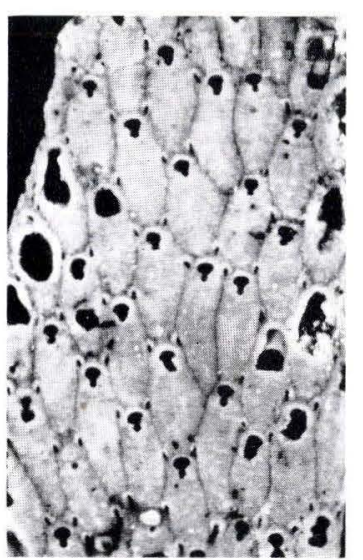

3

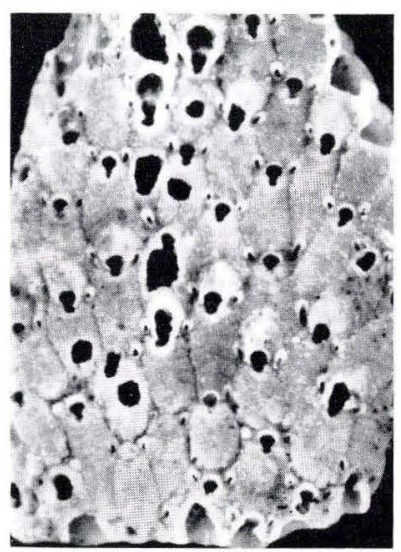

4

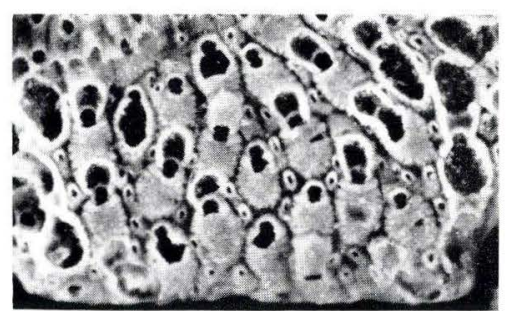

2

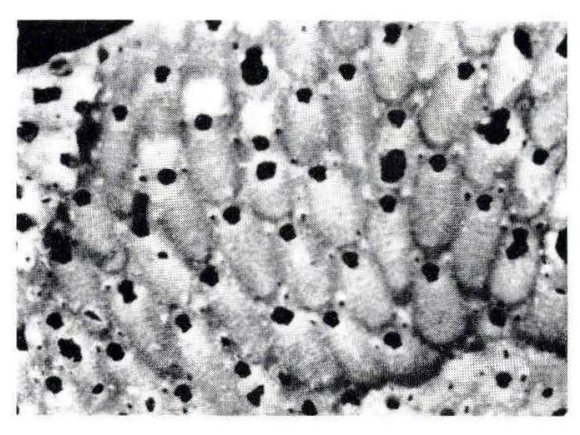

5

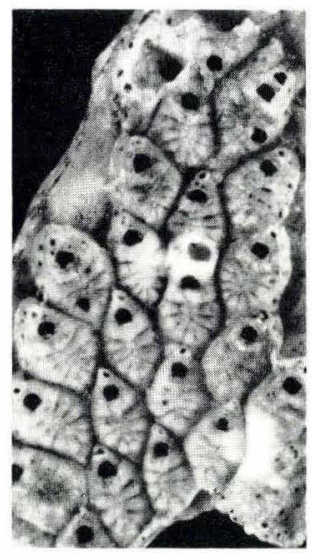

6

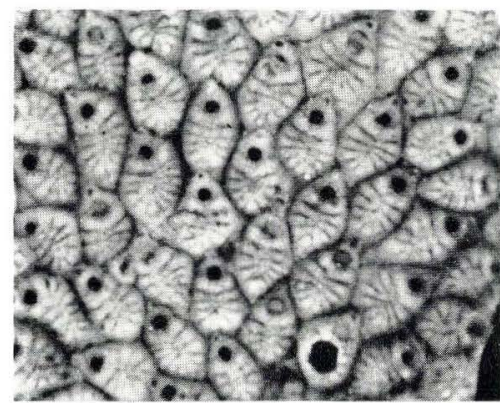

7

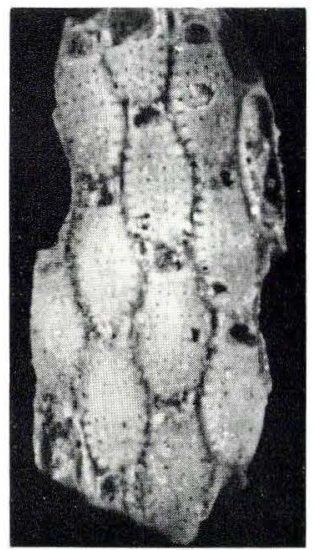

8

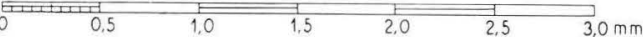




\section{Plate 20}

All magnifications $\times 20$.

Fig. 1. Pachydera densa Lang. Faxe. Page 174.

Figs. 2-4. Pachydera fissa n.sp. Page 175.

Fig. 2. Faxe.

Figs. 3-4. Daersdorf.

Fig. 5. Tricephalopora cerberus LANG. Herfølge. Page 177.

Fig. 6. Tricephalopora subtriceps n.sp. Faxe. Page 178.

Fig. 7. Tricephalopora circumvallata (LEv.) Faxe. Page 179.

Fig. 8. Haplocephalopora uniceps LANG. Herfølge. Page 182.

Phot. Chr. Westergatid 

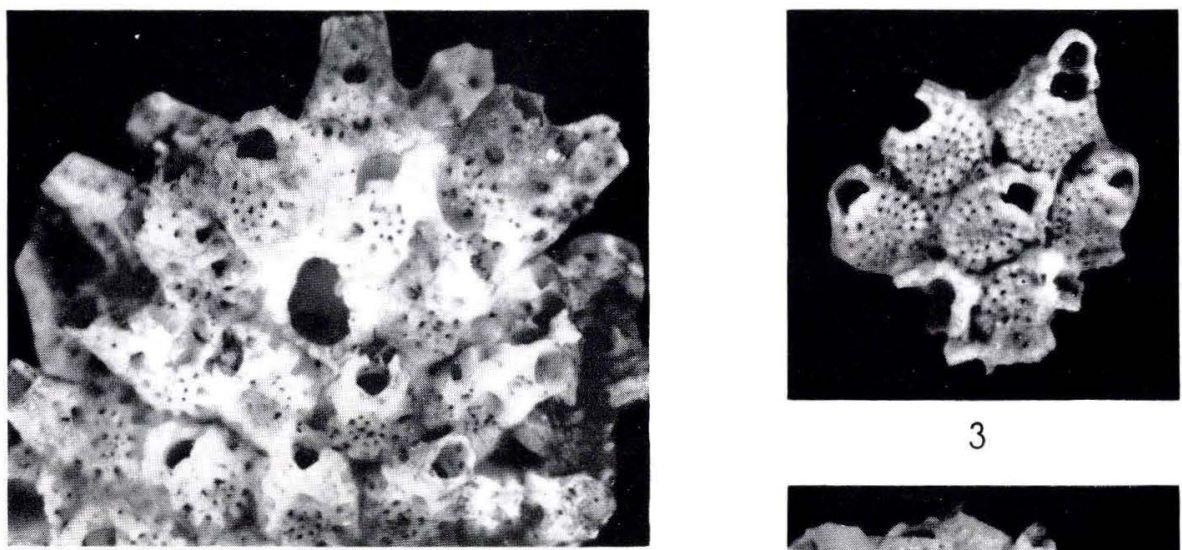

3

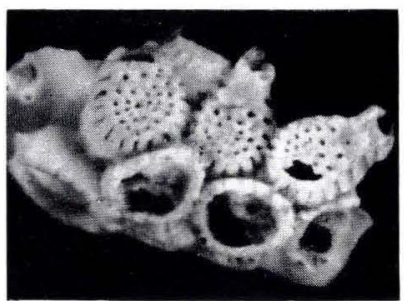

4

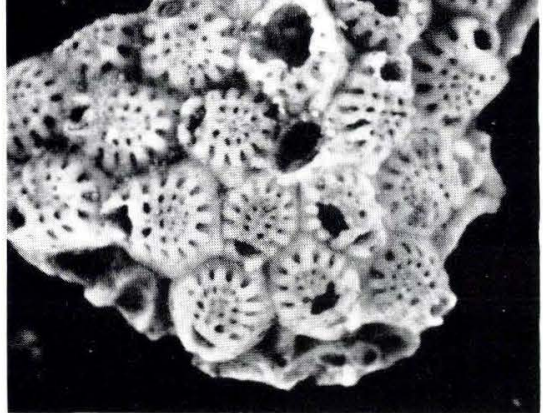

2

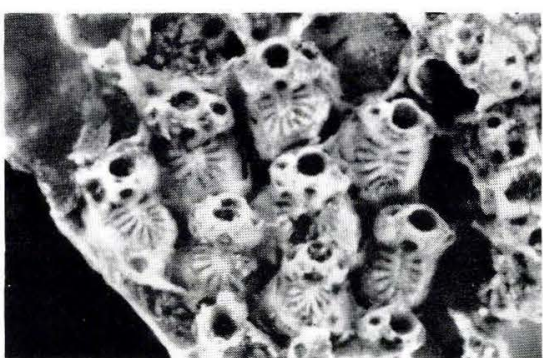

6

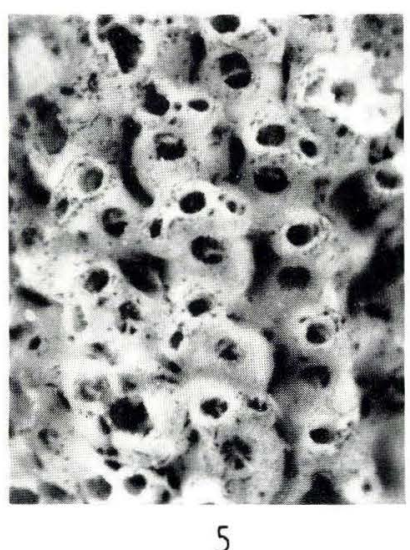

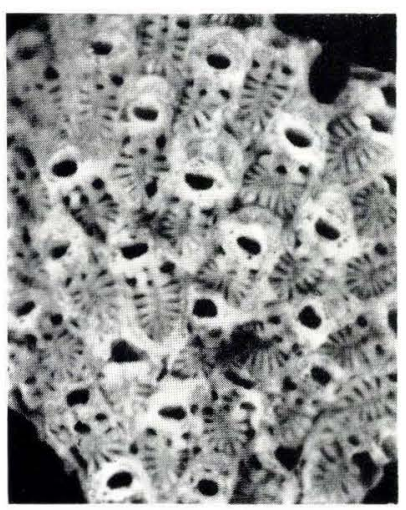

7

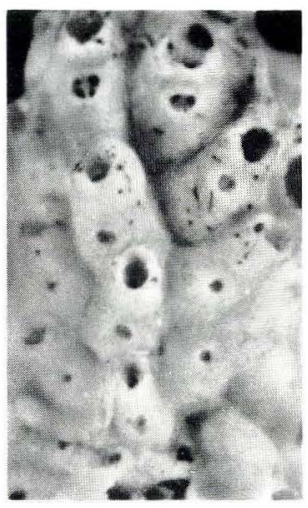

8 


\section{Plate 21}

All magnifications $\times 20$.

Fig. 1. Tricephalopora robusta n.sp. Faxe. Page 180.

Fig. 2. Phractoporella cordiformis (LEv.). Faxe. Page 183.

Figs. 3-4. Diacanthopora bispinosa LANG. Herfølge. Page 184.

Fig. 5. Diacanthopora reticulata n. sp. Herfølge. Page 185.

Fig. 6. Anornithopora polygona Volgt. Faxe. Page 187.

Fig. 7. Rhiniopora globulosa n.sp. Herfølge. Page 190.

Phot. Chr. Westergaard 


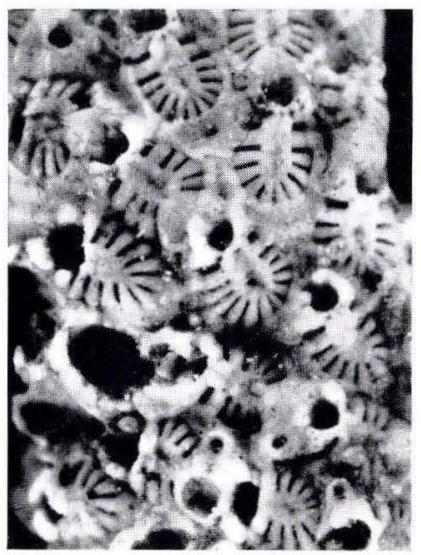

1

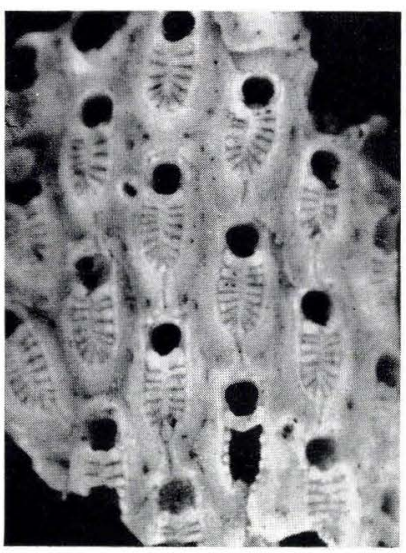

3

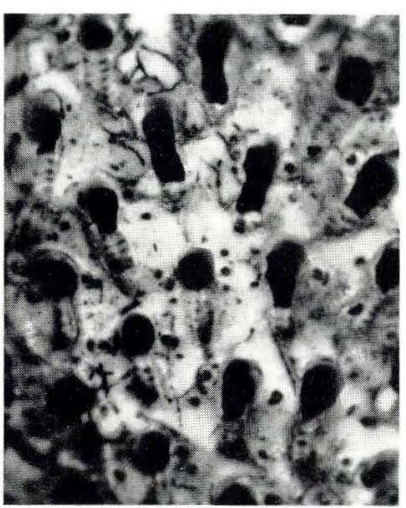

5
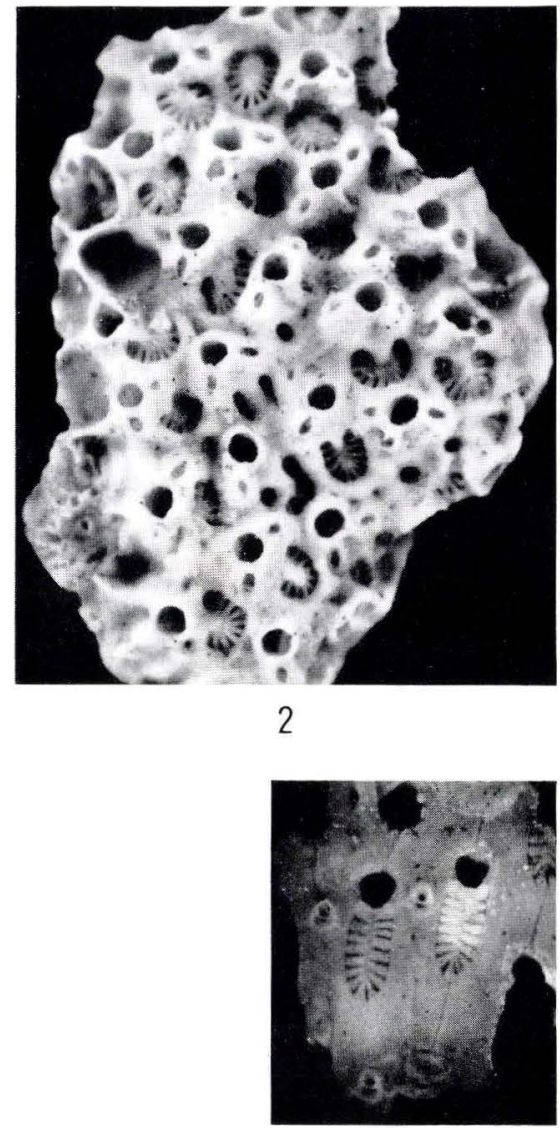

4

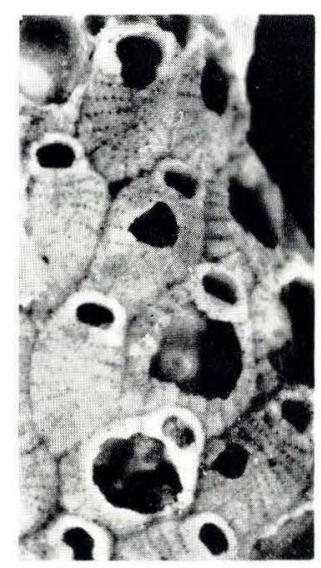

6

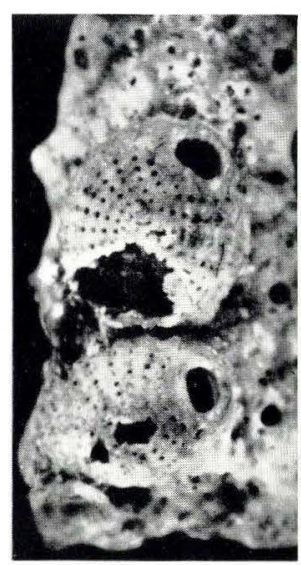

7

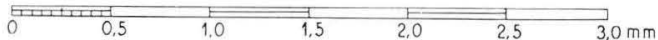




\section{Plate 22}

All magnifications $\times 20$.

Fig. 1. Anornithopora minuta Voigt. Faxe. Page 186.

Figs. 2-3. Anornithopora circulata n.sp. Faxe. Page 188.

Fig. 4. Anornithopora isolata n.sp. Saltholm. Page 189.

Fig. 5. Stichocados subbrachiata n.sp. Faxe. Page 192.

Figs. 6-7. Porina cylindrica Voigt. Herfølge. Page 193.

Phot. Chr. WestergaArd 
Plate 22

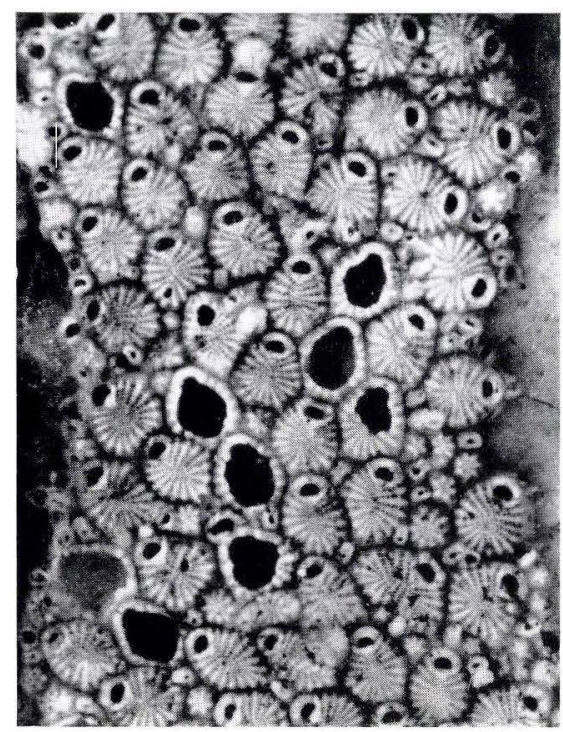

1

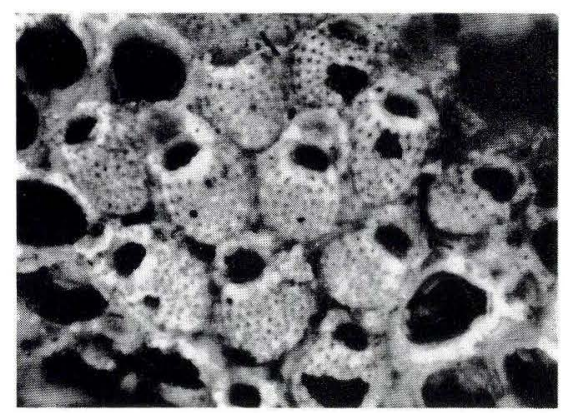

5

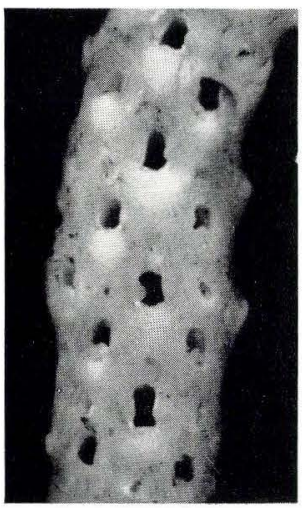

6

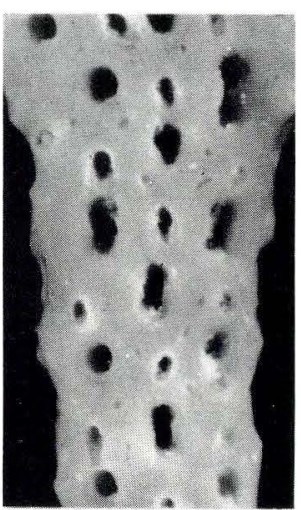

7

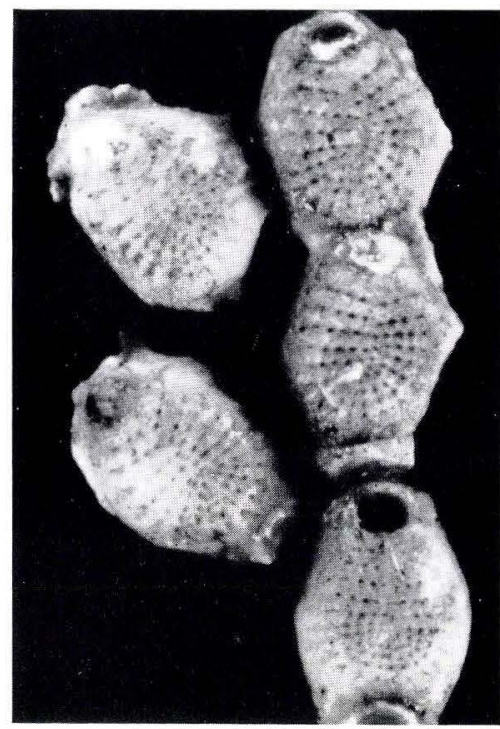

4

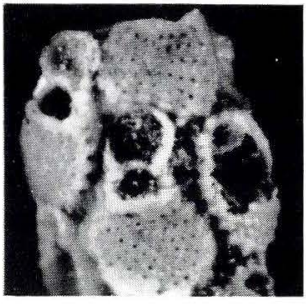

3

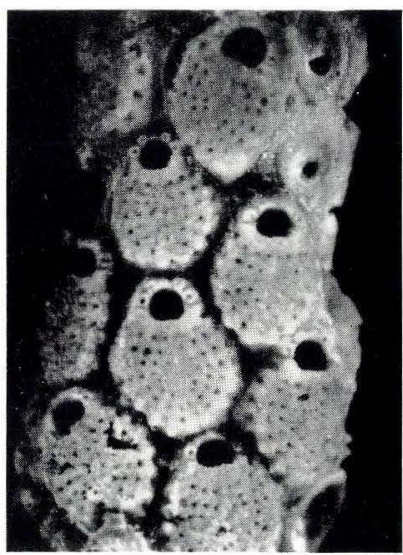

2

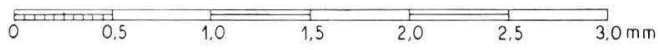




\section{Plate 23}

All magnifications $\times 20$.

Figs. 1-4. Porina salebrosa Marsson. Page 195.

Fig. 1. Fragment with large triangular avicularia. Faxe.

Fig. 2. Colony with large triangular as well as small verticillate avicularia. Faxe.

Fig. 3. Møn.

Fig. 4. Fragment with dome-shaped apertural area and verticillate avicularia $=P$. salebrosa faxensis LeVINSEN. Herfølge.

Figs. 5-7. Beisselina nobilis (Levinsen). Herfølge. Page 197.

Fig. 5. Colony with elliptical apertures and small distal avicularia.

Fig. 6. Intermediary type.

Fig. 7. Colony with circular or elliptical apertures and large distal avicularia.

Phot. Chr. Westergaard 
Plate 23

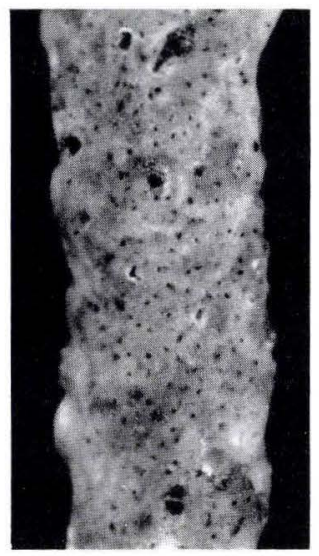

1

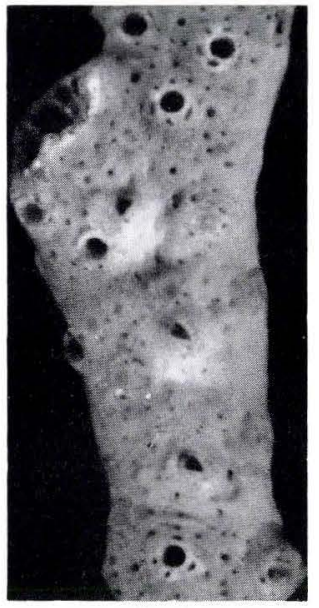

2

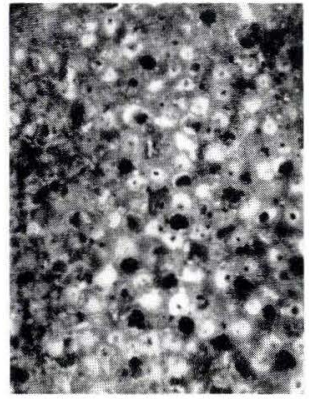

3

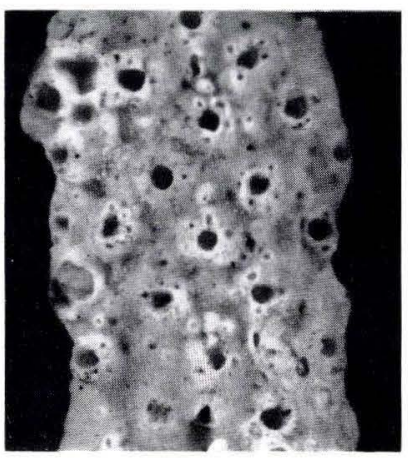

4

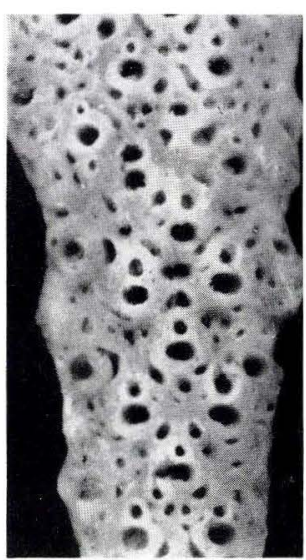

5

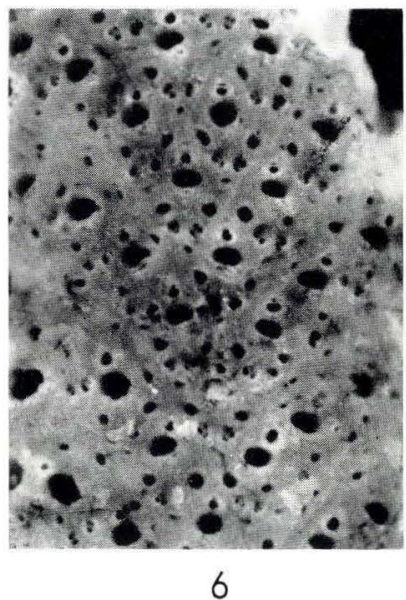

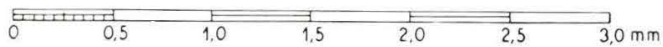




\section{Plate 24}

All magnifications $\times 20$.

Figs. 1-2. Beisselinopsis tubulifera n.sp. Faxe. Page 200.

Figs. 3-5. Beisselina celleporoides (VoIGt). Herfølge. Page 199.

Fig. 3. Colony with "primary" zooecia.

Fig. 4. Colony with "secondary" zooecia.

Fig. 5. Marginal avicularia.

Fig. 6. Beisselinopsis oblita (KADE). Herfølge. Page 201.

Fig. 7. Columnotheca cribrosa Marsson. Herfølge. Page 207.

Phot. Chr. Westergatrd 


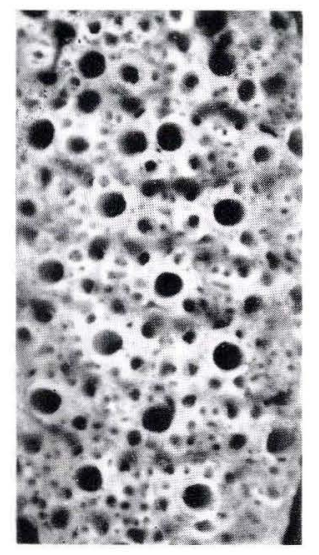

1

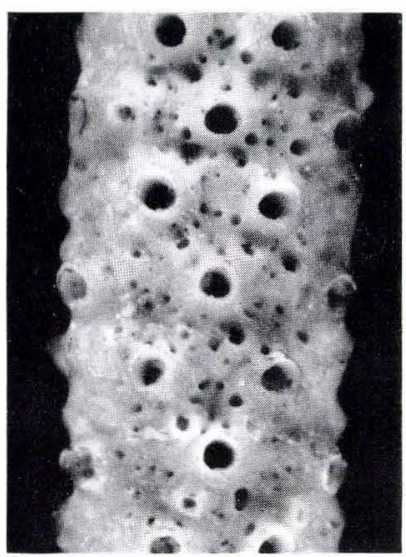

2

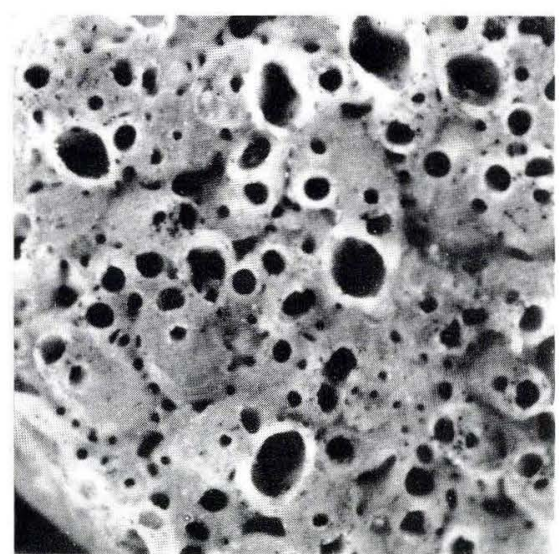

4

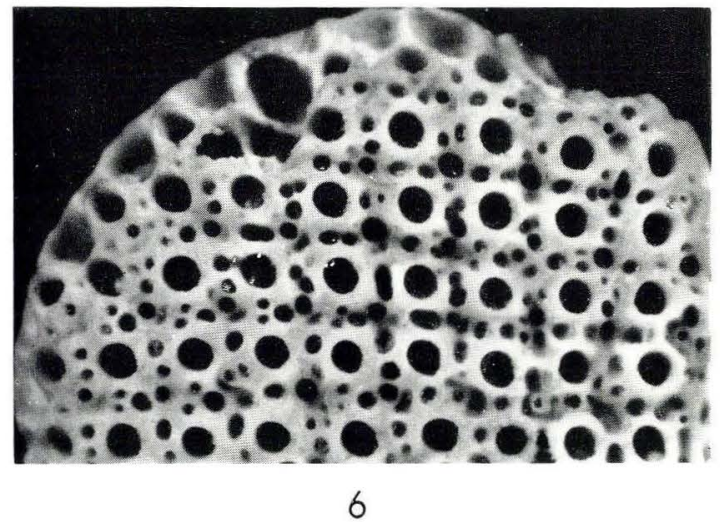

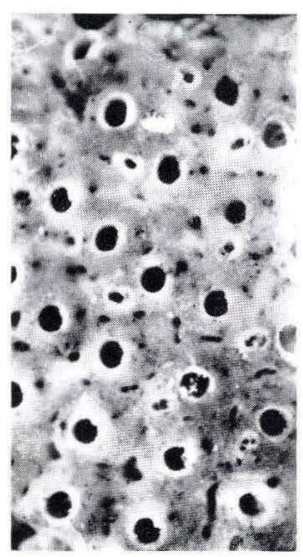

3

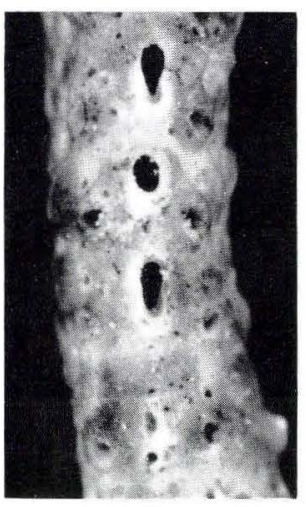

5

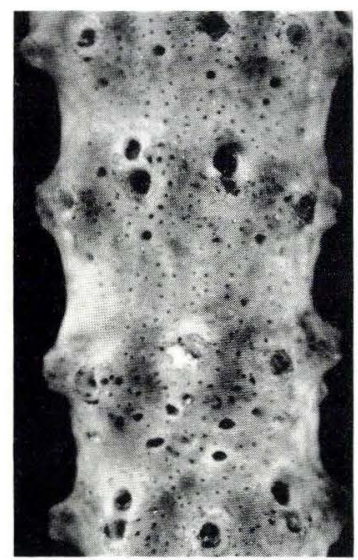

7

IV 


\section{Plate 25}

All magnifications $\times 20$.

Figs. 1-3. Pachythecella anhaltina (Vorgt). Page 203.

Fig. 1. Vinculariform colony. Stevns.

Fig. 2. Bilamellar (eschariform) colony. Faxe.

Fig. 3. "Flabelliform” zoarium. Herfølge.

Fig. 4. Pachythecella filiformis (D’ORB.) Faxe. Page 204.

Figs. 5-6. Pachythecella lundgreni (Perg. and Meun.). Page 206.

Fig. 5. Stevns.

Fig. 6. Faxe.

Figs. 7-8. Ochetosellina areolata n.sp. Faxe. Page 211.

Phot. Chr. WestergaArd 
Plate 25
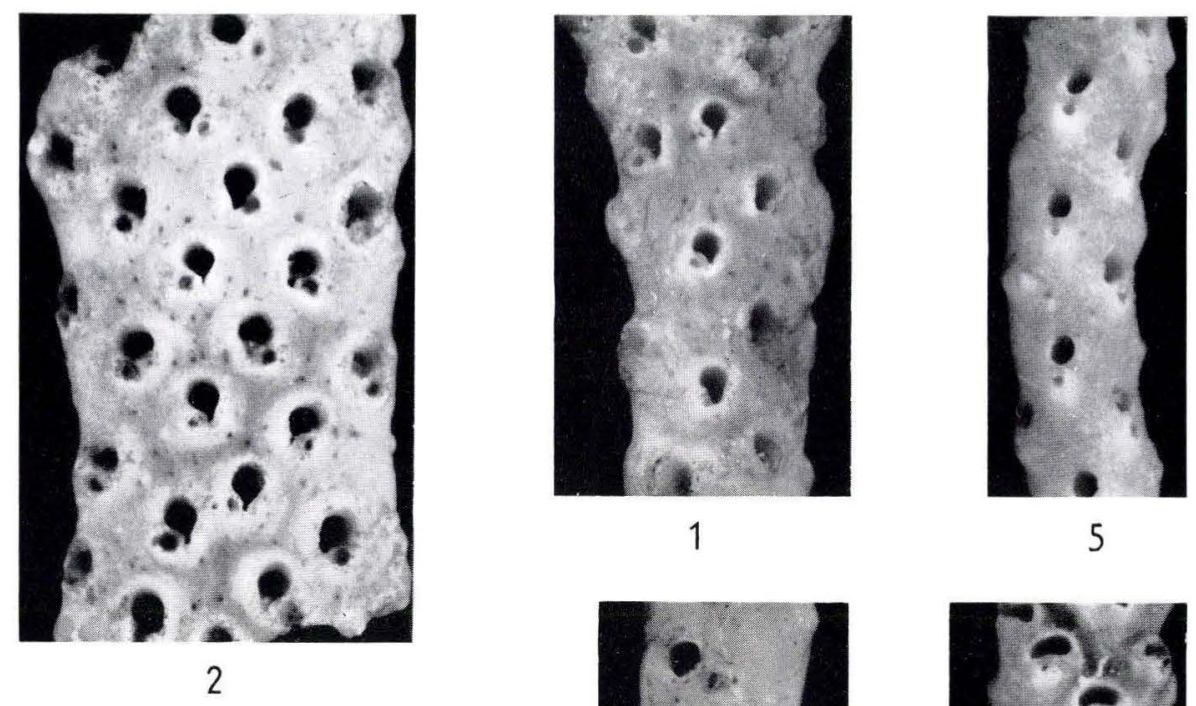

1

5
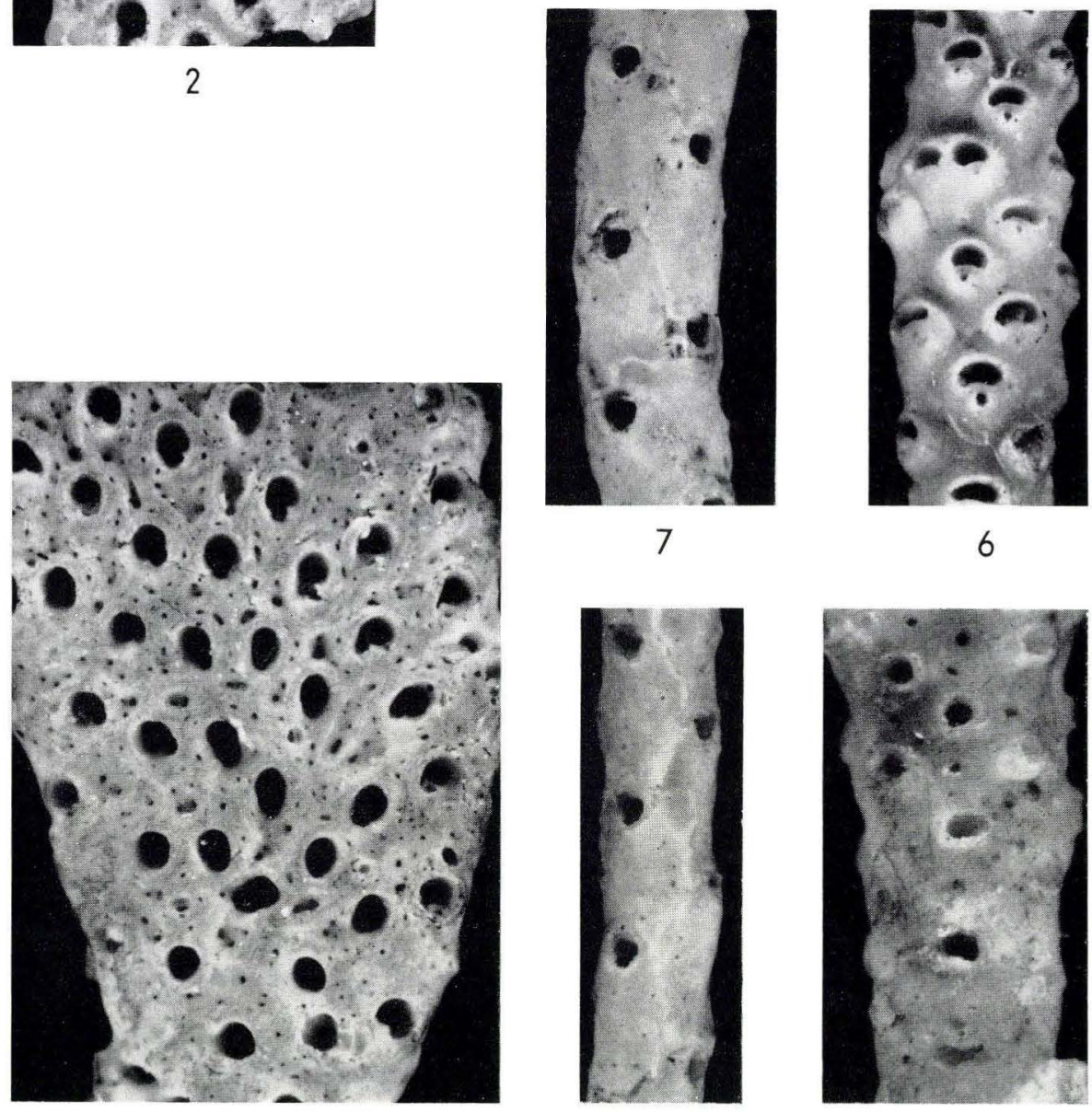

8

4

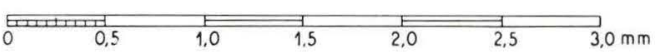




\section{Plate 26}

All magnifications $\times 20$.

Fig. 1. Taeniporina articulata Voigt. Faxe. Page 208.

Figs. 2-4. Diplotresis europaea n.sp. Herfølge. Page 209.

Fig. 5. Systenostoma verticillata LEv. Herfølge. Page 212.

Figs. 6-7. Systenostoma pontifera n.sp. Herfølge. Page 213.

Fig. 8. Mucronella hians HenNig. Faxe. Page 215.

Phot. Chr. Westergaard 
Plate 26

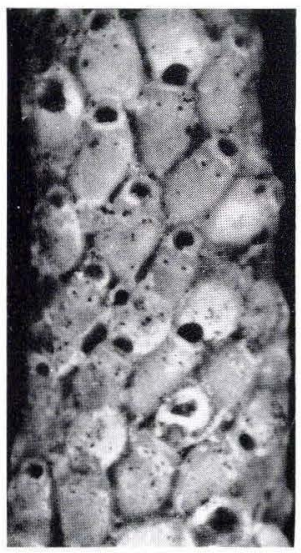

2

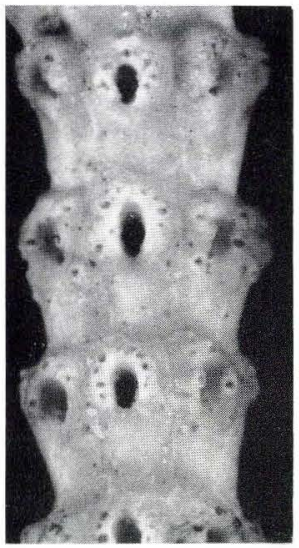

5

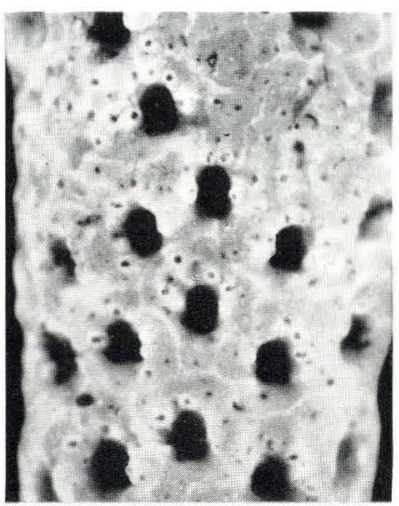

7
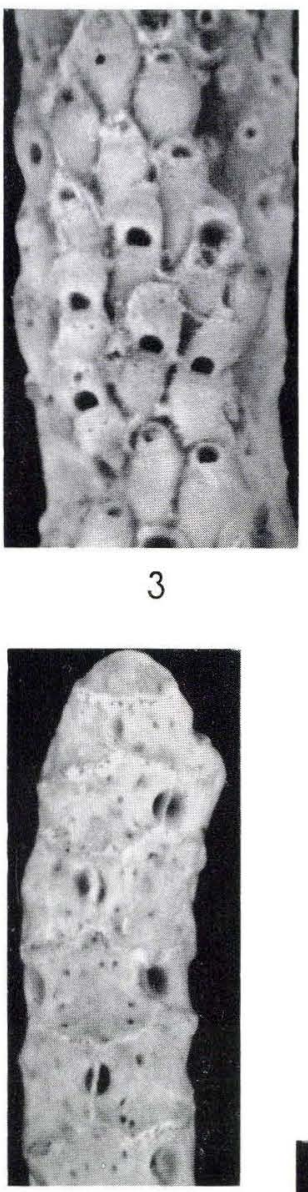

1

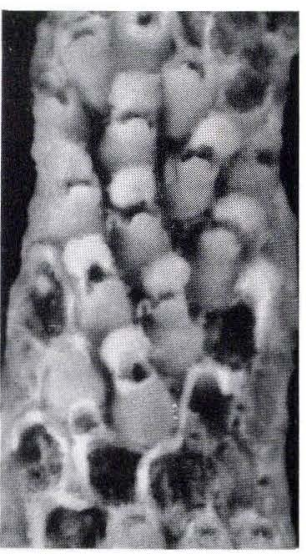

8

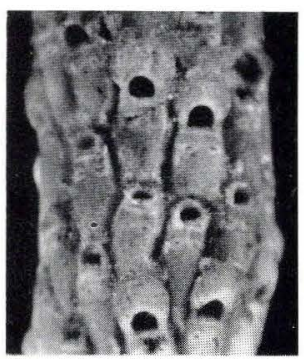

4

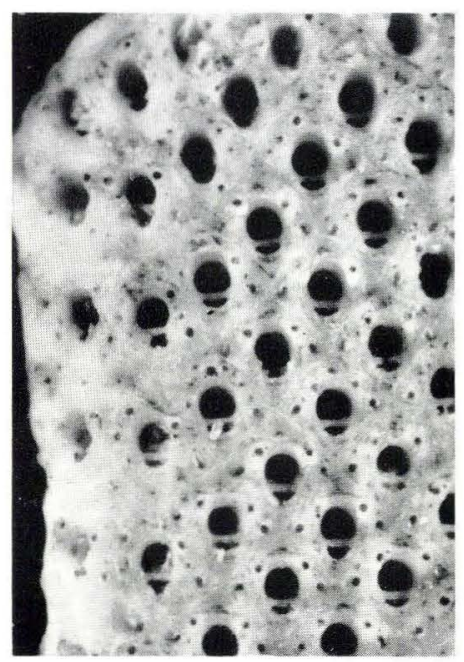

6

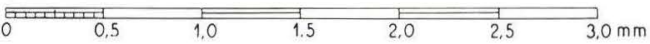




\section{Plate 27}

All magnifications $\times 20$.

Fig. 1. Cryptostomella pectinata n.sp. Faxe. Page 216.

Fig. 2. Cryptostomella gastropora (MARsson). Rügen. (Page 217).

Figs. 3-4. Psilosecos angustidens (Lev.). Page 217.

Fig. 3. Herfølge.

Fig. 4. Faxe.

Fig. 5. Cellepora daniensis Vorgt. Stevns. Page 219.

Figs. 6-8. Crassicellepora voigti n.sp. Page 220.

Figs. 6 and 8. Herfølge.

Fig. 7. Faxe.

Phot. Chr. Westergaard 
Plate 27
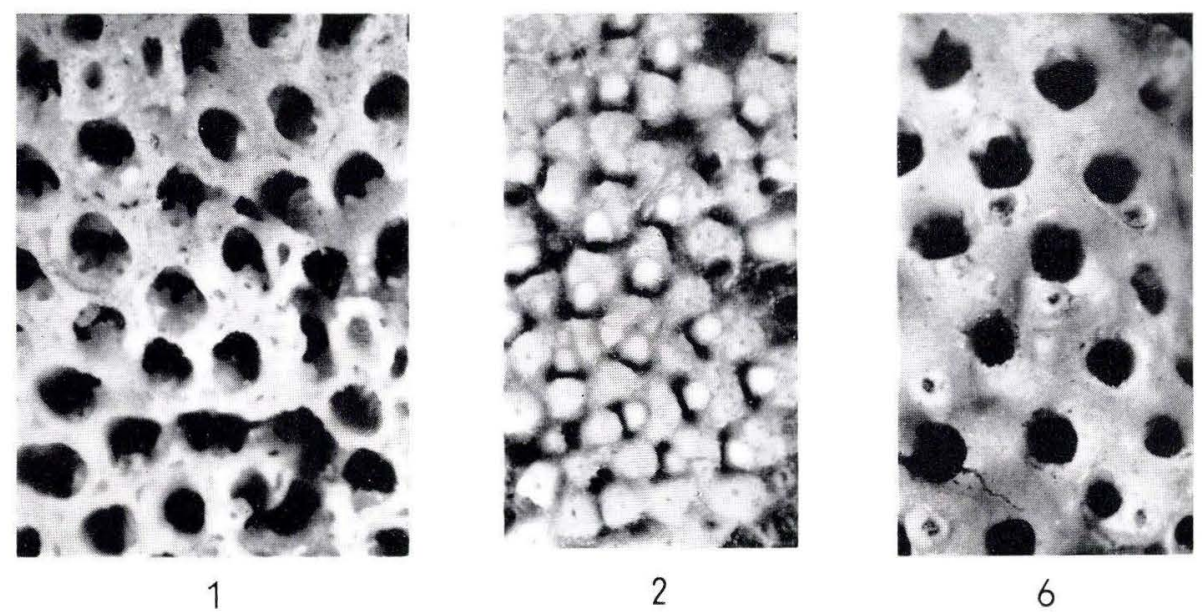

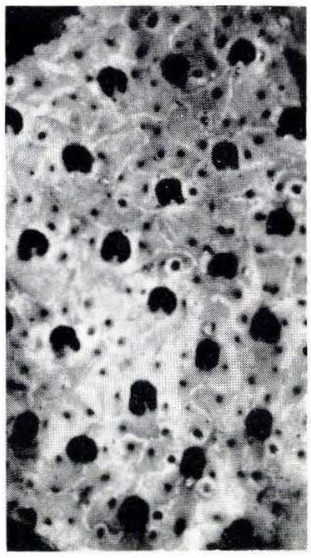

3

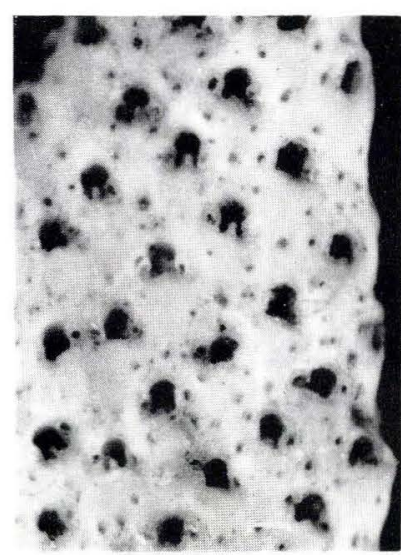

4

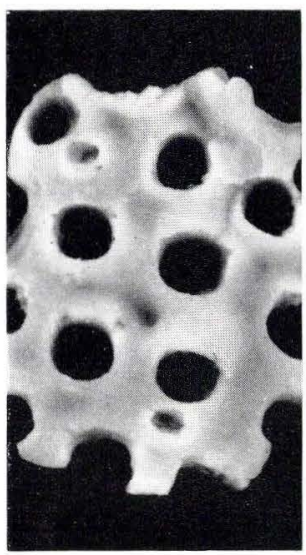

7

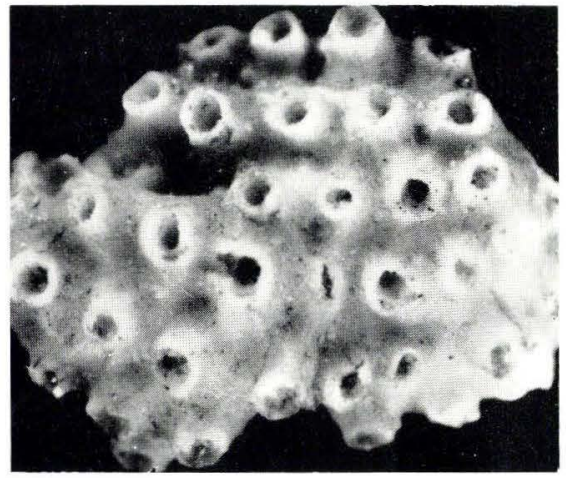

5

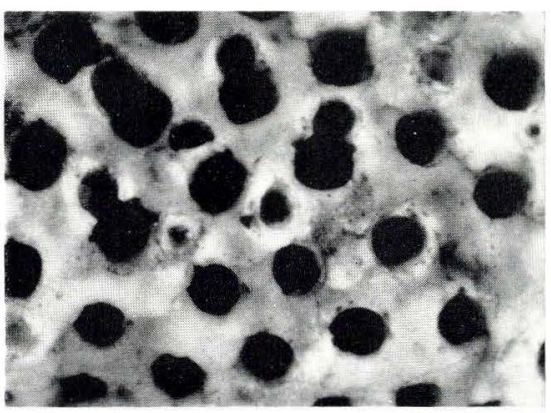

3

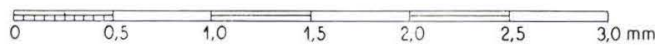




\section{Plate 28}

All magnifications $\times 20$.

Fig. 1. Callopora invigilata (BRydone). Herfølge. Page 80.

Figs. 2, 3 and 6. Floridina fragilis n.sp. Kagstrup. Page 127.

Fig. 6. Back of zoarium.

Fig. 4. Semiescharinella pulchra (Ulrich and BASSLer). Saltholm. Page 137.

Fig. 5. Aechmella tenuis n.sp. Faxe. Page 144.

Phot. Chr. WestergaArd 
Plate 28

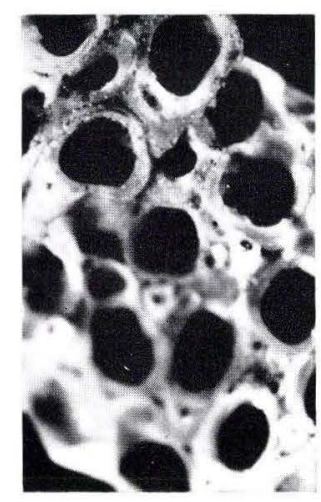

1

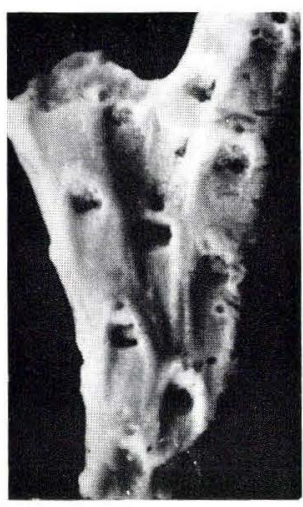

4

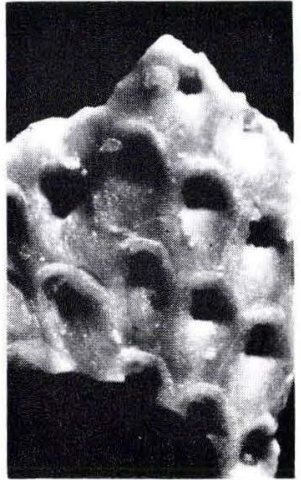

2

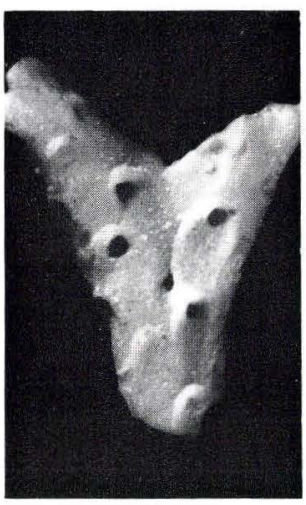

5

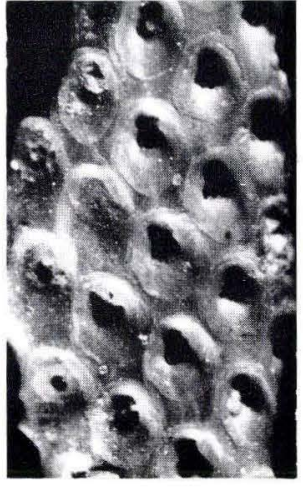

3

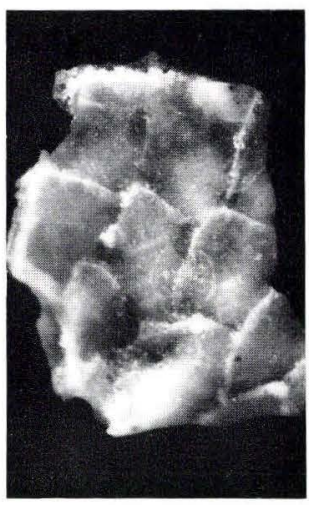

6

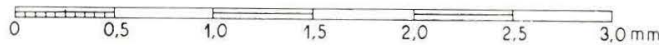

